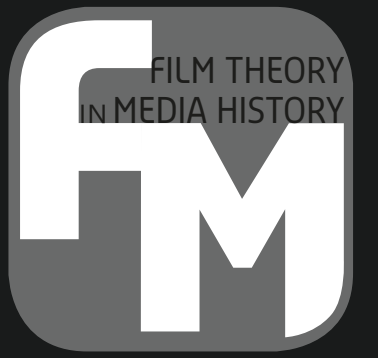

\title{
CHRISTIAN METZ AND THE CODES OF CINEMA FILM SEMIOLOGY AND BEYOND
}

\section{EDITED BY MARGRIT TRÖHLER AND GUIDO KIRSTEN}


Christian Metz and the Codes of Cinema 


\section{Film Theory in Media History}

Film Theory in Media History explores the epistemological and theoretical foundations of the study of film through texts by classical authors as well as anthologies and monographs on key issues and developments in film theory. Adopting a historical perspective, but with a firm eye to the further development of the field, the series provides a platform for ground-breaking new research into film theory and media history and features high-profile editorial projects that offer resources for teaching and scholarship. Combining the book form with open access online publishing the series reaches the broadest possible audience of scholars, students, and other readers with a passion for film and theory.

\section{Series editors}

Prof. Dr. Vinzenz Hediger (Goethe University Frankfurt, Germany), Weihong Bao (University of California, Berkeley, United States), Dr. Trond Lundemo (Stockholm University, Sweden).

\section{Editorial Board Members}

Dudley Andrew, Yale University, United States

Raymond Bellour, CNRS Paris, France

Chris Berry, Goldsmiths, University of London, United Kingdom

Francesco Casetti, Yale University, United States

Thomas Elsaesser, University of Amsterdam, the Netherlands

Jane Gaines, Columbia University, United States

Andre Gaudreault, University of Montreal, Canada

Gertrud Koch, Free University of Berlin, Germany

John MacKay, Yale University, United States

Markus Nornes, University of Michigan, United States

Patricia Pisters, University of Amsterdam, the Netherlands

Leonardo Quaresima, University of Udine, Italy

David Rodowick, University of Chicago, United States

Philip Rosen, Brown University, United States

Petr Szczepanik, Masaryk University Brno, Czech Republic

Brian Winston, Lincoln University, United Kingdom

Film Theory in Media History is published in cooperation with the Permanent Seminar for the History of Film Theories. 


\title{
Christian Metz and the Codes of Cinema
}

Film Semiology and Beyond

\author{
Edited by
}

Margrit Tröhler and Guido Kirsten 
Cover design: Krispin Hée / Suzan Beijer

Layout: Crius Group, Hulshout

Amsterdam University Press English-language titles are distributed in the US and Canada by the University of Chicago Press.

ISBN $\quad 9789089648921$

e-ISBN $\quad 9789048527564$

DOI $\quad 10.5117 / 9789089648921$

NUR $\quad 670$

\section{(9) (1) $(\Theta \Theta$}

Creative Commons License CC BY NC ND

(http://creativecommons.org/licenses/by-nc-nd/3.o)

(a) All authors / Amsterdam University Press B.V., Amsterdam, 2018

Some rights reserved. Without limiting the rights under copyright reserved above, any part of this book may be reproduced, stored in or introduced into a retrieval system, or transmitted, in any form or by any means (electronic, mechanical, photocopying, recording or otherwise). 


\section{Table of Contents}

$\begin{array}{lr}\text { Acknowledgments } & 9\end{array}$

Editorial Note 11

1. Christian Metz and Film Semiology $\quad 15$

Dynamics within and on the Edges of the 'Model': An Introduction Margrit Tröhler

\section{Metz and the Tradition of Film Theory}

2. Two Ways of Thinking

Raymond Bellour

3. Christian Metz and his Theoretical Legacy

Michel Marie

4. Christian Metz for Today

Roger Odin

5. Thinking Cinema

Christian Metz and/in the Tradition of Film Theory

Frank Kessler

6. Barthes' Early Film Semiology and the Legacy

of Filmology in Metz

Guido Kirsten

\section{Questions of Form and Aesthetics}

7. Christian Metz and Aesthetics

Martin Lefebvre

8. Christian Metz and Modern Cinema 
9. Christian Metz, Editing, and Forms of Alternation

\section{Specificities of the Cinematic Code and the Imaginary}

10. Between Classical and Postclassical Theory

Metz on Specificity Then and Now

Philip Rosen

11. Cyber-Metz?

The Notion of Code in the Writings of Christian Metz

Selim Krichane

12. Yes, the Image Lies Beyond Analogy

Understanding Metz with Cartier-Bresson

Marc Vernet

13. The Cinematic Signifier and the Imaginary

Mary Ann Doane

14. Fetishism and Scepticism, or the Two Worlds

of Christian Metz and Stanley Cavell

D.N. Rodowick

\section{Narration, Enunciation, Cinephilia}

15. Cinema: Image or Narrative?

Anne Goliot-Lété

16. Semiotics, Science, and Cinephilia

Christian Metz's Last Book, L'énonciation impersonnelle

Dana Polan

17. “'Theorize", he says...'

Christian Metz and the Question of Enunciation:

A Theory in (Speech) Acts

Alain Boillat 
18. Personal Enunciation: Presences of Absences

Dominique Bluher

19. Metz with Deleuze

From Film-Philosophy to Film Theory and Back Again

Nico Baumbach

\section{Two Interviews with Christian Metz}

20. Thirty Years After

Elena Dagrada

21. The Semiology of Cinema? It Is Necessary to Continue!

A Conversation with Christian Metz

Elena Dagrada and Guglielmo Pescatore

22. Flashback to Winter 1990

Margrit Tröhler

23. 'I Never Expected Semiology to Thrill the Masses'

Interview with Christian Metz

Dominique Blüher and Margrit Tröhler

\section{Postscript}

Conclusion (handwritten note by Christian Metz)

Index - Names

Index - Film Titles 



\section{Acknowledgments}

The editors would like to express their sincere gratitude to the following people:

Roger Odin, Martin Lefebvre, Rosemarie Meyer, Anne Lété-Goliot, Dominique Bluher, and David N. Rodowick who enthusiastically encouraged the idea of a conference as an homage to Christian Metz from the very beginning.

Christian Metz's son, Michaël Metz, and Michèle Lacoste, Metz's life companion of many years, who also gave us all their support and participated in the conference; and Michaël especially for his permission to print photos and facsimiles from Metz's estate in this volume.

Once again, Martin Lefebvre, who lent his support with all kinds of information, assistance, and advice, sharing his in-depth knowledge of the unpublished writings, notes, and correspondence from the Fonds Christian Metz at the Bibliothèque du film (BiFi) in Paris.

Julia Zutavern and Eva Lipecki for their discreet and competent help in organizing the conference.

Robert Riesinger, who was unfortunately unable to attend the conference, for his interest in our project and for the exchange of ideas prior to the event.

Susie Trenka and Adrian Seward, translator and proofreader respectively, for their substantial contributions in preparing and completing this volume, as well as Henry M. Taylor for his competent translations during the conference.

Lorenz Vollenweider for his willingness to conduct research in libraries and online.

All employees of the Department of Film Studies at the University of Zurich for their many small and large services and courtesies as well as their commitment behind the scenes.

Furthermore, we would like to thank the following institutions for their financial support of the conference and of the publication of this book:

The Swiss Society for Cultural Theory and Semiotics (SSCS)

The Swiss Academy of Humanities and Social Sciences (SAHS)

The Swiss National Science Foundation (SNSF)

The French Embassy in Switzerland

Hochschulstiftung der Universität Zürich

The Doctoral programme "Film, Photography, and Other Visual Media" (swissuniversities / University of Zurich, Graduate Campus / University of Lausanne)

The Master's programme of the Swiss Cinema Network 
Last but not least, our thanks go to Amsterdam University Press, especially Maryse Elliott and Jeroen Sondervan, and the series editors of 'Film Theory in Media History', Vinzenz Hediger, Weihong Bao, and Trond Lundemo. 


\section{Editorial Note}

The editors of this volume would like to point out some terminological inconsistencies and editorial decisions. Several fundamental concepts in the field of film semiology possess a certain terminological 'fuzziness'. This is partly due to the differing epistemological discourses in the French and English-speaking worlds. In part, it also goes back to various historical translations of Metz's works or, beyond that, of linguistic and philosophical reference works. This has resulted in the authors in this volume sometimes using different terms for the same concept. To avoid confusion, we would like to briefly explain some of the central terms.

The first instance of such a 'floating' terminology concerns the word pair semiology/semiotics. The distinction is based on two schools of thought established by the American philosopher Charles Sanders Peirce (1838-1914) and the Swiss linguist Ferdinand de Saussure (1857-1913). Their respective theories of signs, which were developed simultaneously, differ in the two scholars' specific approaches: Peirce's general 'semiotics' is rooted in logic and epistemology, while the structuralist focus of Saussure's 'semiology' addresses language (especially verbal language).

When the International Association for Semiotic Studies (Association Internationale de Sémiotique, IASS-AIS) was founded in Paris in 1969, 'semiotics' was officially determined as the general term. However, especially in France (and also in film studies), the term 'semiology' has remained common for all (inter)disciplinary approaches that consider themselves to be part of the Saussurian structuralist tradition (Claude Lévi-Strauss, Roland Barthes, Gérard Genette, Christian Metz, and others). It has also served to mark its distinction from the 'structural semantics' of A.J. Greimas and the Ecole sémiotique de Paris. In the English-speaking world, the term 'semiotics' is more common. The editors of this volume have decided against harmonizing the usage. Thus, while both terms appear in the texts of this book, the authors primarily use them to refer to Metz's structuralist tradition. Where this is not the case, the connection to the approaches of Peirce or Greimas is either clear from the context or explicitly referred to by the authors.

Another term that might lead to confusion is 'apparatus'. Here, the problem is largely due to those English translations where Jean-Louis Baudry's and Metz's dispositif are consistently translated as 'apparatus'. However, in his text 'Le dispositif' (1975), Baudry made a clear distinction: 'In a general way, we distinguish the basic apparatus, which is made up of the ensemble 
of operations and technologies that are necessary to produce a film and to project it, from the dispositive, which concerns only the projection and includes the subject to whom the projection is addressed.' (Communications 23 [1975], 56-72, [pp. 58-59], our translation). The two aspects of the cinematic institution, which are thus translated into English as 'apparatus', are additionally blurred by the fact that 'apparatus theory' has become a common umbrella term for ideological critiques of cinema.

However, there is an increasing emphasis on the distinction between apparatus and dispositive, as evidenced by Frank Kessler's 'Notes on dispositif' [http://www.frankkessler.nl/wp-content/uploads/2010/05/Dispositif-Notes. pdf], or by the volume Ciné-Dispositives edited by François Albera and Maria Tortajada (Amsterdam University Press, 2015). In the present volume, the terms 'apparatus' and 'dispositive' are both meant in the sense of Baudry's 'dispositive' when they refer to Metz's Psychoanalysis and Cinema: The Imaginary Signifier (trans. by Celia Britton and others, Basingstoke \& London: Macmillan, 1982 [1977]). ${ }^{1}$ By contrast, in his last book L'énonciation impersonelle ou le site du film (Paris: Méridiens Klincksieck, 1991), Metz himself often uses 'dispositif' for what belongs to Baudry's 'basic apparatus' - for instance, the camera - as in the chapter 'Exposing the Apparatus' (ImpersonalEnunciation, or the Place of Film, trans. by Cormac Deane, New York: Columbia University Press, 2016, pp. 64-70). Thus, the term 'apparatus' is appropriate in this case.

Another unresolved translation issue has resulted in the synonymous use of 'matter of expression' and 'material of expression'. The concept, introduced into the structuralist debate by the Danish linguist Louis Hjelmslev in Omkring sprogteoriens grundlceggelse (Copenhagen, 1943), was translated into English as 'expression-purport' (Prolegomena to a Theory of Language, trans. by Francis J. Whitfield, Baltimore: Indiana University Publications in Anthropology and Linguistics 1953). Metz, who productively adopted the concept for his film semiology, uses the French translation matière d'expression in order to describe the pre-semiotic, amorphous, physical continuum constituting the five physical foundations of the cinematic language (these five elements are: moving photographic image, dialogue, noise, music, and written materials). Of the two English phrases, 'matter of expression' is the more commonly used, but quotations from Language and Cinema (trans. by Donna Jean Umiker-Sebeok, The Hague/Paris: Mouton

1 The American edition, which was published in the same year(Bloomington: Indiana University Press, 1982), has turned around the title and subtitle: The Imaginary Signifier: Psychoanalysis and Cinema, but the translation and pagination are identical. 
1974 [1971]) sometimes also include 'material of expression'. The same applies to 'matter of content' and 'material of content'. (The editors wish to thank Martin Lefebvre for these explanations with regard to Hjelmslev.)

The Grand Syntagmatique (where Metz isolates eight principal syntagmatic figures of narrative cinema) was translated as 'The Large Syntagmatic Category' in Film Language (Film Language. A Semiotics of the Cinema, trans. by Michael Taylor, New York: Oxford University Press, 1974 [1968]). However, this phrase never established itself. The authors in this volume use 'Grand Syntagmatique' (whether capitalized or not), or sometimes the original French expression grande syntagmatique.

The final note relates to a different level and concerns Metz's final work, Lénonciation impersonnelle ou le site du film (1991). Until the book's first integral English translation by Cormac Deane (Impersonal Enunciation, or the Place of Film, New York: Columbia University Press, 2016; afterword by Dana Polan), which evolved simultaneously with this volume and was published in February 2016, only individual chapters from the book were available in English. Therefore, in most contributions to this volume, the authors or translators themselves have translated quotes directly from the French original. Some authors also refer to Metz's essay, published prior to the book in Vertigo (1 [1987], pp.13-34), which corresponds more or less to the first chapter of the 1991 book and which was available in an English version: "The Impersonal Enunciation or the Site of Film (In the margin of recent works or enunciation in cinema)', trans. by Béatrice Durand-Sendrail with Kristen Brookes, New Literary History, 22/3 (1991), pp. 747-72; reprinted in The Film Spectator: From Sign to Mind, ed. by Warren Buckland (Amsterdam: Amsterdam University Press, 1995), pp. 140-63. 


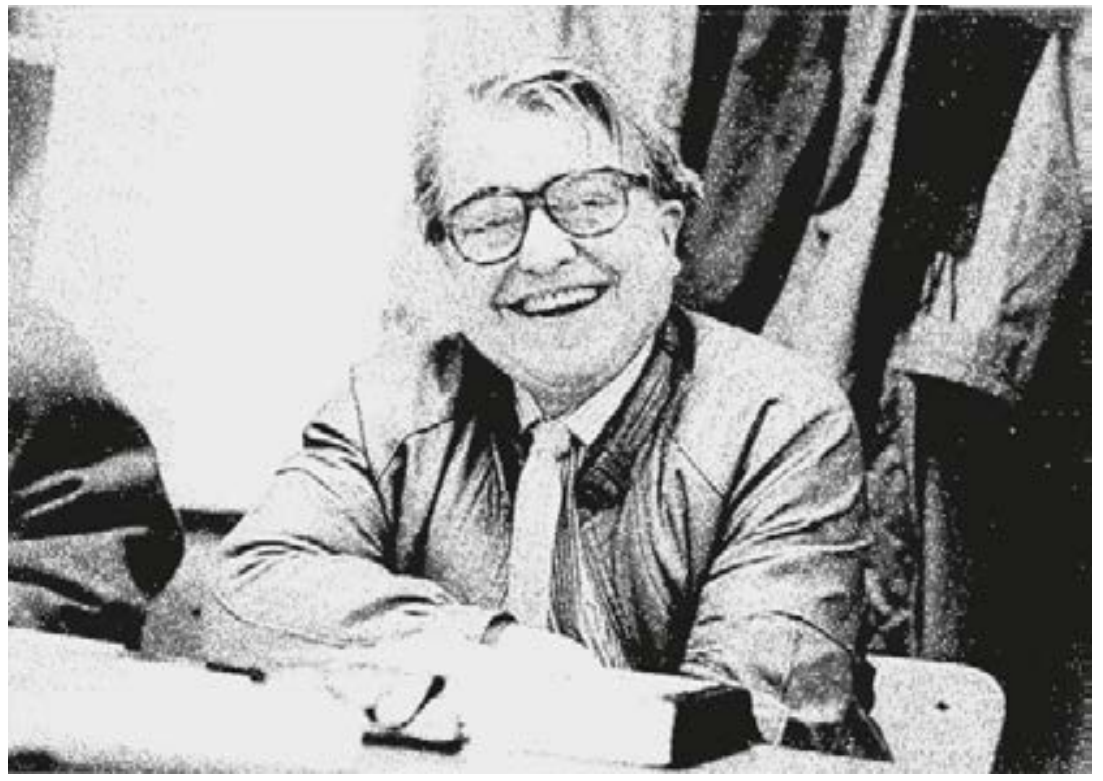

Figure 1.1: Portrait of Christian Metz (undated) 


\title{
1. Christian Metz and Film Semiology
}

Dynamics within and on the Edges of the 'Model': An Introduction

Margrit Tröhler

Tröhler, Margrit and Guido Kirsten (eds.), Christian Metz and the Codes of Cinema. Film Semiology and Beyond. Amsterdam University Press, 2018

DOI: $10.5117 / 9789089648921 / \mathrm{CHO1}$

\begin{abstract}
This chapter aims to introduce readers to the semiological film theory of Christian Metz. First, it presents the premises of film semiology and gives a broad outline of its three phases, in which Metz confronts cinema with concepts from linguistics, psychoanalysis, and the notion of enunciation. The accent is then put on Metz's initial meta-theoretical gesture and on the methodical self-reflection that characterizes his writing throughout. The final section considers the edges of his 'model' and shows how its underlying conditions function as prerequisites for the 'cinematic institution' that Metz is interested in.
\end{abstract}

Keywords: film semiotics/film semiology, psychoanalytic theory of cinema, enunciation theory, methodology, cinematic spectatorship, history of film theory 
There are two ways of subverting the legality of knowledge

(inscribed in the institution):

either to disperse it or to give it. Metz chooses to give;

the way in which he treats a problem of language

and/or of cinema is always generous: not by the invocation of 'human' ideas,

but by his incessant solicitude for the reader, patiently anticipating his demand for enlightenment, which Metz knows is always a demand for love.

Roland Barthes, 'To learn and to teach', $1975^{1}$

In his hometown of Béziers in Southern France, Christian Metz (1931-1993) helped to establish two local ciné-clubs after the war; he then moved to Paris in the late 1940s, where he completed the humanities-based programme (Khâgne) at the Lycée Henri IV before studying classical philology at the Ecole Normale Supérieure. At each institution, he was again active in the management of the film club. In the early 1950s, he taught at the Institut français in Hamburg and worked as a translator for Northwest German Broadcasting (Nordwestdeutscher Rundfunk). Later, he also translated a book about jazz and articles about linguistic psycho-pedagogy from German and English into French, and - under a pseudonym - published a crime novel in the 196os. In addition to various other scholarly activities, ${ }^{2}$ he went on to teach and research at the Ecole Pratique des Hautes Etudes (EPHE) in Paris, a position procured for him by Roland Barthes, whose 'disciple' and companion he was and whom he held in high esteem intellectually and personally. In 1964, Metz published his first, seminal essay, 'Le cinéma: langue ou langage?' ('The Cinema: Language or Language System?'). In 1970, he launched an informal study group on the topic of 'Cinéma et écriture', and in $1971^{-72}$, he taught his first official seminars on film theory, 'La

1 Roland Barthes, 'To Learn and to Teach', in The Rustle of Language, trans. by Richard Howard (Berkeley/Los Angeles: University of California Press, 1989 [1975]), 176-78 (p. 177).

2 In the 1950s, he was temporarily Georges Sadoul's assistant and general secretary of the Laboratoire d'anthropologie sociale under the direction of Claude Lévi-Strauss and A.J. Greimas. Simultaneously, he was also secretary and coordinator during the preparatory phase leading to the founding of the Association internationale de Sémiotique (under the direction of Emile Benveniste and Greimas). 
connotation de nouveau' and 'Trucage et cinéma', ${ }^{3}$ at the Ecole des Hautes Etudes en Sciences Sociales (EHESS). From 1975 until his retirement at the end of 1991, he was professor at EHESS in the Department of Language Studies (Sciences du langage). ${ }^{4}$ Meanwhile, Christian Metz remained a lifelong passionate moviegoer whose heart belonged to classical cinema the cinema of his initiation into cinephilia) but who also showed great interest in and appreciation for more modern trends, such as Italian Neorealism, contemporary French cinema, and films from around the world.

On the occasion of the twentieth anniversary of Christian Metz's death, I organized a conference together with two postdoctoral researchers, Guido Kirsten and Julia Zutavern, at the University of Zurich's Department of Film Studies from 12 to 14 June 2013. The contributions and discussions from this conference are compiled in the present volume (supplemented by two interviews with Metz from the late 1980 s and early 1990s). Like the conference, the volume is first of all intended as a tribute to a pioneering scholar, the father of modern film theory, who initiated several generations of scholars (including some of the authors in this volume) not just into the semiology of film but into a more general theoretical and methodological thinking about cinema. Throughout all his creative periods, Metz's works bespeak a standpoint articulated at once resolutely and circumspectly, as well as a consistent method. They are distinguished by an analytical way of thinking that questions its own premises and presents them as transparently as possible. This rigorous scholarly attitude was paired with an intellectual generosity and humanity that characterized his personality

3 Christian Metz, 'The Cinema: Language or Language System?' [1964], in Film Language: A Semiotics of the Cinema, trans. by Michael Taylor (New York: Oxford University Press, 1974 [1968]), pp. 31-91. His research for the study group on cinema and writing at EHESS was later incorporated into chapter XI of Language and Cinema, trans. by Donna Jean Umiker-Sebeok (The Hague/Paris: Mouton 1974 [1971]), pp. 254-84. The topics of his first seminars led to two corresponding articles in the second volume of the Essais sur la signification au cinéma (Paris: Klincksieck, 1972), which has never been translated in its entirety; however, the two articles were published in English as 'Connotation, Reconsidered' [1972], Discourse: Journal for Theoretical Studies in Media and Culture, 2 (1980), pp. 18-31, and 'Trucage and the Film' [1972], trans. by Françoise Meltzer, Critical Inquiry, 3/4 (1977), pp. 657-675.

4 For more detailed biographical information see, for instance, Iris, 10, (special issue Christian Metz et la théorie du cinéma / Christian Metz and Film Theory; ed. by Michel Marie and Marc Vernet, 1990), pp. 317-18, and the German translation of Le signifiant imaginaire: Christian Metz, Der imaginäre Signifikant. Psychoanalyse und Kino, trans. by Dominique Blüher and others (Münster: Nodus 2000 [1977]), pp. 240-41. For a complete bibliography of Metz's writings, see Ludger Kaczmarek and Hans J. Wulff: http://publikationen.ub.uni-frankfurt.de/opus4/ frontdoor/index/index/docId/13808 (accessed 7 September 2015). I would like to thank Martin Lefebvre and Roger Odin for supplementary information on Metz's biography. 
as a researcher and his commitment as a teacher, as Barthes says in the introductory epigraph.

The volume's second aim is to bring together various views on the genesis and evolution of the semiological approach, to expound on its place in the contemporaneous intellectual context, and to trace its legacy on theoretical debates about film and cinema from the 196os through the 1990 s and up to the present. Accordingly, the volume addresses the historical and theoretical positioning of Metz's works and their spheres of influence over the decades. Our objective is to approach Metz's thinking and the paradigm of film semiology - or the theoretical paradigm as such - at a metatheoretical level. That is to say, our approach is an 'experimental epistemology' that does not seek conclusive interpretations and explanations but that sketches possible relations in order to create an understanding of the emergence, change, and reception of an intellectual edifice and its contingent debates during a certain period. ${ }^{5}$ Often this intellectual edifice, which was very influential in the 1960 s and $1970 \mathrm{~s}$ and provoked several controversies, is only perceived retrospectively and rather indirectly today. But now that the partisan mentality of bygone disputes is history, its historicization offers a chance to give new currency to the semiological concepts, and to reexamine Metz's positions - at an epistemological level - in order to reconnect with them in some way. After all, the intellectual edifice built by Metz reflects the evolution of modern film theory, that is, the beginning of systematic theoretical and metatheoretical thinking about film and cinema. Also, Metz's dynamic and multifaceted work throughout its different phases paved the way for many later developments, and it continues to offer links leading in various directions to this day (thus, Michel Marie speaks of three generations with different backgrounds and focuses). ${ }^{6}$

With this metatheoretical perspective and with its broad range of articles, the present volume also aims to facilitate access to a scholarly discussion - which is often perceived as hermetic - for young film and media scholars. In this introduction, I will try to present some of the fundamental theorems of the paradigm and the development of Metz's film semiology, with reference to the articles in the volume. However, it seems just as important to me to outline Metz's general scholarly attitude, which can be seen in his continuous methodological examination of his

5 François Dosse, Empire of Meaning: The Humanization of the Social Sciences, trans. by Hassan Melehy (Minneapolis: University of Minnesota Press, 1999 [1995]), Chapter 34, pp. 352-57.

6 See Michel Marie [in this volume]. 
own approach and of the concepts of other scholars. This is not only the distinguishing feature of Metzian semiology, it also allows us to understand its innovative potential.

In a first step, this text thus aims to provide an entry point into Metz's writings. In a second step, I will approach his thought - the dynamics within and on the edges of his 'model' - from various perspectives, in order to open up and look beyond this 'model' in various directions, for Metz considered structuralism a productive conflictual space that needed to be reoriented again and again with a view to the 'cinematic institution'.

\section{The Awakening of Modern Film Theory}

With his works, Christian Metz initiated a paradigm shift in the mid-196os. This shift was indebted to the then-current structuralist approach, and it was meant to lead the discourse on film and cinema from 'a state of innocence' (déniaisement) - as Metz himself later put it self-reflexively - to a thorough theoretical and methodical grasp of the symbolic institution of cinema (la machine cinéma). The aim was to constitute 'film'/'cinema' as a scholarly object of study. ${ }^{7}$ To him, this meant first to search for and establish a place for the theoretical thinking about this object of study. His writings not only influenced the theory and analysis of the audiovisual within and outside of France, they also made a substantial contribution to the acceptance of film studies as an academic discipline and thus to its (albeit late) institutionalization. ${ }^{8}$

When Raymond Bellour calls Metz a 'founder of a discursive practice' (following Michel Foucault's text 'What Is an Author?' from 1969), it is mainly because Metz's works opened up a limitless field of possibilities, which provided diverse links to and starting points for other kinds of research: a

7 In his interview with Marc Vernet and Daniel Percheron, Metz uses the French term 'scientifique', which I understand to mean 'theoretical' (developing a systematic approach to the filmic object). For academic-political reasons, Metz was very sceptical of the academic establishment as such (and also towards such authoritative academic role designations as 'directeur de thèse' or 'disciple', etc.). Christian Metz, 'Sur mon travail (Entretien avec Marc Vernet et Daniel Percheron)' [1975], in Essais sémiotiques (Paris: Klincksieck, 1977), 163-205 (pp.192-201). See also the comments by Raymond Bellour, 'A Bit of History', in The Analysis of Film, ed. and trans. by Constance Penley (Bloomington: Indiana University Press, 2001 [1979]), 1-20 (pp. 11-12), or D.N. Rodowick, 'A Care for the Claims of Theory', in Elegy for Theory (Cambridge, MA/London: Harvard University Press, 2014), 168-20o (pp. 198-20o). See also Odin's essay in this volume.

8 Michel Marie, 'Avant-propos', Iris, 10, 7-11 (p. 7); see also Marie's essay in this volume. 
wide field that not only permits differences but inspires their articulation, provokes them, and which we can always return to. ${ }^{9}$

Over the years, Metz developed his film semiology, based on a 'phenomenological (post-)structuralism,', ${ }^{10}$ into a multifaceted edifice of theoretical ideas that systematically approached film (as an open, dynamic production of meaning, as discourse, and as artistic expression) and cinema (as cultural institution and psychic apparatus or dispositif). Apart from repeated polemics against the linguistics-inspired terminology and the (often misunderstood) concepts of semiology and semiotics, ${ }^{11}$ this theoretical paradigm is now rarely resorted to explicitly. But in the course of researching the cinematic signifier, Metz proposed many theorems to describe the functioning of film and cinema, theorems that have become so essential that contemporary film studies is almost unthinkable without them. Indeed, over time, many of the terms introduced by him became detached from their original discussions so that their provenance is no longer - or only partially - known. From his works of the 196os comes the cinema's 'matter of expression' (consisting of five tracks: moving photographic image, dialogue, noise, music, and written materials) or the 'autonomous segments' of his 'Grand Syntagmatique of narrative cinema' (especially the distinction between 'alternating' and 'parallel' montage). ${ }^{12}$ From his 1971 Language and Cinema, the distinction between 'filmic' and

9 Raymond Bellour, 'Le cinéma et ...', Iris,10, 15-36 (pp. 16-17). See also Bellour's essay in this volume.

10 I borrow this phrase from Elmar Holenstein, who describes Roman Jakobson's approach as 'phenomenological structuralism' (I will return to this at the end of my paper). See Elmar Holenstein, Roman Jakobsons phänomenologischer Strukturalismus (Frankfurt a. M.: Suhrkamp, 1975). A French version of this book appeared under the title Jakobson ou le structuralisme phénoménologique (Paris: Seghers, 1975).

11 In this text, I use the term 'semiology', which goes back to the linguist Ferdinand de Saussure and which characterizes the structuralist approaches of Barthes or Metz in France, while Greimas used the term 'semiotics', beginning with his works on structural semantics. In the English-speaking world, 'semiotics' is the more common term, but historically, it initially referred to the philosophical-logical tradition of Charles Sanders Peirce, which found its way into film studies through the work of Peter Wollen, among others. At the first congress of the International Association for Semiotic Studies in 1969, 'semiotics' was declared the general term; nevertheless, it is customary to identify the Metzian approach as 'semiological', especially in France. Both terms appear in the contributions to this volume. However, unless otherwise noted, the authors refer to the Saussurean tradition of Metz.

12 Christian Metz, 'Problems of Denotation in the Fiction Film' [1966-67], in Film Language, 108-46 (p. 119 and especially 125-27). In Film Language, the concept of the grande syntagmatique du film narratif was translated as 'The Large Syntagmatic Category of the Image Track' (p. 119); I prefer the translation by Robert Stam, Robert Burgoyne, and Sandy Flitterman-Lewis in New Vocabularies in Film Semiotics. Stucturalism:Post-Structuralism and Beyond (London/New York: 
'cinematic' established itself. And Metz's discussion of the 'non-specific' and 'specific' characteristics of cinema as a complex ensemble of codes that are activated and combined anew in the 'textual system' of each film is still at times echoed in contemporary works, especially in metatheoretical debates on the semiological paradigm. ${ }^{13}$ From his semio-psychoanalytic phase of the late 1970s, the concept of the 'imaginary signifier' and the distinction between 'primary' and 'secondary identification' in cinema have remained in the vocabulary of film and media studies. ${ }^{14}$ And in the (postmodern) debate about cinematic self-reflexivity and narrativity, Metz's strictly text-pragmatic intervention in the late 1980 s contributed the notion of 'filmic enunciation' - as an anthropoid, non-human, metadiscursive dynamic of the film addressing its spectators. ${ }^{15}$ This concept still serves as a theoretically logical antithesis to all personified concepts such as the implied author, the enunciator, or the narrator (as the enunciator's narratological equivalent).

As a 'founder of a discursive practice', Metz also laid the groundwork for further theoretical developments in the (wide) field of film and cinema for some of these, semiology provided a foundation; to others, it offered a contrasting foil, a background against which differences and new directions could be outlined. To mention just a few areas, film semiology triggered the development of the narratology of film in France, of semio-pragmatics and, subsequently, historical pragmatics, and (in the realm of applied analysis) of media pedagogy ${ }^{16}$ Together with the works on the cinematic apparatus

Routledge 1992), see, for instance, pp. 38-49. On the conceptual pair of 'parallel' vs. 'alternating' montage, see the essay by André Gaudreault and Philippe Gauthier in this volume.

13 Metz, Language and Cinema, pp. 22-39. I will return to all the concepts mentioned here.

14 Christian Metz, 'The Imaginary Signifier' [1975], trans. by Ben Brewster, in The Imaginary Signifier. Psychoanalysis and Cinema, trans. by Celia Britton and others (Basingstoke/London: Macmillan, 1982 [1977]), pp. 3-87.

15 Christian Metz, L'énonciation impersonnelle ou le site du film (Paris: Méridiens Klincksieck, 1991).

16 To mention just a few representative works of the very first generation in these areas: in the field of narratology, Francis Vanoye, Récit écrit, récit filmique (Paris: Nathan, 1989 [1979]) and André Gardies, Approches du récit filmique (Paris: Albatros 1980); in the field of semiopragmatics, the essays of Roger Odin in Iris, the first of which has been translated into English as 'For a Semio-pragmatics of Film' [1983], trans. by Claudine Tourniaire, in The Film Spectator: from Sign to Mind, ed. by Warren Buckland (Amsterdam: Amsterdam University Press 1995), pp. 213-26; in the field of media pedagogy, Geneviève Jacquinot, Image et pédagogie. Analyse sémiologique du film à intention didactique (Paris: PUF, 1977; revised edition 2012); and specifically on educational television, Rosemarie Meyer, Télévision etéducation. D'un apprenant modèle aux spectateurs reels (Paris: Arguments, 1993) and Bernard Leconte, Entre les lignes. Ecrits sur la télévision: usages et usagers (Lille: CIRCAV-GERICO, 1993). 
and with Louis Althusser's ideological critique of the 'institution of cinema', film semiology was also a critical reference point for feminist film theory as it developed in the English-speaking world in parallel to Metz's psychoanalytical works. ${ }^{17}$ His approach was followed by further works about the unconscious processes of subject formation by the apparatus, works that emphasize the historical and social dimension (of film and of the subject). ${ }^{18}$ And many later film-aesthetical and philosophical approaches would have been unthinkable without his writings, even if they decidedly dissociated themselves from Metz. ${ }^{19}$

Beginning with his 1964 foundational essay 'The Cinema: Language or Language System?', Metz also recognized the necessity of dealing with the history of film theory - as a tradition and as a break with tradition, or innovation. By discussing the writings of the past decades (from the $1920 \mathrm{~s}$ in France, Germany, and Russia to André Bazin; from the filmologists of the 1940s and 1950s to Jean Mitry in the early 1960s), he laid the foundation for a metatheoretical reflection on film and cinema. ${ }^{20}$ In striving to establish a systematic, coherent, and genuinely filmic theory, whose innovative potential could only be realized through confrontation with and appreciation of previous approaches, he also originated the historiography of film theory.

\section{Three Creative Periods}

Metz's theoretical works can be divided into three creative periods, with each adding a new conceptual aspect to his film semiology. Various periodizations of his work have already been proposed: in their interview, Michel Marie and Marc Vernet focus on scholarly writing (écriture, here taken to mean the manner or style of academic writing). The first period, which Marie and Vernet do not describe any further, includes the essays from 1964

17 See, for instance, Janet Bergstrom, 'American Feminism and French Film Theory', Iris, 10 (1990), pp. 183-98. See also Mary Ann Doane's essay in this volume.

18 See, for instance, Stephen Heath's book, which collected several essays from the 1970s: Questions of Cinema (Bloomington: Indiana University Press, 1981). See also the two Screen Readers on the topics of 'Cinema/Ideology/Politics' (1977) and 'Cinema \& Semiotics' (1981).

19 Today, this widespread effect makes it possible to read 'Metz with Deleuze' (in a reverse sense, so to speak), as Nico Baumbach does in his essay in this volume.

20 Metz: 'The Cinema: Language or Language System?', pp. 31-61 and 90-91. See J. Dudley Andrew, The Major Film Theories (New York: Oxford University Press, 1976), pp. 212-41; Francesco Casetti, Theories of Cinema, 1945-1995, trans. by Francesca Chiostri and others (Austin: University of Texas Press, 1999 [1993]), Chapter 6; Rodowick, 'A Care for the Claims of Theory', pp. 168-20o. See also Frank Kessler and Guido Kirsten's essays in this volume. 
onwards, compiled in the two volumes of Essais sur la signification au cinéma (1968 and 1972); ;1 the second consists of his opus Language and Cinema (1971), which they regard as exhibiting a very rigorous, 'technical' writing style; the third phase encompasses the psychoanalytical works, compiled in The Imaginary Signifier in 1977 (as well as the essay 'Photography and Fetish', 1985), which are written in a more fluent, almost literary style. ${ }^{22}$ Referring to this periodization, Philip Rosen adds that the three phases each explore different conceptual and epistemological spheres. D.N. Rodowick, for his part, considers these phases as 'points of passage or transition' in the growth of a per se theoretical conception in Metz's work. ${ }^{23}$ Martin Lefebvre and Dominique Chateau propose a similar periodization, but they take Metz's attitude toward phenomenology and aesthetics as their barometer: the three chronological phases they identify from their perspective are 'Metz's early "filmolinguistic" period (1964-1967), his middle or pan-semiological period (1967-1975), and his late psychoanalytic period (1975-1985). In all three of these periods phenomenology plays an important and sometimes pivotal role. ${ }^{24}$ Other structuring options, which focused on the developments and boundaries within the semiological movement from a contemporaneous perspective, were proposed by Dudley Andrew and Raymond Bellour as early as the $1970{ }^{25}$

It is striking that even in later attempts at a periodization, Metz's final preoccupation with the concept of enunciation is barely or simply not present. In order to give an overview of the entire 30 years of his work and to distinguish his creative periods according to their intrinsic focus, I thus resort to Robert Riesinger's afterword to the German translation of The Imaginary Signifier and to Elena Dagrada and Guglielmo Pescatore's interview with Metz. ${ }^{26}$ In Riesinger's view, the first 'filmo-linguistic' or 'filmo-semiological' and the second 'psychoanalytic' phases are followed by

21 Only the first volume of the Essais sur la signification au cinéma (1968) has been translated into English as Film Language. For the second volume, see: Essais sur la signification du cinéma, 2 vols. (Paris: Klincksieck, 1972), II.

22 Michel Marie and Marc Vernet, 'Entretien avec Christian Metz', Iris, 10 (1990), 271-97 (p. 276). The essay 'Photography and Fetish' was originally published in English (translated by Metz himself): Christian Metz, 'Photography and Fetish', October, 34 (Fall 1985), pp. 81-90; see D.N. Rodowick's essay in this volume.

23 See Philip Rosen's essay in this volume; Rodowick, 'A Care for the Claims of Theory', p. 198. 24 Martin Lefebvre and Dominique Chateau, 'Dance and Fetish. Phenomenology and Metz's Epistemological Shift' [2013], October, 148 (2014), 103-32 (p. 105).

25 Andrew, The Major Film Theories, pp. 216-17; Bellour, 'A Bit of History', pp. 10-11.

26 Robert Riesinger, 'Nachwort', in Metz, Der imaginäre Signifikant, pp. 230-239; Elena Dagrada and Guglielmo Pescatore, "The Semiology of Cinema? It Is Necessary to Continue! A Conversation 
a 'third semiology', which performs a text-pragmatic turn with its studies on filmic enunciation under the banner of a return to linguistics. These three stages each reveal a shift in and extension of the perspective of Metz's 'film-semiological adventure' (Barthes), whereas some of the basic premises and methodological reflections - to which I will return below - run through all three of these epistemological spheres.

\section{The Systematic Description of the Filmic Construction of Meaning}

Metz's first essay 'The Cinema: Language or Language System?', published in the journal Communications (no. 4, 1964, special issue devoted to 'Semiological Research'), was followed by other texts attempting to systematically grasp film as a meaningful process, in the vein of the structuralist discourse that had come to pervade the humanities in general. ${ }^{27}$ Metz's contributions to the semiology of film from this early period drew on a phenomenological-aesthetical discussion, but they show a shifting interest towards the filmic construction of meaning: they explored a field that was not only new but also open, where the author dealt rather unconventionally with Saussure's structuralist concepts, or, as Rodowick puts it:

Where one would think that Metz's ambit is to present the value of structural linguistics for the study of film, one finds instead a heartfelt plea to soften the structuralist activity by bringing it into contact with modern film - that is, with art. ${ }^{28}$

As Chateau and Lefebvre also point out, it is in this field of conflicting ideas that Metz searched for a theory - and for a theoretical site - specific to film/cinema, guided by the structuralist paradigm of the linguistic turn. ${ }^{29}$ Two parallel conceptual and methodological moves dominate here. First, the 'negative definitions', which Metz uses to delineate what film and film

with Christian Metz' [1989], trans. by Barringer Fifield [in this volume]. The questions of the two interviewers guide Metz on a comprehensive tour through his work.

27 See Guy Gauthier, 'La flambée structuraliste' and 'Christian Metz à la trace', CinémAction, 60 (1991), pp. 94-107 and 146-53 respectively. A comprehensive history of structuralism can be found in François Dosse, History of Structuralism, trans. by Deborah Glassman, 2 vols. (Minneapolis: University of Minnesota Press, 1998 [1991-1992]).

28 Rodowick, 'A Care for the Claims of Theory', p. 182.

29 See Chateau and Lefebvre, 'Dance and Fetish', pp. 105-6; see also Martin Lefebvre's essay in this volume. 
semiology is not. Based on concepts and methods of linguistics that he confronts critically, he repeatedly returns to his 1964 dictum that film is a language without a language system (langage without langue). Thus, the intent of semiology is not to establish a grammar of film - that is, a fixed, closed system of rules - but rather to describe film as an open, relational, and dynamic system, a network of codes or a set of conventions that result from practice and remain subject to constant change..$^{30}$ This objective not only attests to the beginnings of a poststructuralist attitude, it also leads to the second methodological move in Metz's thinking: the 'positive description' of how film works in its processes of constructing meaning. ${ }^{31}$ This method proceeds through numerous ramifications, temporarily culminating in the 'Grand Syntagmatique', which differentiates the organizing principles of (classical) cinema at a structural and denotative level. Here, Metz resorts to linguistic concepts as methodical tools, but - as Riesinger points out - the analogy between film and language (langue) only concerns 'their shared syntagmatic nature'. $3^{22}$ Metz's focus here is the 'codedness' of the filmic discourse, or of the cinematic signifier, which he analyzes in terms of its forms of expression: he distinguishes (eight) types of autonomous segments according to their specific formal organization segments that also correspond to semantic-narrative units - and describes their internal dynamics. But even if we can agree with Frank Kessler that the Grand Syntagmatique is one of the few well-elaborated 'models' of film semiology, it lays no claim to determining one or the general filmic code: 'at best, it can claim some validity for classical fiction film'. ${ }^{33}$ The Grand Syntagmatique has provoked some conceptual and methodical criticism, from Karl-Dietmar Möller-Nass, Michel Colin, and Emilio Garroni, among

30 Metz, 'Problems of Denotation', pp.117-119, and Metz, 'The Modern Cinema and Narrativity' [1966], in Film Language, 185-227 (pp. 209-10); Metz, Langage and Cinema, p. 103; Metz, The Imaginary Signifier, p. 29.

31 Metz comments on this 'negative' and 'positive' impulse in the interview with Bellour: Raymond Bellour and Christian Metz, 'Entretien sur la sémiologie du cinéma' [1971], in Essais, II, 195-219 (pp. 197-98).

32 Riesinger, 'Nachwort', p. 223.

33 Nevertheless, following Kessler, the Grand Syntagmatique is an attempt to 'make visible a specifically filmic level of organization, which lies above the diversity of individual processes (that are hard to formalize), and simultaneously below the level of narrative articulations, which are not a specifically cinematic code'; Frank Kessler, 'Filmsemiotik', in Moderne Film Theorie, ed. by Jürgen Felix (Mainz: Bender, 2002), 104-25 (pp. 114-15); see also Kessler, 'La grande syntagmatique re-située', Les cahiers du CIRCAV, 6-7 (special issue: 'La lyre et l'aulos. Hommage à Christian Metz', ed. by Bernard Leconte, 1994), pp. 184-94. See also the comment by Metz himself more than 20 years later in Dagrada and Pescatore, 'A Conversation with Christian Metz' [in this volume]. 
others. ${ }^{34}$ However, Metz himself qualified it soon afterwards, together with Michèle Lacoste. By critically testing the segment types and their possible arrangements and combinations in the analysis of a specific 'modern' film, Jacques Rozier's Adieu Philippine (F/I 1962), they transform and adapt them to the new (modern) object of study. ${ }^{35}$ This shows a typical tendency of Metz's work: he is interested on the one hand in the 'structure', the system, the code, and on the other hand in historical practice as an 'experience' in its structural and individual variations, which thus also serves as a corrective to the structure.$^{6}$ For around the time of working on the Grand Syntagmatique (of classical cinema), he also wrote his far-reaching essay 'The Modern Cinema and Narrativity', which deals with the aesthetical and narratological innovations of contemporary French cinema. As Francesco Casetti writes:

Metz highlights two aspects of this novelty. On the one hand, he inquires into the presence of new linguistic procedures, and especially of a new kind of syntagma, which he calls potential sequence; on the other hand, he focuses on the extension of the possibilities of 'saying' something - the extension of the 'sayable' or of the 'representable'. Modern cinema is typified by a capacity to go beyond the usual narrative conventions and beyond the usual representational boundaries - without denying the presence of rules to be followed..$^{37}$

Thus, Language and Cinema (1971) - together with the texts from the same period collected in Essais sémiotiques (1977) - can be considered the apex of the theoretical concern of this first semiology: it showcases the structuralist verve of taxonomy, of segmentation and hierarchization, in its purest form..$^{8}$ According to Metz himself, it was necessary to construct this book 'like a complete machine' and to think this machine through 'coherently', as he

34 See Kessler, 'Filmsemiotik', pp. 114-15; further critical positions are mentioned by Stam, Burgoyne, and Flitterman-Lewis, New Vocabularies in Film Semiotics, pp. 47-48. See also Guido Kirsten, 'Filmsemiotik' in Handbuch Filmwissenschaft, ed. by Britta Hartmann and others (Stuttgart: Metzler) [forthcoming].

35 Christian Metz (together with Michèle Lacoste), 'Outline of the Autonomous Segments in Jacques Rozier's film Adieu Philippine' [1967], and 'Syntagmatic Study of Jacques Rozier's Film Adieu Philippine' [1967], in Film Language, pp. 149-176 and 177-182 respectively.

36 I borrow the conceptual pair of 'structure' vs. 'experience' (as a renewal of and corrective to the structure) from the structuralist anthropologist Marshall Sahlins, Islands of History (London/New York: University of Chicago Press, 1985), pp. vii-xvii and 136-56.

37 See Francesco Casetti's essay in this volume.

$3^{8}$ See Roger Odin, 'Metz et la linguistique', Iris, 10 (1990), p. 90. 
later said in an interview. ${ }^{39}$ The book's clear aim was 'to found a theory' in the sense mentioned above: that is, a 'positive description' through the focused choice of a 'principle of relevance' (principe de pertinence), which also means consistency, transparency, completeness. ${ }^{40}$ He thus sees this study as a consequence of his previous work: it examines the fact of the 'codedness' of film, ${ }^{41}$ the status of codes and their systems of correspondences and deviations as a coherently organized set of rules. This also leads him to take up information theory as a side project, as Selim Krichane and Philip Rosen show in their contributions to this volume. ${ }^{42}$

Metz's methodology is based on an analytical approach to his 'cinematic object'; the 'code' and the 'system' are not material entities but logical ones created by the 'analyst'. ${ }^{43}$ At the same time, he confronts the abstract dynamics of the codes with the more concrete - but still logically substantiated - 'textual system'. This system shows the variations of the codes as they are 'actualized' within a complex ensemble of several films (texts), or in one specific text, where they account for a film's originality. Thus, while Metz proceeds inductively, 'if the Grand Syntagmatique is seen as a general model for the textual actualization of the logic of narrative progression, it does provide a system which can account for the material unfolding of films'. ${ }^{44}$

By thus formalizing the mechanics of the filmic construction of meaning, Metz intended to provoke an 'incisive effect'. The result of this act was a 'severe, quite sombre book (it is intended to be, that's its aspect of a private joke)' that many took as a “terrorizing or discouraging” book'. But, as Metz explains, one writes a book in order to think an idea through to the end; a book is a 'complete object of desire that exhausts something'. ${ }^{45}$

Language and Cinema is based on Metz's Thèse d'Etat (postdoctoral thesis), and it appeared around the same time as Jacques Derrida's of Grammatology (1967), Julia Kristeva's Semiotike (1969), Roland Barthes'

39 For this and the following quote, see the interview with Vernet and Percheron, Metz, 'Sur mon travail', p. 194.

40 Metz, Language and Cinema, pp. 9-15 and 20.

41 Metz, 'Sur mon travail', p. 193.

42 Furthermore, in the Soviet orientation of semiotics, the approach was profoundly linked to cybernetics, for instance in the early work of Jurij Lotman up to his Semiotics of Cinema, trans. and ed. by Mark E. Suino (Ann Arbor: University of Michigan, 1976 [1973]), and in his last book, Yuri M. Lotman, Universe of the Mind: A Semiotic Theory of Culture, trans. by Ann Shukman (Bloomington \& Indianapolis: Indiana University Press, 1990). See also Peter Wuss, Kunstwert des Films und Massencharakter des Mediums (Berlin: Henschel, 1990), especially pp. 478-83.

43 Metz, Language and Cinema, pp. 75-76.

44 Stam, Burgoyne, and Flitterman-Lewis, New Vocabularies in Film Semiotics, p. 48.

For all these quotes, see Metz, 'Sur mon travail', pp. 190-94. 
S/Z (1970), and Michel Foucault's The Archeology of Knowledge (1969) and The Discourse on Language (1971). From an epistemological perspective, Metz's book can thus be seen as a professed entry into what is considered the poststructuralist era (outside of France). Despite consistently remaining within a formalizing, immanent way of thinking, the book shows an awareness of the inadequacy of a purely textual definition. ${ }^{46}$ Time and again, Metz's work allows for openings towards the artistic practice of films, their historical context of production (or their film-historical paradigms), and their collective and individual reception (I will return to this at the end of my essay). Film is not only a production of meaning but also an individual artistic expression, inscribing itself into an evolution that is determined by artistic practice. Or, in the words of Jacques Aumont and Michel Marie: 'Each code constructed in the analysis of a given film thus encounters the history of forms and of representations; the code is the process through which the signifying configurations pre-existing a given text or film inscribe themselves into it. ${ }^{4}$

The textual system of each film, which actualizes the possibilities of organizing the filmic discourse through the experience of the structure, is seen as a process by Metz, a process that destabilizes, deforms, and constantly renews the existing codes in their concrete and historical shapes. ${ }^{48}$

\section{The Imaginary as an Opening in the Cinematic and Theoretical Discourse}

Language and Cinema also prepares the ground for the transition to psychoanalysis and enunciation, as Metz realizes the necessity of introducing a subject as part of the cinematographic institution. This leads him to a semiologically oriented psychoanalysis of the cinematic apparatus (dispositif) and of the 'code of the spectator'. ${ }^{49}$ This phase contains his most personal essays; as Alain Boillat foregrounds in his contribution, they displace the

46 See Riesinger, 'Nachwort', pp. 232-34; Rosen also sees this book as 'a bridge or hinge in Metz's work', which uncovers 'the necessary inadequacies of signification and representation, elaborating with great complexity and force on the theoretical, philosophical, and analytic implications of this premise'; see Rosen's essay in this volume.

47 Jacques Aumont and Michel Marie, Dictionnaire théorique et critique du cinéma (Paris: Armand Colin, 2001; 2d ed. 2008), p. 51, see also 240-41. See also Odin, 'Christian Metz et la linguistique', pp. 82-84.

48 On this point, see also Rosen and Odin's essays in this volume.

49 Dagrada and Pescatore, 'Conversation with Christian Metz' [in this volume]. See also Riesinger, 'Nachwort', p. 235 and Rosen's essay in this volume. 
authorial subject to the intellectual, theoretical field, involving it in the preoccupation with the unconscious processes of film perception. Metz achieves this by 'working through' the writings of Sigmund Freud, Melanie Klein, and Jacques Lacan. The two texts 'The Imaginary Signifier' and 'The Fiction Film and its Spectator: A Metapsychological Study' that appeared in 1975 in the journal Communications 23 were groundbreaking contributions to film studies, which generally turned to psychoanalytical approaches at the time. (Laura Mulvey's 'Visual Pleasure and Narrative Cinema' also appeared in 1975, laying the foundation for feminist theory's perspective on classical cinema. $)^{50}$ As Mary Ann Doane writes:

Metz's intuition that the cinema was on the side of the imaginary generated an enormously productive amount of thinking about the position of the spectator as an aspect of the apparatus. And I would say that one of his major contributions, along with others - Jean-Louis Baudry and Jean-Pierre Oudart, for instance - was to displace psychoanalysis in film criticism from the psychoanalysis of characters (or the auteur) to a consideration of the spectator's engagement with film..$^{51}$

With this transition, Metz leaves behind the immanent perspective of traditional semiology, as he himself emphasizes. On the one hand, he turns to the relation between the spectator and the screen/film, examining the spectator as a 'psychic apparatus', which is required by the institution during a film screening in order for this institution to function. On the other hand, these studies consider the 'cinema-signifier' as a 'specific mixture of the real, the symbolic, and the imaginary' by analyzing the 'condition of the code's possibility' through the imaginary character of the medium (meaning the perceptual conditions in cinema, the oscillation between presence and absence - 'real presence of photography, real absence of the photographed object' - the interplay between identification and projection). But then this also means a 'socio-historic mechanics without which cinema could not exist'. $5^{2}$ Or, as Metz wrote some years later, commenting on these two first essays: the cinematic institution is technologically and economically

50 Laura Mulvey, 'Visual Pleasure and Narrative Cinema', Screen, 16/3 (1975), pp. 6-18.

$5^{1}$ Doane [in this volume]. Metz comments on the two branches of psychoanalysis in cinema, and on the feminist approach which combines them, in an interview by Dominique Blüher and Margrit Tröhler, Christian Metz, “I Never Expected Semiology to Thrill the Masses”: Interview with Christian Metz' [1990], [in this volume].

52 Metz, 'Sur mon travail', pp. 189-90, and Metz, 'Réponses à Hors cadre sur Le signifiant imaginaire', Hors cadre, 4 (1986), 61-74 (p. 65 and 73). 
connected to modern culture and society; the fact that cinema is an industry influences the films in every detail, including their formal characteristics, and this also has ideological consequences. To 'think cinema within history' means to explore the 'comprehensive and partly unconscious apparatus' - which 'to a degree is the same for all films' - and to conceive of cinema 'as a social entity'.53

Two years later, Metz published his monograph The Imaginary Signifier: Psychoanalysis and the Cinema, which included slightly modified versions of the two essays as well as two others. ${ }^{54}$ There is, first, the essay 'Story/ Discourse (A Note on Two Kinds of Voyeurism)', which examines enunciation in classical cinema, thus prefiguring the third phase of Metzian semiology. ${ }^{55}$ Second, the volume contains the comprehensive, dense, and synthesizing essay 'Metaphor/Metonymy, or the Imaginary Referent'. ${ }^{56}$ Here Metz combines three perspectives by trying to answer the question of which theoretical standpoint allows for a coherent discourse about the primary process in the filmic texture. For this purpose, Metz confronts tropes of classical rhetoric (metaphor, metonymy, synecdoche) and their structuralist-linguistic extension by Roman Jakobson, first with the semiological-poststructuralist discussion on the syntagmatic and paradigmatic organization of the film discourse (that he himself had introduced in the 196os), and second with the fundamental psychoanalytical terms of 'condensation' and 'displacement' in the sense of Freud and, later, Lacan. In short, he is concerned with analyzing 'representability' (in Freud's sense, figurabilité in French) and its devices, as they become active in the filmic text itself. ${ }^{57}$ The fusion of these three perspectives leads Metz to locate the psychoanalytic constitution of the cinematic signifier between the primary and secondary process. For Metz, there is an 'interstice' (écart) not a 'barrier' (barrière) - between the two processes, which is displaced

53 Christian Metz, '1977-1984', preface to the second edition of Le signifiant imaginaire. Psychanalyse et cinéma (Paris: Christian Bourgois, 1984), I-V (p. III); this preface has not been translated in the English versions of the book.

54 Christian Metz, Le signifiant imaginaire. Psychanalyse et cinéma (Paris: UGE, 1977); English version from 1982: Metz, The Imaginary Signifier.

55 Metz, The Imaginary Signifier, pp. 89-98 (essay written as an homage to Emile Benveniste). This essay can also be related to Metz's 'Trucage and the Film' (first published in 1972), which already announces the psychoanalytical positioning of the spectator in the perceptual regime of classical cinema, see especially pp. 665-68. See also Frank Kessler, 'Méliès/Metz: Zur Theorie des Filmtricks', Montage AV, 24/1 (2015), pp. 145-157.

56 Metz, The Imaginary Signifier, pp. 149-297.

57 See Metz, 'Sur mon travail', p. 190; see also Riesinger, 'Nachwort', pp. 236-37. 
again and again and thus keeps redefining the conception of 'censorship'. ${ }^{8}$ This interstice creates a 'surplus' (Barthes) of the imaginary in the figural operations: a surplus of metonymy, of the syntagmatic, and of displacement (processes that are by no means homologous with each other). This surplus of the film's movement and of the movement of the unconscious in the spectator's psychic apparatus, however, is contained by the 'corroborated' codes or stabilized figures, which function as processes of secondarization (of semanticizing, symbolizing, and ultimately of meaning). ${ }^{59}$ In justifying this hypothesis, which Metz pursues in his characteristically systematic and consistent way, the eponymous referent somehow fades from the spotlight on the one hand as a phenomenological aspect of the analogy of the image, on the other hand as a symbolic urge, whether in the sense of the visual aspect of objects or as social and cultural practice, as Doane and Vernet observe from two different angles in their respective critical contributions. ${ }^{60}$

As Metz himself explains in retrospect (1986), in an interview with Michèle Lagny, Marie-Claire Ropars-Wuilleumier, and Pierre Sorlin (editors of the journal Hors cadre), the imaginary signifier concerns the imaginary character of the signifier as carrier of the photographic representation, as the 'inevitably unreal correlate of any referent'. At the same time, it involves the fetishistic regime of spectatorial perception (with its specific mix of belief and disbelief, and thus disavowal) that the (fictional) film preferably triggers. Metz thus conceives of the imaginary referent as a 'piece of (imaginary) reality, from which the spectator assumes the story to have been extracted'. And he continues: "assumes" is not the right word, it is more of a feeling, vague but strong, which presents itself as something obvious. Literary theory would call it a referential illusion.' However minimal the film's invitation to the spectator to construct a diegesis, there is a socially and culturally strong desire to imagine a world similar to our everyday world but belonging to the order of dreams (or daydreams) or memories. Nevertheless, radically experimental films demonstrate that 'the imaginary signifier is capable of almost entirely disposing of the imaginary referent ${ }^{\prime}{ }^{6}{ }_{1}$

$5^{8}$ Metz, 'Réponse à Hors cadre', p. 63; see also Metz's preface ('1977-1984') to the second edition of Le signifiant imaginaire, p. IV, and Metz, 'Metaphor/Metonomy', in The Imaginary Signifier, Chapter 21, pp. 253-65.

59 Metz, 'Sur mon travail', p. 19o. And yet, as Guy Gauthier puts it: 'The signifier is as if affected by extra-semantic pressures, to a large part escaping the coherent system reconstructed [...] by the structural analysis.' Gauthier, 'Christian Metz à la trace', p. 150.

6 o See Marc Vernet, 'Le figural et le figuratif, ou le référent symbolique', Iris, 10, pp. 223-34, and Doane's essay in this volume.

61 Metz, 'Réponses à Hors cadre', all previous quotes from pp. 65-69 (emphasis in original). 
Cinema itself then becomes the referent, with all of cinema's possibilities, which the film comments on through the enunciative act.

\section{The Text-Pragmatic Turn - Another Way of Approaching the Spectator}

Thus, we arrive at the third semiology. (The above-mentioned interview in Hors cadre and the retrospective discussion of the imaginary signifier, or referent, are already part of this phase; at the same time, however, Metz's essay 'Photography and Fetish' still deals intensely with the psychoanalytic concepts of structures of belief, which are activated differently by the photographic image and the cinematic image, respectively). From the mid-1980s on, Metz again turned to a concept borrowed from linguistics, more precisely from pragmatic text linguistics: the concept of enunciation. ${ }^{62}$ To create a rationale for his genuinely filmic notion of enunciation, he once more started out with a 'negative description' (how is film different from verbal language?). His main points of reference, which he critically honoured, are the works of the semiological linguists Emile Benveniste and Catherine Kerbrat-Orecchioni, and of the literary critic and philosopher Käte Hamburger. ${ }^{63}$ With his nuanced contribution, Metz injected himself into the French debate on enunciation, which was already in full swing at this point. In linguistics, which had generally turned to (textual) pragmatics, it was headed by Oswald Ducrot's theory of argumentation in language (which is itself based on John R. Searle's speech act theory); in the field of literary theory, it was connected to Gérard Genette's work; and in the field of cinema, it was also associated with the interests of narratology, as, for instance, articulated in Jean-Paul Simon's Le filmique et le comique and in the essays in Communications 38 edited by Jean-Paul Simon and Marc Vernet. ${ }^{64}$

62 In the meantime, Metz was working on a study about the joke in Freud's work as well as on a study of Rudolf Arnheim. Neither of these studies was ever published (on Arnheim, see Kessler's essay in this volume).

63 Emile Benveniste, 'Subjectivity in Language' [1958], in Problems in General Linguistics, trans. by Mary Elizabeth Meek, 2 vols. (Coral Gables: University of Miami Press, 1971 [1966]), I, pp. 223-30; Catherine Kerbrat-Orecchioni, L'énonciation. De la subjectivité dans le langage (Paris: Armand Colin, 1980); Käte Hamburger, The Logic of Literature, trans. by Marilynn J. Rose (Bloomington: Indiana University Press, 1993 [1957]).

64 See, for instance, Oswald Ducrot, Le dire et le dit (Paris: Minuit, 1980); Gérard Genette, Narrative Discourse. An Essay in Method, trans. by Jane E. Lewin (Ithaca: Cornell University Press, 1983) and Narrative Discourse Revisited, trans. by Jane E. Lewin (Ithaca: Cornell University Press, 1988); Jean-Paul Simon, Le filmique et le comique. Essais sur le film comique (Paris: Albatros, 1979); Communications, 38 (issue: 'Enonciation et cinéma', ed. by Jean-Paul Simon and Marc Vernet, 1983). 
Contemporaneous theoretical discussions abroad also served as reference works, including Gianfranco Bettetini's semiotic communication theory in Italy ${ }^{65}$ cognitivist narratology (David Bordwell, Edward Branigan), and the more narrowly semiological works of Francis Vanoye, André Gardies, François Jost, André Gaudreault, Francesco Casetti, and others. ${ }^{66}$

However, Metz's interest in the discursive positions of enunciation is already prefigured in the much-debated essay 'Story/Discourse', which he had published in The Imaginary Signifier and, before that, in articles such as 'Notes Toward a Phenomenology of Narrative' (1966), 'Modern Cinema

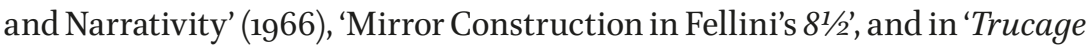
and the Film'. ${ }^{67}$ Francesco Casetti, Anne Goliot-Lété, and Martin Lefebvre point this out in their contributions to this volume. In these earlier texts, Metz already talks of the diegetization of enunciative marks in classical cinema - whether with regard to the aesthetical-technical aspects of 'special effects' or to the film-historical regime - whereas modern cinema exposes these same marks. From Metz's semio-psychoanalytical perspective, which he adopts in 'Story/Discourse', the former equals a disavowal encouraging fetishism, whereas the latter foregrounds the enunciative 'machine' of cinema. From this proposition, Metz develops two forms of cinematic pleasure: the pleasure of immersion in the diegesis and the pleasure of observing the visible work of the cinematic signifier. ${ }^{68} \mathrm{He}$ then interrelates these two forms with two types of voyeurism. With reference to Benveniste, he claims that classical cinema erases the traces of enunciation to the point of a complete transparency of the referential (voyeuristic) illusion of an idealist realism, which characterizes this mode. While this claim has earned him some adamant criticism, ${ }^{69}$ he self-critically returns to it in his last work,

65 Gianfranco Bettetini, La conversazione audiovisiva. Problemi dell'enunciazione filmica e televisiva (Milano: Bompiani, 1984).

66 Vanoye, Récit écrit, récit filmique; Gardies, Approches du récit filmique; François Jost, L'œilcaméra. Entre filmetroman (Lyon: Presses universitaires de Lyon, 1989 [1987]); André Gaudreault, From Plato to Lumière: Narration and Monstration in Literature and Cinema, trans. by Timothy Barnard (Toronto/Buffalo/London: University of Toronto Press, 2009 [1988; 1999]); Francesco Casetti, Inside the Gaze: The Fiction Film and Its Spectator (Bloomington \& Indianapolis: Indiana University Press, 1998 [1986]). For a comprehensive account of Metz's references, see his bibliography in L'énonciation impersonnelle.

67 Christian Metz, 'Notes Toward a Phenomenology of Narrative' [1966], in Film Language, pp. 16-28; Metz, 'The Modern Cinema and Narrativity'; Christian Metz, 'Mirror Construction in Fellini's $81 / 2$ ' [1966], in Film Language, pp. 228-34; Metz, 'Trucage and the Film'.

68 As he himself said later, his heart clearly belonged to the former (at least at that time); see Lefebvre's essay in this volume.

69 Especially the claim that classical cinema is 'story without discourse' as a 'good object' has brought on harsh criticism; see, for instance, Geoffrey Nowell-Smith, 'A Note on Story/Discourse', 
Lénonciation impersonnelle ou le site du film. Here, he describes enunciation as an act and process of discursive activity that is always present as a nonanthropomorphic force in the expression of images and sounds combined into meaningful arrangements. Thus, the 'neutral image' doesn't exist (anymore), it is a 'logical fiction' or a myth of theory.$^{70}$ As the marks of enunciation vary through history - at the textual and perceptive levels - they become more or less noticeable, more or less overtly displayed; but every image bespeaks a 'point of view' (also in the figurative sense), 'meta-filmically', self-reflexively calling attention to its discursive constructedness.

Due to the conceptual rejection of deixis in the filmic discourse, the textpragmatic perspective of this last study about enunciation is dominated by an aesthetical-narratological tendency, which once more gives expression to Metz's cinephilia, as Dana Polan and Martin Lefebvre point out in their contributions to this volume. The 'impersonal enunciation' is also a logical, theoretical concept, one that is necessary to explain how films narrate through their aesthetic form and audiovisual flow. Enunciation and narration, for Metz, coincide in the (classical) fiction film, because all enunciative marks are put at the service of the culturally dominant mode of narration as a discursive activity. ${ }^{71}$ Similarly, filmic enunciation in documentary - with its often hybrid mode combining narration, description, argumentation ${ }^{72}$ - cannot be conceptually equated with verbal communication, for film has no personalized enunciative positions such as 'I' and 'you' (or other deictic indicators such as 'here' and 'now'), which are exchangeable in a conversation. ${ }^{73}$ Admittedly, film does contain traces of subjectivization and the stylistic marks of an author (possibly also of a film-historical trend), which point to a 'signature' and which temporarily stand out against the historically ingrained enunciative marks (the code). ${ }^{74}$

in Movies and Methods, ed. by Bill Nichols, 2 vols. (Berkeley/Los Angeles/London: University of California Press, 1985), II, pp. 549-57.

70 Metz, L'énonciation, see the chapter 'Images et sons “neutres"?', 167-72 (p. 170) and before p. 156. See also the interview by Dagrada and Pescatore, 'Conversation with Christian Metz' [in this volume]. 71 Various pleas for a conceptual distinction between 'enunciation' and 'narration' - for instance by Jean-Paul Simon, Dominique Chateau, and François Jost - can be found in Communications 38 .

72 I take the three 'text-types' from Seymour Chatman, Coming to Terms: The Rhetoric of Narrative in Fiction and Film (Ithaca/London: Cornell University Press, 1990), Chapters I-IV (pp. 1-73). Metz also refers to Chatman elsewhere.

73 See, for instance, Metz, L'énonciation, pp. 186-89, 13-22, and 202.

74 See Metz, Lénonciation, pp. 155-59; see Casetti's essay in this volume. On the subjectivity of the 'author' in cinematic enunciation, or in the enunciation of theory, see the essays by Dominique Bluher or Alain Boillat in this volume. 
Film also contains the addressing of its potential spectators, targeting them (as discursive, theoretical positions) in a mediated way, in order to self-reflexively comment on its own textual production. For Metz, all of these marks are traces of enunciation, which proceeds as an abstract, impersonal dynamic of discourse between the logical positions of an 'origin' and a 'destination'. ${ }^{75}$ Through countless enunciative configurations (as moments of énonciation énoncée), enunciation refers to itself, because the ultimate 'I' - here taken as the real author and the real spectator - always remains outside the text: it belongs to 'another world' (another logical site).$^{76}$ As a prefabricated, 'canned' product, film is a 'monodirectional' discourse, a term Metz takes from Gianfranco Bettetini. ${ }^{77}$ Its enunciation, which doesn't reveal itself deictically, is therefore not reversible, that is, not locatable outside the text, neither temporally nor spatially. With this conceptual set of tools, Metz thus distances himself from most previous propositions on filmic enunciation, above all from Casetti's approach in Inside the Gaze: The Fiction Film and Its Spectator, with which Metz's book deals in detail. ${ }^{7}$ Granted, Casetti uses the personal pronouns metaphorically, so to speak, when he claims that the film (as 'I') addresses the spectator (as 'you') through means such as a close-up or a character's look into the camera. Nevertheless, Metz vehemently opposes a personalization of discursive positions and - through his characteristically consistent reasoning - demonstrates that the transfer of the linguistic concept of deixis to film cannot work.

As part and parcel of this consistent, logical approach, Metz ultimately returns to a text-immanent model here: this had already earned him some criticism with regard to his filmolinguistic phase, for instance from Robert Stam, whose cultural criticism attempted to close the theoreticalmethodical gap between textual and historical enunciation based on Mikhail Bakhtin's 'social semiotic':

While Metz, somewhat 'blocked' by the Saussurean langue/parole schema, tends to bracket questions of history and ideology, Bakhtin locates both history and ideology at the pulsating heart of all discourse. [...] Speech is

75 Metz, L'énonciation, especially Chapter I (pp. 9-36).

76 Ibid., p. 189 on the author, p. 202 on the spectator, and pp. 199-205 on spectator and author, (especially on the logical site of the other world, p. 203).

77 Ibid., p. 17; see also Dagrada and Pescatore, 'Conversation with Christian Metz' [in this volume].

78 Casetti, Inside the Gaze. 
always cast in the form of an utterance belonging to a particular speaking subject, and outside this form it cannot exist. ${ }^{79}$

On a different conceptual level, Roger Odin also dissociates himself from Metz's purely textual - or rather, text-pragmatic - conception of enunciation. Building on Metz's earlier works, Odin outlines his own 'semio-pragmatic' notion of enunciation. He performs a reversal of the theoretical viewpoint, so to speak, in order to think of the film's enunciation from the spectator's perspective, when trying to understand - following Metz's dictum - 'that films are understood'. ${ }^{80}$ Although this 'spectator' remains an abstract, generalized concept in Odin's view, too - spectators are not persons but 'actants' - he nevertheless takes a step towards 'pragmatics'. Starting at the end of the $1970 s$ with documentaries, and specifically home movies, Odin develops his heuristic model, which centres on the 'reading' of a film: while stylistic devices instruct spectators to read a film one way or another, the spectators always have the option to refuse such a reading. However, the institutional conditions of reception and their constraints are far more important to Odin when it comes to understanding which contexts activate which 'modes of producing sense and affect'. ${ }^{81}$ Frank Kessler, in turn, historicizes Odin's approach in his historical pragmatics in order to bridge the gap between the filmic text and its specific context (especially with regard to early cinema). ${ }^{82}$

79 Robert Stam, Subversive Pleasures: Bakhtin, Cultural Critcism, and Film (Baltimore/London: The Johns Hopkins University Press, 1989), p. 40. Regarding the pluralization of subjectivity at a less ideological level but rather based on a critical history of theory, see Karl Sierek, 'Beyond Subjectivity: Bakhtin's Dialogism and the Moving Image', in Subjectivity: Filmic Representation and the Spectator's Experience, ed. by Dominique Chateau (Amsterdam: Amsterdam University Press, 2011), pp. 135-46.

8o Metz, 'Problems of Denotation', p. 145: 'The fact that must be understood is that films are understood.' (emphasis in original); Odin, 'For a Semio-pragmatics of Film', p. 213. In his review of L'énonciation impersonnelle, Odin critically examines Metz's conception of enunciation: 'L'énonciation contre la pragmatique?', Iris, 16 (1993), pp. 165-76.

81 Roger Odin, Les espaces de communication. Introduction à la sémio-pragmatique (Grenoble: Presses universitaires de Grenoble, 2011), p. 23. Beginning with the essays 'Rhétorique du film de famille', Revue d'esthétique, 1-2 (1979), pp. 340-72, and 'A Semio-pragmatic Approach to the Documentary Film' [1984], in The Film Spectator: from Sign to Mind, ed. by Warren Buckland (Amsterdam: Amsterdam University Press, 1995), pp. 227-35, Odin has been enlarging upon his semio-pragmatic 'model'. In a similar vein, Hans J. Wulff in Germany has developed his own semio-pragmatic 'communication-model' based on Metz's semiology: Hans J. Wulff, Darstellen und Mitteilen. Elemente einer Pragmasemiotik des Films (Tübingen: Gunter Narr, 1999).

82 Frank Kessler, 'Historische Pragmatik', Montage AV, 11/2 (2002), pp. 104-12, and Frank Kessler, 'Viewing Pleasures, Pleasuring Views: Forms of Spectatorship in Early Cinema', in Film - Kino Zuschauer: Filmrezeption / Film - Cinema - Spectator: Film Reception, ed. by Irmbert Schenk, Margrit Tröhler, and Yvonne Zimmermann (Marburg: Schüren, 2010), pp. 61-73. 


\section{The Initial Meta-Theoretical Gesture}

As should become apparent from this outline of Metz's works, his film semiology cannot be reduced to one theory - even if some of its premises are maintained and corroborated throughout. Just the fact that his works have been and still are an inspiration for countless other works and fields of research warrants his status as a 'founder of a discursive practice'. Bellour elaborates further on what made Metz's position so innovative in the historical context of the 196os, allowing it to become such a creative force: on the one hand, it is the 'outside' perspective, which Bellour designates with the formula 'le cinéma et...' ['the cinema and...']; on the other hand, it is Metz's scholarly stance, which finds expression as style, as 'writing' (écriture in the sense of Barthes) in his texts and oral contributions. ${ }^{83}$

The two aspects are interlocked, especially at the level of the methodological reflection that pervades Metz's works. I will thus discuss the two aspects together, with shifting emphases, and return to some of the points addressed earlier.

The perspective of 'le cinéma et...' manifests itself in how film/cinema as an object of study is approached from the outside, through a theoretical and systematic confrontation of cinema with concepts coming from other theoretical fields or concerning other artistic 'languages'. Metz already articulates this conscious and explicitly methodological stance in his first essay 'The Cinema: Language or Language System?', thus distancing his position from film criticism and film history as interior perspectives. In this way, he can draw on the interdisciplinary approaches of the French filmologists (especially Gilbert Cohen-Séat, Edgar Morin, Albert Michotte, or Etienne Souriau) - as Guido Kirsten points out in his essay in this volume - while also radicalizing their works through his systematic method and reframing them with regard to cinema. He also extensively addresses the works of Jean Mitry, Albert Laffay, Marcel Martin, and many others who, as predecessors of modern film theory, attempted to conceive of film as a 'language' from a phenomenological point of view. Their theoretical concern, however, was focused on individual aspects of cinema (and often combined with a perspective from the inside, as described above) ${ }^{84} \mathrm{By}$

83 Bellour, 'Le cinéma et ...', pp. 17-24; it is particularly the first point that Bellour returns to in his essay in this volume.

84 See Metz, 'The Cinema: Language or Language System?', pp. 42-43, 90-91; and 'Propositions méthodologiques pour l'analyse du film' [1967], in Essais, II, 97-110 (p. 100). See also Metz, Language and Cinema, pp. 9-15. On how Metz deals with his predecessors, see also Andrew, The Major Film Theories, pp. 212-16. 
contrast, what Metz envisions is to penetrate all areas of cinema with a newly created, consistent theory; Andrew speaks of his 'early optimism' in this respect. ${ }^{85}$ What connects Metz with the filmologists - who also cultivated an experimental (empirical) approach - is an epistemological quest to induce an encounter of cinema with the human and social sciences. ${ }^{86}$ Metz wants to get to the bottom of the frequently used metaphor of 'film as language, ${ }^{8}{ }^{87}$ and he is indebted to the 'linguistic turn' due to his biography and his intellectual environment. Thus, his perspective - unlike that of the filmologists - is not rooted in philosophy, aesthetics, psychology, sociology, or biology but in semiology as shaped by Saussure and Barthes. ${ }^{88}$ With the aim of grasping the audiovisual construction of meaning by the signifier, he approached cinema through structural linguistics and later through psychonanalysis. In other words: he used the two disciplines 'interested in meaning as such', that is, the only ones dealing with the 'meaning of meaning', as he said in an interview in $1990 .{ }^{89}$ However, in the aesthetic field, the propagated approach from the outside also implies a confrontation of cinema - not just with the older arts of painting, theatre, and literature but also, especially in Language and Cinema, with television and video: as 'languages', as dispositifs, as institutions. ${ }^{90}$ This comparative view of his object of study is another aspect, among others, linking Metz to the filmologists (I will return to this). ${ }^{91}$

85 Dudley Andrew, Concepts in Film Theory (Oxford/London/New York: Oxford University Press, 1984), p. 17 and 57. However, as Metz later points out again and again: 'Semiology, the way I understand it, is a "modest" discipline, which doesn't cover all areas: the history of film, for instance, should be approached with historical methods.' Blüher and Tröhler, 'Interview with Christian Metz' [in this volume].

86 Martin Lefebvre, 'L'aventure filmologique: documents et jalons d'une histoire institutionelle', Cinémas, 19/2-3 (2009), 59-10o (p. 61); the journal's double issue is entirely dedicated to the ambitious project of filmology, which began after World War II and officially lasted from 1950 to 1962 as the Institut de filmologie.

87 Bellour and Metz, 'Entretien', p. 195. On the metaphor of the 'cinematic language' as a 'methodological abstraction', see also 'The Cinema: Language or Language System?', p. 61, footnote * (these footnotes are commentaries added by Metz himself at the time of compiling the essays for the first volume of Essais sur la signification au cinéma in 1968).

88 See François Albera and Martin Lefebvre, 'Présentation. Filmologie, le retour?', Cinémas, 19/2-3 (2009), pp. 13-56.

89 Blüher and Tröhler, 'Interview with Christian Metz' [in this volume].

90 Metz, Language and Cinema, pp. 235-40.

91 See Albera and Lefebvre, 'Présentation', p. 21-22; see also Anne Souriau, 'Filmologie', in Etienne Souriau. Vocabulaire d'esthétique, ed. by Anne Souriau (Paris: PUF, 199o), pp. 745-46. She insists on the fact that Souriau considers the semiological approach part of the aesthetic branch of filmology from the outset. 
From this standpoint, Metz privileges - logically and methodologically a priori - the relationship or the interrelating (mise en rapport) - the 'and' in the phrase 'le cinéma et...', as Bellour points out..$^{92}$ This reveals Metz's fundamental aim of grasping his object of study theoretically: it is the foundational gesture trying to shape a place for film theory, to give it a raison d'être, and to sketch an outline, a kind of programme, for the theoretical activity. This foundational gesture, which motivates 'theory' as a dynamic field of relational possibilities in order to 'construct' the 'cinema' as object, testifies to Metz's driving force, 'his implicit desire to establish the parameters of theory as a discursive genre', as Rodowick puts it..$^{93}$ The gesture is a turning point, a break in the thinking and writing about cinema and film, but it also situates itself within a tradition and meta-theoretically reveals itself as a historical gesture: in order to establish a new film theory through semiology, it is necessary for Metz - much like for Jakobson - to address the history of theory. ${ }^{94}$ That means dealing critically with preceding positions in order to understand them but also to re-orient them with a view to the new approach and thus to root oneself within a non-teleological genealogy of theoretical reflection..$^{95}$ This epistemological activity as a necessary step in the theoretical renewal of scholarship is certainly not a solitary act in the context of the late 1960s and early 1970s (especially with regard to structuralism). We find it not just in the works of Jakobson but also those of Barthes, Foucault, Claude Lévi-Strauss, Michel de Certeau, and Pierre Bourdieu, to name but a few. ${ }^{96}$ But in Metz's work, the purpose

92 Bellour, 'Le cinéma et ...', p. 17 (emphasis in original).

93 Rodowick, 'A Care for the Claims of Theory', p. 172.

94 Roman Jakobson, 'A Glance at the Development of Semiotics' [1975], trans. by Patricia Baudoin, in Selected Writings, ed. by Stephen Rudy, 9 vols. (Berlin/New York/Amsterdam: Mouton 1962-2014), VII (1985), pp. 199-219; see Holenstein, Roman Jakobsons phänomenologischer Strukturalismus, p. 28. As Rodowick points out, this meta-theoretical, historicizing gesture is valid for Metz beginning with his first essay in 1964 and it continues through the two texts about Jean Mitry's Esthétique et pyschologie (2 vols., 1963 and 1965): Christian Metz: 'Une étape dans la réflexion sur le cinéma' [1964] and 'Problèmes actuels de théorie du cinéma' [1967], in Essais, II, pp. 13-34 and 35-86, and 'On the Impression of Reality' [1965], in Film Language, pp. 3-15. See Rodowick, 'A Care for the Claims of Theory', p. 174.

95 See Rodowick, 'A Care for the Claims of Theory', p. 176.

96 Some exemplary works are: Roman Jakobson, 'Linguistics in Relation to Other Sciences' [1967], in Selected Writings, II (1971), pp. 655-96; Barthes, S/Z; Claude Lévi-Strauss, Structural Anthropology, trans. by Monique Layton, 2 vols. (Chicago: University of Chicago Press, 1976 [1973]), II; Michel Foucault, The Archaeology of Knowledge, trans. by A.M. Sheridan Smith (New York: Pantheon Books, 1972 [1969]); Michel de Certeau, The Writing of History, trans. by Tom Conley (New York: Columbia University Press, 1992 [1975]); Pierre Bourdieu, Outline of a Theory of Practice, trans. by Richard Nice (Cambridge: Cambridge University Press, 1977 [1972]). 
of this reform is to establish the theory and the discipline of cinema in the first place.

Thus, choosing the act of interrelating as the basic methodological and epistemological gesture means more than just viewing the object of study from a distance or even constructing it from a radical position of exteriority. Rather, this attitude demands that Metz develops a coherent and nuanced 'model', 'a complete machine, with all its cogs, even the tiniest ones'; 97 in other words: 'every filmic study must clearly and consciously select its principle of relevance'. ${ }^{9}$ It is important, however, that the conceptual and methodical rigour Metz demands of himself does not lead to a view of theory as a hieratic or self-sufficient, permanently arrested construction. Andrew speaks of Metz's notion of theory as a constant 'work in progress' and of a semiology that 'begins by examining its own raw material before tackling the raw material of cinema'. ${ }^{99} \mathrm{Or}$, as Odin writes: 'The conception that Christian Metz has of theories is basically instrumental. To him, the theoretical models are but working hypotheses, more or less apt tools for resolving this or that problem. ${ }^{100}$ Thus, a theoretical perspective should and must be adapted to the issue in question. This approach permits twisting the object over and over to examine it from various directions by means of new theoretical tools. It also makes it possible to exchange the object of study and thus to verify the theory and question its limitations, that is, to falsify it (this is part of its principle of relevance). In other words, theory is seen as a process, a practice, a 'discursive genre', and in this modern sense, we can also grant it 'scientificity'. ${ }^{101}$

What this position implies from the beginning is a self-reflective distance from the chosen concepts and from one's own approach. It is an approach immersing itself deeply in the issue at hand, exploring the chosen perspective - in Metz's case the semiological perspective, which develops from a semio-linguistic into a semio-psychoanalytical, and eventually a semio(text-)pragmatical one - as completely, consistently, and systematically as possible. Simultaneously, this approach keeps a distance from its own intellectual edifice and from the theoretical issues Metz confronts it with.

97 Metz in the interview with Vernet and Percheron, 'Sur mon travail', p. 194.

98 Metz, Language and Cinema, p. 20 (translation modified).

99 Andrew, Major Film Theories, p. 216 and 215.

100 Odin, 'Christian Metz et la linguistique', p. 93, and Odin [in this volume]. See Metz himself in the interview with Bellour: 'Entretien', pp. 197-99 and 219, and in the interview with Vernet and Percheron, 'Sur mon travail', p. 184.

101 See Odin, 'Christian Metz et la linguistique', p. 93; see also Gauthier, 'Christian Metz à la trace', p. 148. 


\section{Structuralism as a Conflictual Space}

It is only in the way outlined above that we can understand Metz's use of concepts from linguistics and of Saussure's structuralism, and how he benefited from this approach within the context of the era's scholarly debates. What Odin calls the 'méthode metzienne' encompasses not only Metz's borrowings from neighbouring disciplines in order to create his theory of cinema but also the fact that he chooses them for their 'resilience', testing their suitability for investigating the cinematic language. He starts from a sort of negative motivation, which seeks intellectual, theoretical conflict and supports the exteriority of his approach. Thus, with his initial descriptive gesture, ${ }^{102}$ Metz the semiologist meta-theoretically confronts (verbal) language in Saussure's sense as a system of rules (langue) with film as a langage, that is, a 'system' of possibilities with the capacity for expression and communication. The concept of language (langue) serves as a 'métalangage' or 'métacode' in relation to all other semiotic systems or 'languages' (langages). The reason for this is that language (langue) is a 'universal commentator'; it is indispensable for everyday communication as well as for scholarly discourse - including the discourse about 'objectlanguages' (langages-objets) such as cinema - as he explicitly states. ${ }^{103}$

In this conceptual confrontation (which, from today's perspective, sometimes appears as a provocation), Metz is more interested in the 'disjunctures' than in the 'conjunctures', as Rosen also points out: 'By determining where cinema resists application of major Saussurian linguistic concepts, Metz marked and defined a need to develop concepts and methods beyond structural linguistics to account for signification in film. ${ }^{104}$ In his first text, 'The Cinema: Language or Language System?', Metz already makes it clear that film has no double articulation comparable to verbal language (as stated by André Martinet): ${ }^{105}$ 'Not only does this limit the arbitrariness of the cinematic sign, but it constricts any film

102 On 'description', see Metz, Language and Cinema, pp. 11-12.

103 Christian Metz, 'The Perceived and the Named' [1975], trans. by Steven Feld and Shari Robertson, Studies in Visual Communication, 6/3 (1980), 56-68 (pp. 62-63, emphasis in original). On the 'langages-objets', see also Christian Metz, 'Au-delà de l'analogie, l'image' [1970], Essais, II, 151-62, (p. 161). 104 Rosen [in this volume].

105 André Martinet, Elements of General Linguistics, trans. by Elisabeth Palmer (London: Faber, 1964 [1960]). This does not mean that cinematic language has no structuring levels or units: Metz distinguishes five levels (and addresses the propositions of Umberto Eco, Claude Lévi-Strauss, and Pier Paolo Pasolini); Metz, 'The Cinema: Language or Language System?', pp. 61-63 (see also the long footnote *). 
semiotics based on Saussurian principles. ${ }^{106}$ This leads Metz to describe the 'cinematic language' with the well-known phrase 'langage sans langue'. Extending and countering Saussure's approach, he states that cinema is parole from the outset, or even more, discours. It is not a system of rules but always already realized or actualized - in the pragmatic sense of speech acts and in the formalist sense of renewal and displacement. ${ }^{107}$ The notion of a cinematic language is thus to be understood in the 'figurative sense', as a language of art - though at least in Language and Cinema, Metz is more interested in the language and the construction of meaning than in the aesthetic approach: 'if the cinema is an art it is equally a discourse'. Thus, Lefebvre speaks of Metz's notion of a 'logomorphic art'. ${ }^{108}$ In other words, at the level of the film - of each individual film - one can detect a system of combinations of codes, specifically cinematic as well as non-specific codes. Yet these are not the product of a finite rule-system but rather the expression of variable, evolving conventions. As Metz explains: 'The proper task of the filmic system is to modify the codes that it integrates. ${ }^{109}$ This shift implies a questioning and extension of the linguistic premises. In doing this from the beginning, Metz discards not only the Saussurian concept of language (langue) for the study of cinema but also notions such as the 'sign', replacing these linguistic terms with semiological ones such as 'code', 'message', 'text', 'system', 'discourse' - terms that are valid in all signifying systems. ${ }^{110}$ These signifying systems he treats as complex semiological forms of organization, which must be constituted as theoretical objects through media-specific characteristics or codes. All these shifts and dynamizations push the boundaries of the rigid 'structuralist theoretical stance', as Casetti points out. ${ }^{11}$

106 Rosen [in this volume]. On the cinematic sign as 'non-arbitrary' (in contrast to verbal language) but 'motivated', see Metz, 'The Cinema: Language or Language System', p. 59 and 61-67; Metz, 'Problems of Denotation', pp. 108-10; and Metz, 'The Perceived and the Named', p. 59. In Language and Cinema, Metz returns to a discussion of the 'sign' and eventually dismisses the term entirely for his approach: pp. 193-94, 204-7, 286-88. See also Kirsten [in this volume].

107 Christian Metz, 'Montage et discours dans le film' [1967], in Essais, II, 89-96 (p. 93). On actualization and partial renewal, see Metz, 'Propositions méthodologiques', p. 106. On the level of the signifiers and their 'recurring arrangements', see Bellour and Metz, 'Entretien', p. 196. 108 Lefebvre [in this volume], with reference to the quotations above, Metz, Language and Cinema, p. 11 and 38 .

109 Metz, Language and Cinema, p. 106.

110 See Rosen [in this volume]; see, for instance, Metz, 'Problèmes actuels de théorie du cinéma', p. 83; Christian Metz, 'Les sémiotiques. A propos des travaux de Louis Hjelmslev et d'André Martinet' [1965]; including 'Postface 1977', in Essais sémiotiques, 9-24 and 25-30 (p. 29).

111 Casetti, Theories of Cinema, p. 144. 
Thus, transferring the meta-language of theory from linguistics to cinema also requires a new terminology. For Metz, however, this vocabulary doesn't need to be invented; rather he works through the existing concepts and terms of linguistics - and later of psychoanalysis - with great care and precision in order to adapt them to the new 'object' of cinema and to integrate them into a comprehensive semiological conception. ${ }^{112}$ But even the most comprehensive ('optimistic') structuralist project of the time, which finds its clearest and strictest expression in Language and Cinema and which aims at a 'general semiology', can only be attained through such assimilations, distinctions, and adaptations of the tools with regard to the objects of study and their material of expression (including their phenomenological character). Although a 'semiological interference' between language and media can be observed, and there are various ways of transferring codes between media-specific materials of expression (to which the codes adapt and thus change), it is illusory for Metz to establish a common terminology for all semiological research. ${ }^{113}$ It cannot be a matter of claiming the transferability of codes à l'identique, because the relations between forms and materials from one signifying system to another or from one medium to another are subject to manifold technical-sensory variations. ${ }^{114}$ Thus, we can only agree with Rosen when he writes: 'Consequently, it appears that for the early Metz, even a general semiotic theory must pass through specificities.' Metz qualifies this position later in Language and Cinema, regarding specificity 'as a practice of signification more aligned with one medium than another but not necessarily exclusive to it', stating that 'mixtures and hybridities of media and aesthetic forms are constitutive of film history' as well as of cinematic language from a synchronic perspective. ${ }^{115}$ From this viewpoint, it seems logical that the technological aspect of film as a medium - and thus also the analogy of the cinematic image - fades from the spotlight, and that the analogy itself is described as coded. ${ }^{116}$ The ontological question is

112 See, for instance, Metz, 'Les sémiotiques', pp. 21-24.

113 On the dynamics of 'semiological interferences' and the forms of 'transposition', see Language and Cinema, pp. 214-16; on the translatability between perception and (verbal) language, see 'The Perceived and the Named', pp. 61-64, especially 62. See also Chateau and Lefebvre, 'Dance and the Fetish', p. 113, and Rosen's essay in this volume.

114 See Metz, 'Les sémiotiques', p. 28, or Metz, Language and Cinema, p. 223.

115 Rosen [in this volume]. However, as early as 1967 , Metz writes that there are only varying 'degrees of specificity': Metz, 'Propositions méthodologiques', p. 105 and footnote **.

116 Thus a development can be traced by looking at the concept of analogy as it changes from the early text 'On the Impression of Reality in the Cinema' [1965], pp. 3-15 to 'Au-delà de l'analogie, l'image' [1970], pp. 151-62, or Language and Cinéma [1971], p. 228. However, there are different 
pushed aside (though never completely obliterated) by the methodological and epistemological one. ${ }^{117}$

And yet the project of a general semiology as a long-term goal never leads to a conceptual machine of equalization. Each language (langage) must be characterized through a plurality of specific and non-specific codes so that each form of expression or each medium contains an 'overlapping of specificities', and the complex combination of codes in the 'textual system' of each film is unique. ${ }^{18}$ Because Metz approaches film - as well as other dynamics of meaning-making - by way of the signifier, the intelligible codes remain tied to the distinctive features of the audiovisual form of expression and thus linked to the 'physical realization of the signifier', the 'work of the form in the material.' ${ }^{119}$ This, in turn, means that the theorist Metz never loses touch with the perceptible surface of the film image, which - due to the absence of an actual physical substance at the level of the films - develops the imaginary qualities of an immaterial 'body'. ${ }^{120}$

While Metz dedicates himself to the relationship between cinema and verbal language (langue/langage) in the first semio-linguistic phase of his works, there is always this 'remainder' of the everyday film experience. The phenomenological aspects of the cinematic signifier (such as the analogy of the cinematic image and the image's impression of reality, which escape structural linguistic analysis in his early writings) are gradually subjected to the scholarly examination of textual and cultural codification. Yet Metz never dismisses the reality of the films, their production and reception, their aesthetics or history. They reach him as an individual passionate moviegoer, as a cinephile, but also as a scholar who leaves his subjective traces in the enunciation of his writing (écriture), as Dana Polan, Alain Boillat, and Dominique Bluher show in this volume. Films as social practice and historical development and cinema as an anthropological institution also find their way into his thinking, either on the edges or as a basic frame

levels of analogy; see Jacques Aumont, The Image, trans. by Claire Pajackowska (London: BFI, 1997 [1990]), pp. 154-55; see also Vernet and Rosen [both in this volume].

117 See Casetti, Theories of Cinema, p. 14, 91. Several authors in the present volume also explicitly address this conceptual shift in Metz's works (which was and remains a conflict); see the essays by Doane, Lefebvre, Rodowick, Rosen, and Vernet.

118 Metz, Langage and cinema, p. 234 (translation modified); see Metz, 'Problèmes méthodologiques', p. 106.

119 Metz, Language and Cinema, p. 234; here, he addresses specificity 'as a notion which is at the same time material and systematic' (emphasis in original; translation modified), and p. 253 (translation modified).

120 In Blüher and Tröhler, 'Interview with Christian Metz' [in this volume]; on cinema as fetish, see also his interview with Vernet and Percheron, 'Sur mon travail', pp. 176-77. 
of reference. ${ }^{121}$ Or, as Odin puts it: 'Metz never separates theory from life', not even in the most consistently structuralist phase of Language and Cinema (1971). ${ }^{122}$ Even in the theoretical and analytical description of the cinematic image - 'as composed of "purely relational unities"', Metz continues to reflect on the conditions of the possibility of perception. ${ }^{123}$ Thus, Vernet claims that, for Metz, 'semiotics must treat both what comes before analogy (what constitutes it or what it is founded upon) and beyond analogy (what supplements it; it is clear that here he reinitiates reflection around denotation and connotation), with respect to all of the diverse systems that come to inform the image'. ${ }^{124}$ In 'The Imaginary Signifier' (1975) and 'The Imaginary Referent' (1977), this 'remainder' increasingly resurfaces - as revealed by the essay titles - in the spectator's imaginary relationship to the screen. In his meta-psychological studies, Metz grounds this imaginary relationship in the 'absent' materiality of the cinematic signifier (consisting of light and shadow), which nevertheless causes 'the spectator's strong sensation of reality' ${ }^{125}$ As Metz himself writes: 'the quasi-real that the film presents is always considered as imaginary by the spectator. ${ }^{126}$

But not only is it impossible to 'separate theory from life', the reverse is also true for the study of cinema because 'without the [theoretical] machine, we are certain to see nothing' - at least nothing new and nothing that would allow us to see the object of study from varying, ever-new perspectives. ${ }^{127}$ Thus, Metz also says of research that it is 'a work that makes you schizophrenic, that needs to be maintained against everyday life'. ${ }^{128}$ Nevertheless - or precisely because of this: 'Le cinéma et...' is the engine of the theoretical machine, which Metz is so enthusiastic about, also as a dynamic of thought. ${ }^{129}$

121 See, for instance, the first pages of Language and Cinema.

122 Odin, 'Christian Metz et la linguistique', p. 98.

123 Vernet [in this volume]. Here, the author refers to Metz, 'Au-delà de l'analogie', p. 156. On the conditions of possibility of perception, see also Christian Metz, 'Le perçu et le nommé' [1975], in Essais sémiotiques, pp. 159-60; unfortunately, the final section entitled 'Sémiologie et phénoménologie' has been omitted in the English translation of 'The Perceived and the Named', between p. 66 and 67 .

124 Here, Vernet [in this volume] refers to Christian Metz, 'La connotation, de nouveau' [1971], in Essais, II, pp. 161-72 (p. 163).

125 Vernet [in this volume].

126 Metz, 'Problèmes actuels de la théorie du cinéma', p. 43, note 22; see also his interview, 'Réponses à Hors cadre', pp. 66-69.

127 Metz in his interview with Vernet and Percheron, 'Sur mon travail', p. 185; see also the comment by Odin, 'Christian Metz et la linguistique', p. 99.

128 Metz, 'Sur mon travail', p. 179 (emphasis in original).

129 Metz, 'Sur mon travail', p. 177; see also Blüher and Tröhler, 'Interview with Christian Metz' [in this volume]. 


\section{Method - Methodology}

I would now like to switch perspectives once more. By explicitly addressing Metz's method and methodology, I will approach theory as practice, as a reflection of the working and thinking process, and link this with Metz's scholarly attitude.

When Metz chooses his theoretical methods for approaching cinema based on the theories' 'resilience' (according to Odin), this choice cannot be reduced to a polemical 'Le cinéma contre...'. The method of interrelating requires that an approach, once chosen, be thought through completely, that the theorist immerse himself deeply in this process of 'relationship building'. Thus, the fundamental exteriority becomes an interiority in a second phase, although the reflection at the meta-level is never abandoned. ${ }^{130}$ When the goal is to coherently and consistently pursue a position - chosen for a limited time and for a specific task - as a principle of theoretical and analytical distinctiveness, then the object of study must be distinguished from the method, as Metz points out: the 'cinematic phenomenon' is vast and diverse, and a variety of perspectives and disciplines can yield valuable knowledge about this object of study. Thus, the semiology of film can draw on psychology, sociology, aesthetics, or history. But regarding the methods, Metz speaks of 'the sole division of labor within the study of film' in Language and Cinema, because 'methods are things which cannot be interchanged (and which cannot be "combined" without great danger of giving rise to monstrosities)'. This view is in line with the 'rigour' mentioned earlier and with the chosen method's 'principle of relevance' regarding the object of study. In a later phase, these methods could be joined in 'a true, not syncretic synthesis' (in the spirit of the period, which envisioned a general semiology). In this synthesis, different approaches would illuminate different aspects of the cinematic object - aspects that are related but that nevertheless must recognize their own limits. However, for the time being, a 'necessary methodological pluralism' is in order, as Metz explains in the first, methodological chapter of Language and Cinema. ${ }^{3{ }^{1}}$

130 See also Andrew, Major Film Theories, p. 215: according to Andrew, earlier theorists 'saw their writing as the fluid development of a total view of the art. [...] Metz, however, has reversed the order of labor, beginning with particular problems and searching only later for the potentially unifying relations between the problems'.

131 All quotes in this paragraph are taken from Metz, Language and Cinema, pp. 17-21. Later, Metz commented rather sceptically on the interdisciplinary exchange at which this methodological pluralism aimed, because it would only be possible among specialists from various disciplines who reflect their epistemological and methodological premises; see the three interviews Metz, 
Thus, semiology - even as a general semiology - is by no means allencompassing. But it should aim to grasp film as 'a total signifying-object' and as 'a general study of cultural configurations and logic'. ${ }^{132}$ It deals with the form of films as 'textual systems' (the form of expression and the form of content, in Hjelmslev's terms). ${ }^{133}$ When Metz chooses linguistics to approach his object of study in this first phase, this is also a matter of dealing with linguistics as a method. Although, like Saussure, he sees linguistics only as a subdiscipline of a general semiology, the young discipline of semiology must take linguistics as its starting point because linguistic research has dealt with language (langage) more deeply than any other discipline. Linguistics provides concepts that film semiology - or 'the "filmolinguistic" venture', as Metz initially also calls his approach - can work with. ${ }^{134}$ The first process of a 'negative definition', where Metz confronts the notions of linguistics by aiming to describe cinematic language and emphasizing the differences from verbal language as disjunctures, can be combined with a second, 'positive' process, which draws on the methods of linguistics. ${ }^{135}$ These methods are then questioned with regard to their suitability and usefulness and tested for their 'resilience' (Odin). Or, as Metz himself often emphasizes, for instance in the interview with the trio Lagny, Ropars, and Sorlin from Hors cadre: 'I haven't applied anything, I've just presented cinema in the light of more comprehensive notions $[\ldots] .^{13^{13}}$

Such a stance requires constant self-reflection of one's own activity. ${ }^{137}$ And it requires a thorough examination of the current international state of research in linguistics - not just structural linguistics (Saussure, Martinet, Hjelmslev, Jakobson) but also generative linguistics (Noam Chomsky, Nicolas Ruwet) and pragmatics (Charles W. Morris) - as well as in anthropology

'Réponses à Hors cadre', p. 62; and Marie and Vernet, 'Entretien', pp. 277-78, and Blüher and Tröhler, 'Interview with Christian Metz' [in this volume].

132 Metz, Language and Cinema, p. 19 (emphasis in original).

133 See Louis Hjelmslev, Prolegomena to a Theory of Language, trans. by Francis J. Whitfield (Madison: University of Wisconsin Press, 1953; rev. Engl. ed. 1961 [1943]), especially Chapter 22. 134 See, for instance, Bellour and Metz, 'Entretien', pp. 195-200. In turn, linguistics can also profit from semiology on its way to a general semiology (p. 197).

135 See Metz, 'Some Points in the Semiotics of Cinema' [1966], in Film Language, p. 107; and Bellour and Metz, 'Entretien', pp. 197-98.

136 Metz, 'Réponses à Hors cadre', p. 62.

137 This is not only evident from the explicit passages in all his texts but also from the many interviews he gave in the course of his life, which belong to his works as paratexts, as well as from the many forewords and afterwords in revised editions of his books, or the self-critical footnotes he added to reprints of his essays. See Conversations with Christian Metz: Selected Interviews on Film Theory (1970-1997), ed. by Warren Buckland and Daniel Fairfax (Amsterdam: Amsterdam University Press, 2017). 
(Lévi-Strauss) and, of course, in the emerging field of cultural and literary semiology (Barthes), graphic semiology (Jacques Bertin), etc. ${ }^{1{ }^{8}}$ Later, in the fields of psychoanalysis and enunciation, Metz adds an equally meticulous examination of concepts from Freud, Lacan, and Klein, and from Benveniste, Hamburger, and Bettetini. This contrastive approach to film/ cinema is even more evident in Metz's (meta-)theoretical perspective. In addition to the classical film theorists and filmologists mentioned before, he also examines the first parallel attempts at film semiology (Umberto Eco, Pier Paolo Pasolini, Emilio Garroni) or the diverse perspectives on the theory and analysis of film (Bellour). ${ }^{139}$ Thus, methodological reflection is a fundamental principle of Metz's work, which aims 'to look at the semiological endeavour as an open research, permitting the study of new forms'. ${ }^{140}$

In this first semio-linguistic phase, Metz's focus shifts from the individual cinematic image (which cannot be equated with the 'sign', nor does it contain any signs) to the syntagmatic ordering of images, to 'transphrastic' units, and the plurality of codes. In a next step, the idea of a structure is replaced by that of a dynamic textual system and of 'writing' (écriture). ${ }^{141}$ The two methodological steps of positive and negative description run parallel (that is, in the sense of a 'shifting dominant' in Jakobson's terms). ${ }^{142}$

\section{Commutation - Comparative Method - Systematics of Analogical Thinking}

An important method that Metz borrows from linguistics is commutation. It pervades all of his works as a movement of thought (sometimes in modified form) and shapes his scholarly attitude. This method, which is more than just a tool, is exemplary of the two fundamental positions that supplement each other throughout Metz's work, allowing him to approach the cinematic

138 This list of names is not meant to be exhaustive. See also Odin, 'Christian Metz et la linguistique', pp. 90-91.

139 E.g. Metz, Language and Cinema, pp. 70-90 and 91-120. See also Bellour and Metz, 'Entretien', pp. 209-10, 215-18; and Bellour's essay with the self-explanatory title 'Two Ways of Thinking' in this volume.

140 Metz, 'The Cinema: Language or Language System?', p. 89; and Bellour and Metz, 'Entretien', pp. 196-97. See also Rodowick, 'A Care for the Claims of Theory', pp. 199-200; and Rosen [in this volume].

141 Metz, Language and Cinema, especially pp. 254-84, as well as the Conclusion, pp. $285-88$. See also Casetti, Theories of Cinema, p. 144. I will return to this concept below.

142 Roman Jakobson, 'The Dominant' [1935/1971], trans. by Herbert Eagle, in Selected Writings, III (1981), pp. $75^{1-56 .}$ 
object in a complementary way. As a method of structural linguistics, commutation shapes his early works on the construction of meaning in film. In the modified - but no less systematic - form of a comparative method, it pervades his examination of cinema in comparison with the other arts and his view of the history of theory. If the first method seems to confirm a strictly structuralist approach, the second definitely goes beyond the structuralist framework.

Commutation as an operational, heuristic method of structural linguistics is characterized by omission and addition, exchange, and replacement of linguistic units within a defined corpus (it also serves as an elementary method for describing transformative processes in generative linguistics, especially in glossematics). Intuitively recognized regularities at the level of expression thus become objectifiable, allowing for an examination of the changes at the level of content. Through this linking of form and content, the relevant characteristics are determined as invariants, which indicate shifts in meaning. ${ }^{143}$ In Metz's works, this commutative method guides, for instance, the systematic examination of codes in the Grand Syntagmatique by means of segmentation and classification. The method serves to identify the 'distinctive units' and 'autonomous segments' and to distinguish the alternatives in their combination within a sequence of images. With this process, Metz is not so much interested in the semantic level, in the result, but more in the construction of meaning, the filmic-enunciative process of textual meaning-making. ${ }^{144}$ Thus, 'the filmic orderings that are codified and significant [...] organize not only filmic connotation, but also and primarily, denotation'. They also allow us to understand how films, on the basis of the photographic image, 'transform the world into discourse'. ${ }^{145}$

On several occasions, Metz accurately and critically deals with determining and naming the units that guide the activities of commutation (segmentation and substitution) while also addressing the taxonomy and the adaptation of these methods to film. ${ }^{146} \mathrm{He}$ even exhibits a kind of obsession when it comes to hierarchically organizing the units obtained through découpage (e.g. the segments of the Grand Syntagmatique) or the

143 See especially Hjelmslev, Prolegomena, Chapter 14.

144 Metz, 'Problems of Denotation', pp. 119-24, and Language and Cinema, pp. 170-73.

145 Metz, 'Problems of Denotation', p. 117 (emphasis in original) and 115.

146 See, for instance, Metz, 'The Cinema: Language or Language System?', pp. 69-70; Christian Metz, 'La connotation, de nouveau', p. 171; Metz, 'The Perceived and the Named', pp. 56-57; or Language and Cinema, pp. 28-29 and 165-66. Metz critically deals with the taxonomy of generative linguistics in his essay 'Sémiologie audio-visuelle et linguistique générative' (in Essais sémiotiques, pp. 110-28; incl. Postface 1977). 
constructed systematic entities (e.g. the codes), all of which he attempts to assign to different levels and processes. ${ }^{147}$ However, he further notes the inevitable circularity of paradigmatics and syntagmatics, which results whenever the focus on categories and structures is relinquished in favour of the functioning of these processes in the textual system. ${ }^{148}$ For Metz's 'taxonomic rage' is not limited to typologizing and classifying. ${ }^{149}$ Ultimately, his aim is not just to describe the individual elements and characteristics of the cinematic signifier but to determine their performative function in the dynamic audiovisual processes of meaning, a function that is always polysemous and multifarious. His main interest is the theoretical-logical description of the filmic system, of the 'architecture justifying the film's existence', as Casetti writes (Metz distinguishes this description from the analysis of a specific film's codes in action). ${ }^{150}$ In the course of this, perspectives and levels keep changing constantly. Thus, even in Language and Cinema, Metz guides his readers from strict commutation to a dynamic organization of the individual elements by way of ever-changing perspectives and an increasing complexity of his method. When Vernet and Percheron compare this work to a 'machine à la Tinguely', this could mean that the 'model' fabricated by Metz is completely self-referential and self-sufficient. But it could also mean that it already goes beyond the structuralist machine because the components identified at the structural level are never arrested in their complex interaction, distribution, and combination within the textual system. ${ }^{151}$ Film is not grammar, film is art - this insight underlies Metz's conception of his theoretical object, far beyond this book.

Thus, the method of commutation is not limited to the issues inspired by linguistics. As an extended method of differentiation, it also characterizes Metz's methodology when it comes to discussing terminology. Remember, for instance, the distinction between signifier and signified, which

147 In the sense of a Hjelmslevian 'hiérarchie des sections' of a language, with the sections in turn belonging to interrelated categories, see Metz, 'Les sémiotiques', p. 20.

148 Metz, Language and Cinema, pp. 127-30, especially 128; see also Casetti, Theories of Cinema, pp. 142-49, and Casetti [in this volume].

149 The term 'taxonomic rage' comes from Odin, 'Christian Metz et la linguistique', p. 9o. See also Gauthier, who writes with respect to the structuralist approach in general: 'this period in love with growth - which was believed to be unlimited - convinced that a new civilization based on the American model would flourish, was remarkably consistent in privileging a fanatical scientificity, a mastery through numbers, a faith in abstraction, all of which reflected the only order that could be set against the disorder of the world - that of the spirit.' Gauthier, 'La flambée structuraliste', p. 106 (my emphasis).

150 Casetti, Theories of Cinema, p. 144.

151 Metz, 'Sur mon travail', p. 190. 
he confronts with Hjelmslev's conceptual pairs of 'form'/'material' and 'expression'/'content'. Here, both signifier and signified are assigned a level of form and of material, of expression and of content. This is a debate he often returns to, especially in his semio-linguistic or filmo-semiological phase. ${ }^{15^{2}}$ Or think of the semio-psychoanalytical reflection about the rhetorical figures of metaphor and metonymy: Metz unfolds these across the syntagmatic and paradigmatic textual dimensions, associating them with the mental processes of condensation and displacement (but without equating them). ${ }^{153}$ This differentiating approach never lapses into the simple binarism that is inherent to the strict structuralist activity and which Metz was sometimes accused of. Instead, his aim is a descriptive, flexible, neverending differentiation in the sense of correlating, of surveying parallels and fundamental differences - not a strict definition, which ties down a concept or a relationship between concepts.

This is also true of Metz's second, complementary focus in his endeavours to grasp his object as completely as possible from within and without. This focus concerns the artistic forms of expression or 'languages' (langages), which - in a comparative method - appear as 'a complex blend articulated through resemblances and differences'. ${ }^{154}$ Apart from the comparison between verbal language and cinema, this also means the interrelating of cinema's traits and of its manners of functioning with other languages (as the comprehensive filmological project had already envisioned). Once again, we note Metz's concern with advancing the formalization of his approach to the object as far as possible; a concern that is nevertheless faced with a more open conception from the beginning:

The task would consist in establishing the distinctive traits of the signifier's material through the commutation of languages (langages) among each other. This would mean playing Hjelmslev off against himself (since

152 See, for instance, Metz, 'Propositions méthodologiques', pp. 97-110 (essay from 1967); Christian Metz, 'The Saying and the Said' [1968], in Film Language, 235-52 (pp. 242-44); in the course of his discussion of Hjelmslev's concepts, Metz reduces the three notions of material, substance, and form to two - subsuming substance under material - and relates them to the level of expression (signifier) and the level of content (signified) of film; Metz, Language and Cinema, especially pp. 208-11 and 251-53. On Metz's discussion of Hjelmslev's concepts, see also Margrit Tröhler, Offene Welten ohne Helden: Plurale Figurenkonstellationen im Film (Marburg: Schüren, 2007), pp. 169-76.

153 As mentioned above, for this connection between rhetoric, linguistic semiotics, and psychoanalysis, Metz notably refers to the respective works of Jakobson, Freud, and Lacan; Metz, 'The Imaginary Referent', especially pp. 197-206, 235-44, 266-92.

154 Metz, in the 'Postface 1977' to the essay 'Les sémiotiques', pp. 26-27 (emphasis in original). 
to him, a material trait cannot be distinctive, nor vice versa). It would also mean to let each language reappear at the end, that is, each entity that normally passes for a language in the sense of a socially confirmed starting point. Language would thus be taken as the ultimate combination (= the endpoint) of a certain number of specific traits of socialized sensory perception. ${ }^{155}$

Thus, like the semiological interferences between languages and media (in which Metz is more interested in Language and Cinema), the specific traits of a language' are coupled with their respective expressive materials. These traits influence the forms of expression and content that a language can develop in the course of constructing meaning. But in order to compare the use of these forms and to distinguish the languages from each other, the semiologist must be guided by social and sensory perception and experience, which form the starting point and endpoint of his examination..$^{56}$

This comparative method, which is related to the structuralist method of commutation, does not result in a taxonomy, neither with regard to languages nor regarding the confrontation between the arts. Beginning with 'The Cinema: Language or Language System?' (1964), and especially with 'On the Impression of Reality in the Cinema' (1965), Metz takes up the traditional comparative approach, which has characterized film-theoretical reflection from the beginning (as a continuation of debates in art theory). However, he is not interested in continuing the 'paragon discourse', the 'competition of the arts' from art theory; nor does he want to pursue the debate on cinema as a legitimate art as it was discussed in classical film theory up to Bazin, Laffay, and even Mitry. ${ }^{157}$ In the classical 'ontological theories', this was a normative debate, which aimed at determining the essence of film (that which constitutes cinema as such). In the paradigm of 'methodological theories' (which begins after World War II but, according to Casetti, only becomes established as a 'break' through Metz), what counts are the viewpoint and the method with which research confronts its object: 'As a result, it underscores what is pertinent rather than what is

155 Metz uses the conditional here because this work had not been done up to that point; Metz, 'Sémiologie audio-visuelle', p. 115 (emphasis in original). With his notion of 'distinctive traits' (traits pertinents), Metz refers to the functionalist linguist André Martinet; see also Language and Cinema, p. 24. About Metz's somewhat paradoxical reference to both Hjelmslev and Martinet, see Odin, 'Christian Metz et la linguistique', p. 93.

156 Metz, 'Sémiologie audio-visuelle', pp. 115-17.

157 See, for instance, the discussion of various positions regarding the comparison between film/cinema and theatre in Metz, 'Problèmes actuels de théorie du cinéma', pp. 66-70. 
essential. ${ }^{15^{8}}$ The aim is to describe the set of possibilities in cinema from a certain viewpoint, one that also consciously reflects its own boundaries. The cinematic specificities are distinctive traits that can be described by means of commutation, as Rosen also argues. ${ }^{159}$ Nevertheless, through these traits, the processes of meaning remain tied to the phenomenal surface, to the material and artistic expression. To emphasize this once again: although Metz's chosen perspective is characterized by linguistic methods, he also - or even predominantly - sees cinema as a language of art'.

Thus, the analogical method of comparison and correlation between the specificities of various arts and media - between film, photography, painting, literature, music, radio play, television, video, etc. - appears as a complement to commutation, its 'softer' counterpart. In fact, this method has its own systematics, but it ultimately follows similar thought patterns. Once again, Metz proceeds from a nuanced negative description - film does not function like verbal language, it is different from literature, theatre, painting, or photography - to arrive at a positive description. He includes a discussion of the 'tools' in this comparative process when reflecting on his own viewpoint at the synchronous level. Similarly, the comparative approach also enters into his historical-epistemological discussion of classical film theory. He doesn't simply subsume the earlier approaches under a general paradigm. Instead, he considers their insights and diverse perspectives in terms of their premises and juxtaposes them pointedly with regard to specific cinematic configurations.

As mentioned before, this interest in the history of film theory pervades all phases of Metz's work. It begins with his examination of the language-metaphor - especially Eisenstein's 'ciné-langue' - in 'The Cinema: Language or Language System?' ${ }^{160}$ Another early example is the study on 'punctuation and demarcation in the fiction film' (1972) about the transitions between sequences. Through a detailed analysis of the aesthetic positions of Béla Balázs, Rudolf Arnheim, Marcel Martin, and Jean Mitry, Metz concludes that transitional moments in the narrative filmic discourse always simultaneously mark connection and separation (though with varying emphasis), thus giving the film its rhythm. ${ }^{161}$ Another example

158 Casetti, Theories of Cinema, p. 15; see also 89-91.

159 See Rosen's essay in this volume.

160 Metz, 'The Cinema: Language or Language System?', pp. 56-59; see also his 'Montage et discours', pp. 91-94. On the language-metaphor as a trigger for the history of theory, see Bellour and Metz, 'Entretien', pp. 195-96 and Rodowick, 'A Care for the Claims of Theory', pp. 189-98. 161 Christian Metz, 'Ponctuations et démarcations dans le film de diégèse' [1971], in Essais, II, pp. 111-37. 
(from his final work, L'énonciation impersonelle ou le site du film) is the comparison between various objects of study and theoretical approaches, especially with respect to literature and literary theory (but also film theory), when it comes to establishing the impersonal source of the enunciative process. Here, he distances himself from Genette's position, who fundamentally argues against the existence of an enunciative process in the medium of film. Instead, Metz draws on Cohen-Séat's 'logomorphism' of the cinema-machine and on Laffay's 'structure without images' of 'the great image-maker' (le grand imagier).$^{162}$ Although the enunciative process in literature is equally abstract and non-anthropomorphic for Metz, its material of expression is nevertheless tied to language, which is a means of expression connected to the notion of what is human. By contrast, Metz argues, the cinema-machine generates a non-linguistic, audiovisual enunciation and narration. ${ }^{163}$

The comparative approach - whether employed as commutative method or as analogical systematics - encompasses all levels of analysis: Metz is interested in the various 'languages' and arts, in structures and codes, in textual processes, in the forms and materials of expression with their dynamics and their various media dispositifs. Film and cinema are the centre of attention, and, even at the scholarly level, Metz never loses 'contact' with them. Based on the 'theoretical possibilities in the sense of logical considerations', he approaches film as a 'corpus' but also as a 'body' that he loves. ${ }^{164}$ On the one hand, he examines those potentials of the 'cinematic language' that can claim transhistorical validity. On the other hand, he looks at the possible deployment of this language in the 'textual system' of specific films or ensembles of films - with regard to a historical context or a (classical vs. modern) paradigm of film history. ${ }^{165}$ Again and again, Metz also deals with the relationship between convention and style (in the sense of a specific, individual expression, a deviation from the norm). ${ }^{166}$ Although his primary interest in all these questions finds expression at a

162 Metz, L'énonciation, p. 12, 182-83, and 193-94. Gilbert Cohen-Séat, Essai sur les principes d'une philosophie du cinéma I: Introduction générale (Paris: PUF 1946), pp. 120-28; Albert Laffay, Logique du cinema. Création et spectacle (Paris: Masson), p. 71, 80-83. On Laffay's concept of the 'great image-maker' and Metz's reading of it, see François Jost, 'La sémiologie du cinema et ses modèles', Iris, 10 (1990), pp. 133-41.

163 Metz, L'énonciation, p. 195, 208.

164 Blüher and Tröhler, 'Interview with Christian Metz' [in this volume].

165 About these two poles of Metz's theoretical thinking, see especially the final section of Casetti's essay in this volume.

166 See, for instance, Metz, Language and Cinema, pp. 267-68, or L'énonciation, pp. 154-59. See also Lefebvre [in this volume]. 
theoretical-logical level ('I'm an abstract person, I think in concepts'), he always explicitly announces a change in perspective, comparing approaches and marking transitions to a specific and unique level. Metz seldom dedicated himself to the analysis of a single film ('If I start with a specific film, I'm paralyzed.') ${ }^{167}$ But in addition to the possibilities of the codes, even in Language and Cinema, his attention always also belongs to the aesthetic 'figures' and 'enunciative configurations', which mobilize all 'five matters of cinematic expression' ${ }^{168}$ And when he examines the interaction of meaning-making and narration, he never forgets that cinematic images have an expressive and enunciative presence, and that they can only narrate by means of the film's performance, the dynamics of images and sounds. ${ }^{169}$ As Anne Goliot-Lété emphasizes in her contribution to this volume, even filmic narrativity 'causes a sensation' for Metz. Thus, he also includes the 'orientation' of images and sounds, that is, the film's address of its potential spectators - as targets of filmic enunciation or as imaginary correspondents, as psychic apparatus, as metapsychological field of study. ${ }^{170}$ Heuristically, for Metz, the spectator is not 'the person going to the cinema in their concrete totality, but only the part of them that goes to the cinema. ${ }^{171}$ Yet on the edges of Metz's 'model', the spectators are always kept in mind as social subjects, as historical audience, as sensually receptive bodies (I will return to this shortly).

A last step in the analogical move that pervades Metz's view of theory as practice concerns his notion of writing (écriture) at various levels. Take, for instance, the following statement about filmic writing, from the conclusion of Language and Cinema: 'Writing is neither a code nor a set of codes, but a working of these codes, by means of them and against them, a work whose temporarily "arrested" result is the text, i.e. the film.' This statement concerning the levels and processes of the object of study also applies to his own work, that is, his construction of the object, his reflection on this construction, and the relationship between his complementary theoretical perspectives. While he focuses on analyzing the codes, his 'model' of the cinematic language ('the set of codes and subcodes') is repeatedly adjusted

167 In Blüher and Tröhler, 'Interview with Christian Metz' [in this volume].

168 See the connection of enunciative configurations with numerous film examples in L'énonciation, and Dana Polan's essay in this volume.

169 Metz, 'On the Impression of Reality', pp. 4-12; 'The Cinema: Language or Language System?', pp. 67-69 and 75-84, or L'énonciation, p. 22.

170 Metz, Lénonciation, especially Chapters I and III; and The Imaginary Signifier, especially Parts I and III.

171 Metz in the interview with Vernet and Percheron, 'Sur mon travail', p. 189. 
through his view of performative filmic writing ('the set of textual systems'). ${ }^{172}$ What's more, this understanding of writing also characterizes his scholarly stance towards his own theoretical edifice and his own activity, that is, the writing of his texts, both of which he considers as only temporarily 'arrested'.

In his address to his readers, the writing corresponds to the 'code of communication and of knowledge, within which Metz situates his work'. But what characterizes Metz as a 'founder of a discursive practice' is the style, as Bellour writes (here, Bellour comments on Barthes' text about Metz; see also the quote at the beginning of this essay). What finds expression in the style is not just the radical insistence on clarity and precision, which Metz demands of himself, but also 'the subject's very voice' (Barthes): 'It is the style taking possession of writing', as Bellour states. Metz's complete dedication to his task - with regard to the issues of theory and cinema - also testifies to his communicativeness, generosity, and openness, which are characteristic of the way he addresses his listeners and readers. ${ }^{173}$

As mentioned, this openness is also of a conceptual kind. It manifests itself in Metz's writing with respect to the historical position of the writer, the theorist, and the cinephile. It also shapes his perspective on cinema as a cultural phenomenon, as anthropological entity, and as a realm of experience.

\section{On the Edges of the 'Model'}

Many of the authors in this volume have (here and elsewhere) pointed out Metz's conceptual openness and his momentary but repeated transgression of the structuralist framework. This is part of what makes Metz's work so colourful and, despite all his rigour, so communicative and human. It is also what makes the aspect of style so pervasive in its relationship to writing, as a politics and ethics ofform (in the sense of Barthes in Writing Degree Zero). ${ }^{174}$

To conclude this introduction and to once again venture a change of perspective, I would now like to address the subtitle of the present

172 Metz, Language and Cinema, pp. 285-86. See also Metz, 'Sur mon travail', p. 190.

173 Bellour, 'Le cinéma et ...', p. 20; Barthes, 'To Learn and to Teach', p. 176.

174 Roland Barthes, Writing Degree Zero, trans. by Annette Lavers and others (New York: Hill and Wang, 1968 [1953]). Except for the already quoted passages on the relationship between writing and the codes, this attitude is especially explicit in Metz, 'The Saying and the Said', as well as in the only recently published manuscript: Christian Metz, 'Existe-t-il une approche sémiologique de l'esthétique?', 1895. Revue d'Histoire du cinema, 70 (2013), pp. 154-67 (published and presented by Martin Lefebvre). 
volume, Film Semiology and Beyond. The phrase alludes to all the ways in which the semiological concepts have been extended and transcended, both by Metz himself - who transgressed his 'model' in order to address the conscious perception of film and cinema - and by others. I'm going to outline these transgressions from three angles: phenomenology and aesthetics, diachrony and historicity, and Metz's conception of the subject and spectator.

As the model's 'exterior', the components of art, culture, and the imaginary always resonate on the edges of Metz's intellectual edifice. They precede theory, not as side issues but as a basic condition or foundation of the 'cinematic institution' that Metz is interested in.

Once again, the essays in this volume provide the reference points for the following remarks. Several authors have meticulously explored some of the three above-mentioned aspects with respect to certain periods or issues. I'm not going to summarize the results of their analyses here (see the abstracts preceding the essays). Instead, I will conclude this introduction by approaching the three aspects from a more general point of view. Elmar Holenstein's reflections on Jakobson's 'phenomenological structuralism' will serve as my point of departure. This is not the place to go into great detail about the intellectual kinship (or the differences) between the two semioticians, who were an entire generation apart. Nor do I want to demonstrate a direct influence of Jakobson on Metz (although Metz frequently refers to the Russian semiotician, who was a co-founder of the Prague Linguistic Circle in 1926). Rather, I suggest that there is a kinship in the two scholars' thinking. This kinship allows us to see Metz's work from yet another point of view. ${ }^{175}$ There are, for instance, similarities in how the two deal with the structuralist premises and with Saussure's legacy, which are not completed doctrines for them. As Holenstein observes with respect to Jakobson, structuralism and Saussure are taken as a promising start, as an introduction to a generous search for insight into the organization and functioning of language(s) (langage $(s)) .{ }^{176}$ For Metz, like for Jakobson, structuralist semiology is a timely tool for summarizing the diverse manifestations of a group of phenomena and for treating them 'as a structural whole':

175 This might seem surprising given that Jakobson is known for his 'binary analyses' (remember 'Les chats', together with Lévi-Strauss), and is certainly more interested in cybernetics and information theory than Metz (see 'The Cinema: Language or Language System?', pp. 34-36). But Metz also characterizes the relationship between linguistics and poetry with recourse to Jakobson (pp. 85-86). See Roman Jakobson, 'Linguistics and Poetics' [1960], in Selected Writings, III (1981), pp. 18-51.

176 Holenstein, Roman Jakobsons phänomenologischer Strukturalismus, pp. 29-30. 
[T] he basic task is to reveal the inner, whether static or developmental, laws of this system. What appears to be the focus of scientific preoccupation is no longer the outer stimulus, but the inner premises of the development; now the mechanical conception of processes yields to the question of their functions. ${ }^{177}$

According to Holenstein, the cornerstones of Jakobson's semiotics include the assumption that the world and all phenomena are structured; the examination of the relationship between the whole and its parts, of the relational characteristics of all elements; and the inquiry into the function of structures and processes, that is, their meaning as construction and their meaning for a subject. Thus, Holenstein argues, Jakobson brings together Saussurian structuralism with Edmund Husserl's phenomenology, a phenomenology that forms 'structuralism's historic and factual condition of possibility'.178

Although phenomenology does not have equal weight throughout, neither for Jakobson nor for Metz, and although the two semioticians do not lean on the same reference works continuously, a similar thing can be claimed for Metz. ${ }^{19}$ Among other things, this applies to his works on the effect of presence and on the expressivity of the analogue film image, where he often makes recourse to the phenomenological aesthetics of philosopher Mikel Dufrenne (who is not averse to semiology himself). ${ }^{180}$ The recurring

177 The quote is from an article that Jakobson published in the Czech weekly ČIN in 1929 and which was included in Roman Jakobson, 'Retrospect' [ca. 1969], trans. by [unknown], in Selected Writings, II (1971), pp. 711-22; quoted in German in Holenstein, Roman Jakobsons phänomenologischer Strukturalismus, p. 11.

178 Holenstein, Roman Jakobsons phänomenologischer Strukturalismus, pp. 13-14, 31, and 57 . Jakobson also repeatedly refers to Holenstein when arguing that phenomenology is an important foundation of structuralism; see, for instance, Jakobson's theoretical-historical, epistemological study 'A Glance at the Development of Semiotics', p. 204.

179 Even after expressing reservations about phenomenology, Metz writes on the relation between semiology and phenomenology: 'We are all phenomenologists sometimes' - the 'cogito perceptif' cannot be denied. See the end of his essay (written as an homage to Mikel Dufrenne) 'Le perçu et le nommé', Essais sémiotiques (Paris: Klinksieck 1988), pp. 159-6o; this section has not been translated into English but we can also refer to the conclusion of The Perceived and the Named, p. 67 for Metz's relation to phenomenology in general and especially with respect to the point mentioned here, see Chateau and Lefebvre, 'Dance and Fetish', p. 121 and 130.

180 See, for instance, Mikel Dufrenne, The Phenomenology of Aesthetic Experience, trans. by Edward S. Casey (Evanston: Northwestern University Press, 1973 [1953]) and his essay 'Lart est-il langage ?' [1966] in Section II entitled 'Art et sémiologie', in Esthétique et philosophie, 3 vols. (Paris: Klincksieck 1967-1981; repr. 1988), I, pp. 73-112. There are numerous references to Dufrenne's writings especially in Metz's early works; see ‘The Cinema: Language or Language 
relationship between the comprehensive and the comprised (englobant and englobé), for instance, which ties him to the filmologists, testifies to the phenomenological basis of Metz's work. With reference to and in opposition to Cohen-Séat, Metz distinguishes between the 'cinematic fact' and the 'filmic fact', which are in a doubly (if not more) tense relationship. On the one hand, the 'cinematic fact' includes everything that surrounds the films: their context of production, their reception, and also their perceptive, psychic, and symbolic context, in short, the 'cinematic institution'. This he distinguishes from the 'filmic fact', that is, from the films as 'texts', as 'concrete units of discourse', whereas 'cinema' can also mean all films as an 'ideal set', as 'the virtual sum of all films'. On the other hand, at the more refined level of semiological analysis, the filmic also stands for everything that can appear in a film or in some films. It is opposed to the specific characteristics of cinematic language, which organizes the 'different structures of signification [...] potentially common to all films'. Thus, it becomes clear that Metz's interest in the abstract whole always includes an awareness of its phenomenological parts: 'The film is an object in the real world, the cinema is not.' However, 'the notions of film and cinema are distinct, but not the study of the film and the study of the cinema; the study of the film is a part of the study of the cinema.. ${ }^{181}$ Thus, what is at stake is also the relationship between code and function, a relationship that is able to grasp the change of forms, the variants in their relation to the invariants, and the interior regularities of change within the whole.

Further, for Metz, like for Jakobson, the reference to art is an important source of inspiration. ${ }^{182}$ Film is a form of expression in which language and art are linked inseparably, which is why semiological and aesthetic analysis are tightly interlocked, too. ${ }^{183}$ Art serves Metz as a background against which he can confront his theoretical parameters with cinematic practice - structure with experience, in Marshall Sahlins's terms. This allows him to qualify or adjust his theory again and again, whether with regard to specific films or to historical ensembles, which he conceives as narrative modes or perceptive patterns (régimes). Classical cinema serves

System?', pp. 75-84; 'Some Points in the Semiotics', p. 98; or 'Problèmes actuels de la théorie du cinéma', pp. 52, 59, 63, 69, 83-84.

181 All quotes from Metz, Language and Cinema, pp. 22-24 and 156 (emphases in original), see also pp. 12-14. Metz returns to this from a psychoanalytic perspective in 'The Fiction Film and its Spectator', Chapter 10, pp. 138-42.

182 Holenstein, Roman Jakobsons phänomenologischer Strukturalismus, p. 32.

183 This was already shown above; see, for example, Metz, Language and Cinema, pp. 15-17 and 38. See also Metz, 'Existe-t-il une approche sémiologique de l'esthétique?', pp. 154-67. 
as the primary reference point for him, as his theoretical 'vanishing point', so to speak, as the 'socially dominant reading pattern'. ${ }^{184}$ But he is always also interested in transformations, in breaks with convention, in historical change - for instance when dealing with montage in the films of Sergei Eisenstein and Vsevolod Pudovkin, or with modern cinema, which he considers a progressive, avant-garde movement, even though it still adheres to narrativity. ${ }^{185}$ In his search for more or less transhistorical invariants and their relation to the many variants and actualizations, Metz overcomes the dichotomy of stasis and dynamics. What's more, he also loosens the rigid relation between synchrony and diachrony, which are strictly separate for Saussure in terms of their perspective. ${ }^{186}$ Thus, for Metz too, every period, every synchronic, historical situation contains 'virulent modernisms, which attempt to take hold as future forms of expression and which determine the value of established forms', as Holenstein writes about Jakobson. ${ }^{187}$ Even in Language and Cinema and in his Grand Syntagmatique, which can both be considered strictly systematic texts, Metz does not exclude the historical dimension. An awareness of the cinematic signifier's changing forms and functions - changes stemming from artistic practice and confirmed by film history - frames his theoretical reflections. ${ }^{188}$ In 'Trucage and the Film', for example, there is an element of ideological critique with regard to classical film, to technology in its relation to economics, and to the cinematic institution, all of which are historicized by Metz. Similarly, in 'The Saying and the Said', Metz grapples with what was sayable, representable, and thinkable at a certain time under certain conditions in film, in the cinematic institution, in society, and in scholarship: 'The plausible [...] is cultural and arbitrary.' ${ }^{\prime 89}$

All these aspects linking the theoretical 'model' with the artistic practice of films, with the historical situation, and with dynamic change in various institutional contexts enter the theoretical model from the edges - or they appear in it like 'inlays' - yet they remain rather general and abstract for the most part. They rarely refer to a specific historical context, and when they

184 Metz, 'Réponses à Hors cadre', p. 69.

185 See Metz 'The Cinema: Language or Language System?'; 'Montage et discours'; and 'The Modern Cinema and Narrativity'.

186 On synchrony and diachrony, see Metz, 'Some Points in the Semiotics', pp. 101-2; and 'Problems of Denotation', pp. 117-18.

187 Holenstein, Roman Jakobsons phänomenologischer Strukturalismus, p. 39 ('value' in the sense of Saussure); see also p. 48; on the dynamic relationship between synchrony and diachrony in Jakobson, see pp. 23 and 45-46.

188 See, for instance, Metz, 'Problems of Denotation', p. 135.

189 Metz, 'Trucage and the Film', pp. 657-58, 674-75; and also Metz, 'The Fiction Film and its Spectator', pp. 140-42; Metz, 'The Saying and the Said', p. 244 (emphasis in original). 
do, then mostly through anecdotal - though clever - examples. Nevertheless, through these 'outposts', Metz constantly resituates the evolution of his film theory and the historical position of his writing about cinema - most decidedly in The Imaginary Signifier.

The anthropological and (implicitly) pragmatic dimension of the cultural phenomenon of cinema also appears in Metz's intersubjective conception of the spectator throughout his works. Thus, narrativity and fictionality combine in the fiction film as components of cinema's socially dominant mode, responding to the spectator's 'desire for narrative and need for understanding' ${ }^{190}$ Much like Bazin (though at a different level), Metz argues that the spectator's attitude between belief and disbelief is 'on the one hand, shaped by the entire Western tradition [...] of art as imitation, imitation of daily life or of some fabulous universe'. One the other hand, he claims, the characteristics of the imaginary signifier affect the spectators as an audience that has completely 'internalized' these characteristics: 'The Signifier is social and historical', it is an 'institution'. ${ }^{191}$ In his psychoanalytical works, Metz is concerned with the metapsychology of the spectator as code, that is, the spectator's relationship to the screen and to the film, the psychic apparatus as part of this institution, 'the specifically cinematic scopic regime, ${ }^{192}$ This is 'one ethnography of the filmic state, among others remaining to be done'. It is a filmic state required of the spectator in order for the cinema-machine and the cinematic fiction to function. ${ }^{193}$ What is at issue here is not the individual spectator with their psychology and biography but the spectatorial subject, conceived intersubjectively in a certain culture and period, as a 'relation of forces' outlining a 'social-psychic space' and thus enabling individual variations. ${ }^{194}$ Thus, the imaginary signifier and the imaginary referent (in the sense of the referential illusion) are effects produced by the film. They correspond to the functional principles of the filmic text with its specific traits, an invitation to the spectators which they can accept or decline, and which they complete. Similarly, the concept of enunciation refers to a performative activity, the filmic discourse directed from a 'source' to a 'target', addressing the spectator. But even if the spectator is more than a 'blank space in the text' (as is often claimed of the text-immanent approach), Metz does not envisage the spectator

190 Metz, 'Réponses à Hors cadre', p. 69.

191 Ibid., p. 65; see also Metz, 'Sur mon travail', p. 186.

192 Metz, 'The Imaginary Signifier', p. 61 (emphasis in original); see also Dagrada and Pescatore, 'Conversation with Christian Metz' [in this volume].

193 Metz, 'The Fiction Film and its Spectator', p. 138 (emphasis in original).

194 Metz, 'Sur mon travail', p. 188. 
inside his 'model'. It is a potential spectator, constructed by the film, a theoretical-abstract subject, in other words, a 'generic' figure of the theorist. ${ }^{195}$ Nevertheless, for Metz, on the edge of this text-immanent conception, there is an awareness of a real counterpart outside the film and the model, a flesh-and-blood spectator. Without this spectator, there would be no film, because nobody would know of the film; yet the spectators can do anything they want and understand the film any way they like, without changing the film. In addition, with reference to Genette, Metz introduces the 'image' that the filmmaker has of their audience or of an individual spectator as an anthropological, imaginary entity - just like the spectator creates their own image of the author. Not everything situated outside the film is real; 'there is an extra-textual imaginary'. ${ }^{196}$

And when it is understood as real, the conception of the spectator once again changes colour like a chameleon as Metz introduces yet another aspect: the spectators or audience as a social group, 'a group of participants in a culture, today we would say "users". ${ }^{197}$ These are sometimes invoked very concretely in order to exemplify a theoretical problem. Regarding the intelligibility of filmic language, Metz writes:

The audience of local shopkeepers who booed Antonioni's L'avventura [I/F 1960] at the Cannes Film Festival had understood the film, but either they had not grasped, or were indifferent to, its message. Filmic intellection has nothing to do with their attitude; what bothered them was simply 'life' itself. It is normal that the problems of the couple as stated by Antonioni should leave a large section of the audience indifferent, puzzled, or derisive.

In the footnote added later about the local shopkeepers', he explains: 'They are given free tickets by the municipality of Cannes and constitute what one refers to as the Festival audience. ${ }^{198}$

The example's (sociological) concreteness is baffling in such a highly theoretical text. Such everyday examples appear like inlays, bringing theory into everyday life - and vice versa - through an unexpected change of the

195 Metz, L'énonciation, p. 35.

196 Ibid., pp. 199-205 (here p. 205).

197 Metz, 'Some Points in the Semiotics', p. 101; Metz even speaks of a 'group of users' (groupe d'usagers), though, of course, he doesn't mean the users of today's media culture.

198 Metz, 'The Cinema: Language or Language System?', p. 74. The last sentence is again followed by a long footnote (added later in 1968) about the 'saying' and the 'said' with regard to this historical case. 
perspective and the point of reference. ${ }^{199}$ Because cinema is above all a cultural technology and the spectators a social group of users, 'the semiotics of the cinema must frequently consider things from the point of view of the spectator rather than of the filmmaker. ${ }^{200}$

Thus, although the spectators are only implicit in this model, they are a real social entity. And the theorist includes himself in this: he loves going to the movies, declares himself a 'cinema native', and intersubjectively shares the everyday experience of moviegoing and of the films (as well as of social life) with other participants of the culture. ${ }^{201}$ At the same time, as a semiological analyst and theorist, he situates himself outside. ${ }^{202}$ His reading of films is a 'meta-reading', which is distinct from 'the "naïve" reading (in fact, the cultural reading) of the spectator. ${ }^{203}$ As Metz explains: "The idea of a film semiology came to me by bringing these two sources into contact. ${ }^{204}$

As we have seen, this simultaneously exterior and interior view of the writer is reflected at the methodological level, culminating in the subjective enunciation described in The Imaginary Signifier. This is certainly his most personal work, in which he reveals himself as an individual - a writing and theorizing individual. The notion of writing, which is based on the semiologist's 'meta-language', is ultimately a pragmatic concept. As Metz writes with reference to Jean Louis Schefer, 'the image only exists in terms of what one reads'. This 'one' is situated both on the side of production and the side of reception, in writing as well as in film perception. ${ }^{205}$

I have dwelt at length on the various aspects of the spectator in Metz's works because the notion of the subject thus inscribed in his texts once again comes close to what Holenstein says of Jakobson: 'In the structuralism of Jakobsonian provenance, the subject appears in threefold shape: 1 . as observer who is part of their own observation, 2. as intersubjective, and

199 Another example out of many is the one used to explain the non-specific filmic codes of characters' clothing at the level of the 'form of content'. Here, Metz gives a flowery description of the 'Dandy of the VXI arrondissment' in an unnamed film from 1967, contrasting the character's clothing with that of a blue-collar worker (Metz, 'Propositions méthodologiques', p. 101). On the relationship between theory and everyday life, see also Bellour, 'Le cinéma et ...', p. 23; or Odin, 'Christian Metz et la linguistique', p. 94.

200 Metz, 'Some Points in the Semiotics', p. 101.

201 Metz, 'Sur mon travail' p. 173, and Metz, 'The Perceived and the Named', p. 67.

202 Metz, 'Sémiologie audio-visuelle', p. 115; Metz, 'The Fiction Film and its Spectator', p. 138; and the interview with Vernet and Percheron, Metz, 'Sur mon travail', p. 177.

203 Metz, Language and Cinema, p. 74 (emphasis taken from the French original).

204 Metz, 'Sur mon travail', p. 173.

205 Metz, 'Au-delà de l'analogie', p. 161. 
3. as unconscious producer and recipient of the linguistic message. ${ }^{206}$ Of course, with regard to Metz, 'linguistic' must be supplemented by 'filmic', that is, by a plurality of materials or channels of expression, including the linguistic. These enrich the perception of film, they allow for its offer of significations, and they enable the spectator to create sensual and semantic sense in a mixture of conscious and unconscious processes. ${ }^{207}$ The theorist is exposed to these same processes.

On the basis of phenomenology (that of Husserl in the case of Jakobson), the Kantian subject 'is expanded by the dimensions of intersubjectivity and of the unconscious', according to Holenstein. And he goes on to note that Foucault's 'death of the subject' is not a Jakobsonian motto. Lacan's 'decentring of the I' comes closer to Jakobson. ${ }^{208}$ We can discern a similar position in Metz's work:

The image of the I [...] is the only analogous entity we have to follow the activities of the characters on screen. From what other source could we infer, for instance, any knowledge about what crying means to a character? How to understand acts of evil, except by mobilizing whatever real or virtual evil is inside of us? This recourse is most often unconscious, we include it in ourvery notion of understanding. It is a recourse - we need to emphasize this - to an image of the I rather than the I (we don't know ourselves), unless we define the I, in the sense of Lacan, as the slipping away of images. ${ }^{209}$

Thus, Metz counters or qualifies the egocentricity of phenomenology ('the lure of the ego' as 'blind spot') by way of psychoanalysis and the semiology of the signifier, which decentre the subject, each in their own way. ${ }^{210}$ For Metz, the spectator's psychic processes set to work in front of the screen are part of the institution, part of the cinema-machine. Neither the film nor

206 Holenstein, Roman Jakobsons phänomenologischer Strukturalismus, p. 56; see also Chapter 2.2 on the relationship between 'object and subject', pp. 55-76.

207 Metz, 'Au-delà de l'analogie', p. 161; Metz, 'Le perçu et le nommé', pp. 159-6o (in the section not translated at the end of 'The Perveived and the Named'); Metz, 'Metaphor/Metonomy', pp. $285^{-86}$.

208 Holenstein, Roman Jakobsons phänomenologischer Strukturalismus, p. 56 .

209 Metz, 'Réponses à Hors cadre', p. 74 (emphasis in original). For the allusion to Jacques Lacan, see Ecrits. The First Complete Edition in English, trans. by Bruce Fink (New York/London: W.W. Norton and Company, 2002). Lacan's 'fuite du sujet' was translated to English as 'the slipping away of the subject' (e.g. p. 166); as translator Bruce Fink notes, 'Fuite (slipping away) also means flight, leaking away, or fading' (p. 783).

210 See Metz, 'The Imaginary Signifier', pp. 52-53 (emphasis in original): ‘[L]ight must be cast by the real conditions of society and man' (p. 53). 
the spectator are interpreted hermeneutically or in individual-psychological terms. What are at issue are always the materials and forms of expression, the imaginary signifier, and the cinematic apparatus.

The anti-humanism that has often been attributed to structuralism (Althusser, Derrida, Foucault, Lévi-Strauss, and at times Barthes - at least until $S / Z$ ) does not find its most radical expression in Metz. Granted, in his systematic intellectual edifice, this anti-humanism appears consistent or even 'logical'; the constructed 'model-like object' must be self-contained. However, this is not meant in an immovable and historically absolute way: 'the large syntagmatic category of the narrative film can change, but no single person can make it change over night'. ${ }^{211}$ And during a seminar on his last big topic, enunciation, Metz answered a question about the historical change of enunciative configurations as follows (I quote from memory): 'It is language that does that.' What he said around the same time in an interview sounds like a comment on this: 'I'm a materialist."212

And yet, on the edges of the 'model' - as theory's other side, so to speak cinema is a lived practice, and films are a phenomenal manifestation, culturally and historically. From the viewpoint of production, films are (individual) realizations of enunciative figures. In this discursive sense, they are a 'creation' because each film has to 'invent the cinematographic language [...] to a certain extent' - an act that is sometimes recognizable as personal style. ${ }^{213}$ From the view point of reception, films are aesthetic experiences that each spectator can participate in - socially, intersubjectively, and individually, as conscious and unconscious producer and perceiver.

The scholar Metz has a clear and rigorous focus (he is a child of his time), but as a native of a (film) culture, he oscillates between direct everyday experience and scholarly observation: 'Interwoven into every analytical undertaking is the thread of a self-analysis. ${ }^{214}$

Finally, the oft-quoted statement on the 'pleasure in the toy' reads like an echo of Barthes' 'third degree'. The toy, which must be broken - sometimes with great effort - if we want to see and understand how it works, can be turned both ways. ${ }^{215}$ Cinema and the specific films are as much a toy as are

211 Metz, 'Some Points in the Semiotics', p. 102; also Metz, 'Sur mon travail', p. 169. 212 In Blüher and Tröhler, 'Interview with Christian Metz' [in this volume].

213 Metz, 'Some Points in the Semiotics', p. 101 (emphasis in original); on the relationship between enunciation and style, see Metz, Lénonciation, pp. 155-59.

214 Metz, 'The Imaginary Signifier', p. 79.

215 Metz in the interview with Vernet and Percheron, 'Sur mon travail', pp. 170-72; Metz, 'The Imaginary Signifier', p. 8o. On the 'third degree', see, for instance, Roland Barthes, The Pleasure of the Text, trans. by Richard Miller (New York: Hill and Wang, 1975 [1973]), pp. 11-14; or Roland 
theory, the 'model-object', or cinematic language. To break one in order to 'burst' it or open it towards the other means to turn the other into one's pleasure. And thus, I cannot help but invoke once again the oft-quoted words from the conclusion of The Imaginary Signifier: "This is the theoretical break, and like all breaks it is also a link: that of theory with its object.' And 'I have loved cinema. I no longer love it. I still love it.' ${ }^{216}$

Translated from German by Susie Trenka ${ }^{217}$

About the author

Margrit Tröhler is Professor of Film Studies at the University of Zurich. She studied in Basel and Paris and was a doctoral student under the supervision of Christian Metz at EHESS. After his death, she completed her thesis under the direction of Francis Vanoye at the University of Paris X (Nanterre). She was co-editor of the journal Iris (Paris/Iowa) from 1992 to 2002 and President of the interdisciplinary Swiss Society for Cultural Theory and Semiotics (SSCS) from 2007 to 2014. Since 2009, she has also been the co-director of the National Centre of Competence in Research 'Mediality - Historical Perspectives', which focuses on the historicity of media. She has published widely on topics such as the intersection of fiction and nonfiction film, gender, aesthetics, and the history of film theory. She recently co-edited the historical anthology Die Zeit des Bildes ist angebrochen! Französische Intellektuelle, Theoretiker und Filmkritiker über das Kino. Eine historische Anthologie. 19o6-1929 (with J. Schweinitz, 2016).

\section{About the translator}

Susie Trenka completed her PhD entitled Jumping the Color Line: Vernacular Jazz Dance in American Film, 1929-1945 at the University of Zurich, where she was also a research assistant, lecturer, and translator in the Department of Film Studies. She now lives in New Orleans, working as a freelance translator, film critic/writer, and swing dance teacher.

Barthes, Camera Lucida. Reflections on Photography, trans. by Richard Howard (New York: Hill and Wang, 1981 [1980]), pp. 6-7, 48, 117-19, and the final chapter.

216 Metz, 'The Imaginary Signifier', p. 79.

217 I would like to thank Lorenz Vollenweider and Adrian Seward for their assistance as well as Susie Trenka for the English translation. 


\section{I}

Metz and the Tradition of Film Theory 



\title{
2. Two Ways of Thinking
}

\author{
Raymond Bellour
}

Tröhler, Margrit and Guido Kirsten (eds.), Christian Metz and the Codes of Cinema. Film Semiology and Beyond. Amsterdam University Press, 2018

DOI: $10.5117 / 9789089648921 / \mathrm{CHO} 2$

\begin{abstract}
How the most intimate friendship there could be was strengthened by the close brush between two ways of thinking as alien to each other as possible: between an experience of the real that ultimately presupposed the impossibility of any theory attempting to account for it, and the inherent logic of a system so oriented as to never encounter that real - a real that nevertheless engendered a passion. For in the end, that system's target was itself.
\end{abstract}

Keywords: film semiotics/film semiology, friendship, epistemology, film analysis, methodology

I thank Margrit Tröhler most warmly for inviting me to this conference dedicated to Christian Metz, and for asking me to be the first speaker. I can't help remembering that I had the pleasure, 24 years ago already, of opening the first major conference in Christian's honour, organized by Michel Marie at Cerisy-la-Salle, and that Christian attended it from beginning to end, responding at length to everyone with the patience, the attention, and the respect for others that were among his best qualities, making those ten days as warm and friendly as they were rich in ideas and viewpoints.

So it's not easy finding myself here opening this conference in the presence of Christian's son, Michaël, and his companion, Michèle; I have not seen them that often since his death. The emotion and the grief, which remains deep, are compounded by the difficulty of not repeating what both Christian and I felt I had really succeeded in expressing at Cerisy: both the uniqueness of his work, so fundamental in its domain, and the effect that that same uniqueness could have on others, particularly me, since one always speaks best about what one knows most intimately. ${ }^{1}$

1 Raymond Bellour, 'Le cinéma et...', Iris, 10 (1990), pp. 15-35; reprinted in my book L'Entre-

Images 2. Mots, images (Paris: P.O.L., 1999), pp. 79-102. 
In the wake of the long interview we had at the end of the 1960 s on his work, ${ }^{2}$ Christian had become, rather quickly, one of my closest friends - a friendship in which our respective fields of research obviously played a part. But they did not play the largest part: it was life in general, as it were, that concerned us the most - life in all its aspects, its triviality, its surprises, to which friendship brought its questions and its unexpected answers. This is probably what made our friendship so precious.

Above all, something unusual happened at that time, through the friendship that then connected us, together and separately, to Thierry Kuntzel: the formation of a kind of small-scale community, between beings as different from each other as you could imagine. The age differences between us were of a half-generation, a little less than ten years: differences that were acknowledged but that did not define us. There were also differences in temperament - Christian's willfully obsessive and secret side, the strange character of the artist that Thierry would soon become, and the slightly scatterbrained, jack-of-all-trades nature I had at the time (signing a book once, Christian called me 'my dear pensive ludio's). The quality of a feeling is always hard to describe: I'd say that by way of those different temperaments, and through each of our inevitable problems - to a large extent because of them - the three of us shared an unreserved friendship, based on mutual aid, and most importantly free of any kind of competitiveness in our development of the thoughts on cinema that brought us so close together. For our benefit, I would willingly revise Montaigne's comment, which had always seemed so beautiful to me, on his extraordinary friendship with La Boétie: 'Because it was them, because it was me.' As far as our work went, the issue of Communications entitled Psychanalyse et cinéma that we jointly edited and that the three of us wrote for the most part was the most obvious social and professional expression of this congenial, trusting relationship. ${ }^{4}$

For Christian, this was the occasion of his second founding gesture, for which he had been long preparing: after linguistics, psychoanalysis, in order to shed light on cinema from a new exterior. In my talk at Cerisy, I had

2 Raymond Bellour and Christian Metz, 'Entretien sur la sémiologie du cinéma', in Christian Metz, Essais sur la signification au cinéma, 2 vols. (Paris: Klincksieck, 1972), II, pp. 195-219.

3 From Latin, plural 'ludiones', 'ludion' in French. 'Roman Antiquity: Dancer, circus performer who came from Etruria to Rome. "The ludiones [...] performed improvisations comprised of movements to which they added neither singing nor speech" - Jacques Baril, Dictionnaire de danse (Paris: Seuil, 1964)' [From the Trésor de la Langue Française online dictionary, http://atilf. atilf.fr/tlf.htm, accessed 4 April 2014 - translator's note].

4 Communications, 23 (Psychanalyse et cinéma, eds. by Raymond Bellour, Thierry Kuntzel and Christian Metz, 1975). 
described this all-embracing gesture with the words 'The cinema and...' to try and mark the special place Christian Metz held in the area of film study where he appeared, commensurate with this same externalizing gesture, as one of those founders of discursive practice whose portrait Michel Foucault had rendered in one of his most penetrating essays, 'What Is an Author?'

I'll take a moment to recall what Foucault wrote, for I think it has become even more essential today. Returning to my 1990 text, where I quote him extensively: 'The distinctive contribution of these authors [these initiators of discursive practices] is that they produced not only their own work, but the possibility and the rules of formation of other texts. [...] They established [an] endless possibility of discourse.' In this, unlike the novelist who makes subsequent analogies possible, the founders of discursive practice (Marx and Freud, for example, 'the first and the most important') 'not only made possible a certain number of analogies [...], but, as importantly, they also made possible a certain number of differences'. On the other hand, in contrast to the initiation of a science, or a scientific practice, which 'can always be rechanneled through the machinery of the transformations it has instituted [...], the initiation of a discursive practice is heterogeneous to its ulterior transformations'. It remains in the background, or hangs above. This is why, adds Foucault, we can 'return' to these heroes of a new kind (in this way opposing 'return' to 'rediscover' or 'reactivate'): 'the barrier imposed by omission' is incorporated into their works:

[T] he act of initiation is such, in its essence, that it is inevitably subjected to its own distortions; that which displays this act and derives from it is, at the same time, the root of its divergences and travesties. This nonaccidental omission must be regulated by precise operations that can be situated, analysed, and reduced in a return to the act of initiation. The barrier imposed by omission was not added from the outside; it arises from the discursive practice in question, which gives it its law. Both the cause of the barrier and the means for its removal, this omission - also responsible for the obstacles that prevent returning to the act of initiation - can only be resolved by a return.

As a result, in the final characteristic that Foucault ascribes to these discursive practices, these returns 'tend to reinforce the enigmatic link between an author and his works. A text has an inaugurative value precisely because it is the work of a particular author, and our returns are conditioned by this knowledge'. ${ }^{5}$

5 Michel Foucault, 'What Is an Author?' [1969], [translator unknown], in The Art of Art History: A Critical Anthology, ed. by Donald Preziosi (Oxford: Oxford University Press, 1998), 321-34 (pp. 330-332). 
Christian Metz's particular inaugurative force was then to encourage thinking on cinema to build itself through a systematic confrontation with disciplines that are inherently external to it. This is what I condensed into the phrase 'The cinema and.... The idea was to give a visible, fully recognizable reality to a project that was both scattered and vast, but prophetic, delineated in France by the Revue internationale de filmologie, with its references to psychology, sociology, biology, and aesthetics. Published from 1947 to 1962, its final issue came two years before Christian's first article, 'Cinema: Language or Language System?' (Since then, mostly as a result of the new pathways opened by the cognitive and neurosciences, the importance of this whole movement, all too neglected, has been reasserted.)

Without getting into the subtle nuances of Foucault's text, those words, omission and return, are ones to which we can only be immediately sensitive. After having been celebrated up until the mid-199os as a sort of pope of film semiotics, of which he was historically the founder - an image whose excessiveness amused him, while he sensed the threat it posed and all the risks for backlash that it implied - Christian Metz has over time been quite forgotten. He had a premonition that this would happen, and it troubled him, with that lucidity of his that allowed him to understand so well the periods of enthusiasm, then of indifference, that comprise the history of thought, with its share of fashion as well. I remember that after I'd given him a text (something I would do from time to time), one with which I'd been having trouble, he'd told me how appreciative he was that I could think highly of both his work and Deleuze's, if it's true that we can symbolically date the beginning of the indifference shown toward semiology with the publication of Deleuze's two seminal books on cinema, which explicitly reject French semiology. In this respect, we can only point out that although Deleuze did not carry out on a philosophical basis a transfer of notions like the one that Metz accomplished on a linguistic or psychoanalytical basis, his endeavor still comes under the heading of 'the cinema and...' that Metz had first called for.

So much for omission. What of return? Its essence is to be improbable because we cannot anticipate what has not yet occurred. Perhaps this conference will become one of its early traces - it is necessarily too soon to say. We can only imagine, for example, that the day, if that day ever comes, when the cognitive sciences demonstrate a capacity to orient their knowledge on cinema without the reductionism and the ignorance that they have generally demonstrated about it up to this point, they may perhaps find in some of the more demanding postulates of film semiotics (I'm thinking 
particularly of the constantly refined distinctions in Language and Cinema ${ }^{6}$ ) an incentive that leads them to develop structured arguments - that would still seem improbable today - on what's going on inside the mind of the spectator of the film-object in a cinema context.

More modestly, the return could also be the support for a small step forward found in each person's work in this area, with the guarantee that every proposition in Metz's writings is substantiated with enough care that you can be sure it will inspire you, even if this means taking a back road to it. This was the case for me and for the propositions I had made in Le Corps du cinéma on an analogy between the dispositifs ${ }^{7}$ of cinema and hypnosis. ${ }^{8}$ In 'The Fiction Film and its Spectator', ${ }^{9}$ where Christian very carefully developed the analogy between film and dreams, I found all the distinctions I needed to build a second analogy that seemed to me to be more precise and more inclusive, thereby benefiting from the first analogy without, however, repudiating it, as I've always found it more useful, both in intellectual life and life in general, to add rather than oppose or subtract. On a greater scale, the inspiration I got from Daniel Stern's views on early childhood in order to work out the reality-fiction of a body in cinema owes a lot, as different as it tries to be, to the 'cinema and psychoanalysis' effect so forcefully presented in 'The Imaginary Signifier'. ${ }^{10}$

Before I get to what concerned me most when I thought back on Christian and his work, I'd like to say one more thing in passing on the status of science that this work gave itself, more or less - which could also have an impact on omissions and returns. Christian was wary of the word 'science', of its harmful psychic effects, while recognizing in semiotics a sort of aspiration towards a model for which linguistics was the ideal. Everyone knows about the extreme seriousness Christian applied

6 Christian Metz, Language and Cinema, trans. by Donna Jean Umiker-Sebeok (The Hague: Mouton, 1974 [1971]).

7 For more information on Bellour's use of the term dispositif, which in his view cannot be translated by 'apparatus' or 'environment', see Raymond Bellour, Between-the-Images, trans. by Allyn Hardyck (Zurich/Dijon:JRP/Ringier/Les presses du réel, 2012 [1990]), p. 396 [translator's note].

8 Raymond Bellour, Le corps du cinéma. Hypnoses, émotions, animalités (Paris: P.O.L., 2009), pp. 83-88, 98-99, 110-11, 114 .

9 Christian Metz, 'The Fiction Film and Its Spectator: A Metapsychological Study' [1975], trans. by Alfred Guzzetti, New Literary History, 8/1 (Autumn 1976), pp. 75-105; reprinted in The Imaginary Signifier, trans. by Celia Britton and others (Bloomington: Indiana University Press, 1982 [1977]), pp. 99-147.

10 Christian Metz, 'The Imaginary Signifier' [1975], trans. by Ben Brewster, in The Imaginary Signifier, pp. 1-87. 
to that end; one could almost speak of his positivism. But it was a special kind of positivism that found its most precise formulation in a phrase by Roland Barthes, when he saw in Metz 'the idea's insistence that it be expressed completely'. Barthes added: '[A] radical demand for precision and clarity generates a free, somehow dreamy tone, a tone I should say sounds almost drugged [...]: here an enraged exactitude prevails. ${ }^{11}$ This rage is indeed what makes Metz's work so eminently personal, with such a recognizable style, through the objectivism that pervades it throughout and beyond. The word 'drugged' is probably the most exact, for it implies a commensurability between the subject and itself, an impossibility of getting out from within oneself, so strange in someone so profoundly open to otherness: I'd always been convinced that he would have made an outstanding psychoanalyst.

By comparison and contrast, I think of Gérard Genette, who had been so close to Christian in their youth. Genette is one of the greatest inventors ever of categories and notions in the related areas of stylistics, rhetoric, and literary aesthetics: in a word, poetics. But through a kind of detachment, of internal irony, all these categories, which are moreover conceived in such a way as to not really fit in with each other, take as a result, more or less explicitly, a kind of fictional dimension that brings them just slightly in touch with Borges' taxonomies, with which Foucault admitted his fascination in the preface to The Order of Things. This is also why, in eloquent retirement, Genette could produce entirely subjective books of such personal irony - Bardadrac and the two volumes that followed, all three of which were published in the 'Fiction et Cie' collection at Les Editions du Seuil rather than in their 'Poétique' collection. To say it another way, in these works science was explicitly put in perspective through humour and reverie. Nothing of the kind for Christian: he did not have that sudden burst of inventive retirement. I realize today that I don't really know what he thought deep down about the more or less scientific aspect of his work. I only know that he often said that instead of being an intellectual, he would rather have been a florist or a gardener.

I now come to what most concerns me, which is the uncertain relationship, in my view, between the two large domains that Metz considered as both distinct and complementary in the undertaking of film semiotics: what we could call general theory, and 'the textual analysis' of films, in which he

11 Roland Barthes, 'To Learn and to Teach' [1975], in The Rustle of Language, trans. by Richard Howard (New York: Hill and Wang, 1986), 176-78 (p. 176). 
saw 'at least half of the work to be done in film semiotics.' ${ }^{12}$ This was what he insistently brought to the fore in Language and Cinema by means of the two categories of 'cinematographic language' and 'filmic writing'. This necessarily brings me personally into the midst of this opposition, where I - along with many others, though perhaps more clearly than some - represented the second category. I won't repeat what I've already discussed, at length, regarding the issue of alternation (especially since André Gaudreault has made it his specialty) or the relationship between words and images, so that I may concentrate on this supposedly permeable divide between film theory and film analysis.

What surprises me first of all is the hesitancy that Christian maintained in his books, texts, or interviews regarding his personal relationship to film analysis. I will just remind you, for its symptomatic value, of the episode (to which I already alluded in the introduction to my book The Analysis of Film ${ }^{13}$ ) that brought us together, at the end of the 196os, on the project of a joint analysis of a film excerpt. It involved the moment in Hitchcock's Suspicion (USA 1941), of which we managed to find a print, where Joan Fontaine and Cary Grant meet on a train. We watched the excerpt three times in a row on the editing table, but nothing came out of it. No desire for anything. In my case, was it my inhibition when faced with the specific act of breaking the film down, of stopping it, an inhibition that I was to dispel shortly afterward? In Christian's - at least the way I imagined it - was it a much greater resistance? Or was it the very fact that, as close as we were then becoming, we were entering an experience together, insufficiently aware that it concerned desire at its most intimate?

If I am not mistaken, out of all of his writings Christian carried out just three analyses or para-analyses of films: three analyses based on one code, but using quite different modes and extensions. First, in 1966, came his relatively classical approach, though carried out with his usual scrupulousness, to the mise en abyme structure of Fellini's $81 / 2$ (I/F 1963): a stylistic choice in the screenplay that gives its form to the whole of the film. Then, just afterwards in 1967 , he wrote his famous commented breakdown of the 'autonomous segments' of Jacques Rozier's Adieu Philippine (F/I 1962)..$^{14}$ This was an attempt to implement an example of the grande syntagmatique

\footnotetext{
12 Christian Metz, 'Sur mon travail (Entretien avec Marc Vernet et Daniel Percheron)' [1975], reprinted in Metz, Essais sémiotiques (Paris: Klincksieck, 1977), 163-205 (p. 175).

13 Raymond Bellour, The Analysis of Film, ed. by Constance Penley (Bloomington: Indiana University Press, 2000 [1979]).

14 The two articles appear in Film Language - A Semiotics of the Cinema, trans. by Michael Taylor (New York: Oxford University Press, 1974), pp. 228-34 and 149-76.
} 
of narrative film, whose first version had appeared a year before. It came with all the familiar problems of the partial discrepancy between an actual film and the code supposed to manifest itself within it, ultimately clarified through a substantial critical apparatus: footnotes designed to dispel the easy answers, to rule out any ambiguity, any more or less obvious contradiction. What's strange when one thinks about it is to have chosen a film from 1962 , in other words a modern film from the Nouvelle Vague, when the grande syntagmatique is increasingly seen as dealing strictly with classical narrative cinema (I won't go into the details). The great love Christian had for this film - so close to his idea of life, to his love of the Riviera and of women - was probably behind this choice, one however which led to a greater difficulty in application (and in any case, the contingent classicism of the film is not sufficient to reduce this difficulty, as I demonstrated in detail in my study of Minnelli's Gigi [USA 1958], 'To Segment/To Analyze ${ }^{\prime 15}$ ). Finally, Christian's third analysis, in Language and Cinema, concerns the alternating structure throughout Griffith's Intolerance (USA 1916), the main example in the section 'Cinematic and extra-cinematic: from duality to mixture'. ${ }^{16}$

Then come the examples - just to give a quick, certainly non-exhaustive overview that gathers enough evidence to make the case - of what we could call Christian Metz's flirtation with the idea of the textual analysis of films. Most of them are to be found in Marc Vernet and Daniel Percheron's fine interview with him, 'Sur mon travail'. In this interview, held when he was working on The Imaginary Signifier, Metz started by recognizing he had 'an object relationship with theoretical discourse as such'. He then put it more simply: 'What grounds theory is a taste for theory. ${ }^{17} \mathrm{He}$ admitted that he had difficulty getting two 'series' (film watching and linguistics) to join together within him, adding: 'and that's why, I think, that until now I've analyzed relatively few films ${ }^{\prime}{ }^{18}$ But things get more complicated in the part of the interview entitled 'Fear and Desire of Textual Analysis'. ${ }^{19} \mathrm{He}$ recognizes his 'resistances' and his desire 'to overcome them'. He reveals his 'intention to start by analyzing a short film' because 'with a short film, you can have a complete textual system, but one which is more quickly containable in terms of the quantity of elements and the relationships

15 Raymond Bellour, 'To Segment/To Analyze (on Gigi)' [1976], trans. by Diana Matias, in The

Analysis of Film, pp. 193-216.

16 Metz, Language and Cinema, pp. 107-12.

17 Metz, 'Sur mon travail', p. 166.

18 Ibid., p. 174.

19 Ibid., pp. 174-76 (for all the quotes preceding the following note). 
between them'. He adds: 'Then I'd like to analyze some of the films I loved the most when I was young, particularly Orson Welles' Citizen Kane [USA 1941]: I'd want to analyze it image by image. That would probably take a book to do, not an article.' He seems to contradict himself a little when at the end he declares that he doesn't have 'the desire to bring out all the codes in a film', claiming that such 'exhaustiveness [...] is not part of the semiotic program'. But the desire to analyze a short film seemed to imply just that, as did the wish to reconnect with Citizen Kane 'image by image'. Moreover, the very characterization of the textual system in Language and Cinema is that ' $[\mathrm{i}$ ]deally, the final construction of the analyst (the singular system of the film) should account for all traits of any importance which appear in that film'. ${ }^{20}$ In short, it just goes to show that the 'resistance [...] summoned up by the text as such' (the last words in the section 'Fear and Desire of Textual Analysis') won out, and that in the end Metz never undertook a full analysis as such of either a short or a feature film.

This is also why I've always wondered about the words with which Christian, in 'The Imaginary Signifier', had generously described my analysis of North by Northwest (Alfred Hitchcock, USA 1959) in our issue of Communications $^{21}$ - I don't think I'd ever asked him what they ultimately meant. By way of my text, he wrote, thanks to the mapping of a sequence analyzed in detail to the narrative as a whole, 'we are really getting close to the order of the textual system as I understand it'. ${ }^{22}$ As a reminder, I'll point out that this text, without counting the pictures and diagrams, is at least 200 standard pages long, ${ }^{23}$ so even by coming close to really existing, something like an infinite realm is opened, the realm of the total textual system, with the terror that that can arouse. An assertion of Christian's that rings true comes to mind, one that only reinforces that terror. In one of his essays he pointed out that the elements of the shot, as opposed to the discrete elements of language, 'are indefinite in number and undefined in nature', and whereas '[o]ne can decompose a shot, [...] one cannot reduce

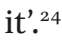

This is tantamount to saying that we are perhaps confronted with an unbridgeable chasm between film analysis and film theory as such, even

20 Metz, Language and Cinema, p. 96.

21 Raymond Bellour, 'Symbolic Blockage (on North by Northwest)' [1975], trans. by Mary Quaintance, in The Analysis of Film, pp. 77-192.

22 Metz, 'The Imaginary Signifier', p. 33.

23 A standard page or author's page (un feuillet calibré in French) is typically taken to be 1500 characters without spaces [translator's note].

24 Metz, Film Language, p. 116. 
though each time an analysis is made, it becomes part of that same theory. At the same time, however, that analysis holds itself almost in reserve, on the sidelines, without ever finding itself absorbed or included within theory, or even really establishing a point of connection with it. In reality, theory and analysis do not operate on the same level: the first is carried along by its desire for ideas while the second is inspired by its desire for objects, and their logics could never correspond to each other, despite the links between them.

Actually, I can only see one developed example of an analysis that managed to occupy a truly mediate position between its very effectuation and the theorization that it made possible: Barthes' $S / Z$ (1970), whose pointby-point development, commented along the way, allowed for a constant exchange between the signifier stricto sensu of the text, broken down into fragments, and the signifier as a general theoretical force, as a destiny offered to the literature of its time. ${ }^{25}$ Such an example, only a year before Language and Cinema, fires the imagination when we consider the abyss that it opened, in a sense, before any possible analysis of a film, well beyond the structural analysis of narratives to which Barthes had, some years earlier, offered an 'Introduction'; ${ }^{26} S / Z$ gloriously signaled the counterexample to such analyses and, to some degree, their abandonment. At the same time, such a feat was possible only because this was literature: in this case, the transformation of one text into another.

I also think that it was this whirlwind of contentious issues that led me to abandon the adjective 'structural' in the title of my collection, The Analysis of Film. It would have made the title more distinguished, and it would have been expected, given that these analyses were indeed partly structural. But they weren't exclusively structural, and that was the whole problem: letting the expressiveness associated with the films that made those analyses possible come through in their very organization, in how they unfolded. That expressiveness, the desire clinging to the ghost of films - a ghost yet alive - was what was behind the abandonment of an adjective that presupposed the effectiveness of an order as well as the stipulation of a method.

Fundamentally, I can't see film analysis - as permeated with science, hypotheses, and theoretical viewpoints as it may or sometimes should beas anything other than a mimetic activity, substituting its own narrative for 
that of its object, while at the same time finding inspiration from that object (this of course also goes for the approach toward supposedly non-narrative films, where the material of the film comprises the narrative; in fact, they coincide with each other). As a result, the analysis separates itself from its object in the proportion necessary for its own invention, but without ever leading to the belief in an autonomy that would place it in another world. The day - a turning point for me - when I encountered Meghe Dhaka Tara (The Cloud-Capped Star, IND 1960) by Ritwik Ghatak, the great Indian director, I found the expression for such an operation. I developed a commentary on the film, from the first shot to the last in a way, but by selecting certain moments as I went along that could maintain a sense of proportion to the film's consequently restructured totality. I called this text 'The Film We Accompany ${ }^{127}$ in order to underline the reality of this movement that remains - precisely in that separation that establishes itself between the film and the text that comments on it - a text whose consistency is to some degree an illusion. But that illusion is in my view essential, as if within the very time of the film that we would like to follow 'image by image', although that goes beyond reason and seems endless.

I will finish where I started: with friendship. I owe a great deal to Christian, without even speaking of what is not really expressible. At a time when I had entered into an academic career at the $\mathrm{CNRS}^{28}$ without really thinking it through, Christian convinced me to submit a Doctorat d'Etat based on previous research, as was then possible in some fields considered as innovative, and as he himself had done. Without his backing and the unfailing support of Etienne Souriau, who allowed me to stay at the CNRS, that would have been impossible. Christian also persuaded me to compile in one volume my scattered essays of film analysis, convinced that without the 'book effect', they would not have the impact that he felt they deserved. Finally, he was for me an exceptional reader, one who was both inflexible and gentle. Gentle, because he had always made himself so available that I sometimes felt that I was taking advantage of him, but he made me feel like it was something natural and simple, in accordance with a pact of friendship as implicit as it was explicit. (Christian liked thoroughness; he is definitely the only person who has ever suggested to me that we spend an evening together working out the schedule that was needed to keep our

27 Raymond Bellour, 'The Film We Accompany' [1992], trans. by Fergus Daly and Rouge. Accessed 16 March 2014. http://www.rouge.com.au/3/film.html.

28 Centre national de la recherche scientifique, The French National Center for Scientific Research [translator's note]. 
friendship going.) He was also an inflexible reader, because in the expression of agreement as well as the formulation of a criticism, he demonstrated that 'enraged exactitude' that Barthes spoke of so well, which was his own way of confronting reality and protecting himself from it. Leafing through the letters of Christian that I still have - with the melancholy that you can imagine - in order to write this text, I came upon one that I had completely forgotten about: six pages covered with his large green handwriting, as he tried to work out the expression of a misgiving, just one, but one that he wanted to set forth at all costs, concerning 'The Unattainable Text', an article that I had written for the issue of Ça Cinéma dedicated to him. ${ }^{29}$ After several nuances following each other in quick succession, he finally wrote what follows - forgive me, this is somewhat long, but I thought it was worth it:

What your text lacks is a little dash of stupidity: that somewhat basic stupidity, somewhat "I'll get to the heart of the matter", that quality (or that flaw, ultimately it's the same thing) that alone adds to the truly analytical utterance a kind of raw thrust that makes it possible to win over outside people, people who'd never thought about the problem, where it's not a matter (at least on the first reading) of convincing them, enlightening them, but of winning them over, getting them to shift position. In short, what I mean is that you're not dumb enough.

Two pages later came these 'Practical conclusions':

1) Given the place where this will be published, if I were you, I'd leave it as is without changing anything.

2) But: some day, on this same issue (because there's a real idea there that's really yours, and that's new, especially concerning the question of the quotable) I'd ("I" = me, Christian; so make what you will of it) like you to write something different. Different yet saying the same thing, but saying it a little louder.

That is what's called knowing how to read and knowing how to love.

To conclude, this time definitively, I have a hard time denying myself the pleasure of quoting from one of the 'usual Metzian maniachemes' - the expression is obviously his - with which he accompanied (the Internet 
didn't exist yet) a few lines thanking me for sending him my book Mademoiselle Guillotine, which dealt with Alexandre Dumas's series of novels on the French Revolution, a book for which he had done so much under difficult circumstances and whose final metamorphosis delighted him: "Villers-Cotterêts is written with a circumflex on the last "e" since August 10, 1539, the date of Francis I's ordinance that became law in that city and that, appropriately enough, called for the use of French instead of Latin in a whole series of circumstances.'

Translated from French by Allyn Hardyck

\section{About the author}

Raymond Bellour is a researcher, writer, and emeritus research scientist at the CNRS (CRAL, Paris). He has been responsible for the edition of the complete works of Henri Michaux in the Pléiade-series (1996-2004) and cocurated the 'Passages de l'image' exhibition at the Centre Georges Pompidou in 1990. His books include L'Analyse du film (1979); L'Entre-Images: Photo, Cinéma, Vidéo (1990); L’Entre-Images 2: Mots, Images (1999); Le Corps du cinéma: Hypnoses, Emotions, Animalités (2009); and La Querelle des dispositifs: Cinéma - installations, expositions (2012). Since 1991, he has been involved with Serge Daney in the creation and editing of Trafic: Revue de cinéma.

\section{About the translator}

Allyn Hardyck is a translator living in Paris. He earned a BA in film from the University of California, Berkeley, followed by two degrees in philosophy from the Université Paris 8 . He works regularly with Raymond Bellour and has also translated texts by Michel Chion and Philippe Grandrieux. He is currently at work on a translation of François Bovier's book on H.D. and the Pool Group. 



\title{
3. Christian Metz and his Theoretical Legacy
}

\author{
Michel Marie
}

Tröhler, Margrit and Guido Kirsten (eds.), Christian Metz and the Codes of Cinema. Film Semiology and Beyond. Amsterdam University Press, 2018

DOI: $10.5117 / 9789089648921 / \mathrm{CHO} 3$

\begin{abstract}
This chapter is a synthesizing account of the conference that took place in Zurich in June 2013. The conference is briefly situated with respect to that of 1989 in Cerisy-la-Salle, which took place in the presence of Metz himself. The author then identifies three successive generations of scholars and highlights some of the Zurich conference's core themes: research on the theories of enunciation; changes within the cinematic institution between the period of classic cinephilia, which was based on film viewing in the cinema, and the contemporary period, with its variety of modes of consuming moving images. These developments are tied back to Metz's hypotheses proposed in The Imaginary Signifier, which contains a theory of the cinematic apparatus.
\end{abstract}

Keywords: film semiotics/film semiology, Metz conference 1989, generations of scholars, enunciation theory, history of film theory, apparatus theory

It has been 24 years since the first colloquium devoted to Christian Metz at Cerisy-la-Salle, in Normandy, in June 1989. Thanks to Marc Vernet's initiative, the conference proceedings, representing a generation of scholars, were promptly published the following April, under the title Christian Metz et la théorie du cinéma. ${ }^{1}$ Between that conference and the one in Zurich, we find an overlap of six speakers: Raymond Bellour, Roger Odin, Marc

1 Iris, 10 (special issue Christian Metz et la théorie du cinema / Christian Metz and Film Theory, ed. by Michel Marie and Marc Vernet, 1990) [Conference proceedings from the 1989 Cerisy-laSalle conference]. 
Vernet, Francesco Casetti, André Gaudreault, and myself. No longer living are Christian Metz, who died tragically in September 1993, Marie-Claire Ropars-Wuilleumier, Jean-Louis Leutrat, and Guy Gauthier. I organized the 1989 colloquium with the active collaboration of Metz himself; he played a principal role in selecting the invited speakers, and even had a say in who was to attend. A quarter of a century later, I thank Margrit Tröhler, Julia Zutavern, Guido Kirsten, and the University of Zurich for having organized this second international colloquium and for having invited me. Admittedly, the organization of a ten-day symposium differs from a three-day university colloquium. For the latter, the papers have been shorter, idem the exchanges with the audience. But the number of speakers has been relatively constant: nineteen at Cerisy and seventeen in Zurich. Meanwhile, the participation of foreign scholars demonstrates the French theoretician's renown; today he is perhaps more widely celebrated abroad than at home. In 1989, besides France, the speakers invited by Metz came from Italy, the Netherlands, Denmark, Canada, America, Uruguay, Japan, and China. He actively desired this global participation in the conference, including representatives from the Far East (China and Japan) and from Latin America, where he often traveled. The international scope of the Swiss conference in 2013, on the other hand, was more circumscribed: in addition to France and Switzerland, the contributors came from the Netherlands, Canada, and the United States. It's worth noting that the North American delegation was the strongest, providing undeniable proof of the vitality of theoretical studies of film there. It is also proof of Metz's unabated fame on the other side of the Atlantic, no doubt extended and reinforced by the controversies that characterize the intellectual climate of that great continent. Scholars from the most prestigious American universities were on hand: New York University, Harvard, Yale, Berkeley, Brown, and Columbia, as well as from the Canadian universities of Montreal and Concordia. Their attendance confirms both the major role played by translations in discussions on semiology and film semiotics and the enthusiasm for theoretical approaches in Anglo-Saxon countries more generally.

Still, we shouldn't draw any hasty conclusions about such national participation. Absent in Zurich were representatives from Italy, Spain, England, or Belgium, even though teaching and research focused on film theory are very active in all of those European countries. Undoubtedly, busy schedules prevented these colleagues from attending.

The three generations present at the Zurich conference assure the posterity of Metzian studies. There was the senior generation, who co-founded film theory at the end of the 196os, including Raymond Bellour, Francesco 
Casetti, and Roger Odin. There was the intermediary generation of theoreticians, many of whom attended Christian Metz's seminar in the 1970 s and went on to teach in university film departments. This includes Dana Polan, D.N. Rodowick, Frank Kessler, André Gaudreault, and the quintet from the journal Iris: Margrit Tröhler, Dominique Blüher, Claire DupréLa-Tour, Anne Goliot-Lété, and Marie-Françoise Grange. Last but not least is the generation of young theorists who continue the Metzian legacy by prolonging it or challenging it. The dynamism of this group is demonstrated by the contributions of Guido Kirsten on the filmological heritage, Selim Krichane on the concept of code in semiology, and Nico Baumbach on the relationship between the theories of Metz and Deleuze. Additionally, Julia Zutavern played a key role in the organization of the Zurich meeting.

One of the stated goals of the Zurich colloquium was to verify Metz's place in the history of film theories today. This objective was definitely reached, since several speakers made it the principal subject of their talks. Raymond Bellour, for example, revisited in detail the relationship that has developed since the 1960 s between a general film theory and a textual analysis of film, the first being represented by the Metzian approach and the second by that of Bellour himself. For D.N. Rodowick and Frank Kessler, Christian Metz literally invented film theory by establishing a theoretical attitude in this field. But both Rodowick and Kessler were quick to point out the contributions of earlier theoreticians - Rudolf Arnheim, Hugo Münsterberg, and Jean Leirens - whose writings Metz glossed in his writings. For Phil Rosen, the cardinal concept of the Metzian approach in its initial phase is that of 'specificity'. What mattered was defining the specificity of film language and the modes of cinematic expression. Other contributors, like Selim Krichane, emphasized the strategic place of the notion of 'code', as described in Metz's masterwork Langage et cinéma (1971). ${ }^{2}$ These concepts have allowed us to evaluate the strategy of the disciplinary transfers that Metz questions throughout Le signifiant imaginaire (1977), ${ }^{3}$ transfers mobilizing linguistics, rhetoric, and psychoanalysis. In this regard, despite the violent shocks of cognitivism and philosophical approaches largely hostile to the heritage of structural linguistics, the central position of Metzian theory within film theory remains secure. The phenomenon of fashion regularly modifies its centres of interest because that is its raison d'être.

2 Christian Metz, Language and Cinema, trans. by Donna Jean Umiker-Sebeok (The Hague: Mouton, 1974).

3 Christian Metz, The Imaginary Signifier: Psychoanalysis and the Cinema, trans. by Celia Britton and others (Bloomington: Indiana University Press, 1982 [1977]). 
Thus, structuralism is now out of date, as is film semiotics. More generally, theory itself is no longer popular. Theory has been replaced by various approaches, both subjective and personal, whose links to theory are more tenuous, peppered with references to new authors à la mode.

Discussions during the colloquium highlighted a paradigm change in the reference framework. The most radical change concerns what Metz called 'the cinematic institution', which has been altered over the last twenty years by the appearance of digital technology and the widespread diffusion of digital images on very different platforms. There has been an indisputable diminution of the heretofore dominant model, which was represented by the movie theatre and the screening of films therein. Throughout his writings, from the initial Essais sur la signification au cinéma I (1968) ${ }^{4}$ up until Le signifiant imaginaire (1977), Metz continued to examine the cinematic institution, for which he provided a definition and whose characteristics he enumerated, particularly regarding the dispostif or apparatus and the position of the spectator. Had he lived, he surely would have extended his investigations to include these spectacular transformations of the institutional model. Returning time and again to André Bazin's fundamental question, Qu'est-ce que le cinéma? (What is Cinema?), Metz responded in lexical, grammatical, expressive, psychological, and sociological terms. Obviously, film is no longer what it was at the time of the theoretician's death in the early 1990s. In this regard, current research is consistent with Metz's examinations in Le signifiant imaginaire regarding the spectatorial apparatus and the institutional status of cinema vis-à-vis the screening of moving images. Examples include Raymond Bellour's most recent book La querelle des dispositifs. Cinéma - installations, expositions, ${ }^{5} \mathrm{Jacques} \mathrm{Au}-$ mont's Que reste-t-il du cinéma?, ${ }^{6}$ André Gaudreault and Philippe Marion's La fin du cinéma?,7 and Francesco Casetti's current research on the postcinematographic period 'The Relocation of Cinema'. ${ }^{8}$ Today, screenings take place in the most diverse settings and depend upon increasingly personal and miniature formats, like cell phones.

4 Christian Metz, Film Language: A Semiotics of the Cinema, trans. by Michael Taylor (Chicago: Chicago University Press, 1991 [1968]). The second volume of the Essais sur la signification au cinema (1972) has never been integrally translated [translator's note.]

5 Raymond Bellour, La querelle des dispositifs. Cinéma-installations, expositions (Paris: POL, 2012).

6 Jacques Aumont, Que reste-t-il du cinéma? (Paris: Vrin, 2012).

7 André Gaudreault and Philippe Marion, La fin du cinéma? (Paris: A. Colin, 2013).

8 Francesco Casetti, “The Relocation of Cinema”, Necsus, 2 (2012): http://www.necsus-ejms. org/the-relocation-of-cinema/ (accessed 20 July 2015). 
What were the principal highlights of these three days of discussion? First, there has been a very noticeable renewed interest by scholars in the concept of enunciation, based on Metz's last book L'énonciation impersonnelle ou le site du film (1991). ${ }^{9}$ At least three speakers - Dana Polan, Dominique Bluher, and Alain Boillat - used the Metzian line of questioning as a point of departure: 'Who enunciates the film?'; 'What is the source of the enunciation?'; 'To whom is it addressed and in what form?' All of these questions return to the initial question 'What is cinema?'

A second field of reflection has to do with the genesis of Metzian thought. By analyzing issues of the Revue internationale de filmologie and Roland Barthes' articles on film, Guido Kirsten carefully evaluated the complex connections between filmological research in the 1950 s and the first semiotic research at the time of the Essais sur la signification au cinéma I (1968). Martin Lefebvre embarked on a particularly ambitious endeavor, studying the theoretician's unpublished archives at the Library of the Cinémathèque française $(\mathrm{BiFi})$. The Metz archives assemble a wealth of documents, book manuscripts, correspondence, and work notes. These notes comprise literally thousands of annotations on the films that Metz saw and commented upon almost daily. Both mnemonic aids and personal appreciations, they testify to a profound and constant cinephilia bordering on an obsession. They demonstrate that Metz's theoretical drive was developed and nourished by a compulsive and passionate cinephilia. For several pages in Le signifiant imaginaire (1977), Metz put this drive under the microscope. Here are a few excerpts from the section entitled 'Loving the Cinema':

What is it that I want to say about these writings whose approach is that of love? ... The effort towards knowing is necessarily sadistic insofar as it can only grasp its object against the grain, re-ascend the slopes of the institution (whereas the latter is designed for one to 'follow' them, to

9 Christian Metz, L'énonciation impersonnelle ou le site du film (Paris: Méridiens Klincksieck, 1991). The first chapter of this book is based on an essay that was published in Vertigo, 1 (1987), pp. 13-34, and would appear translated into English as 'The Impersonal Enunciation or the Site of Film (In the margin of recent works on enunciation in cinema)', [translator unknown], New Literary History, 22/3 (1991), pp. 747-72; reprinted in The Film Spectator: From Sign to Mind, ed. by Warren Buckland (Amsterdam: Amsterdam University Press, 1995), pp. 140-63. Another two extracts from Metz's final book have been translated by Cormac Deane, 'Secondary Screens, or Squaring the Rectangle' and 'Film(s) within Film', New Review of Film and Television Studies, 8/4 (2010), pp. 358-71. Deane's translation of the whole book was published by Columbia University Press in 2016 [translator's note.] 
descend them), like the interpretation that goes back along the path of the dream work, acting by nature in the manner of a counter-current.

And the following, oft-cited lines have achieved a cult status:

To be a theoretician of the cinema, one should ideally no longer love the cinema and yet still love it: have loved it a lot and only have detached oneself from it by taking it up again from the other end, taking it as the target for the same scopic drive which had made one love it. ${ }^{10}$

The work of the scholarly team at Concordia University, coordinated by Martin Lefebvre, is surely going to modify the image we have of a fanatic scholar, obsessed with scientific rigor. In his essay on the relationship between semiotics and aesthetics, Lefebvre comments upon this view; Lefebvre's contribution also usefully provided the occasion for the publication of a previously unknown Metz paper in the film history journal $1895 .^{11}$

Metz is most certainly the founder of a research discipline called cinema and/or film studies. His articles between 1964 and 1968 enabled university research on film to become established by acquiring an institutional position through teaching and scholarship. It is no exaggeration to say that without Christian Metz's work, the creation in 1983 of a research centre like IRCAV (Institut de recherche sur le cinéma et l'audiovisuel) at the University of Paris III (Sorbonne Nouvelle) and its equivalents at other French and foreign universities would have been impossible.

Two decades after his death, the Zurich colloquium also confirmed the broad influence of Metzian thinking and its effect on research on language, the semiotics of the image, gender studies, feminist studies, and a psychoanalytical approach toward film in general. Metzian hypotheses contributed to the birth of the textual analysis of film and have spread into vastly different analytic approaches to film. His hypotheses gave legitimacy to a detailed and erudite study of filmic works, which we can today undertake in the same manner and with the same rigour and insight

10 These excerpts are taken from Ben Brewster's translation, 'The Imaginary Signifier', published in Screen, 16/2 (Summer 1975), 14-76 (pp. 25-26). The English translation antedates the 1977 publication of Le signifiant imaginaire, because Metz first published his research as an article 'Le Signifiant imaginaire' in Communications, 23 (1975). The fact that the translation appeared almost simultaneously with the original corroborates the intense interest in Metz's work among Anglo-Saxon scholars at this early date [translator's note.]

11 Christian Metz, 'Existe-t-il une approche sémiologique de l'esthétique?' previously unpublished text, presented by Martin Lefebvre, 1895, Revue d'Histoire du cinéma, 70 (2013), pp. 154-67. 
as the analysis of a literary work, a painting, or a musical composition. In the last two decades, there has been a significant increase in monographic series that tackle the analysis of individual films, either in the form of personal essays or in a more pedagogical form, whether in English, French, or Italian. Such works continue the post-war tradition of notes, proposed by the ciné-clubs and exemplified by André Bazin's notes on Marcel Carnés Le jour se lève (F 1939). ${ }^{12}$ From Bazin to Metz: twenty years later, applying his grande syntagmatique, Metz created a breakdown of Jacques Rozier's Adieu Philippine (F/I 1962) that proved a turning point in how to study a film. ${ }^{13}$

Metz's legacy is particularly noticeable in recent years because of the proliferation of film studies around the world, just when there is a change of guard. One after another, the professors-scholars who worked with him or who knew him are retiring, replaced by a new generation who did not live through the Structuralist wave of the 1960s. This generational change is accompanied by a lively competition between disciplines, which safeguards research. Today, linguistics and structuralist thought are no longer obligatory references. They have been replaced by philosophy (under its cognitivist or Deleuzian aspect), aesthetics, art history, sociology, political history, the history of cultural productions, and cultural studies (popular in Anglo-Saxon countries) with its multiple ramifications.

\section{Translated from French by Sally Shafto}

\section{About the author}

Michel Marie is Professor Emeritus at the University of Paris III (Sorbonne Nouvelle), where he taught for nearly 40 years, beginning in 1973. In the early 1970s, he was a student of Christian Metz, who co-supervised his doctoral thesis with Marie-Claire Ropars. Together with other students of Metz's seminar, Marie co-wrote several introductory handbooks of film studies, such as Lectures du film (1975), Esthétique du film (1983), and L'Analyse des films (1988, new edition in 2015), which have been translated into several languages. He has been editor of the 'cinéma' series at Editions Nathan,

12 André Bazin, 'Fiche du Le jour se lève, de Marcel Carné', in the review Doc (Paris: Peuple et Culture, 1948). Reprinted in: Regards neufs sur le cinéma (Paris: Editions du Seuil, 1953 and 1962), and André Bazin, Le cinéma français, de la Libération à la Nouvelle Vague (1945-1958), (Paris: Cahiers du cinéma, 1983) pp. 53-75, texts collected and prefaced by Jean Narboni.

13 Christian Metz in collaboration with M. Lacoste, 'Syntagmatic Study of Jacques Rozier's Film Adieu Philippine' [1967], in Film Language, pp. 177-82. 
and later at Armand Colin, since 1988. In 1989, he organized the conference 'Christian Metz et la théorie du cinéma' and co-edited the conference volume with Marc Vernet in 1990. Currently, Marie is researching the works of Pierre Perrault and co-editing the correspondence between Perrault, Louis Marcorelles, and Guy Gauthier for Presses de Rouen.

\section{About the translator}

Sally Shafto is a specialist on Godard and the author of The Zanzibar Films and the Dandies of May 1968 (Editions Paris Expérimental, 2007). Her translations have appeared in Cahiers du cinéma, Yale French Studies, and other journals. From 2010 to 2015, she taught in Morocco, where she also actively followed Maghrebin and African film for two online film journals (Senses of Cinema and Framework). Currently, she is at work on the English-language edition of the writings of Danièle Huillet and Jean-Marie Straub (forthcoming, Sequence Press, New York). 


\title{
4. Christian Metz for Today
}

\author{
Roger Odin
}

Tröhler, Margrit and Guido Kirsten (eds.), Christian Metz and the Codes of Cinema. Film Semiology and Beyond. Amsterdam University Press, 2018

DOI: $10.5117 / 9789089648921 / \mathrm{CHO} 4$

\begin{abstract}
This chapter attempts to explain the currency of Christian Metz: his way of conceiving of research (particularly his mistrust of research directed from above, whether by an institution or by a thesis supervisor), his conception of the relation between theory and cinema (Metz approaches cinema from the outside, a well-forgotten paradigm now that everyone proposes their definition of cinema), and the objectives he set for research. At a time when mobile phones and computers more generally turn cinematic language into a language of everyday communication, it is more important than ever to examine film's functioning within this new framework.
\end{abstract}

Keywords: film semiotics/film semiology, research ethics, epistemology, conception of cinema, portable media devices

Re-reading the interview between Christian Metz, Michel Marie, and Marc Vernet in the proceedings of the Cerisy colloquium Christian Metz et la théorie du cinéma, I was struck by something in the final section, entitled 'For Roland Barthes'. Here, Metz declares, 'Roland Barthes was the only true master I ever had.' Instantly, I became aware of an obvious fact: 'Christian Metz was the only true master I ever had.'

Until that moment I had barely thought of Christian Metz in these terms. When I spoke of Christian, it was as a friend who had greatly influenced me in my research. However, I have many other, closer friends than Christian Metz (even though, at my time of life, a certain number of them disappear with each passing year), and I have been influenced by many people other

$1 \quad$ Michel Marie and Marc Vernet, 'Entretien avec Christian Metz', Iris, 10 (1990), 271-97 (pp. 295-96). 
than Metz. For example, I owe my passion for scholarly research to Jean Bruneau (a specialist in comparative literature and a Flaubert expert), with whom I did my DESS in comparative literature on George Bernard Shaw's Saint Joan at Lyon. And I also owe much to A.J. Greimas, with whom I completed a $3^{\text {rd }}$ cycle thesis on Joan of Arc in Primary School Textbooks, and whose theoretical model I still find convincing in a lot of ways. And to Sol Worth, whom I met only once, I owe the starting point of my semiopragmatic model as a model of non-communication. ${ }^{2}$ So I have other friends, and other people have influenced me, but I am now convinced that what is particular about my relationship with Christian Metz is that he was 'the only true master I ever had'.

To describe this relationship, I could repeat almost verbatim what Metz says about his relationship with Roland Barthes: 'having had a master' like that involves 'something else' besides influence, 'something that no book can convey', 'a closeness in ways of doing things', the transmission of a 'practical philosophy' more than an education, a 'tone', 'a general attitude'; above all, the transmission of 'a kind of ethics'. ${ }^{3}$ It is this transmission of 'a kind of ethics' that is so important. It 'constantly inspired me' or 'I at least constantly aspired to it' (I'm quoting Metz on Barthes again), ${ }^{4}$ in particular for the entire twenty years that I headed (rather than directed) the Institut de Recherche sur le cinéma et l'audiovisuel at the University of Paris III (Sorbonne Nouvelle). In this article it is my aim to present some positions (or propositions) of Christian Metz that seem to me to be particularly worth recalling today.

\section{Metz's Position on Research}

In an interview with Daniel Percheron and Marc Vernet, published in the magazine Ça cinéma, Metz points out the dangers of an ill-conceived research strategy:

The majority of organised efforts to do research have the principal outcome, if not the unconscious goal, of making all research very difficult due to the weight of their own bureaucracy, their latent authoritarianism, 
due to the time and energy wasted at meetings, writing up reports, and so on. ${ }^{5}$

And:

We spend hours relating pieces of research to one another, their main point in common being that they have none. Sometimes it takes a long time to conclude that none will ever exist. And at the same time, we will notice that every one of these participants has carried out some work, or written something, which he has not really spoken about at meetings. But it was something that he truly wanted to do, and which he all of a sudden has gone to the trouble of doing. ${ }^{6}$

I am convinced that many of my colleagues will identify with these descriptions, all the more so because, since Metz's day, the situation, far from improving, has become considerably worse, what with the top-down management and organisation of research; encouragement to bring together research teams with different histories, experiences, and ways of working that create disparate, awkward and unendurable partnerships; the necessity of registering with (European or international) 'programmes' made up of enormous 'machines' that are very difficult to manage in a productive manner; the multiplication of reports and evaluation procedures, etc. Of course, one must respond to these demands, otherwise one cannot take advantage of the means to make a research team function, but this must be done so it does not hinder research. This is hard to do and takes up a large amount of energy. Metz's solution was succinct: 'Research needs space to breathe' (the emphasis is mine) because 'the real motivations of scientific work, as with any kind of activity, are instinctual, because researchers are human beings'? In concrete terms, it is about creating not a 'scientific space' (this can only come afterwards), but first of all a space to breathe, something which is very rare (it is easier to research if you can breathe): it is not enough to create research ex nihilo, but such a space at least makes it possible not to kill research at an embryonic stage when, in a group, a real spirit of research is being established.

5 Marc Vernet and Daniel Percheron, 'Entretien avec Christian Metz', Ça cinéma, 2/7-8 (1975), 18-51 (p. 44); reprinted as 'Sur mon travail (Entretien avec Marc Vernet et Daniel Percheron)', in Christian Metz, Essais sémiotiques (Paris: Klincksieck, 1977), pp. 163-205.

6 Vernet and Percheron, 'Entretien', pp. 28-9.

7 Raymond Bellour and Christian Metz, 'Entretien sur la sémiologie du cinéma', in Christian Metz, Essais sur la signification au cinéma, 2 vols. (Paris: Klincksieck, 1972), II, 195-219 (p. 219). 
Metz goes on to say:

the 'policy' that I am thinking of consists of a small number of elements, but attention is rarely paid to these few elements and they are not easily realized. A tone, a general attitude, that consists of various minimal acts of approaching (which, however, have to be quite finely tuned) and also withholding, [...] being ready to talk to people (and, above all, to listen to them), not to let your own problems displace theirs, to let them speak.

Metz means to create as relaxed a relationship as possible among colleagues, which is, he rightly adds, 'something rare, because intellectuals are no more intelligent than other people, and they're generally more uptight'.

The current policy of putting universities in competition with one another and of making teams within a university - as well as people within teams - compete with each other makes it even more difficult to achieve this kind of breathing space. In a world where everything is done to encourage individuals to prevail over one another, where structures foster hierarchies, and where the tendency is to give more power to those in administrative positions (in the university, in a department, in a team), thus multiplying the number of 'little bosses', Metz is an example of a researcher who did everything not to put himself 'in the position of boss', ${ }^{9}$ even to the point that he refused to edit a journal. ${ }^{10}$ Metz was particularly reluctant when it came to the idea of a school ('the more a school is informal and dilute, the more real and vibrant it is; which is to say, this would not be a school'),, as seen in his determined refusal to found one. ${ }^{12}$ This was one of his major points of disagreement with Greimas and with what some people called the Paris School (Ecole de Paris), which is the title of an edited volume that came out in $1982 .{ }^{13}$ Metz denounced what he called 'the non-stop, stupid psychodrama of memberships and affiliations ${ }^{14}$ as well as the "posture of disciple, which calls forth a paternalistic image':15 'I like neither the term

8 Vernet and Percheron, 'Entretien', pp. 44-45 (source for all cited texts since previous footnote marker; emphasis in original).

9 Marie and Vernet, 'Entretien', p. 280.

10 'I have never wanted [...] personally to edit a journal, as it would straightaway put me in the position of boss.' Marie and Vernet, 'Entretien', p. 280.

11 Vernet and Percheron, 'Entretien', p. 41.

12 'I have never wanted to found a school.' Marie and Vernet, 'Entretien', p. 280.

13 J.-C. Coquet and others, Sémiotique. L'Ecole de Paris (Paris: Hachette, 1982).

14 Vernet and Percheron, 'Entretien', p. 47.

15 Ibid., p. 45 . 
nor the idea of "disciple": they diminish the disciple and are burdensome for the "master". ${ }^{16} \mathrm{He}$ expressed equally serious reservations in relation to the status of a thesis 'supervisor' (the quotation marks are his): 'Institutionally, I find myself obliged to "supervise" theses [...] "Supervise" is an absurd term, as the job is to discuss matters with candidates, if need be to advise them on what to read, ${ }^{17}$ and above all to allow each one to choose his or her area of research in genuine freedom: 'There is one very important thing in research, something very simple, and perhaps for that reason frequently forgotten: everybody must study what they want to study. ${ }^{18}$ Metz never tired of repeating that research is driven by desire, and there is nothing worse than stymied desire. The main task of the thesis 'supervisor' is to free up this desire. "The best thing that any of us can do for the "research community", such as it exists at all, is to find our own path and our own voice. ${ }^{19}$

More broadly, Metz was always concerned with avoiding any disciplinary imperialism: 'Cinema is just one object of study among many others, semiology is only one way of approaching it, and I myself am only one of several semiologists of cinema. ${ }^{20}$ In his interview at the Cerisy conference, he returned to the subject with genuine feeling:

I am not the head of a school or the 'Pope of Audiovisual Studies'! This idiotic notion that is sometimes used to describe me is not based on reading my work or on knowing what I do. On the contrary, I am very mistrustful of imperialist forms of semiology ... for me, semiology must remain one approach among others that is well suited for doing certain things, but not everything. ${ }^{21}$

With Metz, we are a long way from the gibes, snide remarks, and broadsides with which rival researchers attack each other, particularly (but not only) in America. Metz truly believed in Barthes' vision of theories as 'different languages that are more or less apt in any given case to discuss this or that object', ${ }^{22}$ and he demonstrated this by example. He gently mocked the psychodramas that flare up in research communities, describing certain theorists who had "first "fought" the battle of classical semiology, then

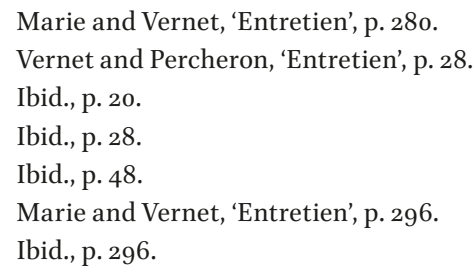


the battle of sign-analysis, and today the battles of Deleuze-Guattari and Lyotard, in every case with the same enthusiasm in a torrid atmosphere of apocalyptic interrogation, ${ }^{23}$ while for him, moving from semiology to psychoanalysis seemed natural:

Those who look superficially or who share the ritual eagerness to detect 'changes' as often as possible will perhaps think that I have abandoned certain positions or turned away from them when in fact, more simply - less simply, of course - I am giving in to the temptation (the attempt) to drive a little deeper into the very procedures of knowledge. ${ }^{24}$

This non-hostile relationship with other fields and disciplines remains, despite everything that we hear about inter- or multi-disciplinarity, the thing that is least widely shared in the world of research today. But there is more. Metz was clearly concerned about 'integration'. This is a term I have taken from Laurent Jullier: 'I have come to realise, after fifteen years of reading books of film theory, that researchers rarely have the reflex to integrate in the way that we see in the hard sciences. I have two meanings of "integration" in mind; the researcher integrates his or her work into what already exists, and makes it available to be integrated by others. ${ }^{25}$ Metz said as much himself: ' $[\mathrm{M}]$ ethods are things that cannot be exchanged, [...] but information and understanding, morsels of acquired knowledge, can and must circulate. ${ }^{26}$ All we have to do is re-read Metz's work to see the care that he took to demonstrate what previous analyses had achieved (classical film theory, filmology). He always sought to point out his connections, in particular to phenomenology, ${ }^{27}$ to open up to other approaches (theories of writing in the final chapter of Language and Cinema, ethnography, cultural and social analysis, the analysis of ideology at the end of 'The

23 Vernet and Percheron, 'Entretien', p. 50.

24 Christian Metz, 'The Imaginary Signifier' [1975], in The Imaginary Signifier: Psychoanalysis and the Cinema, trans. by Ben Brewster and others (Bloomington: Indiana University Press, 1982 [1977]), 1-87 (p. 3).

25 Laurent Jullier, 'Psychologie cognitive et études cinématographiques', in L'apport cognitiviste à l'esthétique du cinéma (Diploma in Research Supervision, Université de Paris I; supervisor: D. Chateau, 2001): http://laurent.jullier.free.fr/TEL/LJ2001_Psycho.pdf(accessed 8 April 2016). 26 Christian Metz, Language and Cinema, trans. by Donna Jean Umiker-Sebeok (The Hague/ Paris: Mouton, 1974 [1971]), p. 20 (translation modified).

27 See the end of Christian Metz's article, 'Le perçu et le nommé', in Essais sémiotiques, 129-61 (pp. 16o-61). 
Fiction Film and its Spectator, ${ }^{28}$ pedagogy ${ }^{29}$ ). He drew comparisons (with the analysis of literature, theatre, and music), or suggested other possible kinds of analysis, particularly for other cinematic contexts (Africa, Egypt, etc.). Metz's studies are anything but self-enclosed texts. Rather, they build bridges of understanding and open up perspectives. If Christian Metz's reflections on the work of research seem still relevant to me today, the same can be said for his position on the relations between theory and cinema.

\section{Metz on the Connections between Theory and Cinema}

There is a well-known phrase by Metz that, in a certain way, sums up the essence of what he has to say to us: 'Without a machine, we can be sure in advance of seeing nothing. ${ }^{30}$ Obviously, he means without a theory machine. At the end of my paper at the colloquium at Cerisy, ${ }^{31}$ I suggested that these words be inscribed in gold everywhere in universities where cinema is taught. And now they seem more necessary to me than ever, and I am not alone in this. In the conclusion of his recent book, L'invention du concept $d u$ montage, Dominique Chateau deplores the 'current tendency' to 'neglect' the 'box of tools' ('The analyst needs a box of tools') and insists on the 'necessity of using a method of analysis or of creating one'. ${ }^{32}$ I might also add here what I said in 2007 in the introduction to an issue of the journal Cinémas: 'Theory is finally in crisis':

In my field of cinema and audiovisual studies at the university in France, theory is barely on the agenda at all. [...] We are witnessing the return of older forms of criticism that I had thought it would be impossible to speak of without ridicule. This is a reaction against jargon, and against the 'ravages' of analytic frameworks, and more generally against every approach that is slightly scientific (obviously cognitivism is the target here). There are some who have no problem speaking in this regard about a 'fascistic stranglehold' 'that aspires to doctrinal control' in the university, and they cite Gombrowicz: 'every theory is an error of thought.' The fashion is to

28 Christian Metz, 'The Fiction Film and its Spectator. A Metapsychological Study' [1975], in The Imaginary Signifier, 99-147 (pp. 140-42).

29 See the section 'Images et pédagogie', in Metz, Essais, II, pp. 141-50.

30 Vernet and Percheron, 'Entretien', p. 34.

31 Roger Odin, 'Christian Metz et la linguistique', Iris, 10, pp. 81-104.

32 Dominique Chateau, L'invention du concept de montage: Lev Kouléchov théoricien du cinéma (Paris: Editions de l'Amandier, 2013), p. 162. 
eulogize the 'je ne sais quoi', a 'je ne sais quoi' that constitutes, seemingly, 'the appeal of the university'.33 And I who believed that the university was supposed to teach rigorous thinking - I was going to say rigorous epistemology, but that's a big word nowadays. ${ }^{34}$

In 'Theory, Post-Theory, Neo-Theories: Changes in Discourses, Changes in Objects', Francesco Casetti says something similar: 'there is an increasing de-legitimization of rationality and rationalized discourses', and he speaks of 'the end of explanation'.35 I have to admit that I no longer detect among my students the same desire for theory that I found in my early years of teaching at Paris III. It's true that theory was fashionable then, but, as Metz points out, 'that tells us something about fashion, not about theory. ${ }^{36}$ Rather than lament this state of affairs, we need to ask why it has come to this. Dominique Chateau suggests two possible answers: 'Perhaps due to laziness, because it [theory] requires work. Or perhaps also in line with the postmodern tendency that too often traces theory back to ideology. ${ }^{37}$ For my part, I have advanced several hypotheses: What if theory has become discredited by its own polemics? What if theory has become too distant from common sense, from the social life of films (the problem of immanentism), and from the individual's relation with film (the problem of interpretation)? I could add what Metz left us above all, that theory can only happen by destroying its object of desire: 'To study cinema: what a strange thought! How to do this without "breaking" film's benign image and its idealization as a full and simple "art", the seventh "art"? ${ }^{38}$ But we need to put this sentence back into context. In this passage, Metz is taking himself to task - as the film lover that he was - above all. How can we be surprised if students refuse to do theory if we start by telling them this? On the contrary, I think that Metz's work can help to reposition theory at the centre of students' attention. In reality, Metz is the epitome of somebody who theorized cinema because he loved it. Chateau is certainly correct in saying that any theoretical approach requires work to master its tools, but I am not convinced that the problem lies here. What students need to be made to understand is

Charles Tesson, 'Et la critique continue', Panic, 2 (2006), pp. 57-62.

34 Roger Odin, 'Présentation', Cinémas, 17/2-3 (2007), p. 9.

35 Francesco Casetti, 'Theory, Post-Theory, Neo-Theories: Changes in Discourses, Changes in Objects', Cinémas, 17/2-3 (2007), pp. 39-41.

36 Marie and Vernet, 'Entretien', p. 276.

37 Chateau, L'invention, p. 162.

$3^{8}$ Metz, 'The Imaginary Signifier', p. 80 (translation modified). 
precisely that these tools enable us to deepen our relationship with the thing we love. The quotation from Metz that we should remember is this: 'in wishing to construct the film into an object of knowledge, one extends, by an additional degree of sublimation, the passion for seeing that made the cinephile and the institution what they are' ${ }^{39}$ For my own part, I can think of many instances where it was theoretical reflection about a film that brought me to love it - not least A Day in the Country (Jean Renoir, F 1936), which I had no special feelings for until I examined it as an example of how the fiction film functions.

From the point of view of researchers who persist with theory, things have also changed considerably since Metz. In 'Le Cinéma et ...', the opening article from Christian Metz et la théorie du cinéma, Raymond Bellour shows that what makes Metz a 'founder of discursivity' lies in his position of 'self-imposed exteriority'. ${ }^{0}$ Metz insisted on this on several occasions: 'I am a little outside of the world of cinema, engrossed in a different mental universe. 'For me, cinema is rather a corpus. It is my reservoir of examples, it is the thing in relation to which I say things that stir me. In short, cinema is my "theme" rather than my "predicate". ${ }^{41}$

In saying this, Metz inserts himself into a tradition going back to filmology, which he actually refers to in his thesis application ${ }^{42}$ and in some of his writings. However, when I look at publications by cinema theorists in recent years (at least from a certain number of them, and they are many), I notice that I am faced with a totally different discourse. Everyone has a go at defining cinema, or rather, at defending his 'idea of cinema', to use Dudley Andrew's phrase. ${ }^{43}$ I will limit myself here to some examples taken from writings by theorist friends, which I find important and interesting for several reasons. In the deliberately provocatively titled What Cinema Is!, Dudley Andrew straightaway emphasizes that there are different 'ideas of cinema' (the cinema of attractions, non-narrative cinema, educational cinema, industrial cinema, even amateur cinema), and that each one obliges us to have an open mind on cinema as a whole. But his entire argument is a defence and illustration of an idea of cinema, an idea that he opposes to another that is related to digitization:

Ibid., p. 79 (translation modified).

40 Raymond Bellour, 'Le cinéma et ...', Iris, 10, 15-35 (p. 19).

41 Vernet and Percheron, 'Entretien', pp. 26-27 (emphasis in original).

42 Rediscovered by Martin Lefebvre and published in 'L'aventure filmologique. Documents et jalons d'une histoire institutionnelle', Cinémas, 17/2-3 (2007), 59-100 (pp. 59-6o).

43 Dudley Andrew, What Cinema Is! (Chichester: Wiley-Blackwell, 2010). 
The films some of us most care about - and consider central to the enterprise of cinema in toto - have a mission [...]: they aim to discover, to encounter, to confront, and to reveal. If anything is endangered by the newly digitalized audiovisual culture, it is a taste for the encounters such voyages of discovery can bring about. Apparently, many today feel that the world and the humans who inhabit it have been sufficiently discovered, that no new revelations await, at least not in a medium dominated by entertainment and advertising. ${ }^{44}$

So, the whole book aims to present us with forms that are captured by this movement of revealing in the acts of recording, composing, and screening.

Raymond Bellour addresses this question in terms of dispositive in $\mathrm{La}$ querelle des dispositifs. His definition is precise and final:

[T] he experienced screening of a film, in a dark room, for a prescribed duration in a more-or-less-collective viewing experience, has become and remains the condition of a unique experience of perception and memory that defines the spectator and that every other situation of vision more or less distorts. And only this can be called 'cinema'. ${ }^{45}$

The aim of this strict definition is to make it possible to distinguish the cinematic experience from various experiences that are related to the use of cinematic language in other contexts, experiences that are 'sufficiently different' for us not to confuse them. ${ }^{46}$ But these other experiences are not held in low regard; in fact, the majority of this work by Bellour is devoted to them and to detailed analysis of an impressive number of installations and productions of all kinds, in order to determine their specificity.

In Que reste-t-il du cinéma?, Jacques Aumont imposes a different limit on the cinematic experience. He admits that the 'mental model' of cinema can function in several dispositives - for instance, in front of a domestic television and even in front of a computer - and that the advent of the digital has changed nothing at this level, ${ }^{47}$ but he considers that 'any presentation of a film which enables me to interrupt or to modulate the experience is not cinematic'; 'it is not cinema'. For Aumont, cinema is defined by 'the

44 Ibid., p. xviii.

45 Raymond Bellour, La querelle des dispositifs. Cinéma-installations, expositions (Paris: P.O.L., 2012), p. 14.

46 Bellour, La querelle, p. 16.

47 Jacques Aumont, Que reste-t-il du cinéma? (Paris: Vrin, 2012), p. 78 and 80 respectively. 
production of a gaze that is captured in time ${ }^{48}$. It's worth noting that the same theorist proposed a rather different definition of cinema in $A$ quoi pensent les films: 'The object of analysis is the animated image insofar as it considers itself to be an image, and insofar as it produces thought', to which he added, 'many run-of-the-mill films do not satisfy this condition'. ${ }^{49}$ The phrase 'object of analysis' insists on the explicitly constructed character of the cinema object, thereby avoiding any essentialist definition. Cinema is understood here as a specific 'place of ideation'. A few years earlier, in 'Mon très cher objet', Aumont anticipated Andrew's stances and saw the digital as the death of cinema.

It is in its final death throes if we think of it as a machine for showing the world. [...] we are already in a position, technically speaking, to fabricate things that will seem like film but which will be entirely reconstituted. [...] (I am not saying that this will not also have the bonus of giving pleasure and a sense of appreciation. I am saying that this will no longer be, that it no longer is, cinema)..$^{50}$

Unlike the authors I have just mentioned, whose concern is to arrive at a precise, limiting definition of cinema, Philippe Dubois has taken on the heroic task of developing a (very) broad conception that includes everything that goes on these days in museums and galleries as installations:

With all due respect to purists of every stripe, who hold tight to a lost, dreamed-for, regressive identity for cinema, and who still live in the nostalgic belief of an unimpeachable (but exploded) specificity, yes this is cinema, open and multiple - an 'expanded' cinema that has overstepped its boundaries and frames. This is non-theatrical cinema, cinema outside the walls, outside the dispositive..$^{1}$

In short, Dubois finds cinema wherever there is a moving image. In Eye of the Century, Francesco Casetti occupies a somewhat in-between position. $\mathrm{He}$ suggests that we need to distinguish between two forms of cinema-Cinema 1.o, which is 'photographic' cinema, cinema of the 'trace', that is produced

48 Aumont, Que reste-t-il, pp. 82-84 (emphasis in original).

49 Jacques Aumont, À quoi pensent les films (Paris: Séguier, 1996), p. 8.

50 Jacques Aumont, 'Mon très cher objet', Trafic, 6 (1993), 53-69 (p. 62).

51 Philippe Dubois, 'Introduction/Présentation', in Oui, c'est du cinéma. Formes et espaces de l'image en mouvement (Pasian di Prato, Italy: Campanotto, 2009), p. 7. 
for screening in a theatre for a spectator who is invited to adopt a specific discipline of the eye, and Cinema 2.o, which is digital cinema and can be seen in extremely varied dispositives and which also is more often found in the fields of interactive multimedia communication (gaming) or of physical effects (speed, vertigo, hybridization of humans) than in narrative film. It is quite clear that Casetti is rather perplexed in the face of this second kind of cinema, but in a slightly desperate attempt to preserve his object of study, he insists on the fact that it really still is cinema: 'Cinema continues to be discussed, and, indeed, discussed a great deal. Even now, it has an important role to play [...] So, in spite of the far-reaching changes it has undergone, it remains a significant presence. $5^{2}$

The first observation that arises from this quick review and comparison with Metz is that we realize how resolutely different things are today. Some of these definitions give rise to theoretical developments that are extremely detailed, others less so, but what they all have in common is that, to various degrees, they are written in defence of an object of love. You get the feeling that something very profound is being touched upon here, each person's passion for cinema, for the very raison d'être of a person or their life - where to oppose their conception of cinema is experienced as a kind of sacrilege. In fact, what we are witnessing is a paradigm shift, from one of exteriority to one of interiority, from a descriptive theory to a prescriptive theory that defines cinema in terms of values. We have seen this happen before. As early as 1948, Gilbert Cohen-Séat pointed out in La Nef, with a certain wickedness, cinema's great appetite for defining itself - 'to define itself, we must first understand that cinema attempts to do this from within. Convinced that it can give some internal logical coherence to its own conception of itself, it is more than ready to feel satisfied'. And he equated this position to 'puerility of egocentric thinking' as Piaget defined it, before proposing 'leaving the cinema, thinking about it from the outside, and completely changing our bearings', ${ }^{53}$ which opened the way towards filmology. For his part, Metz opposes two kinds of 'theory' at the start of Language and Cinema:

$[T]$ heory which is concerned with films to come, which sees things in terms of influence, which does not hesitate to counsel and prescribe,

52 Francesco Casetti, L'occhio del Novecento. Cinema, esperienza, modernità (Milan: Bompiani, 2005), p. 297. Casetti's book has been published in English: The Eye of the Century. Film, Experience, Modernity, trans. by Erin Larkin (New York: Columbia University Press, 2008).

53 François Albera and Martin Lefebvre, 'Présentation. Filmologie, le retour?', Cinémas, 17/2-3 (2007), 13-56 (p. 43). 
which seeks to respond directly to the technical problems of the 'creative artist' and is significant only from this perspective. On the other hand, there is that type of theory which is concerned with discourses which already exist and which seeks to analyze them as givens. ${ }^{54}$

There is something striking in this back-and-forth between the two paradigms; the internal one still seems to prevail, to the point that we may ask if it is perhaps not cinema itself that resists the external approach. We could support this argument by noting that filmology has practically disappeared from view, and that Metz himself in 'Cinema: Language or Language System?', even though he had already decided to pursue a linguistic approach, clearly defended an 'idea' of cinema, i.e. the cinema of Rossellini against the 'montage-roi' cinema of Eisenstein, ${ }^{55}$ and he did so with a virulence that easily bears comparison to those that I discussed before. ("This essay springs from the conviction that the "montage-roi" approach is not a fruitful path for film..$^{5}$ ) As for the present day, in the post-Metz period, we have just seen what it has become ... However, I should point out that these examples do not illustrate the same story at all. As Martin Lefebvre makes clear, if filmology petered out, it is not so much because it proposed an external approach; rather, it had institutional problems, personnel problems (see the case of Cohen-Séat) and also, to an extent, the scientific results were not of the quality its practitioners were counting on (especially the experimental results). ${ }^{57}$ The fact that Metz started by positioning himself partly outside the paradigm of exteriority is due to something else entirely: for Metz as a film-lover, leaving the fusing, affective positioning in reference to the object remained difficult, even if he had the will to do it. So it was not cinema that was resistant; it was the film-lover in Metz, someone who had a certain vision of his object of love (and this is true for all objects of love, not just for cinema). These days, still other reasons are given for abandoning the paradigm of exteriority. Confronted with the digital, and with the

54 Metz, Language and Cinema, p. 11 (emphasis in original).

55 Metz's expression 'montage-roi' was translated as 'montage-or-bust' in the English edition of 'The Cinema: Language or Language System?' [1964], in Film Language, trans. by Michael Taylor (New York: Oxford University Press, 1974 [1968]), 31-91 (pp. 31-39; translation modified). I have decided to use the French original instead, which could be understood as 'the king montage' or 'the all powerful montage' [translator's note].

56 Metz even goes into a long diatribe against the 'spirit of manipulation' that he says characterizes our society and culminates in productions that have been programmed on computers. The parallel here with Dudley Andrew's negative views on the digital is striking. Christian Metz, 'The Cinema: Language or Language System?', p. 38.

57 Lefebvre, 'L'aventure', pp. 59-100. 
dispersion of 'cinema' into extremely diverse spaces (museums and galleries, computers, tablets and mobile phones, etc.), these theorists see cinema as threatened. So, according to them, a defence needs to be mounted. The definitions I've described are attempts to intervene to preserve the object of research (and of love), by circumscribing it in a precise way (Andrew, Bellour, Aumont), or by making large claims for it (Dubois), or by accepting more or less unwillingly (Casetti) its protean quality. Both kinds of theories that Metz mentions (as quoted above) are about saving cinema. How can we not approve of approaches like this? But this should not prevent us from asking certain questions. On the one hand, we should ask whether the threat is actually greater today than it was in the past. We could put forward a counterargument that cinema has never been better off, and never have so many films been seen by so many viewers. On the other hand, in some of the best writing, the goal is to defend not just cinema but a set of values. Yet what is striking is that these values change depending on the author (and even, as we saw with Aumont, for the same author). Discovery, attention, the production of thought, encountering the real, openness ... each writer clearly considers these values essential to cinema. My feeling is that we could keep debating forever because there is no essence of cinema. Like all social constructions, cinema is multiple and variable. For D.N. Rodowick, this plasticity is one of the best reasons for speaking of 'the virtual life of film':

I think there is a deeper and more philosophical way of discussing 'virtuality' in relation to both film and cinema studies. One consistent lesson from the history of film theory is that there has never been a consensus concerning the answer to the question 'What is cinema?' And for this reason the evolving thought on cinema in the twentieth century has persisted in a continual state of identity crisis. ${ }^{8}$

Given this situation, Metz's position is to propose an attempt to describe this social construction (and not to promote one). This description, contrary to what we see in the other texts I have cited, is devoid of drama: 'For me, the fact of imagining the cinema as one social fact among others, and not more important than them, calling on the same general methods of analysis as them, is a painless operation that does not require a prior victory against an internal sacrilege. 59

59 Vernet and Percheron, 'Entretien', p. 27. 
The definition of cinema that Metz provides diverges radically from those we have been reading: " $[\mathrm{C}]$ inema is nothing more than the combination of messages which society calls "cinematic". ${ }^{60}$

There are two ways to interpret this definition. Either cinema is what society as a whole accepts as cinema; what everyone is ready to recognize as cinema (a common denominator). Or, cinema is everything that is called cinema in the social space; cinema in all its diversity. In 'Sémiologie audio-visuelle et linguistique générative', Metz privileges the first of these, speaking of the definition of film insofar as it 'functions in a real way in society'. ${ }^{6}$ We note, however, that, in both cases, the definition of cinema depends on the judgement of the society and that it is thereby susceptible to change as society evolves historically. In 'The Fiction Film and its Spectator', Metz notes, moreover: 'The cinema as a whole, insofar as it is a social fact, and therefore also the psychological state of the ordinary spectator, can take on appearances very different from those to which we are accustomed. ${ }^{162}$ So, what society as a whole called 'cinema' during film's early years is quite different to what was understood by the term in the 1950s. Likewise, if we compare the definition given by Metz (in terms of the pertinent aspects of the matter of expression) and what is going on today, the situation has been somewhat reversed: while Metz excluded animation from the territory covered by cinema because it does not make use of the quality of mechanical duplication, a number of theorists (Lev Manovich, Sean Cubitt) consider that from now on, owing to the advent of the digital, animation is at the heart of the definition of cinema. In a general way, it is clear that the term 'cinema' covers a wide variety of things whose history Metz invites us to trace. Let me make myself clear: what I am saying here implies no negative judgement of the principle of a normative theory. To defend cinema in the name of values is not only a praiseworthy project, it is also necessary - and the fact that there are several competing definitions of cinema is a good sign as far as the vitality of the object of cinema is concerned in society and for democracy. But it seems to me that it is important today to recall the existence of the external paradigm - i.e. the Metzian paradigm - because, on the one hand, we tend to forget quite how much the internal paradigm has come to dominate, and, on the other, because to reintroduce this paradigm into theoretical thinking gives us some perspective on the debates that rage in

60 Metz, Language and Cinema, p. 26.

61 Christian Metz, 'Sémiologie audio-visuelle et linguistique générative', in Essais sémiotiques, 109-128 (p. 112).

62 Metz, 'The Fiction Film and its Spectator', p. 138. 
the field. In short, we need to consider these debates as something to be analyzed. Viewed this way, the definitions of cinema that I have listed here become part of the object of analysis. This passage to a meta-level radically alters how we view the situation. Aumont, who switches levels in this way in Que reste-t-il du cinéma?, which I cited earlier, thus suggests that the entire problem arises from the fact that we lack a word:

If we say that cinema no longer has an exclusive claim over moving images, it is not to say that it has disappeared, no more than it has dissolved into a greater whole where it is more difficult to distinguish. What is missing in the end, to put this relatively simple situation simply, is a word, a unique word that would express 'various social usages of moving images'. But this word does not exist, not even in English, nor in Greek, and this is probably the entirely silly reason why we want so much to say that cinema is everywhere: it is not the thing that we want to universalize, it is the word and by default ...6

In La fin du cinéma?, Gaudreault and Marion believe they have discovered this word: 'animage'. ${ }^{64}$ The problem is that this word focuses on a sole aspect of contemporary moving images - for instance, it says nothing about their capacity to circulate and stand in for one another, as this has never previously been the case. Personally, I would say most simply that we need to distinguish between theory of cinema and theory of cinematic language, as cinema is a specific (which is not to say homogeneous) space of communication among all the spaces of communication that mobilize cinematic language. ${ }^{65}$

\section{Analysis of Cinematic Language Today}

If we can regard Metz as a 'founder of discursivity', it is in his capacity of 'founder' of the semiology of cinema, which is to say the 'science' of cinematic language. (I am putting scare quotes around 'science' because Metz was very wary and even mistrustful of the term.) Yet, what strikes

63 Aumont, Que reste-t-il, pp. 59-6o.

64 André Gaudreault and Philippe Marion, 'L'animage” et la nouvelle culture visuelle', in $L a$ fin du cinéma? Un média en crise à l'ère du numérique (Paris: Armand Colin, 2013), pp. 210-43.

65 On the concept of space of communication, see Roger Odin, Les espaces de communication. Introduction à la sémio-pragmatique (Grenoble: PUG, 2011). 
me is that today barely anybody is interested in the question of cinematic language.

It must be said that everything has been done to delegitimize the linguistic approach to cinema, which is still described as an approach that diminishes cinema at the expense of language, even though Metz intended otherwise. His aim was to oppose the cinematic language system to language but to make use of methods drawn from linguistics (and the questions posed by linguistics) in order to explain how this language system works. As for the cognitivists, they continue to assert that cinema is not a language system even as they analyze how cinema produces meaning, affect, and relations, which could very well be considered to be the definition of a language system; let us remember that Metz defined semiology as the study 'of mechanisms by which human significations are transmitted in human societies ${ }^{6}{ }^{6}$ One thing is certain - today, cinematic language is everywhere, and it has never been so widely exploited as a means of expression and communication.

There is a great temptation to see in this phenomenon the proof of the prophecies of Alexandre Astruc from the period of 1948-49, when he announced the arrival of the camera-pen (caméra stylo): 'The future of cinema is entirely in its potential to develop like a language. ${ }^{167}$ This is, however, to miss the point. When he said this, Astruc was dreaming of an auteurist cinema, in the sense of a cinema that could be compared to literature: 'Cinema has had its chroniclers and its photographers, and now it is awaiting its Stendhal, its Shakespeare, its Pascal, its Valéry and its Proust. ${ }^{68}$ So, with Astruc, we are in the space of communication of 'cinema as art'. Yet what is going on today is quite different. Certainly, it is possible to make films at home, like a writer writes books - films that could probably be classed as art $-{ }^{69}$ but the real revolution is elsewhere: cinematic language has invaded the space of everyday communications. This is something else entirely.

To my knowledge, only one work addresses this question directly: Lev Manovich's The Language of New Media. The computer is at the centre

66 Metz, 'The Cinema: Language or Language System?', p. 91.

67 Cited in Pierre Lherminier, L'art du cinéma (Paris: Seghers, 1961), pp. 592-93. Astruc was thinking at the time of the new possibilities opened up by $16 \mathrm{~mm}$ film. His concept of the caméra stylo has now become an almost obligatory reference point for new work on the mobile phone; cf. Elena Marcheschi, 'Videophone: A New Camera Stylo?' in Dall'inizio, alla fine / In the Very Beginning, at the Very End, ed. by Francesco Casetti and others (Udine: Forum, 2010), pp. 389-94. 68 Lherminier, L'art du cinéma, pp. 592-93.

69 See Roger Odin, 'Quand le téléphone portable rencontre le cinéma', in Téléphone mobile et création, ed. by Laurence Allard and others (Paris: A. Colin, 2014), pp. 37-54. 
of Manovich's attention, but it is cinematic language that he uses as an analytical tool, saying 'the theory and history of cinema serve as the key conceptual "lens" through which I look at new media'.70

Manovich's book is organized around two movements. He first asks: In what ways do new media change cinematic language? He suggests these possibilities: the capacity that the computer affords for navigation, the transformation of the concept of point of view in gaming, the development of spatial montage connected to the possibility of multiplying windows on the screen, and hybridization (Manovich uses the term 'cinegratography' to describe the mix of cinematic language and graphical elements) $\cdot{ }^{71}$ Second: What does cinema bring to new media? Manovich insists on the fact that cinematic language truly flows through the veins of new media: 'a hundred years after cinema's birth, cinematic ways of seeing the world, of structuring time, of narrating a story, of linking one experience to the next, are being extended to become the basic ways in which computer users access and interact with all cultural data' ${ }^{72}$

Later, Manovich says:

Cinema, the major cultural form of the twentieth century, has found a new life as the toolbox of a computer user. Cinematic means of perception, of connecting space and time, of representing human memory, thinking, and emotions become a way of work and a way of life for millions in the computer age. Cinema's aesthetic strategies have become basic organizational principles of computer software. The window in a fictional world of a cinematic narrative has become a window in a datascape. In short, what was cinema has become human-computer interface. ${ }^{73}$

Manovich even shows that the seeds of some of what we think of as the 'novelty' of new media already existed in pre-cinema (for instance, the structure of the loop). ${ }^{74}$

My aim here is not to summarize the contribution of this extremely rich and, for that matter, remarkably clear book - I can only invite readers to look

\footnotetext{
70 Lev Manovich, The Language of New Media (Cambridge, MA: MIT Press, 2001), p. 35.

71 Ibid., p. 262.

72 Ibid., p. 87 (my emphasis).

73 Ibid., p. 87 and 92.

74 Manovich, 'New Temporality: Loop as a Narrative Engine', in Language of New Media, pp. 264-69. A striking illustration of this is the current vogue for GIFs (named after the name of the format, Graphic Interchange Format), which are short animated films consisting of a repeated movement. GIFs were not used in this way when Manovich's book came out.
} 
at it. I would like to pursue these thoughts starting not with the computer but with a tool that Manovich does not deal with much: the mobile phone. The book dates from 2002, which pre-dates the advent of smartphones and the spread of video onto mobile phones. We should note that everything that Manovich says about the relation between cinematic language and computers also applies to the mobile phone, which by now is simply a small computer. But the mobile is also more than a computer; it is a private device that we always have with us, and it seems to me that this changes quite a few things in relation to the usage of cinematic language.

So, if there is a tool that enables cinematic language to function like a language of everyday communication, it is the mobile phone (more than computers, even portable ones). Today, thanks to the mobile phone, everyone can communicate through this language whenever or wherever they want, and what is more, they can choose from several modes of communication (text message, email, social networks).

However, in the same way that Manovich shows that cinematic language is changed when it is enabled by computers, we ought to ask ourselves in what ways it changes when conveyed by mobile phones. This is a complex issue, and I will limit myself to a few examples. Two questions raised by Metz in Impersonal Enunciation, or the Site of Film ${ }^{75}$ may serve as our starting points.

The first concerns the status of cinematic enunciation and deictics. In cinema, Metz tells us, what 'makes the deictic aspect of enunciation difficult is, for a start, a fact that has often been broached but whose importance we have not assessed enough. When a message is sent, there is nobody there, and there is no body, there is only text. ${ }^{76}$ Most of the time, the film viewer does not think about the enunciator of a film, and 'doesn't even think of the Image-Maker' (this is a reference to Albert Laffay). 'On the contrary, he does not believe that things reveal themselves: he simply sees images. ${ }^{77}$ Filmic enunciation is impersonal. And yet the problem with the mobile phone is rather to escape from personal enunciation. In general, video that is produced on mobile devices is received as if it has been uttered by an 'I', the owner of the phone; 'Look at the pictures that $I$ have taken' is the message that we read when we view a video on a mobile phone. It is certainly not impossible to block this personification of enunciation, but this requires a

75 Christian Metz, L'énonciation impersonnelle, ou le site du film (Paris: Méridiens Klincksieck, 1991).

76 Marie and Vernet, 'Entretien', p. 294.

77 Metz, L'énonciation, p. 18. 
specific effort and, above all, a switch in the space of communication (for example, by passing into the space of communication of the fiction film). In the same way, every image that is produced on a mobile says 'here' (it is not insignificant that the question you hear most often in mobile phone conversations is 'Where are you?') and 'now'. This is very much deictic enunciation..$^{8}$

The second question concerns audiovisual conversation, to use the title of Gianfranco Bettetini's La conversazione audiovisiva. ${ }^{79}$ Metz comments on it to emphasize its paradoxical status:

The paradox is that he has chosen the metaphor of conversation for types of discourse that are radically different from it, and the second paradox is that Bettetini's work, which does not lack subtlety, insists greatly on this separation. Film is not interactive, it does not receive feedback, so the conversation that this book discusses is imaginary and, as it were, fantasmatic. $^{80}$

Metz hammers the point in his interview with Michel Marie and Marc Vernet: 'There is no exchange. ${ }^{81}$ With the mobile phone, due to the possibility of immediately disseminating images and speech either from afar or up close (two or more people using Bluetooth can exchange videos face to face), cinematic language enables situations that really are similar to conversation. It would be interesting to see if these exchanges followed the equivalent 'rules' that govern conversations using language. All of the questions that Catherine Kerbrat-Orecchioni puts forward ${ }^{82}$ in relation to verbal interaction demand to be put in this context: Does turn-taking occur? What structure does interaction take? What kind of interaction are we dealing with (dialogue, interview, debate ...)? What are the objectives of this interaction? One thing is certain: today we are witnessing interactions through the medium of cinematic language that are unprecedented.

In the face of these new situations, there is a great temptation to ask whether it is the nature of cinematic language that has changed or its status (the fact that it is conveyed by mobile phones). In fact, it seems to

78 Regarding the shift from impersonal to personal enunciation, see also the articles by Dominique Blüher and Alain Boillat in this volume.

79 Gianfranco Bettetini, La conversazione audiovisiva, problemi dell'enunciazione filmica e televisiva (Milan: Bompiani, 1984).

80 Metz, L'énonciation, p. 22.

81 Marie and Vernet, 'Entretien', p. 294.

82 Catherine Kerbrat-Orecchioni, Les interactions verbales (Paris: A. Colin, 1990). 
me that this misses the point. It would be difficult to separate the analysis of how language functions from the analysis of how it functions in this or that communication context, because it is the context, to some extent at least, that determines how that language functions. In the examples that I have looked at, it is definitely the mobile phone that says I, here, now, and which enables audiovisual conversation to happen, but it is the mobile phone inasmuch as it is inscribed in the frame of the space of everyday communication. On the other hand, Metz's analysis is still valuable in the 'cinema' space of communication. The proof of this is that when we watch a feature film on a mobile phone, enunciation functions in the way that Metz describes it, i.e., in an impersonal way. It is clear from this how necessary it is to adopt a pragmatic approach to language that takes into account the context of its enunciation.

We should also pay attention to the major modes used in communicating with cinematic language in everyday life..$^{83}$ While the fictionalizing mode is sometimes brought into play (in the space of everyday communication, young people in particular play by fabricating mini fictions on their mobiles), the documentarizing mode is without doubt one of the most important; for example note-taking, memory aids, documents, witness accounts (today, as soon as there is an event, everyone takes out their phone), and personal archives (concerts I've been to, exhibitions I've visited, etc.). The mobile also enables the private mode. It has, for example, replaced the home movie; from now on, it is the mobile that circulates from hand to hand among family and friends. As Jean-Louis Boissier has acutely remarked, 'pass me the film' has come to mean 'pass me the mobile. ${ }^{84}$ The intimate mode is also extremely present: 'The mobile phone', observes Laurence Allard, 'while remaining a technology of communication with other people, has also become an authentic means of communication with oneself. ${ }^{85}$ So cinematic language, like verbal language, functions as an operator that constitutes the ego (some psychologists regard the mobile as an ego substitute). ${ }^{86}$

83 On the concept of modes, see Odin, Les espaces de communication, pp. 43-82.

84 In an interview for the Pocket Films Festival in July 2006, 'Le film téléphonique comme shifter', Boissier observed, 'Because we had not previewed the material to pass these films onto the big screen, I said to the audience: "I'm passing the film to you." And at the very moment I said that, I thought to myself, "To pass a film," that could be it. The phone is passed from hand to hand among the audience members.' See www.festivalpocketfilms.fr.

85 Laurence Allard, 'Express Yourself 3.0 ! Le mobile comme technologie pour soi et quelques autres, entre double agir communicationnel et continuum disjonctif soma-technologique', in Téléphone mobile et création, p. 140.

86 Serge Tisseron, personal correspondence. 
Finally, I think I can maintain that the mobile compels viewing the world in the aesthetic mode. In La vie esthétique, Laurent Jenny observes:

As so often, my eye is drawn to the picturesque display of one of these 24-hour New York grocers run by Pakistanis who offer a great swathe of merchandise, from ball-point pens to bouquets [...]. Mechanically, I take out my mobile phone ... and so that I can see more, I am once again seized by the mania of magnifying with the digital zoom and absorbed by the differing levels of transparency between cubes of ice and cubes of pineapple. The result, which I check instantly, fills me with astonishment. The object has become totally unrecognizable and gives rise to an undeniably cubist composition, from that marvellous period between 1908 and 1912 when Braque and Picasso competed at the edges of abstraction. ${ }^{87}$

More generally, the mobile invites us to view the world via its screen: 'Have you noticed', remarks once again Laurent Jenny, this time in an interview in Le Monde, 'that people use their mobile phones not to photograph and archive, but to look straightaway at what they've just taken? They want in some way to see "framed" either themselves or what they are looking at in a frame ... ${ }^{88}$ To see through a frame: is this not the primary gesture of aestheticizing the world?

These thoughts have sought simply to show that we would be well advised to pursue Metz's work on cinematic language while taking new developments into account, in particular the new equipment that enables us to convey this language. There is here a kind of social urgency, just as Metz recognized the urgency of initiating semiological thinking by means of the fiction film (because 'it is the fictional formula that the public likes, that is what responds to dominant forces ${ }^{89}$ ); today, it is at the level of the most common usage that work needs to be begun again. After language itself, cinematic language has become the most important language of our times for everyday communication and perhaps for the construction of our identities.

In this article, I have endeavoured to reconstruct what, for me, is current about Christian Metz's work, at the level of how to think of research, at the level of the relation between theory and cinema, and at the level of the aims of research. I might also have called this paper 'What I learned from 
Christian Metz, ${ }^{90}$ because his ideas are what have guided me and continue to guide me as a researcher. And so I will conclude by once again quoting Metz on Barthes: 'Today, I am the one who is committed to return it to him, to tell it to other people, to everyone who would like to understand (me) beyond words. ${ }^{91}$

Translated from French by Cormac Deane

\section{About the author}

Roger Odin is Professor Emeritus of Communication at the University of Paris (Sorbonne Nouvelle) where he was the head of the Film and Audiovisual Institute from 1983 until 2003. A theorist of the semio-pragmatic approach (Cinéma et production de sens, 1990; De la fiction, 2000; Les espaces de communication, 2011), Odin directed a research group on documentary films (L'âge d'or du cinéma documentaire: Europe années 50, 2 vols., 1997) and initiated research about home movies and amateur films (Le film de famille, 1995; 'Le cinéma en amateur', Communications, no. 68, 1999). Today, he is interested in the mobile phone ('Il cinema nell'epoca del videofonino', Bianco e Nero, no. 568, 2011, Téléphone mobile et création, en collaboration avec L. Allard et L. Creton, 2014).

\section{About the translator}

Cormac Deane is Lecturer in Culture and Media Studies at the Institute of Art, Design and Technology in Dublin. He was a recipient of the Government of Ireland Postdoctoral Fellowship Award in 2013-14. In 2016, Columbia University Press will publish his translation of the final work of Christian Metz, Impersonal Enunciation, or the Place of Film. His recent articles have appeared in Science, Technology and Human Values (2015), Television Aesthetics and Style (2013), and The Journal of Sonic Studies (2012).

9o This is the title of the paper that I presented at the Metz colloquium at the University of Zurich in June 2013.

91 Marie and Vernet, 'Entretien', p. 296. 



\title{
5. Thinking Cinema
}

Christian Metz and/in the Tradition of Film Theory

Frank Kessler

Tröhler, Margrit and Guido Kirsten (eds.), Christian Metz and the Codes of Cinema. Film Semiology and Beyond. Amsterdam University Press, 2018

DOI: $10.5117 / 9789089648921 / \mathrm{CHO}$

\begin{abstract}
Christian Metz once stated that he had always worked 'in the company' of the film theorists whose work preceded the turn towards a semiotics of cinema inspired by structuralist semiotics. This chapter tries to understand which 'canon' of film theory can be found in Metz's own writings. Who are the authors he refers to and in what way does he build upon their ideas to develop his semiotics of cinema? In the second part, the example of the so-called 'impression of reality' shows how Metz reframes a problem discussed widely in the 1950 s from a semiotic perspective. The final part is dedicated to Metz's reading of Rudolf Arnheim's Film als Kunst in his seminars of 1982 and 1983 .
\end{abstract}

Keywords: film semiotics/film semiology, classical film theory, filmology, history of film theory, impression of reality

In an interview that Paul Verstraten and I conducted with Christian Metz in 1986, we asked him about the relation he saw between his own work as a semiologist and the tradition of film theory, to which he so amply referred in his writings. In his answer he affirmed that he always felt that he worked 'in the company' of those theorists, whom he admired and was profoundly interested in. He also observed that in this respect he considered himself something like a 'traditionalist'. 'I think, he added, 'that in order to innovate we need to take [these writings] up again and push things further.' So, in a way, Metz stated here that the problems he dealt with in his own research

$1 \quad$ Frank Kessler and Paul Verstraten, 'Het verleden en heden van de filmtheorie. Interview met Christian Metz', Versus, 3 (1986), 101-14 (p. 103) (my translation). 
had generally been identified by this tradition, but that he himself looked at them through a different lens: the lens of semiology, or psychoanalysis. He also mentioned in the interview that he had explicitly stated his debt to the tradition of film theory in his first important article, "The Cinema: Language or Language System?'. 2 This essay was originally published in 1964 in the seminal fourth issue of Communications, which was one of the key publications of the then-emerging new wave of structuralist semiology, and contained, in addition to Metz's text, contributions by Roland Barthes, Claude Bremond, and Tzvetan Todorov. In the conclusion to his article, Metz wrote:

These few pages were written in the belief that the time has come to start making certain conjunctions. An approach that would be derived as much from the writings of the great theoreticians of the cinema as from the studies of filmology and the methods of linguistics might, gradually - it will take a long time - begin to accomplish, in the domain of the cinema, and especially on the level of the large signifying units, the great Saussurian dream of studying the mechanisms by which human significations are transmitted in human society. ${ }^{3}$

In closing the article by launching the project of film semiology - 'time has come for a semiotics of the cinema ${ }^{4}$ - Metz actually conceived of this enterprise as a combination of three strands of thinking: classical film theory (Eisenstein, Balázs, Bazin), filmology (Cohen-Séat, Morin), and linguistics. One could add that these three strands also bring with them their own modes of questioning cinema as an object of semiology. Linguistics provides the concepts that, to begin with, allow the semiologist to interrogate the notion of a cinematic language (langage cinématographique). In his writings, Metz draws extensively on key structuralist theorists such as Ferdinand de Saussure and Louis Hjelmslev, but also on André Martinet, Emile Benveniste, Roman Jakobson, and many others, depending on the problems that he intends to explore. ${ }^{5}$

2 Christian Metz, 'The Cinema: Language or Language System?', in Film Language: A Semiotics of the Cinema, trans. by Michael Taylor (Chicago: The University of Chicago Press, 1974 [1968]), pp. 31-91.

3 Metz, 'The Cinema: Language or Language System?', p. 91.

4 Ibid., p. 91 (in French, Metz uses the term 'sémiologie' the English translation 'semiotics' follows international terminological conventions).

5 On the relationship between Metz and linguistic theory, see Roger Odin, 'Christian Metz et la linguistique', Iris, 10 (1990), pp. 81-103. 
From filmology, too, Metz adopts a variety of concepts, in particular the terms constituting the 'vocabulary of filmology' - the profilmic, diegesis, etc. - as presented by Etienne Souriau, ${ }^{6}$ or Gilbert Cohen-Séat's distinction between 'filmic fact' and 'cinematic fact'? In addition, Metz takes up certain problems discussed by the filmologists, such as the 'impression of reality', which he re-read in 1965 and re-framed in a semiological perspective. ${ }^{8}$ And thirdly, filmology functions as an example demonstrating how cinema as an object can be studied with scientific rigour from a variety of perspectives involving different disciplines: psychology, sociology, anthropology, aesthetics, etc.

Finally, the third strand: the tradition of the 'great film theorists' had addressed many fundamental questions that semiological theory is also concerned with, including issues of meaning ('how to express something in such a way that the spectators can understand it immediately? how to articulate narrative space and time? etc.') and the specificity of film as a means of expression (which is summed up so aptly in the title of André Bazin's collected writings: What is Cinema?).

The difference for Metz between the two approaches of film theory and filmology seems to reside in their perspective. In the first of his two long articles dedicated to the two volumes of Jean Mitry's The Aesthetics and Psychology of the Cinema, he states that the former - film theory - looks at cinema 'from within', from the point of view of critics and filmmakers, and considers it first and foremost as an art. Filmology, in contrast, considers it - as Gilbert Cohen-Séat put it - as 'a fact' that is, as a social, anthropological, psychological, aesthetical, etc. phenomenon to be studied with the appropriate conceptual and experimental tools made available by these disciplines. ${ }^{9}$ Interestingly, in 'The Cinema: Language or Language System?', Metz observes that it is not quite clear whether one should consider certain authors as film theorists or as filmologists - he names Rudolf Arnheim, Albert Laffay, and, somewhat surprisingly, Jean Epstein..$^{10}$ For Arnheim

6 Etienne Souriau, 'La structure de l'univers filmique et le vocabulaire de la filmologie', Revue Internationale de Filmologie, 2/7-8 (1951), pp. 231-40; 'Préface', in L'univers filmique, ed. by E. Souriau (Paris: Flammarion, 1953), pp. 5-10.

7 Gilbert Cohen-Séat, Essai sur les principes d'une philosophie du cinéma I. Introduction genérale. Notions fondamentales et vocabulaire de filmologie (Paris: Presses Universitaires de France, 1946), pp. 53-55.

8 See also Frank Kessler, 'Rêve et impression de réalité', Revue belge du cinéma, 42 (1997), (47-50), pp. 48-49.

9 Christian Metz, Essais sur la signification au cinema, 2 vols. (Paris: Klincksieck, 1981 [1972]), II, p. 13 .

10 Metz, 'The Cinema: Language or Language System?', pp. 90-91. 
and Laffay, as well as for Mitry (whose two volumes on film theory had just been published when Metz's important first article appeared), it is indeed obvious that they combine normative statements on cinema as an art form with considerations based on, most notably, the psychology of perception, and which try to explore the specificity of the cinematic image.

\section{The Metzian Canon of Film Theory}

Whenever Metz refers in a general way to the traditions of film theory and filmology, he comes up with more or less the same list of authors: Arnheim, Balázs, Bazin, and Eisenstein on the one hand, Cohen-Séat, Laffay, and Morin on the other, with Mitry in a privileged position, as it were, because he is the one film theorist to whose work Metz has dedicated long, detailed studies, published as reviews of the two volumes of The Aesthetics and Psychology of the Cinema in 1965 and 1967.11 These authors may be considered to constitute something like the 'canon' or 'pantheon' of film theory for Metz, even though there are several others who also figure more or less prominently in his writings, such as, most notably, Marcel Martin and André Malraux. Regarding the non-francophone theorists, Metz apparently worked with the German edition of Arnheim's Film als Kunst, while for Balázs he generally drew upon the English translation but also referred to the German editions of Der sichtbare Mensch (1924) and Der Film (1949). Eisenstein is quoted from both the French and the English translations that were available to Metz.

There are some interesting absences in this 'canon', presumably mostly due to difficulties of access, or the fact that some theorists were simply absent from the French debates at that time. It may also have been the case, however, that Metz did not consider them relevant to his semiological approach. One of the authors whom he never mentions is Walter Benjamin, whose 'Work of Art' essay was more or less compulsory reading for German film theorists in the late 196os and 1970s. The same goes for Siegfried Kracauer's Theory of Film, published first in English in 1960 and translated into German in 1964. In both cases, it is evident that the importance of the Frankfurt School in the German and American intellectual landscapes respectively gave both authors' views on cinema a particular weight. Maybe more surprisingly, Hugo Münsterberg's book from 1916, The Photoplay: A

11 See Christian Metz, Language and Cinema, trans. by Donna Jean Umiker-Sebeok (The Hague: Mouton, 1974 [1971]), p. 10, and Essais, II, p. 14 and 195. 
Psychological Study, which was re-edited in the US in 1970, is apparently not referenced in any of Metz's published writings. And finally, even though Metz does indeed mention him on several occasions with regard to his films, Pudovkin seems not to have interested Metz very much as a theorist, as he hardly ever actually refers to Pudovkin's Film Technique, which was rather widely read (at least in the US). When he discusses Soviet montage theory, Metz generally comments on Eisenstein.

In this respect, it is quite striking that Eisenstein, more often than not, appears as a negative example. Metz's essay 'The Cinema: Language or Language System?' is in large part a critique of what he calls the 'montageor-bust' (montage-roi) attitude, and also of the idea of a ciné-langue, both attributed by Metz to Eisenstein as a theorist (while Eisenstein's status as a filmmaker is not at stake here). Obviously, the critique of the latter concept is the central point of the article, and Metz uses conceptual tools borrowed from (structuralist) linguistics to provide arguments against the idea that there could ever exist something like a ciné-langue. His scepticism towards the idea - or rather: ideology - of the montage-roi attitude, which Metz associates with a 'spirit of manipulation', tends, however, to lean towards a rather normative aesthetical position that is close to the Bazinian conception of cinema, to a certain degree at least. ${ }^{12} \mathrm{~A}$ few years later, in Language and Cinema, Metz admits this in a self-critical footnote: 'In our early articles (notably 'Le cinéma: langue ou langage?' [...]), we were not wary enough of this conception (the influence of André Bazin on cinematic studies was stronger then than it is today). ${ }^{1_{3}}$

So, in many of his references to them, the 'companionship' with both Eisenstein and Bazin is for Metz more or less distanced and often openly critical. While the Soviet theorist is taken to task for overemphasizing the powers of montage, Metz finds exactly the opposite flaw with Bazin; a 'fanaticism' in favour of staging in depth and non-editing. ${ }^{14}$ So when Metz reflects on the tradition of film theory, he is increasingly careful to distance himself from the normative aesthetics that usually is the foundation of the theories. ${ }^{15} \mathrm{In}$ this respect, Metz often sides with Mitry, who generally holds a nuanced position between the extremes, even though he, too, does sometimes pronounce himself on certain questions in rather normative terms.

12 See Metz, 'The Cinema: Language or Language System?', pp. 34-44.

13 Metz, Language and Cinema, p. 103 (translation modified to match the French original).

14 Metz, Essais, II, p. 32

15 See also Essais, II, p. 28, the long footnote where he explains why a normative approach in film theory and film criticism is of little interest to him. 
Yet Metz does adopt, for instance, Bazin's conception of photography as a trace, ${ }^{16}$ and in his detailed review of the second volume of Jean Mitry's The Aesthetics and Psychology of the Cinema, he patiently and approvingly reconstructs Bazin's view on the relationship between cinema and theatre, ${ }^{17}$ characterizing it as the one 'which by today has become classic'. ${ }^{18}$ This latter example also illustrates the fact that Metz's two review articles on Mitry constitute not only his most comprehensive (published) discussion of a film theorist but also his most extensive engagement with the tradition of film theory and filmology. In order to demonstrate the importance of Mitry's books - which Metz indeed considers something like a milestone and at the same time the final stage of a certain way of thinking about cinema - he sketches a vast panorama of discussions, showing how a variety of issues have been addressed by others and what kinds of answers Mitry provides to these questions. This is where Metz displays his immense knowledge of the history of film-theoretical debates that clearly underpin his own work, even though he generally does not refer in the same encyclopaedic way to all the theorists that he enumerates in these two review articles.

\section{Revisiting the 'Impression of Reality'}

Among the problems discussed by classical film theory and by filmology, and which Metz later reworked from a semiological point of view, the so-called 'impression of reality' issue is one of the earliest. ${ }^{19}$ In an article originally published in the Cahiers du cinéma in 1965, he draws on Rudolf Arnheim, Albert Michotte van den Berck, and Edgar Morin to explain how the perception of the cinematic image both bears a resemblance to and also differs from the way in which we perceive the world around us. ${ }^{20}$ He refers to Bazin and Barthes to characterize photography as a trace of something that 'has been there' and thus addresses the specific relationship

16 Christian Metz, 'On the Impression of Reality in the Cinema', in Film Language: A Semiotics of the Cinema, trans. by Michael Taylor (Chicago: University of Chicago Press, 1974), 3-15 (p. 8 and 14).

17 Metz, Essais, II, pp. 66-69.

18 Essais, II, p. 67.

19 Metz, 'On the impression of Reality', pp. 3-15.

20 Rudolf Arnheim, Film als Kunst (Berlin: Rowohlt, 1932); Albert Michotte van den Berck, 'Le caractère de "réalité" des projections cinématographiques', Revue internationale de filmologie, 1/3-4 (1948), pp. 249-61; Edgar Morin, The Cinema, or the Imaginary Man, trans. by Lorraine Mortimer (Minneapolis: University of Minnesota Press, 2005 [1956]). 
between the photographic still image and reality. ${ }^{21}$ He once more evokes Bazin, together with Jean Leirens, Henri Wallon, and, again, Arnheim, to discuss the specific reality that is produced on a stage. ${ }^{22}$ On the basis of the observations of these various theorists concerning the specific impressions of reality that photography, film, and theatre can produce, Metz develops his own argument, first separating then bringing together (in an almost dialectical move) two strands of thinking that appear in these discussions of the reality effect. On the one hand, Metz remarks, there are what he calls the 'indices de réalité', these being the aspects of the real that are included in a medium's material affordances. (In photography, the fidelity of the image, to which cinema adds movement and sound, whereas theatre is characterized by three-dimensionality and physical presence.) On the other hand, there is the degree of spectatorial engagement (participation) with the diegesis that these different media can induce. While Arnheim ${ }^{23}$ - whom Metz critiques on this point - sees a linear interdependence between the number of reality-indices a medium can reproduce and the resulting degree of participation (today one would probably rather use the term absorption, or maybe even immersion), Metz suggests that there is a more complicated relationship:

The truth is that there seems to be an optimal point, film, on either side of which the impression of reality produced by the fiction tends to decrease. On the one side, there is the theater, whose too real vehicle puts fiction to flight; on the other, photography and representational painting, whose means are too poor in their degree of reality to constitute and sustain a diegetic universe. [...] Between these two shoals, film sails a narrow course: It carries enough elements of reality - the literal translation of graphic contours and, mainly, the real presence of motion - to furnish us with rich and varied information about the diegetic sphere. Photography and painting cannot do this. Like both these arts, film is still composed of images, but the spectator perceives it as such and does not confuse it with a real spectacle [...] The total reality of the spectacle is greater in the theater than in motion pictures,

21 André Bazin, What is Cinema?, trans. by Hugh Gray, 2 vols. (Berkeley/Los Angeles/London: University of California Press, 2005), I [1958], pp. 9-16; Roland Barthes, 'Rhetoric of the Image', in Music Image Text, trans. by Stephen Heath (London: Fontana Press, 1977), pp. 32-51.

22 Bazin, What is Cinema?, I, pp. 76-124; Jean Leirens, Le cinéma et le temps (Paris: Editions du Cerf, 1954); Henri Wallon, 'Lacte perceptif et le cinéma', Revue internationale de filmologie, 4/13 (1953), pp. 97-110; Arnheim, Film als Kunst.

23 Arnheim, Film als Kunst, p. 39. 
but the portion of reality available to the fiction is greater in the cinema than in the theater. ${ }^{24}$

The way this argument is constructed is quite typical of Metz's thinking and writing. (Those familiar with Metz's work will easily recognize from this quote, and from the brief summary preceding it, his method of circling around a phenomenon, looking at it from a variety of angles, and then carefully unpacking his observations and conclusions.) This example is also rather typical of how he appropriates, discusses, and reworks the positions formulated by classical film theory and filmology. Metz indeed reframes a problem posed by other theorists by transposing it to another level. Interestingly, in Film Language: A Semiotics of the Cinema, this article was put in a section entitled 'Phenomenological approaches to film', but Metz's argument is in fact shaped decisively by his attention to the various media's signifiers, or, more precisely, their 'material of expression', as he would call it in Language and Cinema. So while this article does not frontally address a semiological problem, it clearly does imply a genuine semiological viewpoint.

\section{Reading Arnheim: The Seminars of 1982 and 1983}

Within Metz's various publications, the major part of his references to such debates concerning aspects of classical film theory are to be found in the two volumes of his Essais sur la signification au cinéma and in Language and Cinema. In the Essais sémiotiques there are none (understandably, because cinema is not a central object of study here), and in The Imaginary Signifier and L'énonciation impersonnelle they are rare. In his last book, certain concepts such as Albert Laffay's grand imagier ('the Great Image-Maker') or the discussions which started in the late 1940s regarding the so-called 'first-person-film' are obviously important issues, but overall Metz refers primarily to more recent theoretical debates. So, arguably, his most intense examinations of and engagements with classical film theory and the Ecole de filmologie occured during the 1960 s and early 1970 .

Yet in 1982 and 1983, Metz dedicated his seminar at the Ecole des Hautes Etudes (which was actually held at the Sorbonne Nouvelle, Censier) to a very thorough and systematic reading of Rudolf Arnheim's Film als Kunst. For the following I draw upon my notes, which I took throughout the seminar 
and which I then typed out. ${ }^{25}$ This was actually the first time that I attended the seminar, and I think I owed this honour to the fact that, just before the summer break in 1981, Metz had Michel Colin ask me to buy for him, in Germany, the new edition of Arnheim's 1932 book as well as the volume of essays edited by Helmut H. Diederichs, both of which had just come out as pocket books. ${ }^{26}$ It is quite interesting that Metz chose that time to return to a classic of film theory that happened to have been published exactly $5^{\circ}$ years earlier; that is, after having had to abandon his project of publishing a volume on Freud's Der Witz und seine Beziehung zum Unbewussten, an effort for which he had temporarily withdrawn from the realm of Cinema Studies. One of his motives certainly was to introduce Arnheim's book to an audience in France, where his work on film theory was virtually unknown (and to provide the Anglophone participants with a more elaborated version of Arnheim's theory than they could find in the selections presented in the English translation that was available at the time).

After a general introduction on the theory of perception that formed the basis of Arnheim's theory of film, Metz patiently summarized Film als Kunst section by section, chapter by chapter, reconstructing Arnheim's argument and commenting upon it. Partly, he positioned Arnheim in relation to theorists from the same period such as Balázs, Eisenstein, or Pudovkin. Partly he referred to subsequent theoretical debates, drawing most notably on Bazin, Cohen-Séat, Mitry, Souriau, and several others. Finally, he sometimes 'translated', as it were, the problems discussed by Arnheim into a semiological framework, showing that the issues Arnheim addressed were still valid as theoretical problems, and also at least some of Arnheim's answers continued to be relevant when they were rephrased in a different terminology.

To give one example as an illustration: Here is how Metz approached Arnheim's chapter on 'What is being filmed' (Was gefilmt wird), and, more particularly, the paragraph on mental processes (Seelische Vorgänge). Metz began his discussion of the chapter by showing that Arnheim does not operate a simple split between form and content but rather sees both as complexly locked into each other. This brought Metz to refer to Hjelmslev's quadripartite model of form and substance on the levels of both expression and content (or 'signifier' and 'signified') and to his own

25 To be precise: as this was in the pre-computer age, I had taken handwritten notes during the seminar meetings, which I later typed out on a typewriter in order to share them with Martine Joly, who was unable to attend the seminar in those two years.

26 This, too, may sound somewhat strange today, but in the early 1980 s, even in a city such as Paris, it was rather difficult to get hold of foreign books, and in particular books on film theory, which booksellers generally did not consider a profitable market. 
adaptation of Hjelmslev in the first section of his 1967 article 'Propositions méthodologiques pour l'analyse du film. ${ }^{27}$ Metz also evoked Eisenstein's 1925 essay on a materialist approach to film form, published in French in the Cahiers du cinéma in 1970 and subsequently in the first volume of the French edition of Eisenstein's collected works. ${ }^{28}$ Moving on to the representation of mental processes, Metz started his discussion by recapitulating Malraux's distinction describing three ways of using dialogues in novels and films (in the prepublication of his Outlines of a Psychology of the Cinema in the journal Verve) and the relation between dialogue and narration. ${ }^{29}$ According to Metz, Malraux's ideas were similar to Arnheim's discussion of gestures and facial expressions and their relation to narrative action, particularly when expressing the internal motivations of characters. In analyzing Arnheim's remarks on acting and bodily expression, Metz argued that Arnheim's account should be seen as an implicit critique of Balàzs's theory of the gesture as a central element of cinema, and that Arnheim's move to privileging action over expressive gestures is ultimately not unlike the behaviourist conception of cinema that emerged in the mid-1940s.

As this brief example has tried to show, Metz apparently wanted to demonstrate that Arnheim's book could offer relevant contributions to a number of issues in film theory. In his concluding remarks at the end of the seminar, he insisted once again on what he saw as the principal merits of Film als Kunst. Here is a summary of his concluding comments:

- Arnheim speaks to some extent from outside the world of cinema, which makes him different from most other film theorists at that time. In that respect, his position is similar to that of the Russian formalists.

- He has wide cultural knowledge and a scientific mind, though that does not prevent his theory from being strongly normative.

- His normative attitude, however, is a broad-minded one. He was in favour of a cinema where the expressive effects (the 'effects of the signifier') are strong, autonomous, and free but always functioning to the benefit of the diegesis.

- His theory insists on the difference between the ways in which we perceive the outside world versus its image on the screen (which Metz

27 See Metz, Essais, II, pp. 97-100.

28 Sergei M. Eisenstein, Au-delà des étoiles (Paris: UGE, coll. 10/18, 1974), pp. 145-56; English as 'The Problem of the Materialist Approach to Form', in The Eisenstein Reader, ed. by Richard Taylor; trans. by Richard Taylor and William Powell (London: BFI, 1998), pp. 53-59.

29 André Malraux, 'Esquisse d'une psychologie du cinéma', Verve, 2/8 (1940), pp. 69-73. 
called a theory of 'factors of differentiation' [ facteurs de différenciation]), making it an important (and anticipated) critique of the 'cosmophanic' theories that would emerge in the 1940 s. $^{30}$

The seminar on Arnheim was, thus, something like an expedition into the history of film theory and Film als Kunst was positioned with regard not only to the debates of the 1920s and 1930s but also later ones, including Metz's own writings. I personally feel very privileged to have first come to know Rudolf Arnheim's theory of film through the reading of it by Christian Metz.

I do not know whether Metz had turned to Arnheim because this seminar would offer him an opportunity to delve once more into discussions of film theory and thereby to find a new topic to work on himself, some way allowing him 'to push things further'. If so, this enterprise apparently did not quite provide him with the results he had hoped for. During the two following years he discussed a variety of texts in his seminar, addressing a broad range of different issues, and there were also comparatively large numbers of guest lectures. In November 1986, however, the seminar headed in a new direction. Metz finally set out to tackle a topic on which he would continue to work for the years to come: enunciation.

\section{About the author}

Frank Kessler is Professor of Media History at Utrecht University and currently the Director of Utrecht University's Research Institute for Cultural Inquiry (ICON). His main research interests lie in the fields of early cinema and the history of film theory. He is a co-founder and co-editor of KINtop. Jahrbuch zur Erforschung des frühen Films and the KINtop-Schriften series. From 2003 to 2007 he was president of Domitor, an international association to promote research on early cinema. Together with Nanna Verhoeff, he edited Networks of Entertainment. Early Film Distribution 1895-1915 (2007). $\mathrm{He}$ is also the author of Mise en scène (2014). 



\title{
6. Barthes' Early Film Semiology and the Legacy of Filmology in Metz
}

\author{
Guido Kirsten
}

Tröhler, Margrit and Guido Kirsten (eds.), Christian Metz and the Codes of Cinema. Film Semiology and Beyond. Amsterdam University Press, 2018

DOI: $10.5117 / 9789089648921 / \mathrm{CHO} 6$

\begin{abstract}
This chapter discusses how Christian Metz was inspired by the French filmology movement. Filmology, having been founded in the years after WWII, endeavoured to study cinema in its psychological, sociological, and philosophical complexity. Metz was impressed by the distance filmology took from the institutions of film production and criticism. Also, several important terms introduced by filmology found their way into Metz's writings. Furthermore, the essay speculates about the more subcutaneous influence of two essays by Roland Barthes from the Revue internationale de filmologie. Although Metz never discusses these texts in detail, they may have played an important role in formulating his own project. By sketching this possible line, this essay contributes to the genealogy of Metz's thinking.
\end{abstract}

Keywords: film semiotics/film semiology, filmology, history of film theory, terminology, cinematic signs

In the year following Etienne Souriau's death in 1979, Christian Metz published an article in an issue of the prestigious Revue d'esthétique dedicated to the philosopher and aesthetician. Metz pays tribute to Souriau's contribution to French filmology after WWII, highlighting the importance of essays such as 'The Structure of the Filmic Universe and the Vocabulary of Filmology' (originally published in 1951 in the Revue internationale de filmologie) and 'Les grands caractères de l'univers filmique'. In passing, 
Metz stresses the impact that filmology had on the development of his own film semiotics:

Basically, filmology was in certain regards a rather direct prefiguration of the semiology of the cinema. In both cases, it is a matter of approaching the cinema from the outside, of placing it within the discourse of the human sciences, and not that of cineastes, cinephiles or critics. ${ }^{2}$

Alain Boillat has remarked that the words 'basically' and 'in certain regards' qualify Metz's claim to some extent, ${ }^{3}$ and it is true that the relationship between his own project and the filmology movement is not without ambivalence - at least in retrospect. For while certain filmology concepts had a considerable influence on the thinking of the young Metz, conversely, his writing has also had a great impact on the knowledge and understanding of these concepts. And this impact has been twofold: the renewal of cinema studies in the 196os through semiology introduced filmological notions into common usage by researchers, but it has also for a long time obscured knowledge of this heritage. Indeed, it would appear that the success of semiology has contributed to the forgetting of filmology.

Filmology was only rediscovered in the Anglophone world during the 1980 s, after the period of semiology's hegemony, thanks to Edward Lowry's seminal study. In Italy and France, it returned to critical attention through Francesco Casetti's history of film theories, and it was introduced to the German-speaking audience in the years after 1997, when over ten articles of the Revue internationale de filmologie were published in translation in the review montage AV. Crucially, the extraordinary 2009 double issue of Cinémas significantly deepened understanding of the filmological project. ${ }^{4}$

The influence of filmology on Metz is as much epistemological as terminological. The epistemological dimension emerges primarily in filmology's general attitude to cinema and cinematic culture, and then, more

Hediger, and Guido Kirsten (Amsterdam: Amsterdam University Press [forthcoming]); Etienne Souriau, 'Les grands caractères de l'univers filmique', in L'univers filmique, ed. by Etienne Souriau (Paris: Flammarion, 1953), pp. 11-31.

2 Christian Metz, 'Un profil d'Etienne Souriau', Revue d'esthétique, 3-4 (1980), 143-6o (p. 145), quoted in Edward Lowry, The Filmology Movement and Film Study in France (Ann Arbor: UMI Research Press, 1985), p. 169 .

3 Alain Boillat, "La "diégèse" dans son acceptation filmologique. Origine, postérité et productivité d'un concept', Cinémas, 19/2-3 (2009), 217-45 (p. 226).

4 Lowry, The Filmology Movement; Francesco Casetti, Les théories du cinéma dépuis 1945 (Paris: Armand Colin, 2005); montage AV, 6/2 (1997), 12/1 (2003), 13/1 (2004), 19/2 (2010); Cinémas, 19/2-3 (2009). 
specifically, with the semiological or proto-semiological ideas promoted in the Revue.

After briefly addressing the general position that attracted Metz, I will comment upon the terminology that he used and popularized, before finally building a hypothesis concerning the possible influence of two 1960 articles on semiology by Roland Barthes published in the Revue internationale de filmologie. These articles are the first examples of structuralist film semiotics, and for this reason it is surprising that Metz barely mentions them in his first writings. It is no less astonishing that the literature on the genesis of Metz's thought has completely ignored this possible source of influence. While the affinity of Metz's writing with filmology has generally been acknowledged, ${ }^{5}$ the connection between Barthes' articles and Metz's first essays remains unexplored. ${ }^{6}$ I will argue that even though Metz's reaction to the ideas Barthes advanced in these articles appears to be present only 'negatively' (through its absence, so to speak), their analysis may help us gain a clearer understanding of Metz's semiotics. It may also go some way toward explaining the specific outline of his project, illuminating for instance why Metz carefully avoided a definition of filmic signs, concentrating instead on the syntactic axis.

In an article entitled 'Introduction à une filmologie de la filmologie', published in 1951 in the Cahiers du cinéma under his pseudonym Florent Kirsch (composed of his son's first name and his wife's maiden name), André Bazin attacked the filmologists for their alleged 'scientific' methods that, he argued, led them to completely ignore individual filmic works. ${ }^{7}$ In Bazin's eyes, the 'distinguished professors' of the filmology movement still considered cinema to be a minor art, one that could become a legitimate field of academic study only when ennobled by established disciplines such

5 Lowry, The Filmology Movement, pp. 163-69.

6 The only paper I am aware of that deals with these questions is by Kate Ince. I am collaborating with her and Vinzenz Hediger on Filmology and the Origins of Film Studies, an anthology of writings from the Revue internationale de filmologie [see Note 1]. Her talk, 'Roland Barthes, Filmology and the History of Audiovisual Media Study in France', was given at the Film-Philosophy conference in Amsterdam on 11 July 2013 and has not been published.

7 This did not prevent Bazin from taking part in a filmological congress in 1955, documented in the Revue international de filmologie, 20-24 (1955), pp. 95-97. It would appear that using a pseudonym was indeed a judicious move. 
as psychology, philosophy, biology, and so on. In a rather polemical tone, Bazin writes:

To be a distinguished filmologist, one will need to be only as familiar with the classics of the big screen as a candidate for a high school diploma would need to be with medieval manuscripts. This, far from being an inherent handicap, is for the filmologist a source of pride. Certainly, there's nothing stopping filmologists from going to the cinema, but one would not advise them do to so, for this superfluous baggage may well darken the nascent science. Filmology is the study of Cinema-in-itself, with little concern for its history and works. ${ }^{8}$

But filmology's habit of ignoring the critical discourse pertaining to individual films, which inspired Bazin's strident polemic, was for Metz precisely to filmology's credit. As the above quotation from his homage to Souriau demonstrates, Metz was fascinated by the distance that filmology introduced between itself and established filmic culture.

In the conclusion to his first essay 'Le cinéma: langue ou language?' Metz distinguishes between four ways of approaching cinema: film criticism, cinema history, film theory and, finally, filmology. The principal difference that he identifies between film theory and filmology is that film theorists were 'either film-makers, enthusiastic amateurs, or critics' and that as such they were 'part of the cinematographic institution'. Filmology, on the other hand, was 'the scientific study conducted from outside by psychologists, psychiatrists, aestheticians, sociologists, educators, and biologists. Their status, and their procedures, place them outside the institution.' ${ }^{9}$

It was precisely this distance that initially attracted Metz to filmology. One finds it also in the outline for a thèse d'Etat research project that he submitted to the Centre National de la Recherche Scientifique (CNRS), which was recently rediscovered by Martin Lefebvre. Metz here underlines 'the independence [of filmology] with respect to cinema criticism and

8 Florent Kirsch [André Bazin], 'Introduction à une filmologie de la filmologie', Cahiers du cinéma, 5 (1951), 33-38 (p. 36). Similar criticism was uttered some years later in Positif: '[F]ilmology appears overall [...] like a monstrous excrescence of psychology, pedagogy and the sociology of Saturday night cinema. Filmology wants to be a science and for that it must pay the high price of objectivity's ransom.' Xavier Tiliette, 'Les filmologues en congrès', Positif, 14-15 (1955), pp. 164-65. 9 Christian Metz, 'The Cinema: Language or Language System?', in Film Language: A Semiotics of the Cinema, trans. by Michael Taylor (New York: Oxford University Press, 1974), 31-91 (p. 9o). 
history', and he proposes to integrate his filmic-linguistic approach into filmology as a new area of research. ${ }^{10}$

2 Terminological References

The epistemological distance interested Metz to the extent that it generated research methods and a technical vocabulary that differed from those of filmmakers and critics. The need to invent a new and precise terminology had been stressed time and again by filmologists such as Gilbert Cohen-Séat, Etienne Souriau, and others. Metz borrowed many notions from filmological writings, introducing them into the field of cinema studies. Some of these notions today form part of the basic vocabulary that students learn during their first semesters of study, and include terms such as 'diegesis' and 'diegetic', 'profilmic' and 'impression of reality'.

Alain Boillat reconstitutes the trajectory of how Metz appropriates and employs the concept of 'diegesis'. He writes:

As soon as one begins to examine the discussions in detail, one notes that the concept of 'diegesis' and the questions raised by its definition number among the original concerns of the semiology of the cinema, which filmology does indeed appear to have 'prefigured', even if this relationship is sometimes rather underestimated by Metz's thurifers. ${ }^{11}$

Metz appears to have used the concept for the first time in his 1965 essay on the impression of reality. ${ }^{12}$ But it assumes a more important position in his terminological system in the article 'Some Points in the Semiotics of the Cinema', which first appeared in French in the review La linguistique in 1966 and was republished in the first volume of his Essais sur la signification au cinéma. Here he writes:

10 Martin Lefebvre, 'L'aventure filmologique: documents et jalons d'une histoire institutionelle', Cinémas, 19/2-3 (2009), 59-100 (pp. 59-6o). Metz even proposes to use an 'experimental method' to study differences in viewers' understanding of a silent film, where some watch the film with intertitles and some without (pp. 61-62).

11 Alain Boillat, 'La “diégèse”', pp. 59-6o; see also Frank Kessler, 'Von der Filmologie zur Narratologie. Anmerkungen zum Begriff der Diegese', montage AV, 16/2 (2007), pp. 9-16.

12 Christian Metz, 'On the Impression of Reality in the Cinema' [1965], in Metz, Film Language, 3-15 (pp. 10-12). 
The concept of diegesis is as important for the film semiologist as the idea of art. [...] The term was introduced into the framework of cinema by Etienne Souriau. It designates the film's represented instance [...] - that is to say, the sum of a film's denotation: the narration itself, but also the fictional space and time dimensions implied in and by the narrative, and consequently the characters, the landscapes, the events, and other narrative elements, in so far as they are considered in their denoted aspect. ${ }^{13}$

Here, Metz clearly thinks of diegesis as equivalent to everything denoted in the film, and it includes things and events that are only indirectly or implicitly represented. This interpretation is evidently very close to Souriau's original concept. ${ }^{14}$

In the same fashion, Metz began to use the word 'pro-filmic' in his very first writings on cinema and in a way that was quite similar to its accepted usage in filmology. As early as the third page of 'Le cinéma: langue ou langage?', he evokes the pro-filmic. In a footnote he clarifies and condenses Souriau's definition: 'Pro-filmic is everything that is placed before a camera or in front of which one puts it so that it "records". ${ }^{15}$ To my mind there is no more exact and synthetic way of expressing Souriau's notion of the pro-filmic than one finds here.

In the introduction to his German translation of 'The Structure of the Filmic Universe and the Vocabulary of Filmology', Frank Kessler notes that of the eight terms that denote the seven levels of the filmic universe, only 'pro-filmic' and 'diegetic' survived the project of filmology. ${ }^{16}$ The fact that Metz used exactly these two terms in his writings of the 1960 s is evidently no coincidence. From this, one can affirm how Metz's writing was a catalyst for these crucial notions in film studies.

Metz equally played a significant role in popularizing the notion of the 'impression of reality'. His 1965 article in the Cahiers du cinéma was to become a point of reference because it supplied one of the keywords in the debate about the ideology of the camera that was to wage from 1969 to 1972

13 Christian Metz, 'Some Points in the Semiotics of the Cinema' [1966], in Metz, Film Language, 92-107 (pp. 97-98).

14 One might also say that the diegetic is the entirety of filmic signs' 'extension', at least if one allows for extensions to be fictional, as Lubomír Doležel suggests in Heterocosmica: Fiction and Possible Worlds (Baltimore/London: Johns Hopkins University Press, 1998), p. 26.

15 Metz, 'The Cinema: Language or Language System?', p. 100.

16 Frank Kessler, 'Etienne Souriau und das Vokabular der filmologischen Schule', montage AV, 6/2 (1997), 132-39 (pp. 136-37). 
in the Cahiers and in Cinéthique, and which was baptized retrospectively as 'the quarrel of the impression of reality.'.

Metz's article, which is less semiological than phenomenological, ${ }^{18}$ is above all a presentation of the views advanced by Albert Michotte in his important 1948 article, "The Nature of "Reality" in Cinematic Projections'. ${ }^{19}$ Later, in an issue of Cinéthique 9-10 (1971), Metz was even accused of an 'uncritical adoption' of the term 'impression of reality' and the problematic related to it. ${ }^{20} \mathrm{But}$ in fact Metz does not only repeat and reframe Michotte's ideas. He also adds a number of important points, such as the distinction between the 'objective' and the 'subjective' side in the creation of this impression. 'Objective' factors are to be found in all of the aspects in which the filmic images resemble reality's appearance, while the subjective part is 'the vital, organizing faculty of perception [...] to realize (to make real) the object that it grasps.' 'Between the two factors, there is a constant interaction', Metz adds. ${ }^{21} \mathrm{He}$ also contributes another phenomenological argument, adding to Michotte's ideas, where he affirms that movement in cinema is even more important for creating the impression of reality since its nature is 'immaterial', because it offers itself in the first instance to sight and not to touch. ${ }^{22}$ Furthermore, he underlines that the impression of reality is not only linked to cinema's realist aspect but also to its capacity to render purely fantastic and extraordinary phenomena. ${ }^{23}$

17 Daniel Serceau, 'La querelle de l'impression de réalité', CinémAction, 6o (1991), pp. 108-12.

18 Frank Kessler is right, however, to stress that Metz uses semiological concepts to reframe and reformulate this phenomenological question. See Kessler's article in this volume. For Metz's relation to phenomenology, see: Dominique Chateau and Martin Lefebvre, 'Dance and Fetish: Phenomenology and Metz's epistemological shift', October, 148 (2014), pp. 103-32.

19 Albert Michotte van den Berck, 'The Nature of "Reality" in Cinematic Projections' [1948], trans. by Marc Jones, in Filmology [forthcoming].

20 'This notion is first introduced in the problematic developed out of the work of the Institut de Filmologie and the Revue internationale de filmologie, of which the article by Christian Metz in

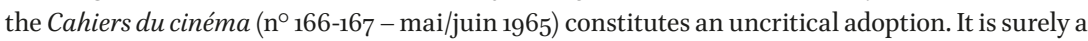
memory of this text that led us to revive the term as an element able to solve quite different problems.' Anon. [Jean-Paul Fargier, Gérard Leblanc], '(Texte collectif)', Cinéthique, 9-10 (1971), 1-70 (p. 51).

21 Metz, 'On the Impression of Reality', p. 6.

22 'The strict distinction between object and copy, however, dissolves on the threshold of motion. Because movement is never material but is always visual, to reproduce its appearance is to duplicate its reality' (Metz, 'On the Impression of Reality', p. 9; emphasis in original). This argument is somewhat doubtful, because motion can of course be felt (as in a punch or in getting hit by a flying object). In addition, even if Metz's description were right, it would also be true of colours and of shadows - both of which are indeed 'always visual'.

23 'The feeling of credibility, which is so direct, operates on us in films of the unusual and marvellous, as well as in those that are "realistic". Fantastic art is fantastic only as it convinces (otherwise it is merely ridiculous), and the power of unreality in film derives from the fact that the unreal seems to have been realized, unfolding before our eyes as if it were the flow of common 
Metz himself picks up and reworks the notion of the 'impression of reality' in his 1975 article 'The Fiction Film and its Spectator', where he utilizes it to depict one of the major effects of the cinematic apparatus. ${ }^{24}$

Finally, the influence of notions of 'filmic fact' and 'cinematic fact' upon Metz merits consideration. The idea of this distinction is already present in the final passages of 'Le cinéma: Langue ou langage?', but they figure more significantly in the first two chapters of Language and Cinema, where they open discussion of the concepts of the filmic and the cinematographic. Firstly, Metz affirms Gilbert Cohen-Séat's distinction between cinematic and filmic facts, the former being more institutional, the latter tending towards the perceptive or psychological. ${ }^{25}$ Thus the filmic event is found within cinema, because the cinematic encompasses a whole array of processes that arise before and after the production and the reception of a film.

However, Metz refers to this distinction so as to introduce another, changing the meaning of the words 'cinema' and 'cinematic' so that they now designate specific codes at the interior of the filmic event. His terminological discussion allows him to isolate terminologically the real subject of his semiology of the cinema, which he calls the 'filmic-cinematographic', that is, film traits that are 'cinematographically relevant', like, for instance, the codes of editing and camera movements. ${ }^{26}$

The First Articles of a Semiology of the Cinema, from Barthes to Metz

I would like to explore the third thematic field in greater detail, which concerns the degree to which filmology can be considered a forerunner of film semiotics in a more specific way.

occurrence - not the plausible illustration of some extraordinary process only conceived in the mind. The subjects of films can be divided into the "realistic" and the "non-realistic", if one wishes, but the filmic vehicle's power to make real, to realize, is common to both genres, imparting to the first an impression of familiarity which flatters the emotions and to the second an ability to uproot, which is so nourishing for the imagination.' (Metz, 'On the Impression of Reality', p. 5). Tom Gunning has stressed this point in his 'Moving Away from the Index. Cinema and the Impression of Reality', Differences: A Journal of Feminist Cultural Studies, 18/1 (2007), 29-52 (pp. 44-47).

24 Christian Metz, 'The Fiction Film and its Spectator: a Metapsychological Study', trans. by Alfred Guzzetti, in The Imaginary Signifier: Psychoanalysis and the Cinema (Bloomington: Indiana University Press, 1982 [1977]), pp. 99-147.

25 Christian Metz, Language and Cinema, trans. by Donna Jean Umiker-Sebeok (The Hague: Mouton, 1974), pp. 9-21.

26 Metz, Language and Cinema, pp. 22-49. 
In the aforementioned outline of his thèse d'Etat research project, Metz noted that while filmology had integrated psychologists, psychoanalysts, sociologists, and experts from other disciplines, it had barely connected with linguistics. This was the void he sought to fill with his project.

However, the idea of a film 'language' can be found in filmological writings from early on. In the very first article in the first issue of the Revue internationale de filmologie, Mario Roques affirms that 'essentially film, as I understand it, is an intention, a will to communicate thoughts and feelings, that is, precisely, a language; for there are not only phonetic languages passing by word of mouth'. ${ }^{27}$

Prior to that, Cohen-Séat had devoted three chapters of his seminal Essai sur les principes d'une philosophie du cinéma (first published in 1946) to the question of 'language' or 'discourse' in film, ${ }^{28}$ a subject he would take up in an article in the fifth issue of the Revue internationale de filmologie. Cohen-Séat's position towards the problem of cinematic language is beguiling. On the one hand, he affirms a 'natural brotherhood' between cinematic expression and verbal expression: the fact that one can make oneself understood in a succession of filmic images appears to justify speaking of film as a language. But on the other hand, Cohen-Séat warns that the tendency to insert new realities (like film) into familiar categories (like 'language') can easily lead to deceptive results. Finally, he suggests a pragmatic way of dealing with the analogy:

Reasoning by deliberate analogy has certainly proved successful in some cases. It is easy to predict that the assimilation of filmic events to 'words' and the collection of these signs to a linguistic conception of expression will not be achieved without a profound revision of ideas. This is one more reason for its examination. ${ }^{29}$

In 'Le discours filmique', Cohen-Séat returns to the question of whether linguistics can be of any direct help in elucidating the nature of filmic communication. He now asserts that the idea of a film language is mistaken, even 'absurd', but that this does not mean that speaking of filmic discourse needs to be eliminated as well..$^{30}$ To prove that film is not a language, Cohen-

27 Mario Roques, 'Filmology' [1947], in Filmology [forthcoming].

28 Gilbert Cohen-Séat, Essai sur les principes d'une philosophie du cinéma. Nouvelle Edition

(Paris: Presses Universitaires de France, 1958 [1946]), pp. 107-64.

29 Cohen-Séat, Essai, p. 119.

30 'Let us limit ourselves for the moment to the idea that film can be treated like a language. The idea has proved nothing if not seductive; yet this need not, of course, stop it from being 
Séat starts from a definition of language ('any system of conventional signs which can serve to exchange communications between individuals') and argues that filmic images are not signs, even less conventional ones, that they are naturally the opposite of a system, and that communication is most commonly unidirectional.

Cohen-Séat sees the principal difference in the fact that filmic communication does not rely on any shared knowledge (as verbal language does) and that it is not secondary to anything - in the cinema, 'the spectator is never informed of something, but by something'. ${ }^{31}$ This also implies that meaning is less stable and more open to subjective interpretation..$^{32}$

In a later article, Cohen-Séat compares verbal to filmic discourse in a similar fashion. He again argues for a more direct understanding of meaning in film: 'Filmed behaviour, before being interpreted in terms of a meaning hidden beneath the moving image, is understood within this same image. There is therefore here no distinction between sign and thing. No more words, no more language. ${ }^{33}$

Even though Metz would later defend the idea that film is in some ways a language ('langage'), albeit not in the sense of a system ('langue'), his comments concerning the differences between film and verbal language are quite close to those uttered by Cohen-Séat. When Metz argues that cinema does not have any equivalent to words, that there is no phenomenological difference between signifier and signified, and that it is indeed hard to define any delimited unit of sense in film,$^{34}$ he could have cited the protosemiotic writings of Cohen-Séat. Also, the idea of using linguistics as a tool of comparison to illuminate the problem of film language could have been taken directly from the inventor of filmology.

The most direct link, however, between writings from the Revue internationale de filmologie and Metz's own film semiotics, can be found in two essays by Roland Barthes, published in $1960 .{ }^{35}$ These articles are

absurd. We are going to assure ourselves, carefully, because the affair is important, that film, in its essence, is not, can not be nor can it become a language. We will then assure ourselves that in the study of filmic communication, eliminating the idea of language does not lead to eliminating the idea of discourse.' Gilbert Cohen-Séat, 'Le discours filmique', Revue internationale de filmologie, 5 (1949), 37-48 (p. 39).

31 Cohen-Séat, 'Le discours filmique', p. 43.

32 Ibid., p. 44.

33 Gilbert Cohen-Séat, 'Nature et portée de l'information par les techniques visuelles', Revue internationale de filmologie, 29 (1957), 21-32 (p. 27).

34 Metz, 'The Cinema: Language or Language System?', pp. 61-72.

35 Roland Barthes, 'Le problème de signification au cinéma', Revue internationale de filmologie, 32-33 (1960), pp. 83-89; Roland Barthes: 'Les 'unités traumatiques' au cinéma', Revue 
relatively little-known and have received little critical attention. Indeed, many articles on Barthes and cinema fail to mention them at all. ${ }^{36}$ These articles by Barthes were translated into Italian, published in 1995 under the title I segni e gli affetti nel film, with a foreword by Francesco Casetti, ${ }^{37}$ and the only article translated into English was published in a specialized university film journal with limited distribution..$^{8}$

This situation provokes a series of hitherto unanswered questions. If we know that Metz read the Revue attentively and also that he worked under Barthes' supervision from 1963 at the Ecole Pratique des Hautes Etudes, and that he considered Barthes to be his only real teacher, ${ }^{39}$ why then do we find practically no references to these articles by Barthes that seem to anticipate the entire problematic of the semiology of the cinema? Why does he refer to texts such as Mythologies, 'Rhetoric of the Image', 'The Structuralist Activity', and others, but (with the exception of one footnote) not to those that deal principally with the semiology of the cinema? Why, in Metz's early writings, is there no systematic recourse to the issues that Barthes raises?

Before attempting to respond to these questions, I will first outline the principal arguments of these two articles.

'The Problem of Signification in Cinema' begins with the statement that if film cannot be defined as a pure semiological field - because it cannot be reduced to a grammar of signs - there is nevertheless a system of signs at work in filmic communication. Barthes qualifies Cohen-Séat's claim that signs are absent from cinema, seeing the process of signification as subordinate to the more direct form of cinematic communication. Signifying units should first be isolated from the audiovisual flux. According to Barthes, the opening of a film has the greatest density of signifiers because of its heavy

internationale de filmologie, 34 (1960), pp. 13-21.

36 See, for example: Dana Polan, 'Roland Barthes and the Moving Image', October, 18 (Autumn 1981), pp. 41-46; Réda Bensmaïa, 'Une vision perverse du cinéma: Roland Barthes', CinémAction, 20 (1982), pp. 129-31; Dominique Païni, 'D’une théorie douce à une lecture poétique: Barthes et le cinéma', CinémAction, 20 (1982), pp. 132-42; Jonathan Rosenbaum, 'Barthes \& Film: 12 Suggestions', Sight and Sound, 52/1 (1982), pp. 50-53.

37 Roland Barthes, I segni e gli affetti nel film (Florence: Vallechi, 1995). I thank Frank Kessler who brought this to my attention.

38 I thank Dana Polan for bringing this to my attention. His translation was published in 1985 as 'The "Traumatic Units” of Cinema: Research Principles', On Film, 14 (1985), pp. 48-53. New translations by Kate Ince of this and the other essay are about to appear in Filmology [forthcoming]. All quotations from these articles by Barthes are sourced from the Ince translation.

39 Michel Marie and Marc Vernet, 'Entretien avec Christian Metz', Iris, 10, 271-97 (pp. 295-96). This article has been translated into English in Conversations with Christian Metz: Selected Interviews on Film Theory (1970-1991), ed. by Warren Buckland and Daniel Fairfax (Amsterdam: Amsterdam University Press, 2017), pp. 243-274. Cf. also Roger Odin's article in this volume. 
explanatory function. If a film recounts the characters' personalities and 'backstories', these are typical signifying moments. Barthes attributes three traits to the filmic signifier. It is 1. heterogenous, because it engages two senses (sight and hearing); 2. doubly polyvalent, because one signifier can express numerous signifieds, and, conversely, a signified can express itself through numerous signifiers; 3. combinatory, because numerous signifiers can contribute to the creation of a semantic unit. For Barthes, the art of film consists precisely in the elegance with which directors establish and unify different signifiers. ${ }^{40}$

By way of illustration, Barthes studies the collection of signs at the beginning of Claude Chabrol's film, Le beau Serge (F 1958), which he had already reviewed one year earlier. ${ }^{41} \mathrm{He}$ analyzes the attributes that signify the character traits of the lead role, François Baillou, played by Jean-Claude Brialy, whose clothing 'contrasted with the clothing of the local peasants' and signifies 'young bourgeois' (Figure 6.1). Indeed, the 'dandyism in the detail of his clothing' signifies liberated', while the 'adolescent features to his dress', like the 'loosely tied scarf', signify 'young' (Figure 6.2). The 'large books in the room' and the 'reading glass' signify 'intellectual' (Figure 6.3). The 'Swiss label on the suitcase' signifies 'former invalid' (Figure 6.4), and, finally, reading the 'Cahiers du cinéma over breakfast' signifies 'cinephile'. ${ }^{42}$

40 Roland Barthes, 'The Problem of Signification in Cinema', trans. by Kate Ince, in Filmology [forthcoming]. Before this article, Barthes had touched upon the question of filmic signs in his text 'The Romans in Film' (in Mythologies [1957], trans. by Annette Lavers [New York: Noonday Press 1972], pp. 24-26), where he treats the 'fringes' on the actors' foreheads as signs of 'Roman-ness'.

41 Roland Barthes, 'Cinéma droite et gauche', in CEuvres complètes. Tome I. Livres, textes, entretiens 1942-1961 (Paris: Seuil, 2002), pp. 943-45. This critique is revealing, for it anticipates Barthes' notion of the 'reality effect' (effet de réel), developed nine years later with regards to Flaubert's A Simple Heart and a passage from Jules Michelet's History of France. See Roland Barthes, 'The Reality Effect', in The Rustle of Language, trans. by Richard Howard (Oxford: Blackwell, 1986), pp. 141-48. The 'reality effect' arises from 'concrete details' that have no immediate narrative function - details such as the barometer in A Simple Heart, which seem to denote the general category of 'the real'. Very close to this idea are Barthes' descriptions of Chabrol's 'micro-realism': 'In sum, the good in this film is what one might call its micro-realism, the elegance of its choices; Chabrol has a power of correction; for example, when the children are playing football on the street, Chabrol knew how to find the essential gestures, those that persuade by using what Chabrol termed "denotating the evident". Formally, in its descriptive surface, Le Beau Serge has a Flaubert-like quality.' Barthes, 'Cinema droite et gauche', p. 944 (emphasis in original).

42 Barthes, 'Problem of Signification' [forthcoming]. 

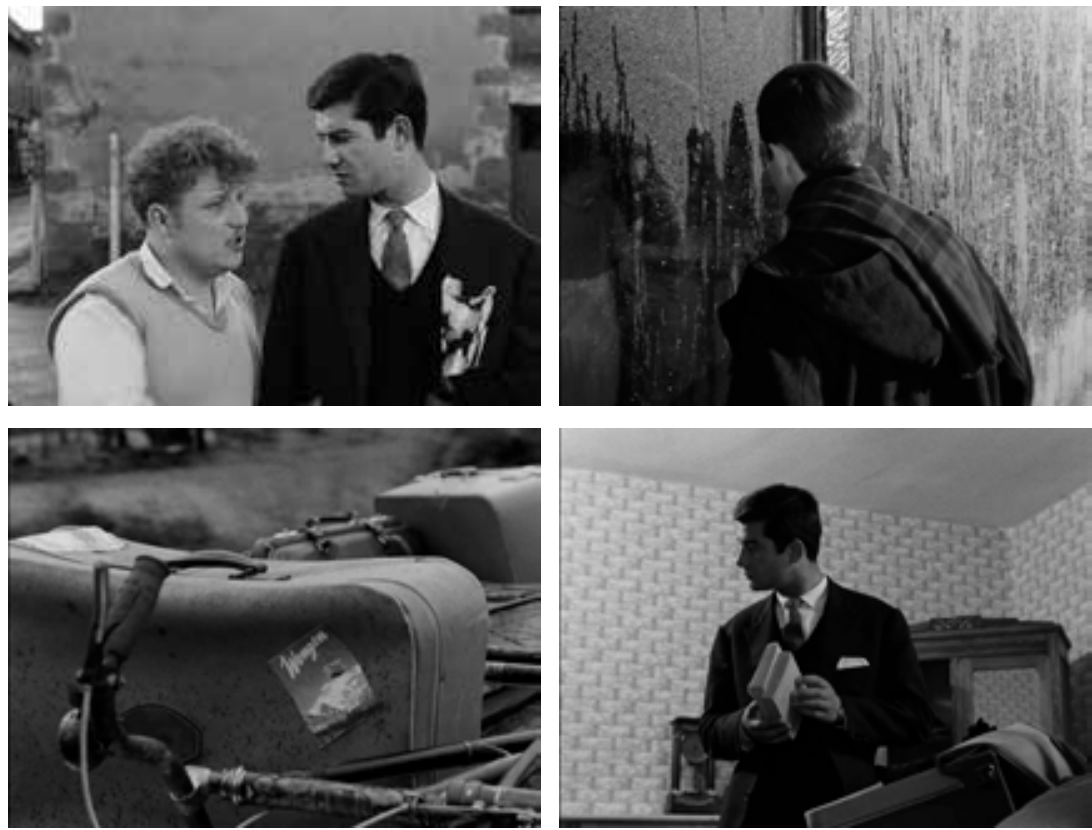

Figs 6.1-6.4: Signifying character attributes in Le beau Serge (Claude Chabrol, F 1958)

With respect to the question of the signified in cinema, Barthes reaffirms his conviction that not everything in the film is sign:

The most important problem posed by the filmic signified is: what is signified in film? In other words, to exactly what extent is semiology relevant to film analysis? Film is obviously not made up just of signifieds; film is not an essentially cognitive medium, and in it, signifieds are only episodic, discontinuous, often marginal elements. ${ }^{43}$

He also offers a definition of the filmic signifier:

The signified is everything outside the film that needs to be actualised in $i t$. If, on the other hand, a reality is entirely contained within the film - invented and created by it - then that reality cannot be the object of signification. ${ }^{44}$ 
This definition seems to be founded on a notion of the sign as necessarily designating an object that exists only outside the sign itself. In this way, Barthes establishes a conceptual difference between the 'showing' (of immediate diegetic realities) and the 'signifying' (which implies a reference to diegetic realities that are not shown):

For example, if a film narrates and shows an amorous encounter between two characters, this encounter is experienced directly before the viewer and does not need to be reported, and we are in the order of expression and not signification. If the encounter has taken place outside the film, either before it or between two of its sequences, the viewer can only learn of it via a precise process of signification, which exactly defines the semiological element in film. ${ }^{45}$

From this delimitation of the semiotic in cinema, Barthes draws the conclusion that signification can never be central to a sequence, that it always remains marginal. While it is quite possible to imagine sequences that are purely non-signifying, the opposite is not possible: there cannot be, according to this notion, sequences that are purely signifying.

In the second article, entitled "Traumatic Unities" in the Cinema', Barthes does not appear entirely happy with the answers given in his first article. He reformulates the questions in the following way:

What are the loci, forms and effects of signification in film? More precisely, does everything in film signify, or are there gaps between the elements that do so? What is the nature of the relationship linking filmic signifiers to their signifieds? ${ }^{46}$

On this occasion, Barthes refers to Thematic Film Tests (T.F.T. or tests filmiques thématiques) which were used by the Institut de filmologie from 1957. These tests involved making and screening different versions of silent short films so as to study variations in audience reactions. Barthes uses T.F.T. $\mathrm{n}^{\circ} 8$ as an example, which shows a young man and a mature woman. Spectators are asked their opinions concerning the identity of the two and the nature of their relationship. It is possible to see them as mother and son, as lovers, or as having an ambiguous parental relationship. For 
Barthes, the events presented subsequently become signs when and if they gradually communicate information about the status of the relationship. In this manner it appeared possible to first determine the signifieds. Then one had to find the signifiers that cause meaning to differ. Barthes compares two versions of T.F.T. $\mathrm{n}^{\circ} 8$, which contain the variation of the look that the young man gives the lady, which is prolonged in the second version and thereby changes the signified: in the second version, the relationship between the two appears clearly amorous.

Barthes deduces the following pattern:

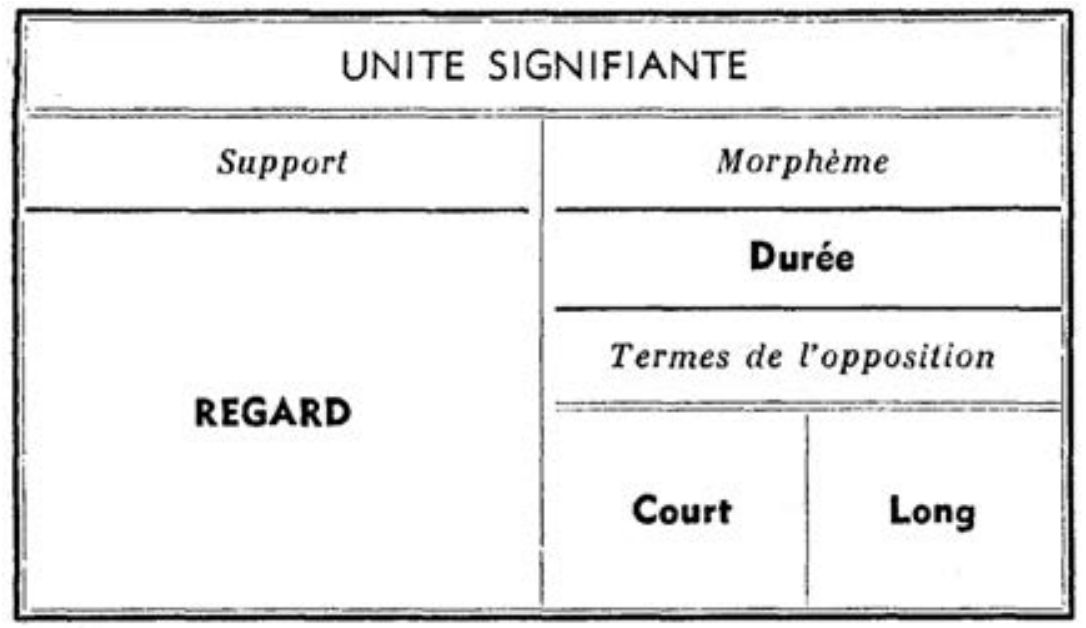

Fig. 6.5: Diagram from Barthes, "Les 'unités traumatiques'”, p. 20

The look [regard] itself is not meaningful; the meaning lies in its length [durée], either short or long. From this example, Barthes reconstructs a signifying unit analogous to the morpheme in natural languages. The object of this procedure is 'to compile a reasoned inventory of film signs'. He defines this as a dual task of semiological research:

[T] he inventory of signifying unities has to be established, which is essentially a task of delimitation in which the film is cut into as many layers as there are distinct signifieds; next, these signifying unities have to be compared to one another (without referring further to the chain of images) then grouped into sets of oppositions, the play between which engenders their meaning. ${ }^{47}$ 
Yet this research programme was never realized, not by Barthes, not by Metz, nor indeed by anyone else. The only research experiments of which I am aware that tend in this direction were made within a completely different theoretical framework, that of cognitive psychology. ${ }^{48}$

If one compares this research programme of Barthes' with Metz's early writings from 1964 to 1966, it would appear that something like an epistemological break must have taken place. Metz is not at all bothered with an inventory of filmic signs. Indeed, what is most astonishing is that Metz hardly ever discusses the idea of filmic signs and even less tries to define or categorize them. He even seems to abandon the search from the outset when he states in 'The Cinema: Language or Language System?' that there are no delimitable signs in cinema, because the 'signifier is coextensive with the whole of the signified'. ${ }^{49}$ Later, in Language and Cinema, Metz openly declares himself hostile to the idea that it may be possible to find 'a single sign or a single cinematic type of articulation', which would be 'of nearly stable and more or less familiar size' and which would also, 'like the morpheme, [...] necessarily be segmental'. $5^{\circ}$ The idea of the cinematic sign seems to him 'doubly dangerous: from the perspective of the internal development of semiotic research, and from that of the public debate with its adversaries'. $5^{1}$

Metz never tried to establish an inventory of filmic signs or to search for elementary signifying units. Even the idea that there are signifying and non-signifying elements to be distinguished in the audiovisual flux does not seep into his semiotics.

Hence my hypothesis that if Barthes' filmological articles had an impact on the development of Metz's thought, this appears only ex negativo. This is to say that it seems to me that Metz felt that Barthes' programme was not accomplishable and that this saved him a detour. Rather than looking to define cinematic signs, he deduced the specificity of cinematic language from the impossibility of doing so. This allowed him to concentrate on questions concerning the syntagmatic and, later, in Language and Cinema, to develop the principle of the theoretical predominance of code (or codes) over minimal units

48 In Germany, for instance, by Peter Ohler and Gerhild Nieding, two researchers who have often worked with slightly different versions of short films to test audience reactions and variations in cognition: Peter Ohler, Kognitive Filmpsychologie: Verarbeitung und mentale Repräsentation narrativer Filme (Münster: MAkS, 1994); Peter Ohler and Gerhild Nieding, 'Kognitive Filmpsychologie zwischen 1990 und 2000', in Film und Psychologie - nach der kognitiven Phase? (Marburg: Schüren, 2002), pp. 9-40.

49 Metz, 'The Cinema: Language or Language System?', p. 43 (translation modified).

50 Metz, Language and Cinema, p. 205.

51 Ibid., p. 206. 
(or 'signs'). To put it differently: where Barthes had looked for signifying units in the content of filmic images (the length of a glance from one character to another, for example), Metz is more concerned with the form of cinema's matter of expression and the different ways in which one shot may relate to another.

And yet, this new approach is in fact what Barthes suggests in a 1963 interview with the editors of Cahiers du cinéma. Three years after the publication of his filmological articles - of which he makes absolutely no mention in the interview - Barthes appears to offer a negative assessment of them himself: 'For myself, it's probably because I have not succeeded in integrating the cinema within the sphere of language that I consume it in a purely projective manner, and not as an analyst. ${ }^{52}$ But in the same interview, Barthes confirms the usefulness of a semiology of the cinema:'All this seems to prove that there are possibilities of exchange between linguistics and film, providing you choose a linguistics of the syntagm rather than of the sign. ${ }^{53}$ It is quite possible that Barthes had already read a first draft of Metz's 'The Cinema: Language or Language System?' at this point. In any case, he indeed anticipates the work that Metz would accomplish on the syntagmatic axis of filmic signification in the 196os, especially the renowned 'grand syntagmatique. ${ }^{54}$

To conclude briefly, it is possible to identify three areas where filmology's influence on Metz has played out: the epistemological distance that filmology deliberately introduced with respect to cinematic culture, the technical terms that certain filmologists had invented, and, finally, the semiological reflections in the writings of Cohen-Séat and Barthes. The importance of the last-mentioned for the genealogy of Metz's theory is less evident because, as I have tried to show, they are indeed relevant only in that they suggest an approach that Metz would not follow; an approach from which he would distance himself so as to develop his own version of the semiology of the cinema - and with the success for which he is today remembered. Of course, this does not mean that we necessarily have to agree with Metz's scepticism towards the notion of filmic signs. Whether we need to postulate signs and, if so, how to conceptualize them, can be left open to further debate within the semiotics of cinema.

\section{Translated from French by Anthony Cordingley}

52 Roland Barthes, 'On Film', in The Grain of the Voice. Interviews 1962-1980 (Berkeley/Los Angeles: University of California Press, 1991), 11-24 (p. 13).

53 Barthes, 'On Film', p. 18.

54 Christian Metz, 'Problems of Denotation in the Fiction Film' [1968], in Metz, Film Language, pp. 108-46. 


\section{About the author}

Guido Kirsten is a postdoc researcher at Stockholm University. He obtained his doctorate in 2012 from the University of Zurich. In 2013, his thesis was published under the title Filmischer Realismus. He is co-editor of the German film and television studies journal montage $A V$ (since 2007), for which he organized thematic issues on André Bazin (2009), filmology and the sociology of cinema (2010), film and politics (together with Chris Tedjasukmana and Julia Zutavern; 2014), and Roland Barthes' cinema-related writings (2015). With Karl Sierek, he edited the anthology Das chinesische Kino nach der Kulturrevolution (2011). Together with Kate Ince and Vinzenz Hediger, he co-edited the forthcoming Filmology and the Origins of Film Studies. Selected Writings from the Revue international de filmologie.

\section{About the translator}

Anthony Cordingley is Maître de Conférences in English and Translation at the Université Paris 8, Vincennes-Saint-Denis. He publishes on twentiethcentury literature, translation, and philosophy, and especially on the works of Samuel Beckett. 


\section{II}

Questions of Form and Aesthetics 



\title{
7. Christian Metz and Aesthetics
}

\author{
Martin Lefebvre
}

Tröhler, Margrit and Guido Kirsten (eds.), Christian Metz and the Codes of

Cinema. Film Semiology and Beyond. Amsterdam University Press, 2018

DOI: $10.5117 / 9789089648921 / \mathrm{CHO} 7$

\begin{abstract}
Critics of semiology, and of Christian Metz's work in particular, often alleged that he was not a cinephile, that he had no interest in films (since he hardly ever analyzed a film), and that semiologists like Metz were putting aside everything that made cinema an art and a source of aesthetic pleasure. In short, Metz was frequently attacked for being indifferent to film as an aesthetic artefact. This chapter seeks to develop a more nuanced view by examining the place that the aesthetic occupies in Metz's intellectual trajectory as well as its links with semiology. This place can be divided, broadly speaking at least, into three 'sites' between which the aesthetic moves: expressiveness, stylistics, and poetics.
\end{abstract}

Keywords: film semiotics/film semiology, film aesthetics, filmology, film phenomenology, cinematic expressiveness, cinephilia

Amongst the least-explored themes in discussions of Christian Metz's work are all those that could be categorized, generally speaking, as pertaining to the 'aesthetic'. 'There are several reasons for this. First, Metz's writings themselves, marked from the outset by the structuralist and semiological ${ }^{2}$

1 By 'aesthetic' here, I mean issues concerned with art, including what is sometimes labeled under stylistics and poetics. One exception, however, is Dominique Chateau's 1993 article, 'Une contribution de Christian Metz à l'esthétique: autour du thème de "l'hallucination paradoxale"', Les cahiers du CIRCAV, 6-7 (1993), pp. 65-76.

2 Throughout this paper I shall avoid using the term 'semiotics' and instead use 'semiology' as a translation for the French 'sémiologie'. Two reasons explain this choice: 1) in English, 'semiotics' is used in reference to the tradition inaugurated by American philosopher Charles S. Peirce (though Peirce rarely used 'semiotics', preferring instead 'semiotic', 'semeiotic', 'semeiotics', or even 'semeotic' to translate Locke's semiotikè). Since this tradition differs in profound ways from that inaugurated by Saussure, who used the term 'sémiologie', it seems appropriate to signal the distinction; 2) in structuralist circles in France, 'sémiologie' was used by authors such as Metz 
quest for 'cinematic language' and its specificity, appear to resolutely turn their back on everything that might be described as criticism, embracing instead what ought best be called theory. In this regard, Metz was somewhat like the filmologists who preceded him and who provided part of the inspiration for his doctoral dissertation proposal in 1961 at the Sorbonne entitled 'Cinéma et langage' ('Cinema and Language'). Then came the introduction of psychoanalysis. Here, Metz's most enduring work has been on the concept of the 'dispositif' and, in his own terms, not the psychological study of individual films but rather the relations between psychoanalysis and the cinematic situation, 'with the mirror stage, with the infinity of desire, with the voyeuristic position, with the ebb and flow of disavowal's helping to grasp the unconscious of the cinematic institution, 'imprinted', as it were, in the viewer's psyche as a code. ${ }^{4}$ Then, finally, there was the return to structuralist linguistics with his book L'énonciation impersonnelle, ou le site du film. It is true that in Metz's writings the idea that cinema might be an art or even an art-in-the-making, one to be defended against its detractors - an overriding theme in so-called 'classical' film theory, from Münsterberg to Mitry by way of Freeburg, Arnheim, Bazin, Balázs, Kracauer, and many others - largely shifts over to the idea of cinema as something akin to a language, of cinema as logomorphic. We thus find in Metz no defence and illustration of how cinema functions as an art or of its artistic value. And yet, as momentous a shift as this may have been, I shall endeavour to

or Barthes and it came to distinguish their work from that of A.J. Greimas who used the term 'sémiotique' which then became associated with Greimassian semiotics.

3 Christian Metz, The Imaginary Signifier: Psychoanalysis and the Cinema, trans. by Celia Britton and others (Bloomington: Indiana University Press, 1982 [1977]), p. 151.

4 The expression belongs to Metz, who uses it in a document accompanying his application to become Directeur d'Etudes at l'Ecole des Hautes Etudes en Sciences Sociales in October 1975: 'It is the cinematographic institution [l'institution cinématographique] itself (for it truly is an institution, as the theatre was in classical Greece), it is this historically and socially new fact, which is a never-before-seen signifier [signifiant inédit] (an 'audio-visual' signifier), which can, it appears to me, be productively enlightened by Freud's discoveries. Institutions also have their own unconscious which is 'imprinted' [imprimé] in the (socially conditioned) psyche of each of its users, which is to say, in the case of cinema, the spectator: this equally pertains to the 'code', the object of study of semiotics.' Christian Metz, ms. CM1227. Programme d'enseignement et de recherche, accompanied by a letter dated 9 October 1975 to Jacques Le Goff, president of the EHESS at the time. All manuscripts cited in this article come from the Fonds Christian Metz of the Bibliothèque du film (BiFi) in Paris. Reference to them will use the current manuscript number. English translations are ours. The Fonds has not been catalogued and was not available to the public at the time of writing this essay. I wish to thank the estate of Christian Metz for granting me access to archival materials and to acknowledge the support of the Social Sciences and Humanities Research Council of Canada who made possible consulting the Fonds at BiFi. 
show that the break with aesthetics signalled by Metz's semiology was not as thorough or absolute as it has often been made out to be. My aim here, therefore, is to examine what in Metz's project belongs to the aesthetic or originates from it.

This shift, from cinema as 'art' to cinema as 'language', it turns out, was not perfectly smooth as far as film scholarship is concerned. Those who resisted the move saw it for what it was, namely nothing short of an attempt to realign the study of cinema and reposition it in the epistemic field: moving it from the domain of art and aesthetics, where it had often been pigeonholed at the hands of primarily self-taught authors (self-taught at least as far as cinema was concerned, certainly), to that of semiology, a domain for which linguistics served as the 'guiding' science ('science pilote' was the set phrase to characterize linguistics' ties with semiology during the 1960s). There, in true Saussurian spirit, the study of film would fall under the general rubric of social psychology. ${ }^{5}$ To generalize somewhat, we might say that this project, riding the structuralist wave that was at the time spreading wildly and with remarkable success throughout the humanities and social sciences, managed, if only for a brief moment, to carry through the rift initially created in France by the filmology movement between an academic discourse on cinema (and sometimes on films) and an aestheticcritical (and sometimes historicist) discourse on films. While the Institut de filmologie had succeeded in carving out a small niche for itself in the university through its connection with the Sorbonne in the $1950 s,{ }^{6}$ it was in large measure with Metz, despite the relatively peripheral position he occupied - if only with respect to the university - in the sixth section of l'Ecole Pratique des Hautes Etudes [EPHE] (which in 1975 became l'Ecole des Hautes Etudes en Sciences Sociales [EHESS]) that film studies definitively took up a place in higher education in France, leading semiology to hold sway for a few years as the dominant discourse in the discipline. We must acknowledge that, beyond the impact of his publications and research, Metz also found himself shaping film studies by either supervising the research or sitting on the dissertation committees of practically an entire generation of future French academics, not counting the numerous foreigners who

5 Let us recall that the linguistic sign for Saussure is a two-faced entity, both sides of which are psychological: the signified which is a concept (and therefore a res mentis) and the signifier which is a sound-image ('image acoustique'), described by Saussure as the psychical imprint of a sound. The union of the two entities is arbitrary and social.

6 On this topic, see my article 'L'aventure filmologique: documents et jalons d'une histoire institutionnelle', Cinémas, 19/2-3 (2009), pp. 59-10o. 
studied under him. And, as was the case with filmology,7 a number of voices were raised, some in France and many abroad, criticizing what they saw as the inordinate wish in Metz's work to render abstract and to formalize as well as the lack of any proper aesthetic consideration toward film art, individual films, or the pleasures they afford. Thus Sam Rhodie, in an article dating from 1975, reported the attacks by the British critic Robin Wood before he, too, embraced certain structuralist principles:

A year ago, at a seminar at the British Film Institute centering on the work of Christian Metz and on cinesemiotics, a well-known critic spoke. Robin Wood found Metz insufficiently concrete, too concerned with abstract proposals, instead of with the actual analysis of 'real' films. Wood himself has repeatedly stressed the organic quality of specific films - the singularity of the body of the text. 'What does all this have to do with films?' Wood wanted to know. The suspicion was that he knew already in the very insistence of his demand to know what the 'pay-off' was, what the 'returns' of this theorizing were. Could it be 'used', 'exploited' in filmic analysis? ${ }^{8}$

It is true that prior to the publication of Lénonciation impersonnelle in 1991, Metz's writings mention very few films. In this, also, he was following the example of the filmologists: not a single film title was so much as mentioned in Gilbert Cohen-Séat's Essai sur les principes d'une philosophie du cinéma in 1946. Metz drew on this volume, adopting in Language and Cinema, with a few minor modifications, its distinction between cinematic (cinématographique) and filmic. In short, Metz was condemned in certain quarters for not being a cinephile, for having no interest in films, and for putting aside everything that made cinema an art and a source of aesthetic pleasure. Those making such reproaches were perhaps unaware that Metz had co-directed and led discussions at the ciné-clubs of Lycée Henri IV in Béziers and then Lycée Henri IV in Paris, and then finally at that of Ecole Normale Supérieure on rue d'Ulm between 1947 and 1953, when post-war cinephilia in France was in full swing. Or, that he had briefly been Georges Sadoul's assistant in 1955-56, just after finishing his Master's degree in Greek and his aggrégation in classical literature (Lettres classiques). They

7 See in particular the acerbic criticism levelled against filmology by André Bazin (under his pseudonym Florent Kirsch) in the pages of Cahiers du cinéma: 'Introduction à une filmologie de la filmologie', Cahiers du cinéma, 5 (September 1951), pp. 33-38.

8 Sam Rohdie, 'Metz and Film Semiotics: Opening the Field', Jump Cut, 7 (1975), 22-24 (p. 22). 
were also undoubtedly unaware that Metz wrote long screening notes for himself on the thousands of films he viewed at the cinema, on videocassette, or on television. These were, of course, intended to jog his memory, but in them one can also find indications of his taste and expressions of his cinephilia: on Wim Wenders' Alice in the Cities (FRG 1974) for example, he writes: 'the film is very dull, slow, dragged out[,] the dead moments are overwrought, and not just anybody can make themselves Antonioni, here the dead moments are really dead; we are gently bored to death, without violence.' Then, unexpectedly, he adds: 'curiously, this very set of "faults" creates a kind of personal touch, or personal style; it's true that this doesn't resemble anything else, that it has a real tone. But we will have to wait for his maturity for this tone to be linked with something solid. Here it remains very adolescent. ${ }^{9}$ Metz also expresses in these notes his admiration for films as different as Steven Spielberg's Duel (USA 1971), struck as he was by the 'remarkable [...] pure virtuosity' and 'astounding' 'science of camera angles on the two vehicles; ${ }^{10}$ or Robert Bresson's The Ladies of the Bois de Boulogne (F 1944) which he describes quite simply as 'sublime,' noting its 'minimal, stripped-down compositions, yet well-marked and strongly set apart from one another visually' and commenting that 'everything is realistic, though it doesn't seem so [because] the stylization transfigures everything, thanks to the resolutely literary dialogue (even though it is minimal and very simple), the diction (not yet "blank" but already very sober and stately) [and] the plain elegance of the image."

Beyond such anecdotes and lists of personal favourites, however, what interests me most of all here is the place that the aesthetic occupies in Metz's intellectual trajectory as well as its links with semiology. This place can be divided, broadly speaking at least, into three 'sites' between which the aesthetic moves: expressiveness, stylistics, and poetics.

\section{Expressiveness}

Elsewhere I have had the opportunity, along with Dominique Chateau, to demonstrate how Metz's notion of expressiveness is organized around a phenomenological strain which, in his earliest writings, had a certain degree of difficulty in distinguishing itself from the perspective provided 
by semiology. ${ }^{12}$ In fact, it is possible to view a good many of Metz's writings, from 'The Cinema: Language or Language System?' to The Imaginary Signifier, as an attempt to bring semiology and phenomenology into dialogue. Before June 1967, however, the date of the Pesaro conference where he met Umberto Eco, this dialogue was such that it is difficult to distinguish, if one considers solely what the image shows (the purely 'visual-recording' aspect of cinema), where the phenomenological search for meaning ends and where the semiological analysis of cinematic signification, properly speaking, begins. At the centre of this ambiguity lies the problem of the analogical nature of photo-filmic imagery and its relation with expressiveness - both that of the world and that of art.

In his early work, Metz was deeply influenced by Mikel Dufrenne, and especially by his book The Phenomenology of Aesthetic Experience, as his copious reading notes on it demonstrate. Metz actually reprised passages from these notes in his great programmatic article 'The Cinema: Language or Language System?'. It was from Dufrenne, moreover, that he borrowed the concept of expression understood as a properly phenomenological dimension of meaning. Dufrenne proposed to distinguish between representation or signification - which is what ordinary language does when it is used to denote - and expression, whether natural or artistic, as in the case of poetry. 'The work of art', Dufrenne explains, 'says something directly - something beyond its intelligible meaning - and reveals a certain affective quality which may not be easy to translate but can nevertheless be experienced distinctly. Does not a particular painting, even if it has no subject, express the tragic, just as a piece of music expresses tenderness or a particular poem anguish or serenity? ${ }^{13}$ It follows for Dufrenne that it is the expressivity of an object or work of art (i.e., its ability to make us aesthetically aware of a certain quality) and not representation or signification (i.e., its ability to stand in for a thing or a concept) that gives rise to the aesthetic dimension, whatever the object or work. In short, representation, which is synonymous here with signification and denotation, is not a necessary or sufficient condition of the aesthetic.

For Metz, who in his early writings followed Dufrenne in this regard, expression in art is the meaning offered directly to us via a medium but beyond what is represented, which is to say beyond the manifest denoted

12 See Dominique Chateau and Martin Lefebvre, 'Dance and Fetish: Phenomenology and Metz's Epistemological Shift', October, 148 (2014), pp. 103-32.

13 Mikel Dufrenne, The Phenomenology of Aesthetic Experience, trans. by Edward S. Casey (Evanston: Northwestern University Press, 1973 [1953]), p. 326. 


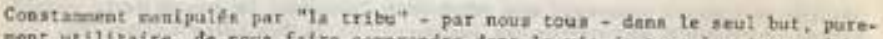
nent utilftaire, de nous falte sogprendre dans la vie de toun los fours, les mots peuvent avas etre l'objet g'une alchinte plus subtile, qui lea readra

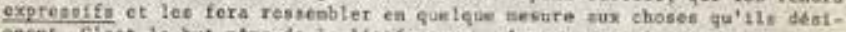
geent. C'eat le but abe de la litéfrature, c'est ee qui la diatingue do langsie uivol (ce derafer ne recherche l'expressivice qque par tastanta, comse

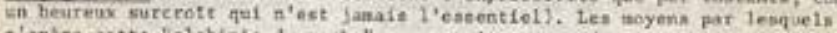
n'opdre cecte "alehinie de verbe" peuvent tire groupés en stoks principaux.

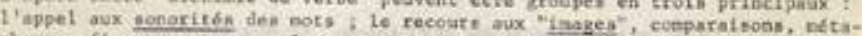
phores, flguren, ete... ; Ie groupentit des nots oe pbrases. Enste con troin

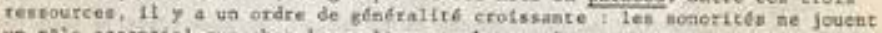
un rote egentiel que cher lea pottes ot cher quefquel prosateurs: ies inages sont presented dens prebque tous les livrea, nals pas a chaque lizine; Ie thotx et I'artangeseat den nots pour en falte den phrases const fluebs in souct necessalte de toist ectyain a tout instant.

\section{1) - La augazite des nots come expression du nonde.}

Noull cositations tout a I'heure gue la sooorité d'an nat ne refle-

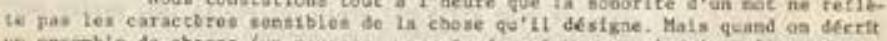
un ensenbte de choses (un paysage, un sofe de printenps...). rien n'Interdit

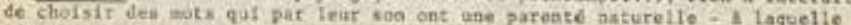
t'arefile et la scesiblisé the se troepent pas - aves l'atmosphere que lion yeut " rendre". Decrire It solt, ce n'eat pai seut mrent le nonter (ie not

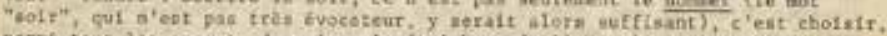

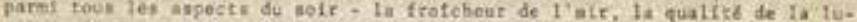

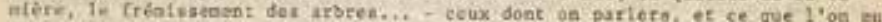
dira. Des lors. In not "solr" a'eat plua-le seui qui a'offre a la plune, et pafni lee centalaes de vecables qui se probenteat, le peate eherehora, cons-

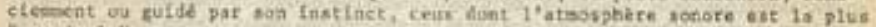
vesperale".

dire :

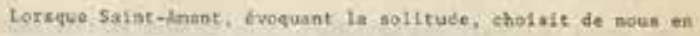

Nob I Que j'atne la soircuee I

Que ces lieux wicrén a in nete.

Rolends der moade et de bruits.

Platisent a mon isqut $a$ tode $1 "$ "

("Li. solitude", strophe 1)

got he volt, in feoutant chaser ces eustre, vero pourtant al afiples, qoe la douceur un peu feutrie dei rimes en "vad" et le crissonent discret des deux "uI" sont aervellieusenent talts pour neas resdre geneible une certiaine qualive de shemce, que troublent postant quelques brutta "bloignes" - to craquenent $d^{\prime}$ wre brancbe d'arbre, ie roulement d'une lourde charrette - sass leaqueta te stlence; privf de conterpofof, ne pourrait mene pas atce "entenda"?

Afabs, alors que daas la vie coufante - et nche en prose Iftet. ratre, bien sowent - on n'utilise les sots que pour leur cone, ot que I'in

Fig. 7.1: Typescript; Fonds Christian Metz, Bibliothèque du film, Paris: ms. CM5000, p. 3

\section{content or signification of the work. In a set of 'answer sheets' (corrigé) prepared for literature students at CUDES ${ }^{14}$ in 1965 , Metz wrote:}

14 The Centre universitaire d'enseignement supérieur, whose director was the philosopher Denis Huisman, was a 'boîte à bac', as these were sometimes called, i.e., a private institution where one went to do a 'bachotage', a period of intensive training to prepare lycée students to pass their baccalauréat exams. 
Words, constantly manipulated by 'the tribe' - by all of us - with the sole, purely utilitarian goal of making ourselves understood on a daily basis, can also be acted upon by a subtler alchemy, rendering them $e x$ pressive and making them resemble to a certain extent the things they designate. This is the very goal of literature and is what distinguishes it from everyday language. ${ }^{15}$

What is interesting in these study notes, for the purpose at hand at least, is how they attest, in the early writings of Metz, to the persistence of an aesthetic conception of literature that first appeared in print a year earlier in 'The Cinema: Language or Language System?' and against which, by contrast, he placed the cinema. This conception, inspired by Dufrenne's work, can be summarized as follows: in the arts founded on representation (or on signification), as is the case with literature, whose material is the language system (la langue), the aesthetic dimension lies in the expressive ability of a work to deliver 'content' other than the mere denoted signification. With respect to such a linguistic-based object, this 'alchemy of words' implies a curious development, however, in that it consists in making expressive a material that originally was in no way expressive because, as linguistic theory overwhelmingly maintains - from Aristotle to Saussure - there exists a complete 'divorce' between words and things. For Metz, the issue with respect to literature thus consists in 'reconciling discourse and the world', that is to say, in recovering the meaning of the world through language. But how is this 'alchemy' to be achieved? In 'The Cinema: Language or Language System?', the credit for bringing verbal language into the realm of art, into the 'world expressed', falls to connotation. The CUDES answer sheets, for their part, filled in additional details by specifying three paths along which the work of literature - in particular the work of literary style - can be carried out: by employing the sonorous quality of words; by resorting to images (meaning tropes and figures such as metaphor or comparison); and finally by grouping words together into sentences. (I will return to these latter two further on.) Through the work of style, literature can render or evoke the world - it can create, in Metz's words, 'profound agreement [...] between words and things' and 'render sensible a certain quality [of the world]. ${ }^{16}$

These ideas sum up the properly aesthetic section of 'The Cinema: Language or Language System?' (entitled ‘Cinema and Literature: The Problem of

15 Christian Metz, Corrigé no. 1, Français littéraire, 'Poésie des mots et pouvoir des mots', ms. CM50oo, p. 3 (Figure 7.1).

16 Metz, 'Poésie des mots', ms. CM50oo, p. 7 and 3. 
Filmic Expressiveness'), where Metz explains that, as representational arts, literature and cinema are by nature condemned to connotation, because denotation always comes before their artistic endeavour'. He goes on to explain that ' $[\mathrm{i}] \mathrm{n}$ the final analysis it is by the wealth of its connotations that Proust's great novel can be distinguished - in [semiological] terms - from a cookbook, or a film by Visconti from a medical documentary'. ${ }^{17}$

This similarity between literature and cinema, however, is only partial; Metz's aim, among other things, is to better identify the difference between the two art forms on the semiological and phenomenological fronts. This difference, he explains in 'The Cinema: Language or Language System?', is that, in literature, representation, or denotation, is founded on the arbitrary nature of the linguistic sign, while in cinema, at least with respect to the photographic dimension of the image, it is founded on analogy. Metz sums this up in the following way: literature is an art of heterogeneous connotation (expressive connotation added to non-expressive denotation) while the cinema is an art of homogeneous connotation (expressive connotation added to expressive denotation).$^{\prime 18}$ One of cinema's specificities is thus its ability to render the world directly with its own expressivity, apart from any artistic labour. For the natural expressiveness of the world is that through which the latter speaks to us, touches us, has meaning for us - even though the world itself isn't a sign, a representation. We recognize in this a central theme of the phenomenology of cinema as it was developed by numerous French authors who preceded Metz, including Merleau-Ponty, Bazin, and Mitry. At the same time, the idea that cinematic art qua art must possess its own expressiveness beyond and above that which belongs to the world as it is denoted by the image is in line with that other central theme of 'classical' film theory, to the effect that what distinguishes the filmic image from the 'world' is what gives cinema its artistic potential. For Metz, therefore, cinema as an art form possesses a dual expressiveness: 'aesthetic expressiveness is grafted onto natural expressiveness - that of the landscape or face the film shows us' in such a way that in film '[o]ne is forever shifting from art to non-art, and vice-versa. The beauty of the film is governed to some extent by the same laws as the beauty of the filmed spectacle: in some cases it is impossible to tell which of the two is beautiful and which of the two is ugly.'19

17 Christian Metz, 'The Cinema: Language or Language System?', in Film Language: A Semiotics of the Cinema, trans. by Michael Taylor (Chicago: University of Chicago Press, 1974), 31-91 (pp. 76-77).

18 Metz, 'The Cinema: Language or Language System?', p. 79.

19 Ibid., p. 77 and 82. 
We should note two consequences of this conception. First, it upsets any too-hasty association, in the case of cinema, between denotation and signification as well as between connotation and expression because it is only on the aesthetic level proper to art that connotation and expression are inseparable. This undoubtedly explains why Metz thought - as he emphasizes, in particular in his 1966 article on 'The Modern Cinema and Narrativity' - that it was an almost categorical error, one Bazin and others had made, to derive a normative aesthetic or an ars poetica from the cinema's peculiar denotative-phenomenological relation with the world. Second, and to the extent to which, as Dufrenne maintains, expression gives a phenomenological dimension of meaning which must be distinguished from the semiological dimension, which is founded on a code, we can see how this conception blurs the boundaries - in the very heart of denotation, i.e., the most fundamental semiological zone - between meaning and signification, phenomenology and semiology. With respect to the above, too little attention has perhaps been paid to Metz's argument in 'The Cinema: Language or Language System?' (despite the fact that this argument is famous and often commented upon) for the almost phrastic status of the shot in cinema. In film, Metz maintained, '[a] close-up of a revolver does not mean "revolver" (a purely virtual lexical unit), but at the very least, and without speaking of the connotations, it signifies "Here is a revolver!"'20 This is why, for Metz, "the shot [which is like] a "sentence" and not a word [...], is indeed the smallest "poetic" entity'. ${ }^{21}$ While the filmic/linguistic dimension of this distinction has been widely glossed over, it seems to me that commentators have not sufficiently underscored the use of the term 'poetic' in this passage. In his answer sheets prepared for students at CUDES, Metz explains what distinguishes the sentence (as a literary and poetic unit) from the word (as a linguistic unit):

[A] book is not a list of words. While it is true [...] that each word is unconnected to what it signifies, it remains that the choice and ordering of words in sentences confers upon the latter something like a unique and living countenance, different each time, or like a singular respiration which can maintain secret 'relations' with the tangible features of the real event that the sentence sets out to evoke. ${ }^{22}$

Metz, 'Poésie des mots', ms. CM50oo, p. 5 (Figure 7.2). 
expriner ube Idee ou un sentireat, biae tras sisples, par un seul eot. The sensation assol elenentaire que "J'ns frodd" requlert deja trols note, dis. posfa dans un certatn ordre, pour etre portle a la cenhatsounce d'autrui. C'eat seuleseat dans les diettonnaires - ou lorkqu'on apprend une langue etrangère - que 1 'units du langage est lo net. Da a qu' on veut dire quelque chose, 1'unite du langage est ia ghrame lou la propostetion, eu le "groupe

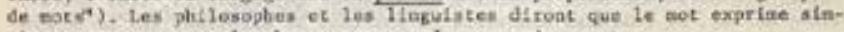
plenent uil coscept, la phrase une pensefe ou un fugenent.

De la nene fagon, us livre a'ent pas une liste de sots. $5^{\prime}$ 'il est vzai, eome nous ie reeareuions au debut, que chaque not eut par tut-nome. etrager a ce qu't1 signifle, 11 reate que Ie eholx et 1'srrangenent des nots au sein des phrakes conferent a cea deralkres quelecue chose come un visage propre, vivant et chaque fols different, ou conee une resplraticn sioguliere equl peat entratenir de secrates "correspondences" avec les caractèren senaibles du spectacle rél que la phrase se propose d'ovocuer. Quil ne reconalt is phrase de Chatesubriand, la phraeo de Ylachert, ia phrase de Froust I Unite eabeatielle do langage vivant, la phrake nowa livre is is fois ua aspect du asade, ot te tegard d'un avteur.

Scoutoas lloussemu nous dectre un paysage des environs de Chanblity: "Tion loin d'une wontazne coupte que $f^{\prime}$ con appelle le Pas-de-1'tebelie, au-

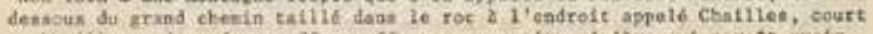
et boullioone dano des goeffree affreux une potite flviere eut parate svoir

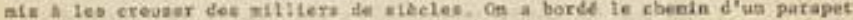
pour provenit tas malheurs ; cela fassite que fe poovale conteapler at fond et gugaer des vertiges cout a mon afse (...). Diea appuye sur le parapet. j'avançals te nos, of je fextals ta des beuren estieres. entrevoyant de teapo

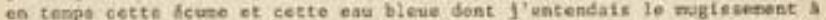
travers tes cria des corbeavx ot des of ceeux do prote gut yotalent de roshe

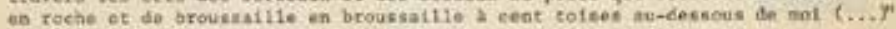
("hes Coafessiens", IIvre IV)

Pourgeiol cette descriptioa, eut n'est pourcant pas parni tes chefoA'eeuvrs du grare - 1 'exenple n'ea est que plus probsat - ent-elle ni vive, $=1$ pitterasque? Quel secret lel permet de dreiser dasa notre Inagination ua

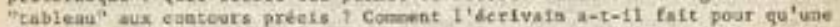
partie au wotns des asfects de paysage pusse dass ses ybrases ? Ce ne sont pan tes mots, teli gu'ch les trowve danin un lexdque, qui oat pu l'y afder : les teraes "tivlare", "Lrounsalile", "parapet", ete...t. n'evoquent par eux-

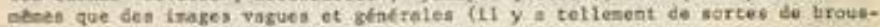
Aaflies, al diverses par lect forme, leur havteur, teur couleur 1), Mais

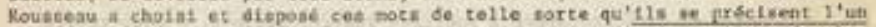
1'alatre. et que 1'expressivise qui a'etait cans aucus d' eux ae trouve finalement dans lesr soeme curleuse nathentique $1 \mathrm{O}^{-}$est pouttant usi deo princlpes les plas glnfrajx - nexe s'II reste Inpltefte - de teute entreprise poetique. ronanesque ou sinplesknt descriptive.

Une "montarne cosper" ; neus woyons devant nouk la nasse rochesae quil a 'arrete net, cone briste dasa la continuite d'un elan, séparfo do son

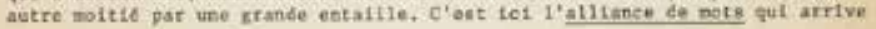

Fig. 7.2: Typescript; Fonds Christian Metz, Bibliothèque du film, Paris: ms. CM5000, p. 5

Then, taking up a description by Jean-Jacques Rousseau of a landscape near Chambéry in Book IV of the Confessions, he explains:

How did the writer manage to make at least some parts of the landscape pass into his sentences? Words as they are found in a dictionary were of no help to him: on their own, the terms 'river,' 'undergrowth,' 'parapet' etc. [...] evoke only vague and general images. [...] But Rousseau chose to order these words in such a way that they give precision to one another, 
and the expressivity found in neither is, in the end, found in their sum: strange mathematics! Yet this is one of the most general principles - even though it remains implicit - of any poetic, novelistic or simply descriptive enterprise. ${ }^{23}$

With the shot 'naturally' and automatically carrying out what the sentence is capable of accomplishing in literature, the filmic image inherently pertains to the expressive register proper to the aesthetic, even if this is not yet sufficient to create an art form in the strict sense (art being just one dimension of the aesthetic: a sunset may offer an aesthetic experience but it is not art). 'Film', Metz remarks, 'is immediately and automatically situated on the plane of rhetoric and poetics. ${ }^{24}$

Of course, Metz never systematically examined the cinematic means by which film becomes an art and expresses itself aesthetically through connotation. ${ }^{25}$ But this does not mean that he was insensitive to such questions, as can be seen in particular in his comments on a scene from Grigoriy Aleksandrov and Sergei Eisenstein’s ¡Quéviva Mexico! (USA/MEX 1930) in 'The Cinema: Language or Language System?', or in some of his personal film-viewing notes. In the former, Metz wrote:

In Eisenstein's Que Viva Mexico, there is a famous shot of the tortured, yet peaceful faces of three peons buried to their shoulders being trampled by the horses of their oppressors. It is a beautiful triangular composition, a well-known trademark of the great director. The denotative relationship yields a signifier (three faces) and a [signified] (they have suffered, they are dead). This is the 'subject,' the 'story'. There is natural expressiveness: suffering is read on the peons' faces, death in their motionlessness. Over this is superimposed the connotative relationship, which is the beginning

23 Ibid., p. 5 .

24 Christian Metz, 'The Cinema: Language or Language System?', p. 81 (my emphasis).

25 Nevertheless, in a text from 1966, 'Some Points in the [Semiology] of Cinema', he remarks: '[T] he art of film is located on the same semiological plane as literary art: the properly aesthetic orderings and constraints - versification, composition and tropes in the first case; framing, camera movements and light "effects" in the second - serve as the connoted instance, which is superimposed over the denoted meaning. In literature, the latter appears as the purely linguistic signification, which is linked, in the employed idiom, to the units used by the author. In the cinema, it is represented by the literal (that is, perceptual) meaning of the spectacle reproduced in the image, or of the sounds duplicated by the sound-track.' Metz, in Film Language, 92-107 (p. 96). Among the signifieds of connotation mentioned by Metz, one finds literary or cinematic style; genre (epics, Westerns); symbols (whether philosophical, humanitarian, or ideological); and the poetic atmosphere of a work. 
of art: the nobility of the landscape as it is structured by the triangle of the faces (form of the image) expresses what the author, by means of his style, wanted it to 'say': the greatness of the Mexican people, his certainty of their eventual victory, a kind of passion in that man from the North for all that sunny splendor. Therefore, aesthetic expressiveness. And yet still 'natural': the strong and savage grandeur rises very directly out of the plastic composition that turns suffering into beauty. Nevertheless, two language systems exist side by side in this image, since one can identify two signifiers: (1) three faces in a barren stretch of land; (2) the landscape given a triangular shape by the faces - and two [signifieds] - (1) suffering and death; (2) grandeur and triumph. ${ }^{26}$

In the case of Metz's personal viewing notes, we find there, as we did in his discussion of Rousseau's Chambéry landscape and Eisenstein's Mexican landscape, a sensitivity towards what art - in this case cinematic art, in films of very different styles - succeeds in rendering, expressing or evoking of the sensible world, of faces, bodies, and places. Of Sylvester Stallone's Staying Alive (USA 1983), for example, he writes: 'John Travolta [is] magnificent with his primitive ambition, vulgarity and peevish intensity = breathtaking presence.' He then adds with respect to the cinematography: 'the film is punctuated by solitary walks in New York (= magnificent cinematography of skyscrapers, Central Park, tall buildings seen from the Brooklyn Bridge, etc. [...] it is one of the finest films on New York there is. ${ }^{27}$ Regarding the 'studio jungle' in W. S. Van Dyke's Tarzan the Ape Man (USA 1932) he writes that it 'is much more powerful than any documentary jungle or jungle shot on location, precisely because what it evokes directly is childhood imagination', meaning that the film 'brings back to life with astounding sureness all the myths and adventure books of childhood, all the more so in that the studio jungle and set can be seen as such and are more reminiscent of drawn illustrations in books, such as those by Jules Verne'. ${ }^{28} \mathrm{~A}$ final example: Max Ophüls' Letter from an Unknown Woman (USA 1948), about which he notes that 'it is a complete masterpiece [...] like a great novel' (du grand romanesque), that its black-and-white photography is 'marvellous', and that 'Vienna around 1900 is evoked in a very poetic and very novelistic

26 Metz, 'The Cinema: Language or Language System?', pp. 79-8o. For a different version of this passage as first written in Metz's notes on Dufrenne's The Phenomenology of Aesthetic Experience, see Chateau and Lefebvre, 'Dance and Fetish'.

27 Metz, ms. CMo756, p. 44-45.

28 Metz, ms. CMo657. 
manner, with corners of narrow streets in the rain, a fountain, the corner of a building, cobblestoned streets and especially the horse-drawn carriages, three steps leading to a house, the style of furniture and the decked-out uniforms of the dignitaries and officers of the Empire in its twilight years. ${ }^{29}$

The 'vulgarity' and 'peevish intensity' of John Travolta in Staying Alive, the evocation of 'childhood imagination' with Tarzan's studio jungle, and the 'novelistic' depiction of the Belle Epoque in Ophüls' film are all, for Metz, the work of connotation. In other words, they are affective qualities which belong to a realm of aesthetic meaning that the cinema can express without, however, denoting it (which is not to say that denotation isn't germane to such connoted qualities).

Naturally, between his thoughts on iQué viva Mexico! and those on Stallone's film twenty years later, Metz greatly shifted his theoretical frame of reference, particularly with respect to phenomenology, as I have demonstrated elsewhere. ${ }^{30} \mathrm{I}$ will not go over this demonstration again here except to emphasize that the phenomenological conception of expression, understood as a 'natural' and uncoded manifestation of meaning, disappeared from Metz's work after 1967 , when he adopted a pan-semiological approach in which the arbitrary nature of the code reigned supreme, including, of course, over connotation. And yet, beyond any epistemological consideration, this semiological radicalization was in the end of little consequence because it was a case not so much of denying phenomenology as it was of looking behind it, or under it, for the cultural codes that it is otherwise too 'naïve' to recognize, whether for lack of scientific rigour or because of an absence of reflexivity, even as it is able to grasp their effects. From that point on, phenomenology for Metz took up a complementary and no longer competitive role alongside semiology and psychoanalysis, whose combined task it was to exhibit the codes - including the connotative codes - which preside over our grasping the affective qualities and impressions that cinema and films provide and which can by turns be a source of aesthetic pleasure or displeasure. This is why the phenomenological perspective, which first appeared with Metz's early thoughts on aesthetics, never entirely disappeared from his work. That said, both semiology and psychology increasingly began to take on a 'counter-cinephilic' aspect for him, their common goal being to lay bare the codes presiding over cinematic desire and thereby over the pleasures that films can provide. 
In addition, in one of the few essays after 'The Cinema: Language or Language System?' in which Metz directly took on the relation between semiology and aesthetics - a talk from May 1971 entitled 'Existe-il une approche sémiologique de l'esthétique?' ('Is There a Semiological Approach to Aesthetics?'), which he reprised in his seminar in 1972-73 - Metz laid stress on the idea that the only aesthetic that semiology could ever endorse, beyond the structural study of the greatest possible number of aesthetic objects (i.e., objects intended to be judged for their aesthetic value) from diverse cultures and periods in the hope of 'brotherly openness toward aesthetic alterity', would be 'an aesthetic of cultural illegitimation and unaccomplishment of desire' ${ }^{31}$ Like psychoanalysis which - to the extent that its object is repression and deceit - is oriented 'against psychic functioning, out of the patient's assertions, but against them', semiology works against the cultural functioning of codes, against their naturalization ('against the clear conscience of the code', Metz remarks) ${ }^{32}$ :

Every film in actual fact puts into play primary processes (such as condensation and displacement), but normally they remain unnoticed (by the filmmaker and audience alike). And this is why (see Lyotard) they can be led to wish fulfillment [accomplir le désir; Wunscherfüllung] (a hallucinatory fulfillment of desire, not a true fulfillment of it).

It is clear, however, that a broader semiology would continue to a certain point a film that would take as its subject, as its aim, the analytical exhibition of the way in which condensation and displacement operate. But in this very act this film would inevitably be deceptive and would mobilize one's defences. Desire would find there its unaccomplishment (except to the extent that a part of libidinal energy would really move over to a desire to unmask, a desire to know, meaning in the end a voyeurism that accepts itself as such, an attitude that would be at once perversion and its opposite. Establishing such an economy in each of us, however, is no simple matter. $)^{33}$

Clearly, this entire discussion on pleasure and perversion ought to be situated in the context of Metz's later work on enunciation, to which I will return later. For now, suffice it to point out that, during the same year, in an essay

31 Metz, ms. CM1436. This manuscript was recently published in 1895, Revue de l'Association française de recherche sur l'histoire du cinéma, 70 (2013), 154-67 (p. 164) (Figures 7.3 \& 7.4).

32 Metz, ms. CM1436. Manuscript published in 1895, p. 164 (emphasis in original).

33 Ibid., p. 167 (emphasis in original). 


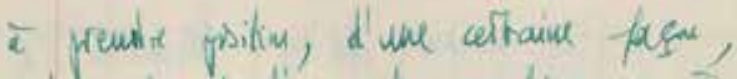
contre a forstionment pijdique. Tauke avalye $x$ ensorvit à pathir des marting du pationt, arais contre elles.

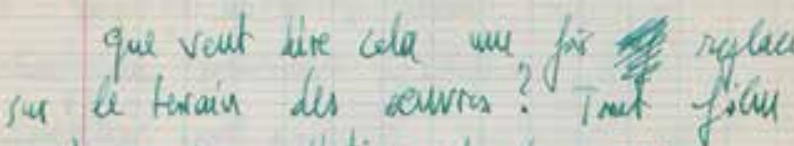
wiet en jeu efectivement des procesm,

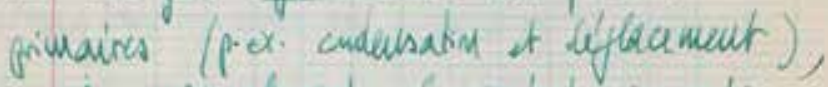

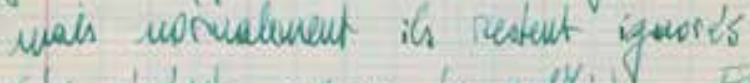

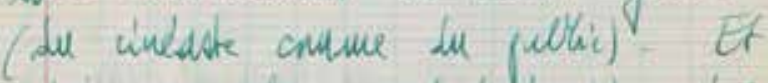
cos gur war. (4. lyörard) qu'ich peuvent acomglír le visit (pas le

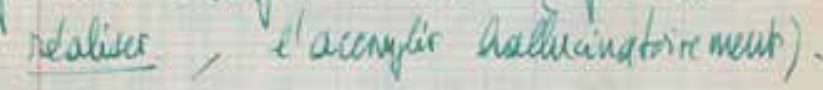
Or, ic sir doir fu'me zievirlogie elegie serait amenet a cantruner jusqu à un uitaid poict un filcu

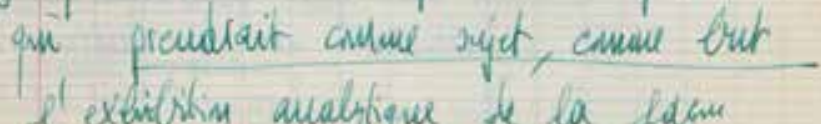

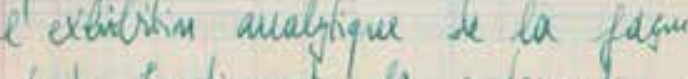

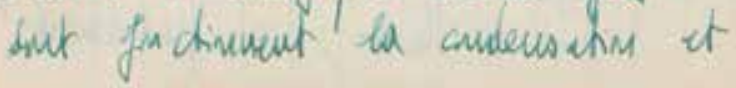

Fig. 7.3: Manuscript; Fonds Christian Metz, Bibliothèque du film, Paris: ms. CM1436(a)

he wrote on special effects and trucages, Metz moved to distinguish plainly between two kinds of pleasure afforded by the cinema: the pleasure derived from the diegesis (on the side of which one finds invisible special effects) and that derived from the 'cinematic machine', closer to enunciation (where the trick effect or trucage, identified and recognized as such, functions as an admired tour de force in filmmaking). ${ }^{34}$ It would be fair to say that, for the most 


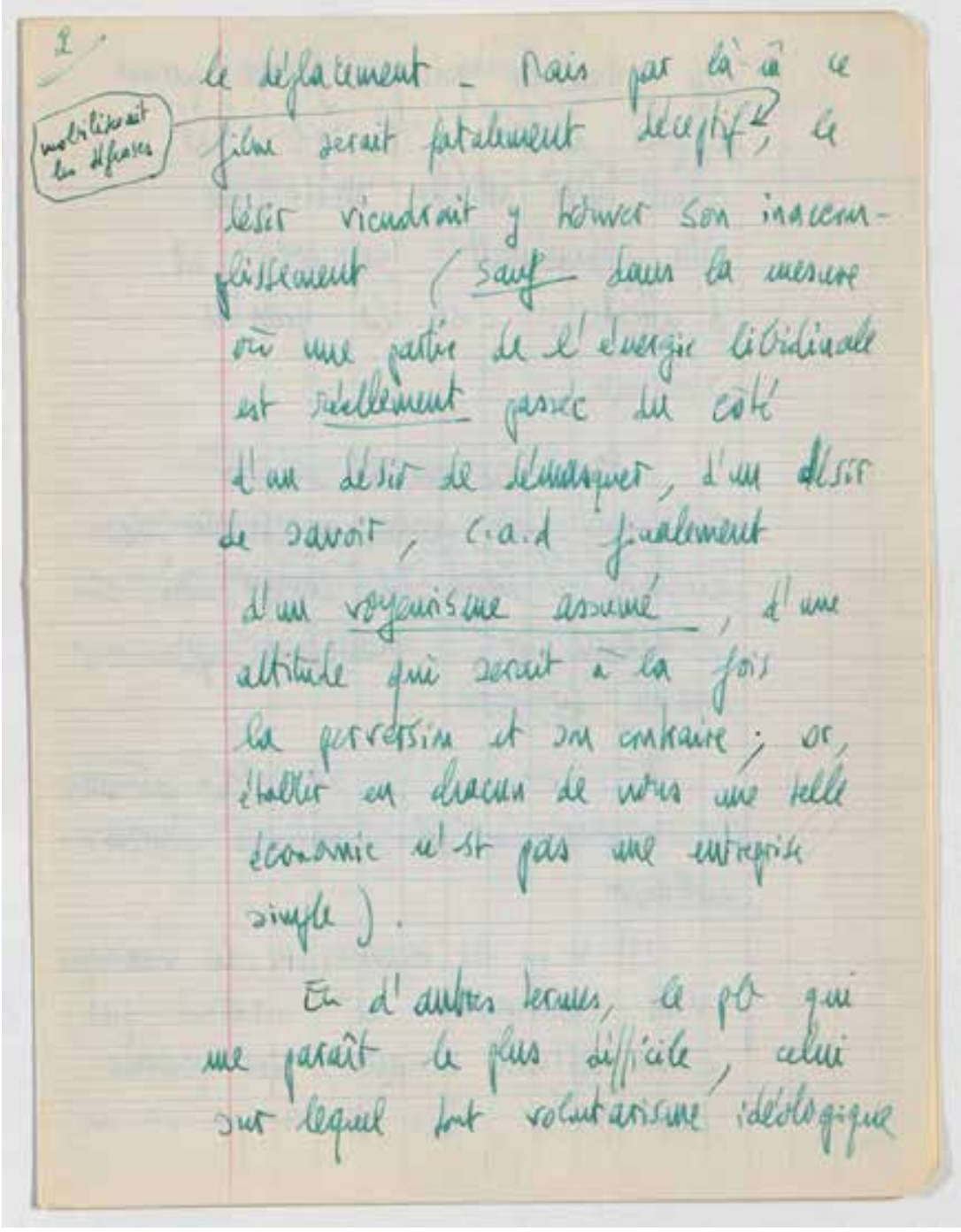

Fig. 7.4: Manuscript; Fonds Christian Metz, Bibliothèque du film, Paris: ms. CM1436(b)

part, Metz came down on the side of the former of these two pleasures (the pleasure afforded by the diegesis, the romanesque in film), if only indirectly and by means of theoretical discourse. For although he never truly sought to back one aesthetic school over another, a great deal of his theoretical work is at once founded on and supportive of (you cannot have one without the other) a conception of cinema or, better yet, of cinematicity, understood as an affective quality and source of filmic pleasure. It is a single common conception that runs through the various stages of his work all the way up to 
Lénonciation impersonnelle and which, in essence, can be summed up by the cinema's special hold on the viewer, by the power that emerges from a very particular regime of presence and absence, by virtue of which cinema stands apart from other media or art forms and gives rise to both the impression of reality (this is the early Metz) and the phenomena of spectatorial identification with and belonging to the film's novelistic fiction (this is the Metz of The Imaginary Signifier). It is this conception that manifests itself more privately in his comments on Tarzan and the evocative power of its studio jungle, and quite publicly (and theoretically) in this famous statement in The Imaginary Signifier: 'Every film is a fiction film. ${ }^{35}$ It is equally the same conception in the piece he wrote in honour of Emile Benveniste, 'Story/Discourse (A Note on Two Kinds of Voyeurism), ${ }^{36}$ about which he later said that it was 'an almost lyrical article, in any event a personal expression, a piece of Hollywood film criticism while being at the same time an almost loving paean to this cinema, with which my entire cinephiliac side was smitten'. ${ }^{37}$

Such is also one of the themes in the opening essay of The Imaginary Signifier as it investigates the object relation that binds the semiologist to the film texts he analyzes and studies, cinephiliac pleasure in this case being both an object of study and what the analysis (the analyst?) represses, to varying degrees. In some respects, The Imaginary Signifier is the theory itself of this repression. Looking at Metz's work, it now seems obvious that it is aesthetic discourse, as it emerged in 'The Cinema: Language or Language System?', that becomes more or less repressed, more or less displaced in the movement that leads all the way to L'énonciation impersonnelle..$^{8}$ And yet, as we have already seen above, aesthetic concerns never truly disappear from Metz's work. Rather, they are displaced and work subterraneously. Is that not, moreover, the way the repressed functions?

2 Stylistics

'The semiology of cinema', Metz wrote in 1966, 'can be conceived of either as a semiology of connotation or as a semiology of denotation. ${ }^{39}$ Nevertheless,

Ibid., pp. 89-98.

37 Christian Metz, 'Lidée d'énoncé sans énonciation', ms. CM1509, handwritten lecture, n.d.

38 In this final book of Metz's, new traces of cinephilia emerge, ones more connected this time with the pleasures associated with the 'cinema machine' and enunciation than those associated with the diegesis. See also the essay by Dana Polan in this volume.

39 Metz, 'Some Points in the Semiotics of Cinema', in Film Language, p. 96. 
apart from a few articles, including two that were openly phenomenological, each concerning a central aspect of Metz's conception of 'cinematicity' (viz., the impression of reality and narrativity) ${ }^{40}$, what mostly drew his attention, until his psychoanalytical turn in the mid-1970s, were problems of denotation. Methodologically, this choice was justified by the fact that, in keeping with the tradition inaugurated by Louis Hjelmslev and to which Metz subscribed, relative to denotation, connotation is a second-order signification and therefore incapable of being understood without the former. It thus appears quite appropriate to proceed with a discussion of denotation first. For while art can cope with signification (in Dufrenne's sense of the term), its goal is to go beyond it and thereby by definition to go beyond what, for Metz, is specific to cinema (cinematic denotation, and even more specifically, its denotational signifier). In Hjelmslev's model, both elements of denotation (signified and signifier) serve as connotation's signifier; for this reason, connotation cannot be a purely cinematic entity, as its own signifier goes beyond the medium-specific domain of film language alone. Indeed, because it includes the non-specifically cinematic signified of filmic denotation, the signifier of filmic connotation also includes the extra-cinematic domains of culture and symbolism associated with the denoted objects and situations. ${ }^{41}$ Film art is thus superimposed on a complex multi-coded system containing several articulated strata.

In a presentation he made in A.J. Greimas's seminar at the EPHE in November 1967 entitled 'Les articulations au cinéma' (The Articulations of Cinema), ${ }^{42}$ Metz laid out five major levels of articulation which, in tandem with perceptive analogy regarding the first three of these, provide the means for understanding a film. First, there is space as an intelligible structure which we 'read' in culturally and historically determined ways. While this is not a code in the strict sense, Metz explains, it is nevertheless a coherent and organized system that conveys meaning (in the 1968 version of

40 The two articles are 'On the Impression of Reality in the Cinema' [1965] and 'Notes Toward a Phenomenology of the Narrative' [1966], both found in Metz, Film Language, pp. 3-15 and 16-28 respectively.

41 According to Hjelmslev (and Metz), what we call 'meaning' is not medium specific: it is common to all semiotic phenomena. See Christian Metz, Language and Cinema, trans. by Donna Jean Umiker-Sebeok (The Hague: Mouton 1974 [1971]), p. 211.

42 Christian Metz, 'Les articulations du cinéma', ms. CM1447. Part of this talk, namely the distinction of five levels of articulations or codifications, was added as a footnote to the 1968 re-edition of 'The Cinema: Language or Language System' for the first volume of Essais sur la signification au Cinema (Paris: Klincksieck 1968), p. 67, note 2. In English, see the footnote that begins on p. 61 of Film Language. The same five 'types of systems' (catégories de systèmes), as they are later called, also find their way in Language and Cinema, pp. 33-34. 
this taxonomy, Metz will refer to it, more broadly, as the 'perceptual level'). Next there is the identification of objects, or the iconological system through which what is filmed yields its 'literal' sense and becomes recognizable/ identifiable. Third, there is the symbolism of objects, meaning the ensemble of significations that the presence of objects on the screen can evoke or connote and which are iconographical in nature. Fourth is the narrative system, which calls upon our knowledge of how and why people act the way they do. All these strata of meaning are strictly extra-cinematic and are founded on knowledge acquired culturally (through cultural codes). It is only with the fifth stratum that, properly speaking, cinema intervenes through cinematic language, seen by Metz as a true meta-cultural system whose signifying task consists in ordering the cultural material of the preceding levels into a filmic discourse in such a way as to yield a diegetic universe as the signified of denotation. In one sense, what Metz calls cinematic language - that ensemble of codes and sub-codes described in Language and Cinema - is quite clearly distinct from verbal language because of the cultural 'position' it occupies, more after than before culture (i.e., verbal language forges culture and meaning, whereas cinematic language comes after and piggybacks on culture). As Metz emphasizes in his 1967 presentation, to understand cinema,

one must have understood a host of other things. It is a meta-cultural language which presupposes that one possesses, first of all, the basic culture of one's group. [...] This also explains why it may be very difficult to understand a film, whereas learning filmic ${ }^{43}$ [cinematic] language itself is relatively easy. For the basic units in a film are non-filmic [noncinematic] (only their ordering is filmic [cinematic]). ${ }^{44}$

The situation is almost the opposite for verbal language, Metz adds, because 'it is through the learning of a language that we learn everything else'. He concludes: 'this is why it is correct to say that cinema is an art more than it is a language - or at least that it is through its artistic effort that it becomes, in addition, a language - for, like all arts, it is the conclusion of a culture and not, like all languages, the beginning.45

43 This talk was written before the publication of Language and Cinema, when Metz had evidently not yet incorporated into his work the distinction between filmic and cinematic.

44 Metz, 'Les articulations du cinéma', ms. CM1447, p. 4.

45 Ibid. 
As we can see, Metz's semiology, even as it refrains from critical value judgements, does not go so far as to dismiss the aesthetic. This may appear surprising if we consider his views on denotation and cinematic language. But it must be understood that study of the latter is a methodological prolegomena to the study of the cinema as art, as writing (écriture), ${ }^{46}$ because it is an attempt to grasp the conditions which make cinematic art possible. In one sense, it would be possible to read the filmo-semiological project, which reached completion in Language and Cinema, as entirely directed towards the study of filmic writing without ever completely succeeding, somewhat in the manner of an asymptote. Consequently, in a later version of his presentation in Greimas's seminar, Metz added a sixth stratum, ${ }^{47}$ which he named film stylistics and which became 'textual analysis' in Language and Cinema. Its role, Metz explains, 'is to study how the five [preceding] strata combine on the level of the individual film, which is to say, more precisely, to bring out the general choices whose particular manifestation (échéance) (or particular combination thereof) appears in a given film'. ${ }^{8}$ In the written version of a talk on connotation dating from after 1971 - thus after the publication of Language and Cinema - Metz wrote: 'the textual analysis of films is wholly the study of connotation. The same is true of the psychoanalytical perspective and the study of ideology. ${ }^{39}$

Thus the film - a singular object that cannot be generalized, the site of the emergence of aesthetic qualities and subject to aesthetic judgement of pleasure or displeasure - becomes the finality of cinematic language! What we thought we had driven out one door comes back through another! Metz more or less implicitly admits this, moreover, in the final chapter of Language and Cinema, when he realizes that the division in cinema between what plays a role analogous to Saussure's langue - that is, cinematic language - and its artistic use as writing (in Barthes' sense of écriture) 'does not pass between general codes and sub-codes'.$^{50}$ First, Metz recognizes that it was by developing its denotation strategies that the cinema became an art; what distinguished one strategy from another shooting a scene in a long take versus using editing, for example - is chiefly a question of connotation (in both cases, denotation - the diegesis - is

46 See Chapter 11 and the Conclusion of Language and Cinema.

47 This version dates from February 1969 and was presented at the Centre audio-visuel de Saint-Cloud. It is included in CM1447.

48 Metz, 'Les articulations du cinéma', ms. CM1447, p. 5.

49 Christian Metz, 'Exposé ou conférence sur la connotation' (Presentation of Conference on Connotation), ms. CM1448, p. 12.

50 Metz, Language and Cinema, p. 270. 
the same; the difference lies in what they connote). The cinema is not an art because it denotes but because beyond the analogy of denotation it calls for choices, the differences between which form a manner or style or genre, even on the level of general codes. The same general code can thus serve both to denote and to connote, which is to say that it can serve both the langue function of the initial (more or less 'literal') understanding or intelligibility of a film and the second-order writing function (i.e., the connotative dimension of ideological and aesthetic choices). In his notes for a talk on connotation, mentioned above, Metz observes: 'In the cinema, practically every code is a connotation code, with the exception of: 1) iconic analogy; 2) editing, in part..$^{51}$ This, moreover, is the sense of the comment quoted above, to the effect that it is through its artistic effort that cinema becomes a language. Second, the reverse trajectory also exists: in the cinema, initial/literal understanding or intelligibility normally associated with the langue function, and thus with general codes, sometimes mobilizes major sub-codes normally associated with the writing function (precisely because they are not general). This, for Metz, is the case with the grande syntagmatique, to the extent that it serves the first intelligibility of temporal relations in the film at the same time as it 'marks - and in so doing returns to a state of writing - a certain era of cinema, a certain face of cinematicity (the one to which we give the name "classical découpage")'.52 'In the cinema', Metz concludes, 'that which serves as a langue has certain characteristics of a writing, and [that which serves as] writings certain functions of a langue. ${ }^{53}$

Thus Language and Cinema bears within it a somewhat unacknowledged stylistic (and thus aesthetic) project whose foundations it nonetheless clearly lays. The project isn't fully acknowledged because it isn't really carried out in the book, nor, for that matter, even foregrounded. And yet the endeavour cannot be overlooked. Its importance can be measured with

51 Metz, 'Exposé ou conférence sur la connotation', ms. CM1448, p. 11.

52 Ibid. In his notes for his 1990-91 seminar, Metz comments: 'The cinema [compared to literature] had more difficulty, and historically took some time to achieve the novelistic malleability of time which enabled it to take over from the great classical novel (19th C.), which in the meantime had been exhausted and had moved on to a reflection on writing (Joyce, Nouveau Roman, Oulipo, etc.). This is the somewhat laborious evolution, the continuation of a sentimental education, which I wished to demonstrate in my grande syntagmatique = how the editing together of shots creates a supple, manoeuvrable, living, affectivized, novelistic space-time.' Metz, ms. CM1507d, p. 14. Note that ms. 1507 is made up of four texts. In order, they are: a) a version from the 1970s; b) a revised version in English written in 1982; c) a much longer version for the 1990-91 seminar; and d) a later text synthesizing version (c).

53 Metz, Language and Cinema, p. 271. 
respect to the distinction Metz continuously made, ever since "The Cinema: Language or Language System?', between verbal langue and cinematic language, despite what unites them. Indeed, as we have just seen, a key distinguishing factor between the two - whether we are dealing with the natural expressivity of the film image (the 'semiological-phenomenological' approach) or with strata of articulations and the impossibility of making clear distinctions, on the level of the code, between denotation and connotation (the 'semiological-cultural' approach) - is the idea that meaning, as established by la langue, always precedes cinema..$^{54}$ This explains why in Metz the cinema is, to a degree, always already art (it is first art, then language: a logomorphic art, not an artistic language), and why in Language and Cinema the aesthetic dimension (through issues concerning style, genre, writing, and other affective qualities) is brought back in, precisely where one thought it had been driven out - viz., in the denotation codes - even though Metz is at pains to separate the semiology of denotation (which concerns language) and the semiology of connotation (which concerns art and forms of expressivity).

\section{$3 \quad$ Poetics}

A third aesthetic topos in Metz concerns poetics. Once again, as we shall see, the original impulse is given by 'The Cinema: Language or Language System?' and its comparison of cinema with literature.

Psychoanalysis provided Metz with an opportunity to look back, critically and reflexively, on a number of themes in his early work, such as the impression of reality and phenomenology. It also enabled him, through the pairing metaphor/metonymy, to take up the topic of non-literal signification - second-order or symbolic signification - something common to both connotation and rhetorical figures, in addition to the field of the Freudian unconscious. The chapter of The Imaginary Signifier devoted to these questions, 'Metaphor/Metonymy, or the Imaginary Referent', was the only previously unpublished text in the volume when it appeared in French in $1977 .{ }^{55}$ It alone takes up more than half of the monograph. Metz presents

54 To employ the terminology used by the Russian semioticians of the Tartu school (Lotman, Ouspenski, Ivanov), we could say that what Metz recognizes from the outset is that verbal language is a primary modelling system, while cinematic language is a secondary modelling system.

55 The source for the piece was an extra section written for the essay entitled 'Le signifiant imaginaire' initially published in Communications, 23 (1975), pp.3-55. Upon advice from the two 
it as the product of a different concern than the other chapters, one less focused on the institution's 'dispositif' because, he said, the question taken up 'directly concerns the filmic text'. ${ }^{56}$ From the outset, he is closer to the very ground (the film as text) that his earlier work had sought to avoid.

Language and Cinema, as we have seen, ends with the imbrication of connotation and denotation in cinema. 'Metaphor/Metonymy, or the Imaginary Referent' reformulates this question in Freudian terms in order to inquire into the 'particular overlapping of primary and secondary' processes in cinema. ${ }^{57}$ Here a large part of the work consists in unravelling the tangled theoretical connections between a series of conceptual pairs - metaphor and metonymy, of course, but also paradigm and syntagm and condensation and displacement - by calling in turn on three disciplines: rhetoric, linguistics, and psychoanalysis. In a handwritten manuscript, dating from 1978, for a talk at the University of California Berkeley, Metz provided this very succinct explanation of his project:
Apply psychoanalysis to the film text's great processes of signification, to its internal linkages, its logic.
On this point, classical semiology (because of its highly secondarized model $=$ linguistics) had a weakness $=$ it studied the coded parts of the film well, but it was a little inadequate in the face of more emergent, more nascent constructions.
Precisely, however, for these constructions the Freudian theory of primary process (= condensation, displacement) and the Jakobson-Lacanian ho- mology with deep rhetoric (metaphorical process, metonymical process) help considerably: they show that, even when there is no code, there are typical trajectories (= associations)..$^{8}$

It is thus a matter of describing how in films there emerge, through rhetorical/poetic-type operations, meaning effects that are not planned or determined by the codes of cinematic denotation whose task is to ensure the initial/literal intelligibility of the film. Already in his CUDES corrigé,

other editors of the issue, Raymond Bellour and Thierry Kuntzel, Metz removed this section from what was already a long essay, and developed it further for his book.

56 Metz, The Imaginary Signifier, p. $15^{2}$.

57 Ibid., p. 163. Recall that for Freud, primary processes characterize unconscious thought, where ideas are connected through displacement and condensation, as in dreams, while secondary processes are present in conscious and rational thought.

$5^{8}$ Metz, ms. 1435, p. 2. 
which we discussed earlier, Metz had zeroed in on the use of metaphors, metonymies, and other rhetorical figures for their expressive and evocative power in literary art: 'if figures are expressive, if they let us touch with our finger a small corner of sensuous reality, it is because they play on the splitting (dédoublement) of meaning. [...] And to split is to augment: through figures, words succeed in going beyond and signifying more than themselves, in resembling the world. 59

Since time immemorial, the rhetorical figures of metaphor and metonymy have always played a significant role in carving poetic language and literary art. In the cinema, however, the situation is somewhat more complicated, as we shall see. We might speculate that this is one reason why Metz's early writings place the aesthetic dimension as a whole under the sign (rather vague, there is no denying) of connotation, without addressing rhetorical questions. It remains that under the rubric of structuralism, rhetorical figures and connotation have clear affinities. In addition, before going any further, we should first of all recognize how connotation can have something in common with metaphor and metonymy, beginning with the definition of it provided by Hjelmslev and its liberal appropriation later on by Roland Barthes.

For Hjelmslev, connotation has to do with levels of language, stylistic form (prose, verse, etc.), style (creative style, normal style), register (vulgar, formal, etc.), media (written language, speech), idiom, tone, etc. Any given use of language will connote either a vernacular, literary, or oratorical style, or a tone such as anger or joy. In each case, the connection between connotation's signifier and signified is marked by inclusion or contiguity (such as the way a novelistic style connoted by a novel is, in some respects, co-extensive with it), something that does not elude Greimas and Courtés, who explain in their dictionary that connotation is related to metonymy. ${ }^{60}$ With Barthes, however, connotation takes on new meaning. ${ }^{61}$ As Metz notes, 'Barthes was the one who generalized [connotation], and he was right,' adding that its 'scope is quite vast: every phenomena such as an artist's "style," the

59 Metz, 'Poésie des mots', ms. CM500o, p. 3 .

6o 'From a semantic perspective, connotation could be interpreted as the establishment of a relation among one or more semes located on a surface level and the semene to which they belong, which must be read at a deeper level. Their connotation is akin to metonymy, the well-known rhetorical figure.' A.J. Greimas and Joseph Courtès, Semiotics and Language: An Analytical Dictionary, trans. by Larry Crist and others (Bloomington: Indiana University Press, $1982[1979])$, p. 53 .

61 For a critique of Barthes' borrowing of Hjelmslev, see Jean Molino, 'La Connotation', La Linguistique, 7, Fasc. 1 (1971), pp. 5-30. 
so-called "aesthetic" dimension, all ideological discourse, every form of rhetoric'. ${ }^{62} \mathrm{He}$ continues: '[I] t's the idea that language always says more than it appears to, that it is run through and worked on from top to bottom by social forces, and that literal meaning (which today we call denotation) is never the sole meaning of the message. [It's an] open door onto ideological and psychoanalytical study. ${ }^{63}$ For Barthes, the reader will recall, connotation is 'the way into [...] polysemy'.64 But by opening up to every meaning effect unregulated by linguistic convention, it is no longer contiguity alone that serves as the basis of connotation but also every connection involving comparability or resemblance, which is to say every relation associated with metaphor.

This subtle slippage between connotation and rhetorical figurativity is all the more important if, like Metz, one seeks to minimize the properly rhetorical dimension of second-order meaning with the goal of highlighting, in its place, operations common to the work of the unconscious (condensation/displacement) and to the structuring of units of langue (selection [paradigm]/combination [syntagm]). Because, from the perspective of rhetoric alone, distinguishing between figures of speech and connotation is a simple enough task: only metaphor and metonymy require a dual substitution, namely in the positional axis of discourse (the order of words) and in the semantic axis of reference. In the case of metaphor, for example, one term takes the place of another in such a way that the referent of the absent term - absent but nevertheless 'felt' - is represented under the guise offered by the referent of the present term for which it is substituting. The entire operation is made possible by a qualitative relation (resemblance or comparability) between the two referents. Connotation, for its part, also evokes a second-order meaning, one absent from denotation but which tends to join up with the initial, first-order meaning of the present term rather than driving it out, as is the case with metaphor.

Metz, however, is intent on distancing himself from an exaggeratedly strict (or 'by-the-book') understanding of rhetoric, whose usefulness to cinema, to be sure, would be too narrow. The reason is that the substitutive figures of rhetoric, taken literally, hardly occur in films, at least in the dominant realist mode. For as the members of Groupe $\mu$ point out, the problem with pictorial metaphor (in the strict, substitutive, rhetorical sense) is that 'it is easier with verbal language to suspend overly concrete

62 Metz, 'Exposé ou conférence sur la connotation,' ms. CM1448, p. 11.

63 Ibid., p. 9 .

64 Roland Barthes, S/Z, trans. by Richard Miller (New York: Hill and Wang, 1974 [1970]), p. 9. 
determinations'. ${ }^{6}$ Metz's strategy, in this light, consists in liberating the figural from its rhetorical yokes by turning to the contributions of Jakobsonian linguistics (paradigmatic and syntagmatic relations) and Freudian-Lacanian psychoanalysis (primary processes: condensation and displacement) in order to bring out the underlying principles, the deep structure of semantic operations of a metaphorical or metonymical kind but which do not necessarily result in actual metaphors or metonymies in the strict sense of classical rhetoric. These principles, general in scope, are based on comparability and contiguity and apply to verbal discourse, the unconscious, and the cinema alike. In particular, the Freudian description of primary processes enables Metz to let go of discursive substitution as a defining criterion for the 'figures' in this 'expanded' rhetoric. In the case of metaphor, for example, it is a matter of taking as one's model work done on oneiric condensation (with which it has been associated since Lacan) and noting that it admits of the co-presence (rather than the substitution) of the figuring and the figured in the dream. Condensation, furthermore, unlike the metaphor of classical rhetoric strictly conceived, which is too deeply secondarized, is related to connotation. Indeed, Metz remarks that condensation is the analogue of the linguistic polysemy studied by those interested in connotation, in the 'affective nuance' of words and in poetic creation, in the way it actualizes 'several distinct "valencies" around one manifest element', which analysis has the task of bringing to light. ${ }^{66}$ This overlapping of the figural and the connotative is most clearly brought out in a passage in which Metz analyzes the famous monocle in Battleship Potemkin:

In The Battleship Potemkin the Tsarist doctor's pince-nez - momentarily immobilised and, so to speak, kept from falling into the sea by the insistent gaze of the close-up (as well as the ropes in which it is entangled), 'caught' by the camera when its owner has just dropped it (there is a hint of a negative metaphor, a 'contrast') - the pince-nez conjures up in the spectator the representation of the doctor himself (that is why it is there): synecdoche. But in the preceding images we saw the doctor wearing the pince-nez: metonymy. The pince-nez connotes the aristocracy: metaphor. But it can do so only because the nobility - outside the diegesis, in the

65 'One can undoubtedly praise a young person's "swan-like neck", but a painter who depicts this person with the long white neck of this winged creature would achieve the opposite effect.' Groupe $\mu$, Traité du signe visuel: Pour une rhétorique de l'image (Paris: Seuil, 1992), p. 274. 66 Metz, The Imaginary Signifier, p. 238. 
society of the time: another level of the 'referent' - liked to wear pince-nez: metonymy again. And so it goes on. ${ }^{67}$

There is thus imbrication of the metaphorical and the metonymical but also of the figural and the connotative, the polysemous, the oneiric, and the poetic. It is this imbrication that Metz seeks to grasp all at once in the movement of the film itself, in the ordering of its immeasurable parts and fragments, in the subterranean meanings contained in this very ordering, as it constantly brings into relation various elements more or less pregnant with symbolic trajectories ready to take shape and emerge. These subterranean meanings exist below and beyond the code (both as source of coded secondarizing and as what exceeds the code), where language, ideology, the unconscious, and art meet and overlap. Here we see the culmination of an idea found in 'The Cinema: Language or Language System?' which I quoted above, according to which 'film is immediately and automatically situated on the plane of rhetoric and poetics' (my emphasis).

That said, am I right to think that in this magic square of meaning (which brings together language, ideology, the unconscious, and art), it is above all art, and in particular film art (or better yet film as art) which, for Metz, dominates as a kind of purpose or causa finalis? After all, most of the films called upon to assist him in his demonstration are recognized masterpieces and favourites of classical art house cinephilia - Eisenstein's Battleship Potemkin (SU 1925) and October (SU 1928), Fritz Lang's M (GER 1931), Orson Welles' Citizen Kane (USA 1941), Charlie Chaplin's Modern Times (USA 1936) - and in each case the wealth of symbolic trajectories is highlighted. Yet, be that as it may, Metz also brings up examples of standardized (i.e. heavily secondarized) and routine or banal (at least nowadays) 'figurations', including 'images of flames in the place of a love scene', ${ }^{68}$ as well as crosscutting and dissolves. The fact of the matter, then, is that Metz seems to carefully avoid distinguishing, as far as cinema is concerned, between obvious examples of artistic usage and the unconscious- and language-based foundations of the figural which are manifested by every dream, every speech act, every film. But why avoid such distinction? It isn't really a paradox, however. Indeed, in this regard, Metz's position is not unlike that of Julia Kristeva, to whom he moreover does not hesitate to refer when he stresses that 'ordinary language, as Julia Kristeva has so 
often emphasised, is a temporarily depoeticised and limited subset of more basic symbolisations which resemble those of poetic language'. ${ }^{69}$ Poetic language for Kristeva is connected to that which precedes language, the archaic pre-language of the infant which eventually turns into language, with the idea that everyday speech comes to repress the poetic - though it is still present in speech. But to apply any such a conception to cinema, is this not to recognize from the outset, for just about any shot or any edited sequence, a true poetical power (latent or not, repressed or not), a true artistic potentiality and force equal to that of poetry - equal to that which poetry or literary art liberates though it is present in all forms of language? Indeed, if Metz once more approaches cinema like a language, if one can transfer onto cinematic discourse the figural (poetic) source/origin of language (what Kristeva calls the semiotic), is it not in the end to underscore above all its always present, though sometimes latent, poetic dimension, the very product of its orderings and trajectories, out of which cinematic art can emerge? Behind every image, every shot, every editing sequence - just as behind every word - a boundless associativity is woven: by privileging a given symbolic trajectory at any given moment (as examples from Modern Times or October illustrate) and leaving others latent (they never disappear and can always resurface), what emerges from this network, for Metz, is the figural. To the question 'Why privilege this or that trajectory and not another?', Metz offers the following reply which, with the return of the concept of expressivity, squarely places art and the unconscious side by side: 'Linguists know that a lexical formation or a phrase catches on by virtue of its "expressiveness" rather than by its logic [...] and the notion of expressiveness takes us straight into those kind of harmonics which, if one only follows them up far enough, lead to the unconscious. ${ }^{70}$

The final aspect of poetics on which Metz worked concerns what is sometimes referred to as 'genre theory' in literary scholarship but for which he, like his friend Gérard Genette, preferred the term 'modal theory' (théorie des modes). His final book, Lénonciation impersonnelle, grew out of this work, but he began exploring the topic long before writing the book and continued to work on it after its publication in 1991, namely in his 1990-91 seminar and then in his final conference paper, 'Le Cinéma et les formes du dire' (Cinema and the Forms of Speech), on 13 January 1993. Metz himself described this research as a comparative aesthetic and semiological project. ${ }^{71} \mathrm{He}$ gave an

69 Ibid., p. 161.

70 Ibid., p. 164-65.

71 Christian Metz, 'Film, Between Theater, Novel and Poem', ms. CM1527, 1982, p. 1. 
initial version of this talk, under the title 'Le Cinéma classique entre roman, théâtre et poésie', in 1974 in Florence and Parma and then in São Paulo in 1975 and Caracas in 1978. In 1979, a Spanish-language version was published in the Venezuelan magazine Video-Forum, ${ }^{72}$ and in 1982, during a sojourn in Australia, he gave a different version in English before developing further the same comparative approach in the 1990s. In this context, L'énonciation impersonnelle appears to be a kind of outgrowth, or even a kind of narrow magnification of a broader aesthetic-semiotic argument initially developed fifteen years earlier.

What interests Metz here is the theoretical and enunciative conditions under which the cinema historically succeeded in overcoming, in part, its natural dramatic (or monstrative) vocation in order to develop its epic (or narrative) capabilities. This transformation, in his view, enabled classical cinema to blossom and then to take on the cultural role that literature had played in the nineteenth century: that of a veritable school of life which 'formed or deformed lifestyles, styles of affectivity and models of seduction and cheekiness'.73 In the notes for his final seminar before his retirement, we find a long, remarkable passage (which recalls Edgar Morin in Les Stars) in which Metz lists aspects of this socio-cultural contribution on the part of (mostly) classical cinema:

From Ava Gardner young girls learned to be sumptuous, from Louise Brooks how to do their hair, from Marlene Dietrich to be tough-yetwomanly and to have legs. From Gary Cooper's westerns boys learned that people were impressed by the slow, silent type and from the young Gabin they learned how to roll their eyes. With Edwidge Feuillère, and later Danielle Darrieux, women saw how one becomes a duchess, a prefect's wife or the wife of a minister. French 'poetic realism' told everyone what a 'man of the people' is like = he's like Carette, Bussière or Gaston Modot. From James Dean, we know how to charm girls by acting the child or looking sulky. With Marlon Brando, we make people think we have the phallus. With musical comedies, we learn to dream in gaudy Technicolor and without embarrassment. With film noir we see ourselves as tough guys with a crooked smile (Bogey), bitter yet courageous and good. Westerns teach us sober camaraderie between men without affectation, and beyond that contempt for women. Breathless [Jean-Luc Godard, F

72 Christian Metz, 'El cine clásico entre el teatro, la novela y el poema', Video-Forum, 4 (1979), pp. 7-17.

73 Christian Metz, ms. CM1507c, pp. 51-52 (Figures 7.5 \& 7.6 ). 
1960] was a lesson in modernity for an entire generation, just as Marilyn Monroe, for the men of a certain time, was a prototype of the desirable body (with a deliberate coefficient of ironic exaggeration in this case, as with Jane Russell and Jane Mansfield). Tyrone Power revealed that D'Artagnan is not dead. Gaby Morlay consoles ugly women by reminding them of the many roles left for them. And what can be said about Greta Garbo, who unleashed an incredible social (and literary) phenomenon? In sum, in classical films, as in classical novels, there is something addressed to adolescents, to those learning about life, who want to change it, whatever the age of the hero or the audience, something that suggests to us ways in which to adjust our bodies and our hearts. ${ }^{74}$

On the level of structural factors, the existence of this initiatory function of classical cinema, Metz explains, is made possible by the blossoming of a composite enunciative regime marked by the introduction of novelistic elements into a material that was in the beginning closer to theatre. For whether it shows or tells, if the cinema is an art it is equally a discourse this is the notion of 'logomorphic art' which is at the very heart of Metz's thought ${ }^{75}$ - and as such it can only call upon the three logical and timeless modes of discourse, upon the three modes of enunciation or forms of speech, described by the Greeks: the dramatic, the epic, and the lyric. ${ }^{76}$ While it is rare for these forms to appear in a pure state - in the theatre, for example, there are epic enclaves when a chorus appears; in novels, there are dramatic enclaves when characters speak directly; etc. - Metz believed that the cinema, in its classical period, had succeeded in removing itself from the dominance of the dramatic and in developing a previously unseen hybrid form through a new enunciative configuration. By combining the dramatic and the epic, he said, the cinema created 'one of the most complex and engaging forms of telling that exists' ${ }^{77}$ In one sense, we might see this relation between the two principal enunciative modes, first discussed by

74 Metz, ms. CM1507c, pp. 51-52.

75 “'Film"', Metz writes, 'merits more than the other arts the name "discourse". It enables developments, resumptions (reprises), arguments, gradual transformations, anaphora, demonstrations (= didactic-scientific films) and, of course, narratives [...]' Metz, ms. CM1507d, p. 2. 76 The Greek theory of modes recognized in the first place two great forms of telling: either we are 'given' a scene, which unfolds on its own - this is the dramatic mode in which the 'telling' imitates the world (Plato's mimesis) - or we are told the scene as it unfolds - this is the epic mode (diegesis). As for the lyric mode, it pertains to the epic, but no longer concerns fiction: here the real world is the subject but as seen through the subjectivity of a speaker.

77 Metz, ms. CM1507d, p. 11. 


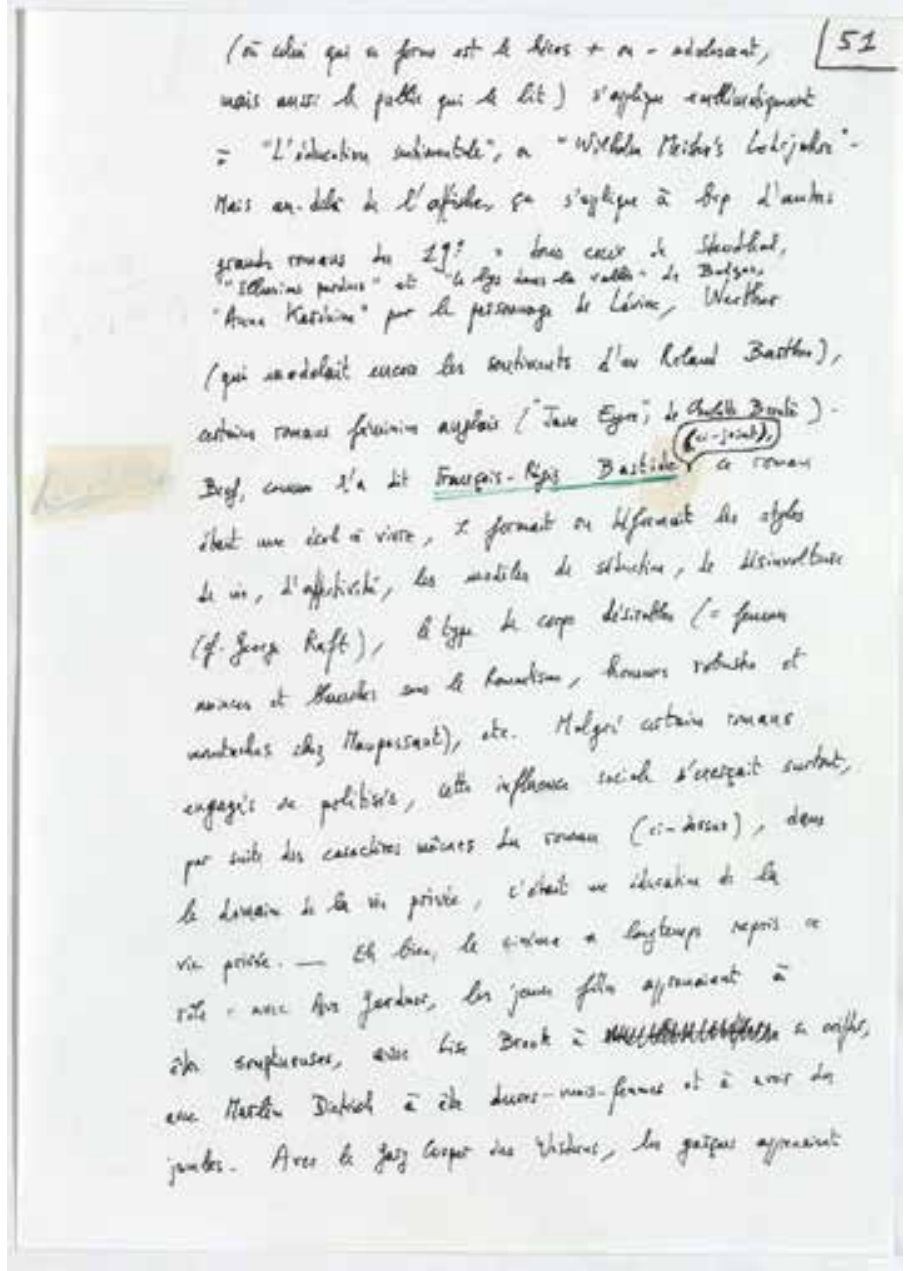

Fig. 7.5: Manuscript; Fonds Christian Metz, Bibliothèque du film, Paris: ms. CM1507, pp. 51

Metz as early as 1974, as somehow prefiguring (albeit in a substantially different form, of course) the distinction made famous by Tom Gunning and André Gaudreault in the mid-1980s between the cinema of attractions (marked by the 'dramatic' quality of showing) and narrative cinema (marked by the 'epic' quality of telling).$^{7}$ Metz, for his part, recognized that cinema's

78 For Gunning, it is monstration (which for Metz pertains to the dramatic mode) which defines the cinema of attractions: 'What precisely is the cinema of attraction? First it is a cinema that bases itself on the quality that Léger celebrated: its ability to show something. Contrasted to the voyeuristic aspect of narrative cinema analysed by Christian Metz, this is an exhibitionist 


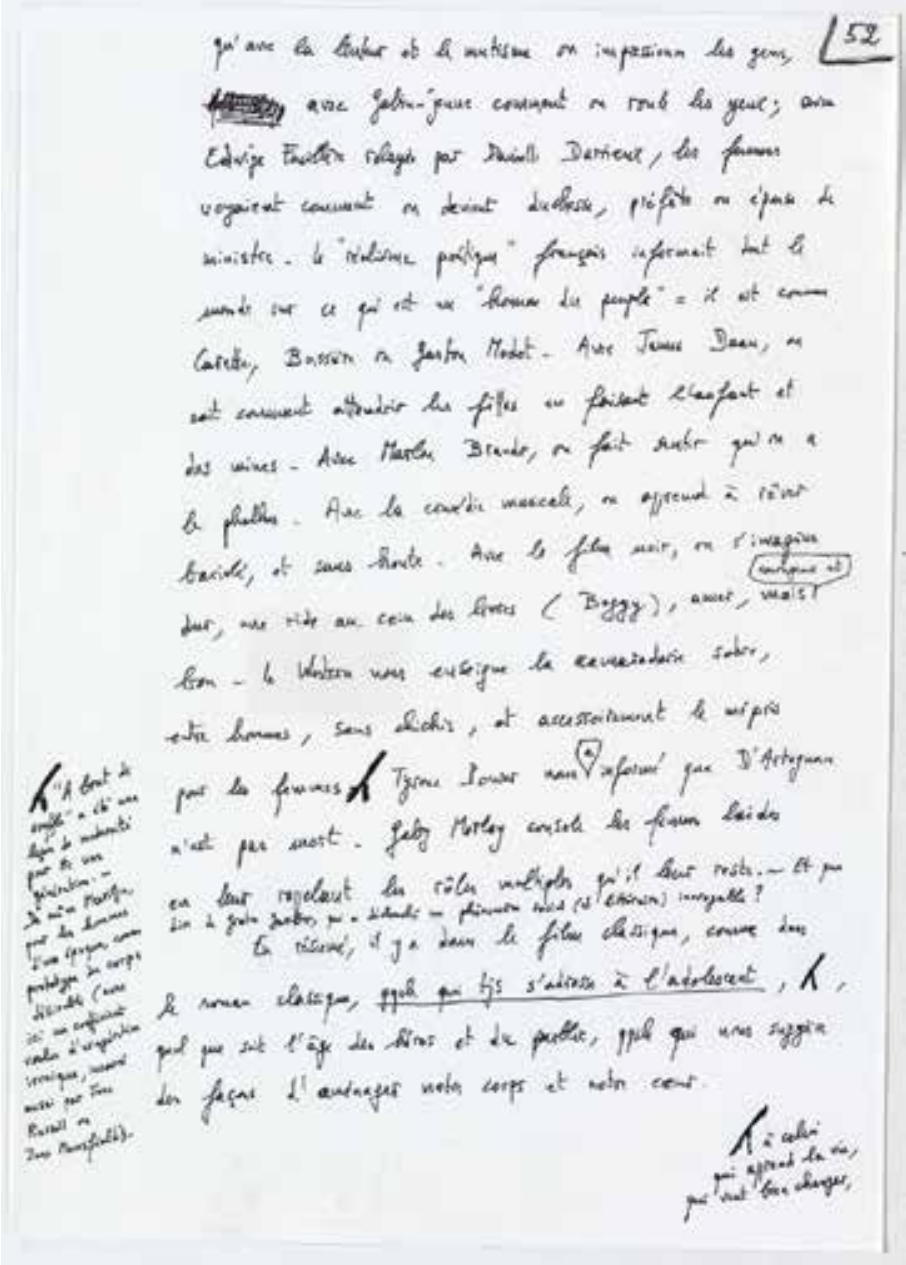

Fig. 7.6: Manuscript; Fonds Christian Metz, Bibliothèque du film, Paris: ms. CM1507, pp. 52

cinema.' Tom Gunning, 'The Cinema of Attraction: Early Film, Its Spectator and the Avant-Garde', Wide Angle, 8/3-4 (1986), 63-70 (p. 64). Of course, one could also, from another perspective, trace the attraction/narration distinction back to Bazin and his antithesis between filmmakers who believe in reality (the avatar of the dramatic: the world is revealed, the 'telling' is imitative) and filmmakers who believe in the image (the avatar of the epic: the world does not reveal itself on its own, it is 'told'; a telling agent is felt, perceptible - this is Laffay's 'great image-maker' [grand imagier] - and it organizes for us the material it yields up). Metz also anticipated in part André Gaudreault's thesis on cinema's combination of the textual and the theatrical, despite Gaudreault's rereading of the Greek concepts mimesis and diegesis. See André Gaudreault, From Plato to Lumière: Narration and Monstration in Literature and Cinema, trans. by Timothy Barnard (Toronto: University of Toronto Press, 2009 [1988]). 
particular enunciative form (combination of dramatic and epic) was in no way inevitable, that this was in no way some sort of essence of cinema. He wrote:

For the past ten years or so now, although most films remain novelistic and there subsist reportages, didactic films, etc., a new possibility is taking shape (under the influence of the video clip and the TV commercial, of hip advertising), a cinema that is distancing itself somewhat from both literature and the theatre in favour of imagery or thundering fireworks = Beineix, Besson, sometimes even Carax, Bertrand Blier, certain films by Coppola, Star Wars, James Cameron, Ridley Scott, Zemeckis, etc. These are images the way children see them: flat, gaudy, attractive surface. ${ }^{79}$

For the novelistic to take up a place in cinema, spectators must sense that they are being told a story - even as they seek paradoxically to forget this fact in order to better enjoy the film and its imaginary world. This story, Metz says, can only emanate from 'a non-character agent, a primary, impersonal (and temporarily manifest) enunciation [whose presence] shifts the entire diegesis into a different gear'. ${ }^{80}$ The term 'impersonal enunciation', a kind of oxymoron if one holds to pure classical modes (which imply an entirely 'theoretical' purity, without empirical existence), in fact demonstrates the hybridity of the novelistic in the cinema. This hybridity, moreover, accounts for why it is a simple matter to see enunciation practically everywhere in films or, on the contrary, to diegetize (viz., to see as diegetic) so many of the enunciative traces left in a film narrative. Metz sums up his position as follows: 'on the one hand, the most run-of-the-mill film reveals the enunciative agent in every fade to black, every somewhat abrupt change of shot, in the credit sequence itself [...] on the other hand, all that does not prevent a powerful, vital, imaginary world from taking shape, into which we transfer and which makes us more or less forget its fabricated nature. ${ }^{81}$ In his book on enunciation, Metz examines a dozen or so enunciative figures, all of which contribute to the cinema's novelistic and epic status because they enable a 'meta-discursive' reading of what is seen and heard.

Alongside these figures, however, are those traits that distance the cinema from the most purely dramatic form of theatre: commentary, 
intertitles, live spoken accompaniment, optical/special effects, etc. In other words, everything that contributes to cinema's narrative impression - the impression that we are being told something above and beyond the pure dramatic monstration found in a medium that gives us something to see and hear. In his 1990-91 seminar, moreover, Metz added supplementary marks of the epic mode. These include sequences without characters, facial expressions, and everything to do with human beings' relation with their surroundings. In the first case, Metz remarks that the presence in cinema of natural landscapes and animals but also of urban landscapes, automobiles, aerial combat, etc. - in short, the presence of all the world's furnishings, whether real or imaginary - distances the cinema from the theatre and brings it closer to what can be read in novels. In these moments without actors, without dialogue 'is conveyed the impression [...] that things can happen without characters and thus without speech'. ${ }^{82}$ Which is to say that in the cinema, contrary to theatre, 'the story can take form somewhere other than in the characters' mouths, in a series of images from an exterior source, which thus have a narrative quality even though they are not words $=$ images, yes, but which recount ${ }^{8}{ }^{{ }_{3}}$ With respect to facial expressions, Metz observes that in the cinema, unlike the theatre, 'they can be as varied and "natural" as in novels. ${ }^{84}$ Finally, he explains, the theatre is ill equipped to examine the relation between people and their surroundings: we have the impression of seeing real people (because of the real presence of actors) moving about on a mere 'set' and not in a world. In the cinema, on the other hand, the homogeneity of the setting and the character makes possible 'fine-grained and detailed analyses [...] of the relations between people and their surroundings'. ${ }^{85}$ In addition, Metz emphasizes, 'in both films and novels it is not a case of "a character on stage or set (décor)" but of a unique and encompassing picture presenting itself more or less forcefully as a complete world containing things, people, animals, etc. $=$ the world-effect $^{\prime}{ }^{86}$ Metz could just as easily have taken up here the impression of reality, which never ceased to be a profound part of his conception of cinema. But if this world-effect is possible - if Metz, at first sight somewhat counter-intuitively but in the end quite logically, compares the face in cinema with that in the novel rather than with that in the real world - it is because in the 
cinema the world is made of images. This means that imitation in cinema is heterogeneous to what it imitates (it is hetero-semiotic: the world itself is not made of images), while in theatre it is homogeneous, the world imitating the world, real speech and gestures imitating real speech and gestures (it is homo-semiotic). There is thus in cinema, at the very heart of the mimetic relation, a degree of heterogeneity, a gap that favours the introduction of the epic or novelistic dimension. In the end, it is because both novel and film, contrary to theatre, cannot offer us the real world that they can create one that seems so complete, even if it is imaginary.

Consequently, epic marks can at times serve the fiction while at others be seen to act as meta-discursive traces of the film's impersonal enunciation, meaning that they contribute to the impression of narrativity which makes it possible to assert that only in the cinema can one see the landscapes found in Westerns or the expressions on Falconetti's face (i.e., through them, and countless other such examples, one may become meta-discursively aware that one is watching a film): what ensures our immersion into the film world is also what ensures its separation from the world as discourse and as that which is specifically cinematic. Béla Balázs, to mention only him, was therefore not mistaken with respect to the close-up.

Having now reached the conclusion of this essay, is it at all surprising that we should find here, once more, notwithstanding a few shifts in perspective, some of the same issues and aesthetic objects with which we began? These include the relation between words (but also images) and things; the ability of an art (literature, theatre, cinema) to evoke a world; the importance of the landscape and the face in cinema (at times as marks of expressivity and at others as marks of epic discourse and meta-discursive/enunciative traces); etc. One need only recall the various quotations I have provided from Metz's film viewing notes - on Travolta and New York in Staying Alive, on Tarzan's fake jungle and the imaginary, on turn-of-the century Vienna and the novelistic in Letter from an Unknown Woman - to see solid confirmation of this. Moreover, when these quotations are considered alongside everything else that has been discussed above, we can perhaps get a brief glimpse of what might have resembled a Metzian cinematic ars poetica. In any event, we see a clear and remarkable unity stretching over a period of more than twenty-five years of theoretical labour, despite variations in the angle of attack and conceptual swings. And we might well wonder what this unity is an indication (or symptom) of, if not first and foremost an aesthetic conception of cinema. We 
know that Metz has been accused over and over of wishing to turn cinema into a branch of linguistics and of abdicating every kind of aesthetic concern regarding it. As we have seen, however, nothing could be further from the truth. For never did Metz's project discount the aesthetic; on the contrary, as I have tried to demonstrate, it thrived on it, the aesthetic having a constant subterranean presence in his work, partially buried by and yet informing that other parallel and more visible continuity, one more professed on the surface and more 'scientific': the theme of language. These are the two threads which meet in the fundamental idea championed by Metz, that of the cinema as a logomorphic art. The last word will go to Metz himself, taken from the conclusion of the final manuscript in his archives and summing up quite well his work as a whole and what he tried to grasp in his own way. It is on the basis of this statement than we can render final judgement on his æeuvre: 'aesthetics is not logic per se, but there is $a$ logic to aesthetics'. ${ }^{87}$

\section{Translated from French by Timothy Barnard}

\section{About the author}

Martin Lefebvre is Honorary Concordia University Research Chair in Film Studies at the Mel Hoppenhein School of Cinema. He is Director of Concordia's PhD programme in Film and Moving Image Studies, and editor of Recherches sémiotiques/Semiotic Inquiry. He has published widely on film and semiotics. Among his publications are the edited volume Landscape and Film (2006) and the monograph Truffaut et ses doubles (2012).

\section{About the translator}

Timothy Barnard is the translator of volumes on film theory by Jacques Aumont, André Bazin, André Gaudreault, and Jean-Luc Godard in addition to numerous catalogues of modern and contemporary art. He is the proprietor of 'caboose', an independent scholarly publisher of books on film, and the author of Découpage (2014), a brief historical and theoretical study of this aesthetic concept in cinema and the only volume on the topic in any language.

87 'L'esthétique n'est pas la logique, mais il y a une logique de l'esthétique.' Metz, ms. CM1507d, p. 25 . 



\title{
8. Christian Metz and Modern Cinema
}

\author{
Francesco Casetti
}

Tröhler, Margrit and Guido Kirsten (eds.), Christian Metz and the Codes of Cinema. Film Semiology and Beyond. Amsterdam University Press, 2018

DOI: $10.5117 / 9789089648921 / \mathrm{CHO} 8$

\begin{abstract}
In three essays written in 1966-1967, Christian Metz retraces the debate on 'modern cinema' and foregrounds his own interpretation: 'new cinemas' are characterized on the one hand by unprecedented linguistic procedures - among them what Metz calls potential sequence - and on the other hand by an extension of the possibilities of 'saying' something - an extension of the 'sayable' or of the 'representable'. Such a novelty implies a greater role of the 'possible' and the 'potential', both in a discourse and in the linguistic system, as well as requiring a reconsideration of some of the axioms of structuralism. What emerges is a more flexible and comprehensive theoretical framework, which Metz and film semiotics would develop in the following years.
\end{abstract}

Keywords: Film semiotics/film semiology, cinematic narrativity, modern cinema, forms of representation

In 1966, taking part in a wide debate promoted by the Cahiers du cinéma, Christian Metz penned an insightful analysis of modern cinema. At the time, 'The Modern Cinema and Narrativity' represented one of the most powerful attempts to inject some of the concerns and categories proper to the then-developing field of film semiotics into the body of film criticism. Two years later the essay was included in Metz's first book, Essais sur la signification au cinéma, in a section entirely devoted to 'modern' cinema (quotation marks appeared in the title of the section). ${ }^{1}$ Included in the section were also 'Mirror Construction in Fellini's 81/2' (previously published

1 Christian Metz, 'Le cinéma moderne et la narrativité', Cahiers du cinéma, 185 (1966), pp. 4368, later included in Essais sur la signification au cinema, 2 vols. (Paris: Klincksieck, 1968), I, pp. 185-222, translated as 'The Modern Cinema and Narrativity' [1966], in Film Language. A 
in Revue d'esthétique in 1966)² and 'The Saying and the Said: Towards the Decline of Plausibility in Cinema?' (a speech given at a roundtable during the Pesaro Film Festival in 1967, then rewritten for a special issue of the journal Communications). ${ }^{3}$ The triptych deserves a re-visitation: it bears witness to one of the rare attempts by Metz, and by the first generation of semioticians more broadly, to come to terms with film history, and consequently to test the theoretical framework of the discipline. It results in a rich and flexible picture, which also outlines some of the future developments of film semiotics. In the golden era of structuralism, Metz, facing contemporary cinema, develops an approach and a set of categories that will play a great role in the following years.

\section{The Newness of 'New Cinema'}

What characterizes modern cinema? The entire first part of 'The Modern Cinema and Narrativity' is dedicated to a discussion of the characteristics that critics attribute to contemporary cinema: 'Everyone agrees in recognizing the new cinema as defined by the fact that it "has gone beyond" or "rejected" or "broken down" something." The new cinema is new because it has traits opposed to the traditional ones: it overturns them and goes beyond them. Through an attentive and systematic reading of the ongoing debate around new cinema, Metz identifies nine of these 'traits' and asks if they are indeed useful for defining modern cinema.

First of all, new cinema is said to reject any ties with spectacle: it is allergic to the traditional rituals of consumption as well as to traditional forms of representation. What it wants is to be and to feel free. Second, new cinema is seen as dismissing any form of mise-en-scène; it is, and it wants to be, quite far from theatre, yet it also wants to pay attention, and even adhere directly, to the depicted events. Third, it refuses to follow a prewritten script and instead relies on improvisation. Fourth, it repudiates

Semiotics of the Cinema, trans. by Michael Taylor (New York: Oxford University Press, 1974), pp. $185^{-227 .}$

2 Christian Metz, 'La construction "en abyme” dans Huit et Demi, de Fellini', Revue d'esthétique, 19/1 (1966), pp. 96-101, then in Essais, I, pp. 223-28; translated as 'Mirror Construction in Fellini's 81/2', in Film Language, pp. 228-34.

3 Christian Metz, 'Le dire et le dit au cinéma: vers le déclin d'un Vraisemblable?', in Metz, Essais sur la signification, I, pp. 230-44; translated as 'The Saying and the Said: Towards the Decline of Plausibility in Cinema?', in Film Language, pp. 235-52.

4 Metz, 'Modern Cinema', p. 188. 
traditional dramaturgy, renouncing a compact and continuous narrative in favour of numerous 'dead' spaces. Fifth, according to most critics, 'the new cinema should be defined as a more direct approach to the real' ${ }^{\prime 5}$ as opposed to having an inclination toward fiction and narrative machinations. Sixth, new cinema is a 'film-maker's cinema', as opposed to the old 'script-writer's cinema'. ${ }^{6}$ Seventh: 'the modern cinema [is] a cinema of the "shot", as distinguished from the old cinema, which was more concerned with racing from shot to shot, straight to the sequence'. Eighth, according to Pasolini, modern cinema leans toward poetry more than toward prose; it is not a plain illustration of a set of events but a report filtered through a subjective sensibility. Ninth and finally, modern cinema is characterized by 'the noticeable presence of the camera[,] whereas, in traditional films, on the contrary, the camera tried to make its presence unfelt, to make itself invisible before the spectacle it was presenting. ${ }^{8}$

Critics tend to attribute one or more of these traits to new cinema, but Metz disagrees with this characterization:

Spectacle and nonspectacle, theatre and nontheatre, improvised and controlled cinema, dramatization and nondramatization, basic realism and contrivance, film-maker's cinema and script-writer's cinema, shot cinema and sequence cinema, prose cinema and poetic cinema, the camera-in-presence and the invisible camera: None of these distinctions seems to me to account for the specific character of modern cinema. ${ }^{9}$

There are two reasons behind Metz's dissatisfaction. First, there is the question of content: these traits seem to be confused and often contradictory. They are difficult to define, and they are often countered by the presence of other characteristics. Take, for example, the inclination towards realism: new cinema is also 'a cinema of premeditation and indirection [...] that believes only in reconstructed truths', ${ }^{10}$ as exemplified by the films of Alain Resnais. Then there is the question of method: Metz does not directly address this, but it is deducible from his approach. The nine conceptual pairs are not true oppositions and do not pass the characteristically structuralist operation of the commutation test. The presence of the first trait should

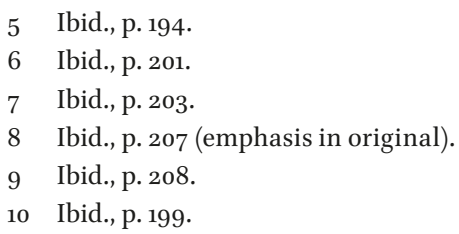


define classical or traditional cinema, while the second should characterize contemporary cinema. In reality, however, "[i]n each one of these conceptual pairs, the feature claimed as "modern" is too often found in the films of yesterday and too often is lacking in the films of today'. ${ }^{11}$ As a result, it is impossible to construct two clear categories of film.

How can this impasse be overcome? Metz calls upon semiotics and narratology. Many critics suggest that new cinema refuses the story, and more broadly speaking, lacks grammatical and syntactic rules. Metz takes another position: instead of claiming that modern cinema is 'less' narrative than the classical one, he puts forward the idea that it is 'more' narrative. '[The conceptual pairs] are so many partial expressions of a same underlying idea: That in the past the cinema was entirely narrative and no longer is so today, or is so at least to a much lesser extent. I believe on the contrary that the modern film is more narrative, and more satisfyingly so, and that the main contribution of the new cinema is to have enriched the filmic narrative. ${ }^{12}$ The same could be said about the grammatical and syntactic rules. ${ }^{13}$ Films which belong to modern cinema, 'far from demonstrating the nonexistence of the "syntax", [...] are really discovering new syntactic regions while remaining (at least as long as they are intelligible, as is the case almost always) entirely submissive to the functional requirements of filmic discourse'. ${ }^{14}$ Hence the necessity of studying new cinema from a more analy tical perspective: its novelty resides not in a reversal of previous characteristics but in a certain number of linguistic constructions.

\section{A New Syntagma: The 'Potential Sequence'}

Metz highlights two aspects of this novelty. On the one hand, he inquires into the presence of new linguistic procedures, and especially of a new kind of syntagma, which he calls potential sequence. On the other hand, he focuses on the extension of the possibilities of 'saying' something - the extension of the "sayable" or of the "representable". Modern cinema is typified by a capacity to go beyond the usual narrative conventions and beyond

\footnotetext{
11 Ibid., p. 208.

12 Ibid., p. 208.

13 It is worth recalling that, according Metz, 'cinema has never had either a grammar or a syntax in the precise linguistic sense of these terms', and yet 'there are a certain number of structural configurations that are in actual fact laws and whose details are constantly evolving'. Metz, 'Modern Cinema', pp. 209-10.

14 Metz, 'Modern Cinema', p. 211.
} 
the usual representational boundaries - without denying the presence of rules to be followed.

Let's start with the potential sequence. In the same year (1966) that Metz published 'The Modern Cinema', he also wrote one of his most famous essays, 'La grande syntagmatique du film narratif', ${ }^{15}$ in which he defined a chart of the essential narrative structures. 'I have identified, from the origins of the cinema to the present, only a limited number (eight) of large basic syntagmatic types. ${ }^{16}$ The more recent cinema - well exemplified by Godard and a film like Pierrot le fou (F/I 1965) - elaborates new kinds of syntagma that are not included in the previous chart. In particular, there are aggregates of shots which include actions that take place before or after the depicted event, and sometimes that could have taken place, but whose actuality remains uncertain. This new syntagma breaks the temporal consecutiveness, the spatial coexistence, the sense of repetition, the parallelism of two actions, and so on that define the traditional forms of narrativity; moreover, it challenges the certainty of the representation, merging what really happens in the story with what could have happened. Hence its name, potential sequence (séquence potentielle), a portion of discourse in which we face side by side both an accomplished action and a conceivable event, and in which we must consider both aspects as components of the same whole. The potential sequence is a sort of paradox: it mixes two different levels of diegesis, the actual and the virtual; it overlaps them, avoiding any clear distinction, as if they were the two sides of a coin; and it gives them full expression - both of them, the actual and the virtual, are fully enunciated - in their difference and in their reversibility.

Through this type of segment, a film keeps telling a story. '[The potential sequence is] an undetermined sequence that represents a new type of syntagma, a novel form of the "logic of montage", but that remains entirely a figure of narrativity. ${ }^{17}$ Simply, the film can develop a new form of sensibility. Metz reminds us of the Proustian distinction between two forms of intelligence: to penetrate a situation means to grasp all its sides, the whole of what actually happens; to predict it means to be able to envision also what could have happened and what could happen, the whole of the possibilities. The potential sequence opens the filmic narrative to the second front; it

15 The text first appeared in Communications, 8 (1966), pp. 120-24 (the issue was devoted to The Structural Analysis of Narrative); then, merged with two other texts, it was published as 'Problèmes de dénotation dans le film de fiction', in Essais, I, pp. 111-48, translated as 'Problems of Denotation in Fiction Film', in Film Language, pp. 114-33.

16 Metz, 'Modern Cinema', p. 217 (emphasis in original).

17 Ibid., p. 219 (emphasis in original). 
gives the story a new chance - the chance that modern cinema is inclined to explore.

I want to add just two notes. This idea of 'potentiality' that Metz connects to a new kind of syntagma also emerges in other passages of 'The Modern Cinema and Narrativity'. In particular, discussing the alleged 'nondramatization' of modern cinema, Metz praises Michelangelo Antonioni for his ability 'to gather together within the skein of a more subtle dramaturgy all those lost significations of which our days are made. Even more: that he was able to prevent them from being entirely lost, without, however, marshaling them. ${ }^{18}$ The potentiality is exactly this: the capacity of keeping alive what is otherwise lost - because it is no more or not yet actual - without concealing the very fact that what is kept has not been fully realized. ${ }^{19}$

Second, the potential sequence is not the only narrative construction that characterizes modern cinema. Metz also mentions the presence of the still photograph, the use of the off-screen voice, or written titles - not by chance all moments in which the linear flow of the story is suspended, and the depicted event either overlaps with other kinds of components, like a character's thoughts and the author's commentary, or is kept on hold, ready to transform itself into something qualitatively different. The sense of potentiality permeates modern cinema.

\section{A New Dimension: Beyond Plausibility}

The 'potential' and the 'possible' as specific traits of modern cinema also come to the fore in 'The Saying and the Said: Towards the Decline of Plausibility in Cinema?'. What characterizes new cinema is its desire to 'say', and to 'say' everything: "The "new" film-maker does not look for a film subject: he has something to say, and so he says it in film. ${ }^{20}$ From its inception, cinema has been nourished by the 'mad hope' of expressing whatever was necessary and useful: if this 'mad hope' is still far from being realized, '[n] evertheless, in the newer accents, which are more real and more diversified

18 Ibid., p. 194 (emphasis in original). Metz synthesizes this process saying that Antonioni 'was able to preserve [the lost significations] without "finding" them' (p. 194).

19 We could say that Godard's 'potential sequences' and Antonioni's 'empty moments' deal with virtuality in two different and yet comparable ways: the potential sequences 'merge' actual events and occurrences that could have happened; the empty moments 'suspend' the course of the actual events, and thanks to such a suspension they let emerge sides - and meanings - that could have been attached to the story.

20 Metz, 'The Saying and the Said', p. 235. 
than those of the great films of the past, of the best recent films, the cinema is beginning to accept the challenge of that hope.. ${ }^{21}$

In order to reach such a goal, cinema must fight three kinds of censorship: the first censorship, in the hands of State, watches over the moral contents of a movie; the second, in the hands of industry, impedes what is not profitable; the third, more subtle, consists in a sort of auto-limitation by film-makers 'who, once and for all, have stopped trying (or have never tried) to break out of the narrow circle of recommended topics for films. ${ }^{22}$ This third censorship discloses the existence of 'an insidious restriction of filmic possibilities': in representing reality, cinema almost automatically chooses what is considered most effective, believable, acceptable, and so on, according to society's expectations and habits. In a word, cinema chooses what is plausible and tends to exclude the rest. "The arts of representation [...] do not represent all that is possible - all the possibles - but only the plausible possible. ${ }^{23}$ What is the Plausible (Vraisemblable, in French)? Metz reminds us that Aristotle defines it as 'that which is possible in the eyes of common opinion'; in the French literary theories of the 17th century, it becomes 'everything that conforms to the laws of an established genre'. ${ }^{24}$ According to this definition, the Plausible is what a discourse is ready to endorse, because it corresponds either with the audience's beliefs or with a genre's norms. It is an accepted or an approved possible, and as such, it also implies the very fact that other possibilities that are neither accepted nor approved also exist - yet are not considered possibilities at all, because they lie outside what public opinion or genres consider permissible to represent. 'Thus, from its inception, the Plausible is a reduction of the possible; it is an arbitrary and cultural restriction of real possibles; it is, in fact, censorship. Among all the possibilities of figurative fiction, only those authorized by previous discourse will be "chosen".'25

Metz adds that the Plausible provides a restriction especially at the level of the way in which something is said. What is kept under control

21 Ibid., p. 236.

22 Ibid., p. 237.

23 Ibid., p. 238 (emphases in original).

24 Ibid.

25 Ibid., p. 239 (emphasis in original). Metz adds: 'Thus, behind the institutional censorship of films, around it, beside it - beneath it, but larger than it - the censorship of the Plausible functions as a second barrier, as a filter that is invisible but is more insidious than the openly acknowledged censorships; it bears on all subjects, whereas institutional censorship is concentrated around only a few political and "moral" aspects; it controls - and that is the worst thing about it - not exactly the subjects themselves, but the way the subjects are handled, that is to say, the very content of films [...]. 'The Saying and the Said', pp. 241-42 (emphasis in original). 
is not so much the substance of content - a topic - but rather the form of content, the manner in which the topic is represented. ${ }^{26}$ In any case, the Plausible does not let all the possibilities come into full existence; it includes only some of them, while excluding what is not endorsed in the sphere of social discourses. In this sense, it is defined by the presence of borders: 'the Plausible [...] resides in the very existence of a line of division, in the actual act of the restriction of possibilities'. It is a closed domain: 'Always and everywhere the work that is bogged down in pure Plausibility is a closed work, and it adds no new possibility to the "corpus" of previous works in the same genre and in the same civilization. ${ }^{27}$

And yet the fence can be breached. Such is the case with modern cinema: in trying to say everything, the new film-makers prove to be able to capture what was previously excluded from the domain of filmic representations. Hence a sense of openness: '[T]he work that is partially freed from the Plausible is an open work, a work that, here and there, enacts or re-enacts one of the possibilities of life (if it is a "realistic" work) or of the imagination (if it is a "fantastic" or "non-realistic" work), whose previous exclusion through the plausibility of earlier works had succeeded in losing it from memory. ${ }^{28}$ In other words, new cinema's task is to redeem what was lost and make possible what was impossible. The number of choices in the 'sayable', previously reduced, is now expanded, and new topics and new ways of representing them become available. It is not a move without costs. To break the borders of the Plausible, to open its domain, calls for a considerable effort; an effort to utter things that have never been said: "[T] here adheres an enormous weight that must be raised by whoever wants to say them first. The sayer's task is double therefore: In addition to the always considerable labour of saying things, he must also somehow say their exclusion from other sayings. ${ }^{29}$ New cinema on the one hand provides an increase of possibilities; on the other, it raises meta-linguistic awareness, which ends the taking of these possibilities for granted and develops a self-conscious use

26 Metz directly refers to Louis Hjelmslev (see Metz: 'The Saying and the Said', p. 242, note 3). In short, Hjelmslev defines the substance as the stuff that lies under both the content plane (i.e. our thoughts) and the expression plane (i.e. sound in spoken language); the substance must be 'cut' in single portions in order to create single concepts and single phonemes; the form is precisely the specific way (specific to any culture and any language) in which substance is 'cut', therefore providing the speaker a set of distinct possibilities. According this definition, the Plausible is a form of content (a way of creating internal and external borders relative to the substance of content).

27 Metz, 'The Saying and the Said', p. 245.

28 Ibid.

29 Ibid., p. 246. 
of representation. (I would add, as parenthesis, that this meta-linguistic awareness is precisely what Metz praises in Federico Fellini's 81/2 [I/F 1963] in his essay 'Mirror Construction in Fellini's $8^{1} / 2$ ').

The very act of giving a chance to what was otherwise only an unexpressed possibility triggers not only a sense of novelty - 'a shock in the viewer ${ }^{30}$ - but also a sense of truth..$^{31}$ The occurrence of what was unseen brings the feeling of a discovery or a revelation. "E]ach time it occurs it renders forty films, retroactively devoted to the pure Plausible, obsolete in a single stroke. ${ }^{32}$ And yet this revelation soon becomes something that is accepted and even expected: '[...] the truths of today can become the plausibilities of tomorrow'. What was a fresh and candid insight into reality and fantasy - that brought to fore new content and a new way of representing it - soon becomes a rhetorical device.

The impression of truth, of a sudden liberation, corresponds to those privileged moments when the Plausible is burst open by some new point, or when a new possibility makes its appearance in the film; but once established, this possibility in turn becomes a fact of discourse and of "writing", and hence the germ at least of a new Plausibility. ${ }^{33}$

The novelty loses its strength; I would say, instead of being the 'arising-of-apossible', it becomes a 'taken-for-granted-possible'. The field of possibilities is flattened again.

\section{The Potential and the Possible}

How do 'The Modern Cinema and Narrativity' and 'The Saying and the Said' (and partially 'Mirror Construction in Fellini's $8^{1} / 2^{\prime}$ ) interact and converse?

30 Ibid.

31 I would note that the meaning of the French word, vraisemblable, implies the idea of truth and at the same time the idea of seeming. The vraisemblable is not what is true but what looks true. In the same years in which Metz penned his contribution, A.J. Greimas was designing an even more complex layout: besides the Truth and the Plausibility, we also have to take in account the Veracity, i.e. the ability to say the truth. Hence a triplets of concepts: the being-true, the seeming-true, and the saying-true (in French: Vérité, Vraisemblance, Véridiction, that we can properly translate as the True, the Verisimilar, and the Veridictive). See A.J. Greimas, 'The Veridiction Contract', trans. by Frank Collins and others, New Literary History, 20/3 (1989), pp. 651-6o; or 'Le contrat de véridiction', Man and World, 13 (1980), pp. 345-55.

32 Metz, 'The Saying and the Said', p. 246.

33 Ibid., p. 247. 
How do they explore and set up the field of the Potential and the Possible? The idea of the 'potential sequence' and the breach of the Plausible trace two parallel and yet different processes.

In the first case of the potential sequence, we deal with something that is already in the domain of diegetic possibilities but that is not expected to appear on the screen because the story has followed another course of events. The potential sequence overturns this expectation: an action that could have occurred, if something else had not taken its place, is nevertheless represented on the screen, together with that which actually occurred. What we encounter is a sort of 'suspended' element that enters the film narrative. The potential sequence outlines what is suspended; what could have happened is staged along with what really happens. Consequently, the virtual and the actual meet; both are realized in the discourse. There is no more suspension, everything can occur at the same time - the now includes the no more, the not yet, the coming soon, the almost. Impending actions, lost opportunities, real behaviour all mingle.

In the second case we go far beyond what belongs to the sphere of diegesis, what is just suspended, or placed on hold. We deal with something that is not part of the domain of the authorized filmic representations either because it goes against common sense or because it falls outside the rules of the genre. Hence, what a film shows is not simply an action or a character that is not expected to be on the screen, because another course of events had taken its place, but an action or a character that, according to the social and linguistic norms, cannot - or even must not be shown. Rather than a suspended element that is made present, we face an unprecedented element that becomes available. The breach of the Plausible overcomes an exclusion - and not simply a suspension. It changes the map of what is sayable, it expands the border of what we can include in our discourses.

In other words, with the potential sequence we mix the possible with the actual, and in this way we allow a film to capture a multilayered state of things; with the breach of Plausibility we authorize what otherwise is excluded - not only from 'this' film but also from 'all' films - to become 'sayable'. In both cases, what is not supposed to be on the screen appears in the film as an actual part of it. But the values and the implications of such occurrences are different. In the potential sequence, the possible is something that stays on hold and that becomes actual because a film wants to witness it as well: it is something that already exists in the diegesis and that is 'hosted' in the film along with what is presented as an actual course of action. In the breach of the Plausible, the possible is something that comes 
to life: what was excluded from the cinema because of its non-conformity with the Plausible - what indeed was a non-existent element - becomes a component that a movie can take into account; it becomes such a component because it occurs in a movie that dares to overcome its exclusion; and once incorporated, this component is ready to be taken up by other films as well, to the point of inevitably slipping from the unexpected to the habitual, and in this way it is reabsorbed into the domain of Plausibility.

The two paths cross but move along different lines. In the first case we are engaged in a process of aggregation of different states and stages of an event. As I said above, the potential sequence is a segment that encompasses what happens, what is to happen, what just happened, and what could have been happening. It is not by chance that the potential sequence may recall the idea of 'Crystal-image' that Gilles Deleuze will foreground in his work on cinema. The Crystal-image is formed by the collision of present, past, and future as well as of perception, memory, and anticipation; in it, the actual and the virtual crash and merge, becoming indiscernible. In this respect, the Crystal-image is a perfect specimen of time as duration: 'What we see in crystal is time in itself, a bit of time in the pure state. ${ }^{34}$ In the case of the breach of the Plausible, we face instead a process of $r e$ articulation of a semantic field. The borders that define the great domain of what can legitimately be represented move outward and inward; what was previously forbidden becomes acceptable, and what was acceptable becomes obsolete; novelties open breaches and then are seen as standard; the geography of vision is remapped. And new images - new realities, new meanings - become available, while others lose their force and legitimation. Not by chance, this process aligns with cinema's work of a re-configuration of the visible, which many scholars claim is the most specific and precious legacy of cinema. (Among these scholars is Pietro Montani, who works with great analytical detail on this topic..$^{35}$ ) Cinema is precisely the art that has ceaselessly redefined the visibility of the world: in film after film, things shown on the screen and the way in which they were displayed have made some portions of reality accessible for spectators, while at the same time secluding other parts. A possibility ready to be manifested, and a possibility that is not yet or no longer included in the set of possibilities - let's say possibilities still invisible - have found, on the screen, a permanent site of confrontation and mutual exchange. 


\section{Beyond Structuralism, and Toward a History of Forms}

Metz's interest in the Potential and the Possible has significant consequences for his theoretical framework. At the heart of an epoch devoted to Structuralism, Metz moves against some of the axioms that underpin its approach. In particular, Metz dismantles two main principles: first, the idea of a clear divide between paradigmatic axis and syntagmatic axis; and second, the primacy (and the relative stability) of a system.

Structuralism provides an oppositional definition of paradigm and syntagm. A paradigm is a set of linguistic items that form mutually exclusive choices; it is the site of a selection. On the contrary, a syntagm is a set of linguistic units that have been chosen by the speaker in order to create a discourse: it is the site of a combination. The passage from the paradigm to the syntagm is the passage from a linguistic system to a linguistic manifestation - the passage from a domain of virtuality to a domain of realizations. The 'potential' syntagma spoils this picture: it breaks the rigidity of this divide, and conceives the discourse as a site where the actual can coexist with the virtual - a virtual that is realized, since it enters into the discourse, but whose realization does not strip it of its status of virtuality. Hence a new and richer dynamic: a discourse can host what is otherwise on hold; and the paradigmatic can break into the syntagm, still keeping its status as paradigmatic. It is not a simple superposition of principles, as with the 'poetic function' described by Roman Jakobson, in which the linearity of the discourse is punctuated by contrasts and repetitions proper to the syntagmatic organizations. ${ }^{36}$ On the contrary, it is the ultimate attempt by the discourse to escape the need for a limited - and limiting - choice and also to include possibilities within it. It is in this manner that the 'potential sequence' can depict not only what happens but an 'idea' of an event that also includes what could have happened - the virtual and the actual together.

As for the 'primacy' of the system, Structuralism claims that linguistic activity is mainly - and typically - based on a passage from a set of preestablished possibilities to a realization; it is the system that determines the discourse. The breach of the Plausible changes the picture: the discourse creates possibilities that later are included in the system. Modern cinema shows pieces of reality that are outside the usual things that a film is expected to represent. Once shown in a movie, the representation of this piece

36 Roman Jakobson, 'Linguistics and Poetics', in Style in Language, trans. and ed. by Thomas Sebeok (Cambridge, MA: MIT Press, 196o), pp. 350-77. 
of reality becomes legitimately available also for other movies. Therefore, the usual set of choices that films can refer to is implemented; but it is implemented thanks to a filmic realization - through a bottom-up and not a top-down process. In short, the discourse inflects the system, instead of the system governing the discourse. Or, put in another way, it is the 'said' of a film that defines the 'sayable' of cinema, and not the 'sayable' that determines the 'said'.

I would like to add that such a primacy of realization - and not of system - echoes the first great Metz essay, "The Cinema: Language or Language System?' written in $1964,{ }^{37}$ in which he claimed that cinema rests upon a language that is developing from film to film more than upon an already well-established system of signs. The same primacy will re-emerge in the last pages of Language and Cinema, written in $19711^{38}$ in which the idea of 'writing' elucidates the fact that a film constantly 'reworks' the codes that underlie its manifestation, to the point of 'restructuring' the pre-existing system of choices. Metz perpetually worked - and often in advance - with a semiotics far from the rigidity of Structuralism.

There is a second and final issue tied in with the picture sketched by Metz. It is not by chance that it emerges in conjunction with a study of modern cinema: a historical approach highlights the richness of the ways the films are put together and their dialectic relationships with the preexisting set of authorized choices. From this viewpoint, Metz synthesizes the novelty of 'new' cinema as follows:

Rather than some cataclysmic 'breakdown' of filmic syntax, we are witnessing with the new cinema a vast and complex trend of renewal and enrichment, which is expressed by three parallel developments: (1) Certain figures are for the time being more or less abandoned (example: slow motion or accelerated motion filming); (2) others are maintained, but as more flexible variations, which must not prevent one from recognizing the permanence of a deeper semiological mechanism (example: the shot/reverse shot, the scene, the sequence, alternate montage, etc.);

(3) finally, new figures evolve, increasing the cinema's possibilities of expression. ${ }^{39}$

37 Christian Metz, 'The Cinema: Language or Language System?', in Metz, Film Language, pp. 31-91.

38 Christian Metz, Language and Cinema, trans. by Donna Jean Umiker-Sebeok (The Hague: Mouton, 1974 [1971]).

39 Metz, 'Modern Cinema', p. 217. 
This passage is quite important: here Metz opens the doors to what David Bordwell would call a History of Film Styles. ${ }^{40}$ And yet Metz follows a path that is different from Bordwell's, despite some similarities. To him, such a history is not a simple list of the main formulas and procedures in use at a given moment. On the contrary, it includes what is customary but also what is outmoded, what is a variation of current norms, and what is a novelty in search of legitimization. To grasp such a landscape, we must keep in mind the dialectical relationships between manifestation and language system as well as the determining role of manifestation. It does not suffice to describe what films do in one epoch; we have to uncover what they are ready to do, what they are able to do, what they do not want to do anymore - according to a set of opportunities that are always expandable, also on the impulse provided by realizations.

Once again, the idea of the Possible and the Potential displays its full relevance: it is thanks to it that we can trace such a flexible and dynamic landscape. The Possible and the Potential provide the horizon within which each option takes place: they represent the reserve of opportunities that a movie may refer to. In one word: they give a 'thickness' to the picture, making evident that a style is not only a spread mode of expression but overall something that comes to life in the interval between what is in use and what can be in use.

In this vein, we understand better the strategy that Metz deployed in his research and that is even clearer in the pages we have reread here. What he constantly praised - and in his discussion on the modern openly practiced - was a double insight: on the one hand, general semiotics provides a trans-historical picture that highlights the general conditions proper to cinema; on the other hand, analyses of specific corpuses enable researchers to see how the general conditions fit and adapt to an actual context. There is a 'theory' that orients and sustains examinations, and there is a set of 'cases' that test, endorse, or readjust the 'theory'. ${ }^{41}$ Research must go back and forth between the two poles: the furst emphasizes the background of a manifestation; the second represents the site that implements the sphere of choices. Hence the usefulness of the go-between the actual and the virtual: it gives a full perspective to both sides. This is the great lesson that Metzian semiotics imparted. This is its legacy.

40 David Bordwell, On the History of Film Style (Cambridge, MA/London: Harvard University Press, 1997).

41 On Metz and film theory, see D.N. Rodowick, Elegy for Theory (Cambridge, MA/London: Harvard University Press, 2014). 


\section{About the author}

Francesco Casetti is Professor of Film and Media at Yale University. He is the author of Inside the Gaze. The Fiction Film and its Spectator (1999); Theories of Cinema, 1945-1995 (1999); Eye of the Century: Film, Experience, Modernity (2008); and The Lumière Galaxy: Seven Key Words for the Cinema to Come (2015). With Jane Gaines, he is the co-founder of the 'Permanent Seminar on Histories of Film Theories'. Prior to his arrival at Yale, he taught in Italy for thirty years, where he served as President of the Italian Academic Association of Film and Television Teachers (Consulta Universitaria del Cinema). 



\title{
9. Christian Metz, Editing, and Forms of Alternation $^{1}$
}

\author{
André Gaudreault and Philippe Gauthier
}

Tröhler, Margrit and Guido Kirsten (eds.), Christian Metz and the Codes of Cinema. Film Semiology and Beyond. Amsterdam University Press, 2018

DOI: $10.5117 / 9789089648921 / \mathrm{CHO9}$

\begin{abstract}
The goal of this chapter is to understand the role of Christian Metz's work in the history of theories of film editing, and in particular with respect to alternation devices. The authors discuss how Metz's propositions (with the Grand Syntagmatique in particular) cleared up a great deal of ambiguity around definitions of these editing devices. They examine Metz's syntagmatic analysis of the images in the film Adieu Philippine (Jacques Rozier, F 1962) in order to identify three problems that the Grand Syntagmatique's 'alternating' techniques posed for him. These three problems represent areas for future research that will have to be pursued if new light is to be cast on the forms in which crosscutting first emerged.
\end{abstract}

Keywords: film semiotics/film semiology, Grand Syntagmatique, editing devices, forms of alternation, parallel editing, crosscutting

1 Research for this article was carried out under the aegis of GRAFICS (Groupe de recherche sur l'avènement et la formation des institutions cinématographique et scénique). GRAFICS is a member of the international partnership TECHNÈS, which since 2012 has joined the efforts of three French-language university research groups, each of which is associated with a film archive and film school. The authors would like to thank Kim Décarie, Jéremy Houillère, Emmanuel Jory, and Sophie Rabouh for their research assistance prior to the writing of this article. They would also like to thank Anne Bienjonetti, Alain Boillat, Dominique Chateau, Michel Marie, and Martin Lefebvre for the discussions they have had with them, which enabled them to refine some of their hypotheses. A French version of this article has been published in the following two issues of Cinémas: André Gaudreault and Philippe Gauthier, 'De la filmologie à la sémiologie: les figures de l'alternance au cinéma', Cinémas, 25/2-3 (2015), pp. 159-73, and 'Christian Metz, le montage et les formes de l'alternance', Cinémas, 26/1 (2015), pp. 157-75. 
For the Zurich conference on the work of Christian Metz, we believed it germane to seize the opportunity it presented to discuss the advances that the French semiotician made possible with respect to understanding the various 'mechanisms' of film editing. More precisely, here we will examine Metz's ideas on alternation. The two authors of the present text have been engaged for many years in far-reaching explorations of the advent of crosscutting, through two research projects funded by the Social Sciences and Humanities Research Council of Canada: ${ }^{2}$ the first studied the emergence in early cinema of the forms of the discursive practice of alternation, founded on the recurrence of the terms of two series; while the second, with broader aims, had as its goal the classification and analysis of the earliest forms of editing in the kine-attractography era. ${ }^{3}$

Because alternation has a leading role in the history of editing, ${ }^{4}$ we thought it important to analyze the different forms that this configuration can take before cinema's institutionalization and to highlight the techniques used before this discursive practice was codified by the institution. We feel it is all the more essential because, in the view of some scholars, alternation made it possible to instill a new mode of expression. Noël Burch, for example, believes that 'the emergence of the alternating syntagm[a] has to be seen as the foundation-stone of modern syntax'. ${ }^{5}$

It was primarily through his work on the grande syntagmatique ${ }^{6}$ (hereafter the GS) that Metz, in the late 196os, set out to untangle the maze of names proposed in numerous 'editing charts' produced by film theorists since the late 1910s. One of Metz's most important feats with his GS chart was his success in clearing up a good deal of the ambiguity around definitions of editing techniques, developing a detailed and precise nomenclature by looking at things from a fresh perspective despite also drawing on tradition, as

2 These two projects were carried out under the leadership of André Gaudreault at the Université de Montréal from 2004 to 2007 for the former and from 2010 to 2013 for the latter.

3 For an understanding of what is meant by the term 'kine-attractography', see André Gaudreault, Film and Attraction: From Kinematography to Cinema, trans. by Timothy Barnard (Urbana: University of Illinois Press, 2011 [2008]).

4 See in particular Nicolas Dulac and André Gaudreault, 'Crosscutting in the Face of History: The Case of Attack on a China Mission', trans. by Timothy Barnard, Early Popular Visual Culture, 7/1 (2009), pp. 1-18.

5 Noël Burch, Life to those Shadows, trans. and ed. by Ben Brewster (Berkeley: University of California Press, 1990 [1991]), p. 157.

6 Christian Metz, Film Language: A Semiotics of the Cinema, trans. by Michael Taylor (New York: Oxford University Press, 1974 [1968]), in particular the chapter 'Problems of Denotation in the Fiction Film', pp. 108-46. Note that this translation employs the expression 'large syntagmatic category' for Metz's term grande syntagmatique, which we have retained here. 
he clearly indicates. Indeed, Metz himself stated that his eight syntagmatic types were based on "certain "presemiotic" analyses by critics, historians, and theoreticians of the cinema' who preceded him:

Among the authors who have devised tables of montage, or classifications of various kinds - or who have studied separately a specific type of montage - I am indebted notably to Eisenstein, Pudovkin, Kuleshov, Timoshenko, Béla Balázs, Rudolf Arnheim, André Bazin, Edgar Morin, Gilbert Cohen-Séat, Jean Mitry, Marcel Martin, Henri Agel, François Chevassu, Anne Souriau and one or two others perhaps whom I have unintentionally overlooked.?

One of the achievements of the GS was to distinguish between crosscutting and parallel editing, ${ }^{8}$ two of the main forms of alternation. Because Metz's writings have been so widely read, this distinction has taken hold, to the extent that it is almost universally acknowledged by French-language scholars.

The situation was quite different a scant fifteen years before Metz's initial writings on the subject, however. This at least is what can be deduced by consulting the writings of Etienne Souriau and his daughter Anne Souriau. The title of an important text published by the former in $195^{1}$ in the

7 Metz, 'Problems of Denotation', p. 120.

8 One might wonder, incidentally, why authors such as Metz, Agel, Martin, and Mitry grant so much importance to such a little-used technique in classical narrative cinema as 'parallel editing' (Metz makes it one of his eight syntagmatic types). In our view, the great use French theorists made of the work of their Russian counterparts plays a part in this. Martin, for example (but also Agel), refers to the ideas of Pudovkin, who distinguishes three techniques we might describe after the fact as parallel editing (the synthesis here is by Martin): 'Antithesis (an opulent storefront - a beggar), Parallelism (the demonstrators - the ice in Mother), [and] Analogy (the metaphor of the slaughterhouse in Strike [Sergei M. Eisenstein, SU 1925].' It would seem that Agel and Martin granted a special role to parallel editing after reading Pudovkin (and the other Soviet film theorists), thereby inaugurating a tradition amongst French-language scholars. The situation was entirely different in English: as we explained in an earlier publication, the distinction between simultaneous events and not-relevant temporal relations (between what French-language scholars call 'montage alterné' [crosscutting] on the one hand and 'montage parallèle' [parallel editing] on the other) does not exist in the same way in the English-speaking tradition. Indeed, in English the two expressions are completely interchangeable. See Marcel Martin, Le langage cinématographique (Paris: Editions du Cerf, 1955), p. 140; Henri Agel (in collaboration with Geneviève Agel), Précis d'initiation au cinéma (Paris: Editions de l'école, 1957); and André Gaudreault and Philippe Gauthier, 'Crosscutting, a Programmed Language', in The Griffith Project, ed. by Paolo Cherchi Usai, 12 vols. (London: BFI, 1999-2008), XII (2008), 30-47 (pp. 37-38). 
Revue internationale de filmologie, 'La structure de l'univers filmique et le vocabulaire de la filmologie', indicates off the bat its author's concern for questions of vocabulary. We cannot help but notice, however, the obvious lack of terms to identify alternation techniques:

I am shown the course of two simultaneous events in alternating slices. I see Dolores embroidering in the parlor [...] while stopping at times to look towards the window with expectation. Then I see Ramiro galloping down the road. Then I see Dolores again. I understand perfectly that Ramiro is galloping while Dolores awaits him: the two events are contemporary in the diegetic time; they alternate in filmophanic time. Nothing could be clearer. ${ }^{9}$

There can be little doubt that Souriau's 'alternating slices' are what film theory would end up identifying as 'crosscutting' ('montage alterné), but Souriau, otherwise so careful in his vocabulary, does not yet go so far as to use a suitable expression (such as 'montage alterné' [crosscutting]). Paradoxically, although his entire text is attached to suggesting 'terms in order to [...] avoid having to repeat these explanations each time', ${ }^{10}$ this desire concerns not editing devices but rather 'levels of existence of the filmic universe, ${ }^{11}$ leading him to conceive his famous 'filmology vocabulary' (with its concepts afilmic, profilmic, filmographic, filmophanic, screenic, diegetic, etc.).

In the present case, what Souriau suggests is that we distinguish, in the case of a kind of editing that presents 'two simultaneous events unfolding in alternating slices', the diegetic level (what is 'depicted by the film'12) from the filmophanic level ('the phenomena related to this depiction that is projected for viewers ${ }^{\prime \prime 3}$ ). In filmophanic time, Dolores's adventures (time A, say) and those of Ramiro (time $\mathrm{B}$ ) are depicted in an alternating and discontinuous manner $\left(\mathrm{A}^{1}-\mathrm{B}^{1}-\mathrm{A}^{2}-\mathrm{B}^{2}\right)$. But in diegetic time, each series - taken

9 Etienne Souriau, 'La structure de l'univers filmique et le vocabulaire de la filmologie', Revue internationale de filmologie, 7-8 (1951), 231-41 (pp. 233-34) (our emphasis).

10 Souriau, 'La structure', p. 234 (our emphasis). Souriau's complete remark is as follows: 'Nothing could be clearer, but it still needs to be said and to have the terms with which to say it: first in order to avoid having to repeat these explanations each time, or to count on a more or less vague and confusingly suggestive term to fill in for such explanations; and also because these words have a role in a structural whole.'

11 See in particular Souriau, 'La structure', p. 238, where he asks: 'Have we finished our exploration of the filmic universe through its various levels of existence?'.

12 Ibid., p. 237.

13 Ibid., p. 236. 
as a block - is in continuity (in the diegesis, $\mathrm{A}^{2}$ follows $\mathrm{A}^{1}$ and $\mathrm{B}^{2}$ follows $\mathrm{B}^{1}$ ), and the events in each block are presented as unfolding at the same time as the events in the other block $\left(\mathrm{A}^{1} \mathrm{~A}^{2}\right.$ takes place at the same time as $\left.\mathrm{B}^{1} \mathrm{~B}^{2}\right)$.

We may thus presume that in the early 1950s, film theory did not yet have a stable vocabulary to describe alternation techniques. This fact is even more bluntly apparent in a volume Souriau edited in 1953, two short years after the publication of his text quoted above. In an article of almost surgical theoretical precision entitled 'Succession et simultanéité dans le film', Anne Souriau explored all the ins and outs of what would later be described as 'crosscutting', describing it from top to bottom and from side to side without ever allowing herself, like her father, to give it a name:

Most often, however, the two simultaneous actions are simply shown to us in alternating order. The single succession of shots in a film is made up of two intertwined successions.

When the interlacing is not tight enough, the viewer can no longer tell whether the scenes being shown took place one after the other or at the same time.

Through spontaneous interpolation, we follow in a continuous manner the parallel existences of two stories shown discontinuously.

The alternation effect is reinforced when the alternation is prompt.

Moreover, the scenes are not, properly speaking, parallel. They are, more precisely, converging.

In the face of a well-done chase sequence the audience is stirred, because the encounter of alternating scenes is virtually contained in these actions. ${ }^{14}$

Here, as can be seen, circumlocutions abound: simultaneous action, alternating order, interlacing succession, intertwining, the parallel existences of two stories shown discontinuously, alternation effect, parallel scenes, converging scenes, alternating scenes.

This lack of clear and precise terminology is just as obvious in the work of French film theorists and historians of the 1950s and early 1960s (with one exception, that of Marcel Martin writing in 1955, which we will discuss below). Here are examples from three figures of the period, Henri Agel, André Bazin, and Jean Mitry:

14 Anne Souriau, 'Succession et simultanéité dans le film', in L'univers filmique, ed. by Etienne Souriau (Paris: Flammarion, 1953), 59-73 (pp. 67-68; our emphasis). 
1. In 1957 , inspired by the work of Vsevolod Pudovkin on montage, ${ }^{15}$ Henri Agel used the expression 'montage parallèle' ('parallel editing') to describe a sequence that we today would see instead as an example of crosscutting ('montage alterné): 'Parallel editing shows us in alternation two simultaneous actions taking place in different places. ${ }^{16}$ Agel also uses, in a somewhat consistent manner, the expression 'montage alterné' ('crosscutting') to describe a sequence that we today would see instead as an example of parallel editing:

Griffith's Intolerance ([USA] 1916) remains to this day one of the boldest attempts at crosscutting. The film has four episodes which are initially shown separately and then interlock with each other: the Fall of Babylon, the Passion of Christ, the St. Bartholomew's Day Massacre and the Mother and the Law (the Modern story). ${ }^{17}$

2. In 1958, in the chapter entitled 'Montage interdit' in the first volume of Qu'est-ce que le cinéma?, André Bazin also uses the expression 'montage parallèle' (parallel editing) to describe a sequence that we today would see instead as an example of crosscutting. This sequence alternates between events taking place simultaneously (on the one hand, a young boy bringing a lion cub back to his family's encampment, and on the other the lioness tracking the boy from a distance: 'Up to this point everything has been shown in parallel editing and the somewhat naive attempt at suspense has seemed quite conventional.') ${ }^{18}$

3. Jean Mitry, for his part, in his Esthétique et psychologie du cinéma (1963 and 1965), makes no distinction between the expressions 'montage alterné' (crosscutting) and 'montage parallèle' (parallel editing). He uses them indiscriminately (as English speakers still do today with the respective

15 An English reprint of Pudovkin's book on editing was published in 1954 under the title Film Technique and Film Acting (London: Vision), and it is to this edition that Agel refers. The first English editions of Film Technique and Film Acting were published in 1929 and 1933 respectively.

16 Agel, Précis d'initiation, p. 97 (our emphasis).

17 Ibid., p. 96.

18 André Bazin, 'The Virtues and Limitations of Montage', in What is Cinema?, trans. by Hugh Gray, 2 vols. (Berkley/Los Angeles/London: University of California Press, 1967), I [1958], 41-52 (p. 49) (our emphasis). Note that this translation of Bazin employs the expression 'parallel montage' rather than 'parallel editing' as given above. This chapter is a reworking of two previously published articles in Cahiers du cinéma. Note that the section of the text we quote here is not found in either of these two articles but was added for the 1958 version. The sequence analyzed by Bazin is from the film Where No Vultures Fly (Harry Watt, UK 1951), about the life of a young family in South Africa during the Second World War. 
terms indicated here) to describe a technique that alternates two series of events presented as unfolding simultaneously in the diegetic universe suggested by the film. Writing about The Birth of a Nation (D.W. Griffith, USA 1915), Mitry remarks:

In a series of faster and faster crosscuts, we pass from sequences showing the town of Atlanta in flames to scenes of terror in the Cameron farm, returning to the battle scene and scenes of brother killing brother. And so on. In the final sequence, at the end of which the Camerons, holed up in a tiny hut, are saved in the nick of time by the Ku Klux Klan, the parallel editing is made to fit a clever quasi-musical rhythm. [...] For instance, we cut from a wide angle showing the besieged hut to shots becoming ever closer revealing the Camerons preparing for the fight. We see the face of one of them, the actions of another, etc. From the Camerons, we cut to the ride of the Klansmen. [...] A series of closeups and extreme closeups picks up the galloping horses' hooves [...] and once again we see the whole cavalcade crossing the prairie. [...] We return to the hut. [...] Back to the ride. [...] And the alternation is kept up until the final crescendo with which the film is resolved. ${ }^{19}$

We should note that, despite the fact that Mitry uses crosscutting on some occasions and parallel editing on others, the only technique being discussed in this long excerpt is what French-speaking scholars would call 'montage alterné' (strictly speaking: crosscutting, in keeping with the principles of the GS, which have taken hold amongst French-speaking scholars).

One page earlier in the same book, Mitry uses the expression 'contrast editing' to describe a technique that alternated two series of motifs in a kind of parallelism between two situations whose temporal relation to each other is not relevant (this technique thus corresponds instead to a sequence in parallel editing [montage parallèle]). Thus Mitry wrote the following about The Ex-Convict (Edwin S. Porter, USA 1904):

In The Ex-Convict, Porter opted for what we know nowadays as contrast editing. In this drama, which shows the problem of an ex-convict being refused work by a wealthy industrialist, the American director contrasts

19 Jean Mitry, The Aesthetics and Psychology of the Cinema, trans. by Christopher King (Bloomington: Indiana University Press, 1997 [1963]), pp. 96-97 (our emphasis). Note that, in the final sentence, this translation of Mitry employs the term 'crosscutting' rather than 'alternation' as given above. 
scenes showing, on the one hand, the luxurious interior of a bourgeois home and, on the other, the miserable hovel of the ex-convict. This use of editing in a sequence of comparison where the dramatic development depends on alternating scenes brought the technique one step closer to the art it was to become some years later. ${ }^{20}$

\title{
It is clear that in 1963, when the first volume of Esthétique et psychologie du cinéma was published, vocabulary around these techniques was not yet settled, as is apparent in the fact that Mitry also wrote the following about what we might call the 'macrostructural' editing of Intolerance:
}

\begin{abstract}
Enlarging upon the technique of interwoven editing and parallel action, Griffith, with four separate story lines to maintain, was to jump continually from one to the other and follow, through time and space, the course of four tragedies whose events, related thematically to one another, contributed cumulatively to the overall theme. ${ }^{21}$
\end{abstract}

20 Mitry, Aesthetics and Psychology, p. 95 (our emphasis). Note that Mitry's description of the film is a little 'whimsical'. Whether what he describes is in the film or not, however, Mitry nevertheless defines what, for him, is 'contrast editing'. One might presume that Mitry used this expression under the 'influence' (the word is not strong enough) of Lewis Jacobs, for we can find the entire passage we have just quoted, but in English, in a volume published twenty-four years before Mitry's volume in French: 'In The Ex-Convict, for instance, a wealthy manufacturer refuses to give an ex-convict work. It was necessary to contrast the two men's life situations in order to emphasize for the audience the drama of their encounter. Porter therefore employed the formal device now known as contrast editing. Scenes of the poverty-stricken home of the ex-convict were opposed to scenes of luxury in the manufacturer's household, and thus by implication and inference the sympathy of the audience was directed. This new application of editing, not straightforward or direct but comparative, pointed to future subtlety in film expression. Not until years later, however, was contrast editing to be properly valued and developed.' Lewis Jacobs, The Rise of the American Film: A Critical History (New York: Teachers College Press, 1969 [1939]), pp. 46-47. We have provided the published English translation of Mitry's text. Because the translator was not aware of the 'influence' of Jacobs on Mitry's remarks, the two texts do not match in English. In order to enable the English reader to appreciate the degree of Jacobs' influence on Mitry, we provide here the French text: 'Dans The Ex-Convict, un industriel refuse du travail à un ancien condamné. Pour signifier le drame et surtout pour agir sur l'esprit du spectateur, il était nécessaire d'insister sur la différence de situation des deux hommes. Porter fut donc amené à ce qu'on appelle aujourd'hui le montage contrasté. Des scènes de vie dans le misérable intérieur de l'ancien condamné étaient opposées à d'autres scènes de vie luxueuse dans l'intérieur bourgeois. Cette application du montage dans une suite comparative dont la progression reposait sur l'alternance des scènes apportait un point de plus à l'actif d'un art qui ne devait généraliser cette formule que beaucoup plus tard.' It is an almost perfect match. Jean Mitry, Esthéthique et psychologie du cinéma, 2 vols. (Paris: Editions universitaires, 1963-1965), I [1963], p. 275 (our emphasis).

21 Mitry, Aesthetics and Psychology, p. 97 (our emphasis). 
In one case (The Ex-Convict), Mitry uses the expressions 'contrast cutting' and 'alternation', while in another (Intolerance), he chooses to use 'interwoven editing' ('montage entrecroisé') and 'parallel action'. True, these two films operate under different paradigms: The Ex-Convict is a worthy representative of kine-attractography, while Intolerance is a product of institutional cinema. ${ }^{22}$ At the same time, Mitry proposes a number of other terms and expressions, which he grafts onto the terminology he already uses, running the risk of adding more confusion to the already prevailing state of confusion.

In 1968, when the definitive version of the GS table appeared in the first volume of Christian Metz's famous Essais sur la signification au cinéma, ${ }^{23}$ this vocabulary was still up in the air in French. Metz emphasized that alternate ${ }^{24}$ syntagma are 'well known by the theoreticians of the cinema' under a variety of names ('montage alterné' [crosscutting], 'montage parallèle' [parallel editing], 'synchronisme', etc.). ${ }^{25}$ By contributing to 'institutionalizing', at least in the French-speaking world, a clear and wellmarked distinction between crosscutting (his term: alternate syntagma)

22 For an understanding of what is meant by the term 'institutional cinema', see Gaudreault, Film and Attraction, passim.

23 This table appears at the end of chapter five, entitled 'Problems of Denotation in the Fiction Film', of Metz, Film Language, p. 146. As noted in the French edition only, the chapter is an '(extensively "augmented") reworking' (Essais sur la signification au cinéma, 2 vols. [Paris: Klincksieck, 1968-1972], I [1968], p. 245) of three previous texts: 'Problèmes de dénotation dans le film de fiction: contribution à une sémiologie du cinéma', report at the International Preparatory Conference on the Problems of Semiotics (Kazimierz, Poland: 1966), reproduced in Signe, langage, culture, ed. by A.J. Greimas and others (The Hague/Paris: Mouton, 1970), pp. 403-13; 'La grande syntagmatique du film narratif', Communications, 8 (1966), pp. 120-24; and 'Un problème de sémiologie du cinéma', Image et son, 201 (1967), pp. 68-79. Although Metz's ideas evolved between 1966 and 1968 and his major syntagmatic types shifted a little, the distinction between crosscutting and parallel editing remained the same for him. This is why we will not examine here the evolution of Metz's ideas with respect to the GS. For more information on this question, see Alain Boillat, Cinéma, machine à mondes (Chêne-Bourg: Georg Editeur, 2014), p. 214.

24 In conformance with the published English-language translation of Metz, the present authors use here the English expression 'alternate syntagma' to render Metz's term 'syntagme alterné', which is confusing because the syntagma being described is not 'alternate' but rather 'alternating'. Our ideal translation would thus be 'alternating syntagma'. Metz's English translator, however, reserved this latter term to translate the expression 'syntagme alternant', which we describe here as a 'configuration of alternation'. The published English translation has left us with no choice but to follow its lead and to use the expression 'alternate syntagma' for 'syntagme alterné'.

25 Metz, 'Problems of Denotation', p. 128. Note that this translation of Metz employs the expressions 'alternate montage' rather than 'crosscutting', and 'parallel montage' rather than 'parallel editing' as given above. 
and parallel editing (his term: parallel syntagma), Metz made proposals that contributed, like no others, to dissipating much of the confusion around alternation techniques in his day. 'Much of the confusion', we maintain, because the syntagmatic analysis that Metz carried out on the image track of the film Adieu Philippine (Jacques Rozier, F/I 1962) demonstrates that some confusion still remained (to which we will return below).

Metz's definitions appear at first to be clear, plain, and precise. For him, crosscutting arises from a form of alternation that has a particular relation with narrative temporality. His definition of the 'alternate syntagma' describes the situations in which it becomes possible:

The editing presents alternately two or more series of events in such a way that within each series the temporal relationships are consecutive, but that, between the series taken as wholes, the temporal relationship is one of simultaneity (which can be expressed by the formula 'Alternation of images equals simultaneity of occurrences'). ${ }^{26}$

One of the essential criteria for crosscutting is thus that the series of events unfold simultaneously in the diegetic universe suggested by the film.

As for parallel editing (parallel syntagma in Metz's vocabulary), this arises from a form of alternation which, on the contrary, has no precise temporal relation:

Editing brings together and interweaves two or more alternating 'motifs', but no precise relationship (whether temporal or spatial) is assigned to them - at least on the level of denotation. This kind of editing has a direct symbolic value (scenes of the life of the rich interwoven with scenes of the life of the poor, images of tranquility alternating with images of disturbance, shots of city and the country, of the sea and of wheat fields, and so on). ${ }^{27}$

In this case, the two series of motifs suggest a kind of symbolic parallel between situations whose temporal relation is not relevant.

26 Metz, 'Problems of Denotation', p. 128. Note that this translation of Metz employs the expressions 'montage' rather than 'editing', and 'alternating of images' rather than 'alternation of images' as given above.

27 Metz, 'Problems of Denotation', p. 125. Note that this translation of Metz employs throughout this quotation the term 'montage' rather than 'editing' as given above. 
Although Metz does not come out and say so, ${ }^{28}$ we might imagine that he drew on the work of Marcel Martin for the principle by which crosscutting and parallel editing are differentiated according to the criterion of narrative temporality (simultaneous series of events in the former and non-relevant temporal relation in the latter); in Martin's book Le Langage cinématographique, published in 1955, we find a clear and precise proposal in this sense. ${ }^{29}$ There Martin explains that, for him, crosscutting connects motifs whose temporal relation is one of simultaneity: 'crosscutting is a form of editing by parallelism based on the strict contemporaneousness of the two actions it juxtaposes, which moreover most often conclude by meeting at the end of the film' $3^{\circ}$

In addition, Martin specifies that parallel editing connects motifs whose temporal relation is not relevant: 'parallel editing: two (and sometimes several) actions are brought to the forefront by the intercalation of fragments belonging alternately to each of them in order to create meaning from their juxtaposition. [...] This form of editing is characterized by its indifference to time'. . $^{1}$

Note that Martin, to define what he understands by parallel editing, uses the word 'alternately', just as he uses the word 'parallelism' in his definition of crosscutting. In truth, as any dictionary will point out, the semantic fields of the words 'parallel' and 'alternating' overlap enormously: what a crosscutting ('montage alterné) sequence does is mix together two events taking place, in a sense, parallel to one another ('in parallel' in this case indicating that the actions are simultaneous), while what a parallel editing sequence does is mix together two series shown to viewers in an alternating manner. It is apparent that, if one is not careful, there is enormous potential here for

28 In an unnumbered footnote from which we quoted a part above, Metz states 'Because there is not enough room here[,] I will not (at least in this text) indicate how the various classifications of these authors [to whom he is indebted] are distributed in relation to each specific point of my chart.' Metz, 'Problems of Denotation', p. 121.

29 Marcel Martin, Langage cinématographique, pp. 147-50.

30 Ibid., p. 149. In this quotation, the emphasis is in the original, except for the word 'parallelism', which is our emphasis.

31 Ibid., p. 147. In this quotation, the emphasis is in the original, except for the word 'alternately', which is our emphasis. Martin also drew on the work of Pudovkin and Balázs to refine his definition of parallel editing: 'One sees that Pudovkin's montage by antithesis, analogy and leitmotif correspond to what I call parallel editing, which also encompasses the metaphorical, allegorical and poetic forms of montage defined by Balázs, as all these forms of editing consist in bringing together, without any consideration for temporal co-existence (or spatial co-existence either, but space has much less importance, as we shall see), events whose juxtaposition should give rise to a precise and generally symbolic ideological meaning.' (pp. 148-49). 
confusion: ${ }^{2}$ the overlap between the two lexical fields is considerable, and it is only by decree (and this in a sense is what Metz did, following Martin) that one can impose a clear distinction in the definition and terminology of the two most important forms of alternation. This, moreover, explains the haziness that existed before the 'Metzian decree' and the interchangeability of the two terms even today in English.

That said, the sources of confusion did not all magically disappear with Metz's 'decree'. One only has to look at how Metz himself juggles his own definitions once he passes from the conceptual world of theory $y^{33}$ to the quite real world of film practice (and its corollary in film studies, film analysis). For Metz had the felicitous idea of trying out his nomenclature (with the collaboration of Michèle Lacoste) on a film, in two articles first published in 1967 in the magazine Image et son..$^{34}$ Metz and Lacoste propose a table

32 This probably explains not only the prevailing confusion around the terms in question but also the lack of consistency in their use and the great instability of their meaning from one author to the next, if not within the work of one and the same author. This is the case with Mitry, for example, who proposes the following to describe certain features of crosscutting: 'Naturally this means of expression in no ways denies the relevance of using shots separately whose meaning and purpose are quite different. Moreover, it must be obvious that the simultaneity of scenes being played out in different locations (otherwise known as parallel action), can only be suggested by alternating events with successive fragmentation.' Mitry, Aesthetics and Psychology, p. 97 (emphasis in original). The mere fact that the attributive adjective 'parallel' can be used in such a context (even when done so quite adequately, as is the case here) can be a source of confusion, because what Mitry is describing here is well and truly crosscutting (according to the 'Martin/Metz' system of nomenclature, which we adopt).

33 It is true that Metz's ideas are relatively abstract, particularly in the case of the 'parallel syntagma', because as one of the main exegetes of the GS, Michel Colin, explains, 'Note that here Metz does not exemplify with a concrete example, unlike what he would do with the bracket syntagma, for example, but rather with ad hoc examples which have not been manifested or may never be.' Michel Colin, La Grande Syntagmatique revisitée (Limoges: Trames and Université de Limoges, 1989), p. 20. The same is true for alternate syntagma, for which Metz does not give concrete examples from films: 'Typical example: shot of the pursuers, followed by a shot of the pursued, and back to a shot of the pursuers.' Metz, 'Problems of Denotation', p. 128.

34 The texts are 'Outline of the Autonomous Segments in Jacques Rozier's film Adieu Philippine' and 'Syntagmatic Study of Jacques Rozier's film Adieu Philippine', in Film Language, pp. 149-76 and 177-82 respectively. These were included in the first volume of Essais sur la signification au cinéma in 1968 (translated as Film Language, from which we quote here), but were published before under the common title 'Un problème de sémiologie du cinéma' in Image et son, 201 (January 1967), pp. 81-98. In Essais, and its English translation, the two texts make up a section (section III), about which the author indicates in a note on the title page of the section: 'The following analysis was conducted with the assistance of Michèle Lacoste' (p. 147 of the English edition). In the initial version (the magazine publication), however, the second text is identified as the work of Metz and Lacoste and the first as the work of Lacoste alone. The latter version was in addition extensively revised (we will mention one of the modifications below). 
of autonomous segments - by way of a fine-grained, segment-by-segment analysis - for the film Adieu Philippine and a syntagmatic study of the same film. These studies provide us with a series of self-critical comments that are very useful to anyone seeking to understand all the ins and outs of the GS table. In their syntagmatic analysis of Adieu Philippine, Metz and Lacoste encountered a series of problems, particularly around alternation techniques. Naturally, part of the difficulty lies in the fact that the syntagmatic organization of Rozier's film resists somewhat Metz's predefined criteria, as might logically have been expected. But the main problem, in our view, lies in the lacunae in the definitions found in the GS itself. ${ }^{35}$

These lacunae are nowhere more tangible and visible than in the syntagmatic types that weave together two (or more) series of events. Metz was quite aware of this and identified three problems that alternation posed for him..$^{6}$

\section{Problem Number One}

Metz admits that, in its final state, the GS does not make it possible to account for every technique that could be classified as what we can identify as the 'configuration of alternation'. It is thus impossible for him to fit certain segments of Adieu Philippine into the GS table. This is the case with segment 32, for example, which is described as follows:

Liliane's room. The two girls are confiding in each other. Liliane tells Juliette that she has gone out secretly with Michel. The alternation in this case occurs between two series, each of which has a different diegetic status: one is actual; the other is past and is told by one of the characters. ${ }^{37}$

Because there is alternation, we should be in the presence here of either an alternate syntagma or of a parallel syntagma. The problem is that the segment does not meet the criteria of either of these categories: segment 32

35 It would be astonishing if this were not the case, for what Metz proposed with his GS table was an immense construction site, something no one before him had dared take on. His goal, he himself stated, was to 'determine the number and the nature of the main syntagmatic types used in current films' (Metz, Film Language, p. 120), or more precisely to draw up 'a list of all the main types of image-orderings occurring in films' (Metz, 'Problems of Denotation', p. 121). That's quite a programme, one has to admit!

36 Metz, 'Outline of the Autonomous Segments', p. 164.

37 Ibid., p. 163 . 
cannot be a parallel syntagma because alternation assigns a 'precise [temporal] relationship' to the 'alternating motifs' which, at the same time, have no 'symbolic value'. ${ }^{8}$ This is why Metz 'associate[s] it provisionally with the alternate syntagma' but of a 'relatively rare' type which, combining present and past, cannot (cannot yet, say) find a place in the GS table: 'the two series, even when each one is considered as a whole, are not simultaneous; the series "Liliane-Juliette conversation" is subsequent to the series "LilianeMichel" (alternate flashback). ${ }^{39}$

Metz could perhaps have gone a step further and created a new category (the alternateflashbacksyntagma, for example), but he held back: 'No doubt, it will be necessary eventually to redefine [this type] as a specific type, whose position in the outline of the syntagmatic categories remains to be determined. ${ }^{40}$ The configuration of alternation can thus give rise to a number of techniques other than alternate and parallel syntagma alone. Metz himself said, in notes written some time after his book's publication ${ }^{41}$ and in which he undertakes a critique of his GS table, that 'at a minimum what is needed is to subdivide the alternate syntagma into several sub-types'. ${ }^{42}$ The vexing question of segment 32 of Adieu Philippine would, moreover, come back to haunt him in these same notes:

38 Metz, 'Problems of Denotation', p. 125.

39 Metz, 'Outline of the Autonomous Segments', p. 163.

40 Ibid., pp. $163-64$.

41 See Christian Metz, 'Topo susceptible de servir de "partie introductive” et/ou conclusive à tout exposé sur ma "grande syntagmatique", pour situer cette dernière à l'usage d'un quelconque public peu sémiologisé (ou même un peu plus sémiologisé),' handwritten note preserved at the Bibliothèque du film (BiFi) in Paris (ms. CM1441). Nine undated sheets of paper. The authors thank Martin Lefebvre for having brought this document to their attention and for making a copy available to them.

42 Metz also suggests, in these same notes, that he would have to rethink his syntagmatic types from zero, using in particular the ideas of Noam Chomsky: 'I started from the principle that the units of these two orders coincided: a non-Chomskian structuralist hypothesis. [...] Chomsky would thus be useful for his hypothesis of the dual structure (surface/deep), rather than precise rules for grammatical generation, which is something different.' To the best of our knowledge, Metz did not go down this path, but Dominique Chateau (1986) and Michel Colin (1989) did, each on his own. Chateau extends Metz's model by setting out the prolegomena of a generative 'modeling' based in particular on the work of Chomsky (see his Le cinéma comme langage [Brussels: AISS, 1986]). Colin, for his part, drew on Chomsky's rules for lexical sub-categorization to propose, for example, new classification rules for the syntagma of the GS in order to 'deduce many more types than those shown in the [GS] table' (Colin, La Grande Syntagmatique revisitée, p. 76). For a detailed analysis of the work of Chateau and Colin around the grande syntagmatique, see Warren Buckland, The Cognitive Semiotics of Film (Cambridge: Cambridge University Press, 2000), pp. 109-40. 


\section{Criticism of the table}

[...] Even in films whose editing is fairly traditional, some sequences fit nowhere in my table.

For ex., no. 32 of Adieu Philippine (p. 163 of my book). ${ }^{43}$

\section{Problem Number Two}

Metz acknowledges the impossible task he is confronted with, in the absence of a 'rigorous semiological theory' ${ }^{44}$ capable of resolving the problem, of determining whether a sequence intercut with inserts should be seen as an autonomous segment comprising multiple inserts ${ }^{45}$ or as belonging to one or the other of the two kinds of alternating syntagma (parallel and alternate). In his analysis of Adieu Philippine, Metz encountered a number of examples of sequences intercut with inserts ${ }^{46}$ leading him to search for criteria that would enable him to determine the threshold from which semioticians could conclude that alternation is truly present. There are two such criteria.

\section{The First Criterion}

Of the two criteria, the one which appears more circumscribed (and which is thus more clearly distinguished) involves the treatment given to some inserts by the filmmaker, by having them extend over two (or possibly more) successive shots. When we encounter, in a sequence intercut with inserts, an insert made up of more than one shot, the original syntagma into which these inserts are placed loses its 'status' as an autonomous segment

43 See Note 41.

44 Metz writes: 'The solution would seem to assume that a rigorous semiological theory be established in order to account for two facts that are both very "pronounced" in films though neither of them has yet been satisfactorily explained [...]:(1) [...] the transformation of the insert [...] into an alternate type [...] (2) the distinction between true alternation [... ] and pseudo alternation [...].' Metz, 'Outline of the Autonomous Segments', p. 164; emphasis in original).

45 To identify what we call here a 'sequence intercut with inserts,' Metz constantly employs the expression 'autonomous segment comprising multiple inserts', but it seems to us that this formulation is confusing and even a contradiction of terms. For Metz, the first kind of autonomous segment (recall that the seven other kinds are 'syntagma') is the 'autonomous shot'. Because Metz truly does see inserts as segments, it would have been preferable, in our view, for Metz to speak of a 'syntagma comprising multiple inserts' rather than of an 'autonomous segment comprising multiple inserts.' This is all the more true in that an 'autonomous shot' cannot, by definition, contain inserts, precisely because it is ONE shot.

46 These are 'segments 12, 20, 22, 24, 30 and 31.' Metz, 'Outline of the Autonomous Segments', p. 164 . 
comprising multiple inserts (to use Metz's expression). This is the case with segment 24, one of whose inserts, showing Michel on the telephone, is a compound (or pluri-punctiliar ${ }^{47}$ ) insert: '[...] two [ofthe shots showing Michel] are organized sequentially; they function not as inserts but as a series. ${ }^{48}$

As a result, Metz sees the segment in question as an alternate syntagma.

Metz refers on two other occasions to the criterion of the 'pluri-punctiliar.' The furst concerns segment 12 and the second concerns segments 22 and 23 . Segment 12 is a sequence intercut with inserts but, because one of these is a compound insert, we cannot view the inserts in question as autonomous shots. The mere fact that one of the inserts is pluri-punctiliar seems sufficient for a series of inserts to acquire a 'higher' status which, in the case under study here (as with segment 24), enables the segment to be recognized as an alternate syntagma:

Inside the screening room. We see alternately the room itself (with the two girls, Pachala, and the client), and the screen on which the rushes of an unsuccessful commercial are flickering by. Between these rushes, increasingly funny, are interspersed shots of the spectators. [...] at least one of the images of the spectators (in all other respects similar to the others) comprises two consecutive shots. ${ }^{49}$

The lack of a pluri-punctiliar quality is, on the contrary, invoked to describe the nature of segments 22 and 23. There we are truly in the presence, Metz writes, of 'a scene with inserts, rather than an alternate syntagma,' one of the reasons being that 'the girls' faces [are] never more than a single shot'..$^{\circ}$ Thus the two segments under discussion remain autonomous from each other.

\section{The Second Criterion}

The second criterion that arises out of Metz's analysis of Rozier's film comprises two complementary aspects, both of which, in a sense, concern the extent of the series of inserts: on the one hand, what we could identify as the number of inserts, and on the other, their duration.

47 For discussion in greater detail of what is meant by the term 'pluri-punctiliar' (as well as the term 'punctiliar'), see André Gaudreault, From Plato to Lumière. Narration and Monstration in Literature and Cinema, trans. by Timothy Barnard (Toronto: University of Toronto Press, 2009 [1988]), in particular chapter 1.

48 Metz, 'Outline of the Autonomous Segments', p. 16o (our emphasis).

49 Ibid., p. 156 (our emphasis).

50 Ibid., p. 160. 
Let's look first at segment 20, made up of four autonomous shots of Michel inserted in segment 19, as Michel speaks on the telephone with the two girls. Here, Metz concludes, the number of inserts showing Michel (there are four) is not enough to qualify as a 'series.' There are simply not enough of them. In addition, the ensemble they form is not long enough to constitute one of the two parts of an alternate syntagma (Metz deems their development too embryonic). ${ }^{51}$ What is at issue in segment 19 is thus not only the frequency or recurrence of the inserts (their number), but also the temporal extent of the ensemble they make up, its temporal significance in a sense (its duration):

The episodes are experienced from the point of view of the girls; the shots of Michel are not sufficiently elaborated, or frequent enough, to constitute the second series of an alternate syntagma. ${ }^{52}$

The shots of Michel, Metz writes, are 'spatially discontinuous diegetic inserts', which represent 'four occurrences of theme B', 'four images [seen] as four variations of a single insert.'. ${ }^{53}$ This sequence intercut with inserts (this segment comprising multiple inserts, Metz would say) cannot be classified as a type belonging to the configuration of alternation, hence its categorization as an episodic sequence.

Metz brings out two other cases involving this second criterion - associated with the question of number and duration - but in terms that do not always make it possible to distinguish clearly, in his filmic examples, what pertains to the former and what pertains to the latter. Thus segments 22 and 23 (discussed above with respect to the criterion of the pluri-punctiliar), alternate in a way that is only faintly apparent:

The emphasis on the details of the studio atmosphere (shots of the head engineer at the sound monitor) and the very briefreferences to the girls' faces $[. .$.$] indicate that this is a scene with inserts, rather than an alternate$ syntagma..$^{54}$

$5^{1}$ How long exactly must a segment be to be considered an alternate syntagma? The text is silent on this question.

$5^{2}$ Metz, 'Outline of the Autonomous Segments', p. 159 (our emphasis).

53 Ibid.

54 Ibid., p. 160 (our emphasis). 
The case is clear: mere reference is not enough, in Metz's eyes, to forge links between two series that will be solid enough for us to describe their relation as giving birth to an alternate syntagma.

Metz also identifies a case in which alternation is so faintly apparent that it is not even worthwhile to treat the inserts involved as autonomous shots (they thus lose even their quality as inserts). The segment concerned is no. 68:

The sequence ends with alternating shots of Horatio left behind and the others driving off, laughing, but it is an alternation that is too subtly suggested to produce a distinct syntagma..$^{55}$

The shots that exude this hint of alternation are so minor, have so little significance, that Metz does not deem them sufficiently developed to constitute a legitimate alternate syntagma in the relations they establish with the shots showing the main action.

By way of a comment arising out of his analysis of segment 20, Metz adds an interesting proviso, this time concerning the duration of inserts alone (he speaks of the 'temps d'occupation de l'image' in French, the time the shot occupies the screen). This duration, moreover, is not significant enough for the segment under study to become an alternate syntagma:

We find within an autonomous shot A not one insert B but three or four inserts $B$, all of them repeating the same theme and separated from each other by returns to the original syntagma. When the quantitative difference between the duration of the image in A and the duration of the image in B is too great, it becomes impossible to speak of an 'alternate syntagma'. ${ }^{6}$

In other words, for the original segment of a series of inserts to attain the status of alternation, the inserts must have at least a certain amount of screen time.

Another obvious case of segments to categorize as references, and which Metz considers only according to the question of duration, is the telephone conversation between Pachala's wife and Michel (segments 30 and 31). Metz remarks about the first of these two segments: 
Phone conversation, with inserts of one of the speakers. Pachala's wife answers a call from Michel; the latter is seen only briefly. On the other hand, Pachala's study, where Pachala is sleeping on a couch, is described at length, the scene continuing after the phone call. ${ }^{57}$

There are also cases where Metz makes reference only to the question of number in the second criterion. This is the case with segment 24 (which also, as we have seen, meets the criteria of the pluri-punctiliar), which interlaces shots from two 'themes,' on the basis of a fairly significant recurrence, such that the inserts lose their status as such. ${ }^{5}$ Hence the recognition of the segment in question as an alternate syntagma (and not as an autonomous segment comprising multiple inserts):

[...] there is no strict equality between the two 'themes.' But the shots of Michel are numerous [...] they function not as inserts but as a series that alternates with a longer series. ${ }^{59}$

\section{Problem Number Three}

Metz concedes that his GS, to be fully operational, must be able to base itself on the rigorous semiotic theory he advocates, which would enable him to distinguish between 'true alternations' and 'pseudo alternations'. For Metz, true alternations are those that 'establish a narrative doubling in the film'. ${ }^{60}$ This is the case in particular when a sequence alternates between series of images from two 'distinct' ${ }^{\text {'1 }}$ events. Such a sequence is thus an

57 Ibid., pp. 162-63 (our emphasis).

$5^{8}$ Here is a criterion whose boundaries are somewhat unclear. How many inserts exactly are needed for a segment comprising multiple inserts to be seen instead as an alternate syntagma? The text is silent on this question as well.

59 Metz, 'Outline of the Autonomous Segments', p. 16o (our emphasis). In the initial version of the text, written by Michèle Lacoste alone ('Tableau des segments autonomes du film Adieu Philippine', p. 87), the passage we have just quoted reads as follows: '[...] the shots of Michel are numerous and, especially, an absolute criterion, two of them are grouped in a sequence [...]' (our emphasis). The idea that this is an absolute criterion fell out of the formulation. Because we have been obliged, in order not to muddy the waters, to cut the later version of this quotation on two occasions, we believe it would be useful here to provide the reader with the passage in full: "[... the shots of Michel are numerous, and two of them are organized sequentially; they function not as inserts but as a series that alternates with a longer series (Metz, 'Outline of the Autonomous Segments', p. 16o; our emphasis). 60 Metz, 'Outline of the Autonomous Segments', p. 164.

61 'The story [...] contains a fair number of passages in which that narrative ramifies, and two distinct series of "telling little facts" appear alternately. This contrapuntal construction 
alternate syntagma. As for pseudo alternation, this is 'reduced to a mere visual alternation within a unitary space or else derives simply from the fact that the filmed subject itself assumes a vaguely "alternating" aspect within a certain relationship'. ${ }^{62}$ Pseudo alternation is thus characterized by the fact that, despite appearances, the action shown creates one and only one event unit. This is the case, for example, with segment 3 , whose shot-reverse shots might at first appear to be examples of alternate syntagma but which Metz classifies instead as another type of syntagma, that of the scene:

During the conversation [...] a series of shot-reverse shots shows us alternately each of the speakers as he or she is speaking. The alternation of shots [...] does not impede the action of the scene, which is a conversation in a café. [...] To check that in this case we are dealing with a scene and not with an alternate syntagma, one can try to commute the scene in one's mind with an autonomous shot. The communication is perfectly possible: A single shot would have allowed one to treat the same subject with no difference other than that of connotation. The alternation, a simple switching back and forth of the camera, has no distinctive function in this instance. ${ }^{63}$

Thus one of the criteria for separating the wheat ('true alternation') from the chaff ('pseudo alternation') could be summed up as follows: if it is possible to film the sequence in a single shot (giving rise to a sequence shot, which for Metz is a sub-variety of the autonomous shot), then we are in the presence of pseudo alternation.

Nevertheless, we find in the analysis of Rozier's film two examples that appear to contradict this differentiating criterion: Metz sees segments 12 and 43 as alternate syntagma even though these sequences unfold in a single space and, as a result, could have been filmed by a single camera in a single sequence shot. ${ }^{64}$

is maintained through the alternate syntagmas.' Metz, 'Syntagmatic Study', p. 180 (our emphasis).

62 Metz, 'Outline of the Autonomous Segments', p. 164 (emphasis in original).

63 Ibid., pp. 151-52 (emphasis in original).

64 Segment 12 (viewing the rushes of a commercial in the production studio) could indeed have very easily been done in one shot by a single camera placed behind the viewers and with the screen and the image on it in the background. It is true that what is shown on the screen is taking place in another location. This is probably why Metz decided to classify the sequence as a form of alternate syntagma. Strangely, segment 43 is seen as an alternate syntagma, even though the action is taking place in a single location, as Metz himself describes: 'In the same location (the set in the television studio), three simultaneous diegetic series alternate rapidly 
As can be seen, concern for understanding the diegesis (the signified) takes precedence in the GS over the formal composition when determining whether one is in the presence of an alternate type.${ }^{65}$ Martin Lefebvre is in agreement with us when he writes:

That's what interests Metz in the end: the fiction (meaning the diegetic, the construction of a world through fictional operations and the codified operations of film language). This is the price he is willing to pay to drop certain formal 'details'. What counts most of all is the understanding of the signified (the diegesis). ${ }^{66}$

Indeed, analysis of the world constructed through the operations of film language appears to interest Metz the most in the end, even though his work on the GS, in principle, takes two directions: the 'form' of film language and the 'content' of the film diegesis.

Accordingly, for Metz a full analysis of a film can only be carried out by studying both the diegesis (the filmic universe shown on screen) and editing (the units of time that make up the film). Otherwise, one is left 'examining the signifieds without taking the signifiers into consideration' or the opposite, 'study[ing] the signifiers without the signifieds'. ${ }^{67}$

For us it is more important, in our long-term work mentioned at the outset of this text, to grant a special place to concerns of a strictly formal nature (without at the same time overlooking the question of content) than it was for Metz in his work on the GS. In fact, as our main goal is to produce a finegrained genealogical study of alternation ${ }^{68}$ and to set out the parameters of

on the screen.' Metz, 'Outline of the Autonomous Segments', p. 166 (our emphasis). It is true that the set is subdivided into three distinct 'sub-locations': 1) 'sound monitor'; 2) the 'set' properly speaking; and 3) 'monitoring screens', which probably explains Metz's choice.

65 In this sense the case of segment 12 is an exception, in that the reasons given by Metz to view it as an alternate syntagma appear in this case to privilege the 'form' over the 'content': 'If we were to consider this autonomous segment as a scene [...], we would be able to give just as exact an account of the literalness of the narrated events, but we would not be able to account for the construction that organizes their narration; the alternating effect is clearly deliberate and systematic'. Metz, 'Outline of the Autonomous Segments', p. 156.

66 E-mail correspondence with the two authors dated 11 June 2014.

67 Metz, 'Problems of Denotation', pp. 143-44. Note that this translation of Metz employs the term 'significates' rather than 'signifieds' as given above.

68 This volume, on the emergence of crosscutting, is in the process of being written under contract with Columbia University Press. Its working title is From Pathéto Griffith:The Emergence 
its establishment in the heart of institutional cinema, we believe that we must first identify the formal techniques that were used before discursive editing practices were 'codified'. This in any event has been the guiding principle behind the systematic study of moving pictures from this period that we have carried out over the past few years. The results have led us to conclude that the editing devices that can be identified during the period when the 'kine-attractography' paradigm reigned did not obey (of course not, we are tempted to say) any established rule and varied in many often quite subtle ways. Because of the absence of any standardization (such absence is an essential condition for a paradigm such as 'kine-attractography'), we believed it crucial to study every arrangement of shots displaying any kind of alternation (of which there were many, moreover, in the early 19oos).

As we continue our research, we will try to overcome the various aporia found in Metz's texts (and which are still seen today, nearly fifty years later, such that film theory and history still have a long road ahead). We will thus have to return to Metz's work in an attempt, in particular, to resolve the question of what role should be occupied in the history of crosscutting by a 'genre' known as the keyhole film, which proliferated between 1900 and 1906 and in which a character (most often a building concierge) indiscreetly bends down to observe a scene through a keyhole. This action was normally depicted by means of editing that alternated systematically on screen between the subject looking and the object of its gaze. ${ }^{69}$ Are we, in such a case, in the presence of a patent example of crosscutting?

The same question arises in the cases of other recurring series of pictures, also based on the act of looking, whose underlying 'plot' boils down to showing characters who, through the use of optical instruments such as microscopes, telescopes, and other kinds of magnification lenses, scrutinize the world around them..$^{70}$ In a case such as this, there is clearly systematic alternation between the subject looking and the object of its gaze, but does this mean that we are, here too, in the presence of patent examples of crosscutting?

We might also pronounce judgment, in a manner as 'definitive' as possible, on the place in history that should be occupied by the alternation

of Crosscutting to 1915 [forthcoming 2020].

69 Examples include Par le trou de la serrure (What Happened to the Inquisitive Janitor, Pathé, F 1901), Un coup d'oeil par étage (Scene on Every Floor, Pathé, F 1904), and The Inquisitive Boots (Hepworth, UK 1905).

70 As in pictures such as Grandma's Reading Glass (George A. Smith, UK 190o), As Seen through a Telescope (George A. Smith, UK 1900), Ce que l'on voit de mon sixième (Scenes from My Balcony, Pathé, F 1901), and Un drame dans les airs (A Drama in the Air, Pathé, F 1904). 
configuration of the perennial favorite Attack on a China Mission (James Williamson, UK 190o). Often seen as the earliest example of crosscutting, we should examine how its 'narrative' ${ }^{71}$ structure, despite being based on a form of alternation, does not meet the minimum criteria for crosscutting.

\section{Translated from French by Timothy Barnard}

\section{About the authors}

André Gaudreault is professor in the Département d'histoire de l'art et d'études cinématographiques at the Université de Montréal, Canada Research Chair in Cinema and Media Studies, and director of the Canadian section of the TECHNÈS international research partnership. As of 1992, he heads GRAFICS (Research Group on the Emergence and Development of Cinematic and Theatrical Institutions), and from 1997 to 2005, he was head of CRI (Center for Research on Intermediality). In 2010, in collaboration with filmmaker, producer, and visiting professor Denis Héroux (producer of Atlantic City and Quest for Fire), he founded the Université de Montréal's OCQ (Observatory of Cinema in Quebec) whose objective is to support research and studies on cinema in Quebec. His publications include From Plato to Lumière: Narration and Monstration in Literature and Cinema (2009) and Film and Attraction: From Kinematography to Cinema (2011); he has also co-authored The End of Cinema? A Medium in Crisis in the Digital Age (with Philippe Marion, 2015) and Le récit cinématographique. Films et séries télévisées (with François Jost, 2017).

Philippe Gauthier lectures on cinema and media at Queen's University, Canada. He is the author of Le montage alternéavant Griffith (2008). Gauthier is currently working on a book on editing in early cinema in collaboration with André Gaudreault (to be published in 2020 by Columbia University Press). He acted as the guest editor of a special issue of the journal Animation (2011) and the New Review of Film and TV Studies (2014). He had the honor of receiving three international awards for his doctoral work on film historiography: the Domitor Student Writing Award (2008), the FSAC Student Writing Award (2011), and the Gerald Pratley Award (2012). His work on

71 The scare quotes are used here to indicate that, despite its evident narrative euphoria, this picture from 1900 is also in keeping, considerably so, with the imperatives of the attraction system. For more information on this topic, see Dulac and Gaudreault, 'Cross-cutting in the Face of History', pp. 1-18. 
cinema, animation, television, and comic books has appeared in a number of edited collections and journals such as Film History, Studies in French Cinema, International Journal of Comic Art, Cinémas, and Cinema \& Cie.

\section{About the translator}

Timothy Barnard is the translator of volumes on film theory by Jacques Aumont, André Bazin, André Gaudreault, and Jean-Luc Godard in addition to numerous catalogues of modern and contemporary art. He is the proprietor of 'caboose', an independent scholarly publisher of books on film, and the author of Découpage (2014), a brief historical and theoretical study of this aesthetic concept in cinema and the only volume on the topic in any language. 


\section{III}

Specificities of the Cinematic Code and the Imaginary 



\title{
10. Between Classical and Postclassical Theory
}

\author{
Metz on Specificity Then and Now
}

Philip Rosen

Tröhler, Margrit and Guido Kirsten (eds.), Christian Metz and the Codes of Cinema. Film Semiology and Beyond. Amsterdam University Press, 2018

DOI: $10.5117 / 9789089648921 / \mathrm{CH} 10$

\begin{abstract}
While Christian Metz saw cinema semiology as instituting a break with classical film theory, one of its key concerns - cinematic specificity remained an important question throughout his own work. This chapter traces Metz's conceptions of cinematic specificity in the succession of influential arguments he made about the applicability and non-applicability of linguistic concepts to film. It argues that he actually did not achieve a break with classical conceptions of cinematic specificity in the much-discussed essays collected in Essais sur la signification au cinéma. Rather, he developed the question most originally and productively in Language and Cinema, by successfully de-essentializing it. The essay also suggests that this concept of specificity may have potential utility for the theorization of contemporary digital culture.
\end{abstract}

Keywords: film semiotics/film semiology, cinematic specificity, cinematic codes, classical film theory, poststructuralist theory, digital culture

\section{From Classical Film Theory to Semiology and Back}

The question of cinematic specificity was one of the central themes in the history of classical film theory, something indicated by the elaboration of a variety of terms and phrases various theorists coined to designate the special qualities of cinema, such as montage, photogenie, the redemption of physical reality, and others. At first glance, the interest in debating and interrogating specificity seems to go much against the spirit of our own times, 
which emphasizes mixtures and crossovers among various media. Perhaps this emphasis in our own time has to do with developments within theory as well as with intensely heightened awareness of cultural hybridities. But also, it often seems to be attributed to technological shifts, in particular those which bring the digitized integration of the practices and histories of several media into simultaneous play in individual works, texts, and practices throughout contemporary culture. On the other hand, within the narrower sub-fields of film and media theory, such contemporary concerns have sometimes led to rereading certain tendencies in the tradition of classical film theory, including its various elaborations of medium specificity, for they now seem to take on a revised significance.

Christian Metz always argued that semiotics marked a break with previous - henceforth 'classical' - film theory. Would this be true of Metz's deployment of the notion of specificity? For he still retained that theme, both circling around it and steering semiotics through it, which in turn meant reframing it in various ways. In fact, the definitions and functions of cinematic specificity in his work might be a productive key to testing the supposed differences of his conceptions from those of classical film theory.

In thinking about Metz's place in the history of film theory and also in our own time, it may therefore be useful to begin with some broad points about this particular aspect of classical film theory. First, it must be remembered how new cinema was in the era of classical film theory, from its beginnings in the 1910 sight through its culmination, which Metz situates in the $1960{ }^{1}{ }^{1}$ Thus, it is not surprising if a major tendency in classical film theory was to treat cinema as a new medium and a relatively new art form, even though it was often acknowledged that it might draw on previous media and forms. To take an important example, one of the standard logics of classical film theory was to reason from certain technical or technological characteristics of the medium to a claim for distinctive aesthetic experiences - and psychological or sociocultural or even epistemological experiences as well as cinema's artistic possibilities and predilections. This line of thought could often become prescriptive. That is, various aesthetics based on various claims about unique technical and hence (the arguments went) formal specificities of cinema coalesced with the drive for legitimation of what

1 For Metz, the two volumes of Jean Mitry's 1963 treatise The Aesthetics and Psychology of Cinema, trans. by Christopher King, (Bloomington: Indiana University Press, 2000), marked the synthesis and culmination of classical film theory. In conversation with me in the early 1970s, Mitry recalled his boyhood memory of seeing the Paris first run of Intolerance (D.W. Griffith, USA 1916). This is an anecdotal indication of how recent the inception of cinema was for classical film theory. 
was, after all, the new global medium. That this kind of logic could be employed across different kinds of aesthetic attitudes may be illustrated by quick reference to two well-articulated and canonical early examples in the work of Hugo Münsterberg and Rudolf Arnheim. Münsterberg's The Photoplay: A Psychological Study (1916) develops such an argument while supporting anti-modernist aesthetic proclivities, while Arnheim's Film as Art (1932) has modernist aesthetic proclivities.

All of this illustrates how much classical film theory participated in a problematic that was broadly modern, no matter whether its aesthetic prescriptions were anti-modernist or modernist or something else. For both Münsterberg and Arnheim sought to describe what was radically new about cinema. That the question of the cinematically specific can be positioned within discourses of modernity and modernization is tangentially supported by the fact that contemporaneous avant-garde and radical filmmakers were likewise attracted to the idea of specificity, best exemplified by slogans like 'pure cinema', and 'absolute cinema'. More broadly, classical film theory may be understood in part within a lineage of discursive responses to a recurrent experience of capitalist modernity, namely the innovation, dissemination, and formalization of new media technologies: ever more rapidly produced cheap print texts; photography; phonography and radio; film; television; digital media. Now, this means that the question of responding to new media technologies with claims for consequent historical transformations is recognizable in our own contemporary period of media history. The experience of, and search for, the new is an old thing, but it continues anew - for example even in our current emphasis on mixtures and hybridities with respect to the latest emergent media technologies and their predecessors. ${ }^{2}$

Of course, when Metz began writing, cinema was no longer the new medium. The association of specificity with aesthetic value was one of the aspects of classical film theory Metz claimed to reject. Yet one can find a recurrent concern with specificity in Metz's major writings. So given Metz's consistent concern with theorizing specificity, we may ask how the concept functions in his writings. The mature text where he most elaborately considers cinematic specificity as a concept seems to me to be Language and Cinema. Published in 1971, the same year he defended his Thèse d'Etat under the linguist André Martinet, Language and Cinema is a great technical summary

2 This paragraph draws on ideas I develop elsewhere at slightly greater length with the same examples. See Philip Rosen, 'From Impurity to Historicity', in Impure Cinema: Intermedial and Intercultural Approaches to Film, eds. by Lucia Nagib and Anne Jerslev (London: I.B. Tauris, 2014), pp. 3-20; on the logic of specificity and classical film theory, see esp. pp. 3-6. 
that assumes, restates, but to a significant extent revises problematics and issues that had dominated his work through most of the 196os. It may be seen as a new, transitional phase of Metz's theoretical development. On the one hand, it looks like the culmination of a first phase of prolific investigations of the possibility of a cinema semiotics; on the other hand, in certain ways I will gloss later, some of its aspects look forward to his later concerns with psychoanalytic theory and enunciation. ${ }^{3}$

A central question for most of his prior work on semiotics had been the conjunctures and disjunctures of the structuralist account of verbal language with a valid semiotics of cinema. The disjunctures were crucial to his conceptions and arguments. By determining where cinema resists application of major Saussurian linguistic concepts, Metz marked and defined a need to develop concepts and methods beyond structural linguistics to account for signification in film. Thus, by the time of Language and Cinema, Metz had already argued at length that there are concepts suitable for linguistics that are inadequate to deal with cinema. For example, by the mid-196os, Metz had initiated important debates through his argument that cinema has no langue and no double articulation comparable to language. Not only does this limit the arbitrariness of

3 In a 1989 interview, Metz consented to Marc Vernet's periodization of his theoretical corpus into three phases: essays of the 1960 s, collected in the two volumes of Essais sur la signification au cinema, published respectively in 1968 and 1972; Language and Cinema (trans. by Donna Jean Umiker-Sebeok, The Hague: Mouton 1974); and a subsequent turn to psychoanalytic conceptions, bleeding into his late concern with filmic enunciation [see Michel Marie and Marc Vernet, 'Entretien avec Christian Metz', Iris, 10 (1990), 271-79 (p. 276)]. Vernet's standard for these divisions is changes in writing style for each phase, but it seems useful to see them as reflecting conceptual developments in Metz's thinking. For a different tripartite periodization of Metz's writings, see the recent account in Dominique Chateau and Martin Lefebvre, 'Dance and Fetish: Phenomenology and Metz's Epistemological Shift', October, 148 (2014), 103-32 (pp. 105 and passim). The standard for Chateau and Lefebvre is changes in the attitude to phenomenological approaches and aesthetics throughout Metz's work. Compare D.N. Rodowick, Elegy for Theory (Cambridge, MA: Harvard University Press, 2013), chapter 18, 168-20o (pp. 198-20o). Rodowick's concern with the concept of 'theory' itself leads him to emphasize the point where Metz differentiated his work from classical film theory and therefore his early semiotics (especially the breakthrough formulations in 'Le cinéma: langue ou langage?' in 1964). Rodowick therefore has a very different kind of account than mine, as is indicated by moments when he drafts Metz's early work into ethics and morals. There are several commentaries on Metz's corpus that are closer in various ways (historically and/or intellectually and/or personally) to the era of cinema semiotics. Two that are especially useful on Language and Cinema are: J. Dudley Andrew, The Major Film Theories (New York: Oxford University Press, 1976), Chapter 8; and Raymond Bellour, 'A Bit of History', in Bellour, The Analysis of Film, ed. by Constance Penley (Bloomington: Indiana University Press, 2001), pp. 1-20, a 1979 essay especially interesting here for nuanced and personal evaluations of the concept of textual system emphasized below. 
the cinematic sign, it constricts any film semiotics based on Saussurian principles.

However, he made such negative conclusions grounds for more positive points about the possibilities of cinema semiotics, based on claims about cinema. In his much-discussed breakthrough formula, he decided that even if cinema has no langue like verbal language, cinema is nevertheless a langage - a langage sans langue. Now, in Saussure's foundational definitions, a langage is composed of langue and parole. So if cinema does not possess a langue, all that is left to the Saussurian is the other element of langage, namely parole, speech. But of course, Saussure had argued that the object of systematic linguistics should be langue and could not be parole.

So Metz's formulations would seem to present a conundrum to any approach to cinema through Saussure. Metz went on to argue that there was codification in cinema 'above' the level of the uncodifiable image, such that coding in this medium was always a kind of rhetoric. This rhetoric seemed to have very much to do with the ordering of images; however, the image itself could not be semiotically analyzed.

Of most importance for present purposes is his most basic reason for arguing that cinema could not be understood in terms of an underlying langue. That reason lay in his claim for a certain irreducibility of the cinematic image. He sometimes characterized that irreducibility with the term analogy. This is an idea that may be rooted in some of his earliest essays, which were explicitly phenomenological, and perhaps also in certain studies associated with the Institute of Filmology. At any rate, it seems clear that this irreducibility of the film image is a specificity. This attribution of an irreducible analogical component to the film image led Metz to argue for various consequences, such as the greater importance of cinema's syntagmatic axis over its paradigmatic axis in comparison to verbal language. ${ }^{4}$

4 Metz led up to his emphasis on analogy with an essay written in a non-semiotic, purportedly phenomenological vein, 'On the Impression of Reality in the Cinema', in Christian Metz, Film Language: A Semiotics of the Cinema, trans. by Michael Taylor (New York: Oxford University Press, 1974), pp. 3-15. The classic originary statement of Metz's earlier position on cinema, film theory, and linguistic-based semiology is 'The Cinema: Language or Language System?' ('Le cinéma: langue ou langage?'), the source of the formula of langage sans langue; see in Film Language, pp. 31-91. However, caution is necessary in using this English-language volume of Film Language. It is a translation of Essais sur la signification au cinéma, I (Klincksieck, 1968), but unfortunately, its renderings can be very erratic. Even for some key Saussurian terms it is surprisingly inconsistent and intermittently mistaken. Any close reading of Metz based on this version must constantly check it against the French original in order to avoid distortions and confusions of Metz's conceptions. I have tried to do this, although I continue to refer to it since I am writing in English. For clarity's sake, I use the French terms, langue and langage. 
But we may pause here to note that this seems to imply a larger general principle for semiology or semiotics as such. If cinema has elements specific to it that resist some of the conceptualizations of linguistics, this could presumably be true of other complex, highly developed signifying systems such as music, theatre, painting, gesture, and so forth. Consequently, it appears that for the early Metz, even a general semiotic theory must pass through specificities. I previously suggested that specificity is a historical concern of film theory, and one that links classical film theory to discourses of the modern. Yet, within Metz's thought, there is a remainder of specificity, which is fundamental to his most influential early formulations. It is an obdurate level of cinema that obstructs semiotic investigation - that is, the kind of approach which, Metz asserted, was superseding classical film theory.

\section{The End of Classical Film Theory?}

But then, in the very short time leading from these formulations to the next phase of his thought, in Language and Cinema, Metz did not follow up on this line. On the contrary, he changed his conception of the image. Already in the first volume of the collected Essais, published in 1968 - just four years after his seminal essay 'Le cinéma: langue ou langage?' - he added footnotes that criticized certain of his own formulations even as he republished them. Now he effectively decided that the description of cinema as langage sans langue went too far towards the idea that the film image qua image has a fundamentally uncoded, unsystematizable residue, and hence could only be analyzed in comparison to speech. To begin with, he no longer agreed with Saussure that speech itself is unsystematizable: with reference to Chomsky and Soviet semiologists and then to other semiotic theorists, Metz now decided that a 'linguistics of speech' is indeed possible. This was connected to the idea that even speech is penetrated by a number of codes and sub-codes, which meant that langue is not the only code at work in parole. A decisive turning point seems to have been the ${ }_{1967}$ Pesaro International Festival of New Cinema. There Metz met Italian theorists, some of whom confronted him and his early semiotics critically. In both the new footnotes in his republished essays and in Language and Cinema, Metz cited such figures as Gianfranco Bettetini, Umberto Eco, Emilio Garroni, and Pier Paolo Pasolini, often approvingly, sometimes in debate (especially with Pasolini).

In one of the most fundamental modifications of his thinking, Metz abandoned his earlier view of the image as irreducible. He began to push 
coding into the heart of the flows of cinematic images. Against his own earlier ideas, he accepted Umberto Eco's counterargument that the image can have several levels of articulation - the argument Eco made in a paper presented at Pesaro. This meant that analogy, the supposed basis for the irreducible quality of the image, can be coded and still function as analogy, that is, still function as if it possesses a 'natural' or perceptual correspondence to the depicted objects or visual field. And given this functional signifying correspondence, it would import a host of non-specific codes, including codes not necessarily dependent on analogy as such (including, for example, some with which he had previously been concerned such as codes of narrative). Again, the concept of the sub-code intervenes, for another point in Eco's argument was that while his triple articulation applied to only one code that might be unique to cinema, there are a plurality of codes operative in image analogy. ${ }^{5}$

For Metz, among other consequences, this means that an uncoded residue could no longer define cinematic specificity. One of the most succinct consequences of treating analogy as coded culminated in Language and Cinema, where the coding of analogy is traced to the coding of perception itself, which (as Eco had argued) is itself said to be subject to an articulation whereby it could be reduced to non-recognizable units:

There is good reason [...] to recall the partial similarities between filmic perception and everyday perception (sometimes called 'real perception'), similarities that certain authors (including the present author) have sometimes misinterpreted. They are not due to the fact that the first is natural, but to the fact that the second is not; the first is codified, but its codes are in part the same as those of the second. The analogy, as Umberto Eco has clearly shown, is not between the effigy and its model, but

5 For Metz's self-criticism, see Film Language, pp. 111-13, footnotes: 61-63, 68, 69. The paper Metz says was instrumental in changing his mind on analogy is Umberto Eco, 'Articulations of the Cinematic Code', in Movies and Methods: An Anthology, ed. by Bill Nichols (Berkeley: University of California Press 1976), pp. 590-607. Compare, for example, Metz, Language and Cinema, pp. 30-32 on linguistics, speech, and heteroclite coding. Eco's paper, which criticized Pasolini as much as early Metz, called his three articulations of the cinematic codes figures (non-meaningful graphic elements that can be combined); signs, which are the combination of iconically recognizable elements of the image composed of figures; and semes, which are the combination of the signs to make an overall whole. Eco associates this third level with time and movement, calling on kinesics as a model of analysis needed in cinema. That is, in opposition to Pasolini, he argues that objects in movement can be decomposed and hence analyzed as an articulation. This, he writes, is exactly what cinema does in its relation of still photograms to the film shot in motion. 
exists - while remaining partial - between the two perceptual situations, between the modes of decipherment which lead it to the recognition of the object in a real situation and those which lead to its recognition in an iconic situation, in a highly figurative image such as that of the film. ${ }^{6}$

In fact, by the time Language and Cinema was published in 1971, Metz's earlier self-criticisms had prepared the way for the extensive elaboration of his new conception of a signifying discourse as a complex network of codes and sub-codes. In this book, Metz once more reviewed some of his well-established questions, including the utility and non-utility of categories taken from structural linguistics. This text's sensitivity to the resistances that cinema offers to linguistic concepts is, if anything, more intensive than in his earlier writings. A number of concepts from linguistics are repositioned, sublated, and/or transformed, while others are explicitly abandoned. At one point, Metz even states that the concept of the sign 'no longer enjoys the privileged and central status which it had with Saussure or Peirce'. ${ }^{7}$ And this seems linked to revisions in his conception of cinematic specificity, which now becomes an explicit question. The devaluing of the concept of the sign means that the question of types of signs that characterize a film or cinema is no longer foundational: 'There is no cinematic sign', he writes, and he attributes the very concept to 'a fanaticism of specificity which is not without some metaphysical notions'. ${ }^{8}$ But a similar point is made about another term that, as we will see shortly, is central to the project of Language and Cinema, namely code. For Metz also insists that there is 'no sovereign code' that imposes its own units on everything in a film. ${ }^{9}$ Yet if Metz now decentralizes some of the key terms of Saussurian semiotics (sign, langue, etc.), there are other terms derived from structural linguistics that Language and Cinema promotes and elaborates at length. This is because they have applicability for codes in general, not just for verbal language. Examples include the paradigmatic-syntagmatic opposition and the commutation test.

What becomes foundational for cinema semiotics in Language and Cinema is the operations constituting a film. As a result, the most central and positively elaborated concepts in Language and Cinema are probably

6 Metz, Language and Cinema, p. 277. As noted below, Eco himself later rejected this position as mistaken.

7 Ibid., p. 207

8 Ibid., p. 194. For similar language about specificity, cf. p. 41 and 97.

9 Ibid., p. 194. 
code, text, and system. The first, code, is the more general term for analyzing semiosis. This concept is more expansive than verbal langue, whose status is no longer a central problem for semiotics, because instead of being privileged it becomes just one kind of code among many. That is, the concept of code is applicable to all signifying systems. As a result, resistance to langue can no longer define specificity. Second, text is the primary phenomenal manifestation of semiosis, which means its underlying operations are the key object of investigation. And third, systematicity is the structural quality attributed to both code and text. In Language and Cinema, Metz decides that the semiotician should conceive of a film as a 'textual system'. This concept, which was very influential for the next few years, means a site consisting of a large number of codes and sub-codes, some of which are specific and some not specific to cinema; furthermore a textual system is a unique conjunction of codes.

As to codes themselves: extra-cinematic codes and sub-codes, and cinematic codes and sub-codes, are ex post facto constructions or logical machines of the semiotician, who treats them as the 'material' of the textual system. This is made clear in Metz's definition of the term code:

If a code is a code, it is because it provides a unified field of commutations, i.e. a (reconstructed) 'domain' within which the transformations of the signifier correspond to variations in the signified, and within which a certain number of elements have meaning only in relation to each other. A code is homogenous because it was meant to be such, never because it was discovered to be such. ${ }^{10}$

Any one code may appear in several films, but crucially, the conjunction of codes and sub-codes in a given film makes up a system unique to each text; hence the concept of the singular textual system. (In fact, he remarks, a segment from a film or several films, as in an auteur or genre study, may be treated as a single text for purposes of analysis.)

If Language and Cinema is a culmination and summary of Metz's conception of cinema semiotics to that point, to that extent it may seem backward looking, even in its clarifications and revisions. But there are also ways in which it looks forward to future work by himself and others. His development of the concept of the singular textual system registers awareness of something not much present in most of his earlier writings, namely poststructuralist theories and attitudes towards signification and 
representation that were quickly emerging in these same years. Thus, Metz now includes brief references to the journal Tel Quel, Jacques Derrida, and, most consequentially, Julia Kristeva.

This is why Language and Cinema can also be read as a bridge or hinge in Metz's work, between the earlier semiological formulations and later work concerned with psychoanalytic theory of cinema and filmic enunciation. Poststructuralist theory stressed the necessary inadequacies of signification and representation, elaborating with great complexity and force on the theoretical, philosophical, and analytic implications of this premise. It is arguable that this acknowledgement of the defects and slippages of signification leads to Metz's later post-Lacanian psychoanalytic theory. It is very clear in 'The Imaginary Signifier' that his investigation of cinema as signification turns to a poststructuralist (albeit Freudian, Lacanian) notion of the inadequacies of filmic discourse, which leads to the need to compensate for them by producing a subject. ${ }^{11}$ In a sense, the basis for this move was established when Metz rejected his own earlier view of analogy as uncoded. Given the intellectual context of the moment, this moved him towards something like a notion of the radical alterity of the real - a poststructuralist and Lacanian idea.

But furthermore, in Language and Cinema the singular textual system becomes the site of a necessary instability and inconstancy of the codes themselves. Metz here envisions the semiotician as rewriting a film as a particular, unique conjunction of codes, which is the textual system. In fact, the operation of the film becomes the interaction between code and its textualization - that is, two levels of systematicity. With reference to Kristeva, Metz explains that the conjunction of codes and sub-codes that makes up a singular textual system is a displacement of codes by one another, due to their very adjacencies. In this process of displacement, the various codes being mobilized in the film are, in varying degrees, deformed by the particular network of adjacencies among codes established in each text.

Thus, the semiotician conceives of any film not just as deploying codes but also and simultaneously as destabilizing them, something necessary

11 This is crystallized in a passage where, with reference to Bazin and Merleau-Ponty, Metz states that the blind spot of most phenomenological film theory is 'the lure of the ego', precisely because phenomenology shares with cinema the construction of a perceptual mastery. If we switch to the semiotic register, this critique is the same as saying the blind spot is an ambition for perfect signification in the service of a reassured subjectivity. Christian Metz, The Imaginary Signifier, trans. by Celia Britton and others (Bloomington: Indiana University Press, 1982 [1977]), pp. 52-53. 
to their very deployment in a pluri-codic system. In that sense, a textual system works not just with but also against the codic systems that compose it. One might say that the text proves stronger than the code. Metz describes the textual system as a 'system of systems' that positions codes: 'It is not the code which decides its own particular place in the system of the film, or which determines which other codes will become its temporary neighbors; it is the system of the film which does this [...]. ${ }^{12}$ Thus, the film semiotician treats the film as a dynamic process, a process of constant transformation of codes subtending apprehension and meanings themselves. This is the basis for the book's short conclusion. Having spent the final chapter unpacking notions of writing (écriture) for cinema, he concludes that the cinema does not evince writing in the Barthesian sense of a textual activity: 'The cinematic is a set of codes [...].' But there is filmic writing, for 'writing is neither a code nor a set of codes, but a working of those codes, by means of them and against them, a work whose temporarily "arrested" result is the text, i.e. the film.'.13

What, then, of specificity? Notions of cinematic specificity reappear throughout Language and Cinema with its new, dynamic conceptualization of coding, starting from the opening, ground-establishing chapters and continuing intermittently throughout the book. The theoretical climax of this concern is the penultimate chapter, which is titled 'Specific/Non-specific'. Without rehearsing the total complex of methodological and conceptual distinctions Metz adduces, let me summarize some of the broad principles that I find on specificity.

First principle: In Metz's own words, 'the specificity which interests semiotics is the specificity of codes, not the "crude" specificity of physical signifiers', although 'the specificity of specific codes [...] refers to certain features of the material of expression'. As he puts it several pages later, specificity is 'a notion which is at the same time material and systemic'. ${ }^{14}$ Thus, Metz does not ignore the technological ground, but this is because it provides the raw (sensory) materials for signification, by including features that may be organized into systems of commutable features. Metz therefore gives priority in defining specificity to the codic systems, which are, remember, a construct of the analyst. (This idea engages him in a running

\footnotetext{
12 For this conception of textual system, see the remarkable passage in Language and Cinema, pp. 102-104, which includes the quoted text. More broadly, for various aspects of the concept of textual system and relations to concepts of coding, see pp. 70-175. On intertextuality, see Language and Cinema, p. 151 and the more cautious formulation on pp. 180-82.

13 Metz, Language and Cinema, p. 285.

14 Ibid., p. 219, p. 234 (emphasis in original).
} 
debate with the work of Louis Hjelmslev, whose theory of verbal language foregrounded the material and substance of signification.)

Second principle: Specificity is not an absolute category. It has gradations, such that codes may be more or less specific. To put it simply, some codes are widely shared with other media, some shared less. For example, codes of sequencing moving, mechanically produced images are shared by television and cinema but not by other means of expression, even related visual media such as photography, figurative painting, and so forth. So these codes are very specific to cinema but yet not absolutely exclusive to it. But additionally, codes and pieces of codes - including very specific ones - are constantly transferred among different media and signifying forms in a process Metz calls 'semiotic interference' and 'codical transposition'. ${ }^{15}$ Metz develops a multi-leveled comparison among pertinent characteristics of various media in which greater and lesser degrees of specificity are likened to a complex scheme of concentric and overlapping circles. For what it is worth as a gloss on Metz's claims here, the most cinematic specificity seems to involve codifications associated with a combination of movement of the mechanically produced image and movement within the mechanically produced image.

Third principle: If it is a matter of codes, we may pose the question differently and ask about a specifically cinematic langage. Here the concept of langage becomes more suggestive. Much as Metz argues that parole is complexly multi-codic and that singular textual systems are complexly multi-codic, he now also conceives of any langage as complexly multi-codic. That is, cinematic langage itself is a cluster and therefore an interaction of codes, ranging from the more or less specific to the more or less unspecific. In that case, one might infer that there are levels of analysis for which the dynamism of semiosis attributed to the model of the singular textual system can likewise be attributed to cinematic langage itself. This is a possibility that Metz himself seems to broach but then short-circuit in his conclusion. At one point, discussing inter-codical relations between langages, he describes each langage as 'a work of structuration, of a specific dynamic which ends up by conferring on the diverse "regrouped" codes positions which they did not have anywhere except in this system'. But in the conclusion, as noted above, the term 'filmic writing' is coined to name the 'working' of the dynamic multiplicity of codes that is the product of the

15 See the discussion of these terms and the distinctions in Metz, Language and Cinema, pp. 212-19. 
singular textual system, but the term 'writing' is said to be inapplicable to cinematic langage. ${ }^{16}$

But it is interesting to contemplate the consequences if one decided that cinematic langage as a conjunction of codes and sub-codes has a semiotic dynamism paralleling that of the textual system. For Metz initiated his semiotic investigations by understanding cinema as a langage sans langue. This meant it does not have its own special or singular underlying code, but it does have specificity, residing in an especially strong analogy in the image. This is explicated as an uncodifiable quality, which necessarily places a limit on the notion of cinema as code on the model of langue. By the time of Language and Cinema, his conception of the scope of coding had evolved. Now the central issue is not that cinematic langage is limited by the irreducibility of the figurative character of the image. Rather, we might say that cinematic langage is composed by a complex surplus of codes over and above any single dominant code, such that even analogy itself is coded. A langage of multiplicity and process is a langage whose phenomenal manifestations might always entail a certain potential for underlying uniqueness and transformations, hence instabilities. This conception would also open up a possible area of research not much theorized by Metz, namely that of the historicity of signifying systematicities, precisely because it could conceivably countenance changes over time.

Fourth principle: According to Metz, given the dynamism of the singular textual system and the complex composition of langage, 'a code which is more specific than another is not necessarily a more important code'. This is because its significance lies in the functional relations it undergoes with other codes, specific or non-specific. 'It is not, after all, certain that the question of importance is of great significance. What is important is the articulation of codes in the langage.$^{17}$ Note that this principle might throw new light on how some of Metz's other writings have been appropriated. For example, Metz proposes that certain codes and sub-codes of identification are specific to cinema as 'imaginary signifier'. But this in itself does not imply that these codes of identification are the 'most important' for what

16 Ibid., p. 242 (emphasis in original) and pp. 285-86.

17 Ibid., p. 243, 244. (This translation actually renders langage as 'language system', but as already noted, I will continue to render it as langage throughout this essay.) The second passage continues: 'It is not indispensable, in order to analyse the cinema, to know if it is the "art of movement" rather than "the art of the image", "the art of space" or - why not? - the art of situated sounds; it is all this at the same time, and it is this "at the same time" which is important. But also, in order to disentangle this "at the same time" without confusion, it is necessary initially to consider its components one by one.' 
any given film does, how it operates, or how it makes significances. This is not a perspective much considered in the extensive literature that discusses or cites Metz's extraordinarily influential essay 'The Imaginary Signifier'.

\section{Metz in a Digital Age: Specificity, Code, and Some Genealogical Notations}

On the basis of these principles in Language and Cinema, we may now turn to some current implications of Metz's semiotic framework in light of my starting points: first, the problematic of specificity in classical film theory; and second, the recent emphasis on the interactions, hybridities, and mixtures of various media that seem to blur or denegate specificities. To review the first: From very early in his semiotic researches, Metz claimed to break with classical film theory, and he certainly opposed the prescriptive nature of a good deal of classical film theory associated with notions of cinematic specificity. Yet as he sought to define the possibilities and the limitations of semiological analysis, there was a kinship with classical film theory at a deeper level. Insofar as Metz's earlier writings posited analogy as a certain stable cinematic specificity in the film image - theoretically formulated as cinema's fundamental resistance to concepts of structural linguistics - then to that extent, the earlier Metz did not escape a logic familiar from classical film theory. This logic was to reason from the technical or material nature of a medium to claims for distinctive aesthetic, psychological, sociocultural possibilities, and/or (most important for semiotics) representational possibilities and experiences.

However, as we have seen, Language and Cinema took a different turn on medium specificity and its implications. I have suggested that this turn marks a more convincing break with classical film theory than Metz's earlier writings, in which he originally argued for such a break. What could be more different from the manifestation of cinematic specificity envisioned by, say, Münsterberg or Arnheim than the concept of the singular textual system as a complex multiplicity of codes whose operative adjacencies and interactions modify one another? The priority of the interplay of codes over and above material substance of the medium inevitably affects Metz's conception of specificity, as if by logical contagion. Specificity as a matter of more or less, and as a matter of langage (a cluster of interacting codes), clearly diverges from the concern with a technological foundation, a concern that underpins the logic of much classical film theory on specificity. Specificity is relativized as a practice of signification more aligned with one 
medium than another but not necessarily exclusive to that medium. It may not only be manifested across texts (films) generated in a given medium (cinema) but can also travel in different degrees and shades across media.

This leads to my second starting point - recent emphases on media hybridities and interactions - which requires more expansive, somewhat speculative comments. One could read much of the Language and Cinema chapter on specificity/non-specificity as opening up a constitutive theoretical space to encompass blurrings and appropriations of specificities across seemingly distinctive media technologies. The capacity for such media mixtures is nowadays generally seen as a central characteristic of contemporary media. Sometimes described in terms of convergence, it is often associated with digital technology and simulation. Early in the digital era, there developed an idea that digital encoding enables computerized discourse to mimic the textual products and forms associated with any other pictorial or sonic medium, a capacity I have elsewhere called digital mimicry. Theoretical and descriptive accounts have often attributed this digital capacity to a purported universality of mathematics, because the digital machines enabling it are built to operate algorithms organizing the fundamental binary coding. ${ }^{18}$ Elements of Language and Cinema can resonate surprisingly with such discussions. This resonance is in part notional because of Metz's emphasis on coding, which is a widespread term in discussions of digital media and culture in the digital era. And it is also in part functional because Metz's theoretical elaboration of coding relativizes the specificities of media technologies. This could be understood as corresponding to digital mimicry, whether that correspondence is seen as a loose one or a more developed rigorous one.

Here it may be useful to pause over one of the book's most pertinent illustrations in the chapter on specificity/nonspecificity, a five-page comparison of cinema and television. This comparison serves as a kind of limit case and pressure point on the concept of the specific, and provides the most complete example of what he calls 'semiotic interference' and 'codical transposition to "neighboring langages"'. This is because Metz finds cinema and television to be unusually close neighbors outlining an unusually full semiotic similarity between the two. In fact, he asserts that,

18 In my original discussion of digital mimicry, I comment critically on the universalizing idea that digital encoding dematerializes media technologies. Philip Rosen, Change Mummified: Cinema, Historicity, Theory (Minneapolis: University of Minnesota Press, 2001), Chapter 8, esp. 304-314 for digital mimicry. While I am here discussing digital mimicry in relation to films and the cinematic, it obviously applies to many other media and cultural-aesthetic practices. 
at many levels, there are difficulties in sustaining a distinction between cinematic langage and televisual langage.$^{19}$ To be sure, he is first careful to list what he sees, in the early 1970s, as the basic divergences between them. He attributes these divergences to both socioeconomic factors and technical, material factors in how the two media form and transmit images and sounds. (He does carefully note that even technological differences are not necessarily eternal, shrewdly pointing out television's smaller screen size as a quick example of something that can change.) But over and above these differences, Metz asserts there is a tight semiotic fit between codic systems in cinema and television. He even argues that while perception of motion in the image (fundamental to cinema) is generated differently in the two media, the difference makes little ultimate difference for most codes; hence television can and does employ the same codes as cinema for organizing and sequencing its moving framed images and sounds.

The important general principle in this comparison is Metz's disjoining of specificity and technology. Nowadays, of course, a film text may traverse several exhibition 'platforms', most involving some variants of video screens such as cable television, DVD display, online distribution, mobile phone display, and more. ${ }^{20}$ But even before the digitization of images and sounds, post-World War II television quickly began exhibiting films originally made for theatrical release. That this practice became normalized so rapidly is historical and notional evidence of the semiotic closeness described by Metz's comparison of cinema and television. Television was the historical threshold for exhibiting a complete film, with all its images and sounds, through a different technology. It was thus the immediate technical ancestor - and an electronic technology at that - for the digital succession of film platforms so crucial to the current media environment, with effects in everything from mainstream film financing and profit margins to media art practices.

19 See note 15 on the terminology of semiotic interference, codical transposition, and neighbouring langages. For the comparison of langages of cinema and television summarized in this paragraph, see Metz, Language and Cinema, pp. 235-40. On the close similarity of cinematic and televisual langages, see p. 239 and also p. 241.

20 To keep the argument focused, I here refer only to the transmission of complete films. But of course the multiplicity of digital platforms supports many other kinds of practices involving selections from, expansions of, and variations on the 'original' film release version, through things like interactive DVD editions including computerized options, electronic gaming, smart phone applications and iconographies, etc. And then there are unauthorized appropriations and variations. 
But it is important to avoid slipping too easily back towards a technological grounding by explaining the practice of circulating media texts among several platforms simply as the realization of a capacity inherent in digital processing of images and sounds. The neutralization of specificities aimed at in such practices was already envisioned as a theoretical matter by Metz, and of course his key example, the cinema-television comparison, was written when television was an analog technology and before the current ongoing digitization of cinema. In this, Metz's approach to cinematic specificity suggests a bracing, useful attitude for thinking about today's media environment, even for those who may not accept his theoretical approach. Of course, the point is not to deny the importance of media technology, much less the importance today of digital operations and the machines that enable them. But when Metz conceives of specificity as a matter of langages and thereby relativizes specificity by making it a matter of degree, he distances the codic from the technological without harshly dividing them. Metz thereby provides one kind of theoretical constellation for thinking about coding over and above technological definitions, determinations, or determinism.

Today when the terminology or concept of coding is omnipresent in relation to a presumed cultural and economic dominant of the digital, it might encourage us to think of the digital as a discourse or a problematic, with a history and functions, as much as a technological procedure and machine. How might we understand this problematic? One possible path is taken in some digital culture studies, including so-called software studies. This is to construct genealogical strands, historical threads that reflect into and upon theoretical interrogations of the digital and the concept of coding.

For example, one well-known strand leading to the interplay of Metz's conceptions with the digital as a problematic involves Roman Jakobson and Claude Lévi-Strauss. They were key figures for asserting the applicability of structural linguistics to cultural practices, the perspective that Metz both inherited and tested with respect to film theory. A noted structuralist claim formulated with tremendous impact by Lévi-Strauss, that all culture should be analyzed as always already coded, already implies that coding clearly exceeds any technical specificity. It was a claim developed seminally with respect to semiology and images by one of Metz's mentors, Roland Barthes.

In one recent account, Bernard Dyonisius Geoghegan has studied the encounter of Jakobson and Lévi-Strauss with U.S. cybernetics and information theory during World War II and the early Cold War. Jakobson decided these fields might provide the basis for a technicization and mathematicization of Saussurian linguistics and communication studies, while Lévi-Strauss 
wished to do something similar for anthropological understandings of cultures. As part of this impulse, Jakobson transformed the Saussurian term langue into the more general, technical term code, in order to facilitate engagement with concepts being developed by engineers. For a time, Jakobson and Lévi-Strauss promoted this approach to other future structuralist and poststructuralist luminaries. However, within a few years the project of applying cybernetics to linguistics dissipated under critiques by a variety of linguists and other theorists, ranging from the young Noam Chomsky to French Marxists. As a result, according to Geoghegan, Lévi-Strauss's great methodological and theoretical statement in his 1962 book, The Savage Mind, turned towards 'experimental' and 'poetic' uses of the concept of code; and the impact of this book and his ultimate conception was on the basis of its infidelity to information theory. ${ }^{21}$

It was just two years later that Metz published the key starting point for his early semiotic researches, 'Le cinéma: langue ou langage?'. It may be read as an intervention in the genealogical strand traced above, for it includes passages explicitly denigrating cybernetics and information theory, mentioning Jakobson and Lévi-Strauss among others. These passages appear within his polemic against the hypertrophy of montage aesthetics in film theory. Metz's insistence that the cinema image is grounded in analogy works against montage thinking and is therefore involved with his desire to break with modes of classical film theory. But within the other genealogical strand, it also works against the schematic reductionist models he attributes to information theory and cybernetics, which he associates with extreme structuralism and Saussurian semiology as well as montage aesthetics. As I argued above, Metz implicitly posits analogy as a cinematic specificity in such a way that it suggests a more general principle, namely that any semiology would encounter its limits in specificities. But furthermore, this unacknowledged reversion to a classical film-theoretical conception of specificity is associated with this anti-cybernetic attitude.

At this point it will not be a surprise if I say that Language and Cinema looks quite different on this score. As we have seen, Metz again rejects the universal applicability of Saussure's concept of langue, but it is on different grounds. He now embraces an expansive notion of codification, subsuming langue and even encompassing analogy itself. At first glance, this seems

21 Bernard Dyonisius Geoghegan, 'From Information Theory to French Theory: Jakobson, Lévi-Strauss and the Cybernetic Apparatus', Critical Inquiry, $3^{8}$ (Autumn 2011), pp. 96-126; on Jakobson's terminological shift to code, see pp. 114-16, p. 124; on key critiques of applying information theory to linguistics, and the turn to infidelity in Lévi-Strauss's work, see pp.121-23. 
to be moving back towards information theory or early structuralism, and it is reminiscent of Jakobson's earlier terminological transformation from langue to code. However, there is also something akin to Lévi-Strauss's move of appropriating and modifying the concept of code for his own purposes. Thus, considered as part of the genealogical strand of information theory, cybernetics, and the associated digital problematics, Language and Cinema is not simply acceding but is again intervening.

In that case, given the tangled genealogical back-and-forth among his later semiotics and ideas derived from engineering, intertwined with the development of digital machines and concepts, a different kind of reading might be tempting - one based on the opposition between analog and digital technologies and coding. Why not just say Metz shifts away from establishing a privileged theoretical space for the analog and towards the idea that all signification depends on the digital? Here, 'digital' would mean a code is analyzable into relations of non-signifying bits, whether phonemes in verbal language, numbers in digital media, intensities and frequencies of light for one of the codes of visual perception, etc. This certainly seems included in what Metz means by code in Language and Cinema. And such a reading might help us formulate conceptual forces or more fine-grained genealogies folding into Language and Cinema while simultaneously opening to a more direct connection to digitization in the present. This is not a new idea. It is a kind of reading that was occasionally foreshadowed in the 1960 and 1970 in contemporaneous commentaries on cinema semiology. Many years later, the filiation was asserted by no less than Umberto Eco. By then he had repudiated the entire account of images and coding that he had formulated in his debates with Metz - that is, the account to which Metz acquiesces in Language and Cinema. In a 1999 text Eco reconfirmed his recantation, yet, contradictorily, expressed pride in the position he had taken. Why? Because he now saw this 'attempt to reduce the analogical to the digital' as a forerunner of 'computational theories of the image' central to the digital era. ${ }^{22}$

22 Metz, Language and Cinema, pp. 276-77, quoted passage on p. 277. Umberto Eco, Kant and the Platypus: Essays on Language and Cognition, trans. by Alistair McEwen (New York: Harcourt, 1999), pp. 341-42. For a sophisticated contemporaneous critique of cinema semiotics utilizing the digital-analog opposition, see Bill Nichols, 'Style, Grammar, and the Movies', Film Quarterly, 28/3 (1975), pp. 33-49. Metz's views of analogy and perception sometimes evince the influence of some research from the Institute of Filmology. One wonders if it is possible to rethink Metz's views on perception and coding in comparison to certain later cognitivist research on perception, and even rejoin it with more recent information theory as it touches artificial intelligence studies. 
But in the end, it is misleading to position Language and Cinema simply or wholly within information theory or to subject it directly and unreservedly to an unproblematized analog versus digital opposition. This would distort Metz's arguments and insights. Even obvious verbal parallels (analog/ analogy, digital coding/digital media) may seem suggestive at a high-level generality, but when interrogated closely can prove loose and slippery. It is most productive to emphasize the idea that the book intervenes within a complex genealogical strand, one that can appear to us today as developing problematics of digitization. For Metz carefully warps ideas about codes that he may be deriving from information theory, cybernetics, and (perhaps and more distantly) digital engineering. He bends the concept of the code to his own purposes and his own sense of how cinema signifies and operates. He does not aim at a reduction of filmic processes to a mathematical schema of fundamental components constitutive or generative of 'communication systems'. Rather, he conceptualizes a constitutive multiplicity composed of systemic elements (codic systems) perpetually subject to modification, in the complex operations of the singular textual system and perhaps also in the complexity of langage. That is, Metz does appropriate some fundamental concepts from the terrain of the information theory/cybernetics/digital complex. Most crucial is probably the concept of code as an abstract, generalizable construct of the analyst. However, he develops even, or especially, this central concept in ways that go against some of its original purposes.

This is fundamental to his crucial move of distancing of the code from an underlying materiality or technological specificity, though without ignoring the latter. This may paradoxically give his approach resonance and critical potential now, at this later moment, when digital technologies and media present themselves to cultural critique and theory - and increasingly to cinema itself - as a universal, inescapable presence. In this context, Language and Cinema appears as something of a balancing act, a consciously divergent appropriation of selected ideas from fields and approaches associated with the genealogy of the digital. This balancing act is intertwined with what I have described as his break with classical film theory on specificity, which I have located in Language and Cinema as opposed to his earlier semiological investigations.

\section{Conclusion}

I have just made some proposals about the genealogy of the conceptual configurations and theoretical approaches that Metz thought enabled him 
to provide an account of cinema that, among other things, was a break with classical film theory. I have spent some time on that genealogy because it resituates Metz's arguments about specificity in terms of a set of discourses that has become fundamentally pertinent to understanding cinema and media in the present, with its proliferation of digital regimes and media mixtures. The central idea organizing all of this, the idea of a rupture with classical film theory, comes from Metz himself. I have argued that Metz achieves this most fully in Language and Cinema, in part because of its codic conception of cinema, which entails a relativization of older ideas about cinematic specificity. But in conclusion, it is necessary to blur or ambiguate this idea of the break with classical film theory. This means acknowledging that my own characterization of classical film theory has been partial and homogenizing.

Metz's relativization of specificity is inseparable from his category of the singular textual system, which operates to displace and deform codes. There is a parenthesis within one of the discussions of the singular textual system in Language and Cinema where Metz writes that the operations of a textual system can be compared to the notion of productivity in contemporaneous Marxist theory. (He presumably has in mind Althusserian approaches to film analysis as inflected by poststructualism right after 1968 in such journals as Cahiers du cinéma and Cinéthique.) But in the same passage, he also compares the singular textual system to the concept of 'composition' in that most legendary of classical theorists, Sergei Eisenstein, whose montage theory he had pilloried in 'Le cinéma: langue ou langage?'. And it is indeed the case that Eisenstein's conceptions of montage well exceed any notion of cinematic specificity, despite scattered contrary indications in some of his early polemics. This is developed expansively and in great depth especially in Eisenstein's later writings, partly through notions of montage in other arts and even in human mentality. At this point, Metz could have said something similar about André Bazin, though it may have been difficult in French film culture of 1971. Despite his so-called ontological essays, in the rich essay 'For an Impure Cinema' - just to mention one of his most fully developed formulations on this question - Bazin comprehensively attacks discourses promoting notions of pure or absolute cinema. He extends the critique to all those who associate cinematic worth with specificity, and asserts that not specificities but mixtures and hybridities of media and aesthetic forms are constitutive of film history. ${ }^{23}$

23 Metz, Language and Cinema, pp. 102-03. These remarks about Eisenstein and Bazin are informed by my recent work on them. See Philip Rosen, 'Revolution und Regression: Zur 
These two classical film theorists certainly do not exhaust the possible references, but they are major examples and enough here to make the point. There is little doubt that Language and Cinema painstakingly develops a distinctive conception of how a film operates, through the deformative processes inherent in organizing pluralities of sensory and signifying materialities (that is, codes). This can only undo the idea of some classical film theorists of a film as the realization or application of a unique medium specificity. However, as Metz briefly acknowledges, it would be wrong to assume that congruent conceptions were completely absent from the prior history of film theory. In some of the most canonical of classical film theorists, one can find some well-developed and committed formulations of cinema as inherently complex, and of the workings of films as mixed, dynamic processes. Of course, the point is not that Eisenstein, Bazin, or other classical film theorists in this vein were doing the same thing as Metz, and, obviously, they were not using the same theoretical terminologies. But one cannot subsume classical film theory tout court by the kind of logic I attributed to Münsterberg and Arnheim without badly oversimplifying the history of film theory.

Still, in my reading of Metz I have employed his own standard of a break with classical film theory. I have argued it did not occur at the point where he first claimed it did but somewhere else, and this 'somewhere else' suggests a potential contemporary pertinence in returning to certain aspects of Metz's work. But as in all such returns, something changes. For example, one aspect of Metz's claim to break with classical film theory in his account of cinema involved critically retooling cybernetic conceptions of the 1940 and

Zeitlichkeit in Ėjzenštejns Theorien des Kinos und der Kultur' [Revolution and Regression: Temporality In Eisenstein's Theories of Cinema and Culture], in Jetzt und dann:Zeiterfahrung in Film, Literatur und Philosophie, ed. by Gertrud Koch and others (Munich: Fink, 2010), pp. 15-34, and Rosen, 'From Impurity to Historicity'.

These two theorists might well suggest other intertwining genealogical strands. For example, some see Eisenstein as one of the originators of Soviet semiotics, which Metz says influenced changes in his position on the coding of parole. See two articles by V.V. Ivanov, 'Eisenstein et la linguistique structurale moderne', Cahiers du cinéma, 220-221 (1970), pp. 47-50; and 'Eisenstein's Montage of Hieroglyphic Signs' in On Signs, ed. by Marshall Blonsky (Baltimore:Johns Hopkins University Press, 1985), pp. 221-36. As for Bazin, Metz always had critical comments on him but also expressed respect for him. In Language and Cinema, he briefly acknowledges Bazin's critique of cinematic specificity (p. 41) but later criticizes him for making the cinema natural and 'cosmophanic' (pp. 275-76.) Some have found parallels between Metz and certain Bazinian descriptions of cinema, even beyond Metz's early opposition to montage aesthetics and his notion of image analogy, including Metz himself; see, e.g. the footnote in Language and Cinema, p. 103. Here one might invoke phenomenological aesthetics in postwar France as context for Metz, as have Chateau and Lefebvre. 
1950s. This line of thinking may look different today, in our era of massive digitization, precisely because it included interesting internal distanciations and redirections of some of those conceptions. A similar point might be made about classical film theory, with its strongest versions of cinematic specificity as well as divergent conceptions.

What does this do to the idea of a break, which Metz proposed and which I have taken over as a kind of fulcrum in my reading of Metz? What is it to declare a break with the past? Historical endings and beginnings are always arbitrary and functional for those who declare them. For Metz, declaring the end of classical film theory was what the philosopher Kwame Anthony Appiah has defined as a typically modernist gesture, the space-clearing move. ${ }^{24}$ Recall that such a gesture was also implicit in classical film theory, much of which was formulated when cinema was still experienced as something new. So we, who come later, must make our own historical understandings and clear our own spaces. This impels us to reconsider demarcations of historical ruptures and continuities. In order to deal with the present, it may be productive to construct another break or new beginning or, for that matter, beginnings, and return to them from a new position. Such beginnings and endings share at least one central characteristic with Metzian conceptions and methods. They are ex post facto constructions made for present purposes of the analyst - much like Metz's codes.

\section{About the author}

Philip Rosen is Professor of Modern Culture and Media at Brown University, where he is also Professor of American Studies and Professor of English. He has written on a wide range of subjects related to film theory as well as media theory and film history. Among his publications are the edited volume Narrative, Apparatus, Ideology: A Film Theory Reader (1986) and the monograph Change Mummified: Cinema, Historicity, Theory (2001).

24 Kwame Anthony Appiah, 'The Postcolonial and the Postmodern', Chapter 7 , in In My Father's House: Africa in the Philosophy of Culture (New York: Oxford University Press, 1992), pp. 137-57. 



\title{
11. Cyber-Metz?
}

\section{The Notion of Code in the Writings of Christian Metz}

\author{
Selim Krichane
}

Tröhler, Margrit and Guido Kirsten (eds.), Christian Metz and the Codes of Cinema. Film Semiology and Beyond. Amsterdam University Press, 2018

DOI: $10.5117 / 9789089648921 / \mathrm{CH} 11$

\begin{abstract}
This chapter examines the historical connection between the structuralist paradigm and cybernetics in order to re-evaluate the epistemological foundation of the notion of 'code' as it appears in the work of Christian Metz. The study focuses on the evolution of the notion of code in Metz's writings from 'Cinéma: langue ou langage?' (1964) to Langage et cinéma (1971). Delineating the genealogy from Metz's semiological model to cybernetics (especially through information theory) subsequently allows us to investigate the potential contribution of the Metzian model to the contemporary study of video games and digital objects.
\end{abstract}

Keywords: film semiotics/film semiology, epistemology, cinematic code, cybernetics, theory of video games

For the study of language in operation, linguistics has been strongly bulwarked by the impressive achievement of two conjoined disciplines - the mathematical theory of communication and information theory [...]. We have involuntarily discussed in terms specifically theirs, of encoders, decoders, redundancy, etc. What, precisely, is the relation between communication engineering and linguistics? Is there perhaps some conflict between these two approaches? Not at all!

$($ Roman Jakobson, 1952)

1 Roman Jakobson, closing statement at the Conference of Anthropologists and Linguists, Indiana University, July 21-30, 1952, published in Selected Writings II: Word and Language (The Hague/Paris: Mouton, 1971), p. 556. Quoted by Jérôme Segal, Le Zéro et le Un. Histoire de la notion scientifique d'information au $20^{e}$ siècle (Paris: Syllepse, 2003), p. 409. 
In this article, I will focus on the different uses of the concept of code at the heart of the 'cinematic thought' of Christian Metz. To do so, I will take as a starting point the premise that there exists a historical lineage between the notion of code as set out in information theory and its application by Christian Metz, mainly in his writings ranging from 'The Cinema: Language or Language System?' to Language and Cinema. ${ }^{2}$

I must specify that this hypothesis does not offer an in-depth review of the linkages Metz establishes between cinema and linguistics or cinema and semiotics. Instead, it aims to shed partial and complimentary light on it, by observing the somewhat metaphorical integration of information theory to the field of linguistics and semiotics, beginning in 1948. This is done in order to better assess its potential effect on the use of the concept of code in Christian Metz's writing.

Indeed, by the late 1940s, mathematical information theory, designed to understand digital encoding and message transmission, namely within telecommunication networks, had seduced some linguists, including Roman Jakobson. Insight into this relationship will later lead me to examine the influence that Christian Metz's work has had on the field of new digital media studies and, more specifically, the study of video games.

\section{'Code': A Cross-Cutting Concept}

It is clear that computer codes do not equate semiotic codes. At the same time, new media code and algorithmic structures do not fit the 'structural' paradigm, which requires that structures be constructed by an analyst and, after identification of distinguishing features, organized into a system.

However, as Peter Wuss notes in Kunstwert des Films und Massencharakter des Mediums, the near absence of the cybernetic model in film studies should not lead us to conclude that the model has had no effect on the evolution of film theory, chiefly through film semiotics. Indeed, cybernetics, in the field of hard sciences, offered a model that would allow for the formalization of communication systems, their regulation, and the circulation of information on a systematic and quantifiable basis. Wuss further notes, without specifying the history of how this took place, that

2 Christian Metz, 'The Cinema: Language or Language System?' [1964], in Film Language: A Semiotics of Cinema, trans. by Michael Taylor (New York: Oxford University Press, 1974), pp. 31-91; Christian Metz, Language and Cinema, trans. by Donna Jean Umiker-Sebeok (The Hague/Paris: Mouton, 1974 [1971]). 
key cybernetic concepts such as 'information', 'systems', or even 'code' have been transposed into the field of film semiotics. ${ }^{3}$

In fact, Metz includes cybernetics and information theory in his description of the structural paradigm of scientific theory, featured in the first part of 'The Cinema: Language or Language System?'. He paints these theories in a fairly unflattering light, pointing out that they "[have] outdone even the most structuralist of linguistics'. ${ }^{4}$ In 1964, Metz therefore sees in cybernetics an extreme example of the formalization of communication, a model that does not fit at all with the methodology he seeks to design. Later, in the same piece, Metz describes the language of the 'American logicians' computers as being 'more perfectly binary than the best analyses of Roman Jakobson'. ${ }^{5}$

The parallel that Metz draws between the binarism of computers and that of Jakobson's analyses is telling. Indeed, while the notion of opposition is central to Jakobson's work since the 1920s, he went on to become an ambassador for cybernetics for a decade, ${ }^{6}$ after discovering it in the late 1940 s. It seems necessary at this point to make a detour into the early days of the structural enterprise in order to assess the 'cybernetic' affiliation of the concept of code as it evolved from its original field to that of linguistics and semiotics.

\section{Cybernetics Meets Linguistics}

It was in New York, at the end of the 1940s and throughout the 1950s, that cybernetics and structuralism intersected. We know how decisive the collaboration between Roman Jakobson and Claude Lévi-Strauss at the New York Free School for Advanced Studies was in broadening the structural approach beyond the confines of linguistics. ${ }^{7}$

3 PeterWuss, Kunstwert des Films und Massencharakter des Mediums (Berlin: Henschel Verlag, 1990), pp. 478-83.

4 Metz, 'The Cinema: Language or Language System?', p. 35. In French, Metz says that cybernetics and information theory 'sont venues déborder sur sa "gauche" la linguistique la plus structurale'. Christian Metz, 'Cinéma: langue ou langage?' [1964], in Essais sur la signification au cinéma, 2 vols. (Paris: Klincksieck, 1968), I, p. 42.

5 Metz, 'The Cinema: Language or Language System?', p. 35.

6 See Bernard Dionysius Geoghegan, 'From Information Theory to French Theory: Jakobson, Lévi-Strauss, and the Cybernetic Apparatus', Critical Inquiry, 38 (2011), 96-126 (p. 109).

7 Céline Lafontaine, L'empire cybernétique. Des machines à penser à la pensée machine (Paris: Seuil, 2004), p. 93; Jean-Claude Milner, Le périple structural. Figures et paradigmes (Paris: Seuil, 2002), p. 197. 
Jakobson first discovered cybernetics in 1948, while taking part in the 5 th Macy Conference. ${ }^{8}$ He developed an interest in the cybernetic approach, which he applied prolifically in his work in the 1950s, all the while actively cooperating with engineers. ${ }^{9}$ The work of Jürgen Van de Walle shows that by the 1950s, Jakobson had begun adapting the precepts of phonology - a discipline he worked on at the Prague School - to the cybernetic and informational model. Jakobson's comprehension of language at the time - as a teleological, functional, and binary system - was strongly and scientifically steeped in cybernetic theory. This came at a cost that Van de Walle describes as a way of psychologizing information theory. ${ }^{10}$

Roman Jakobson, Claude Lévi-Strauss, Charles Hockett, and Thomas Sebeok all took part in the activities of the New York Free School of Advanced Studies in the 1950s and 1960s. Hockett played an active role in spreading information theory within the field oflinguistics by writing a review of Shannon and Weaver's book for the prestigious publication Language in $1953 .{ }^{11}$ As for Sebeok, he was deeply influenced by information theory, which would remain a fundamental theoretical reference in his work throughout his career. ${ }^{12}$

The Free School was financed by the Rockefeller Foundation of New York, whose members included Warren Weaver, Director of the Department of Natural Sciences from 1932 to 1955 . Warren Weaver also supervised Norbert Wiener and Claude Shannon's research during World War II. ${ }^{13}$ As Bernard Geoghegan points out, the Foundation would play a key role in the widespread use of cybernetics and information theory across many American institutions, including the Free School. ${ }^{14}$

It is in this context that Jakobson was swept up in the wave that was cybernetics in the late 1940s. Shortly after the publication of Cybernetics, he contacted Norbert Wiener to share his enthusiasm for the book: 'At every step I was again and again surprised at the extreme parallelism between the problems of modern linguistic analysis and the fascinating problems

8 See Segal, Le Zéro et le Un, pp. 196-97.

9 Jürgen Van de Walle, 'Roman Jakobson, Cybernetics and Information Theory', Folia Linguistica Historica, 29 (2008), 87-123, (pp. 94-97); or Jérôme Segal, Le Zéro et le Un, pp. 410-11.

10 Van de Walle, 'Roman Jakobson, Cybernetics and Information Theory', pp. 113-16.

11 Perry L. Blackburn, The Code Model of Communication: A Powerful Metaphor in Linguistic Metatheory (Dallas: SIL International, 2007), p. 72.

12 See, for example, Thomas A. Sebeok, Signs: An Introduction to Semiotics (Toronto: University of Toronto Press, 2001 [1994]), pp. 140-46; and Thomas A. Sebeok and Marcel Danesi, The Forms of Meaning:Modeling Systems Theory and Semiotic Analysis (Berlin/New York: Mouton de Gruyter, 200o), p. 32. Here, Sebeok explicitly compares the 'language code' to a 'computer code'.

13 Geoghegan, 'From Information Theory to French Theory', p. 109.

14 Ibid., pp. 102-04. 
you discuss. The linguistic pattern fits excellently well into the structures you analyse and it is becoming still clearer how great are the outlooks for a consistent cooperation between modern linguistics and the exact science. ${ }^{15}$ Lévi-Strauss also comments on Cybernetics, lauding it as a piece 'whose importance from the point of view of the future of social sciences can hardly be overestimated'. ${ }^{16}$ That same year, Warren Weaver sent Jakobson a version of The Mathematical Theory of Communication $(1949)^{17}$ as part of an international survey he was conducting on international linguistic methods sponsored by the Rockefeller Foundation..$^{18}$

Shannon was the first to publish a version of the document in 1948, which made up the core of statistical information theory. ${ }^{19}$ Warren Weaver discussed Shannon's findings in the first part of the 1949 version and disseminated Shannon's mathematical and statistical model, while considering the potential impacts this model could have on the fields of verbal and social communication.

The correspondence that Jakobson exchanged with Charles Fahs, Weaver, and Norbert Wiener are a testament to his interest in cybernetics and information theory, which he believed capable of uniting the study of communication with that of language. Jakobson is therefore credited by many researchers as acting as a 'courier' between the budding structuralism of the time and cybernetics. ${ }^{20} \mathrm{He}$ even went on to become a fervent ambassador for cybernetics in the 1950s: he collaborated with Norbert Wiener at the MIT and promoted cybernetics to European intellectuals such as Lacan and Hjelmslev. ${ }^{21}$ After having been in contact with Jakobson, Lévi-Strauss also became very interested in studying the research emanating from the field of engineering as well as in the theoretical promises of cybernetics. ${ }^{22}$

15 Jakobson to Wiener, 24 February 1949, Box 2.92, MC22, Wiener Papers MIT. Quoted by Lily E. Kay, Who Wrote the Book of Life? A History of the Genetic Code (Stanford: Stanford University Press, 200o), p. 299.

16 Claude Lévi-Strauss, 'Language and the Analysis of Social Laws', in Structural Anthropology, trans. by Claire Jacobson and others (New York, Basic Books, 1963 [1958]), 55-66 (p. 55). Quoted by Lafontaine, L'empire cybernétique, p. 91.

17 Claude E. Shannon and Warren Weaver, The Mathematical Theory of Communication (Urbana: University of Illinois Press, 1949).

18 Lafontaine, L'empire cybernétique, p. 300; Geoghegan, 'From Information Theory to French Theory', p. 109.

19 Claude E. Shannon, 'A Mathematical Theory of Communication', Bell Systems Technical Journal, 27 (1948), pp. 379-423.

20 See, namely, Segal, Le Zéro et le Un, pp. 405-12; Kay, Who Wrote the Book of Life?, pp. 300-02; Lafontaine, L'empire cybernétique, pp. 94-97.

21 Geoghegan, 'From Information Theory to French Theory', p. 112.

22 Lafontaine, L'empire cybernétique, pp. 90-92; Geoghegan, 'From Information Theory to French Theory', pp. 116-2o. Geoghegan describes Lévi-Strauss's enthusiasm for cybernetics in 
CONTEXT

ADDRESSER MESSAGE

ADDRESSEE

CONTACT

CODE

Fig. 11.1: Jakobson's communication model

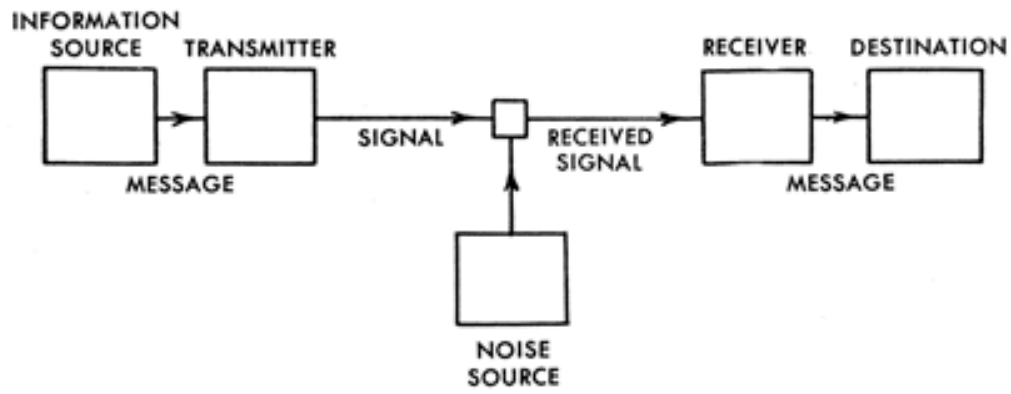

Fig. 11.2: Shannon's communication model

Lévi-Strauss's many references in his writings to the works of Wiener, Von Neumann, and Shannon have recently become the topic of specific research. In 2006, in response to an article on how he had received cybernetics, Lévi-Strauss would note: 'over time, I would draw more inspiration from information theory than from cybernetics'. ${ }^{23}$

The convergence between structural linguistics and cybernetics brought to light in Jakobson's work in the 1950s is replicated in the communication model he presented at the Conference on Style at the University of Indiana in 1958, later published in his article 'Closing Statement: Linguistics and Poetics' (Figure 11.1 and 11.2). ${ }^{24}$

the first half of the 1950s as well as his attempt to create a research laboratory that would apply the precepts of cybernetics and developments in electrical engineering to the field of human sciences. The project did not take place due to lack of funding.

23 Claude Lévi-Strauss, letter to Ronan Le Roux, 20 November 2006. Quoted by Ronan Le Roux, 'Lévi-Strauss, une réception paradoxale de la cybernétique', L'Homme, 189 (2009), $165-90$ (p. 186). Let us not forget that in 1966, the Semio-linguistic section was created, with the help of Lévi-Strauss. Metz would work there alongside Barthes, Greimas, Todorov, and Kristeva.

24 Roman Jakobson, 'Closing Statement: Linguistics and Poetics', in Style in Language, ed. by Thomas Sebeok (Cambridge: MIT Press, 1960), 350-77 (p. 353). 
In Jakobson's work, language communication processes are then modelled based on Shannon's model of information transmission. For Shannon, the aim of the statistical model is to ensure an efficient transmission of the message, be it graphic or auditory, without any concern for sense or meaning. The transposing of the message as a discrete, coded signal occurs only at a material level.

According to Louis Quéré, the four main postulates that lay the foundation of the concept of code in information theory - that it precede the message, that it function as a communication marker, that it be independent of its 'content', and that its position be external to the source, 'the emitter' are transposed into the field of structural linguistics. ${ }^{25}$

In Shannon's model, there is the message on one side, seen as the mathematical representation of a sound, a letter, or audiovisual flow, and the signal on the other, a package of binary digits. For example, we move from a given message to a series of electrical impulses. In this way, the model aims to react to the technical limitations of electrical engineering, and offers formulae to calculate message redundancy, maximum channel capacity, or digital signal compression, all of which are still used in telecommunications and information technology to this day.

Geoghegan describes this transposition in the following terms:

Once imported into linguistics, the diagrammatic strategies of communication engineering imposed an orderly set of distributions and series upon the unruly multiplicity of language-performances; thus, language itself became part of an economically distributed series of technical tasks within an assembly line of communications. Jakobson redefined Saussure's celebrated concepts of la langue (language-system) and la parole (speech or speech act) as 'code' and 'message'. [...] With Jakobson's proposals in place, a new type of knowledge of the human sciences could be produced: one emboldened by the methods of mathematics, refined and restricted by technological instruments, and empowered by the lavish resources and aspirations accumulating around engineering in postwar America. ${ }^{26}$

As Geoghegan states, this transposition requires an alignment between language communication and the fundamental vectors of information

25 Louis Quéré, Les miroirs équivoques. Aux origines de la communication moderne (Paris: Aubier-Montaigne, 1982), p. 2o. Quoted by Lafontaine, L'empire cybernétique, p. 97.

26 Geoghegan, 'From Information Theory to French Theory', p. 115. The Shannon and Jakobson models are featured in Geoghegan's article. 
theory: a technicist approach to communication that divides the operation into distinct modules in order to render message transmission more useful and efficient. By replacing the Saussurian language/speech dichotomy with the code/message dichotomy borrowed from information theory, Jakobson offers a model capable of handling 'acts of speech'. This model will prove particularly useful to semioticians in the 1960 s.

At the end of 'The Cinema: Language or Language System?', Metz states that film semiotics should focus on 'large signifying units' by adopting a method most akin to 'acts of speech'. ${ }^{27}$ He cites as examples Benveniste's discourse analysis, Greimas's transphrasic approach, as well as Jakobson's poetic function. Metz then refers to Jakobson's text, 'Closing statement: linguistics and poetics', which features the famous communication diagram. ${ }^{28}$

\section{Linguistic and Semiotic Codes}

Even though, following the decline of cybernetics, the cyber-structuralist endeavour in which Lévi-Strauss and Jakobson were involved in the 1950s was abandoned in the early 1960 s, traces of it remained in semiotics, a field that was budding at the time. These traces begin with linguistics.

In The Code Model of Communication, Perry Blackburn demonstrates that the code model is a fundamental metatheoretical component of modern linguistic theory. According to him, this model developed gradually over the first half of the 2oth century, by incorporating various communication sub-models and functions. ${ }^{29}$

Blackburn's work retraces the integration of information theory into structural linguistics, as it is assimilated to Saussure's 'speech circuit' to the point of being mistaken for it. According to Blackburn, this integration of the informational paradigm occurred through a misappropriation or mis-reading of said theory. Blackburn makes one important point: in Shannon's model, code is an algorithmic entity that allows for the transition - or 'translation' - from message to discrete signal..$^{30}$

27 Metz, 'The Cinema: Language or Language System?', p. 85. The term was borrowed from Roland Barthes, who used it in an interview conducted by M. Delahaye and J. Rivette and published in Cahiers du cinéma, 147 (September 1963); English as 'On Film' in Roland Barthes, The Grain of the Voice: Interviews 1962-1980, trans. by Linda Coverdale (Berkeley/Los Angeles: University of California Press, 1991), 11-24 (translated here as 'great signifying units', p. 14).

28 Metz, 'The Cinema: Language or Language System?', fn. 9o, p. 260.

29 Blackburn, The Code Model, p. 27.

30 Ibid., p. 67. 
Blackburn notes that the terms derived from information theory spread throughout linguistic research from the 1950s onwards. They appear in the works of Charles Hockett in 1953 as well as the works of Jakobson, Eugene Nida, Noam Chomsky, and even Michael Halliday. ${ }^{31}$ The same comment can be applied to the semiotics of cinema. Indeed, information theory vocabulary is used by Pasolini, who discusses 'codifiable' and 'decodable' signs in Heretical Empricism ('The Code of Codes'), ${ }^{2}$ and by Metz, in the code/message pair. ${ }^{33}$ The relationship with information theory also occurs through Soviet semiotics, namely through the works of Jurij Lotman, who draws an even more direct link to cybernetics, as it appears in his Semiotics of Cinema in $1973 \cdot{ }^{34}$ Furthermore, when Lotman considers the functions of communication he refers to Jakobson, specifying that the 'classic model of communication was brought by Jakobson' ${ }^{35}$ Here, cybernetics is presented in part through the lens of Jakobson's work as well as through its direct link to Soviet semiotics.

Indeed, by the late 1950s, cybernetics would become a predominant model in the USSR, ${ }^{36}$ constituting the main theoretical basis for the Semiot-

31 Ibid., pp. 14-19. For Charles Hockett, for example: 'The Speech Transmitter converts the discrete flow of phonemes which comes to it into a continuous speech signal - a continuous train of sound waves. The code by which the Speech Transmitter performs this transduction is the phonetic system of the language.' Charles F. Hockett, A Manual of Phonology (Baltimore: Waverly Press, 1955), p. 3.

32 Pier Paolo Pasolini, 'The Code of Codes' [1967], in Heretical Empiricism, trans. by B. Lawton and others (Bloomington: Indiana University Press, 1988), pp. 276-83.

33 Which is central to the theoretical structure of Metz's Language and Cinema (The Hague/ Paris: Mouton, 1974 [1971]). I will go into further detail on the matter later in this article.

34 Jurij Lotman, Semiotics of Cinema, trans. and ed. by Mark E. Suino (Michigan: Michigan Slavic Contributions, 1976 [1973]). Here Lotman writes: 'Information is the removal of some uncertainty, the destruction of ignorance and its replacement by knowledge. [...] Thus the quantity of potential information depends on the presence of alternative possibilities.' (p. 13). Later he writes: 'An act of communication is the basis of every narration. It presupposes: 1 . A sender of information (addresser); 2. A receiver of information (addressee); 3 . A channel of communication between them which may be any structure which facilitates communication - from a telephone wire to a natural language, a system of customs, art norms or the sum of cultural monuments; 4. A message (text). The classical scheme for the communicative act was provided by Roman Jakobson.' (p. 36).

35 Maxim Waldenstein, The Soviet Empire of Signs: A History of the Tartu School of Semiotics (Saarbrücken: VDM Verlag Dr. Müller, 2008), p. 19. Waldenstein notes that Muscovite linguists such as Vyacheslav V. Ivanov focus on the transposition of cybernetic terminology into the field of linguistics, as performed by Jakobson. More generally, Waldenstein points out that 'Soviet structural linguistics emerged in the mid-1950s under the auspices of recently rehabilitated and very popular cybernetics' (p. 18).

36 To learn more about how cybernetics was received in the USSR, see Segal, Le Zéro et le Un, pp. 324-25; or Waldenstein, The Soviet Empire of Signs, pp. 17-28. 
ics School of Tartu and playing a part in the popularity of structuralism in the USSR. The first semiotics class given by Lotman in 1962 at the University of Tartu was part of the 'major in cybernetics'. Norbert Wiener would also take part in the first International Federation for Automatic Control conference in Moscow in 1960.

\section{Code in the Work of Christian Metz}

In 'The Cinema: Language or Language System?', the word 'code' is in part attached by Metz to the cybernetic model while also being used in a broader sense, harking back to Saussure's language system. The language system is therefore perceived as a 'highly organized code' ${ }^{37}$ Saussure speaks thus of the 'language' in his Course in General Linguistics. ${ }^{38}$ With regards to Jakobson's work and phonological systems, Metz also mentions this notion, whereby the code refers back to the position of the phonemes in the phonemic grid of each language'. ${ }^{39}$ The concept also appears when describing the cinematic image as a 'rich message with poor code' ${ }^{40}$ implying the quantifiable nature of information in Shannon's theory.

Metz evokes the code/message dichotomy once again when he discusses cybernetics. He ironically criticizes computer scientists who have used machines to 'dissect language'. Cybernetics is therefore present in the work of Christian Metz in 1964, as an extreme example of communication and significance modelling, quite at odds with cinematic language, which is barely coded and eminently 'flexible'. At the end of the text, Metz explicitly aligns natural languages with binary language, contrasting them with cinematic language. ${ }^{41}$

In Metz's writings dating from 1964 to 1967 , certain aspects of the cinematic language and the denotation/connotation dichotomy elude coding, due to the emphasis Metz places on phenomenology. The decisive role given to the analogy of the cinematic image constitutes a leitmotif in his early semiotic thinking. The focus on film 'narrativity' as a factor for the organization of 'large signifying units' is also a recurring feature in 'The

38 Ferdinand de Saussure, Course in General Linguistics [1913], trans. and ed. by Roy Harris (Peru: Open Court, 1983), p. 14. See also pp. 18 and 26.

39 Metz, 'The Cinema: Language or Language System?', p. 64.

40 Ibid., p. 69.

41 Ibid., p. 90. 
Cinema: Language or Language System?', 'Some Points in the Semiotics of Cinema', and 'Problems of Denotation in the Fiction Film'. ${ }^{42}$

In 'Some Points in the Semiotics of Cinema' of 1966, Metz places narration and the diegetic elements ('the characters, the landscapes, the events', etc.) in the denotation camp..$^{43}$ The reason why a semiotics of denotation is possible in film is precisely because the unfurling of the narrative brings forth a reasoned structure of signifiers. Metz explains that such a structure is 'to a certain extent codified', specifying that it is 'codified, not necessarily encoded'. ${ }^{44}$ Here, the code concept within linguistics ('the language code') remains present in Metz's mind as he unveils his argument with customary caution. In the same article, Metz mentions the paradigmatic and clearly associates cinematic framing to 'acts of speech', as opposed to the word within the language system, which, according to Metz, is 'precast by code'. ${ }^{45}$

An important fracture starts to appear in 1967-1968 in Metz's semiotic approach. The pluricodic turning point which then occurs takes place after the meeting between Metz and Umberto Eco in Pesaro. ${ }^{46}$ In 1968, Umberto Eco publishes La struttura assente ['The Absent Structure'], in which information theory plays a substantial role. The mathematical theory of communication is debated and leads Eco to draw the contours of the 'lower threshold' below which semiotic research has no stronghold; an area where 'meaning' gives way to 'signal'. ${ }^{47}$ If the issue of the transmission of information as 'physical units' is outside the scope of semiotics, the model and the terms derived from the mathematical theory of communication nevertheless guide the entire theoretical apparatus developed by Eco.

Thus, the pattern of communication that he features uses terms such as 'signal', 'channel', 'noise', and 'message'. 'The semiotic information' is thought of along the lines of 'physical information' of a given message, borrowed from Shannon's model. Eco stresses that these two types of information 'correspond to the same definitions' and that 'they represent a state of freedom with respect to determinations'. ${ }^{8}$ Hence, evolutions in semiotic

42 See ibid., pp. 44-49; 'Some Points in the Semiotics of Cinema', pp. 93-99; 'Problems of Denotation in the Fiction Film', pp. 117-33.

43 Metz, 'Some Points in the Semiotics of Cinema', p. 98.

44 Ibid., p. 99 (emphasis in original).

45 Ibid., p. 100. In this article, connotation is not discussed in terms of codicity.

46 See Martin Lefebvre's article in this volume.

47 Umberto Eco, La structure absente. Introduction à la recherche sémiotique, trans. by Uccio Esposito-Torrigiani (Paris: Mercure de France, 1972 [1968]), pp. 39-54 (Eco's book has never been translated completely into English).

48 Eco, La structure absente, 118. 
research among Italian authors in the late 196os, which lean towards a greater consideration of the plurality of codes and plurality of 'media', ${ }^{49}$ profoundly influenced the work of Metz.

Thus, the comments put forward by Metz on earlier texts in the footnotes of Film Language show a considerable change in perspective. Expressiveness, which was once an earlier step prior to the process of signification, is now attached to forms of socio-cultural codifications, which are more or less rigid. The domain of the code thus extends itself to cover the full production of meaning in cinema..$^{5}$ Indeed, cinematic language is only part of the overall global message that the film represents. Other levels of the message, whether perceptual, cultural, or narrative, also fall under the code's register. ${ }^{51}$ In 'Problems of Denotation in the Fictional Film', the analogy becomes a threshold between 'specialized codes' and 'cultural codes'. ${ }^{2}$ Metz says then, in his 1968 notes that accompany 'The Cinema: Language or Language System?', that he considers 'the realities codes possess [to be] more complex, more various, subtler [...].'53

\section{Decoding Language and Cinema}

Metz's multi-codic paradigm reaches its peak in 1971 in Language and Cinema. Metz then clearly distinguishes, on the one hand, the codes that are considered 'systematically homogeneous units' and languages, which are 'physically homogeneous units.' ${ }^{44}$ Strong association emerges between languages, which are discussed in the context of the 'material of expression', in Hjelmslev's terms ${ }^{55}$ and codes, which are discussed in terms of their

49 Gianfranco Bettetini and Emilio Garroni's books, published in 1968, are other examples of this pluricodic turning point. Gianfranco Bettetini, Cinema, lingua e scrittura (Milan: Bompiani, 1968); Emilio Garroni, Semiotica ed estetica (Bari: Laterza, 1968).

50 See Metz's ‘self-criticism' expressed in note 1 of 'Au-delà de l'analogie, l'image', Communications, 15 (1970), 1-10 (p. 3); reprinted in Christian Metz, Essais sur la signification au cinéma, 2 vols. (Paris: Méridiens Klincksieck, 1972), II, pp. 151-162. His view of the codifed character of analogy is close to Eco's views described in La structure absente. Eco also contributes to the issue of Communications in question, edited by Metz; Umberto Eco, 'Sémiologie des messages visuels', pp. 11-51.

$5^{1}$ Metz, 'The Cinema: Language or Language System?', see note ** added in 1968, p. 78.

52 Metz, 'Problems of Denotation in the Fiction Film', pp. 110-14.

53 Metz, 'The Cinema: Language or Language System?', see note *, p. 49.

54 Metz, Language and Cinema, p. 35.

55 For a discussion of concepts such as 'form', 'material', and 'substance' as Metz uses them, see Metz, Language and Cinema, pp. 208-23. 
transferability from one language to another, or, on the contrary, to their dependence on a particular medium.

Let us now look at definitions of the code submitted by Metz in Language and Cinema.${ }^{5}$ At first, Metz defines code as a 'domain within which the transformations of the signifiers corresponds to variations in the signified'.57 This broad definition should therefore correspond to all codes described in the book: the 'code of editing', the code of 'cinematic punctuation', ${ }^{8}$ codes of framing, lighting, or even 'technological codes'. ${ }^{59}$

Metz also provides an example of a technological code by way of the code of mechanical reproduction of movement, which ensures the passage of photograms, discrete units, to the uninterrupted visual image on the screen, which produces an impression of movement. Thus, the units of this technological code are photograms. Here, the idea of the code is similar to that formulated by information theory. The code of mechanical reproduction of movement accounts for the shift from a sequence of discrete units to a continuous flow, two levels that depend on the materiality of the cinematic image (or its projected materiality). Metz himself performs this comparison, associating technological codes with computer programmes:

On the other hand, one also finds at least one group of codes in which the photogram is certainly the minimal unit [...]: we are thinking of the technological codes which are involved in the very functioning of the cinematic equipment (of the camera), which are its program (in the sense that one speaks of the program of a computer) and which constitute the very principle of its construction and operation. ${ }^{60}$

This proximity is justified by the mechanical aspect of cinema that is discussed here by Metz. He can thus envisage it in technological terms. In comparison, the units of the film editing code are 'sequences', abstract units that must be identified and defined by the analyst. These units entail a set of correlations between the arrangement of cinematic signifiers and their implications in terms of meaning. This in turn links back to the

56 For a complete and scholarly description of the conceptual framework developed by Metz in Language and Cinema, see Philip Rosen's article in this volume.

57 Metz, Language and Cinema, p. 29.

58 Ibid., p. 108, 129.

59 Ibid., p. 191.

60 Ibid. 
spatio-temporal organization of some elements of the diegesis. ${ }^{61}$ Comparing the technological code mentioned above to the film editing code, one sees how the flexible notion of code is used by Metz to account for a highly diverse set of realities.

The definition of the concept of code in Language and Cinema also crops up many times in comparison with natural languages that are themselves constructed according to a hierarchy of codes: phonological, morphological, syntactic, or by other codes due to their phonation. Moreover, when Metz justifies the distinction he makes between code and system, he comes back to the origins of the concept and evokes information theory:

In its original context, i.e., information theory, it serves to name a system of similarities and differences which, by definition, is designed to serve repeatedly and to remain the same across numerous 'messages'. In linguistics, into which the word was later imported, it refers to langue (but not langage, discourse, or utterance), which presents the same character of anonymous repeated applicability. ${ }^{62}$

Metz then uses ordinary language to justify his use of the term, designed as an infinitely reusable system. ${ }^{63}$ Given the diversity of codes mentioned in Language and Cinema - also diversity of nature, as shown in the example of technological codes - one can imagine that the original meaning of the concept of code as a 'system of similarities and differences' comes into play in the design of Metz's code. Indeed, all the codes and sub-codes in Language and Cinema are not codes on the same footing as Saussure's langue; they do not all represent a 'domain within which the transformations of the signifier correspond to variations in the signified' but they all make up 'systems of similarities and differences': this is the meaning given by Metz to information theory code.

Beyond this terminological development carried out by Metz, the most common definition, in Language and Cinema, to qualify the code is that of a 'unified field of commutations', borrowed from Hjelmslev. ${ }^{64}$ This passage by

61 Ibid., pp. 200-01 (emphasis in original); 'Problems of Denotation in the Fiction Film', pp. 143-44.

62 Metz, Language and Cinema, p. 83 .

63 For more on the rhetorical use of 'ordinary language' in Metz's theoretical approach, see Selim Krichane, 'La sémiologie de Christian Metz: convergence des champs et stratégies de légitimation' (Master's thesis, unpublished, 2009), p. 36.

64 Metz, Language and Cinema, p. 29. Metz notes: 'a (reconstructed) "domain” within which the transformations of the signifier correspond to variations in the signified, and within which 
Hjelmslev is not trivial. On the one hand, his model has the merit of analyzing the processes of signification regardless of the medium at hand, and on the other hand, it supplies a detailed analysis grid of the materiality of language. Thanks to this, his presentation could theoretically be transferred to other mediums besides the phonic or graphic matter of natural languages.

Another feature of glossematics, which was notably commented on by Thomas Pavel: the theoretical paradigm developed by Hjelmslev is exactly in line with the positivist tradition that emerged from the Vienna Circle and thus attempts to provide a formalization of language functioning, in accordance with the foundations of logical empiricism. In Hjelmslev's opinion, theory must be deductive, and due to the constraints of coherence, exhaustiveness, and simplicity, it should be possible for it to provide a formal calculation procedure which, at a later stage, would be confronted with the concrete data of natural languages. ${ }^{65}$ Thus, just as Hjelmslev does, Metz considers codes as purely formal systems.

Hjelmslev's work serves as a theoretical anchor to Metz's developments and is in no way implemented in its entirety. Metz notes on numerous occasions that cinematic codes are more flexible, less rigid than their linguistic equivalents. All textual systems generate a shift in the codes that they activate - in a textual system codes overlap, complement, or cancel each other out - but nothing like this takes place in Hjelmslev's model.$^{66}$ Even if Metz's understanding of glossematics is remote, metaphorical in a sense, the positivist and logical model remains present in the background and provides a guarantee of rigour in Metz's semiotic approach.

Despite the fact that textual systems entail a shift in codes and generate codical interferences, Metz does not abandon the radical possibility of reconstructing, by induction and using films as a base, cinematic language as a set of codes and sub-codes that are specifically cinematic and classified by degree of specificity, based on their dependence on certain traits of the material of expression.

The empirical and logical touch of Metz's semiotics recalls the systematic organization and orderly division of the processes of signification borrowed by Jakobson from information theory, when he set forth his communication model in 1960. This orderly character, quasi-algorithmic of meaning, is

a certain number of elements have meaning only in relation to each other'.

65 Thomas G. Pavel, The Spell of Language: Poststructuralism and Speculation (Chicago: University of Chicago Press, 2001 [1989]), pp. 55-56.

66 Metz, Language and Cinema; in particular see the chapter 'The system of the film as displacement', pp. 99-104. 
reinforced and supported by the positivist and logical model of glossematics. Metz repeats the inaugural gesture of Shannon when he endeavours to completely detach his model of analysis from the content of the observed phenomena. Towards the end of the book, Metz will note that the codes discussed are only 'codes of expression' rather than 'codes of content'. ${ }^{67}$

When he mentions the possibility of preparing an inventory of all the cinematic codes and sub-codes, Metz talks about this undertaking in a contradictory manner. On the one hand, he tells us, cinema is a language that is too rich, too important a cultural phenomenon to be reduced to an inventory of codes. But, on the other hand, film semiotics being a recent field, much younger than linguistics, one cannot exclude the possibility that one day semiotics of cinema will be able to reach a level of formalization comparable to that of linguistic models. ${ }^{68}$ This is where a tension arises that is present throughout Language and Cinema, oscillating between the wish for scientific modelling and applied detailed analysis that measures the necessary gaps, the perpetual differences, between the systematic model and films themselves.

In The Imaginary Signifier, the code cedes its prime place in Metz's theoretical arena. Whereas, a few years ago, the effort to construct a pluricodic model aimed to contest the perception of cinematic language as a unique code, the psychoanalytic turning point in Metz's work allows the code to stay in the singular. Metz speaks about the 'cinematic code' ${ }^{\prime 69}$ to designate the precise arrangement specific to the cinematic experience that materializes as the institution of the ego and the institution of cinema intersect. The code becomes synonymous with the cinematic apparatus as a whole, the singular vectors of experience that make up 'the filmic state'. ${ }^{70}$ Meanwhile, the term is also used to denote features that are unique to this scheme of experience, such as identification codes and sub-codes.

The concept of code therefore plays a variety of roles in the writings of Christian Metz, as I have tried to demonstrate in this brief overview. Language and Cinema is also the code's moment of hegemony in the work of Christian Metz, where its information theory roots are the most apparent.

67 'Codes of content' are defined by Metz as codes that can exist in all types of cultural production, codes free of all traits of the 'material of expression'. Metz, Language and Cinema, pp. 245-51. 68 Metz, Language and Cinema, pp. 286-87.

69 Metz, The Imaginary Signifier: Psychoanalysis and the Cinema (Bloomington: Indiana University Press, 1982), p. 54.

70 Ibid., p. 138. 


\section{Christian Metz and Game Studies}

Between information theory and semiotics, a lexical contagion has arisen, carrying with it the shadow of a model targeted at thinking of communication as a logical and systematic process of encoding and decoding. This was in fact my hypothesis. One may wonder if this relationship, whether we consider it as being simply a terminological one or, on the contrary, a conceptual one, has led some video game theorists to tap into Metz's model in order to reflect on videogame structures, or to think about the gaming experience.

Christian Metz was touched upon in the field of Game Studies at the inaugural debate between 'narratologists' and 'ludologists' that marked the early years of the discipline. As early as 2001, some researchers, such as Espen Aarseth, Gonzalo Frasca, and Markku Eskelinen, advocated for the establishment of a field of research that would have its own analytical and conceptual tools, without regard to literary or cinematic studies. ${ }^{71}$ They believed that the study of video games should focus on the particularities of the video games' structure as a media object. In their view, research should concentrate on the unique position of the player in the gaming environment and on video game mechanics and the objects' other specific characteristics. Other researchers, called 'narratologists' in the early years of the field's existence, started working with video games and tried to apply the tools, or at least the perspectives, that had come from literary theory. ${ }^{72}$

In this divided environment, defenders of the specificity of gaming sometimes referred to Metz to reaffirm the impossibility of conducting a narratological-based study of video games. In 'The Gaming Situation', Markku Eskelinen attempts to lay the foundation for the study of video

71 See, for example, Markku Eskelinen, 'The Gaming Situation', Game Studies. The International Journal ofComputer Game Research, 1/1 (2001): http://www.gamestudies.org/o101/eskelinen/ (accessed 10 March 2014); Gonzalo Frasca, 'Ludology Meets Narratology: Similitude and Differences between (Video)Games and Narrative': http://www.ludology.org/articles/ludology.htm (accessed 10 March 2014); Espen Aarseth, Cybertext: Perspectives on Ergodic Literature (Baltimore: Johns Hopkins University Press, 1997), pp. 13-16.

72 See, for example, Marie-Laure Ryan, Narrative as Virtual Reality:Immersion and Interactivity in Literature and Electronic Media (Baltimore: Johns Hopkins University Press, 2001). For a summary of the controversy opposing 'ludologists' and 'narratologists', see Gonzalo Frasca, 'Ludologists Love Stories, too: Notes from a Debate that Never Took Place', in Level Up: Digital Games Research Conference Proceedings, ed. by Marinka Copier and others (Utrecht: Utrecht University, 2003), pp. 92-99; Selim Krichane, 'Récit et jeux vidéo: l'exemple du scénario d'Assassin's Creed.' (Video Games and Storytelling: Assassin's Creed's scenario), Archipel, revue littéraire romande, 34 (2011), pp. 153-6o. 
games as opposed to the study of literary and cinematic works. Eskelinen quotes Metz to point out that video games do not possess the equivalent of the dual temporality of narrative: according to the famous statement of Christian Metz, 'one of the functions of narrative is to invent one time scheme in terms of another time scheme'.73 Contrary to this, in games there is only one time scheme necessary: the movement from the beginning to the winning (or some other) outcome. In cases where another time scheme is invented, it is not as important as the first one. ${ }^{74}$

Video games therefore would only require one level of temporality; that of the immediate interaction of the player with the video game's environment. This point is also made by Jesper Juul in the same issue of Game Studies, where he states that no distinction is visible in the gaming experience which could be seen as equivalent to that between story time and plot time. Juul also speaks about the dual temporality, as expounded by Metz, to give weight to his argument. ${ }^{75}$ It is Metz as narratologist who is called upon here, in a negative manner in a sense, to distinguish the gaming temporality from the literary or cinematic equivalent.

As for the 'narratologists', they do not mention Metz, and usually limit themselves to a description of the convergence between game and narrative. ${ }^{76}$ Some of the specificities that the two forms have in common are linear progression, space dedicated to the game/narrative, and structures of the 'quest' or the 'riddle'. Some recent work, such as that completed by Sébastien Genvo or Boris Solinski, ${ }^{77}$ lean more toward action semantics, as developed by Greimas, to discuss the relationship between narrative and video games.

Although much research involving video games has been oriented towards textual analysis, often immanentist, of videogame objects, references to semiotics are rare. According to Espen Aarseth, author of Cybertext:Perspectives

73 Christian Metz, 'Notes Toward a Phenomenology of the Narrative' [1966], in Film Language, 16-28 (p. 18).

74 Eskelinen, 'The Gaming Situation', no page number.

75 Jesper Juul, 'Games Telling Stories? A Brief Note on Games and Narratives', Game Studies. The InternationalJournal of Computer Game Research, 1/1 (2001): http://www.gamestudies.org/o101/ juul-gts/ (accessed 1o March 2014).

76 Janet Murray, 'From Game-Story to Cyberdrama', in First Person. New Media as Story, Performance, and Game, ed. by Noah Wardrip-Fruin and others (Cambridge: MIT Press, 2004), 2-11 (p. 2).

77 Sébastien Genvo, Le jeu à son ère numérique. Comprendre et analyser les jeux vidéo (Paris: L'Harmattan, 2009), pp. 147-62; Boris Solinski, 'Pour une théorie hédoniste du jeu: application du modèle circomplexe des émotions à la compréhension de l'acte ludique', in Espaces et temps des jeux vidéo, ed. by Hovig Ter Minassian and others (Paris: Questions Théoriques, 2012), pp. 98-110. 
on Ergodic Literature, methods of analysis of structuralism were developed for linear objects, regarded as sequences or chains of clearly ordered signs. ${ }^{7^{8}}$ At the same time, digital objects have two levels of material arrangement. Aarseth calls them 'interface' and 'database'. ${ }^{79}$ For Aarseth, who is supported by many theorists, video game analysts must create a new theoretical model to understand these objects, a model that is adapted to their dual materiality. Therefore, literary and semiotic approaches are rejected, on the whole.

\section{Play Studies: The 'French Touch'}

In recent years, several French researchers have contested the immanentist approach of Game Studies and have been campaigning for what they call PlayStudies, studies of video games that would focus on the player's experience rather than video games as formal structures.

Mathieu Triclot, author of Philosophie desJeux Vidéo (The Philosophy of Video Games), is one of the main advocates of this approach. According to Triclot, video games produce a unique form of experience, an 'instrumented experience', ${ }^{80}$ due to the rapport of the player to the computer. Triclot examines video games through the realm of the experience, the terms of subjectivity created by the medium. As he describes the characteristics of this experience, Triclot finds inspiration in Metz's notion of 'filmic state', which helps him elaborate and describe the 'gaming state'.

Triclot incorporates the distinctive elements of the 'filmic state', as Metz presented them in the first part of the Imaginary Signifier, to describe the characteristics of the relationship between the player and the visual discourse of video games. Hence, the author tries to describe what takes place during the game in terms of affect, rapport with the image, identification, and desire - but also the relationship to reality. I will not dwell on his cross-analysis, but I would like to note that this comparative approach, using Christian Metz's work, is reminiscent of the starting point of film semiotics in 'The Cinema: Language or Language System?', where Metz defines his theoretical framework by comparing cinema to verbal language, thus differentiating semiotics from linguistics.

78 Aarseth, Cybertext, p. 26. According to Aarseth, semiotics would be unable to take cybertexts into account, since it assumes that text represents a linear sequence of signs (here he quotes Hjelmslev), whereas cybertexts are fundametally non-linear.

79 Aarseth, Cybertext, pp. 103-05.

8 o Mathieu Triclot, Philosophie des jeux video (Paris: La Découverte, 2011), p. 17. 
In a more recent article, dedicated to space and time in video games, Triclot stresses the need to understand videogame objects by various means to truly grasp their complexity. ${ }^{8_{1}}$ Video game spaces can refer to the space outlined by the circulation of video games as commodities, to the geography of production spaces, and also to the typical environments where video games have been played during the last 40 years (the mall, the living room, etc.). But Triclot says that video game spaces also concern spaces internal to video games, which can be comprehended through a semiotics of video games. This study would be mindful of the historical and social conditions that shape the evolution of video game genres. ${ }^{82}$ To illustrate his points, Triclot notably provides a brief overview of the evolution of the internal construction of videogame spaces, using classic arcade games of the first half of the 1970s as examples. The philosopher of technology then identifies strong regularities in the construction of these spaces, a set that combines basic forms and historically identifiable transformations, which lead him to predicate the existence of 'laws specific to gaming space'. ${ }^{3}$

One would have liked Triclot to develop this intuition of a semiotics of video games employing the work of Christian Metz, as he did illustriously in his Philosophie des Jeux Vidéo. If a semiotic approach can today be part of all multidisciplinary research devoted to video games, as Triclot implies, then allow me to say this: the time has come for a semiotics of video games!

\section{Translated from French by Corinne Bou}

\section{About the author}

Selim Krichane is a postdoctoral researcher at the University of Lausanne's Department of Film History and Aesthetics. He recently finished his PhD thesis (supervised by Prof. Alain Boillat) entitled The Imaginary Camera focusing on the influence of film aesthetics in the history of video games. He has published articles on video games and cinema in the journals Décadrages (nos. 9, 21), Archipel (no. 34), and in several collected volumes (Le héros était une femme... Les genres de l'aventure, 2012; Pouvoir des jeux vidéo, 2014; La capture de mouvement, 2014).

81 Mathieu Triclot, 'Dedans, dehors et au milieu: les espaces du jeu video' in Espaces et temps des jeux video, pp. 207-35.

82 Ibid., p. 224.

83 Ibid., p. 228. 


\section{About the translator}

Corinne Bou is a translator and conference interpreter living and working in Geneva, Switzerland. She usually works for the United Nations organizations and the Government of Switzerland and specializes in legal translation and in medical, human rights, and liberal arts subjects. 



\title{
12. Yes, the Image Lies Beyond Analogy
}

\author{
Understanding Metz with Cartier-Bresson
}

Marc Vernet

Tröhler, Margrit and Guido Kirsten (eds.), Christian Metz and the Codes of Cinema. Film Semiology and Beyond. Amsterdam University Press, 2018

DOI: $10.5117 / 9789089648921 / \mathrm{CH} 12$

\begin{abstract}
Metzian semiology dates from the analog era (or the silver screen age), but a text like 'Au-delà de l'analogie, l'image' ('Beyond Analogy, the Image'), which furtively evokes the notion of 'purely relational entities' in the image, perhaps allows us to rethink the analog and its analysis on the basis of the notion of composition, in the sense of a signifying network of heterogeneous elements. By interrelating Metz's text with two photographs by Henri Cartier-Bresson, this chapter seeks a distance from the notion of realism, instead putting the accent on an organized symbolic construction, which is based on relational figurative entities.
\end{abstract}

Keywords: film semiotics/film semiology, visual analogy, realism, image theory, photography

Amidst the clamouring of debate around analog and digital, I sometimes wonder if Christian Metz would have been an analog and analog-only man, or if his semiology can be extended to the digital image. ${ }^{1}$ This somewhat vague but recurrent line of inquiry can be derived from sources here and there throughout Metz's work, in the idea of the mechanical, photographic, or cinematographic image that is distinct from painting; for example, in the profilmic's instantaneous, single shot recording. Would Christian Metz consider an image, isolated as a whole, to be the result of a single shot (this term in itself communicating the idea of the profilmic's instantaneous capture), or wouldn't he? In this vein, I also find myself contemplating the notion that digital allows us to re-examine certain frequently overlooked 
components of analog, such as the act of composing an image; constructing it in or out of studio by adjusting heterogeneous elements, as illustrated beautifully by the Schüfftan process and other rear-projection techniques. The analog image is composite, either by way of special effects, as in the cited example, or in the relating of objects that Francastel called 'figurative'. ${ }^{2}$ Whether an image is constructed from bits of space adjusted through digital compositing or from the coordination of figurative objects in analog is not of differential importance: both concern the image's composition.

Today I would like to test this proposition, building upon Metz's article, 'Au-delà de l'analogie, l'image' ('Beyond analogy, the image') from Essais sur la signification au cinéma, II. Metz himself admitted that the aim of this dense article is undoubtedly 'manifold and somewhat convoluted'. It is not really possible to address this article in isolation, for it is positioned precisely, and by design, between 'Images et pédagogie' (Images and pedagogy) ${ }^{4}$ and 'La connotation de nouveau' (Connotation, Reconsidered), ${ }^{5}$ with this group preceding 'Trucage et cinéma' ("Trucage" and the Film'), ${ }^{6}$ in which we find the first draft of Le signifiant imaginaire (The Imaginary Signifier). ${ }^{7}$ Further, I would like to test this idea as though the image (as an entity) could be reduced to one single, precise, isolated but authenticated image, in the style of the photogram.

'Au-delà de l'analogie, l'image' is partially the development of an endnote to 'Images et pédagogie', which is found a few pages previously (p.149) and is dedicated to the application of semiotics to images, as well as to the didactic concern of this endeavour. In broad terms, the aim of 'Au-delà de l'analogie, l'image' is to express that it is uninteresting to reduce the notion of image to that of likeness, which ultimately leaves nothing to analyze apart from the degree of resemblance (we know that Metz will return to this point in a way in The Imaginary Signifier, addressing Münsterberg's reflections on the absence of materiality in the cinematographic signifier - to which he adds the absence of recorded noise, in contrast to theatre). Further, Metz

2 Pierre Francastel, La figure et le lieu. L'ordre visuel du Quattrocentro (Paris: Gallimard, 1967), p. 63 .

3 Christian Metz, 'Au-delà de l'analogie, l'image' [1970], in Essais sur la signification au cinéma, 2 vols. (Paris: Editions Klincksieck, 1972), II, 151-62 (p. 159).

4 Christian Metz, 'Images et pédagogie' [1970], in Essais, II, pp. 141-49.

5 Christian Metz, 'La connotation de nouveau' [1972], in Essais, II, pp. 163-72.

6 Christian Metz, 'Trucage et cinéma', in Essais, II, pp. 173-92. This article has been published in English as “Trucage” and Cinema' [1972], trans. by Françoise Meltzer, Critical Inquiry, 3/4 (1977), pp. 657-75.

7 Christian Metz, Le signifiant imaginaire (Paris: 10/18, 1977), pp. 92-93. 
underscores the imagination's effectiveness in this absence of physical substance, the paradox of an immaterial medium - the interplay of light and shadow - and the spectator's strong sensation of reality. This grounds the argument that semiotics must treat both what comes before analogy (what constitutes it or what it is founded upon) and beyond analogy (what supplements it; it is clear that here he reinitiates reflection around denotation and connotation), with respect to all of the diverse systems that come to inform the image. Here Metz references, without much elaboration, Panofsky's iconography, the image's multiplicity of codes (Eco), and its 'socio-cultural stratifications' (Francastel, Barthes, and Bourdieu). ${ }^{8}$

Earlier in the text, Metz took care to specify that the divisions applied by semiotics do not necessarily coincide with 'units of socially conscious intention' (= genre) or with 'technical sensorial units' (= material of expression, media and other channels): "The units that semiotics seeks to draw out and toward which it leads [...], are structural configurations, "forms" in the Hjelmslevian definition of the term (forms of content or forms of expression), of systems. These entities are purely relational, commutability fields within which diverse units take meaning in relation to one another. ${ }^{10}$ It is clear that Metz seeks to detach his reflection from both technical objects and language (he does not refer to the image on film), and from a certain positivism (his commentary extends beyond what is present within the image) to highlight, as he repeatedly does, the necessity for theoretical analysis (structures and codes are not given: they are to be constructed) and the abstract character of structural relationships, in which the possibility of commutation is primordial.

What interests me here, and what I see as a deviation from Bazin and the open window onto the world, is this conception of the image as a system of relations or a field of commutability, a set for which the notion of support might be necessary but is not sufficient. In other words, if the technical sensorial unit is a continuum (a photograph, a shot, the field within a frame), the image is a network, a system of relations from which units acquire meaning by participating, by finding their place, and which only analysis can make sense of by breaking down this configuration to draw out its logic and productivity. Metz says 'form of content or form of expression' (emphasis added), because he is concerned with specifying the levels at play. But it seems to me, borrowing the example of Panofsky's 
iconography, that it should be form of expression and form of content; it is the nature of iconography, outside the scope of visual analogy, to connect visual attributes to meaning other than that of represented objects. The lily accompanying the young woman in Christian iconography is certainly a lily, but it is also, when linked to a young woman, a symbol of her purity and virginity. With this woman-lily relationship, we are not far from Eisenstein's reflection on the way in which meaning comes to images. This was also the meaning that Francastel gave to his notion of the figurative object (as evoked not for its resemblance but for its socio-cultural value). In this article, Metz references Jean Louis Schefer's association of image and language, his affirmation that there is no image if it has not been described, and as such invested with writing. ${ }^{11}$ Whether it is invested with Scheferian writing or with semiotics, the result is the same: the image is only an image when analysis has brought systems up to date and revealed the interwoven units that give it meaning. For me, Metz here (and perhaps even better here than if he had gone on to do this in the article on connotation in which he contents himself with underscoring the 'ways to film' $)^{12}$ brings to the fore the notion of composition; that is, the relating of figurative objects within a frame. A doubt remains: it is not certain in Metz's text that the image can be reduced to 'an image'; the image at hand is rather the relationship between filmic images as in the Grand Syntagmatique (the origin of this notion of fields of commutability). I, for one, would make the gamble that Metz's argument also applies to an image, to the representational elements contained within a single frame.

Composition is not only the aesthetic balance of masses and colours: it creates, structures, and elaborates meaning in the relationships that it establishes within the visual field. Units take meaning in relation to one another (and not in relation to the truth, reality, or even ideology). As such, we can conceive of an analog image (photographic or cinematographic) as an editing field within a frame, the establishment of meaning-bearing relationships among heterogeneous parts. The difference between analog and digital is then barely existent, when we speak, for example, of 'compositing'. Even in the era of analog, the image owed something to Frankenstein.

From this point of view, 'Au-delà de l'analogie, l'image' brings Metz rather naturally to "Trucage" and Cinema' which appears two articles later, and to a line of inquiry to which he will rarely return (apart from in parts of

Metz, 'La connotation de nouveau', in Essais, II, p. 164. 
L'énonciation impersonnelle [Impersonal Enuncation]): ${ }^{13}$ that of the spectator's consumption and appreciation of the fiction and the enunciation, the two at once and the two in equal measure. Here, not only does analogy stand dislodged, so does the strongly held fundamental belief that in order for the cinematographic spectacle to succeed, the act of enunciation must be completely forgotten. No, to love an image is to love what it represents as well as its creator (this could be a person, an institution, or a person transformed into an institution). It is to love the warmth of fiction, along with the decisive calculation of he or she who puts it on display and defines it by their choices.

To better grasp this question of form, of relational network, I would like to examine not cinema but photography, with two Henri Cartier-Bresson photos that appear a few pages apart in section 8 (no other title) of his last volume, Paysages (Landscape). ${ }^{14}$ I will begin with a few words about the second (second in the book and also second in my presentation) whose only caption reads 'Brienza Italy 1973' (Figure 12.2). This photograph is very well known for the considerable amiability of the cat passing through it, testifying to the shot's instantaneity, its on-the-fly capture in what the Surrealists might call an instance of objective chance. Brienza is in Basilicata, in the south of Italy; we might say on the boot's sole. I would like to enlighten our understanding of this image with a first photo (Figure 12.1), caption 'Rome 1959', because the two photos make a system in that they inform one another and in that the second clearly appears to be a variation, a refinement of the first.

With the first image, we better understand the absence of the part of the caption that would explain the analogy at hand ('young girl playing in the courtyard' or 'young girl in a sunbeam'). We understand that this is precisely what Cartier-Bresson aims to avoid in indicating only the place and year, or the conditions of the shot, which say nothing about the photograph itself.

Photo 1 is in vertical format with a rather simple system of oppositions: expansive (the buildings) / reduced (the young girl), high / low, shadow / light, the immobility of the building / the mobility of the running young girl. The photo also plays on framing, ${ }^{15}$ not only with the young girl in the slice of light but also with the doors and windows. However, these open into darkness,

13 Christian Metz, Lénonciation impersonelle, ou le site du film (Paris: Méridiens Klincksieck, 1991).

14 Henri Cartier-Bresson, Paysages (Paris: Delpire, 2001), number 87: 'Brienza Italy 1973'; number 83: 'Rome 1959'.

15 Framing indicates the presence, within the image's frame, of other frames that cut up or divide parts of the visual field. 


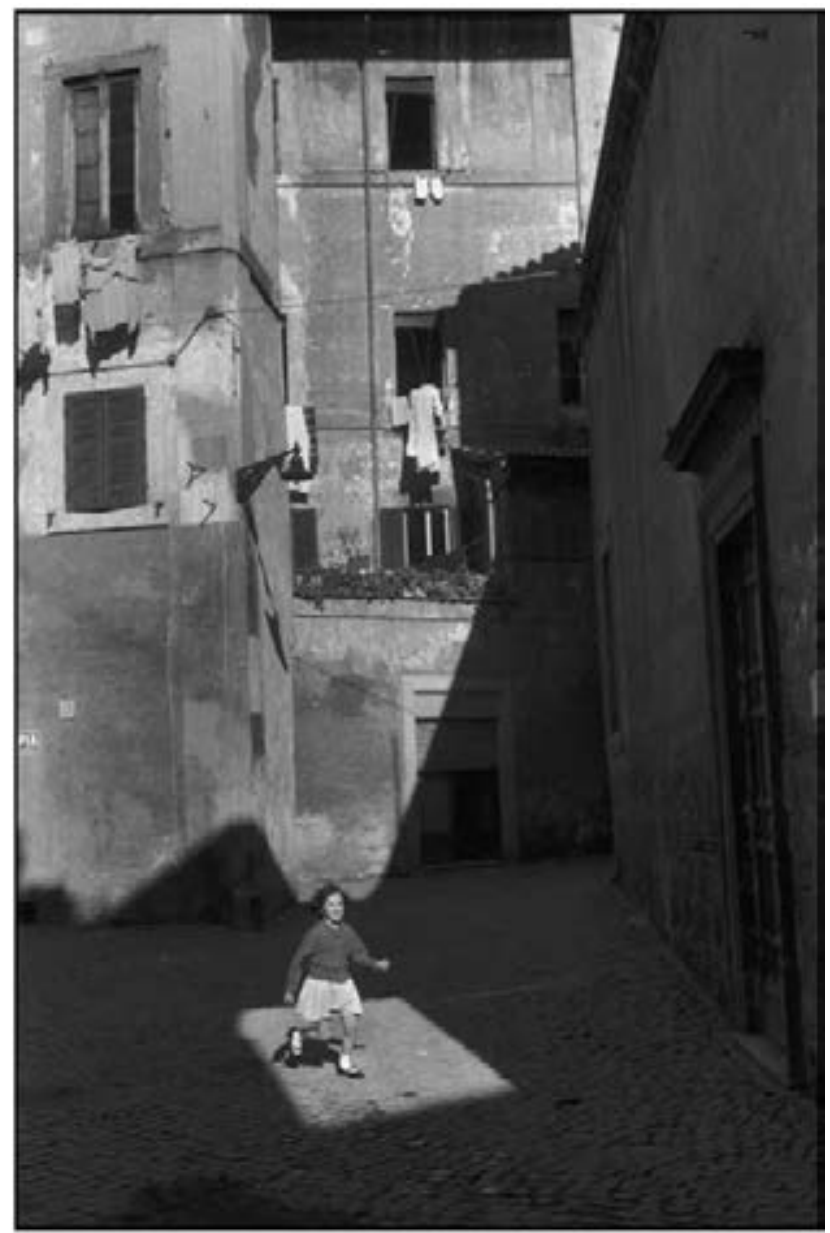

Fig. 12.1: Rome. 1959. @ Henri Cartier-Bresson/Magnum Photos

while the frame in which the girl appears opens into light. Laundry hangs from windows that open into black, while in the puddle of light the young girl emerges and stands out. Here we have, as seen often with Cartier-Bresson, a mise en abyme of the photographic act, the very act of snapping the photo: part framing, part triggering, and of course, part the effect of the conjunction of the two, in a double mastery of space (framing) and time (the fraction of a second, the vivid instant). This photo was possible neither a fraction of a second earlier nor a fraction of a second later than it was taken.

Cartier-Bresson's art is evident in this immensely powerful framing, the shadow precisely bevelled from the front and the right, and in the camera click's precision, immortalizing the young girl in her square of light. But the 
power of this photo is also in what adds to the opposition between the sombre magnitude of the houses and the luminous fragility of the young girl: the repeated opposition between dark and bright, the cold (evidenced by the girl's jacket) and the sunny, the inorganic and the living, the dominant (the buildings, the shadow's diagonal) and the emergent (the young girl), the solitary and the frolicking, the melancholic and the merry. It is clear that Cartier-Bresson could only have made this work after choosing the high contrast black and white that allows him to deal in strong binary oppositions. The material of expression, in addition to the form that it is given, determines the form of the content in this photo's engaging scene, in which our conception of childhood (as playful, irrepressible, etc.) certainly plays a role. What part did production play in this photo? Cartier-Bresson could have asked the young girl to run through the sunny rectangle. I do not know that he did, but luckily Cartier-Bresson is not Doisneau. It also seems that this photo gains power from yet another source: the uniform flatness of the buildings (no balconies, no porches), reinforced by their frontal or lateral positioning, the slightly downward-facing viewpoint, and the small courtyard closed on three sides. These transform this fragment of cityscape into a theatre stage, even if we must add, 'in the Italian style'. In this way this unassuming running child bathed in a ray of light, buoyant with her outstretched arms and free-flying feet, recalls, in resemblance and in difference, the image of a ballerina on stage and in the spotlight. Or, if we consider the courtyard as a volume of space as opposed to a hollow, that of a bird escaping from its cage. The scene revives a childlike imagination, which we gladly lend it, so as to relieve the gloom of the surrounding houses. This photo is the moment of a double miracle: the miracle of hidden composition and the transformation of a small courtyard into a ballet stage.

The second photograph is slightly more complex and promptly dismisses the suspicion that I have just, no doubt falsely, formulated: it is impossible to ask a cat, particularly an Italian one, to please place his head precisely in a ray of light and to keep his front left paw elevated. This photo is thus one of those incredible Cartier-Bresson snapshots (he cleverly reduced this art to the 'decisive moment', explaining nothing), but here again with a remarkable architectural composition. This time the format is horizontal and the interplay of shadow and light composes three true units: the cat nearly in the centre; a group of men and women to the left in the foreground; and a woman's profile above and to the right in the background, at the very back. By a kind of miracle confirmed by the impression of instantaneity (I will return to this), all of the living beings are in light, while the shadow empties the small square of all life. There is again in this photograph something of the theatrical, in the full meaning of the word: a stage (the small square) on which groups are 


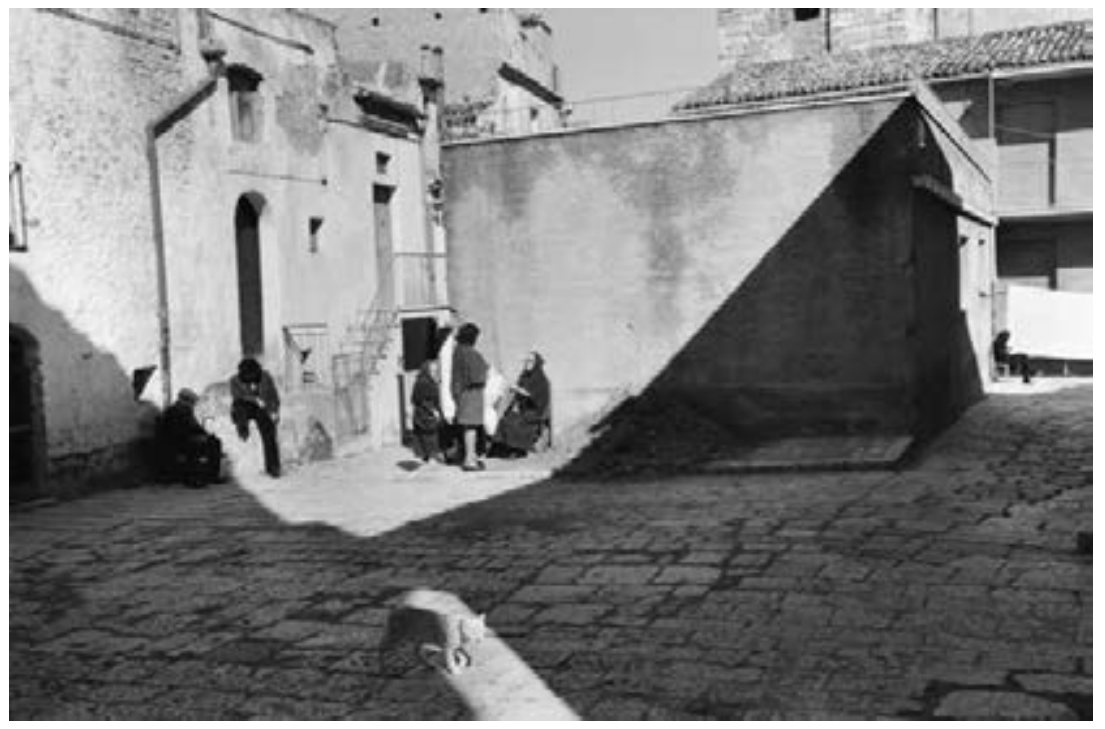

Fig. 12.2: Brienza. Italy. 1973. @ Henri Cartier-Bresson/Magnum Photos

arranged (the cat, the gossipers, and the solitary woman), where three separate 'spotlights' isolate and distinguish these groups from one another. There is also the monumental element that we identified in the preceding photograph: the stoniness of the setting, ${ }^{16}$ which sets the theatrical stage and impacts both the composition (the ratio of the masses of houses and people, the black sheet of shadow stretched between pockets of light) and the dramaturgy (the inorganic against the living, the cold against the hot, darkness creeping towards life). There is, of course, a little sociology at play: in the group on the left, the men do not mix with the women (and vice versa) because their subjects of conversation cannot be the same and because the women seem to be working, while the men do not share this burden. There is also the opposition of the group on the left and the women in the back, those who participate in a community and she who refuses it (from this point of view, the women in the back echoes the cat in front). Like this unornamented village, the photograph is very simple: it does what it can with black and white, with shadow and light.

Is that all? I don't believe so. The power of this photograph also seems to derive from a pleasurably discrete element that I will call the shadow's anchor point, where the upper incline settles precisely at the central cube's front point, in order to oppose and establish a relationship between the two

16 As in the preceding photo, there is no evidence of plant or vegetal life in these spaces: only the stone that we might call 'stripped'. 
human groups on the left (the gossipers) and the one on the right (the exiled woman above and to the right). This photograph was not produced (in that its structural configurations were not deliberately established, to borrow Metz's definition) by Cartier-Bresson. He did not arrange these people, who ignore him completely. The sun took care of this, as these southern Italians, not very young and not very rich, are here in winter (Cartier-Bresson very much likes the winter sun and the way its beautiful white light contrasts with the season's outsized shadows) evidenced by their mantels and shawls, 'taking the sun' (we can imagine that in summer this picture would be reversed, as people flee the sun). With the exception of the cat, it is this natural condition that arranges the subjects' positioning within the field, or rather on the stage, of this small square entirely devoid of any accessory, any plant, any object, further reinforcing the grouping of the humans and the cat's passage. Erving Goffman might call this, 'a presentation of self in everyday life, ${ }^{17}$ with what it communicates about nature (the sun) and culture (a village in the south of Italy). It must also be said that, as in the preceding photograph, the emptiness of the framed space and the stark paucity of urban stone, accentuated by the shadow's hold over it, contributes to the bursting forth of the living beings, who stand dispersed in space while the frame keeps them all together (the other structural configuration). The network is here established on a backdrop of space (the small square), which at once unites and separates, disperses and incorporates, pulls apart and brings together: or, to use Metz's terms, it is of course a technical sensorial unit base that establishes the configuration, which surpasses the simple analogy and the (vain) comparison of terms.

But we must admit that while the signifying units of this photograph were not produced by Cartier-Bresson (in the sense that the scene was not created per the photographer's instructions), they were lengthily observed by the photographer, who certainly identified the place, watched the villagers' practices, saw the shadow's possibility and patiently awaited two things: that the shadow would settle at the corner of the central cube, and that the cat felt like passing through the square of sunlight (to maximize the image's character and power, this small foregrounded square could not remain empty). A snapshot, certainly, but one long meditated, attempted (as in the preceding photo), reworked, and anticipated in order for frame and composition to come together to create these particular systems. If this photograph goes beyond analogy, it is due to the patience and the artistry of the photographer, who saw beyond the snapshot. 
We must also take into account the timelessness that the arrangement, clothing, and habit (to take sun in winter) add to the photograph's immobility: we could be in 1930 just as easily as in 1973 (the photograph's date), in Spain as easily as in Italy. In this way, the fraction of a second that the cat makes evident ironically underscores the scene's timelessness, a timelessness established only by the practices of the particular season (to warm up outside in the sun).

In this way, the photograph requires us to examine the structural configurations that, beyond analogy, make meaning by making the image. Through the photographer's style (Metz would have called it 'his manner of photographing'), we are made aware that this is not an ordinary photo, that it requires an expertise, a particular talent, a capacity not granted to everyone that makes art from black and white or beauty from the manifest poverty of southern Italians, shown as aging and isolated but with lifelong knowledge of how to preserve pockets of pleasure and conviviality. CartierBresson's talent is in his capacity to offer a continuum (a black-and-white photograph, with its oppositions and gradations) in which the paucity of elements commands the viewer's gaze from front to back, top to bottom, and laterally, in order to relate the image's components and construct the scene. But we also understand that Cartier-Bresson is drawn to Southern Italy, Franco's Spain, or Greece for their hardscapes and light, elements that create strong distinctions between the living and the black. The draw is also in the facet of destitution that creates a stark contrast between the men and women in black and the swaths of sunlight: here, the material of expression (the two-dimensional, black-and-white photograph) corresponds with the form of the content (a hard and simple life in the South). We can clearly see how this could become a topos for the photographer: this opposition between the inorganic and the human, life's span and its strength, crystallized in the recurrence of children playing in ruins or in harsh environments. It must be added, though, that this topos only emerges when the snapshot is superimposed with humanist reflection, the artistic choice of black and white, and the even more refined choice of visual planes rid of any unserving accessory, so that the oppositional and sense-making relationships between assembled elements can operate, imposing at once the composition's meaning and its expertise, its emotion, and its art.

By this line of argument, I intended to convince myself that the short passage cited from 'Au-delà de l'analogie, l'image', ${ }^{18}$ in which Metz defines - in positive terms - what an image is for semiotics, had operational 
strength even for an isolated image. I also sought to prove the existence of a syntagmatic for the image (understood as the equivalent of a photogram, a shot, or here a photograph), because within the frame, relational entities are both identifiable and connectable, capable of isolation because they are commutable. It also seems that the Metzian proposition, in his taking up Hjelmslev, allows expression's material and its form (here the blackand-white photograph) to be considered together, in their dialectic. The same applies to the content's material and its form (all that encompasses the signifying network and the photographer's art, since Cartier-Bresson's art is founded at least in part on a reflection on the photographic act), the use of black and white, and the selection of motifs (such as 'the child of the ruins') in which the three powerfully converge. The snapshot as such is no longer to be considered a reflex, spontaneously captured, but on the contrary a slow maturation, choices deliberated with regard to a medium (the black-and-white photo) and a theme (man and his environment). It is the reworking of one photo in another, the hunt for places and times, the wait for the famous 'decisive moment', which is in fact nothing but patience, so that - once the necessary conditions are fulfilled - the composition produces itself, and the elements (the cat in the sunbeam) work together in harmony.

In this way, digital or not, the Metzian notion of an image composed of 'purely relational entities' demonstrates its effectiveness at the heart of the isolated image, the still image or the shot, and not simply as a general attribute of the image as a concept. Here, the image is not valued for its realism, its analogical quality, but for its symbolic dimension (its capacity to signify and to move people), wherein any represented element forms a relational entity by virtue, especially, of its socio-cultural values (the figurative object) and of its valuation in respect to the other elements contained within the frame. Contrary to the consensus ('to take a photograph'), Metz points in many directions with 'Au-delà de l'analogie, l'image'. The first is that any strong image, made to move people or to impress them, is composed and constituted of elements that both belong to networks of meaning and that constitute among them a network of meaning. Analysis must then restrain itself from jumping directly to the content, to a representation of what was in front of the camera during a given moment, but instead to the reconstruction of these differentiating systems that always place the image within a symbolic register. The second is that all viewers rejoice simultaneously in both the story and its telling, in the content and in its form, in the snapshot and in its feat of strength. The example of Cartier-Bresson also affirms that, within a work, analysis must take into account the dialogue 
between images, the reworking of one image presented in another, in search of, as with Hitchcock, a formula that intimately associates the material of expression with the form of the content and with metalinguistic mastery. With Cartier-Bresson - or, more precisely, for the two examples chosen - the snapshot is the fruit of a technical-aesthetic choice (the black-and-white photograph), the election of a theme (the child of the city or of the ruins), the patient hunt on foot (in order to identify places and their potential), the reduction of the focus to its core (the absence of parasitic accessories), the wait for the best possible composition, and the click of the shutter with near millisecond precision. Only at this price do the 'relational entities' emerge that give his photographs their extraordinary power. These are the living evidence of his art and the absolute focus of the analyst's critical eye.

\section{Translated from French by Elisabeth Cramer}

\section{About the author}

Marc Vernet is Professor Emeritus of Film Studies at Paul Valéry University (Montpellier III) where he was the head of the Department of Cinema and Theatre from 2014 until 2016. A graduate of the Ecole Normale Supérieure de l'Enseignement Technique (ENSET) and of the Ecole des Hautes Etudes en Sciences Sociales (EHESS), Vernet wrote his doctoral thesis under the supervision of Christian Metz. He conducted three interviews with Metz and edited the special issue of Ça Cinéma (1975) dedicated to the semiologist. He was a specialist for film archives at the Ministry of Culture for 15 years. He has co-authored Esthétique du film (1983-2010) and Photographies de cinéma (2007) and is the author of Figures de l'absence (1988) and of Fatty and the Broadway Stars de Roscoe Arbuckle (2015). His most recent publication is the forthcoming Ainsi naquit Hollywood, to be published by Dunod.

\section{About the translator}

Elisabeth Cramer is an American writer and translator based in Berlin. She specializes in French to English translation for academic publications and a range of commercial purposes. She also works with NGOs in the strategic development and writing of grant applications. 


\title{
13. The Cinematic Signifier and the Imaginary
}

\author{
Mary Ann Doane
}

Tröhler, Margrit and Guido Kirsten (eds.), Christian Metz and the Codes of Cinema. Film Semiology and Beyond. Amsterdam University Press, 2018

DOI: $10.5117 / 9789089648921 / \mathrm{CH} 13$

\begin{abstract}
Christian Metz's concept of the 'imaginary signifier' is in some sense oxymoronic. Metz claims that the signifier in cinema is absent, but this assertion rests on conflating the signifier and the referent. This chapter links these contradictions to Metz's continuing allegiance to the notion of the image as defined in the phenomenological approaches of MerleauPonty and Sartre. Here, the image is defined primarily by an analogy with the real. Lacan, by contrast, situated the image as a conjunction of the imaginary, the symbolic, and the real. The author's analysis extends beyond the mirror stage essay to describe a relation of the subject to the image that is more productive for an understanding of cinematic space and time.
\end{abstract}

Keywords: film semiotics/film semiology, psychoanalytic theory of cinema, imaginary signifier, visual analogy, image theory, phenomenology

The image has consistently confronted semiotics as a dilemma. Is it a sign even though it lacks the arbitrariness that Ferdinand de Saussure pinpointed as one of the sign's essential qualities? What is its relation to the phoneme (the smallest contrastive unit without meaning in language) and the moneme (the smallest meaningful linguistic unit), and can one isolate in it a double articulation? But even prior to this interrogation, one must address the question 'What is an image?'. Its relation to materiality fluctuates with its usage, since an image can refer to an iconic object such as a painting, an indexical and iconic object such as a photograph or frame of a film, or a purely mental image as in a daydream (or in literature). The painting and the photograph have a certain consistency or materiality they can be touched or held in the hand. The image in film is more fleeting, 
evanescent and although theoretically it can be touched (as a photogram), it is not experienced this way in reception. Least material of all would be the mental image - unlocalizable and ephemeral, an image that was of particular interest to phenomenology. In addition, in optics an image can be real or virtual.

An image can hence be conceptualized from a number of points of view as occupying a position on the threshold of semiotics. Christian Metz, in his early phenomenological work, in his analysis of cinema in relation to linguistics and semiotics, and in his later psychoanalytic approach, struggled with the image's resistance to dissection, its adherence to its referent, and hence its refusal to be reduced to a signifying function. Part of the difficulty of the image, for Metz, was the role of analogy in specifying the image's relation to its referent. The image was the object's Doppelgänger, its quasi-presence, its likeness, its twin. Unlike the word, it could not be wrested away from its referent, which it always seems to carry with it. In Language and Cinema, Metz resolved the problem by making imagistic representation (as in the cinema) analogous to everyday visual perception, both of which he claimed were coded (and culturally variable). Codes of analogy are 'systems of great anthropological importance' and 'operate in view of "resemblance"', causing the 'resembling object to be felt as such.'. This naturalizing effect, however, raised the spectre of phenomenology for Metz because the closeness of filmic perception to everyday perception meant that the visual recognition of objects in film (a feature of its iconicity) was not cinematically specific (being a characteristic of other systems such as painting, photography, and television - indeed, of any figurative system). In his 1975 'Le perçu et le nommé' ('The perceived and the named'), Metz calls for a new form of research on the dispositifs-passerelles ('bridging apparatuses') that make possible a network of relations between language and the image that are entirely interiorized by a culture, so much so that the phenomenologists were 'able to describe them as spontaneous (and they are in effect)'. ${ }^{2}$ That notion of spontaneity in phenomenology is resistant to the operation of coding, but for Metz, this is ultimately resolvable by situating phenomenology as ideological, as complicit in the naturalizing effect of ideology. However, as Metz moves on in his work to psychoanalysis,

1 Christian Metz, Language and Cinema, trans. by Donna Jean Umiker-Sebeok (The Hague: Mouton, 1974 [1971]), p. 228.

2 Christian Metz, 'Le perçu et le nommé', in Essais sémiotiques (Paris: Klincksieck, 1977), 129-61 (p. 133). Originally published in Vers une esthétique sans entrave. Mélanges offerts à Mikel Dufrenne (Paris: UGE, coll. 10/18, 1975) pp. 345-77. 
the crucial analytic problem is no longer the image, as in phenomenology, nor the code as in semiotics, but the Lacanian concept of the imaginary as a psychical repository of imagos and identifications. Yet, as I hope to demonstrate here, phenomenological notions of analogy and of the image as a 'quasi-presence' of the object continue to maintain a strong hold on Metz's thinking. ${ }^{3}$

Metz's crucial essay, 'The Imaginary Signifier', constitutes itself as a formidable struggle between the psychoanalytic orders of the imaginary, associated with a kind of cinephilia, and the symbolic, the realm of analysis and theory. The imaginary emerges as above all a lure, a trap, an enemy that must be conquered by an ascent to knowledge: 'Any psychoanalytic reflection on the cinema might be defined in Lacanian terms as an attempt to disengage the cinema-object from the imaginary and to win it for the symbolic, in the hope of extending the latter by a new province.4 The aggressivity of the language is clear: the imaginary is 'the site of an unsurpassable opacity'; it is 'essential to tear the symbolic from its own imaginary'; one must 'avoid being swallowed up by it: a never-ending task'. ${ }^{5}$ Accompanying this anxiety toward incorporation by the imaginary is a recognition that psychoanalysis inevitably undermines the scientism and taxonomy fever that consistently attracted Metz. Affect - love, cinephilia, fascination, fantasy, and desire - inflect his analysis more here than elsewhere in his writing, threatening intermittently to topple his epistemological structure. It could be said that this text is haunted by a form of paranoia (one of the aspects of paranoia, as Freud tells us, is the compulsion to build systems). For Metz, the cinematic apparatus, understood as system, acts as a defense against this violent threat posed by cinema's affinity with the imaginary.

In all of his major works - Language and Cinema (1971), The Imaginary Signifier (1977), and L'énonciation impersonnelle (1991) - Metz lodges his thinking within the inadequacies of an analogy. As Tom Conley has pointed out, these are all works 'built upon an analogy destined to fail. ${ }^{6}$ Cinema is like a language, and yet not; the cinematic apparatus is analogous to the

3 For a very detailed and illuminating analysis of Metz's relation to phenomenology from his early work through his later psychoanalytic research, see Dominique Chateau and Martin Lefebvre, 'Dance and Fetish: Phenomenology and Metz's Epistemological Shift', October, 148 (2014), pp. 103-32.

4 Christian Metz, The Imaginary Signifier: Psychoanalysis and the Cinema, trans. by Celia Britton and others (Bloomington: Indiana University Press, 1982 [1977]), p. 3.

5 Ibid., p. 4 .

6 Tom Conley, 'L'énonciation impersonnelle ou le site du film by Christian Metz', The French Review, 67/3 (1994), 548-49 (p. 548). 
psyche, but not in every respect; cinema is an enunciation and nevertheless lacks its defining dialogic structures of 'you' and 'I'. 'The Imaginary Signifier' is perhaps most resistant to an acknowledgment of the analogy's failure, and Metz's attempt to view cinema as the incarnation of the psyche (however understood) has a long and venerable history, from Hugo Münsterberg to Edgar Morin and beyond. For Morin, 'It is not pure chance if the language of psychology and that of the cinema often coincide in terms of projection, representation, field, and images. Film is constructed in the likeness of our total psyche.' Dreams, imaginings, representations constitute 'this little cinema that we have in our head'. 'Analogy provides both the infrastructure of Metz's theory and, in many respects, its focus and dilemma. For, despite its deflection onto the notion of the signifier, the problem that always faces Metz, from his early phenomenologically inspired work to his later embrace of linguistics and psychoanalysis, is the concept of an image that differs from a sign insofar as its major operation is analogy. The image is also 'like' what it records, only different. It sticks too closely to its referent.

What is an 'imaginary signifier'? Given the fact that the signifier is the part of the sign that adheres most closely to materiality and that Jacques Lacan insistently situated it in relation to the symbolic, the phrase strikes one as an oxymoron. It might be helpful to break down the conjunction of these terms and ask, on the one hand, what Metz meant by 'imaginary', and on the other, what he meant by 'signifier'. In Metz's differentiation of the types of psychoanalysis of cinema (psychobiography, psychoanalysis of the script, etc.) it becomes clear that the privileged psychoanalysis is that of the signifier. Here the signifier comes to represent form or the medium specificity of cinema ('the signifier of cinema as such', and cinema is distinguished from individual films). The most striking aspect of cinema, in Metz's view, is its unprecedented perceptual wealth (in opposition to literature, music, painting, sculpture). But in order to differentiate cinema from theatre or opera, similarly wealthy, there must be something else at stake and this is, precisely, the image, the fact of a recording, whether photographic or phonic. The real bodies of the actors in theatre or opera occupy a real, present space. In cinema,

everything is recorded (as a memory trace which is immediately so, without having been something else before) [...]. For it is the signifier itself, and as a whole, that is recorded, that is absence [...]. [...] In the 
cinema it is not just the fictional signified, if there is one, that is thus made present in the mode of absence, it is from the outset the signifier. ${ }^{8}$

There is no doubt that Metz has isolated a critical difference between cinema and the other arts, but his insistence upon the term 'signifier' is perplexing. Signifier here denotes that which is filmed, since it is this, the profilmic reality, that is truly absent. If the signifier is the image or images, they are certainly present. The signifier, by definition, must be present as the configurations of lightness and darkness, colour and sound, there, with the spectator in the auditorium. What Metz refers to as the absent signifier, defining it in terms of its absence, must instead be the referent. For even the signified, at least in Saussurean terms, must be present, adhering to the signifier like the recto and verso of a piece of paper. Metz's confusion of the terms signifier, signified, and referent resonates with Saussure's own difficulties. For, as Emile Benveniste has argued, when Saussure insists upon the arbitrary relation between the signifier and signified, he is really thinking of the referent, not the signified: 'It is clear that the argument is falsified by an unconscious and surreptitious reference to a third term that was not included in the initial definition. The third term is the thing itself, the reality.'9 Saussure contradicts himself, since elsewhere (the metaphor of the piece of paper, the thoughts indissociable from signifiers) he insists upon the necessary, not arbitrary, relation between signifier and signified. In Benveniste's view, the significance of the concept of structure or system is precisely that the relations between its elements are necessary, and the disturbance of one element disturbs the entire system. The fact that it is the relation between sign and referent that is arbitrary simply means that the referent must be excluded from the start, situated outside the system. Metz finds this very difficult to do since his analysis depends upon the real in various ways (e.g. the notion that the actor is really there in the theatre and not in the cinema)..$^{10}$

8 Metz, The Imaginary Signifier, pp. 43-44.

9 Emile Benveniste, Problems in General Linguistics, trans. by Mary Elizabeth Meek (Coral Gables: University of Miami Press, 1971 [1966-74]), p. 44.

10 The concept of the referent plays a major role in another psychoanalytically inflected text of Metz's as well, 'Metaphor/Metonymy, or the Imaginary Referent', in The Imaginary Signifier, pp. 150-297. Here, Metz insists on the crucial nature of the distinction between the syntagmatic/paradigmatic opposition and the metonymy/metaphor opposition, based on his idea that metaphor and metonymy point to similarities and contiguities in relation to referents outside the discourse, while syntagmatic and paradigmatic are positions within language (borrowing from Roman Jakobson). With respect to the metaphor 'That man is an ass', for instance, Metz claims: 'I have perceived or felt a resemblance between an animal and a certain 
This argument that Metz misuses the term 'signifier' would be merely academic if it did not have important repercussions for his theory, and, in particular, for his use of the concepts of 'analogy' and 'image'. ${ }^{11}$ Elsewhere in Metz's work, before the entry of psychoanalysis, the image also coincides with what it denotes. In a footnote to 'Cinema: langue ou langage?', he claims that the term image 'can designate either the shot (as opposed to the sequence) or the filmed subject (as opposed to the shot, which is already the product of an initial composing or arrangement.)'. ${ }^{12}$ Here, the image becomes both signifier and referent. And later in this same essay, he claims,

The image is first and always an image. In its perceptual literalness it reproduces the signified spectacle whose signifier it is; and thus it becomes what it shows, to the extent that it does not have to signify it [...]. [F]rom the very first an image is not the indication of something other than itself, but the pseudopresence of the thing it contains. ${ }^{13}$

What is 'perceptual literalness'? I will return to this in a moment but for now suffice it to say that these passages bear a striking resemblance to Jean-Paul Sartre's and Maurice Merleau-Ponty's phenomenological description of the image. For Sartre, the material of a sign does not partake of its object - it is completely indifferent to it (as in the linguistic sign). But there is a special relationship between an image and its object - one of analogy or resemblance: 'The matter of our image, when we look at a portrait, is not only that tangle of lines and colours that I just called it in the interest of simplicity. It is, actually, a quasi-person, with a quasi-face, etc.' ${ }^{14}$ Merleau-Ponty, echoing and extending Sartre, states:

type of man. This resemblance applies to the actual phenomena and not the language, but it has nevertheless modified my sentence, because I have said "ass" and not "fool"' (p. 187). He goes on to point to the circularity of the relations between reference and discourse (hence, the 'imaginary referent'), but the figures of metaphor and metonymy are nonetheless grounded in the referent in their distinction from the syntagmatic and the paradigmatic. Lacan recognizes no such distinction and, for him, language is itself generative of such ideas of resemblance. While the concept of the real is crucial for Lacan, it is never a function of the referents of individual signs. Metz is very reluctant to relinquish the concept of the referent.

11 This misuse is particularly significant since Metz was meticulously precise, throughout his work, in his use of terms and construction of systems. This precision is especially visible in his writing on semiotics.

12 Metz, 'The Cinema: Language or Language System?', in Film Language: A Semiotics of the Cinema, trans. by Michael Taylor (New York: Oxford University Press, 1974 [1968]), 31-91 (p. 68).

13 Metz, 'The Cinema: Language or Language System?', pp. 75-76 (emphasis in original).

14 Jean-Paul Sartre, The Imaginary: A Phenomenological Psychology of the Imagination, trans. by Jonathan Webber (New York: Routledge, 2004 [1940]), pp. 21-22. 
In a singular way the image incarnates and makes appear the person represented in it, as spirits are made to appear at a séance [a metaphor also used by Sartre]. Even an adult will hesitate to step on an image or photograph; if he does, it will be with aggressive intent. Thus not only is the consciousness of the image slow in developing and subject to relapses, but even for the adult the image is never a simple reflection of the model; it is, rather, its 'quasi-presence' (Sartre). ${ }^{15}$

Neither Sartre nor Merleau-Ponty is interested in making distinctions between a painted portrait and a photograph. But Metz certainly is, since the material base of film is photographic. Nevertheless, he follows the lead of Sartre, and 'perceptual literalness' refers to the operation of a spectral analogy. In 'Problems of Denotation in the Fiction Film', Metz defines analogy in a way that anticipates the slippage in 'The Imaginary Signifier' between signifier, signified, and referent: 'The motivation [of the cinematic sign] is furnished by analogy - that is to say, by the perceptual similarity between the signifier and the signified. This is equally true for the soundtrack (the sound of a cannon on film resembles a real cannon sound) as for the image track (the image of a dog is like the dog). ${ }^{{ }^{6} 6}$ Metz insists here on treating the image as an icon rather than an index. In this sense, the photographic image does not differ from the representational painting. The phenomenon of indexicality, as a function of the very technology of the photographic, is repressed in Metz's discourse in favour of the work of resemblance, analogy. ${ }^{17}$

All of this points to an aporia in Metz's use of the concept 'signifier'. The signifier is at one time an image, at another a referent. This is not a simple contradiction but the residue of his early embrace of phenomenology, in which the image is a special entity clinging to its referent, indeed, embodying it in some magical way in relation to an intentionality that aims at an absent object. ${ }^{18}$ However, phenomenology becomes in 'The Imaginary Signifier' the carrier of a delusion. It is nevertheless an appropriate method for describing cinema, because it too is caught up in the web of the imaginary.

15 Maurice Merleau-Ponty, The Primacy of Perception, ed. by James M. Edie, trans. by James M. Edie and others (Evanston: Northwestern University Press, 1964 [1933-34]), pp. 132-133.

16 Metz, 'Problems of Denotation in the Fiction Film', in Film Language, 108-46 (pp. 108-09). 17 In the later 'Photography and Fetish', Metz cites Roland Barthes and claims that it is photography that is indexical but that indexicality is reduced in film due to movement. See 'Photography and Fetish', October, 34 (Fall 1985), 81-9o (pp. 82-83).

18 'I will say in consequence that the image is an act that aims in its corporeality at an absent or nonexistent object, through a physical or psychic content that is given not as itself but in the capacity of "analogical representative" of the object aimed at.' Sartre, The Imaginary, p. 20. 
For Metz, in a very un-Lacanian way, the description of the object precedes its analysis, ${ }^{19}$ and phenomenology can provide that description because it is analogous to cinema - 'For it is true that the topographical apparatus of the cinema resembles the conceptual apparatus of phenomenology, with the result that the latter can cast light on the former.'20 André Bazin is so compelling for Metz because he perfectly describes the operation of the cinema. Yet he is caught up in its imaginary, unable to extricate himself from it, and a psychoanalysis of that operation is crucial to the production of knowledge of the real:

In other words, phenomenology can contribute to knowledge of the cinema (and it has done so) insofar as it happens to be like it, and yet it is on the cinema and phenomenology in their common illusion of perceptual mastery that light must be cast by the real conditions of society and man. ${ }^{21}$

For Metz, as for Louis Althusser, the imaginary is the realm of ideology, and hence it is crucial to accede to the level of the symbolic, where knowledge of the real resides. ${ }^{22}$ Yet, the traces of phenomenology in Metz's theory indicate a constant battle between ontology (What is cinema? What is the cinematic signifier?) and epistemology (How does cinema work? What is its relation to the spectator and his position?).

This brings us to the second term of the equation - the imaginary. The difficulties and contradictions of Metz's use of the term 'signifier' are mirrored (as it were) here. The imaginary, although Metz purports to be using it in the technical psychoanalytic sense, is at some points associated with the purely fictional, with absence (a textual category), and here its opposite is the real; and at other points with identification (a concept associated with the psychoanalytic account of the constitution of the subject, and in this sense it is opposed to the symbolic). As we saw earlier, the cinematic signifier is imaginary because it is (allegedly) absent. Despite the perceptual richness of the cinema, it is haunted by absence. Lacan's mirror phase is critical for Metz's argument and he reads its central feature as the play between presence and absence:

19 'In any domain, a phenomenology of the object to be understood, a "receptive" description of its appearances, must be the starting point; only afterwards can criticism begin [...].' Metz, The Imaginary Signifier, p. 53 .

20 Ibid.

21 Ibid. (emphasis in original).

22 This is a severe deviation from the Lacanian notion of the symbolic, since for Lacan, the symbolic is not equivalent to knowledge. 
More than the other arts, or in a more unique way, the cinema involves us in the imaginary: it drums up all perception, but to switch it immediately over into its own absence, which is nonetheless the only signifier present. [...] Thus film is like the mirror. ${ }^{23}$

As Metz is quick to point out, anything can be reflected in that cinemamirror except the spectator himself. As in Michel Foucault's reading of Las Meninas, representation entails that the viewer 'cannot not be invisible'. ${ }^{24}$ Cinema must be aligned with the secondary processes of consciousness because the spectator's ego has already been constituted, long ago, in the relation to the primary mirror. Yet, in Metz's argument, cinema is inscribed in the wake of the imaginary - in effect, it is a regressive form, demonstrating that the imaginary is never surpassed but simply imbricated, in various ways, with the symbolic.

For Metz, the mirror analogy is primarily useful as a way of ascertaining the position of the spectator. Of course, the spectator is already an ego, but where is that ego? Like many before him, Metz claims that the spectator is at the place of the camera; identifying with the camera's gaze, the spectator shares its ubiquity. This is the primary cinematic identification and it is one that allows the re-entry of the imaginary, whose principal illusion is that of perceptual mastery (like phenomenology): 'the spectator identifies with himself, with himself as a pure act of perception (as wakefulness, alertness): as the condition of possibility of the perceived and hence as a kind of transcendental subject, which comes before every there is. ${ }^{25}$ Aligning the spectator's position with Melanie Klein's theories of introjection and projection reinforces Metz's notion of the spectator as master of images, prey to an illusion of control.

While Metz isolates the absence of the spectator's own body from the screen as a serious difference between cinema and the mirror but proceeds with the analogy, it is this presence of the reflection of one's own body that is definitive in the Lacanian (and earlier) accounts of the phenomenon. Lacan borrows his description of the infant's fascination with its own mirror image from Henri Wallon, who was suspicious of psychoanalysis and its theory of the unconscious. Wallon analyzed the phenomenon in relation to the child's gradual intellectual grasp of the status of the image as image, 
which nevertheless allowed him the vision of his body as a whole, a sight not accessible to the child outside of this reflection. ${ }^{26}$ Merleau-Ponty criticized Wallon's grasp of the phenomenon as a purely intellectual exercise, stressing instead its affective and bodily dimensions. It is not a problem, as Wallon thought, of the existence of two selves in two different places (as a mirror image and a lived, though inchoate, being) and the need for their reconciliation but, for Merleau-Ponty, of a recognition of the body in the mirror as the child's own body, as the aspect of himself that is visible to others, of the way in which his unity appears to others. It is hence a question of the relation between seeing and being seen, and the continued belief in the 'quasi-presence' of his body in the mirror, despite any intellectual understanding, can be attributed to the magical properties of images. ${ }^{27}$

The distinctiveness of Lacan's mirror lies in his emphasis upon division, dehiscence, alienation, misrecognition - the unity of the subject can only be located elsewhere - and this disjunction is never resolved. The mirror certainly witnesses the emergence of the ego but this ego is not defined in terms of 'perceptual mastery' but in terms of defensiveness, a form of totality that is 'orthopaedic' and the 'assumption of the armour of an alienating identity'. ${ }^{28}$ It could be argued that perceptual mastery is a form of defense (in its illusion of power), but for Lacan this defense is that of an extremely fragile identity, one posited as a unity when it is really haunted by fracture and division. If it is linked to perception, it is a self-perception (and a deceptive one at that). Nevertheless, the mirror is not only about the ego as alienating identity but, because it is an externality that seems to contain the unity, it inevitably summons up all the conundrums of the subject's relation to space. Lacan writes, 'I am led, therefore, to regard the function of the mirror-stage as a particular case of the function of the imago, which is to establish a relation between the organism and its reality - or, as they say, between the Innenwelt and the Umwelt. ${ }^{\prime 29}$ Lacan refers to Roger Caillois more than once, and in the mirror-stage essay, his work is linked to the 'signification of space for the living organism'.$^{3^{\circ}}$ In Caillois's analysis of heteromorphic identification as 'legendary psychasthenia', morphological

26 Henri Wallon, 'Comment se développe chez l'enfant la notion de corps propre', Journal de psychologie normale et pathologique, 28 (1931), pp. 705-48.

27 Merleau-Ponty, The Primacy of Perception, pp. 125-41.

28 Jacques Lacan, 'The Mirror Stage as Formative of the Function of the I as Revealed in Psychoanalytic Experience', in Ecrits: A Selection, trans. by Alan Sheridan (New York: W.W. Norton and Company, Inc., 1977 [1966]), 1-7 (p. 4).

29 Ibid. (emphasis in original).

30 Ibid., p. 3. 
mimicry becomes an 'obsession with space in its derealizing effect'. For Caillois, this form of mimicry involves a depersonalization, an assimilation of the subject into space, the loss of any conception of perceptual mastery. ${ }^{31}$ Cinema is, perhaps, the limit case of the derealization of space. But Metz with his attachment to the problem of the impression of reality and to the 'I know very well but even so...' of a fetishistic structure of knowledge - does not, as might be expected, grasp as psychically central this derealizing effect. It would tend to disconcert, to dislocate the spectator - to dislodge any sense of mastery.

Metz's analysis of the imaginary signifier develops along two axes that foreground two binary oppositions: the imaginary vs. the real (understood as non-imagistic presence) and the imaginary vs. the symbolic (where 'symbolic' is often collapsed onto Freudian secondary processes). These two threads of his theory are rarely, if ever, brought together, whereas for Lacan, 'The whole problem is that of the juncture of the symbolic and of the imaginary in the constitution of the real. ${ }^{32}$ Optics is a particularly privileged science for Lacan because, unlike other sciences that cut up or dissect their objects, optics 'sets itself to produce, by means of apparatuses, that peculiar thing called images'. A symbolic language (mathematics) subtends the crucial hypothesis of optics: 'for each given point in real space, there must be one point and one corresponding point only in another space, which is the imaginary space'. ${ }^{33}$ In 'The topic of the imaginary' in Seminar I, Lacan resorts to another optical phenomenon as a supplement to the mirror in grasping the imaginary - the experiment of the inverted bouquet (Figure 13.1). Using a spherical (concave) mirror allows him to deploy a distinction between real images (in optics, those that are the result of the convergence of reflected light rays) and virtual images (in which the rays do not converge, as in a flat mirror). ${ }^{34}$ In this experiment, a vase is placed on a stand and a bouquet of flowers hangs beneath the stand in front of a concave mirror.

31 Roger Caillois, 'Mimicry and Legendary Psychaesthenia', October, 31 (Winter 1984), pp. 16-32.

32 Jacques Lacan, 'The Topic of the Imaginary,' in The Seminar ofJacques Lacan Book I: Freud's Papers on Technique 1953-1954, trans. by John Forrester, ed. by Jacques-Alain Miller (New York: W.W. Norton and Company, Inc., 1988 [1975]), 73-88, (p. 74).

33 Ibid., p. 76 (emphasis in original).

34 A concave mirror such as the one in the experiment of the inverted bouquet will produce a real (and inverted) image when the object is located either at or beyond the centre of curvature or between the centre of curvature and the focal point. When the object is located at the focal point of a concave mirror, there is no image (the light rays are parallel and do not converge or diverge), and when the object is located in front of the focal point, the image will be virtual (and upright). Hence, concave mirrors sometimes produce real images and sometimes virtual ones. But in the experiment of the inverted bouquet, the bouquet is placed upside down at the centre 


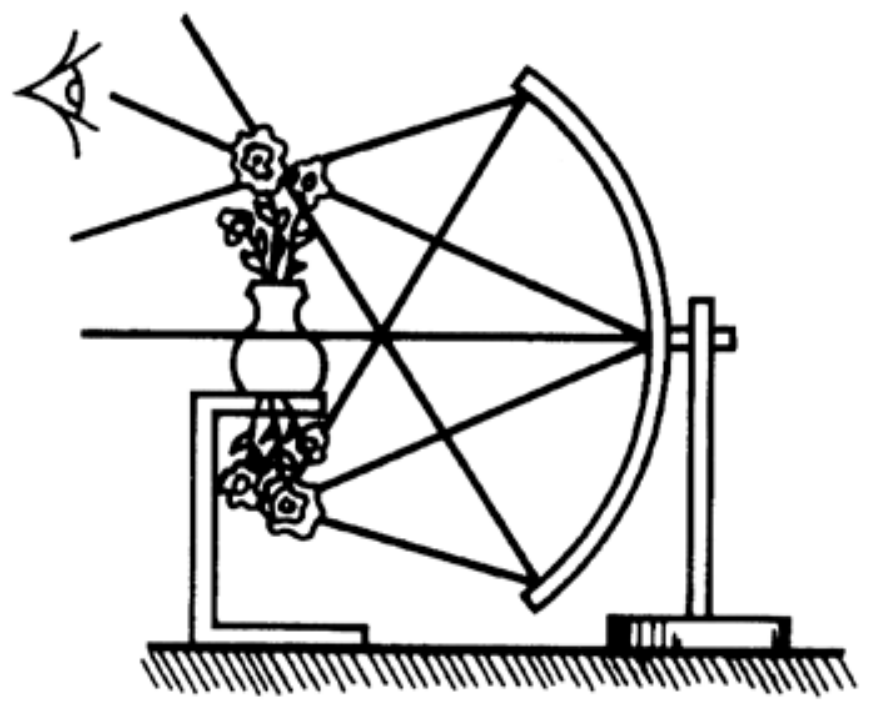

Fig. 13.1: Diagram of 'The experiment of the inverted bouquet' by Jacques Lacan

The subject (represented by a disembodied eye) perceives an image (a bit blurry because the rays do not quite cross at the same place) of a bouquet of flowers (real image) in a vase (imaginary image). Lacan makes sure to point out that flowers and vase could be reversed but he is clearly invested in this arrangement because the vase lends itself so easily as a representation of the body-ego, the container ('the body gives the subject the first form which allows him to locate what pertains to the ego and what does not'), and the flowers, the contained real (reality is 'not delimited by anything, cannot yet be the object of any definition', is neither good nor bad but 'chaotic' and 'absolute, primal'). ${ }^{35}$ Nevertheless, Lacan insists that the arrangement is versatile and that the positions of real and imaginary can be exchanged as long as their relations are maintained. In addition, the entire schema depends upon the eye, the subject, being in the right place:

For there to be an illusion, for there to be a world constituted, in front of the eye looking, in which the imaginary can include the real and by the same token, fashion it, in which the real also can include and, by the same

of curvature and therefore a real (upright) image is produced. See The Physics Classroom: http:// www.physicsclassroom.com/class/refln/Lesson-3/Image-Characteristics-for-Concave-Mirrors (accessed 2 June 2014).

35 Lacan, 'The Topic of the Imaginary', p. 79. 
token, locate the imaginary, one condition must be fulfilled - as I have said, the eye must be in a specific position, it must be inside the cone [...] in the relation of the imaginary and the real, and in the constitution of the world such as results from it, everything depends on the position of the subject. And the position of the subject [...] is essentially characterized by its place in the symbolic world, in other words in the world of speech..$^{36}$

It should not be surprising, then, that Lacan uses this schema as a way to critique Melanie Klein's relation to language and to the imaginary. When she attempts to describe her patient's behaviour in relation to the interplay of projections, introjections, good and bad objects, and sadism, her use of language is 'in the domain of the imaginary'. But when she speaks, 'something happens'. The signifier does not represent, it acts. ${ }^{37}$

The flat mirror in the mirror phase produces a virtual image, which is to say that you see it where it is not. This displacement, this spatial derealization is aligned with the méconnaisance of the specular 'I', its assumption of a fictional identity, always somewhere else. But it is possible to see the real image of the flowers in the imaginary vase only if the eye, representing the 'I' of language, is positioned within a certain field, within a delicate choreography of the real, the imaginary, and the symbolic. In the experiment of the inverted bouquet, the subject is reflected in the mirror only figuratively, through Lacan's conflation of the vase as container and the ego. The eye of the subject of language, already in the symbolic, is somewhere else, nearby. Why did Metz not make recourse to this schema, which seems closer to the cinematic experience? Where anything can be reflected in the mirror except the subject himself, a disembodied eye/I, whose positioning is, nevertheless, crucial to the operation? Where real and imaginary both become functions of images? This is the residual effect of Metz's alliance with a semiotics that rests on binary oppositions, that excludes the category of the real only to see it surreptitiously re-enter the theoretical scene in disguise.

Spatial derealization is a crucial component of the imaginary, but no less crucial is its relation to temporality. The mirror image is ahead of the child who lags behind, caught in a relation of dependency linked to motor incoordination. This is why anticipation is so critical in Lacan's analysis; there is always a projection into a future yet to come. The mirror phase is 'experienced as a temporal dialectic that decisively projects the formation of 
the individual into history. The mirror stage is a drama whose internal thrust is precipitated from insufficiency to anticipation - and which manufactures for the subject, caught up in the lure of spatial identification, the succession of fantasies that extends from a fragmented body-image to a form of its totality that I shall call orthopaedic. ${ }^{38}$ But anticipation for Lacan is not limited to the domain of the imaginary; it also necessarily structures the field of meaning, of signification. In a movement beyond Saussure, the signifier and the signified are dissociated in Lacan, so much so that the bar between the two indicates a barrier resistant to signification, which can only be understood in relation to slippage, movement along a chain that touches down upon the signified only at moments, points de capiton. Hence, signification is never instantaneous (nor is recognition in the mirror phase, ultimately):

For the signifier, by its very nature, always anticipates meaning by unfolding its dimension before it. As is seen at the level of the sentence when it is interrupted before the significant term: 'I shall never...', 'All the same it is...', 'And yet there may be...'. Such sentences are not without meaning, a meaning all the more oppressive in that it is content to make us wait for it. [...] From which we can say that it is in the chain of the signifier that the meaning 'insists' but that none of the chain's elements 'consists' in the signification it can provide at that very moment. ${ }^{39}$

This emphasis upon movement, anticipation, memory, and forgetting in processes of signification could be considered not as a perfect analogy for film but as the very description of its operation. Consider, for instance, the focus on ellipsis here - which in Lacan's examples, suspends a train of signifiers, interrupts it - in relation to the function of ellipsis in film, as annihilating 'real' time (by virtue of the cut) and hence producing a specifically cinematic time that always lays out its meaning before it, never quite catching up. Metz has focused on the difference between photography and film, particularly in the essay 'Photography and Fetish', in relation to temporality (agreeing with Roland Barthes that photography marks a 'that has been' over and against film's 'this is happening'). And in 'The Imaginary Signifier', he cites Lacan's 'Logical Time and the Assertion of Anticipated Certainty'; here, Lacan analyzes a logic problem in which three prisoners, seeing only a white or black marking on the others but

38 Lacan, 'The Mirror Stage', p. 4.

39 Jacques Lacan, 'The Agency of the Letter in the Unconscious or Reason Since Freud', in Ecrits: A Selection, 146-78, p. 153. 
unable to see their own marks, are told that the one who discovers his own colour first will attain freedom. ${ }^{40}$ For Metz, this is a demonstration of the fact that identification is not achieved in a moment but must be continually repeated and renewed - a rationalization for the comparison of cinema to the mirror despite the fact that the spectator is an adult who has long since left the mirror phase. However, for Lacan, what is at issue here is the integral role of hesitation, interruption, temporal tension, and, above all, anticipation in the assertion of certainty (particularly about oneself, hence a connection to the mirror phase). All three prisoners come to the conclusion that they are 'white' based on a reading of the stages of hesitation of the other two, and the entire process is informed by a desire not to be 'too late.' ${ }^{41}$ Anticipation and suspension/doubt are not external to the logical process but an integral aspect of its ambiguity. The pressure of time is that of being left behind.

Metz's intuition that cinema was on the side of the imaginary generated an enormously productive amount of thinking about the position of the spectator as an aspect of the apparatus. And I would say that one of his major contributions, along with others - Jean-Louis Baudry and Jean-Pierre Oudart, for instance - was to displace psychoanalysis in film criticism from the psychoanalysis of characters (or the auteur) to a consideration of the spectator's engagement with film. But his retention of a phenomenological understanding of the image as analogy (and a quasi-mystical one at that) consistently subtended and deflected his deployment of psychoanalysis. Claiming that a phenomenological description of the object precedes and supports a psychoanalytic analysis negates the psychoanalytic account of the complex emergence of the object for the subject and consequently of the bankruptcy of the very distinction between subject and object. For Lacan, the image is not a likeness of, not in an analogical relation to, the real. An image is the convergence or nonconvergence of light rays in relation to the position of the subject. It is produced as a particular conjunction of the imaginary, the symbolic, and the real. Identification is the assumption of an image (an imago) that never coincides with oneself, but it is also the stuttering temporality, the interplay of hesitation and haste in the assertion of certitude about

40 Jacques Lacan, 'Logical Time and the Assertion of Anticipated Certainty' [1945], in Ecrits: The First Complete Edition in English, trans. by Bruce Fink (New York: W.W. Norton \& Company, 2006), pp. 161-75.

41 For Lacan, this scenario is an exemplification of the idea of a 'collective' (he refers to Freud's Group Psychology and the Analysis of the Ego). Certitude about one's identity is inevitably linked to a desire not to be excluded from the category of 'man'. 
oneself. It can only take place through a certain derealization of space. But what impact would this have on a psychoanalytic delineation of cinema? For Metz, cinema's affiliation with the imaginary, conflated with ideology, must be countered by the theorist's embrace of a knowledge grounded in the symbolic ('a fetishism that has taken up a position as far as possible along its cognitive flank'). ${ }^{42}$ The imaginary, as illusion of perceptual mastery, as uncontested love of cinema, keeps the subject in place. But if one emphasizes the imaginary's affiliation with a derealization of space, an alienation linked to the very problem of a spatial location that is a delicate balancing act between real and virtual images, the subject's alleged stability must be interrogated. In the mirror, the reflected rays of light do not converge in the place where the image is, leaving the 'self' stranded in a space that will always be disjunctive, in need of negotiation. And yet - a virtual image such as that of the plane mirror is defined by the fact that it cannot be screened (only a real image can be recorded and screened). Metz was right - the spectator will never see his mirror image on the screen, but the work of the imaginary is not exhausted by an account of the mirror phase. It too must be put into place in relation to the shifting categories of the symbolic and the real. And we must not forget that assurance, certitude about identity - all of those things that Metz links to the imaginary - are a function of the temporal momentum of anticipation and hesitation, interruption and precipitation, all of those modes of temporality incarnated by the film's movement. Metz defines the image as analogous to the real rather than as an aspect of its production for a subject. In the end, much as he would like to, Metz fails to disengage himself from the imaginary - not in the way he acknowledges, through a continual, inevitably inescapable love of cinema, but through a love of analogy as $a$, if not the, primary method of theory.

\section{About the author}

Mary Ann Doane is Class of 1937 Professor of Film and Media at the University of California-Berkeley. She is the author of The Emergence of Cinematic Time:Modernity, Contingency, the Archive (2002); Femmes Fatales: Feminism, Film Theory, Psychoanalysis (1991); and The Desire to Desire: The Woman's Film of the 1940s (1987). In 2007, she edited a special issue of differences: A Journal of Feminist Cultural Studies, 'Indexicality: Trace and Sign'. 


\title{
14. Fetishism and Scepticism, or the Two Worlds of Christian Metz and Stanley Cavell
}

\author{
D.N. Rodowick
}

Tröhler, Margrit and Guido Kirsten (eds.), Christian Metz and the Codes of Cinema. Film Semiology and Beyond. Amsterdam University Press, 2018

DOI: $10.5117 / 9789089648921 / \mathrm{CH} 14$

\begin{abstract}
This chapter brings together Christian Metz and Stanley Cavell, who are rarely discussed on the same page. Metz worked as a semiologist or film theorist, and Cavell as a philosopher. Still, these two influential thinkers are linked through their common interest in the relation between ontology and belief, and especially the perceptual character of expressions of ontology and belief. Both thinkers depict this problem as a nearly universal experience, where evidence of the senses and of cognitive experience come into conflict with one another in the paradoxical structure of belief. For Metz, this rotation of belief around assertions of knowledge and denial is characteristic of the structure of fetishism; for Cavell, it is an expression of the logic of scepticism.
\end{abstract}

Keywords: film semiotics/film semiology, film-philosophy, perceptual experience, photography, fetishism, image theory

In his 'Lecture on Ethics', prepared for delivery at the University of Cambridge sometime between September 1929 and December 1930, though unpublished in his lifetime, Ludwig Wittgenstein suggests that final and conclusive agreements on such ordinary yet powerful human experiences as ethics, aesthetics, or belief cannot be hoped for. But this does not mean that experiences like belief are incommunicable or incomprehensible; hence Wittgenstein's long fascination with intermediate and impure cases as occasions for investigating these experiences philosophically, though often indirectly. In this way, Wittgenstein presents by example two philosophical procedures central to his later philosophy: the examination of intermediate 
cases and the description of similarities and differences across patterns of family resemblance. ${ }^{1}$

Disagreements on judgments of ethics, aesthetics, or belief present cases where humanity expresses its urge to run up against the limits of language. The failure to find an adequate concept or expression may indeed lead us to silence, but it is just as likely to produce in series a variety of different statements or forms of expression, all of which fail to convey these experiences adequately to ourselves or to others but which nonetheless bring forth the blurred outlines of the experience in our repeated attempts to convey it, like lines in a sketch that create the impression of a picture or idea as compelling as it is incomplete. There are thus no pure or final cases but only intermediate ones. However, the assembly of related intermediate cases and perspicuous grammatical investigation may make apparent a latent image that nowhere lies in the expressions themselves but rather emerges in patterns of similarity and difference perceived among or between the expressions so produced.

Consider these images or features expressions, then. But what we want to communicate, convey, apprehend, or understand lies nowhere in the image but rather is only graspable in a pattern of relationships that is itself neither pictured nor expressed, yet becomes 'visible', as it were, if only in an intuited way. Wittgenstein's 'Lecture on Ethics' offers by example procedures for developing or drawing out these pictures through language in a process of comparing a number of more or less synonymous expressions that struggle to assess the defining characteristics of ethics. Though each expression differs slightly from the others, it is nonetheless possible to assemble patterns of difference and commonality in ways similar to the construction of a composite photograph. The effect thus produced is neither a consensual definition of ethics nor a complete and final understanding of the concept. Rather, as Wittgenstein might put it later on, definitions and concepts of ethics are deployed in a variety of language games in order to produce a pattern of family resemblances where different but overlapping conceptual senses can be 'seen'.

In this essay, I want to bring together two powerful thinkers who are rarely discussed on the same page: Christian Metz and Stanley Cavell. Roughly contemporary and equally influential in promoting strong 
versions of academic film studies, Metz and Cavell appear to approach cinema as if from two different worlds. Ever the semiologist (although a semiology tempered by phenomenology), Metz seeks to ground questions of meaning, belief, and perceptual experience in psychology, or rather psychoanalysis. This, of course, was the project of his hugely influential essay on 'The Imaginary Signifier. ${ }^{2}$ Though no less interested in psychoanalysis, Cavell approaches similar problems and experiences as a philosopher influenced by the later Wittgenstein and J.L. Austin's investigations of ordinary language, though again in ways tempered by phenomenology.

Metz works as a semiologist or film theorist, and Cavell as a philosopher. Still, these two influential thinkers are linked through their common interest in investigating the relation between ontology and belief, and especially the perceptual character of expressions of ontology and belief. Both Metz and Cavell depict this problem as a nearly universal experience where evidence of the senses and of cognitive experience come into conflict with one another in the paradoxical structure of belief.

Consider, then, two of the most well-known statements in their respective oeuvres. In 1975, in 'The Imaginary Signifier', Metz reconsiders Octave Mannoni's depiction of the paradoxical logic of fetishism as the prototype of belief. Ten years later in his essay on 'Photography and Fetish', Metz condenses his account in the following description:

Because it attempts to disavow the evidence of the senses, the fetish is evidence that this evidence has indeed been recorded (like a tape stored in the memory). The fetish is not inaugurated because the child still believes its mother has a penis (= order of the imaginary), for if it still believed it completely, as 'before', it would no longer need the fetish. It is inaugurated because the child now 'knows very well' that its mother has no penis. In other words, the fetish not only has disavowal value, but also knowledge value. ${ }^{3}$

2 In this essay, I will work primarily with the original English text. Metz's influential text on 'The Imaginary Signifier' was first published in French in Communications, 23 (1975), pp. 3-55, and quickly translated into English and published in Screen, 16/2 (1975), pp. 14-76.

3 Christian Metz, 'Photography and Fetish', October, 34 (1985), 81-9o (p. 73) (emphasis in original). Metz's essay was published in several French versions as well: 'Limage comme objet: Cinéma, Photo, Fétiche', CinémAction, 50 (1989), pp. 168-75; and 'Photo, fétiche', in Pour la Photographie, ed. by Ciro Bruni and Michel Colin, 2 vols. (Sammeron, G.E.R.M.S. et Revue d'esthétique photographique, 1990), II. I thank Martin Lefebvre for confirming that there are only minor variations across these three texts. 
Here, perceptual experience permanently imprints a past perceptual experience that hovers uncertainly beneath present perceptual knowledge in ways that make indiscernible the borders between reality and fantasy, knowledge and denial. In both essays, Metz repeats and expands Mannoni's propositional expression of this belief: 'Je sais bien, mais quand même ...' - 'I know very well, but even so .... ${ }^{4}$

In the opening pages of The World Viewed, first published in 1971 and then in an expanded edition in 1979, Cavell presents another version of the paradox of perceptual belief in photography and cinema: 'A photograph does not present us with "likenesses" of things; it presents us, we want to say, with the things themselves. But wanting to say that may well make us ontologically restless. ${ }^{5}$ Similar to Metz's characterization, Cavell observes that in looking at photographs, even though we know that a likeness is a representation, we want to say that the image also confronts us with worldly existence. We experience something like certainty, but ironically, it is an uncertain certainty. We are restless, and again our perception vacillates in a space between knowledge and belief.

This rotation of belief around assertions of knowledge and denial, reality and fantasy, is a common thread running through Metz and Cavell's writings on photography and film. Another fascinating family resemblance between Metz and Cavell is their common tendency to approach a problem indirectly - to circle a question probing for original points of entry and then to proceed through loops and digressions. Not uncharacteristic of Metz's writing, his brilliantly argued essay on 'Photography and Fetish' struggles to stay on topic. To begin my examination of the family resemblance between Metz and Cavell's accounts of perceptual belief, I will concentrate on Metz's later essay, for here it is clear that the queer logic of photographic belief is the primary trigger for his curiosity rather than the structure of fetishism.

In 1985, Metz's commitment to psychoanalysis seems strong yet more distant than in his writing of ten years earlier. In this essay, discussions of the fetish and fetishism in psychoanalytic terms are treated more sceptically and contextualized through references to anthropology and myth. If Metz's principal concern is how photography and film raise perceptually paradoxical questions of belief, or rather treat belief as a paradoxical relationship to the world, then the fetish here becomes itself a 'fetish' - a token, charm,

4 See Mannoni's essay, 'Je sais bien, mais quand même', in Clefs pour l'imaginaire ou l'autre scène (Paris: Seuil, 1969), pp. 9-33.

5 Stanley Cavell, The World Viewed: Reflections on the Ontology of Film, Enlarged Edition (Cambridge, MA: Harvard University Press, 1979 [1971]), p. 17. 
or talisman. Grounded in semiology and structuralism, whose residual positivism requires grounding in cultural and social convention, Metz needs a figure attached to psychology as much as to a logic or concept of belief. (Inter alia, this is why his approach is theoretical and not philosophical. I will return to this observation in my conclusion.) Metz seems disinclined here to take for granted the continuing power of psychological fetishism, nor does he assert as strongly that the logic of fetishism informs structures of cinematographic belief. Indeed, one of the principal arguments of the essay is that for a number of formal and perceptual reasons, cinema is a less powerful analogue to fetishism than photography. (Could the image in movement be a counterweight to fetishistic structures of belief or a path to their overcoming?)

In his conclusion, Metz emphasizes that, like Freud, his argument is an 'interpretation' of fetishism, an application and displacement of its possible meanings from one domain, psychology, to another, aesthetics. Moreover, Metz expresses dissatisfaction with the concept in both its Freudian and Lacanian versions because of its androcentrism, among other reasons. Nonetheless, the value of the concept is its potential for activation and production of new knowledge in another field, that of film theory, by testing the powers and limits of its analogical application in other domains.

In the wake of Metz's canonic essay on 'The Imaginary Signifier', one of the most striking conclusions of 'Photography and Fetish', then, is that psychological fetishism is not a strong model for characterizing perceptual belief in cinema. In like manner, while acknowledging the important affinities between photography and cinema, Metz wants to make them ontologically distinct even more than Cavell does, and one criterion of that distinction is their closeness to or distance from the logic of fetishism. And in a final turn, perhaps fetishism is not the main point at all. Again, here in many ways it functions as a heuristic for exploring the deeper and paradoxical character of perceptual belief in relation to our claims about the existence of the image as a world or its presentations of the world.

The point I am trying to make here is that, for Metz, the interest in the concept of fetishism is less the basis for a theory than the drawing of a picture where fetishism yields a concept or itself becomes a new figure of logic. Metz places the figure in a moving metonymic chain whose effect is to shake loose its moorings in psychology, anthropology, and ethnology in order to clarify the peculiar perceptual situations in which photography and film place us. And these situations must be examined by establishing logical criteria, rather than grounding perceptual experience in potentially universalizing psychological causes or structures. 


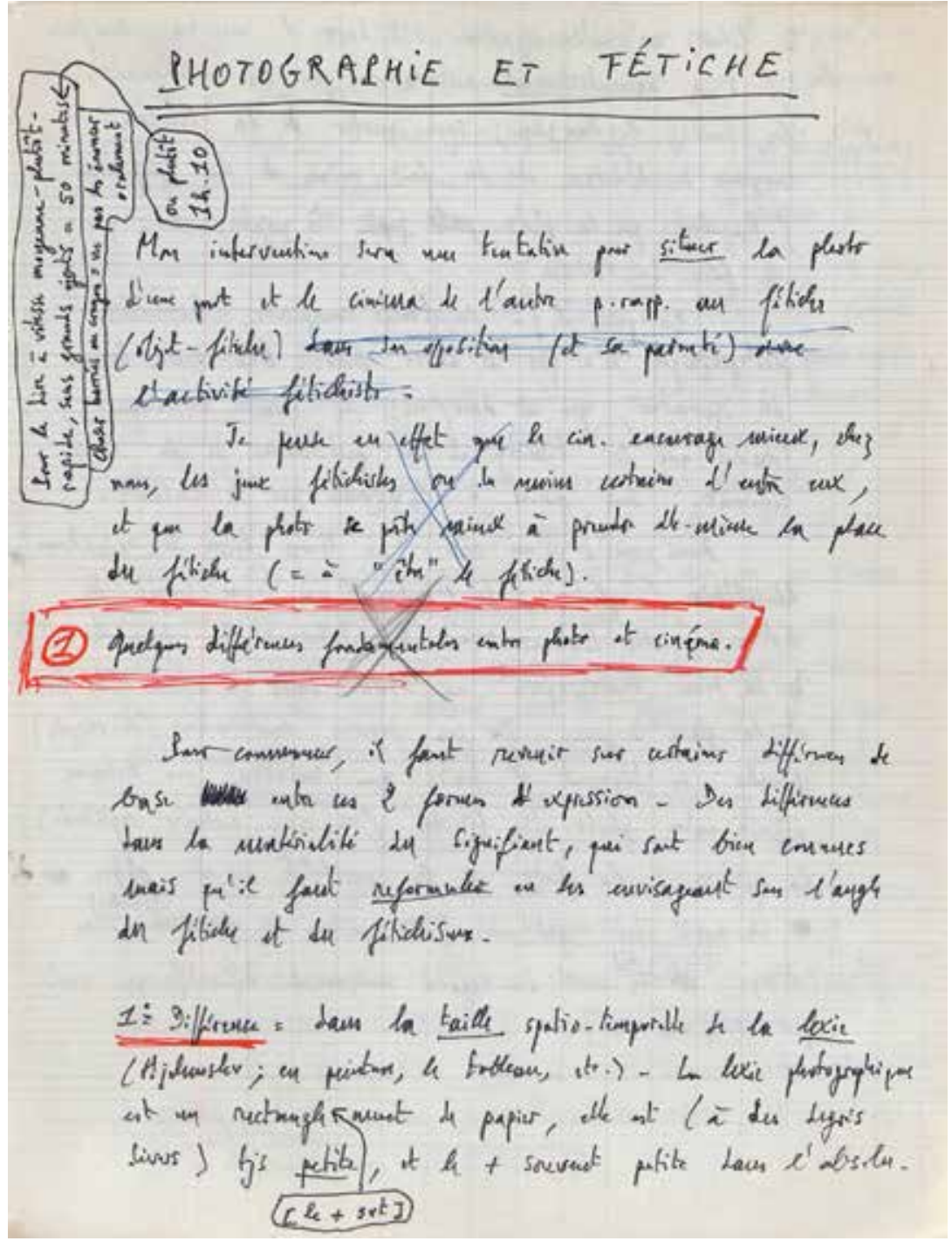

Fig. 14.1: Manuscript of 'Photographie et fétiche'. Fonds Christian Metz, Bibliothèque du film, Paris: ms. CM 1505, p. 1

Herein lies another point of common interest shared by Metz and Cavell. Both assert that photography and film produce a powerful conviction of the real that is nonetheless counterbalanced by an ineluctable sense of unreality, and so much so that the dividing line between reality and unreality becomes indiscernible. Both work in their own ways and from their own perspectives to understand a perceptual vertigo produced by these images 
where knowledge and belief, reality and unreality rotate into and out of one another more or less undecidably.

For Cavell, the key term in this process is automatism; for Metz, indexicality. Yet there is another point of agreement here. Metz argues that the powers of indexicality derive from the photographic act or 'the mode of production itself, the principle of the taking ${ }^{6}{ }^{6}$ Whatever level of force of belief we attribute to the image, its testament to existence is bound to its automatic capacity to record, preserve, and transmit a relation of contiguity and connection to the world. For Metz, there is an interesting seam to the powers of photography and film in this respect. In virtue of its silence, its stasis, and its demotic character, photography 'remains closer to the pure index, stubbornly pointing to the print of what was, but no longer is'. Below, as it were, all their other qualities or characteristics, photographs document and preserve. At the same time, we are on ground familiar to all readers of 'The Imaginary Signifier'. Both the photographic image and the cinematographic image inhabit a curious temporality of presence and absence. In photography, this temporality is expressed as the disturbing co-presence of a past existence in time with a present image in space.

However, even if photography lives genetically in cinematography, Metz argues that it is transformed ontologically by projected movement. (This is the basis of yet another family resemblance to Cavell.) Despite all the documentary power that may reside within it in virtue of photography's documentary powers, in its standard uses film transforms photographic processes in powerfully fictionalizing and creative ways. In other words, film creates new existence, new worlds, as much or more as preserving past worlds. In a kind of Aufhebung, film infuses photography with a new imaginary (and one where the imaginary logic of the fetish resides only unhappily). Through its unfolding in time, its capacity to absorb and put into play additional narrative and perceptual elements, and its power of disconnecting, reconnecting, and recontextualizing images, Metz observes that in cinematography the indexical power of photography frequently serves, paradoxically, as a realist guarantee for the unreal; in other words, it gives the imaginary or the unreal what might be called an unreasonable capacity to convince.

Therefore, photography and film must be distinguished not only by the presence of automated movement but also by their respective powers of temporal expression and stillness. Metz argues that even if cinema

6 Metz, 'Photography and Fetish', p. 82.

7 Ibid., p. 83 (emphasis in original). 
includes photography, cinema absorbs and transforms the still image in the creation of 'a second movement, an ideal one, made out of successive and different immobilities. Movement and plurality imply time, as opposed to the timelessness of photography which is comparable to the timelessness of the unconscious and of memory.8 ${ }^{\prime 8}$ The historical time of the photograph is transformed by serialized movement into the projection of an ideal time, perhaps even a utopic, heterocosmic time, though Metz does not quite put it this way. Nevertheless, in contrast to the transcriptive and preservative time of photography, film presents 'a stream of temporality where nothing can be kept, nothing stopped'. ${ }^{9}$ For Metz, this capacity works against the power of the fetish. By extension, it may also undermine or overturn the fixity of belief in anticipation of new knowledge. Is this an argument for the creative capacity of time?

The qualities of immobility and silence, Metz also observes, are shared by photography and death. There is an authority to the photograph that testifies equally to non-existence and existence, or rather, to the existence of non-existence. In their respective acts of 'taking' or registration, photographic duration is qualitatively distinct from cinematographic duration - they 'expose' time differently. Metz characterizes the photographic act as the transport of the object into another kind of time: 'the snapshot, like death, is an instantaneous abduction of the object out of the world into another world, into another kind of time - unlike cinema which replaces the object, after the act of appropriation, in an unfolding time similar to that of life. ${ }^{10}$ The realism of cinematic projection, if there is one, is to enfold the viewer in the flow of time - a full and heterogeneous duration coterminous with the durée in which she actually lives.

Photographic time seems other to this living durée. In Metz's language, there is something almost existentially murderous about photography. Taking a snapshot is depicted as a violent gesture of cutting inside the referent, as if lifting some segment of its body outside of the flow of time. The cut removes and preserves, but in the form of non-existence. The form of my body has slipped into the past, and as Roland Barthes often insisted, the time of photography thus presents a future anterior where a slipping into nonexistence becomes the future that confronts us all. By the same token, the fact of this temporality informs photography and film as forms of memory. "The two modes of perpetuation are very different in their effects, and nearly 
opposed,' Metz asserts. 'Film gives back to the dead a semblance of life, a fragile semblance but one immediately strengthened by the wishful thinking of the viewer. Photography, on the contrary, by virtue of the objective suggestions of its signifier (stillness, again) maintains the memory of the dead as being dead. ${ }^{11}$ And in a rather subtle though no less astounding statement, Metz asserts that film does not found itself on photography but rather destroys the power and action of photography by energizing it, infusing stillness with ineluctable movement. Automated movement is reanimation.

The reanimating character of automated movement is equally expressed in how the space off-frame or out of frame (hors cadre is the French term) is read differently in photography and film. In both cases, the edges or borders of the frame function less to organize a composition than to enact a displacement, where the logic of fetishism acts as a basis of comparison. The primal scene of castration fantasy displaces knowledge of empirical perception (the missing penis) by, as Metz puts it, stopping the look on a less threatening image, which nonetheless stands next to it. Here again, there is a paradoxical perception where non-existence and existence are simultaneously presented and asserted without the acknowledgement of contradiction while nonetheless incurring an uncanny affect. Space off-frame is anxious. It anticipates certain knowledge yet also delays it - it polarizes perception as if a slight rotation of perspective would reveal something one does not want to see or say. The remarkable expressive logic of fetishism thus combines a double and contradictory function. As metaphor it incites and encourages - it provides a veiling substitute or protective replacement buffering the subject against the acknowledgement of loss and non-existence. Functioning metonymically, it stands beside or is connected to the danger it is supposed to ward off. The fetish is a conduit to unhappy knowledge even while we ask it to ward off the danger sleeping next to it. And as it protects it also attests to an involuntary belief, 'the warding off of bad luck or the ordinary, permanent anxiety which sleeps (or suddenly wakes up) inside each of us'. ${ }^{12}$

Here again, fetishism marks a contrast between the time of photography and that of film. Conventionally speaking (because in both cases there are many unconventional expressions), the frame functions to distinguish photographic and cinematographic belief. In film, the space implied out-of-frame may always, in principle, be returned to the world in frame. Unseen space is not ontologically distinct from that world but 
rather contiguous with it - it may appear, or appear again, through camera movement or editing; the diegetic presence of a character out of frame may be asserted by the off-screen presence of their voice in frame. As Metz puts it,

The off-frame is taken into the evolutions and scansions of the temporal flow: it is off-frame, but not off-film. [...] The character who is off-frame in a photograph, however, will never come into the frame, will never be heard - again a death, another form of death. The spectator has no empirical knowledge of the contents of the off-frame, but at the same time cannot help imagining some off-frame, hallucinating it, dreaming the shape of this emptiness. It is a projective off-frame (that of the cinema is more introjective), an immaterial, 'subtle' one, with no remaining print. 'Excluded', to use [Philippe] Dubois's term, excluded once and for all. Yet nevertheless present, striking, properly fascinating (or hypnotic) -insisting on its status as excluded by the force of its absence inside the rectangle of paper, which reminds us of the feeling of lack in the Freudian theory of the fetish. ${ }^{13}$

If Metz's analogy between photography and fetishism holds, then the photographic frame suspends perception between two incommensurable dimensions of existence and non-existence, knowledge and belief. Here the violence of the photographic act returns in Metz's argument. Metz characterizes the instant of photographic capture, the click of the shutter, as an act figuring castration - a singular and definitive cutting that

marks the place of an irreversible absence, a place from which the look has been averted forever. The photograph itself, the 'in-frame', the abducted part-space, the place of presence and fullness - although undermined and haunted by the feeling of its exterior, of its borderlines, which are the past, the left, the lost: the far away even if very close by, as in Walter Benjamin's conception of the 'aura' - the photograph, inexhaustible

13 Ibid., pp. 86-87. Metz is relying on two important points of reference here. One is Philippe Dubois's fascinating book, L'acte photographique (Paris \& Brussels: Nathan and Labor, 1983). The other is Pascal Bonitzer's work on off-frame space, especially his essay 'Le hors-champ subtil', Cahiers du cinéma, 311 (1980), pp. 4-7. Here Bonitzer makes a distinction between the filmic frame off, which implies a space filled (étouffé) with potential for further revealed and revealing images, and the photographic frame off, whose implied unseen space is more reticent or subtle. 
reserve of strength and anxiety, shares, as we see, many properties of the fetish (as object), if not directly of fetishism (as activity).$^{14}$

Like the fetish, photography is grounded in a peculiar act of apperception - a more or less permanent instance wherein the polarizing affects of frame and off-frame, seen and unseen, presence and absence, belief and knowledge, desire and anxiety are caught in an instant of infinite repetition. Alternatively, film plays with or on these affects by putting them into movement, temporalizing them in narrative scenarios of series and differentiation. As Metz puts it, film enacts the possibility of playing with fetishism, while the photograph itself is more capable of actually becoming a fetish. Film makes drama out of fetishistic repetitiveness, fictionalizes as it were. With its complex formal and narrative play on the out-of-frame, cinema toys with the combination of desire and fear, pleasure and terror evoked by fetishistic belief. Metz writes:

The moving camera caresses the space, and the whole of cinematic fetishism consists in the constant and teasing displacement of the cutting line which separates the seen from the unseen. But this game has no end. Things are too unstable and there are too many of them on the screen. It is not simple - although still possible, of course, depending on the character of each spectator - to stop and isolate one of these objects, to make it able to work as a fetish. ${ }^{15}$

There is thus something like a turn of magic in projected movement, a point that Cavell also makes, and Metz presents this idea as a classical theme in film theory. Invoking again Octave Mannoni's condensation of the expression of fetishistic belief and denial, 'I know very well, but even so ...'. Metz insists again on the uncanny strangeness of both photographic and cinematographic belief. On the one hand, the spectator is never 'fooled' by an image. She or he knows with certainty what a representation is and never

\footnotetext{
14 Metz, 'Photography and Fetish', p. 87.

15 Ibid., p. 88. New technologies of presentation, especially digital presentation, have dramatically transformed the terms in which we now speak about stillness and movement, or cinephilia and fetishism. One of the most interesting accounts is Laura Mulvey's thought-provoking book, Death $24 x$ a Second (London: Reaktion Books, 2006), especially her concluding chapters on the possessive and pensive spectator. Raymond Bellour has been our most brilliant observer of these shifts and transformations of spectatorship with respect to photography, cinema, and video in an electronic and digital age. See his recently translated collection of essays, Between-the-Images (Zurich and Dijon:JRP | Ringier and Les presses du réel, 2012).
} 
confounds an image with what it is an image of. 'But even so ..., and here knowledge rotates into belief. To enjoy the fiction and partake of its pleasures - or in the case of photography, to maintain belief in past existence (and perhaps to ward off knowledge of the passing of existence) - the spectator must displace or transform this knowledge. Metz concludes here, having glossed Mannoni's argument at length in 'The Imaginary Signifier'. Still, as I have tried to argue, his essay on 'Photography and Fetish' suggests many interesting new points of departure from his earlier work. In particular, it is important to insist that what I have characterized as perceptual belief is not a form of illusion nor should it be diagnosed as fantasy. Rather, it is another form of knowledge that has both ethical and philosophical force. This is where a comparison with Cavell becomes both apt and illustrative and perhaps deepens our understanding of these two important thinkers despite their superficial differences.

One might say that Metz's arguments present a diagnosis or symptomology of the fetishistic character of perceptual belief. Cavell targets a similar condition and experience of perceptual belief in his ontological and ethical investigations of the logic of scepticism. Where Freud is the protagonist (or antagonist) of Metz's argument, Cavell implicitly targets Descartes as the foil for his investigations of the sceptical character of belief in photography or cinematography. Descartes is the antagonist in this story for several reasons. Cartesianism places epistemology as the centrepiece of philosophy, and in so doing makes perception the guarantor of knowledge about the world. At the same time, Descartes knows that human perception is limited and therefore unreliable. One last dilemma must be added to this linking of acts of perceiving to the quest for certainty in knowledge: existence. In Descartes' Meditations, the instability of knowing is linked to possible failures of perception and judgment that are at once outward- and inwarddirected. Sitting alone before the fire in his study, Descartes is lulled into wondering, as we all sometimes are, whether I am awake or dreaming, and suddenly fearing that the frontiers between these two states are indiscernible or indistinguishable. What makes such thoughts all the more disturbing is that doubts about the existence of the world lead inexorably to doubts about the reliability of the self and its anchoring in a stable, perceptible, and knowable world, as well as about the power of any transcendental authority to assure the universal coherence and meaningfulness of the world. In a strong sense, one could portray Descartes as the founding author of the experience of modernity in its doubled aspect: presenting the self as divided from the world by its capacities for perception and thought, and thus 
wishing for the self to master both itself and the world, and all the objects in it, by assuring their existence through criteria of certain knowledge.

Scepticism is another aspect or dimension of modernity, in that the desire for certainty is a response to a perceived precariousness of one's relation to the world, as if a sudden and unexpected dislocation of the subject from the object of knowledge. The unacknowledged symptom of scepticism, what Cavell sometimes calls the truth of scepticism, is suppressing recognition that it produces the situation it is supposed to overcome. (This would be another point of contrast and comparison with the logic of fetishism.) In diverse moments of writing, Cavell describes this condition as the difficulty of making ourselves present to the world, and the world present to us. In its response to scepticism, epistemology creates a new and potentially disquieting situation that Cavell pictures as seeing ourselves as outside the world as a whole. (And here one might also entertain comparisons with Metz's discussions of voyeurism.) The self is thus constrained to relate to the world as if ontologically distinct from it. Moreover, since perception is optically unreliable, the self or mind are made distinct from the body, even if the only way of relating to the world is through the frame or window of perception, as if from an immaterial and partial perspective looking out at different aspects of external objects.

In this situation, the character of the subject and the character of the world are both transformed. The world is fashioned here as what Cavell calls a 'generic object', in contrast, perhaps, to the fetish as a partial object; that is, as something that epistemology can treat in its generality as indistinguishable from all the singular and particular things within the world, or alternatively, where singular things serve pars pro toto as tokens of the world as a knowable object. In its need to know the world as a complete object, scepticism expresses an anxiety that Cavell presents in The Claim of Reason as 'a sense of powerlessness to know the world, or to act upon it; I think it is also working in the existentialist's (or, say, Santayana's) sense of the precariousness and arbitrariness of existence, the utter contingency in the fact that things are as they are'.16

In this context, Cavell's early definition of cinema as a 'succession of automatic world projections', which I discuss at length in The Virtual Life of Film, also suggests a programme of philosophical investigation that links the temporality of modernism to the 'movement' or transformative power 
of the image. ${ }^{17}$ Succession indicates types and degrees of depicted motion, of course, both within the frame and across continuous or discontinuous series at various scales. Yet this criterion should also be broadened to include the complex temporalities of the image in its states and phases of becoming. Automatic designates those aspects of the image that are self-producing independent of a human hand, as well as the absence of people and things so produced on the screen. Call this the inhuman dimension or power of screened worlds, which may also be characterized as the passive intentional power of cinematographic expression. World then leads to ontological investigations of the worlds and subjects so made, and the interpenetrating qualities of reality and fantasy experienced through institutional conditions of viewing and response. And finally, projection signals the phenomenological conditions of viewing, as if at a remove or distance from the world, as well as the force of analogy in movement and time between the screened world and the pro-filmic world thus transcribed and projected. Movement, time, and becoming are all complexly linked here, in ways expressive of the unsettled and unsettling force of fantasy and reality (of fantasies of reality, or the reality of fantasy in relation to screened worlds), as well as the passing or becoming of ontological situations thus projected.

In the first phase of Cavell's film-philosophy, the problem of ontology does not wish just to account for the existence of the projected world and perception as screened. Rather, Cavell wants to ask: what are the conditions of my current existence that lead me to desire to see and to experience the world in just this way, as projected and screened? Why does just this kind of picturing of the world hold me? What are the sources of its attraction or attractiveness? These questions are ethical and express a philosophical desire as a psychological one. Cinema itself responds to this question by offering another regime of belief, not necessarily as an escape into fantasy but rather by offering a condition or situation wherein we might understand more clearly how our views of or on reality are burdened by fantasy. This is neither an escape into or out of fantasy, as if somehow our thoughts, perceptions, and expressions could be disconnected from our desires. The screened world is a perfect emblem of scepticism, as I have already pointed out in The Virtual Life of Film, but it also opens to view a range of options for relief from scepticism. And not by bolstering our knowledge of things, not by documenting our certainty of the world either present or past, but by opening to question dilemmas of belief or disbelief framed by a mode of

17 See D.N. Rodowick, The Virtual Life of Film (Cambridge, MA: Harvard University Press, 2007), especially pp. 2-73. 
existence that desires these kinds of pictures of the world; or alternatively, by examining the forms of our responsiveness to a world that wants us to experience it as or through projected moving pictures.

Cavell's version of ontology is transformational. When Cavell in a 1978 essay asks what becomes of things (or people) on film, he want us to comprehend the world viewed as projected on the screen as a space of transformation or, if you will, becoming. Cavell calls this force of becoming on screen and as image 'photogenesis'. These transformations do not only count for objects recorded and transformed to the screen but also for the subjects included there. In his first accounts leading up to Pursuits of Happiness, these subjects are ethical exemplars responding to sceptical belief, usually in comic ways; or in fact, finding such belief to be comic rather than tragic. The figures of Buster Keaton, Charlie Chaplin, or Cary Grant are especially important in this context, not to mention the great actresses of remarriage comedy. Becoming on the screen is a species of (self-)transformation, meaning that it is both automatic or subject to certain automatisms of recording, transcription, narration, and genre, and also that it projects reflexively a picture of self responding to pressures of transformation. (Cavell often refers to this process as the ascendency of actor over character in cinema.)

Ontology in Cavell's sense is therefore not about an attained existence for either objects or persons, which film is then capable of recording, representing, or preserving, nor is it about the preservation or projection of the world as a generic object. The temporal structure of screened worlds and the ethical stakes for our picture of subjectivity so projected are more complex. To understand the concept of ontology as expressing film's relation to reality and thus fantasy, Cavell asks us to investigate the reality of this relation through moving images as images that move us.

Take, for example, Cavell's discussion of the comedy of Buster Keaton in 'What Becomes of Things on Film?' Cavell frames his response to Keaton through Heidegger's characterization of the worldhood of the world announcing itself to us, not as a revelation to the subject but rather through the obstinacy of things, which in opposing us expose the limitations of our acts, knowledge, and preoccupations in our encounters and struggles with material objects. The resistance of the world to our actions and our will not only circumscribes us as subjects - if we are willing, it also opens us sensuously to so far unrecognized textures and capacities of the world, and to our contingent relationships to it as a space of accidents, which are also unforeseen possibilities. In slapstick comedy, every mischance is a gift and an opportunity for evasion. That this occurs in the time and movements of cinema, Cavell explains, says something about 
the human capacity for sight, or for sensuous awareness generally, something we might express as our condemnation to project, to inhabit, a world that goes essentially beyond the delivery of our senses [...]. I understand Buster Keaton, say in The General [Clyde Bruckman \& Buster Keaton, USA 1926] to exemplify an acceptance of the enormity of this realization of human limitation, denying neither the abyss that an an time may open before our plans, nor the possibility, despite that open possibility, of living honorably, with good if resigned spirits, and with eternal hope. His capacity for love does not avoid this knowledge, but lives in full view of it. Is he dashing? He is something rarer; he is undashable. He incorporates both the necessity of wariness in an uncertain world, and also the necessary limits of human awareness; gaze as we may, there is always something behind our backs, room for doubt. ${ }^{18}$

These comments are not a defense of stoicism. The personae of Keaton or Chaplin do not ask that we gracefully accept the obstinacy of fate and the world but rather show that human beings are resourcefully capable of pursuing happiness in spite of these limitations. The comic responses of Keaton or Chaplin to the world's contingency and obstinacy are extraordinary manifestations of what any ordinary human being is capable of. Cavell calls this a willingness to care, or to be attentive to the depth of a human capacity for inventiveness and improvisation in seeking out newly imagined alternatives.

Here the link between reality and fantasy in the screened image is especially important. Or rather, it may be characteristic of the automatisms of the screened image that every transcription of the world is also expressive of a desired stance towards the world - the world as we want to see it or desire it to be. The real and the imaginary are not opposed here as genres of cinematographic expression. Rather, they continually flow into and out of one another in the temporality of the projected image and our responses to it. Cavell calls this an alternation between indicative and subjunctive moods, or unmarked juxtapositions of reality with some unresolved opposition to reality. In 'What Becomes of Things on Film?', Cavell evokes the term photogenesis to describe the image's peculiar quality of becoming, which is also expressive of 'the power of film to materialize and to satisfy (hence to dematerialize and to thwart) human wishes that escape the satisfaction of 
the world as it stands; as perhaps it will ever, or can ever, in fact stand'. ${ }^{19}$ To speak of ontology here is to address not only or not simply a fact of film, as Cavell might put it, but also to focus on a genetic capacity of the image that needs to be interpreted or evaluated in terms of its qualities of attraction.

At various moments in this period of his writing, Cavell asserts that film is a moving image of scepticism. To answer the question 'what becomes of things and people on film' means comprehending all the variety and complexity of what 'movement' means here, in ways that are analogous to Metz's comments on the transformations of stillness by movement in cinematography. We certainly find cinematographic images to be moving, that is, as inspiring affect or emotion. But they are also unsettling; they make us ontologically unquiet. If film is a moving image of scepticism, it does not so much confirm our subjectivity (as modern for example) as shake our belief that we know the basis of our conviction in reality. This unsettling of belief is similar to Metz's account of fetishism and its varying manifestations in relation to photography and cinema, though Cavell is pushing here in other directions, in that in his account movement is also ethically transformational. In cutting conviction loose from its moorings, the subject is made vulnerable to pressures of uncertainty, doubt, and self-questioning and thus open to the possibility of change. And finally, movement is also historical: the passage of scepticism into art or cinema, from the everyday or philosophy into a mode or machine of presentation may also mean that modernity is changing the terms of its existence, as I already argued in Part Two of The Virtual Life of Film. (Here we pass, perhaps, from an experience of modernity to nostalgia for it, or what Cavell calls losing one's natural relation to art or film.)

The concept of photogenesis plays an interesting role in the first phase of Cavell's thought. For Cavell, photogenesis names one of the principal powers or automatisms of cinematographic presentations, where the transcription and projection of screened worlds enacts transformations whose violence is commensurate with the force of becoming immanent to thought and things on film. The concept of photogenesis is complexly linked here to cinema's specific institutional presentation of the sceptical dilemma. For example, in the Foreword to the enlarged edition of The World Viewed, Cavell writes that objects projected on the film screen are inherently reflexive or self-referential, meaning first that one is led to wonder about their physical origins in past times and spaces, but also that the quality of their presence on the screen indicates their ineluctable absence. This situation is 
an emblem of scepticism in that all we need to convince ourselves of the presence of the world is a projected image wherein the world is screened and we are screened from it, as if viewing it from a distance.

Belief in the causal presence of objects on the screen, and our surrender of responsibility for that world to film's automatic transcriptions and projections of it, is one of the satisfactions of scepticism. But the anguish of scepticism is also produced from this situation in two ways, both of which signify a withdrawal or diminution of human agency and autonomy. In viewing this succession of automatic world projections, we are absolved from responsibility for producing views of the world, since another automatic or automatizing (nonhuman) entity has brought them into being.

Cavell's characterization of the expressive powers of the image is not a realism, or not only a realism in a limited sense. The reality of the condition of cinematic viewing, according to Cavell, is ineluctably marked by fantasy, and in turn fantasy is one of the most powerful components of our experience of reality through cinema. This experience is neither the illusion of reality nor the reality-effect so thoroughly studied by contemporary film theory. Rather, it relates to Cavell's close connection of the sceptical dilemma to the experience of modernity in cinematic viewing. There is a powerful reality expressed in this situation since it is the philosophical background of our daily cultural life in modernity - the experience of cinema is a component of that life and also an expression of it. But the reality of this experience is also permeated by fantasy (of belief or conviction, of a world accessible only through the senses, of a past preserved against time, of a self withdrawn into privacy) as a force of attraction inseparable from our lived reality. In philosophy, this situation is not to be negated, overcome, or deconstructed but rather acknowledged and evaluated. The challenge of ontological investigation is not to alter our conditions of knowing but rather our conditions of valuing and living. The photographic and cinematic arts have a special role to play here because they embody and replicate the structure of scepticism, and also because they so powerfully inspire a hesitancy or equivocation with respect to scepticism's powers of conviction, which according to Cavell is inherent in the structure of scepticism itself. In other words, photography both elicits a certain regime of belief and also destabilizes it.

This assertion and destabilization of belief is, again, beautifully expressed in Cavell's statement in The World Viewed that 'A photograph does not present us with "likenesses" of things; it presents us, we want to say, with the things themselves. But wanting to say that may well make us ontologically 
restless. ${ }^{20}$ Here, Cavell wants to describe the powers of photogenesis simultaneously to affirm belief and inspire doubt, to attract us to the image as confirming the existence of the world through its powers of automatic analogical causation, and at the same time, to enact a fantasy of the world's presence through its absent existence. This is another way of asserting that the automatic transcription and projection of the world hovers uncertainly between indicative and subjunctive moods, or a co-present belief of past existence in time and of a world preserved, and the present projection of a world transformed. We misrecognize photography's hold on us if we gravitate too urgently to one pole or the other. Rather, the truth of the image, if there is one, resides in its uncertainty, contingency, and becoming.

Cavell's concept of automatism is therefore not meant to describe, or not only to describe, the fact of mechanical reproduction; it also wants to account for the powers of attraction or fantasy in relation to images so produced in ways both human and inhuman. Automatism thus manifests a specific kind of desire - the wish to view the world unseen and as if by a self hidden behind perception - and this world must be taken to be the world in its totality. This is the modern philosophical wish of scepticism, whose desire for the world as a completely knowable object places it just beyond the reach of our knowing and so produces a situation where our natural mode of perception is viewing as an invisible and anonymous observer. Here, Cavell explains, 'We do not so much look at the world as look out at it, from behind the self.'. ${ }^{21}$ This is a precise description of the perceptual and epistemological situation of scepticism, which seems to want to make the self distinct from perception.

In cinema, this perception appears to be produced independently of the self as an automatic instrumentality. The sceptical attitude thus engenders a peculiar internal division where the mind can only assure itself of the possibility of knowledge by treating its own perception as a separate mechanism that intervenes between itself and the world. At the same time, this mode projects an external division separating self from world, whose only points of contact can take place through acts of viewing. Perception thus becomes both a structure of separation between subject and object, mind and world, and also the only pathway through which mind and world can communicate. In the thrall of scepticism, Cavell suggests, the only way of establishing connection with the world is through viewing it or having views of it. To wish to view the world itself - as it was in the past or is in the present 
past - as a complete causally produced object is therefore to wish for the condition of viewing as such, but in the passive form of an automatic and instrumentalized perception. In turn, to wish for the condition of viewing as such is to desire a sure connection to the world but also to hold at bay, unseen and unacknowledged, recognition that this desire is a fantasy of anonymity, privacy, and power over the world. In theatrical cinema, the deepest irony of this situation is that the condition of collective viewing and of shared experience might reinforce our desire for the privacy and anonymity of scepticism. (Perhaps the contemporary proliferation of home viewing and personal data screens might likewise reinforce and expand exponentially an isolation where our only recourse for connecting to the world or to others is through the image and from behind screens. In this ontology we are not alone together, but rather together alone.) Alternatively, philosophical investigation and criticism might be able to release the hold of this fantasy or to let us see beyond it the attractions of sociality and a shared mode of existence waiting to be acknowledged.

Cavell and Metz both offer us explanations of the attractions and paradoxes of perceptual belief but from distinctly different perspectives: on the one hand, a psychoanalytically grounded semiology; on the other, a philosophical ethics. In this respect, perhaps the comparison of Cavell and Metz from the standpoint of ontology is unjust. Ever the semiologist, Metz examines photography and film as socialized units of meaning or reading, where in his later essay on 'Photography and Fetishism', fetishism becomes more a heuristic model than a psychological explanation. Cavell gives a philosophical account of this experience, where in a number of essays the ontology of photography and film are read as emblematic of the problem of scepticism and its overcoming. Nevertheless, the common interest in the problematic nature of belief links Metz and Cavell's arguments across a number of common themes that present opportunities for comparison and contrast of their two perspectives: the transformative powers of movement and projection; the existential force of indexicality or causality in analogical reproduction; the association of photography with the domestic or private and family life - what Metz calls 'the presumed real'22 - and film with collective reception and an imaginary referent; the curious alternation of presence and absence in space and in time articulated in different ways by photography and cinematography; and finally and most importantly, the critical investigation of the co-constitutive and indiscernible vacillation 
between reality and fantasy, or the real and the imaginary, in perceptual belief.

We might compare the two perspectives by calling upon our own ordinary cultural experience as viewers, and I would guess that many of us would find much to recommend in both accounts. However, I want to conclude here with some observations on method or critical practice inspired by the juxtaposition of Metz and Cavell as they examine respectively the claims that photographic or cinematographic perceptual belief make on us.

In Elegy for Theory, I suggest that we think of the problem of the history of film theory not as fixed and successive periods, or conceptual schemes overturning and replacing one another, but rather as overlapping and intersecting genres of discourse full of retentions, returns, and unexpected extensions, as well as ellipses and omissions. ${ }^{23}$ Nevertheless, the emergence or unfolding of discursive genres, one out of the other, occurs neither progressively nor continuously but rather in series of disruptions and discontinuities that mark real differences, each of which involve turnings and remappings of concepts of theory. Moreover, I hint at the end of Elegy for Theory that in film study, and perhaps the arts and humanities in general, a moment has arrived where contemporary theory reaches its end.

From this perspective, when examined genealogically, 'theory' can only be presented as what Wittgenstein calls an intermediate case. There is a virtual life of theory no less powerful or elusive than that of film. We will never settle on a satisfactory definition of theory, even though one of the attractions of theory may be to demand just this satisfaction from us. I have suggested throughout this essay that Metz's approach is theoretical and that Cavell's is philosophical. Perhaps the moment has finally arrived, then, to state clearly that despite their jagged and irregular borders, and all of the seams or edges that both link and separate them like the ocean meeting the land, both reaching over and withdrawing from it, philosophy is not theory. Philosophy may overlap with and link to many problems of theory, yet my comparison of Metz and Cavell also suggests that it remains distinct from theory as a practice.

One way to characterize theory might be as an activity wherein experience is converted into thought, and so made expressible and communicable to others. Along these lines one might also say that theory is outwarddirected while philosophy is inward-directed. Theory's primary activity is explanation. Theories designate or refer to an object, which they hope to describe completely and whose effects they wish to account for or explain. 
In its generality, this definition counts as much for the criticism of art as it does for investigations of the natural world. Alternatively, in turning to art and other forms of human inventiveness, philosophy expresses knowledge of our selves and our relations with others. Art provokes in philosophy self-referring inquiries and evaluations of our ways of being and styles of existence. Here, interpretation and evaluation are always turning one over the other as mutually amplifying activities. This is why in my latest book I refer to philosophy as artful conversation. The style of philosophical expression is ontological and moral or ethical more than it is epistemological. And in turn, philosophy is a practice of styling the self and of projecting a world, no matter how unattainable, where that self might find new expression.

Here the two forms of explanation might indeed present themselves as two different worlds. Film theories are 'about' film - they take or even construct films as objects of knowledge. They propose explanatory concepts - for example, Metz's appeal to fetishism as a heuristic concept - to examine what film is (and these concepts will give us many competing definitions) and to explain its logics and effects. Here one presumes the empirical existence and history of the object and its effects, and the activities of theory are dependent on our sense of this object, whether aesthetic or psychological.

Alternatively, philosophy turns to film to examine and clarify problems and concepts that are of concern to philosophy. Paradoxically, this means that a (film) philosophy is not necessarily a part of film studies; rather, it belongs to philosophy alone. Philosophy explains nothing 'about' film. However, it might have a lot to say about why and how film and the arts matter to us, why we value them, and how we try to make sense of ourselves and the world with and through them, for example, through attention to the experience of perceptual belief. It may even want to examine our 'theories' of film to test their conditions of sense.

If a philosophical reading returns to film or literary studies some fact or insight regarding the nature or history of the medium and its meanings and effects, it is in the form of a gift. Here, philosophy overlaps with or contributes to theory, perhaps, but it does not become, for all that, a theory of film or art or literature. Perhaps we should reserve for theory epistemological inquiries into the nature of things, matters, and causes? Theory would be epistemological and empirical, then, in diverse and open senses of the concept. And here Christian Metz is one of the greatest exemplars of the practice of theory in the postwar period. Still, there is a point where philosophy and theory touch or find a common join: where in examining an object we also evaluate the conditions and styles of knowing, limits as 
well as possibilities, that confront us in efforts, successful or not, toward knowing. For Cavell, this critical capacity defines the difficulty of philosophy as well as its particular strength, which Cavell himself characterizes as receiving 'inspiration for taking thought from the very conditions that oppose thought, as if the will to thought were as imperative as the will to health and to freedom'. ${ }^{24}$ The possibility of thinking - or better, critical thinking - should also be a potential pursuit of happiness. And happily, both Stanley Cavell and Christian Metz provide us with powerful directions whereby we may investigate how moving images move us, and move us to thought.

\section{About the author}

D.N. Rodowick is the Glen A. Lloyd Distinguished Service Professor in the Division of the Humanities at the University of Chicago. He is the author, most recently, of The Virtual Life of Film (2007), Elegy for Theory (2014), and Philosophy's Artful Conversation (2014), all published by Harvard University Press. Rodowick is also a curator and an award-winning experimental filmmaker and video artist. With Victor Burgin, he was recently awarded a Mellon Collaborative Fellowship at the University of Chicago's Richard and Mary L. Gray Center for Arts and Inquiry to produce a new video work, Overlay. 



\section{IV}

Narration, Enunciation, Cinephilia 



\title{
15. Cinema: Image or Narrative?
}

\author{
Anne Goliot-Lété \\ Tröhler, Margrit and Guido Kirsten (eds.), Christian Metz and the Codes of \\ Cinema. Film Semiology and Beyond. Amsterdam University Press, 2018 \\ DOI: $10.5117 / 9789089648921 / \mathrm{CH} 15$
}

\begin{abstract}
This chapter re-evaluates Metz's relationship with narrative studies as well as his contribution to French narratology. A rereading of his famous 'Cinéma: langue ou langage?' leads us to a conception of narrative that reconnects with perception and restores a direct link between narrative and image, with the cinematic narrative based on the necessity of a contact with the image. This opens the possibility of a narrative 'aesthetics' in which the story is no longer that which is told independently of the images but, on the contrary, that which derives from the images, even from the analysis of images. Finally, the essay exemplifies these ideas based on the concrete narrative experience of Atom Egoyan's film Exotica (CAN 1994).
\end{abstract}

Keywords: film semiotics/film semiology, narratology, cinematic narrativity, aesthetics, film analysis, image theory

\section{French Narratology: With and Without Christian Metz}

If Christian Metz never sensu stricto developed a 'narrative model', narrative is often very close to what he writes about, even occasionally at the centre, notably in his first articles and in his last book (on which these reflections are primarily based). His work thus testifies to a relationship of proximity and familiarity while nonetheless remaining outside of narrative studies. Starting with his 'Notes Toward a Phenomenology of the Narrative' (1966), his writings have played a crucial role in general narratology. While narrative studies were multiplying in literary studies, Metz posed the question of the 
'phenomenology of their subject' and of the conditions of their validity by asking: 'How is a narrative recognized, prior to all analysis?'2 This essay, although published in the first volume of his Essais sur la signification au cinéma (1968), does not specifically focus on cinema. In it, Metz observes that the question applies to all kinds of narratives, regardless of medium (his examples are drawn equally from novels and films). Metz develops here what he will later call 'the structural analysis of actual narrativity - that is to say of the narrative taken independently from the vehicles carrying it (the film, the book). ${ }^{3}$ Of course, it is just one article but one that left its mark as much on Gérard Genette's subsequent Narrative Discourse $e^{4}$ (Genette likewise greatly influenced filmic narratology) as on studies of storytelling in film. But Metz's work contributed specifically to the narratology of film, which in short order came to superimpose itself on literary narratology. His article: 'The Cinema: Language or Language System?' (1964), particularly the part devoted to storytelling (to which I will return at greater length), is here germane, ${ }^{5}$ as is his 'Modern Cinema and Narrativity' (1966). ${ }^{6}$ The latter is a reaction to a critical tendency that perceived modern European cinema as freed from narrativity: Metz demonstrates that certain screenwriters' and filmmakers' abandonment of classical plots - with a highly codified and predictable content of action that is pragmatic, explicit, concrete, visible, represented, and spectacular - as an essential element of storytelling in no way implies the abandonment of narrativity. According to Metz, a loose narrative - with little dramatic action, elliptical, ambiguous, disconcerting, minimalist, unpredictable, incomplete, based on transformations that partially escape representation or causal logic - still remains a narrative. If this text seems important to us today, ahead of its time, it is not only because it reflects narration in all its diversity and forms, including the least normative, but also because it implicitly points out the discrepancy between the structural narratology of the time - preoccupied with analyzing folk tales and classical narratives from the past (or the present) - and a contemporary production that situates itself in a rupture. Metz, however, proposes neither a model nor

2 Ibid., p. 17 .

3 Christian Metz, 'Problems of Denotation in the Fiction Film', in Film Language, 108-46 (p. 144; emphasis in original). [This essay is a compilation of three of Metz's essays from 1966-67; translator's note].

4 Gérard Genette, Narrative Discourse: An Essay in Method, trans. by Jane E. Lewin (Ithaca: Cornell University Press, 1980 [1972]).

5 Christian Metz, 'The Cinema: Language or Language System?' [1964], in Film Language, pp. 31-91.

6 Christian Metz, 'The Modern Cinema and Narrativity' [1966], in Film Language, pp. 185-227. 
analytical tools but an extension of his 'Notes Toward a Phenomenology of the Narrative' by demonstrating the need to recognize narrative plurality.

This article on the modernity of European film comes on the heels of his 'Mirror Construction in Fellini's 81/2', published in January of the same year, wherein Metz analyzes a modern film. In fact, it is one of his very rare studies devoted specifically to a film. Here again, his analysis captures our attention both for its specific contents and for what escapes it. His approach, although not 'narratological' (no mention is made of his then-current research on storytelling), is nonetheless not non-narrative. This study constitutes a first step towards a reflection on enunciation/narration that twenty-five years later would have decisive repercussions in Metz's final work.

In the 1980s, the French scholar's initial investigations subsequently inspired a prolonged reverberation, authored by younger colleagues. ${ }^{8}$ Interestingly, his followers felt the need to strenuously analyze filmic narratives, i.e. films themselves, a practice for which, as we know, Metz felt little affinity. ${ }^{9}$ Thus, in his writings, you will not find a film studies equivalent of works such as Narrative Discourse, SZ, or Maupassant: The Semiotics of Text..$^{10}$ Nevertheless, his explicit homage to analytical activity in the penultimate paragraph of L'énonciation impersonnelle (1991) leaves little doubt about its importance for him:

I cannot close this overview on the works that have most influenced me without saying something about a type of writing superficially very different [from my own] that I frequently practiced (only as a reader, but with a keen interest and with the feeling that something important was at stake), scholarship that attacks the problem by the other end: film analyses. ${ }^{11}$

7 Christian Metz, 'Mirror Construction in Fellini's 81/2' [1966], in Film Language, pp. 228-34.

8 Certain scholars mined different aspects of Metz's thinking: the screenplay, the ties between cinema and literature (F. Vanoye); fiction (R. Odin); sources of 'monstration' and narration (A. Gaudreault); point of view and subjectivity (F. Jost); spatiality (A. Gardies); and the character (M. Vernet).

9 During the Metz colloquium, Raymond Bellour reminded us that we can count a total of three film analyses in Christian Metz's work; see also his article in this volume.

10 See the analysis of Marcel Proust's A la recherche du temps perdu by Gérard Genette (Narrative Discourse); the analysis of Honoré de Balzac's Sarrasine by Roland Barthes ( $S / Z$, trans. by Richard Miller [New York: Hill and Wang, 1974 [1970]]); and the analysis of Maupassant's novel Deux amis by A.J. Greimas (Maupassant: The Semiotics of Text:PracticalExercises, trans. by Paul Perron [Amsterdam \& Philadelphia: J. Benjamins Publ., 1988 [1975]]).

11 Christian Metz, L'énonciation impersonnelle ou le site du film (Paris: Méridiens Klincksieck, 1991), p. 214. 
It is as if, out of caution, Metz often placed theoretical language between himself and a film.

After the initial literary and filmic narratologies of the 1980s, narratology's third phase, which resembles more a punctuation, is that of a Metzian enunciation that represents an acme as well as a swan song in France. L'énonciation impersonnelle perfectly describes its author's intimate and distant ties with storytelling and narrative studies. The first two pages evoke narratology as that Other, foreign to his approach. When he writes in the opening that: 'Narratology never tires of telling us that the enunciator and the addressee are abstract and structural representations, "places", or a little later that 'we mustn't [...] transfer on the enunciative apparatus the characteristics of its representational embodiment, like those narratologists who, after having defined the ideal Reader (Implied, Immanent, etc.) describe for us in detail his reactions in a psychological and novelistic vocabulary', it is understood that his reflection remains on the outside. ${ }^{12}$

The fact that one of the major horizons of L'énonciation impersonnelle is narrative fiction does not suffice to make of it a book on narratology. The last chapter, on the other hand, is unequivocal. We read therein that enunciation and narration,

usually distinct, can only merge when a discourse presents the dual nature of being narrative, and without a preliminary code, an autonomous support comparable to what is the idiom for the novel, so that its enunciation consists entirely in a narration. ${ }^{13}$

A few pages later, Metz adds that:

In certain examples and particularly in narrative films, we no longer have theoretical criteria for distinguishing between narration and enunciation. [...] Narrative film is no longer the only place where enunciation becomes narration, but also where narration takes responsibility (in an underlying manner) for the totality of the enunciation. The recovery occurs by the two ends at once. [...] Narration, on the part of the terrain it occupies, takes charge of all the discursive adjustments, all enunciation. Moreover, when we think about figures that everyone considers enunciative, we generally realize that they are also inseparably narrative: diegetic 
speaker, non-diegetic speaker, voice-over or voice-in, direct regard of the camera, motivated or unmotiaved music, off-screen, etc. ${ }^{14}$

This epilogue summarizes the work and confirms, if that were necessary, that the narrative theoretician was right to feel concerned by L'énonciation impersonnelle with each of its explorations of studied configurations. The reader will leave the book with the precise and clear-cut hypothesis of an impersonal narration whose unique setting is the film itself and its configurations.

Christian Metz thus led the way for a film narratology by posing phenomenological conditions, and he announced the end by implementing a quarter turn in the direction of enunciation. Without directly taking part, he nonetheless remained an attentive viewer and indirect actor, if only through the rich and generous commentaries with which he graced his colleagues' work.

In France, ${ }^{15}$ there followed a fourth period of divorce, a divorce all the more striking because semio-narratology took centre stage in the $1980{ }^{16}{ }^{16}$ It is worth noting that film studies alone was affected by this silence; literary narratology and narratology in general did not experience, it seems, this downward trend. Several reasons can explain the French apathy for the study of filmic narratology in the $1990{ }^{17}{ }^{17}$

Thus, a dual disinterest was symmetrically accompanied by new interests. There was a growing disinterest in so-called 'content' analyses that, on the one hand, did not take into account the work, or even the existence, of images outside of their vehicular function, and that on the other hand addressed filmic content primarily in terms of what constitutes a norm. In sum, narrative analysis was more concerned with acknowledging an ideally universal matter (with actants, narrative diagrams, functions, trials, etc.), or, beyond content, with narrative strategies (what kind of focalization, ocularization, what kind of narration and what narrative authority, what kind of temporal organization, etc.), than with being attentive to the

\footnotetext{
14 Ibid., pp. 183-87.

15 Guido Kirsten tells me that this is not the case in Germany.

16 Michel Marie points out that narrative analysis never really disappeared, even in France. Indeed, what faded is less narrative analysis but narrative theory, a 'narratology' that presents itself as such.

17 I develop this question, here raised only generally, in a subsequent paper whose publication is forthcoming: 'Ce que l'esthétique peut pour le récit filmique', in Tout ce que l'esthétique permet! (à l'endroit et au-delà du cinéma), ed. by Térésa Faucon and Barbara Le Maître (Paris: IRCAV-CRECI [forthcoming]).
} 
singular invention of films, independently of these models or typologies. At best, recalcitrant objects were considered in terms of their deviation from the norm.

More generally, this sudden change of regime displays a mounting disinterest in structural analysis which began, according to Genette, in 1972, just when he was advocating an open structuralism, deeming an overly structural analysis too 'internal'. ${ }^{18}$ For those who assume that the narrative embodies the 'literary' part of the film, this disinterest went hand in hand with the rejection of the linguistic and literary heritage.

Simultaneously, interests shifted in two opposite directions. Some scholars turned towards sociological or context-based approaches, focused either on a film's production or reception. That's what the authors of cultural/ gender/star/queer studies, etc. embarked on. We can call this a centrifugal displacement in relation to the filmic 'text', which encourages connecting the film to its exterior. ${ }^{19}$

Symmetrically, another displacement occurred, this one centripetal, because even though the story was weakened by the context, it shattered from within in favour of the image considered in all its dimensions (plastic, expressive, representational, figural) - image qua image, in its visual and (ideally) audio materiality, directly connected to the sense organs. This change of scale is accompanied by an abandonment of the linguistic and literary legacy in favour of another tradition, that of philosophy and art history. ${ }^{20}$ Film aesthetics then stepped in to recover semiology and narratology.

For the past twenty years, aesthetics has invited us to a reconciliation with images, which is accompanied by a need to differentiate itself from narrative analysis. Even if we are 'trained to accept that films tell stories', as Jacques Aumont writes,

18 See, in particular, Gérard Genette's ‘Critique et poétique', in Figures III (Paris: Seuil, 1972), 9-12 (p. 10). However, this tendency in fact goes back to 1966 with his 'Structuralisme et critique littéraire', in Figures I (Paris: Seuil, 1966), pp. 145-70.

19 If this approach has had the tendency to dispense with the question of narrative, Pierre Beylot's research demonstrates that it can also be articulated therein. His study, Le récit audiovisuel (Paris: A. Colin, 200o) constitutes not only a revival of research on audiovisual narrative but also a crossroads between narrative studies and Anglophone theories. He considers audiovisual fiction films to be cultural productions taking part in the social sphere, taking into account differentiated practices. The word 'practices' should indicate both the manner in which a story is conceived and is developed but also the modes of its reception by a viewer who is likewise a social construct.

20 This movement within continues outside each time film images are questioned in their dialogue with other types of images: pictorial, photographic, cave drawings, etc. Nevertheless, it is no longer the film that 'eyes' the outside but its images taken in their singularity. 
analyzing films is meaningful only if in the moving visual images (and in the inevitably temporal audio images) of which they are made up, something more or something else is said than simply storytelling, which comes under thinking. ${ }^{21}$

It was also a question of showing that 'an image, no longer satisfied just with what it represents' will 'enable a new understanding of an image that coincides neither with its narrative goal, nor with its mimetic effectiveness, nor with its expressive logic'. ${ }^{22}$ To accept that is 'to listen to a visible whose visibility is never completely given, which is to be rebuilt'. ${ }^{23}$ We must be attentive not only to the image but also and especially to what remains unseen in the image, to the dimension no longer representational but figural of the images, which resembles more an energy or a power than a representational or narrative function. Depending on the author, this is formulated in a more or less controversial manner and realized in a mutual indifference between aesthetics and narrative studies.

\section{Rediscovering the Image in the Narrative}

If today it seems to us not only possible but also desirable to restore a connection between image and narrative, it is because a number of narrative and aesthetic analyses are doing it naturally, implicitly, or secretly, without saying so (sometimes without even knowing it). In reality, aesthetic and narrative analyses are preoccupied with a similar material, even if they don't seem to construct the same object: for the first, the film is a sum of images; for the latter a entity.

This question of scale brings us back to Christian Metz, specifically to his well-known article 'The Cinema: Language or Language System?' where he questions the relationship between the narrative and the image. Writing in 1964 , he had this to say about the similarities cinema has and maintains with narrativity:

The rule of the 'story' is so powerful that the image, which is said to be the major constituent of film, vanishes behind the plot it has woven - if we are to believe some analyses - so that the cinema is only in theory the art of 
images. Film, which by nature one would think adapted to a transversal reading, through the leisurely investigation of the visual content of each shot, becomes almost immediately the subject of a longitudinal reading, which is precipitous, 'anxious', and concerned only with 'what's next'. The sequence does not string the individual shots; it suppresses them. [...] It is as if a kind of induction current were linking images among themselves, whatever one did, as if the human mind (the spectator's as well as the filmmaker's) were incapable of not making a connection between two successive images. ${ }^{24}$

Thus, each filmic image summons up the next. As spectators, we are as sensitive - indeed more sensitive - to this flow, this march forward of images and the movement that carries them ahead, than to the images themselves taken individually. ${ }^{25}$ Metz here puts filmic narrative in contact with its root. He conveys a very strong intuition in the place of articulation between the image and what exceeds or overflows from it and which is called the narrative. The effect of this 'inductive current', which makes of the filmic image a smooth surface on which the gaze is invited to continually slide along, is still more powerfully felt when it is compromised than when it is implemented in its ordinary functioning, where it occurs unnoticed.

The denouement of John Sayles's film Limbo (USA 1999) offers a remarkable example of something gone awry. Its screening in a Paris cinema in the $11^{\text {th }}$ arrondissement triggered unusual feelings of dissatisfaction. That the audience liked or disliked the film is perfectly normal; that is not the question. A single image posed a problem to the offended audience members, or more precisely an absent image at the film's end: three characters (a young girl, her mother, and the mother's lover) fleeing a mortal danger become stranded on a desert island; some men arrive by helicopter either to save them or to eliminate them. Perfectly aware of the risk involved, the three decide to reveal themselves. Huddled together, they desperately watch as the helicopter heads towards them; they are filmed in a medium shot in the centre of the image. The last shot shows the sky, white and empty, while we

24 Metz, 'The Cinema: Language or Language System?', pp. 45-46.

25 The term image is here employed in a precise manner: it is a filmic entity not to be confused either with a film still nor with a film shot. It may be a part of a shot or include several shots. Comparable to Roland Barthes' notion of lexie that he develops in $S / Z$, it is a kind of reading unity, a space convenient for observing the senses; see Barthes, $S / Z$, in particular Chapter VII. For more on this idea, see: Anne Goliot-Lété, 'L'image de film inventée par l'analyse', in L'analyse de film en question. Regards, champs, lectures, ed. by Jacqueline Nacache, (Paris: L'Hamattan, 2006), pp. 15-29. 
hear the whir of the propellers: so ends the film as the credits begin to roll. What is surprising here is neither the image of the three characters nor that of the sky, both rather ordinary, but that they remain without echo. The awaited response doesn't come and the film ends very abruptly, denying its characters their right to life or death, thus depriving the audience of their fate. The credits arrive without a transition, without even the visual softening of a fade to black. What a shock for the spectator, even those who are connoisseurs of open endings (in any case, this cannot be construed as one). The unhappy audience members complained to the projectionist, some holding him almost responsible for the misdeed, which couldn't in their minds be attributed to the filmmaker. It was impossible for them to believe in this eternally suspended ending. If they felt manipulated and exploited by the film, it is because their reading, headlong, out of step with the march forward and anxious for the what was to come (in other words, the ending) couldn't cope with such a brutal interruption, with this kind of narrative power outage. The spectacle of Noelle, Donna, and Joe's death would have most certainly been less terrible than that of the violent and transgressive death reserved for them by the narrative. In reaffirming the power of enunciation, this final, strongly 'derealizing' gesture invites a re-evaluation of the film and dismisses it to limbo, disembodying the characters, eliminating their world, and erasing their history. One missing image all by itself can thus raze an entire edifice.

This extreme case emblematically illuminates much more ordinary examples and tells us that a filmic narrative is first and foremost a sensory experience - at least in the empirical approach of an initial viewing (which is but one practice among others), and a fortiori prior to all analysis. There is the feeling of an 'inductive current', of a 'logic of implication' that goes through images, the feeling of an unstoppable flight of visual and audio images in movement that overflow, persist, and become lost outside themselves. If, as Metz writes, 'the sequence doesn't string the individual images; it suppresses them, ${ }^{26}$ it is not because it denies the ontological initial step but rather because it eliminates its borders and is aware of an organic circulation within the film. A succession of shots is more a movement of rolled up images wound up together than a simple accumulation. It is in the movement of this audiovisual flow that a narrative takes form, rather than in its supposedly literary dimension, in the film's words (dialogues, text in voiceover, title cards, etc.) or in its screenplay (which itself makes up a narrative, but another narrative). Whether an expected image is not in its 
place (Limbo), or just the opposite, an unexpected image suddenly appears (as in the narrative breaks Atom Egoyan regularly employs in his films), the flow is suddenly interrupted and we become acutely aware of its force.

To read a narrative is thus to be involved in two distinct activities: one perceptive (I perceive images in movement, which disappear as quickly as they appear and which forge and produce their story); the other cognitive (I build a story based on perceived images that immediately disappear). Perception and cognition are the two routes of access to a filmic narrative. They cannot be exactly parallel or homologous: to build progressively a story is to comply to the logic of increase, accumulation, and summarizing. It is to evoke a memory at a given moment, to synthesize all that came before, that forms an entity: a story calls on memory. In contrast, perception occurs in the moment. Eye and ear are like a cursor moving along a film. The contact that ties the image and soundtrack to the organs of seeing and hearing is reduced to a point. I can only perceive one image at a time (albeit sometimes a very complex image): the one I have before my eyes and in my ears. Thus, if we consider the empirical experience that Metz's text refers us back to, images fade away and are absorbed by the story, but one image always remains in order to assure in the present the specific contact with eye and ear. This is why the phenomenon of the erasing or wiping of the image cannot be confused with a repudiation or a denial of the image. The narrative sensation during the viewing of a film is simultaneously born from the need to unstick the eye from the images and to delete them in favour of an inclusive and totalizing gesture of cognitive construction, all while continuously maintaining a point of contact with the image in movement to ensure perception, without which there can be no story. In other words, a story is based on the necessity of a contact with the image, while coincidentally organizing its disappearance.

Already in his early founding text, “The Cinema: Language or Language System?', which (in the short section devoted to narrative) queries how one senses narrativity, Metz formulates - before asking how one explicitly recognizes a story - his first 'notes toward a phenomenology of the narrative' (here, a filmic narrative). His notes remind us that a filmic narrative, as part of the experience of its screening, before becoming an object of intellection, addresses the senses and causes a sensation. Prior to an 'impression of narrativity', ${ }^{27}$ which François Jost evokes in reference to the impression

27 François Jost, 'La sémiologie du cinéma et ses modèles', Iris, 10 (1990), 133-41 (p. 133) (my emphasis). 
of reality, it seems possible to imagine a sensation of narrativity. Metz subsequently reminds us that this sensation is born in the slide from one image to the next rather than in the images themselves, simultaneously implying that the resulting obliteration from this slide happens little by little, without stopping and astonishingly nowhere more than in the contact with an image on which it completely relies.

Tackling the narrative phenomenon by highlighting the story's 'deletion' of images, as Metz does, paradoxically amounts to restoring a link between the two. As such, the Metzian proposal is diametrically opposed to the structural enterprise.

In 1981, Jacques Aumont wrote that it is 'impossible to assign any place in filmic discourse to narrative procedures' and that these 'slide across the figures of editing but also freeze in framings, slips "in" the represented itself', which doesn't prevent him from defending a few lines later the idea that 'filmic narration [...] has only little to do in itself with the image' and that 'the best studies on filmic storytelling can only address the story in the film and never really the film (the entire film) as narrative'. ${ }^{28}$ Ten years later, Metz responded by saying that we are 'not finished with an explicitly factual framework that corresponds to a kind of screenplay or a skeleton rather than to the film itself' and that 'when a film is narrative, everything therein becomes narrative, even the grain of the film stock or the timbre of the [characters'] voices'. ${ }^{29}$ If Metz and Aumont's statements largely concur that the story is everywhere in a narrative film, they nonetheless differ in how to tackle a film: where Aumont rejects a reconciliation of image and story in narrative studies, Metz perceives instead a necessary challenge, undoubtedly at the price of some difficulties in methodology and terminology.

A reconciliation between narrative and image is readable in narratology's last phase. In his two forewords to Iris's two special issues on 'Cinéma et narration', Marc Vernet observes that thinking has been displaced from overarching structures to micro-figures, which shows a new interest in the 'visual organization of images' $3^{0}$ This double evolution should not be underestimated: the narrative no longer (or not only) merges with the macrostructures, instead reconnecting with small units, details. At the same time, a narrative study can concentrate on an image qua image, as a filmic signifier.

More surprisingly, despite being tacit, this rapprochement can be perceived outside of narratology in Gilles Deleuze. He implies a form of

29 Metz, L'énonciation, p. 187.

30 See Iris, 7 (Cinéma et narration 1, 1986), p. 2; Iris, 8 (Cinéma et narration 2, 1988), p. 6. 
crossbreeding of image and narrative. The very titles of his two-volume opus place them under the jurisdiction of the image, while nonetheless retaining a kind of hesitation or indecision as to the notion of the image. If this is usually confused with a shot, it seems to stretch out beyond the shot when the author characterizes the image-action and, more particularly, the two modalities or aspects of the image-action that are 'large' or 'small' forms. The first is an 'organic and spiral transformation [which] has as its formula SAS (from the situation to the transformed situation via the intermediary of the action)' ${ }^{31}$

The second 'moves from the action to the situation, towards a new action: ASA'. This time, it is the action that discloses the situation, a fragment or an aspect of the situation, which triggers off a new action. The action advances blindly and the situation is disclosed in darkness, or in ambiguity. From action to action, the situation gradually emerges, varies, and finally either becomes clear or retains its mystery. ${ }^{32}$

Isn't what we have here a stretching, an 'elongation' of the image, which carries it irresistibly onto narrative ground, with its actions, its situations, its transformations, so many entities that delight a narratologist? And when films embodying these two forms are evoked, Deleuze cannot help telling stories about them. Thus in The Movement-Image, the philosopher proposes two kinds of images: the little image (the shot) and the big image (the narrative). In The Time-Image, he will retain only the first. ${ }^{33}$ The fact that Deleuze specifically employs the same term to describe two realities that he usually sets in opposition interests us, not so much for the apparent contradiction that we might be tempted to see therein but for the intuition that these remarks tacitly make visible: that of the relationship of proximity between image and narrative, both hewn from the same matter. The second is only a kind of extension and elongation of the first. A narrative begins there, where the image, pushed to the max of its elasticity, ultimately surrenders and migrates into memory.

\section{Perspectives: Narrative and Image in an Analysis}

In 'The Cinema: Language or Language System?', Christian Metz places his thought within the empirical experience of the ordinary reception of a film,

31 Gilles Deleuze, Cinema 1: The Movement-Image, trans. by Hugh Tomlinson and Barbara Habberjam (Minneapolis: University of Minnesota Press, 1986), p. 142.

32 Deleuze, Cinema 1, p. 160.

33 Twice in The Time-Image, Deleuze feels the need to indicate in parentheses what he means by image: 'movement-image (the shot)'. Gilles Deleuze, Cinema 2: The Time-Image, trans. by Hugh Tomlinson and Robert Galeta (Minneapolis: University of Minnesota Press, 1989), p. 28 and 29. 
ideally on a first viewing, during which we perceive, in the ephemerality of their movement and speed, images that produce a story. Still, it is worth emphasizing that there is not one but a multitude of narrative experiences, even of the same film. To watch a film again is not the same thing as seeing it for the first time and supposes a completely different relationship to the narrative. We rediscover a known matter, images already inscribed in our memory, but which will be perceived differently, thus allowing us to construct another story.

I would like now to pause on a film and to propose an extension of the foregoing, rather than an analysis strictly speaking. What follows is a testimony of a narrative experience where what is at stake resides less in the hypotheses themselves than in the development of the reading and in the changes that occur during repeated viewings, a reading that is made in the contact of images in the direction of the story told.

Why did I choose Atom Egoyan's Exotica (CAN 1994)? Perhaps for its natural complicity with Metz's last book, with its many markers of enunciation, and also because it is not an adaptation (and consequently its narrative contents can't be suspected of having an earlier form, outside of the film), also for its somewhat sly narrative construction, and the problematic, intriguing nature of its story. And finally a little by chance, too.

I don't intend to give a detailed summary of each of my viewings of the film, not even of the first, because my memory of it is too vague. Instead, I will try to understand what happened at a certain moment in my study, which, based on an interrogation of several problematic images, completely re-oriented my narrative reading of the film as a whole. What follows, then, is an account of my sudden change in interpretation.

Exotica presents an uneven narrative with intersecting temporalities made up of several series of images whose connections are only gradually understood. Full of holes, incomplete, and elliptical, the narrative leaves a certain number of questions unresolved. All that is not without consequences on the narrative feelings experienced when first discovering the film or on the story's legibility taken together, a story that, far from naturally appearing like a given of the film, has to be constructed.

A first reading focused on the most 'effective' elements, which provide links between a series of images leading to narrative hypotheses. From this interpretation emerged a story that could be that of a man, Francis, grievously tried by the rape and murder of his little girl Lisa. He undertakes the slow, long, and painful work of mourning, until it is then hampered, blocked, and rendered impossible by the violence of the trauma. His wife is also dead, having died shortly after her daughter, in a car accident where 
she was found with Harold, Francis's brother, with whom she was possibly having an affair. (The police think so, and so does Francis, while Harold tells his daughter that Francis is imagining things; we never learn one way or another.) Exotica appears as a tangled web of often strange relationships, governed by contracts.

Francis has a relationship with Christina, a stripper at the Exotica (a tony club for well-to-do men where Francis hangs out several times a week). She was also, we later learn, Lisa's babysitter. His relationship with Christina is both special and ambiguous, mixing eroticism with something like paternal love. Eric meets Christina during the search organized to find Lisa's body (this episode occurs in a series of flashbacks) and was her lover. Eric is jealous of her relationship with Francis and puts Francis on the club's noentry list. In contrast, Eric doesn't feel the same about Zoé, the club's owner, although she has become Christina's significant other. He is doubly tied to Zoé: he is her employee and he agreed to have a child with her, which she plans on raising without him, as per their legal agreement.

Every time he goes to the Exotica, Francis pays Tracey, his niece (and Harold's daughter) who comes over to take care of ... the house? Lisa? and to play music. Finally, Francis, who works for the Canadian tax office, audits Thomas's business. (Thomas sells exotic birds and fish and is rightly suspected of engaging in the illicit and highly profitable trade of rare macaw eggs.) Thomas also engages in a ritual that consists in regularly soliciting 'exotic' men (of very specific types) to whom he sells ballet tickets for 'compensation' after the performance.

Incapable of confronting his bereavement, Francis multiplies a series of rituals that allow him to remain in denial about Lisa's death. Faced with her disappearance and demise, Francis reacts with a multiplication of his daughter's image so that she literally becomes omnipresent, appearing in numerous photos in the living room. She serves as a pretext for the presence of Tracey, who is a kind of babysitter (although without a child to look after); a photo of Lisa as a beginner at the piano occupies the empty place on the piano stool, with Tracey pre-programming the piano to accompany the melody she plays on her flute; Lisa is reincarnated as Christina, who performs at the Exotica wearing the schoolgirl's uniform Lisa wore in photos and on the day she died, etc.).

The film thus presents an ensemble of characters tied to each other by monetary contracts: Francis pays Christina at the Exotica; he also pays Tracey who spends her evenings at his place in his absence; Thomas sells exotic birds for a high price to his customers; he also sells ballet tickets (but later returns the money); Zoé pays Eric for his work as a DJ and as a sperm 
donor; Francis gets Thomas to act on his behalf at the Exotica in exchange for a tax break, etc. Moreover, the characters' distinguishing attributes migrate from one to another: Tracey replaces Christina in her babysitting role (Francis drives both of them home in his car); Christina replaces Lisa in her school girl role; Tracey momentarily replaces Lisa at the piano; the theme of 'assisted' procreation links Thomas and Zoé (she is pregnant, while he carries the macaw eggs against his belly before placing them in an incubator), etc. Certain attributes specific to their surroundings are equally interchangeable: at the airport and the Exotica, we find a two-way mirror and voyeuristic practices as well as the motif of walking through a mirror. ${ }^{34}$ Both at the club and the theatre, we find the rituals of dance, balconies, and eroticism (even if, paradoxically, the erotic charge of the scenes in the theatre is infinitely greater than those at the striptease club). Exoticism links everything together from the Exotica to Thomas's shop.

Up until this point, the narrative rests on a network of characters and places, on a singular and systematic exchange system and on a production of repetition, all of which ensures a kind of balance.

Subsequently, the film narrates the undoing of this equilibrium, the manner in which two characters put an end to the ritualistic evenings at the club (Tracey no longer wants to spend her evenings at Francis's house; Eric, at the Exotica, pushes Francis to break the rules, which leads to his definitive exclusion from the club). It is this severing of an obsessive ritual that leaves an opening for the beginning of the work of mourning.

My reading might have stopped there. But just at the moment when this general coherence and diegetic-narrative homogeneity appeared, some questions arose, first around three disturbing images - repetitive, non-sequential, ${ }^{35}$ and artifactual: ${ }^{36}$ they are the amateur video images that arrive without warning in the film. Secondly, around the final sequence, introduced by a third instance of these video images and leading to a second past, in a 'past perfect', as if, in short, the prologue was found displaced

34 The head customs officer explains to his young recruit the need to know how to interpret the gaze of the person who is being searched, and invites him to look Thomas straight in the eye. Ironically, Thomas happens to be slightly cross-eyed, and as a result his gaze is not easy to read. A little later, we see Francis at the Exotica intensely looking at Christina. It's up to the viewer to apply the customs officer's advice. Although he is not cross-eyed, Francis's gaze is not immediately legible and demands a real work of interpretation.

35 These images occur at 37' 53"; 52' 13"; and 93' 45" in the film.

36 For more on this question, see:Jessie Martin, 'Le choc des images artéfactuelles dans le récit cinématographique', in Textimage (online journal), Spring 2011: http://www.revue-textimage. com/o6_image_recit/martin4.html [Accessed 1 August 2014]. 
to the film's end. These slightly 'disturbing' images intend to reopen the film's ambiguity, uncertainty, and complexity. The question then is: What do these images that match poorly with my initial reading want to tell me?

Detail: A video image shows young Lisa and (probably) her mother, laughing, sitting at the piano. Then we see a hand that, pushing the camera away (signifying to the filmer to stop shooting), invades the space of the image (Figures 15.1 and 15.2). The image accelerates or is paused on an image but never advances at normal speed. Even if the three occurrences refer to the same scene and enter into a process of repetition, producing a haunting effect, for Francis as well as for the film itself, we are not dealing with the same image. Their duration is not identical (they are respectively six, ten, and eighteen seconds in length) and include a different number of freeze-frame images (four, five, then seven). It is less the 'paternity' of these shots, naturally attributed to Francis, than their narrative status that poses a problem here. If these images have something to do with a memory, the transitions, diegetically out-of-focus, suggest that what's at stake is not simply an expression of a memory.

First observation: This shot, seen on two other occasions, is obviously not an explanatory flashback. It poses more questions than it answers. Moreover, the fact that it is an image recorded with a video camera indicates its status as a concrete image within the diegesis, particularly since this image has been manipulated. That it goes from a fast-forward movement to a freeze-frame on successive images points out that it is diegetically viewed (even if we are not shown Francis at home, with the remote control in hand). ${ }^{37}$ If this is a memory, we should first begin by specifying that it is a memory of an image doubled by the memory of its recording. In addition, if we consider the three instances together, we have the feeling of a return of the present of their reception (the temporality of their impact, their resonance, and their harmonics) towards the past of their production, their origin. Together, they thus form a little series that takes time backwards and which makes of the end of the film the beginning of the story. In other words, the link between the present and this past, the past before the tragedy, is accomplished via images that have the status of images within the film..$^{38}$

37 These shots call to mind the fleeting video images seen just once by a character in Egoyan's previous film, Calendar (Canada, Germany, Armenia 1993).

$3^{8}$ It is worth noting that the other series of images from the past - relating to the search through fields - functions completely differently. They exhibit a continuity rather than a repetition from one episode to the next. Even if certain transitions can be problematic, these flashbacks have an explanatory function, providing background information on Christina and Eric's relationship. And they describe an episode that has a precise beginning (their meeting) and a precise end (the discovery of the girl's corpse). 

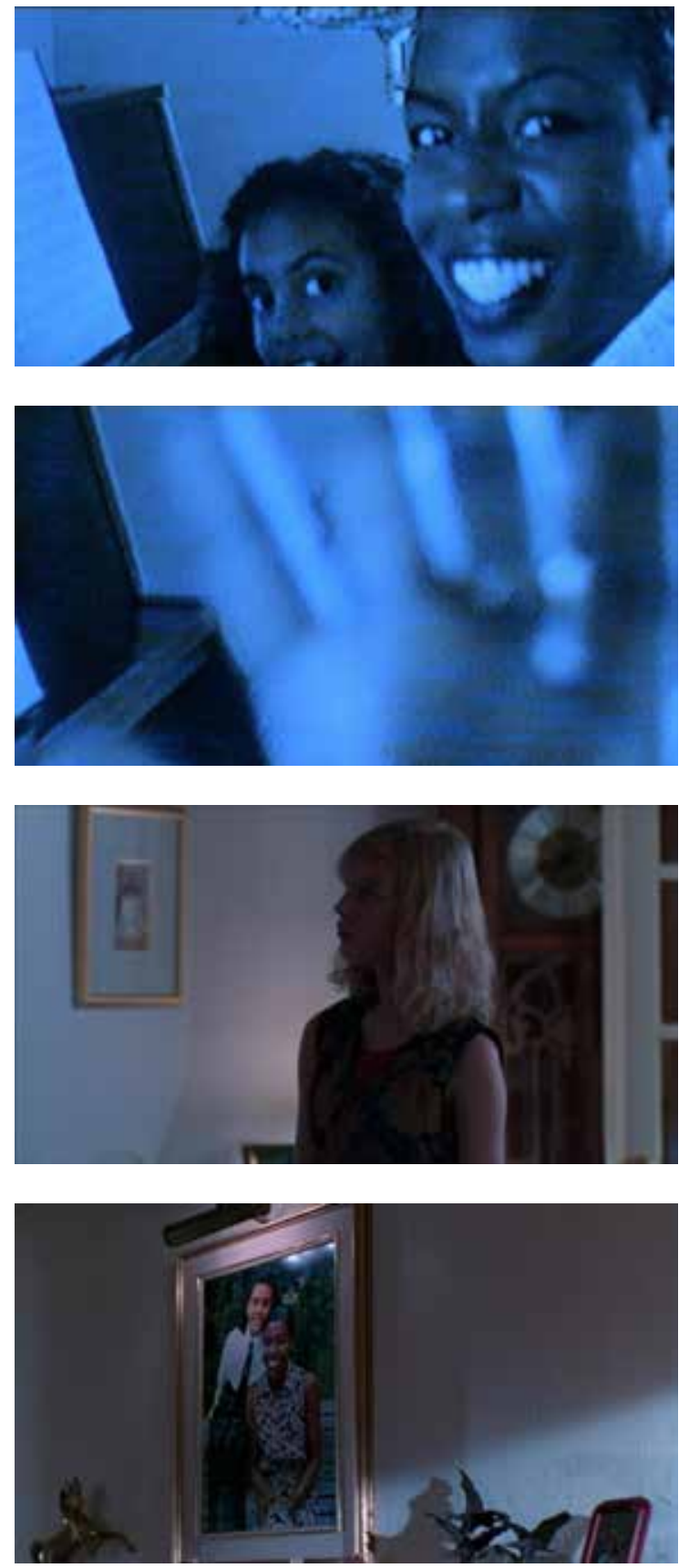

Figs 15.1-15.4: Exotica (Atom Egoyan, CAN 1994) 
Second observation, then a hypothesis: Let us now think about these images in relation to their environment. The first occurrence takes place while Tracey carefully looks at the photos of Lisa and her mother on the side table and hanging on the living room wall (Figures 15.3 and 15.4). It is useful to add, perhaps, that Tracey contemplates the photos right after having played a melody on her flute, accompanied by the piano without pianist; the image emphasizes the empty stool, where Lisa would have sat. Together the photos and the empty stool point to a very strong presence-absence. And it is at this precise moment that the little girl and her mother appear at the piano in a black-and-white image (tinted-blue since it comes from an amateur video), which is a kind of intermediary between a moving image and a still image (due to the freeze-frame). This image that advances jerkily appears like an imperfect attempt at animation or, even better: a re-animation of the two characters in the photos. This passage establishes a link between these images and Tracey. She will later decide to end the babysitting masquerade, telling her father that Francis pretends that she is taking care of Lisa, that he wants to believe that Lisa is still there, and that her presence helps to convince him of it. This series of images (Tracey in front of the photos, then the video image of Lisa and her mother) concretely embodies a denial of death: by her very presence in the house, Tracey brings back to life the dead girl whom she pretends to babysit for (and she becomes aware of this while looking at the framed portraits). The video image, in animating the still images and in showing Lisa at the piano (where her seat remains empty), produces a real resurrection. This transition, at first felt as problematic, suddenly takes on a new aspect. The rupture becomes suture and the narrative feeling is restored where initially it seemed lacking.

The next occurrence is framed by two scenes showing Francis at the Exotica Club, two scenes separated by a short temporal ellipse. The first happens in the restroom: Francis is in a bathroom stall with the door closed while Eric speaks to him and encourages him to break the rules and to touch Christina. The image of Eric giving advice and developing his argument is framed and composed in such a way that his hand - very expressive - is reflected in a mirror. His hand is both cut off from his body and highlighted (Figure 15.5). In the scene following the ellipse, Francis places his hand on Christina's belly while she is dancing for him (Figure 15.6). Here we notice that the video image resonates quite differently: first of all, it lingers much less on the faces (Lisa's is barely visible) focusing instead on the protective hand obstructing the image (Figure 15.7). In addition, the soundtrack of the bathroom scene overlaps momentarily with the video image from the 

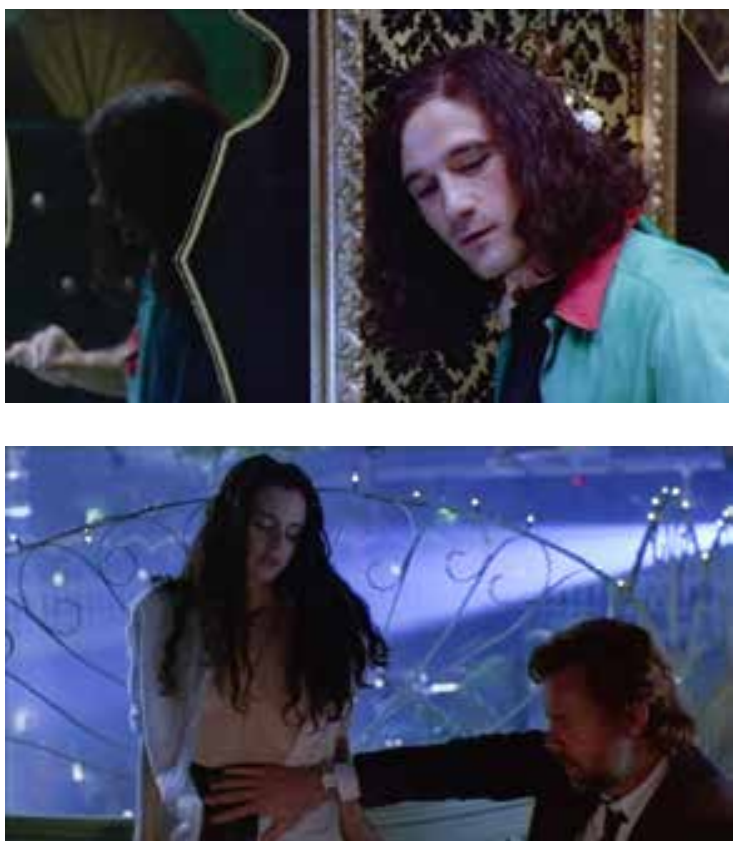

Figs 15.5-15.6: Exotica (Atom Egoyan, CAN 1994)

past. We hear: 'What will happen if I touch her?' The question may relate to Christina or to Lisa. Read at face value, this collection of images, heterogeneous in type and temporality, represents first, a transgressive desire via touching (accentuated by the presence of the hand); secondly, the image of a little girl and a hand that intervenes to protect her; and thirdly, the image of a man touching a young woman when this is forbidden. The young woman in question is dressed in Lisa's school uniform. The protective gesture of the maternal hand arrives thus as a symbolic response to the threat posed by the father's hand. This interpretation, created by the editing, will not be contradicted by the third occurrence of the video image: Thomas, at the Exotica, at Francis's bidding, reiterates the forbidden, placing his hand on Christina's thigh. She takes Thomas's hand and gently gives it back to him (Figures 15.8 and 15.9). This is when the third video image appears. Here again, the apparent rupture of temporalities and textures of images is captured at another level by a form of continuity (Thomas' transgressive hand is gently prevented by Christina's hand, then the mother's protective hand; Figure 15.10). But this time, there won't be a return to the present. This shot marks the transition between the assumed present and the final scene from the past before the tragedy. 

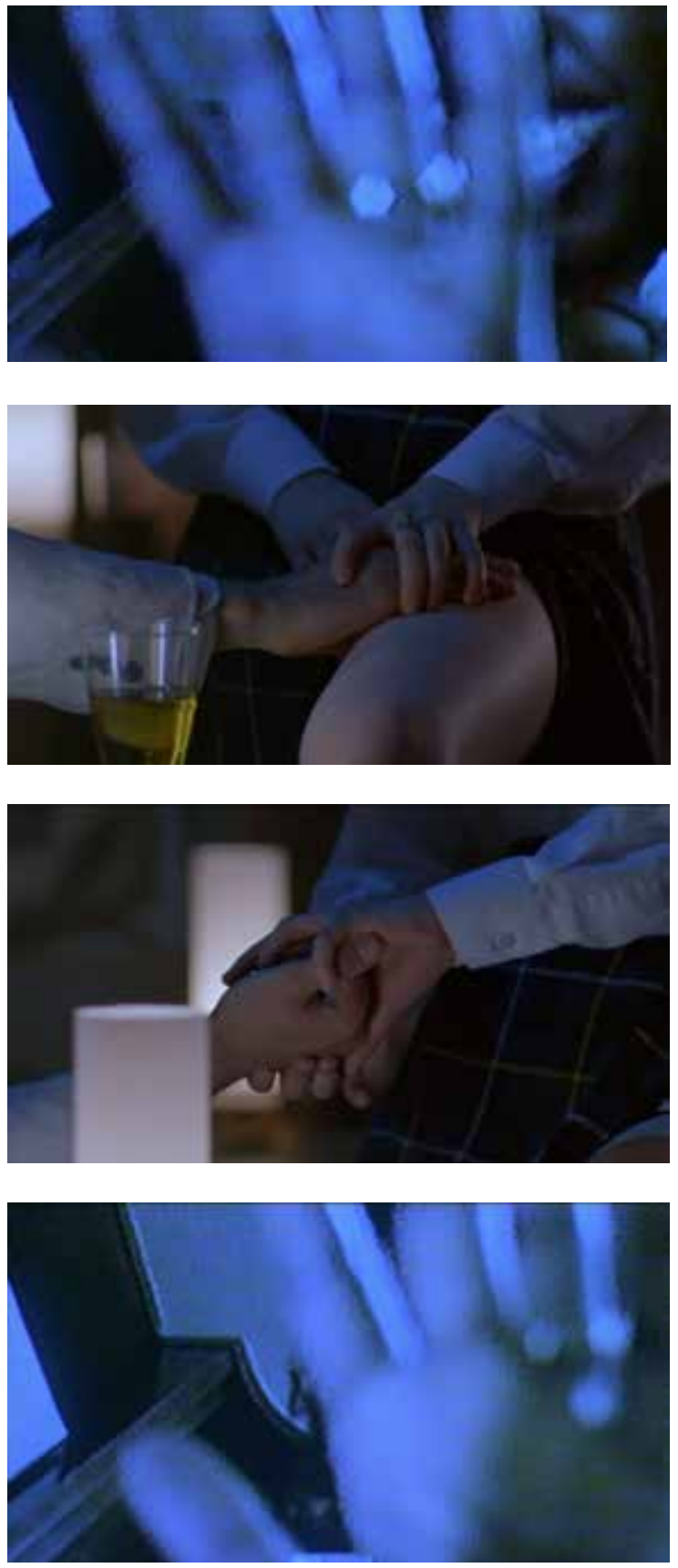

Figs 15.7-15.10: Exotica (Atom Egoyan, CAN 1994) 


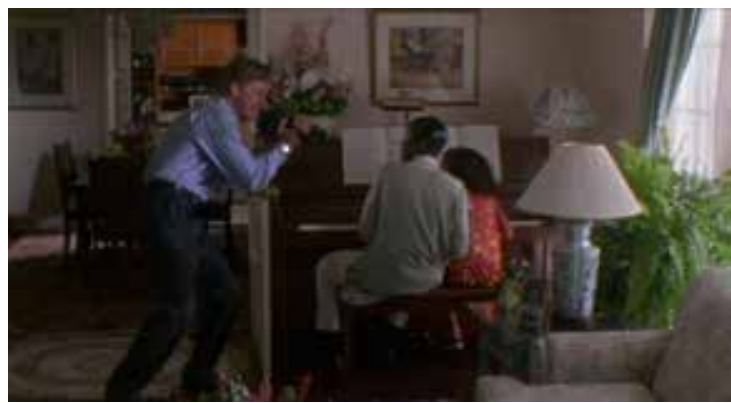

Fig. 15.11: Exotica (Atom Egoyan, CAN 1994)

A younger Francis with a video camera in hand films the mother and daughter at the piano (Figure 15.11); the scene is interrupted by the door bell ringing: Christina, an unhappy, pimply-faced teenager, has come to babysit Lisa. In the final scene, Francis drives Christina home. He questions her on her malaise and makes her feel good about herself by affirming her sense of responsibility. Then, finally, after having emphasized his availability and his desire to listen to her and to help her, he pays her. The scene is troubling because of its latent and diffuse eroticism (Christina's sighs echo the lascivious sighs at the Exotica; the nature, the length, and the insistence of the exchanged looks; the role of money; the tone of the conversation, etc.) and because of all its elements that we have already seen earlier in the film and that we know will reoccur in the diegetic future. (This scene obviously evokes the scenes where Francis takes Tracey home, particularly the scene in which, before paying her, he encourages her to confide in him if she feels the need). This series of images (artifactual video images and the final sequence) makes clear - but only tangentially - a dimension of Francis's character absent from the rest of the film. It is no longer just the image of a father in mourning that we see but also that of a concerned or personally involved man, as shown through this gesture of a masculine, adult hand placed on a youthful, feminine body, the very gesture that deprived him of his daughter. It is not at all a question of making Francis his daughter's rapist and murderer (which the police had for a time considered) or of making his relationship with Christina into an example of pedophilia but only of acknowledging the ambiguity of the character's complexity. Ultimately, the viewer is left with an uncertainty and the mystery remains complete.

We could also arrive at this conclusion by way of a non-narrative reading. This, for example, is what Jacques Rancière proposes in his Film Fables. In analyzing a passage from Fritz Lang's $M$ (GER 1931), he 
opposes the 'narrative's Aristotelian demands' to the 'aesthetic demand of suspended shots'; 'the aesthetic intrigue' to 'the old narrative intrigue' or, better still, 'the logic of the story' to 'that of the image'. ${ }^{39}$ We may well wonder about the validity of this distinction. How can Fritz Lang's $M$ be, following one logic, a child murderer and, following another, a good guy who makes a little girl happy? How is it that Egoyan's Francis seems, based on the story's Aristotelian requirements, a father deep in sorrow and also a man whose relationships with young women are deeply ambiguous as per a more aesthetic reading of the images? Putting an image back into the centre of narrative questions and admitting that the story is told via images, that it is reflected, partially dissolved there, and is endlessly reconstituted, allows us to give back to these two characters - major constituents in their respective narratives - their share of haziness and ambiguity, or to others their share of contradiction or incoherence, thus liberating the story from the corset of 'logical sharpness'. It is also to re-evaluate narrative contents and displace them: they are no longer an objective piece of information that submits to an analysis but rather this 'distant signified', ${ }^{40}$ always slightly fantastical, towards which an analysis stretches and which, as such, is ever capable of transformation, renewal, and variation.

\section{Translated from French by Sally Shafto}

\section{About the author}

Anne Goliot-Lété is Senior Lecturer in Film Studies at the University of Paris VII (Diderot). She was co-editor of the journal Iris from 1992 to 1998 and editor-in-chief of the 'Lycéens au cinema' teaching materials at the Bibliothèque du film from 2001 to 2002. She has co-authored two books with Francis Vanoye - Précis d'analyse filmique (3rd ed., 2012) and the Dictionnaire de l'image (2008) - and edited an issue of the Cahiers du CIRCAV entitled 'Le film architecte' (2005), which was dedicated to cinematic space. Her main research interests are cinematic narration (from an aesthetic perspective), everyday stories in documentary film, and places/spaces in film (closed spaces, landscapes, borders).

39 Jacques Rancière, Film Fables, trans. by Emiliano Battista (New York: Berg, 2006 [2001]), pp. 48-51.

40 Metz, 'Problems of Denotation', p. 144 (emphasis in original; translation modified). 


\section{About the translator}

Sally Shafto is a specialist on Godard and the author of The Zanzibar Films and the Dandies of May1968 (Editions Paris Expérimental, 2007). Her translations have appeared in Cahiers du cinéma, Yale French Studies, and other journals. From 2010 to 2015, she taught in Morocco, where she also actively followed Maghrebin and African film for two online film journals (Senses of Cinema and Framework). Currently, she is at work on the English-language edition of the writings of Danièle Huillet and Jean-Marie Straub (forthcoming, Sequence Press, New York). 



\title{
16. Semiotics, Science, and Cinephilia
}

\author{
Christian Metz's Last Book, L'énonciation impersonnelle
}

Dana Polan

Tröhler, Margrit and Guido Kirsten (eds.), Christian Metz and the Codes of Cinema. Film Semiology and Beyond. Amsterdam University Press, 2018

DOI: $10.5117 / 9789089648921 / \mathrm{CH} 16$

\begin{abstract}
This chapter looks at Metz's last book, L'énonciation impersonnelle, ou le site du film, with an emphasis on the function of the extensive and often appreciative citation of individual films within the book. For all its broad, theoretical concern with capturing the ways in which various figures of film come to talk of the nature of film as an intentional, communicative act, L'énonciation is also a cinephilic venture that luxuriates in the concrete aspects of specific works of cinema and which ranges over vast areas of film over vast periods of time. The book offers not only scientific analysis but also love for the art of cinema, confirming Metz's own affective investments in this most modern of popular cultural forms.
\end{abstract}

Keywords: film semiotics/film semiology, enunciation theory, cinephilia, cinematic figurations, film criticism

What I want to address in particular in this essay is a certain surprise as well as delight but also a perplexity - maybe a delighted perplexity then - that I felt the first time I read Metz's last book, L'énonciation impersonnelle, and which returns each time I come back to the book. ${ }^{1}$ (I know I am not alone in this: most readers of the volume with whom I have conversed have admitted to a similar reaction, and Roger Odin's review of Metz's book, which I will come back to in a moment, offers 'official' recognition of this typical response. $^{2}$ ) I am not sure that those of us who were his students could have

1 Christian Metz, Lénonciation impersonnelle ou le site du film (Paris: Méridiens Klincksieck, 1991).

2 Roger Odin, 'L'énonciation contre la pragmatique? A propos de L'énonciation impersonnelle ou le site du film de Christian Metz', Iris, 16 (1993), pp. 165-76. 
guessed what this volume would look like based on the way he presented some of its arguments in his famed seminar. Of course, that seminar and the publication of part of the eventual book's more theoretical section in the journal Vertigo might have given us some first indications, but it would seem that the final published volume easily provoked (and will continue to provoke ${ }^{3}$ ) a sense of curiousness, a wonder at the essayistic openness of the book as a whole, and at the sometimes chatty or conversational or colloquial quality it bears. To the extent that, as Metz himself explained in his famous interview with Marc Vernet and Daniel Percheron in the journal Ça cinéma, behind any intellectual venture there lie psychical investments, figures, and figurations of desire and so on, ${ }^{4}$ I myself have always thought that the intrigue L'énonciation impersonnelle holds for me (and evidently for others) was that aspect of Metz's corpus that I most wanted to return to and come to grips with. That is why I am presenting these exploratory thoughts as my contribution to this volume in memory of, and in honour of, Christian Metz.

In the aforementioned contemporaneous review of L'énonciation impersonnelle, Roger Odin sets out to invoke some sense of the surprises of the book - for example, the many moments in which the study offers direct, often expansive, expressions of Metz's personal tastes in film (for example, there are recurrent virulent jabs at the new music-video style of 1980 os moving-image culture). Complementing Odin's evocations and extending them, I want to address another striking element of L'énonciation: the sheer rush of references to specific films from across wide ranges of film history. It has been easy to imagine that cine-semiotics and its brand(s) of textual analysis traded breadth of film knowledge for an insistent and incessant concentration on a very few films (for instance, Raymond Bellour on North by Northwest [Alfred Hitchcock, USA 1959] or Stephen Heath on Touch of Evil [Orson Welles, USA 1958] or Metz himself on Adieu Philippine [Jacques Rozier, F/I 1962] or 81/2 [Federico Fellini, I/F 1963]). But whatever the accuracy of that original assessment of film semiology's attitude toward broad knowledge (and I think this critique was often in fact misplaced, if not downright mistaken), Metz's last volume offers a capacious and quite capricious romp across vast reaches of film history. After a downright minimal

3 An English translation of Metz's book by Cormac Deane was recently published by Columbia University Press, and one hopes this might encourage warranted attention for this last book by our most famous cine-semiologue.

4 Christian Metz, 'Sur mon travail (Entretien avec Marc Vernet et Daniel Percheron)', in Essais sémiotiques (Paris: Klincksieck, 1977), pp. 165-205. Originally published in Ça cinéma, 7-8 (1975), special issue on Christian Metz. 
mention of specific films in its first theoretical section (for example, Metz momentarily references Gone with the Wind (Victor Fleming, USA 1939), and here the citation comes only because of Francesco Casetti's citation of it and the need Metz felt to address Casetti's own studies of enunciation in cinema), Lénonciation gives itself over to a vast and admittedly eclectic cinephilia. Examples pour out from the book in exorbitant fashion and dazzle the reader with the author's erudition. Odin captures this:

Never has a book by Christian Metz accorded so much place to examples: the ensemble is striking, both by the extreme precision of the analyses undertaken (something that won't surprise adepts of Metz) and by the diversity of audio-visual productions that are invoked (something that in contrast is newer): fiction films from a range of countries, from all epochs (from early cinema to the present) and from all genres (melodrama, Westerns, films noirs, musical comedies, burlesques, etc.), great classics or rare films, auteur cinema, investigative cinema, popular film, experimental film, militant films, documentaries, journalistic reports, and even television shows. ${ }^{5}$

And, again, as Odin has noted, these prolific citations often arrive accompanied by appreciative adjectives (twice, for instance, we're told that this or that cited film by Solanas is 'remarquable') or serving as the occasion for even longer aesthetic estimations. For example, there is an extended footnote on Robert Zemeckis' Who Framed Roger Rabbit? (USA 1988) within the historical moment of Lucas-Spielberg type cinema that is quite praise-filled:

One would be wrong to despise Roger Rabbit, the Star Wars films, or other works of the same sort [genre]. It is true that an entire swath, a considerable one, of American [film] production tends to become indistinguishable from a cinema for children. There is at times in these films a loud and exploitative vulgarity, a deep stupidity, a worrisome attraction to violence. But (beyond the fact that there is, even today, an other American cinema) these works give witness to an astonishing vitality of visual invention and technical ingenuousness, a vivacity of spirit for concrete objects that is, as Europeans often forget, a real form of intelligence. Failures from French film are often bereft of these qualities. $^{6}$ 
Not that reference to specific films is absent from earlier works by Metz: to take just one example, Language and Cinema mentions, among others, Ordet (Carl Theodor Dreyer, DEN 1955), Intolerance (D.W. Griffith, USA 1916), the genre works of Sergio Leone, Sunrise: A Song of Two Humans (F.W. Murnau, USA 1928), etc. We might well suggest that cinema as an idea and its many realizations in specific filmic works were quite often a sort of magnet for Metz's semiological inquiries, even in cases where cinema might not have inevitably been the logical or necessary point of reference. That is, Metz was drawn to film - and to films - in a way that was more than just convenient: he didn't just use cinema as a good test for certain general linguistic or semiological principles, a test that might even extend those principles in salutary directions. There was also an interest on his part, a psychical investment, in films. Take, for instance, one collection of Metz's writings, Essais sémiotiques, which confesses on its first page that 'unlike my other books, this one, as its title already announces, doesn't centre on cinema, or at least not specifically and not always. ${ }^{7}$ His stated justification for this downplaying of cinema: 'In the order of [scholarly] work, advances often operate on several fronts at the same time. ${ }^{8}$ Yet as early as the second page of the first essay (on whether linguistics is or is not a branch of semiology), cinema makes an appearance as if a Freudian return-of-the-repressed were at work and Metz simply couldn't keep away from invoking the art form that had mattered so much to him in other writings; thus, to refer to the frequent accompaniment of visual culture by verbal support, Metz offers comments on diegetic versus non-diegetic voice in film and then in a footnote describes how the distinctions become blurred by a modernist cinema that has 'started to explore [cinematic voices] in their diversity'. ${ }^{9}$ That is to say, cinematic modernism stands here as the mark of that which upends fixed divisions and therefore serves as a useful heuristic device for the testing of categories and categoricals. And even more than device, cinema manifests itself as a set of known, remembered titles whose empirical qualities can rebound on, and against, fixed theoretical principles and open them up in new directions.

There is, doubtless, the risk that, when used for such a heuristic purpose, the reference to cinema overall and to individual films turns them into

7 Christian Metz, 'Présentation', in Essais sémiotiques, 7-8 (p. 7).

8 Ibid., p. 8.

9 Christian Metz, 'Les sémiotiques. A propos des travaux de Louis Hjelmselv et d'André Martinet', in Essais sémiotiques, 9-30 (p. 12); specific reference is made here to Varda's La Pointe Courte (F 1955) and Resnais's L'année dernière à Marienbad (F/I 1961). 
little more than cases or exemplars or vehicles of larger processes. In other words, there is the risk that films are used to make much bigger points rather than being studied in and of themselves. Thus, to take just one example, if, as noted, it mentioned specific examples from the history of cinema, Language and Cinema also argued that while individual films, as finished works consigned to the fixity of celluloid, came to the spectator as so many messages, the concrete workings of the films in their specificity would have to be transcended for the specific needs of semiological analysis, which had to go beyond the empirical reality of the films themselves to accede either to the textual systems that gave them their signifying potential or to the individual codes, abstract in their own fashion, that individual empirical films instantiated at this or that moment of their material unfolding. That is, this earlier book by Metz uses individual films as cases in the construction of a broader, more abstract, theory. As Metz puts it in Language and Cinema: 'For the semiotician, the message is a point of departure, the code a point of arrival. ${ }^{10}$ The individual film can seem to matter not much at all: as Metz says soon after, 'it would still be possible to directly speak of the codes without involving any of their particular manifestations'. ${ }^{11}$

On the one hand, then, cinema exists to transcend itself in the articulation of theoretical questions. On the other hand, there is also clearly, simply, directly an interest in cinema per se - an interest in individual films in all their aesthetic specificity. If, in the earlier texts, the individual film is only the materialized, manifested, or manifest message to be gone past to arrive at analytical abstraction, L'énonciation impersonnelle frequently seems to linger at the surface of the films themselves, which are often, as Odin also noted, luxuriated over in lovingly poetic language. Significantly, where Language and Cinema sees the individual filmic text as 'a point of departure', L'énonciation strongly offers a converse journey metaphor: as the theoretical first section ends, Metz announces that he will now shift to a new terrain - or what he pointedly refers to as a 'shifting geography $[. .$.$] a$ collective and regulated [reglée] patrimony'. ${ }^{\prime 2}$ The imagery here is spatial but it is a spatiality embodied in a continuous journey, an ongoing process that moves onward to the films themselves rather than a departure from the empirical reality of actual films into the generalities of theory. The expansive set of individual film texts is now what one arrives at, rather 
than the abstraction that results from leaving them behind: "The itinerary I have chosen will make me visit (in whirlwind fashion) a hundred or so enunciative sites. ${ }^{13}$ And the itinerary itself will be termed a 'guided tour' to 'some landscapes of enunciation' (this phrase serves as title of the long, central part of the volume, which itself ends with a declaration by Metz that what he had set out to do across so many pages of citation of individual film was to follow 'traces' of enunciation in 'the geography of the text' ${ }^{\prime \prime}$ ).

In many cases in the long itinerary over the figures of enunciation that Metz offers as part two of his book, the citations of the films - or of sequences or moments from them, a qualification I'll return to - are detailed, evocative, poetic, or even lyrical. Take, for instance, Metz's first discussion of a character's look at the camera in Luis Buñuel's Nazarin (MEX 1959):

In Nazarin, the Buñuelian character of the dwarf, laughable and tortured, very Spanish in a way, often directs his looks toward the spectator, as if to be pitied or even just noticed. When the woman he's absurdly smitten with is taken off to jail, he remains fixed in the middle of the village square (and the middle of the movie screen), crying without hiding himself from view, always turned toward us, uglier than usual. ${ }^{15}$

Once this evocative description winds down, Metz then starts to move from it to a broader point - first of all, that this moment of address is not just the dwarf's but the film's: 'The image is a bit insistent: it wants us to pay witness to his misery. ${ }^{16}$ Here, we encounter an argument typical in L'énonciation: what is initially a wilful activity by a character within the diegetic universe reveals itself to be an intentional activity of the film overall - it is now the film itself that is insisting on this action we see. For Metz - and here I'm at risk of reducing his complex argument, demonstrated at length across so many examples - enunciation is always present in film insofar as any film exists as an intentional object whose very existence embodies that intentionality. But it is only in some cases that this intentionality of the film makes its intentional nature manifest as such, rather than hiding behind the identification-garnering mechanisms of character and narrative fiction. Typically, character helps bolster the construction of diegetic universes, but Metz shows that there are numerous cases where this or that 
character in this or that film can suddenly seem to have an enunciative or narrative role rather than the character functioning within what is narrated or enunciated. That is, such characters help make the story happen as a fictional act rather than just being one more personality that the story is told about. In the case of Nazarin, the dwarf is within the story world of the film but not as a main figure: he is just someone on the margins of the story and this allows him to detach from the fiction and comment on the fact of its narration. From his relatively minor position within the narrative, he begins to move outward from the fiction to its filmic enunciation: it is the film that focuses frontally on him, that has him cry, that renders him more pathetic than before, and this can render the film's operations tangible, expressive, manifest.

In Metz's next move, this general comment on cinema itself as an activity of speaking to us intentionally, built up here from the singular example of Nazarin, is given a more theoretical rendition, complete with scholarly attribution:

The address, here [in Nazarin], is less explicit [franche] than in the Renoir film [Grand Illusion, F 1937, cited on the previous page] and [in the case of the Buñuel film], one might fully connect back to the diegesis what one is seeing and hearing [in other words, there is still justification within the fictional universe of the film for this dwarf to cry in so ostentatious a fashion]: there are thus diverse degrees of "illocutionary force" in address and in other enunciative figures, just as the pragmatists noted well with regards to marks of subjectivity in language, comprising the inescapable deictic as well as the simple affective epithet where there yet transpires an "enunciating" presence (see Catherine Kerbrat's remarkable synthesis $[$ footnote] $) \cdot{ }^{17}$

In other words, we have here a set of argumentative moves: from an evoked scene in a film to the assertion that, in this particular scene, we see the standard fictional effacement of marks of enunciation undone by markers that make enunciation visible, to the conclusion, complete with theoretical jargon and bibliographic reference, that there is thus a variability generally to the process of filmic enunciation. But this conclusion then requires the adducing of more examples drawn empirically from other films, since it is these that will confirm that variability is at work across film's capacious history. 
Thus, Metz declares just after the scholarly mention of Kebrat-Orecchioni, 'pour en revenir au cinema'. ${ }^{18}$ That is, 'let's return to cinema': in other words, let's go back from (to stay with these just-cited pages) general concepts such as the illocutionary, the enunciative, subjectivity in language, deictics, and so on; back to this or that individual film that, each in its own way, offers up examples of an enunciation that comments on itself or reflects upon itself. Cinema - or, rather, its multitude of empirical examples - is what keeps getting discovered and returned to at the end of each trajectory. (I am referring to the chapters that make up the long middle part of Metz's book.) At moments, L'énonciation appears to resemble not so much a guided tour, as Metz put it, (with the connotation of a set itinerary) as a quite random stroll, a stream of consciousness even, where one follows one's follies, one's folies and cinephilic coups de foudre, wherever they might lead. In this errancy, films and filmic moments serve as momentary anchoring points to be delectated in and then passed beyond to reach the next example: for instance, a discussion of subjective voice gives way at one point to a commentary on film musicals as per-se self-reflexive (since they perform acts of performance), which then leads into an appreciative paragraph on Three Seats for the 26th (F 1988) by Jacques Demy (or, as Metz the cinephile puts it, the 'regretté Jacques Demy' - again, a language of cinephilic appreciation). ${ }^{19}$ This is discussed in terms of its fictionalizing of Yves Montand's life and its factualizing of its fiction by the presence of Montand. This wandering discussion, not fully about subjective voice, it must be admitted, is then somewhat re-anchored by a veritably explicit admission by Metz that he has gotten off topic and needs to re-anchor the discussion: 'But I was dealing with juxtadiegetic music [...] And here's another form of it.' (and so he launches into a discussion, replete with examples, of films where we see the rehearsal of a musical number, since these then reflect on their own musical nature). ${ }^{20}$

Where, as we've seen, Language and Cinema proposed the text as a point of departure, a pathway to codes and textual systems, a manifest message that needs to be analyzed to go beyond its material embodiment, L'énonciation often insists on the irreducible particularity of individual film texts. As Metz declares a few pages after his Nazarin analysis: 'The construction of every film, or at least certain of them, can inflect the structural probabilities that abstraction offers up. ${ }^{21}$ Certainly, there are 
general principles to the notion of enunciation - for instance, it relies on the assumption that texts are intentional acts whose intentionality can become manifest in privileged moments (as he puts it late in the book's second part, such moments 'materialize this intentionality proper to the text itself'). ${ }^{22}$ These, however, can best be studied, and appreciated, and admired through the individual moments in films that embody them. Individual films put general theory to the test (rather than the other way around): as other attendees at Metz's seminar on enunciation might confirm, one thing that, in my recollection, took place insistently was the proposing of this or that general assertion about cinematic enunciation, sometimes by students, sometimes by Metz himself, and then a search, sometimes by students, sometimes by Metz himself, for concrete filmic examples that could either confirm or contravene the general assertion and thereby force the theory to extend and develop. Likewise, in L'énonciation impersonnelle, the interplay of abstraction and concrete case can become quite fanciful. Let us return, for instance, to the final moments of Metz's discussion of Nazarin. Here, the contravening of a general theoretical point - in this case, that there would be no constructions that are automatically or manifestly enunciative - is tied to the challenges that individual films and their modes of enactment offer to generalized theory:

One sometimes hears it asked whether this or that construction, in itself 'is' or isn't a mark of enunciation. We must have the courage to discourage at the outset this mode of questioning. Even in language, there are few terms that are enunciative by nature. What in a film (just as in a novel) is capable of more or less 'marking' the enunciation is much more the singular and global construction of a shot or a sequence, a construction that may mobilize conventional procedures but each time modifies their value. ${ }^{23}$

This general point about how filmic singularity puts theoretical generality to the test is then itself given specificity by reference to Nazarin, a quite fanciful reference: 'In the scene from Bunuel, the grimacing ugliness of the dwarf matters as much as the rest, but no one would dream of listing a character's deformity as one of the habitual or functional marks of enunciation. ${ }^{24}$ In other words, in Nazarin, as Metz sees it, the ugliness of 
the dwarf peels away from the diegesis to become part of the film's very mechanisms of enunciation but it (the ugliness) does so in a way specific to this film and not as a generalizable process for all films (thus, ugliness elsewhere wouldn't so easily move from the fictional space to the film's conditions of enunciation; there is no general enunciative figure of ugliness that we could then catalogue and find dependably in other films).

Certainly, as noted, the point about Nazarin's ugly dwarf as an enunciation and not just a character in the fiction is made fancifully - and in this respect, it's in keeping with the frequent presence in L'énonciation impersonnelle of witty asides, whimsical and even invented figurations (this again echoes the seminar where one tried to imagine filmic procedures, however fanciful, that would contravene generality and abstract assertions). But it's also serious in its own way: it intends to reiterate how enunciation is not a structured code within cinema but a process that runs through and throughout cinema and is in many ways beyond structure, beyond code and codification. If Metz fancifully admits that dwarfish ugliness might not belong easily to an official taxonomy of enunciative marks, he still wants it to figure somewhere (if only in the film itself and his own citation of it); not for nothing does the previous page opt for inclusion rather than exclusion of the aberrant, unique enunciative figure within enunciation's taxonomy. Maybe no one would want to make dwarfish ugliness a received, recurrent category of enunciative marking, but Metz suggests on that previous page that the dwarf's tears could well serve, at least in this one case, as an enunciative act. The dwarf doesn't verbalize his misery, doesn't offer it up in words; he simply and heartrendingly cries, and his tears speak no less than words: as Metz puts it: 'The tears replace words: another variant. ${ }^{25}$ In other words, as Metz shows in this chapter, part of whose title deals with 'voices of address to the image', there are cases in cinema where a character's words detach from the fiction to comment on the film itself, but it can also be the case that something other than words - an excessive amount of tears in the example of Nazarin - can also serve the commentative function. Indeed, the mention of 'variant' might well invoke for the reader the classificatory system of the paradigm (one sobs or speaks, and each signifies in its own way its difference from its converse). In other words, Metz's own language allows us to see individual filmic moments as both unique and unclassifiable (no other film might use tears and ugliness as enunciation) and as unique and perhaps classifiable (the ugliness and the tears are a formal variant in relation to words). This emphasis on the singular case, as I've 
implied throughout this essay, certainly pushes L'énonciation impersonnelle towards a sort of empiricism: there are as many films to be cited as there are films that are interesting to cite. In Metz's words, 'The variants [of enunciation] are multiple and each inventive work comes to enlarge their number. ${ }^{26}$ Every film, in its own fashion, can offer useful instruction on the act of enunciation. As Metz puts it, "The marks of filmic enunciation are as varied as is invariable their common foundation in a principle of textual doubling [repli - the idea that when marked, enunciation folds back onto a film's fiction and says something explicit - and unfictional - about its fictionality]. ${ }^{27}$

It is important to be clear about the fact that if Metz cites films for their irreducible particularity - or the irreducible particularity of this or that figuration within them (for instance, dwarfish ugliness functioning as an enunciative marking) - this is in no way intended to suggest that he then sees the singularity of each film as either somehow an organic totality (of the sort so beloved in romantic notions of the artistic text) or somehow an ineffable mystery to be invoked and appreciated and no more or less than that. We remember that the very notion of textual system in Language and Cinema is all about irreducible unity, but not as organic totality and not as indivisible mystery: the filmic text is an effect of interweaving codes, both specific and not, and textual analysis pursues those weaves through their many macro- and micro-imbrications. In a sense, the aesthetic text, as textual form precisely, is all about art's potential to work with and on codification, to extend and distend signification beyond structural fixity. As Metz put it in his 1965 essay on semiology versus linguistics in Essais sémiotiques, 'an idea of strict organization [...] doesn't fit the situation of cinema, [which offers] a supple sémie, poorly formed and always nascent, an indecisive semiology emerging always-in-new-fashion out of iconological analogy'. ${ }^{28}$ In other words, the function of experiment in cinema (an experimentation which can take place in the mainstream as much as in modernist alternatives) is to go beyond codifications and extend cinematic language's resources. The idea of cinema as 'always nascent' is particularly noteworthy here since it clarifies both Metz's interest (quite explicit in L'énonciation impersonnelle) in works of an avant-garde (for example, Michael Snow or Ernie Gehr, two cases he cites) that venture out into new territory, and his frequent reference to moments of emergence 
(for example, the discoveries of early cinema) as sites in which a language has not yet been reified into univocalities of meaning. The sheer range of examples demonstrates the rich variety of ways in which film (and films) can signify. In a sense, and in a way that might seem curious at first glance (but only at first glance), Metz's The Imaginary Signifier was already one culmination of this aesthetic valorization: here, the idea of a language venturing out at its moment of birth and before it sedimented into semantic fixity became so strong that it was now standard, utilitarian language that showed itself to be a momentary reification of essential figurations, primary processes, productivity over product, and so on: poetic language ceases to be secondary - a mere add-on of rhetorical flourish to language's ostensibly fundamental communicative vocation - and becomes its fundamental form.

I've spoken of the singularity of films cited in Lénonciation impersonnelle, but I need to nuance that a bit. It is often not entire films that Metz cites but fragments, moments, instances. True, there are occasions where the whole of a film's plot is summed up - hence, his aforementioned discussion of Jacques Demy's Three Seats for the $26^{\text {th }}$ is all about how its story overall tells a tale of reflexivity, and here we might remember how one of his rare discussions of a film from start to finish is of Fellini's $8^{1 / 2}$, seen as a veritable allegory of cinematic reflection on cinema-making. (Of course, none of these analyses - to which we of course need to add Metz's well-known syntagmatic reading of Rozier's Adieu Philippine - is really a full analysis: they either emphasize one code - the syntagmatic, for instance - or even, as I would argue in the case of Metz's discussion of $81 / 2$, opt for a thematic reading little different in form from typical invocations of European art cinema at the time and not really focusing on all aspects of cinema's specific signifying resources.)

Instead of the entire film, then, Metz hones in on the fragment or the figure or figuration across the unfolding of a film or what he comes to emphasize as the figural: to quote Metz in The Imaginary Signifier speaking of the montage of workers and sheep in Modern Times (Charles Chaplin, USA 1936),

[T] his figure is almost impossible to define properly in rhetorical terms, once again because there are no words [and we might argue that one of the stakes of this book is to argue that even in verbal language, words are no more than momentary intersections of energetic forces of condensation and displacement, metaphor and metonymy]. The binary conception of the figural, on the other hand ... enables us to situate the opening of 
Modern Times in terms of an analysis of referents whose subdivisions are less intricate, but also more real. ${ }^{29}$

Through the figural, fragments open up to vaster fields of signification that go beyond linguistic fixity: there are, for instance, the classes into which individual cases can be fitted (thus, a discussion in Essais sémiotiques of generative linguistics and the audio-visual is at one point concerned with the role of partial models and how 'each one concerns a class of films [...] a field of acceptability' within which individual works find their way ${ }^{30}$ ). There are also the ways in which representations can change across the course of a single film or from one film to the next so that, for instance, an object may have one figuration in one sequence and gain different figuration later in the film. One key example would be the harp image in October (Grigoriy Aleksandrov \& Sergei M. Eisenstein, SU 1928), analyzed by Marie-Claire Ropars-Wuilleumier and then re-cited by Metz in his analysis of mobile figuration in The Imaginary Signifier: in one iteration, the harp is more fully diegeticized and in another moment, less so. As Metz says, following Ropars,

When we speak of a 'figure' in film, any figure, what are we talking about in the first instance? We are talking about the bringing together of two motifs [...] There are of course figures which are more complex and more diffuse, like the figure of the harps [...] but these are still fragments. The difference is that there are several of them, and also that any one of them does not necessarily involve all the filmic material which appears with it. [...] Any figure which is relatively easy to isolate in the flow of a film, and recurs with relative frequency in several films (that is to say, which has been coded in a genre and in a period) can be thought of as the temporarily solidified result of more extensive semantic trajectories which preceded it and brought it into being, and which will disperse it and create others. ${ }^{31}$

And yet, I do think that there is a way in which the use of the fragment in L'énonciation impersonnelle differs from Metz's earlier practices of citation of individual films. It would appear that one word which shows up rarely,

29 Christian Metz, 'Metaphor/Metonymy, or the Imaginary Referent', in Psychoanalysis and Cinema. The Imaginary Signifier, trans. by Celia Britton and others (Bloomington: Indiana University Press, 1982 [1977]), 149-314 (p. 219).

30 Christian Metz, 'Sémiologie audio-visuelle et linguistique generative', in Essais sémiotiques, 109-28 (p. 119).

31 Metz, 'Metaphor/Metonymy', pp. 274-75. 
if at all, in L'énonciation impersonnelle is code, and it appears indeed to be hard to determine the codical status of enunciation (even if one can isolate figurations of it), both because an earlier work like The Imaginary Signifier had already begun to break down codification for more figurative, open-ended movements of meaning across primary and secondary process, and because (and this is no doubt related) enunciation in L'énonciation impersonnelle seems inclined to turn into cinema itself (rather than be just one code among others). Enunciation comes to describe cinema's overall status as a Voici (a 'here it is') intended manifestly to present worlds to viewers. Enunciation ends up as the term for the very act of cinema always speaking about its own conditions of existence even as its fictions pretend directly to offer themselves as un-enunciated diegetic universes. In other words, there is no code to enunciation, since all of cinema is enunciative (even if not always manifestly so). Enunciation is, as Metz says on the last page of the book's theoretical introduction (already quoted from earlier), 'coextensive with film, and a component part of the composition of each shot: not always marked, but acting everywhere'. ${ }^{22}$ Or earlier, 'enunciation is the semiological act by which certain parts of a text speak to us of this text as an act'. ${ }^{3}$ Or later, it is an intentionality internal and integral to film. ${ }^{34}$ Ultimately, enunciation is 'the cinema as such'. ${ }^{35}$

But if this is the case, any and all films and film sequences are citable, including even (and markedly) those moments of film that might seem unmarked (what Metz refers to, in quotation marks, as 'neutral' images and sounds) since the unmarked instance still is as produced, intended, and enounced as are marked filmic moments. Indeed, in his chapter on neutral sounds and images, Metz suggests that cinephilia (of the very sort that runs through his own book, with its capacious engagement with myriad films) can turn the unmarked moment into a marked one: the cinephile notices the cinematicity of cinema and thereby makes manifest what a less critical spectatorial investment (of the sort incarnated by the ordinary viewer) in diegesis can occult. All films are always in every moment enunciative - 'Enunciation - which should not be confused with its marks and configurations [which are] always situated - is omnipresent and responsible for every detail [of a film]' - but cinephilic knowledge focuses attention on those details and makes their enunciative qualities evident: 
Enunciation remains at the level of something presupposed as long as we remain inattentive to the construction of the film. As soon as we look closer, listen closer, we note attempts at [enunciative] marking which, as meagre as they may be, prefigure a "real" [enunciative] orientation [...] The difference [between marked and unmarked] comes not from the object but from the distance we adopt in relation to it, from our more or less exacted, more or less distracted, reading of it. [...] [T] he more the public is educated, the more the neutral images diminish. ${ }^{36}$

I've alluded at several moments in this essay to an undeniable empirical aspect to L'énonciation impersonnelle - the sometimes random stream of citation of film titles, one after the other - but there are evident, necessary limits and limitations to this empiricism. Most immediately, the citation of films or of film fragments includes imaginary or hypothetical works (those contravening examples, for instance, that kept popping up in seminar as Metz or his students tried to imagine possibilities of cinema that wouldn't fit the theory), with the irony that later one can, from time to time, find concrete examples of precisely those imagined cases being produced: thus, in analyzing diegetic narrators (that is, characters who adopt direct address), Metz asks us to 'imagine the [...] construction in its pure and perfect state: for the entire length of a film, a character constantly present in the image speaks to us', ${ }^{37}$ and he needs to make that request, he says, since 'the exigencies of audio-visual figuration, in current narrative cinema, render improbable the full deployment of such an arrangement across the whole of a work' ${ }^{3}{ }^{8}$ But notice already that this is an improbability, not an impossibility. As Metz immediately cautions, 'No one has seen all films, thought about all of them' and in fact, certain films of Godard or Straub-Huillet approach this possibility of a cinema given over to characters who speak in direct address for excessively long periods of time (albeit not for the whole film, but again that's not an impossibility). Clearly, nothing necessarily would prevent such imagining from concretizing, from taking on empirical existence.

There can be no completion to the act of citation, then, short of citing all of cinema. As Metz declares on the last page of the theoretical introduction to L'énonciation, his guided tour is driven by no 'concern for exhaustivity'. Earlier, The Imaginary Signifier had referred what it pointedly called a 
'problem' of research: 'the problem of the status and the list'. ${ }^{39}$ If a 'first temptation is to plunge immediately into "extensive" work, to aspire to an exhaustive inventory - a list', Metz admits that: 'At the stage I have now reached in the writing of this text I have as yet no idea (I mean this literally, in all honesty) of the "table" of cinematic figures I shall end up with, even assuming that I'm heading towards a table - which I am rather beginning to doubt. ${ }^{40}$ In like fashion, the itinerary of L'énonciation offers no tabular finality, no taxonomic completion, no enumerative codification. Thus, Metz speaks at one point of 'the necessity to not close off the inventory of enunciation. Even though it is governed by a certain number of fundamental positions and has its own logic, even though it does not derive from some pure and infinite freedom, it offers combinations which remain very numerous. ${ }^{41}$

There was, as Roland Barthes noted, a gesture toward scientificity in Metz, but it is also one that doubled itself in dream, desire, fancy, and fantasy. ${ }^{42}$ And L'énonciation is certainly a book given over to expressions of cinephilic affect. We might say that, certainly by the time of his later works, Metz was little inclined towards the type of statement that exhaustively enumerates the pertinent features of a concept in the form of an explicit, independent proposition. He was more interested in the phenomena than in the naming process, and his doctrinal apparatus was often only gradually put together, via a series of slips and slides (condensations/displacements), rather than being assembled all at once and once and for all, according to a directly conceptual procedure commonly seen as the only possible form that intellectual 'rigour' can take. L'énonciation offers an odd regime of writing: obsessional and happy-go-lucky, meticulous and inexplicit, punctilious and wide-ranging.

I say 'We might say that' but Metz himself already did. A confession: my last sentences - from 'We might say that Metz was little inclined towards the type of statement that exhaustively enumerates the pertinent features of a concept', etcetera, etcetera, onwards - are actually taken from Metz's own description in The Imaginary Signifier of Freud's writing enterprise and its complicated relationship to scientificity. ${ }^{43}$ For me, the borrowing works well and works especially well for the strange, evocative text that is Metz's last book; a curious book, and resonant for me because of that.

41 Metz, Lénonciation, p. 11.

42 Roland Barthes, 'Apprendre et enseigner', in Le bruissement de la langue (Paris: Seuil, 1984), pp. 205-07. Originally published in Ça cinéma, 7-8 (1975), special issue on Christian Metz.

43 Metz, 'Metaphor/Metonymy', pp. 231-32. 


\section{About the author}

Dana Polan is Professor of Cinema Studies at New York University. He is the author of eight books on film and television studies, including Power and Paranoia: History, Narrative and the American Cinema, 1940-1950 (1986) and Scenes of Instruction: The Beginnings of the US Study of Film (2007). He has a Doctorat d'Etat from the Université de la Sorbonne Nouvelle. There, he also took Christian Metz's seminar at various points in the 1980 s and 1990 . 



\title{
17. “'Theorize”, he says...'
}

\author{
Christian Metz and the Question of Enunciation: A Theory \\ in (Speech) Acts
}

\section{Alain Boillat}

\author{
Tröhler, Margrit and Guido Kirsten (eds.), Christian Metz and the Codes of \\ Cinema. Film Semiology and Beyond. Amsterdam University Press, 2018 \\ DOI: $10.5117 / 9789089648921 / \mathrm{CH1}$
}

\begin{abstract}
This chapter discusses the theoretical foundations and productivity of Metz's reflection on filmic enunciation by commenting on the principal developments in his thinking. The essay thus aims to reinscribe the models proposed by Metz in their context by showing how they are echoed, often implicitly, in other contemporary approaches (or how they are distinct from them), including the field of film criticism. Further, Metz's writing is itself examined at an enunciative level in order to observe the principles according to which the semiologist constructs his object of study and envisions the scholar's position, but also to reveal Metz's inclination to exhibit - through a performative step - the situation of the discursive enunciation that he utters.
\end{abstract}

Keywords: film semiotics/film semiology, enunciation theory, cinephilia, filmic reflexivity, metaphor/metonymy, film criticism

While I intend to approach the 'question of enunciation' in Christian Metz's reflections on cinema, it is almost necessary to point out that I in no way mean to question the validity of the concept of enunciation. That would imply a challenge to the methodological frame of the concept, whereas I am personally convinced of its productivity in the field of film studies, even if I agree that it doesn't have the wind in its sails nowadays (to put it mildly). Indeed, I have tested the relevance of the enunciative approach in many case studies, admittedly making a few adjustments to the models proposed by Metz and combining them with other approaches. The serious hesitations expressed by David Bordwell or by Jean-Marie Schaeffer are 
well known; because of its linguistic derivation, they consider the notion of 'enunciation' too strictly pledged to verbal language to be of any relevance in the framework of film studies (except, as Schaeffer admits, ${ }^{1}$ for analyzing the voice-over process, a topic that has especially interested $\left.\mathrm{me}^{2}\right)$. It is true that, in some cases, the notion of 'enunciation' should not be applied too literally - but in some cases it seems appropriate to me, for the verbal is indeed one of the components of the filmic discourse, or, to express it in Metzian words, one of the 'matters of cinematic expression' (even if he himself tended at times to mask this point when dealing with enunciation).

In any case, the principles developed in the frame of enunciation theories have made it possible to look beyond the immanence of textual systems, which is so specific to semiology, and to open up the debate to include the communication situation, or at least its inscription in the filmic text. The followers of the enunciative approach propose that a production can be understood through the traces of its own creation and that a film resorts to various ways of addressing the spectator. In my opinion, these considerations retain all of their relevance in the contemporary multimedia context.

Especially nowadays, even in the dominant Hollywood cinema, which is supposedly governed by enunciative 'transparency', ${ }^{3}$ the proximity in

1 Bordwell dismisses this kind of approach quickly: 'Enunciation theory has provided a major impetus for the dissection of film style [...]. Yet because a film lacks equivalents for the most basic aspects of verbal activity, I suggest that we abandon the enunciation account.' David Bordwell, Narration in the Fiction Film (Wisconsin: University of Wisconsin, 1985), p. 26. 'It is the same thing for the notions of enunciator, of statement, and so forth. To attempt to apply tools of analysis of this type to the cinematographic device, that is, to propose to analyze "the work that one does when one reads a film", is to take the wrong object.' Jean-Marie Schaeffer, Why Fiction? (Lincoln/London: University of Nebraska Press, 2010 [1999]), p. 273. Here, Schaeffer quotes a sentence from Roger Odin, whose assumption he finds groundless. On the differences between the models of Schaeffer and Odin, both applied to cinema, see my critical review of their most important work on these matters: Alain Boillat, 'Jean-Marie Schaeffer, Pourquoi la fiction? / Roger Odin: De la fiction', Iris, 30 (2004), pp. 158-67.

2 See the model proposed in the chapter 'Voix-narration et énonciation filmique' of my book Du bonimenteur à la voix-over. Voix-attraction et voix-narration au cinéma (Lausanne: Antipodes, 2007), pp. 315-447.

3 Looking at the notion of 'transparency' through the overlapping perspectives of theories coming respectively from linguistics and film studies is interesting: André Bazin, in a metaphysical perspective, advocated 'transparency' in a way quite incompatible with Metz's approach (the latter underlines both the interest and the limits of this 'cosmophanic' approach in the section of 'The Imaginary Signifier' entitled 'On the idealist theory of the cinema') which, following the filmologists, considers the issue of realism in terms of effect and not of image ontology; see Psychoanalysis and Cinema. The Imaginary Signifier, trans. by Celia Britton and others (Bloomington: Indiana University Press, 1982 [1977]), 1-87 (pp. 52-53). However, at the time of Metz's work, the notion of transparency was also studied by linguists, whose intentions 
the same film of heterogeneous picture regimes encourages the spectator to question the enunciative aspect of what he is watching and listening to. These regimes are characterized, for instance, by images of substandard quality whose otherness is made clear (e.g. when characters use their cell phones to film or watch images, or when we see the view of a surveillance camera or of a drone, shown on a diegetic screen and including the image's metadata). I will mention here, using tools provided by enunciation theories and without going into more detail, two examples I recently discussed. First, flashbacks introduced by the viewing of recordings from a surveillance camera inside a casino in Contagion (Steven Soderbergh, USA/UAE 2011). In this example, the shifts regarding the diegetic origin of the gaze could be related to the 'metalepsis' in the sense of Genette. ${ }^{4}$ Second, the various forms of found footage common in contemporary horror cinema, which consist partly or entirely of shots obtained by protagonists who are the victims of a threat and which are filmed using amateur techniques. ${ }^{5}$

How does the film construct the discursive source responsible for the picture and sound recordings? And to whom is the audiovisual representation addressed? These are questions that often lead one to think about strategies that make the source of filmic communication part of the diegesis. I find that enunciation theories can contribute to the study of contemporary audiovisual productions, with their strong multimedia component. I agree with Metz, who wrote in his 1993 preface to Le Signifiant imaginaire about the weakening of psychoanalysis in the humanities in favour of cognitivism, that 'it is right that things move forward (therefore that they change), and they don't cancel what preceded them and made them feasible, and they incidentally coexist with them. ${ }^{6}$ I would therefore position myself in the

were to take into account the pragmatic dimension of speech. For example, François Récanati, who has taught language philosophy at the EHESS since 1975 - at the same time and in the same institutional frame as Metz - published his lessons in a book significantly entitled $\mathrm{La}$ transparence et l'énonciation (Paris: Seuil, 1979). For the epigones of speech act theoreticians (Récanati claims to be a follower of Austin and Searle), the doctrine of 'transparency' serves as a foil, but the debate about the legitimacy of the notion helps to inscribe it among the objects of study of enunciation theory. Christian Metz, referring to pragmatics, which considers the signs as 'reflexive' or 'transparent', clarifies, in brackets: 'These are the words that are used, and their encounter with the ones that we consider is striking', in L'énonciation impersonnelle ou le site du film (Paris: Méridiens Klincksieck, 1991), p. 177.

4 Alain Boillat, 'Stranger than Fiction: Métalepse de Genette et quelques univers fictifs contemporains', Cinéma et Cie, 18 (2012), pp. 21-31.

5 'Linquiétante étrangeté du found footage horrifique: une approche théorique du programme "P.O.V." de l'édition 2012 du NIFF', Décadrages, 21-22 (2012), pp. 146-65.

6 Christian Metz, Le signifiant imaginaire (Paris: Christian Bourgois, 1993), p. VII [our translation; the 1982 translation of The Imaginary Signifier lacks the translation of the 1993 preface]. 
perspective of the history of cinematic theories, with the goal of redrawing and discussing Christian Metz's path through theories of enunciation. In doing so, I will also attempt to grasp how his thoughts and writings on cinema are inspired by principles proposed by the linguist Emile Benveniste.

With these issues in mind, two stages of Metz's work can be outlined: the first one is a linguistic model, used in 1977 for the Imaginary Signifier; the second one is an 'impersonal' model elaborated in his last work, Lénonciation impersonnelle ou le site du film, published in 1991 and evidencing a new position. Having widely discussed elsewhere the theoretical productiveness of the ideas expressed in the Impersonal Enunciation, ${ }^{7}$ and knowing that this text is examined in this volume in an essay by Dana Polan, I will focus on the first stage, trying to also let Metz speak for himself, through his texts.

\section{The Underlying 'Voice' of the Pneumatic Drill}

My goal here is to consider Metz's texts on enunciation from the perspective of enunciation, and to show how much the question of 'Subjectivity in Language' (to quote the title of Benveniste's famous essay) goes deep into Metzian writing itself, which is haunted by the reflexive issue of what Benveniste calls the "capacity of the speaker to posit himself as "subject". 8 Indeed, it is noticeable that Metz accurately locates his writings within the enunciative situation that they belong to; in other words, the place that the current project occupies in the author's own theoretical trajectory is reflected in the writing. This is why the later (French) editions come with prefaces that are updated with each edition, and why the essays are carefully dated and introduced by Metz's methodological explanation, which clarifies the position of the theoretician. In the manner of enunciation, which is a dynamic process producing an utterance, research is an activity that Metz approaches through its progress and that he addresses inside his texts, opting for - as D.N. Rodowick also notes - a 'meta-theoretical' position. ${ }^{9}$ So goes the introduction of the chapter entitled 'The Investigator's Imaginary' from The Imaginary Signifier:

7 Alain Boillat, La fiction au cinéma (Paris: L'Harmattan, 2001), Chapter 3; Boillat, Du bonimenteur à la voix-over, Chapter 6 .

8 Emile Benveniste, 'Subjectivity in Language [1958]', in Problems in General Linguistics, trans. by Mary Elizabeth Meek, 2 vols. (Coral Gables: University of Miami Press, 1971 [1966]), I, 223-30 (p. 224).

9 D.N. Rodowick, 'A Care for the Claims of Theory', in An Elegy for Theory (Cambridge, MA: Harvard University Press), pp. 168-99. 
I ask myself: what in fact is the object of this text? What is the driving uncertainty without which I should not have the desire to write it, and thus would not be writing it? What is my imaginary at this moment? What is it that I am trying, even without illusions, to bring to a conclusion? ${ }^{10}$

In addition to being written in the first person and making use of deixis (this text, this moment), the essay also thematizes the very process of writing; the theoretician projects himself in his text and reflects himself while reflecting on the topic. This anchoring in the specific context of theoretical production is also true for quotations of other authors. For instance, Metz tells us that 'a concept always goes back to the place of its elaboration in the history of knowledge, even, and especially, if it is to be carried over to another field'. ${ }^{11}$ However obvious this might be on a methodological level, it is quite important to be reminded of such a statement, particularly in the context of the google-ized circulation of concepts that, in today's maelstrom, encounter the risk of becoming sterile labels rather than tools for reflection.

In some of the texts in The Imaginary Signifier, compiled at a time when Metz had already become interested in linguistic theories of enunciation, the inscription of the enunciator in the utterance appears to be accentuated. An emblematic example can be found in the 'Metaphor/Metonymy, or the Imaginary Referent' essay. ${ }^{12}$ In the introduction to this essay, Metz problematizes the choice of his object of study, as he often does. More precisely, he insists on the limitations in the thinking of the speaking subject. As a confession of humility in front of the seemingly enormous task, he writes: 'This enormous question [...] involves many other aspects, including no doubt some I am completely unaware of: because he who writes (= 'I') derives his existence solely from such limitations. ${ }^{13}$

The distance from himself, doubly marked by the coldness of the mathematical sign and the quotation marks, contributes to a concept stating that the speaker is associated with a subject position, with a place that can be occupied by others and where the 'I' is only a paradigmatical form, as it happens here actualized and exhibited in its very actualization. His essay is about metonymy and metaphor, seen from a typically structuralist

10 Christian Metz, The Imaginary Signifier, p. 17 (emphasis in original).

11 Metz, The Imaginary Signifier, p. 153. The French text reads: 'une notion n'est vraiment telle qu'à partir de son lieu d'élaboration dans l'histoire des savoirs, même et surtout si on compte la transporter ailleurs' (p. 181); the italic that underlines the place's discursive origin is his.

12 As this essay was new when the book was published in 1977, one could situate it after Metz's earlier discussion of Benveniste's opposition of discourse vs. story.

13 Metz, The Imaginary Signifier, p. 151. 
perspective - following Jakobson, Barthes, and Genette - not as stylistic figures in the rhetorical sense but as dynamic processes associated with operations of displacement and condensation as they have been developed in the Freudian psychoanalytical field. Metz introduces this new topic in this way: 'I have now (autumn 1975) reached a point where I can see another facet of my problem: namely, metaphorical and metonymic operations in the sequence of film images. ${ }^{14}$ One notices here the importance that Metz gives to the moment of reflection, identified with the season of a particular year.

The reader of Metz's essay is invited to follow the author's thinking in the supposed present of its development, like - let us now borrow a filmic example - the spectator of Godard's La chinoise (F 1967), when he reads the words 'A film being made [Un film en train de se faire]'. One recalls Jacques Aumont's text on the film, centred on the issue of spectatorial address. ${ }^{15}$ Other examples are found in some works of Alain Tanner, a director who is strongly indebted to Godard's cinema when it comes to the ideological implications that narrative enunciation involves. ${ }^{16}$ For instance, at the very beginning of The Middle of the World (F/CH 1974), Tanner uses a voice-over to explain that the 'speech and the shape of a movie depend, on a large scale, on where and when this movie is made, and in which circumstances' and that 'this movie has been shot in 1974, in a time of normalization'. Thus, the film is almost contemporary to these Metzian reflections. This kind of discursive strategy is particularly intensified in the 'Metaphor/ Metonymy' essay where, in a remarkable fashion, Metz cites examples derived from his own personal experience, even from his childhood, as in the example of the term 'Roquefort', which has entered language after a process of metonymy:

I have said that the association of ideas which resulted in the name of 'Roquefort' is today no longer alive. But if I know this little town, if I went there once on holiday (it was during the Occupation, I remember; I was a small boy, with my parents, and we used to go to the Aveyron every summer, in search of a few provisions) then the word will evoke a whole landscape for me, Millau and Saint-Affrique, and the stony bend in a

14 Ibid.

15 Jacques Aumont, 'Notes sur un fragment de La chinoise', in Sémiologiques (Linguistique et sémiologie 6), ed. by René Lindekens (Lyon: PUL, 1978), pp. 58-70.

16 Regarding the particular enunciative aspects of the films by Alain Tanner in the 1970s, see the analysis of Le retour d'Afrique (CH/F 1973) that I made in 'Alain Tanner: un cinema idéologique', in Vinzenz Hediger, Jan Sahli, Alexandra Schneider, and Margrit Tröhler, Home Stories, Neue Studien zu Film und Kino in der Schweiz (Marburg: Schüren, 2001), pp. 335-46. 
little street, old and steep: then I am actively retracing the path of the metonymy (not just that of my childhood) [...]. ${ }^{17}$

Let's say first that, reading the hypothetical formula 'if I went there once', we could consider that the ' $\mathrm{I}$ ' is used in the general sense. But the text that follows tells us something else, as the reader enters a recollection, between brackets that underline a change of level (Metz's sensitivity for punctuation marks is well known). It seems that the psychoanalytical approach, which Metz says he experienced himself during therapy before referring to it in his theoretical texts on cinema, is intimately linked, because of the introspection it implies, to the emergence of a linguistic subjectivity in the writing process and perhaps to a growing sensitivity towards questions of enunciation. Metz uses the strategy of displacement precisely where he discusses the way this type of operation works in language, thus giving a performative value to his text.

He first offers as examples the words 'Bordeaux' and 'tesson', and illustrates how these words are metonymically obtained from the homonymous city and from the word 'testa', respectively. Having thus dealt with these words from a perspective of diachronic semantics, Metz offers to illustrate his ideas in other ways. He does so firstly by underlining his presence as enunciator, and by introducing a reference to the addressee ('I am afraid that the reader is beginning to get tired of hearing about "earthenware" fragments and "Bordeaux"'18). Next he uses an interrogative form, a purely rhetorical and phatic one that also works as a way of addressing the reader ('Should we not move on to a different kind of metonymy, more immediately primary, or more obviously so?'19). As Metz establishes in this essay, there are no primary figures for him, only figures that momentarily escape from circulation in the social space. The primary level - on which point Metz strictly follows Freud - calls for narcissism, the object becoming the Ego: 'In which case I shall have to talk more about myself, since any example taken from a language or a cinematic code would be vitiated by the simple fact of its prior existence. ${ }^{\prime 20}$ The theoretician justifies the necessity of mentioning his personal situation, the moment when the metonymy does not yet exist in a lexicalized state; the next sentence starts with a dash (see French text) - as

17 Metz, The Imaginary Signifier, p. 160.

18 Ibid., p. 161.

19 Metz, Le Signifiant imaginaire, p. 192 [our translation; the 1982 translation of the text by Celia Britton and Annwyl Williams lacks the interrogative form of the sentence].

20 Metz, The Imaginary Signifier, p. 161. 
if to introduce a reply - which implies an oralized form and consequently tends to inscribe the sentence in the discourse regime, in Benveniste's sense, and the present tense (of the indicative mood) is immediately followed by a temporal deixis, 'for several days now':

So - for several days now [-Donc, [...] depuis plusieursjours déjà], roughly since the time I began work on this article, a pneumatic drill in a neighbouring street has been constantly getting on my nerves, and continues to do so as I am writing this. I have got into the habit, when 'talking' to myself, of calling this text, whose title is not yet finally decided, the pneumatic drill article. [...] I do hear it and it upsets me: the word 'persecutory' flows spontaneously from my pen. I write in spite of this noise, and also against it. [...] In my fantasy it represents (this time by condensation) all the various obstacles - to which I am by nature cruelly sensitive - which make 'research' into something perpetually impossible, because of the freedom from distraction which it requires and which is almost never to be found: an act [...] which has no place within every day life but only against it: a small schizophrenia. ${ }^{21}$

The production conditions become the very theme of the theoretical discourse, thus lending the essay an almost performative function. The din of the pneumatic drill, which the author describes as being heard, is projected into the text as a link to a component of the physical environment of the writing. From that point, the writing becomes even more of a creative act in that it reflects the very difficulties that were encountered during the text's own creation. This is not a pure digression: the 'schizophrenic' theoretician pursues the development of his example and then describes a case of condensation at the same time. The subject matter of his argument, the metonymy, is considered from the enunciative point of view before it is defined, at the end of the essay, as a 'transfer from the speaker to the statement'. ${ }^{22}$ This metadiscourse can thus be associated with the very topic of the theory of enunciation that will lead Metz to conceptualize the mirror phenomenon, cinema's reflexivity. Situated at the crossroads of psychoanalysis and linguistics, The Imaginary Signifier simultaneously allows the exhibition of the Ego and the staging of the discourse's speaking subject. Thus, the example of the 'pneumatic drill' draws on the two fields at the same time, and their intersection is the location where the author stands. A theory in acts, then. 
Metz even concretely integrates the addressee in his text, as when he refers in a footnote to the comments made by the audience of his seminar from which the essay stems: students suggested other interpretations of the 'pneumatic drill' that would have shown its coded aspect, the way it could be related to the metaphor of a text 'under construction'.

At all levels, construction is an issue: that of a text, and of a thought that is being built before our eyes. The author discusses and explains the position he occupies to somehow show the place of his enunciation, as he describes it accurately in his Story/Discourse essay: 'So, for as long as it takes me to write this, I shall take up a particular listening-post in myself (not, of course, the only one), a post which will allow my "object", the standard-issue film, to emerge as fully as possible. ${ }^{23}$

This kind of alignment between the enunciator and the utterance precisely corresponds to the subject matter of enunciation theories. A chapter of The Imaginary Signifier is significantly entitled “Theorize", he says... "24; the inversion of the title of Marguerite Duras's novel (and homonymous film) Destroy, She Said (F 1969) ${ }^{25}$ stresses the constructive approach of the theoretical initiative, and the declarative verb 'says' indicates the importance Metz gives to the very act of theoretical enunciation; for him, the modelling of a theory is inseparable from the elaboration of the discourse.

\section{Story/Discourse: An Appropriation of Benveniste's Model}

A close look at the importance of enunciation theory in the Imaginary Signifier shows that it plays a relatively small role: the 'Story/Discourse'

23 Ibid., p. 92.

24 Ibid., p. 79 .

25 Marguerite Duras, Destroy, She Said (New York: Grove Press, 1970). The original French title Détruire, dit-elle can be interpreted as the present tense or the simple past. The French homonymy of these forms ('elle dit') confronts the translator with a problem that is linked to the issues of enunciation that are discussed here: the simple present is related to speech (according to Benveniste), the simple past to story. Indeed, although Marguerite Duras's title of the book is clear (it adapts two lines of the novel that are in the present tense), Barbara Bray, the translator, has chosen the past: 'Destroy, she said', perhaps in order to conform to the dominant practices of literary English. The same translation was used for the film's distribution in English-speaking countries. Christian Metz's translator chose a more literal translation by using the present tense but thereby weakened the reference to the novel's English translation. The declarative verb ('to say'), and therefore the underlining of the enunciation, was apparently absent from Duras's first title. It may have come from Alain Robbe-Grillet, who was a literary consultant for the Minuit editor at the time (according to the latter in Les derniers jours de Corinthe [Paris: Minuit, 1994], p. 96). 
essay takes up less than eight pages. It is even shorter than Benveniste's two texts, in which he establishes the basis of what will become 'the enunciation' (there is a disproportion between the shortness of these texts - both Metz's and Benveniste's - and their legacy). The 'Story/Discourse' text is actually independent from the first long essay of about a hundred pages that gives the volume its title. Besides, the writing of this short article was somewhat incidental, for its origin is found in an homage volume to Benveniste, edited by Julia Kristeva and published by Le Seuil in 1975: Langue, discours, société. Pour Emile Benveniste, in which Metz is the only representative of the cinematic field among authors that included Barthes, Todorov, and Lévi-Strauss. Furthermore, the subtitle, 'A Note on Two Kinds of Voyeurism', refers to a textual category that could let us consider it as a minor essay, or as the draft for an in-depth study (which was never realized, at least not by Metz). The absence of footnotes and references to other texts - even Benveniste's aren't referenced - suggests that this is the account of a first intuition. However, if Metz incorporated this text into the Imaginary Signifier, it is because he thought that a detour through the concepts of story and discourse that the linguist Benveniste had discussed had its place in the opus.

What becomes of these notions when Metz applies them to the field of cinema? First of all, he cross-breeds them with psychoanalysis while associating, on the one hand, exhibitionism and discourse and, on the other hand, disavowal and story; this double oppositional couple is then transferred to cinema, where disavowal, for Metz, characterizes the dominant fiction cinema regime - what he calls the 'narration-representation' regime elsewhere in the book, ${ }^{26}$ meaning a cinema that does not show its production operations, that makes the referential illusion come first. He describes it in this way:

The film is not exhibitionist. I watch it, but it doesn't watch me watching it. Nevertheless, it knows that I am watching it. But it doesn't want to know. This fundamental disavowal is what has guided the whole of classical cinema into the paths of 'story' $[. ..] .^{27}$

The word story is still in quotes, but Metz will adopt Benveniste's usage. In fact, the semiologist of cinema resorts to Benveniste because the notions developed by the latter are convenient to Metz for repeating one of his own previous statements: that the signifier of the fiction film 'is employed entirely to remove the traces of its own steps, to open immediately onto the 
transparency of a signified, of a story $[\ldots . .]^{28}$ The word 'story' is not strictly understood in Benveniste's sense, but the distinction the linguist proposes will allow Metz to reveal the phenomenon. One also notices that the notion of 'fiction film' is not defined through a semantic approach of fictionality but solely through the criterion of the signifier's transparency (which makes the term difficult to use, as I have discussed elsewhere ${ }^{29}$ ). Above all, what Metz retains from Benveniste is the principle that distinguishes enunciation and utterance [énoncé], and which allows him to express the dynamics of the textual system. He calls it a 'production rather than a product'. ${ }^{30} \mathrm{~A}$ passage from The Imaginary Signifier is emblematic of this conception:

In Emile Benveniste's terms, the traditional film is presented as story, and not as discourse. And yet it is discourse [...], but the basic characteristics of this kind of discourse, and the very principle of its effectiveness as discourse, is precisely that it obliterates all traces of the enunciation, and masquerades as story. ${ }^{31}$

The idea that a discourse (necessarily at work in every film) 'masquerades' as a different kind of discourse on the surface is linked to the illusionist power of cinematographic representation and to the disavowal process that Octave Mannoni discusses in his essay on theatre, entitled Clefs pour l'imaginaire [Keys to the Imaginary], with the formula: 'I know well, but even so ... [Je sais bien, mais quand même...]'. Metz adopts this, but his idea of masquerade does not fit Benveniste's definitions, which could explain why Metz refers to him only broadly. What really interests Metz is the story, i.e. the dominant narrative fiction film, and not the discourse, which he in some ways conceals in a masquerade exercise of the kind that he attributes to his object of study (i.e. the film), an exercise that results in a theoretical sleight of hand, so to speak. Here, Metz adopts the same point of view he had sketched in a footnote to his article entitled 'Notes Toward a Phenomenology of the Narrative ${ }^{32}$ where, as Marie-Claire Ropars ${ }^{33}$

28 Ibid., p. 40.

29 Boillat, La Fiction au cinéma, pp. 31-33.

3o Metz, The Imaginary Signifier, p. 29.

31 Ibid., p. 91.

32 Christian Metz, 'Notes Toward a Phenomenology of the Narrative' [1966], in Film Language. A Semiotics of the Cinema, trans. by Michael Taylor (New York: Oxford University Press, 1974), 16-28 (p. 25).

33 The author shows that, with the help of a "terminological crossbreeding [croisement terminologique], Metz leaves aside the specific issue of enunciation involved in the "discourse" 
observed, he first mentioned Benveniste's theory, in 1966. But at that time, he distinguished in the writings of Benveniste a broad and a narrow sense of the word 'discourse', leading him to put the narrow sense aside, thus excluding the story vs. discourse opposition. At that point, Metz already aimed to transform the discourse into story. His later rejection of the deictic conception of filmic enunciation ${ }^{34}$ - although truly useful when examining the verbal dimension of a film - would also partly be based on a desire to avoid the formal apparatus of the discourse, whose conception is too strongly based on the oral communication model, whereas cinema allows no reversibility of the enunciator-addressee poles..$^{35}$ If Metz concedes that the story 'can assume the appearance of discourse ${ }^{36}$ and can even refer to an 'oral text, fully and exclusively oral, such as there is on the radio, and as there has been for centuries with the bards and other storytellers', ${ }^{37}$ he does not explore this idea at all because, according to him, cinema is of a different order. Only with the work of the Quebecois researcher Germain Lacasse would the oral dimension of cinema be taken seriously at a theoretical level, from the times of the early cinema's bonimenteur (the moving picture lecturer) to today's dubbing actor. ${ }^{38}$

The definition of the story/discourse opposition given in The Imaginary Signifier with the help of the formula 'in Emile Benveniste's terms' is a tricky one: indeed, the two planes of enunciation, to which the linguist

(strictly speaking) that Benveniste opposes word by word to "the story"'. Marie-Claire Ropars, 'Christian Metz et le mirage de l'énonciation', Iris, 10, 105-19 (p. 118, footnote 3).

34 As I tried to show with Night and Fog (Alain Resnais, F 1955) in Boillat, La Fiction au cinéma, pp. 91-95.

35 'The highest degree of this reversibility occurs in oral exchange. Oral exchange, as opposed to "story", is Benveniste'sprototypical form of "discourse". According to the same author, oral exchange is also the starting point of the whole theory of enunciation.' Christian Metz, 'The Impersonal Enunciation, or the Site of Film (In the margin of recent works on enunciation in cinema)', New Literary History, $2 / 3$ (1991), pp. 747-72 (p. 749). This essay is the translation of the one that had been published in Vertigo, 1 (1987) pp. 13-34, and that would appear later, slightly modified, as the first chapter of Christian Metz's L'énonciation, pp. 9-36.

36 Metz, 'The Impersonal Enunciation', p. $75^{2}$.

37 Ibid. The last part of the sentence does not appear in the essay published by Metz in Vertigo but in Metz, L'énonciation, p. 13 (our translation). What Metz adds here, for the 1991 version, shows that he takes into account the inscription of cinema in the oral tradition.

38 Germain Lacasse, Le bonimenteur des vues animées (Québec/Paris: Nota Bene/Méridiens Klincksieck, 200o); Germain Lacasse, Hubert Sabino, and Gwenn Scheppler, 'Le doublage cinématographique et vidéoludique au Québec: théorie et histoire', Décadrages, 23-24 (2013), 28-51 (pp. 23-24). In this essay, the authors refer to Robert Stam (Subversive Pleasures, Bakhtin, Cultural Criticism, and Film [Baltimore \& London: The Johns Hopkins Press, 1989]), who goes back to Bakhtin's theory in order to nuance the words of Christian Metz when dealing with the supposedly 'impersonal' nature of filmic enunciation. 
proposes to distribute the French verbal tenses, correspond to 'two systems which are distinct and complementary'; they 'both are used in competition with each other and remain at the disposal of each speaker'.39 According to Benveniste, these two categories are therefore mutually exclusive; one can find indeed, in a single utterance, an alternation from one to another, but one must therefore deduce that the formal system has changed. In fact, Christian Metz anticipated the shift of the 'discourse vs. story' opposition from the linguistic field to the communication theory of storytelling as it would be elaborated by Gérard Genette, starting with Nouveau discours du récit published in 1983 . For Genette, story is a subcategory of discourse, a provisional suspension of the enunciation traces. ${ }^{40}$

There is, however, a brief passage in Benveniste's essay where he excludes from his analysis an aspect of the problem - indirect speech - which he describes in these terms: 'historical enunciation can on occasion merge with discourse to make a third type of enunciation in which discourse is reported in terms of an event and is transposed onto the historical plane'. ${ }^{41}$ This scenario opens up the discussion to conceptions of polyphony, as developed by Oswald Ducrot (in the linguistic field) ${ }^{42}$ and Jean Châteauvert (for cinema); ${ }^{43}$ it allows a conjunction of the two regimes nearer to the Metzian conception.

\section{The Ideological Critique: A Repressed 'Discourse'}

Faced with Metz's appropriation of certain concepts proposed in Benveniste's Problems in General Linguistics, one can make the following hypothesis: under the guise (so as to remain inside the trope of masquerade) of notions

39 Emile Benveniste, 'The Correlation of Tense in the French Verb' [1959], in Problems in General Linguistics, p. 206 (translation modified).

40 On this subject, see Sylvie Patron, 'Homonymie chez Genette, ou la réception de l'opposition histoire/discours dans les théories du récit de fiction', in Relire Benveniste. Réceptions actuelles des Problèmes de linguistique générale, ed. by Emilie Brunet and Rudolf Mahrer (Louvain-laNeuve: Academia, 2011), pp. 97-121. The author underlines the fact that the first appropriation of Benveniste's categories by Genette in the field of narratology (before the relation of the two words forming this oppositional couple had been redefined) goes back to his essay 'Frontières du récit' published in Communications, 8 (1966), pp. 158-69, that is, in the same journal in which Metz published the first version of his 'grande syntagmatique de la bande-images' (pp. 126-30). 41 Benveniste, 'The Correlation of Tense in the French Verb', p. 206 (translation modified).

42 Oswald Ducrot, Le dire et le dit (Paris: Minuit, 1984).

43 Jean Châteauvert, Des mots à l'image: la voix 'over'au cinéma (Québec: Nuit blanche \& Paris: Méridiens Klincksieck, 1996). 
coming from a discipline perfectly legitimized on a theoretical plane, Metz transfers the linguistic issues to an opposition between the semblance of fiction and the underlying materiality of the signifier. Thus his conception is the indirect echo of those contemporaneous debates in film theory that posited an ideological critique of the cinematographic apparatus and its productions. Metz does mention his precursors in another passage of The Imaginary Signifier, when he refers to a conceptual field coming from psychoanalysis, but without reference to any specific article: 'In France during the years following 1968, the Cahiers du Cinéma team played an important part in the emergence of this new line of investigation: I am thinking in particular [...] of Jean-Louis Comolli or Pascal Bonitzer's contributions. ${ }^{44}$

Following Bonitzer's essay entitled 'Films/Politics', Jean-Louis Comolli criticized Costa-Gavras's film The Confession (F/I 1970) in October 1970, judging it politically unworthy in the sense that (unlike the Straubs with Othon, FRG 1969) Costa-Gavras delivered a film that 'contains no productive work at the level of its signifiers and thus - since it is one and the same work - never calls into question the conditions of the production/écriture/ diffusion/reading of the film. ${ }^{45}$

In other words (which Metz borrows from Benveniste), one could say that Comolli's critique focuses on the film's failure to inscribe itself in the discourse regime. In his essay, Comolli in fact starts with a politicized version of Metz's interpretation of enunciation: 'It is precisely here, in the relation film/politics that we can distinguish not only the place of films in the dominant relations to production and in the ideology which dominates in their name, but also the place of the films' spectators [...]..$^{46}$ This is opposed to a masking process: the one that the dominant norms produce through a representation mode defined as 'bourgeois' (Bonitzer wrote that 'the bourgeoisie has to instill its principles by masked means $\left.{ }^{47}\right)$. This point of view reverses that of Metz, who favours the dominant form in his research, although the principle of a dichotomy between exhibition and concealment is similar. The interweaving of story and discourse in The Imaginary Signifier allows Metz to consider filmic practices that do not

44 Metz, The Imaginary Signifier, p. 36.

45 Jean-Louis Comolli on The Confession by Costa-Gavras, 'Film/Politics (2)' [1970], in Cahiers du cinéma. 1969-1972: The Politics of Representation (Cambridge, MA: Harvard University Press, 1990), 163-73 (p. 165); originally published in Cahiers du cinéma, 224 (September 1970).

46 Comolli, 'Film/Politics (2)', p. 163.

47 Pascal Bonitzer, 'Film/politique', Cahiers du cinéma, 222 (July 1970), 33-7 (p. 33). Issue 223, which is in between the two texts that are cited here, contains an interview with Straub and Huillet about the film Othon. 
strictly belong to 'fiction film' but which he takes into account - and which he dismisses at the same time - without having to interact with the political positions of the cinephiles. In a footnote to the interview conducted by Marc Vernet and Daniel Percheron, published in the Essais sémiotiques in 1977, Metz retrospectively clarifies (after having stated his interest in films such as the Straubs' Moses and Aron [FRG/AU/F/I 1975]):

It is basically possible that my cautious attitude, deliberately standing in the 'background', owes less to the very avant-garde production rather than to the ideology alongside, fairly hasty and that often escorts them (not always) in manifestoes and that I find a bit too prophetical and idealistic, not exempt from certain theoretical ingenuities, and in other cases unpleasantly terrorist or overexcited. ${ }^{48}$

The discourse category is not approached as such in The Imaginary Signifier, in the sense that it stands in the shadow of the story, which constitutes the norm. Yet the discourse category supplies the theoretician - who has taken a step aside from polemics - with a tool that constitutes a token of seriousness and serenity, and which represents a scientific caution that allows him to stand outside of the field of film criticism.

Benveniste's notions are in fact considered in relation to a split dis/belief in fiction, which is omnipresent in The Imaginary Signifier and which leads Metz to a certain scepticism toward the idea that the unveiling of the production conditions of the image is a political gesture. It is interesting to note here that in The Imaginary Signifier, he discusses several reflexive processes such as the 'film within the film' or the 'voice-over commentary', of which he says: 'The distance it establishes between the action and ourselves comforts our feeling that we are not duped by that action: thus reassured (behind that rampart), we can allow ourselves to be duped by it a bit longer."49 This statement neutralizes any automatic association between the marks of enunciation and processes of distancing. It echoes Metz's analysis of the mise en abyme in Fellini's $81 / 2$ (I/F 1963), where there is a perfect correspondence of the 'film within the film' and the film itself..$^{50}$

Metz's interest in reflexivity is noticeable in his last work, to the point where he reduces all of the enunciation phenomena to this issue.

48 Christian Metz, 'Sur mon travail. Entretien avec Marc Vernet et Daniel Percheron' [1974], in Essais sémiotiques (Paris: Klincksieck, 1977), p. 168.

49 Metz, The Imaginary Signifier, p. 73-74 (for all these quotes).

50 Christian Metz, 'Mirror Construction in Fellini's 81/2', in Film Language, pp. 228-34. 
Significantly, it is in the chapter dedicated to the exhibition of the cinematic apparatus that Metz revisits the ideological critique of the 1970 s and reaffirms his personal distance from it, while deconstructing one of its founding principles:

We could assume that the visibility, the highlighting of the cinema apparatus - its 'denunciation', its 'deconstruction', as the Seventies used to say, forged with militant subversion and ideology - consist of the ultimate enunciative act [marque d'énonciation], for if we follow the vulgate of that time, films let us see and listen to the ones who made them..$^{11}$

The quotation marks suggest the incompatibility of the quoted conception with his own, and the word 'vulgate' points to its dogmatism; one should also notice the subject of the verb 'to say', that is 'the Seventies', therefore an indistinct mass of enunciators from the same period. As he did in the The Imaginary Signifier, Metz mentions this approach in order to underline its naiveté. By emphasizing the historical distance from it, he wants to highlight the gap between his own scholarly position and that of the ideological critique's representatives. In the theoretical assessment at the end of the book, he says about 'the Seventies' - once again a term that encompasses the period while avoiding any individuation of the authors - that they 'wanted to unmask the lie of an absent enunciation and to describe the mechanisms of this concealment' and that 'this conception of a self-produced story, nobody believed in (except its fierce opponents)..$^{2}$ Metz takes up theory in the same way as he talks about cinematic fiction: he dismantles its aspects of belief while remaining at a good distance from his object of study.

\section{An 'Impersonal' Model: The Instances of Technological Mediation}

During the 1976-1986 decade, precisely when the theories of filmic enunciation were on the rise, Metz did not produce any new text that resonated with these contemporaneous theoretical debates. He mainly contented himself with retrospective comments on the semiology of the two previous decades. During this period, the enunciation frame he built showed its productivity through several case studies and found its place in the context of cinema 
education. ${ }^{53}$ One notes in particular Metz's absence from issue 38 of Communications (1983), which brings together the main theoreticians who wrote on the topic of enunciation - his absence here is especially conspicuous since he had previously edited issue 15 ('Image analysis' [L'analyse de l'image]) as well as issue 23 ('Psychoanalysis and cinema' [Psychanalyse et cinema]).

As I have tried to demonstrate, Metz's interest in Benveniste was mostly circumstantial, and the broad sense in which he uses the story/discourse opposition in The Imaginary Signifier attests to his reluctance to apply this type of linguistic terminology more systematically to cinema. This is why he did not take part in the theoretical developments The Imaginary Signifier gave birth to, for the authors following him chose a description of deixis that Metz found groundless, or at least incompatible with his own methodological principles. He later developed this position in the preface to Francesco Casetti's French version of Inside the Gaze (this text also appeared later in the American edition of Casetti's essay first published in Italian ${ }^{54}$ ), in which he praises the work of his colleague and friend while pointing out that he does not always agree with his way of thinking. The formal conception of the filmic deixis developed by Casetti had an effect on Metz's desire to elaborate, in The Impersonal Enunciation, an argument that he had already announced in the preface to Casetti's book: 'In reading Dentro lo sguardo, I decided that my rather long period of leisurely incubation was over, and that I should tackle the study of filmic enunciation in a future work myself. 55 The notion of 'impersonal enunciation' was therefore conceived in reaction to a deictic notion of filmic enunciation and to borrowings from the psychoanalytical field - that is, in reaction to the very ideas whose foundations Metz himself laid in The Imaginary Signifier. In his preface to Inside the Gaze, Dudley Andrew underlines how important and transitional Casetti's book was for Metz's career: 'In effect Casetti helped bring Metz back to his home in semiotics and linguistics, after the Freudian excursions of The Imaginary Signifier and the unpublished opus on jokes. ${ }^{56}$ Andrew

53 A French Swiss example, alongside Michel Marie or Alain Bergala, is the booklet written by François Albera for the Centre of semiological research of the University of Neuchâtel, Problèmes de l'énonciation au cinema (Travaux du Centre de Recherches Sémiologiques, 45 [February 1984]), and whose first chapter reads 'The formal device of the filmic enunciation [L'appareil formel de l'énonciation filmique]'.

54 Christian Metz, 'Crossing Over the Alps and the Pyrenees...', preface to Francesco Casetti, Inside the Gaze: The Fiction Film and Its Spectator (Bloomington \& Indianapolis: Indiana University Press, 1998 [1986]), pp. xi-xv.

55 Ibid., p. xiii.

56 Dudley Andrew, 'Preface to the English Edition', in Casetti, Inside the Gaze, vii-ix (p. vii). 
appropriately mentions the work L'espritet les mots, which Metz intended to publish in order to extend the Freudian reflection on the 'Witz'. The text's manuscript is dated January 1986 and was rejected by its publisher: regarding Metz's biography, one can hypothesize that the great disappointment Metz must have felt at the failure of this project - which was evidence of his desire to inscribe his research in the very heart of a theoretical field that, until then, he had only called on from time to time in order to approach cinema - was one of the main reasons why he reoriented his work at the end of the $198 \mathrm{os}$. From that point, he focused on components he judged more specifically cinematic (the film and its mirrors 'reflect' nothing but cinema itself), and he rejected linguistic phenomena and their interpretation in terms of manifestations of the unconscious.

Although Metz pays special attention to the process of communication in his reflections on the 'mot d'esprit' ('the spiritual effect can only happen if two unconsciouses meet, the one that the "mot d'esprit" objectifies and the one of each listener at the moment of listening'57), he then abandons all investigation of the interaction between two speaking subjects. Rejecting the notion of an anthropomorphic enunciator, he 'turns the page' in order to give way to 'enunciation landscapes' [paysages d'énonciation $]^{58}$ that are specific to cinematic representations. Metz's reaction came quickly, since the new perspective adopted in The Impersonal Enunciation had already been sketched by the end of 1987, appearing in the first issue of Vertigo, edited by Jacques Gerstenkorn. ${ }^{59}$ Metz also presented it in an interview with Michel Marie and Marc Vernet following the Cerisy Symposium in 1989, which was dedicated to Metz's theory. ${ }^{60}$ Metz's goal here is to elaborate a formal theory based only on manifestations of filmic reflexivity, erasing any anthropoid conception. His new perspective is clearly stated in the introduction to his book on enunciation, which was published in English in the journal New Literary History (a few months after its first French version appeared in Vertigo):

57 Christian Metz, Le mot d'esprit, unpublished manuscript, Christian Metz Archives of the Bifi, ms. CM1512, p. 97. My gratitude here goes to Martin Lefebvre.

$5^{8}$ The table of contents of L'énonciation impersonnelle shows a list of cases rather than a wish to propose theoretical principles that would apply to all kinds of reflexive practices: Metz indeed presents his work as a 'guided tour' through 'enunciation landscapes'. The lyrical aspect of the word 'landscape', very rare in Metz's previous work, appears very clearly in the title of the last part of the book: 'Four steps into the clouds (theoretical flight)'.

59 Christian Metz, 'Lénonciation impersonnelle, ou le site du film (En marge de travaux récents sur l'énonciation au cinéma)', Vertigo, 1 (1987), pp. 13-34.

6o Michel Marie and Marc Vernet, 'Entretien avec Christian Metz', Iris, 10, 271-97 (pp. 284-91). 
'For what is enunciation basically? It is not necessarily, nor always, "IHERE-NOW"; it is, more generally speaking, the ability some utterances have to fold up in some places, to appear here and there as in relief, to lose this thin layer of themselves that carries a few engraved indications of another nature (or another level), regarding the production and not the product $[\ldots]]^{, 61}$

The contribution made by this proposition appears considerable to me, in that it allows a return to the machine-like dimension of the cinematic apparatus, something that had been discussed in The Imaginary Signifier, but still independently of enunciation issues. ${ }^{62}$ Nevertheless, I would say that, on the one hand, the idea of the signifiers' materiality is not discussed fully in L'énonciation impersonnelle, especially with regard to the soundtrack. ${ }^{63}$ On the other hand, the rejection of anthropomorphism (linked for Metz to the category of persons in a linguistic sense) is too radical: it diminishes the importance of the verbal in cinema-despite the importance Metz gives to different types of voices - as well as the fact that the enunciative organization of films often adheres to a fictive humanizing strategy through the constitution of discursive sources (especially voice-over narrators) that the spectator has to assimilate to the governing principle of the filmic enunciation (the 'mega-narrator' in the words of André Gaudreault, who proposes a hierarchy of the different discursive sources $\left.{ }^{64}\right)$. In the chapter entitled 'Le film-machine' of his book Un monde à notre image [A world in our own image], François Jost made relevant

61 Metz, 'The Impersonal Enunciation', p. 754.

62 Metz goes back to this aspect of his work when he writes: 'I had placed myself as it were beyond these distinctions [between film, spectator and code], on a sort of common ground which included them all at once, and which was none other than the cinema-machine itself, envisaged in its conditions of possibility', Metz, The Imaginary Signifier, p. $15^{2}$.

63 Therefore I have proposed to add within the filmic enunciation system the issue of filmic sounds' representational nature (Boillat, Du bonimenteur à la voix-over, pp. 388-414). I recently developed this theoretical issue with the help of case studies, taking into account the history of sound recording practices and theories in the field of cinema. See these three essays: 'René Clair et la résistance à la voix synchrone parlée. Ce que nous disent les "machines parlantes" d'A nous la liberté!', 1895. Revue de l'association française de recherche sur l'histoire du cinéma, 72 (2014), p. 85-107; “'On connaît la chanson...", et pourtant! Voix enregistrée et déliaison chez Alain Resnais', in Musique et enregistrement, ed. by Pierre-Henry Frangne and others (Rennes: PUR, 2014), pp. 297-323. 'Phonographie et cinématographie: pour une histoire croisée des discours sur les technologies audio/visuelles (1929-1934)', in Du média au postmédia: continuités, ruptures, ed. by Nicolas Dulac and Martin Lefebvre (Lausanne: Editions L'Age d'Homme, forthcoming). 64 André Gaudreault, From Plato to Lumière: Narration and Monstration in Literature and Cinema (Toronto: University of Toronto Press, 2009 [1988]). 
comments on the limits of the Metzian model, writing that if the text is a thing, we can't even talk of enunciation' and that 'this concept only has a purpose inside an anthropomorphising way of thinking, assuming that it refers to a human presence, situated outside the novel or the film and responsible for the narrative discourse'. ${ }^{65}$ Besides, Marie-Claire Ropars underlined how much Metz tends to objectify the film in The Impersonal Enunciation, thus implying precisely what semiology has been accused of, that is, a confinement to textuality that precludes any account of the communication context. ${ }^{66}$

However, it seems to me that it would be useful to consider the process of filmic enunciation in the diversity of its manifestations, thus reconciling the deictic conception of enunciation (useful for studying the words spoken in films or in the movie theatre, words that are inseparable from the audience's visualization of the speaker) with an impersonal conception applied to the different materials of cinematic expression when they are displayed as artefacts. The degree of the enunciative marks will nevertheless always depend on the perception by a specific audience in a specific institutional context and at a specific time (hence the importance of Roger Odin's semio-pragmatics or of the reception studies that Francesco Casetti later turned to). Thus, the respective importance of discourse and of story cannot be measured solely from the text but is constituted in the act of reception. However, this view by no means precludes an enunciative perspective on cinema, 'where everything depends on machines', as Metz writes. ${ }^{6}$ Such a perspective focuses on the purely technical aspects of the medium and especially on the degree of perceptibility, within the film, of the traces left by the processes of recording, production, and transmission of the audiovisual information. All of this remains relevant in the digital era where a spectator (who is somewhat aware of contemporary technologies) can understand all components of representation as 'generated' (as in CGI) - if they are 'generated', it is by someone or something. Now that the aesthetics and popularization

65 François Jost, Un monde à notre image. Enonciation, cinéma, télévision (Paris: Méridiens Klincksieck, 1992), p. 31. I would personally say that this presence can be thought of as being inside the discourse because of the very discourse that produces this anthropomorphic effect.

66 'If enunciation is only a puckering of the film that shows itself as being so, and therefore designates cinema itself, wouldn't there be then a withdrawal into the refuge of a cinematographic specificity, in a way that cinema could free itself from the communication model, throwing it back outside the film, in language?' Ropars, 'Christian Metz et le mirage de l'énonciation', p. 107. 67 Metz, 'The Impersonal Enunciation', p. 748. 
of the latest technologies rest on a logic of transparent immediacy or a logic of hypermediacy (two sides of the same phenomenon, as were story and discourse for Metz), ${ }^{68}$ the degree to which technological mediation is displayed or concealed - the very topic that interested Metz - is more than ever a key factor in the appreciation and the study of cinematic productions, including their ideological dimension.

Translated from French by Sylvain Portmann and Susie Trenka

\section{About the author}

Alain Boillat is Professor at the University of Lausanne's Department of Film History and Aesthetics. In his teaching, publications, and research he has examined topics such as screenwriting practice, the history of film theory, the role of the voice in audiovisual media, the relation between comics/graphic novels and film, and, more generally, questions of narration and fiction in media. Currently, he is co-director of the research project 'Scriptwriting as discourse: Historical and genetical approaches to filmic adaptations of Stendhal's novels', funded by the Swiss National Science Foundation. He is the author of over 60 scholarly articles and of several books, including Du bonimenteur à la voix-over (2007) and Cinéma, machine à mondes. Essai sur les films à univers multiples (2014) in the series 'Emprise de vue' at Georg (Geneva), for which he is the series editor.

\section{About the translators}

Sylvain Portmann works in the Film Department of the University of Lausanne. He specializes in the history of film criticism and also administers the Swiss cinema review Décadrages. Cinéma, à travers champs.

68 In my opinion, the phenomena envisioned from the perspective of a contemporary numerical culture by Bolter and Grusin clearly echo those discussed by Christian Metz in an enunciative perspective for the narrower field of cinema; see Jay David Bolter and Richard Grusin, Remediation. Understanding New Media (Boston: MIT Press, 1998), pp. 21-44. Doubtless, a look back at certain concepts or methods, employed a few decades ago by theoreticians of filmic enunciation, would enrich the contemporary approaches by allowing for a more accurate analysis of media representations, taking into account the specificities of their discursive organization. 
Susie Trenka completed her PhD entitled Jumping the Color Line: Vernacular Jazz Dance in American Film, 1929-1945 at the University of Zurich, where she was also a research assistant, lecturer, and translator in the Department of Film Studies. She now lives in New Orleans, working as a freelance translator, film critic/writer, and swing dance teacher. 


\title{
18. Personal Enunciation: Presences of Absences
}

\author{
Dominique Bluher
}

Tröhler, Margrit and Guido Kirsten (eds.), Christian Metz and the Codes of Cinema. Film Semiology and Beyond. Amsterdam University Press, 2018

DOI: $10.5117 / 9789089648921 / \mathrm{CH} 18$

\begin{abstract}
In his last book, L'énonciation impersonnelle, Christian Metz tackles the question of enunciation in cinema in order to show that filmic enunciation is not anthropomorphic but textual, impersonal, and metadiscursive. According to Metz, filmic enunciation 'is the semiological act through which some parts of the text speak to us of this text as an act'. In consequence, 'the last I is always outside of the text'. Discussing autobiographical cinema, this chapter explores how Metz's conception of impersonal enunciation can be reconciled with autobiographical discourses that seem opposed to his theory, and how some of its shortcomings can be overcome by resorting to Vivian Sobchack's semiotic phenomenology of film experience and Käte Hamburger's phenomenological narrative theory.
\end{abstract}

Keywords: film semiotics/film semiology, enunciation theory, narratology, autobiographical discourse, documentary film, film essay

In his last book, L'énonciation impersonnelle,${ }^{1}$ Christian Metz tackles the question of enunciation in cinema in order to show that filmic enunciation differs from conceptions of enunciation in linguistics and narratology. Rather than conceiving enunciation as anthropomorphic, Metz shows that filmic enunciation - as with the enunciation in any monodirectional, unchangeable discourse (be it written or audiovisual) - is textual, impersonal, and metadiscursive. '[Enunciation] is not necessarily, and not always "I-Here-Now",' Metz writes.

1 Christian Metz, L'énonciation impersonnelle, ou le site du film (Paris: Méridiens Klincksieck, 1991). All translations, unless otherwise noted, are mine. 
[It] is more generally the capacity of many utterances [énoncés] to fold at certain places, to appear here and there in relief, to shed a thin film of themselves on which is engraved some indications of another nature (or of another level) that concerns the production and not the product, or if one prefers, indications inserted in the product from the other side. Enunciation is the semiological act through which some parts of the text speak to us of this text as an act. ${ }^{2}$

And further:

Enunciation is always enunciation about the film. Metadiscursive rather than deictic, it informs us not about something outside the text, but rather about a text that includes within itself its origin [ foyer] and aim [visée]. [...] This 'metalangage' (which should be put in scare quotes) is sometimes a commentary and other times a reflection of the film, or even both simultaneously. ${ }^{3}$

If the filmic enunciation is not anthropomorphic but always a metadiscursive enunciation about the film, 'the last I is always outside of the text'. However, Metz adds, also in parentheses, 'that it often leaves traces, and that its act IS the text itself. [...] One never catches the last I [...] [T]his feeling of a site of absence, paradoxical figures of origin, even more "absent" in unchangeable discourses that exclude a response.4

Although I was attending Metz's seminar when he was presenting the work on filmic enunciation that would culminate in the publication of his book, I did not know at the time that my research would lead me to study autobiographical cinema. Alas, I never had the opportunity to discuss with him the case of autobiographical films. Hence, this paper seeks to conduct this discussion with Metz in absentia. How can I reconcile Metz's theory of the impersonal enunciation with autobiographical discourses that seem so diametrically opposed to his theory? One key point of contention is Philippe Lejeune's now-canonical definition of the autobiographical pact - '[i]n order [...] to be autobiography (and personal literature in general), the author, the narrator, and the protagonist must be identical'. ${ }^{5}$ Lejeune also stresses that

2 Ibid., p. 20 (emphasis in original).

3 Ibid., p. 30 (emphasis in original).

4 Ibid., pp. 189-9o (emphasis in original).

5 Philippe Lejeune, 'The Autobiographical Pact', in On Autobiography, trans. by Katherine Leary (Minneapolis: University of Minnesota Press, 1989 [1987]), 3-30 (p. 5). 
'[a]utobiography is not a guessing game: it is in fact exactly the opposite. $[\ldots]$ The autobiographical pact is the affirmation in the text of this identity, referring back in the final analysis to the name of the author on the cover. ${ }^{6}$

The criterion of identity between the author, the narrator, and the main character has equally been foregrounded by the literary scholar Elizabeth W. Bruss. In her article focusing on filmic autobiography, Bruss distinguishes three defining parameters for autobiographical expression: 'truthvalue', 'identity-value', and 'act-value'.7 Identity-value equals Lejeune's autobiographical pact, since '[i]n autobiography, the logically distinct roles of author, narrator, and protagonist are conjoined, with the same individual occupying a position both in the context, the associated "scene of writing," and within the text itself. ${ }^{8}$ Act-value refers to the fact that "[a]utobiography is a personal performance, an action that exemplifies the character of the agent responsible for that action and how it is performed'. ${ }^{9}$ And finally, truth-value corresponds to Lejeune's 'referential pact' or 'veridiction pact', which is generally coextensive with the autobiographical pact, and whose formula, according to Lejeune, would be: 'I swear to tell the truth, the whole truth, and nothing but the truth. ${ }^{10}$ According to Bruss, the author also ought to commit to telling the truth, and the veracity of the facts related can or could be verifiable: 'An autobiography purports to be consistent with other evidence; we are conventionally invited to compare it with other documents that describe the same events (to determine its veracity) and with anything the author may have said or written on other occasions (to determine its sincerity). ${ }^{11}$

In written autobiography, the identity between the author, narrator, and protagonist can easily be created by a simple homonymy. The names of the narrator and protagonist thus function as traces. In the case of film, we might also consider including the voice and the body of the filmmaker,

6 Ibid., pp. 13-14.

7 Elizabeth W. Bruss, 'Eye for I: Making and Unmaking Autobiography', in Autobiography, Essays Theoretical and Critical, ed. by James Olney (Princeton: Princeton University Press, 1980), 296-320 (pp. 299-300).

8 Ibid., p. 300

9 Ibid.

10 Lejeune, 'The Autbiographical Pact', p. 22. Lejeune also points out that '[t]he oath rarely takes such an abrupt and total form; it is a supplementary proof of honesty to restrict it to the possible (the truth such as it appears to me, inasmuch as I can know it, etc., making allowances for lapses of memory, errors, involuntary distortions, etc.), and to indicate explicitly the field to which this oath applies (the truth about such and such an aspect of my life, not committing myself in any way about some other aspect)' (p. 22).

11 Bruss, 'Eye for I', pp. 299-300. 
which can lead to the creation of very interesting hybrids. Just as for Metz, for Lejeune and Bruss the 'last I' - the author - is always extratextual, but there are traces that allow the text to be identified as autobiographical. Nonetheless, the homonymy with the author can only be determined by leaving the text per se, by taking into account peri- or paratextual indications: only information given on book covers, in forewords, blurbs, publicity, posters, leaflets, DVD covers, or during the opening and end credits enables us to understand that the name of the author corresponds to that of the protagonist and that the filmmaker is the person in front of and/or behind the camera. In short, any definition and recognition of an autobiography can only be pragmatic. Hence, the autobiographical pact or the identityvalue implies that the spectator of an autobiographical film is invited to consider the enunciating voice not as a purely textual entity, as is the case in fiction, but to perceive the originating I as real and the facts shown as 'true' and referring to the life of the filmmaker. Like all factual discourses, autobiography institutes a referential reading, or a 'documentarising reading' (lecture documentarisante), to use Roger Odin's term. ${ }^{12}$ The author of an autobiography is indeed liable for the truthfulness of the facts and can be sued and required to remove names or parts. Yet, it has to be noted that the author's liability in this case is negotiated outside the text and after the screening, in the courtroom or in the press. ${ }^{13}$

But even if the autobiographical pact is established, the spectator is free to adopt a 'wrong' reading strategy or to switch from one strategy to the other during the screening. Literary critics like Käte Hamburger, Dorrit Cohn, or Michael Riffaterre have tried to identify the markers of fictionality in literary texts. ${ }^{14}$ However, all textual indicators of fictionality can be

12 Roger Odin, 'Film documentaire, lecture documentarisante', Cinémas et réalités, ed. by Jean-Charles Lyant and Roger Odin (Saint-Étienne: CIEREC, Université de Saint-Etienne, 1984), pp. $263-80$.

13 Strangely enough, I know of no examples of filmmakers being prosecuted for defamation by people depicted in their films. But several literary autobiographies made waves throughout the press in France: Claude Lanzmann obtained a court order to have certain passages deleted in his ex-brother-in-law Serge Rezvani's Le testament amoureux (1981), Paul Ricœur had his name removed in Christophe Donner's L'esprit de vengeance (1992), and Camille Laurens' husband tried to have her L'amour (2003) prohibited from publication, though unsuccessfully. Are filmmakers more careful, or do they self-censor themselves harder to avoid troubles? For his film From Somalia with Love (F 1982), Frédéric Mitterrand has written in an Oulipian tour de force, a lipogrammic commentary spoken by himself that doesn't reveal the gender of the lost love he is mourning.

14 See in particular: Käte Hamburger, The Logic of Literature, trans. by Marilynn J. Rose (Bloomington: Indiana University Press, 1993 [1957]); Michael Riffaterre, Fictional Truth (Baltimore/ London: Johns Hopkins University Press, 1990); Gérard Genette, Fiction \& Diction, trans. by 
invalidated by the simple fact that the fictional narrative can feign the appearance of 'serious' narratives, and vice versa. Factual narrative can borrow discursive patterns from fiction, and always has. Conversely, the impact of fake documentaries or mockumentaries, for instance, depends on how successfully they fake the markers of factuality.

On the other hand, the viewing of an autobiographical film calls for another type of attitude, attention, and effort from the spectator, whose expectations are most likely informed even before entering the movie theatre. One usually goes to see a nonfiction or an autobiographical film, en connaissance de cause, with the knowledge that the movie we are going to see will not be a thriller, a romantic comedy, or a science fiction film. As Odin argues, the spectator produces different reading modes depending on the type of film and on his knowledge of the institution that pertains. ${ }^{15}$ We know how crucial the opening and end credits can be in shaping our expectations and understanding of a film, but what happens in between? The author is absent, outside of the text, even if autobiographical screenings are often introduced by the filmmaker and followed by a Q\&A, allowing us to get to know the filmmaker not only through the mediation of the screen but also in flesh and blood. However, I would argue that the presence of the filmmaker in flesh and blood makes us more aware of the likeness and the discrepancies between the real author and her or his screen avatar.

Now, what can be said about the plenitude of images and sounds that fill in during the screening for the bodily absence of the 'real' author? Some answers can be found in Vivian Sobchack's semiotic phenomenology of film experience. Based on the phenomenological philosophy of Merleau-Ponty, Sobchack conceives the film as a direct as well as a mediated experience,

Catherine Porter (Ithaca: Cornell University Press, 1993 [1991]); Dorrit Cohn, The Distinction of Fiction (Baltimore/London: Johns Hopkins University Press, 1999); Jean-Marie Schaeffer, Why Fiction?, trans. by Dorrit Cohn (Lincoln: University of Nebraska Press, 2010 [1999]); and 'Fictional vs. Factual Narration', in The Living Handbook of Narratology, ed. by Peter Hühn and others (Hamburg: Hamburg University Press, 2013), accessed 20 February 2014: http://wikis.sub. uni-hamburg.de/lhn/index.php/Fictional_vs._Factual_Narration.

15 'Boredom will be the sanction pronounced by someone going to see a documentary in the frame of mind of someone going to see a fiction film. Inversely, someone going to see a fiction film in the frame of mind of the reader-actant of a documentary would probably be considered "insane", for he would be accused of confusing different levels of reality. It can be seen that the sanction may apply to the film itself, if its treatment of the material is unacceptable to the institution within which it is meant to operate, or the reader-actant, if he infringes the institutional determinations that are imposed on him.' Roger Odin, 'For a Semio-Pragmatics of Film', trans. by Claudine Tourniaire, in The Film Spectator: From Sign to Mind, ed. by Warren Buckland (Amsterdam: Amsterdam University Press), 213-26 (p. 220). 
in terms of an 'embodied language' or a shared 'expression of experience by experience'. ${ }^{16}$ She considers film experience as a form of communication based on bodily perception, in which the film represents, however, more than just a visible object, since, according to Sobchack, watching a film thus implies that one will 'perceive a world both within the immediate experience of an "other" and without it, as [an] immediate experience mediated by an "other".'17

For Sobchack, as for Metz, the film is simultaneously a representation of a world that transcends the filmmaker, since the film constitutes and locates in itself its origin and address, that is, 'its own perceptual and expressive experience of being and becoming. ${ }^{18}$ But, in contrast to Metz, Sobchack emphasizes not only the film performance but also the performance of the spectator. A major part of her work lies precisely in showing how the film experience is based on the parallelism between the act of perception and expression experienced by the filmmaker, and by the spectator. Metz's purpose is to free the theory of enunciation for the filmic - or for all monodirectional, unchangeable discourses - from its anthropomorphic conception; Sobchack takes it, so to speak, from the other side. She tackles the problem of demonstrating that, in terms of its perceptive and expressive performance, the film acts not only as 'a visible and viewed object' but like a 'viewing subject' without being a 'human subject'. ${ }^{19}$

Sobchack's conception of the viewing experience as a shared act of vision is particularly relevant to the autobiographical film. 'There are always two embodied acts of vision at work in the theater', she writes,

two embodied views constituting the intelligibility and significance of the film experience. The film's vision and my own do not conflate, but meet in the sharing of a world and constitute an experience that is not only intrasubjectively dialectical, but also intersubjectively dialogical. Although there are moments in which our views may become congruent in the convergence of our interest (never of our situation), there are also moments in which our views conflict; our values, interests, prospects, and projects differ. ${ }^{20}$

16 Vivian Sobchack, The Address of the Eye. A Phenomenology of Film Experience (Princeton:

Princeton University Press, 1992), pp. 3-4.

17 Ibid., pp. 10-11 (emphasis in original).

18 Ibid., p. 9 .

19 Ibid., p. 22.

20 Ibid., p. 24. 


\section{Mekas's Lyrical Glimpses}

The most obvious example of an invitation to a shared vision can be found in Jonas Mekas's fleeting cinematographic glimpses, which also refute Bruss's assertion that there is no real cinematic equivalent for autobiography. She argues:

For the autobiographical act must be at once expressive and descriptive; the two are not mutually exclusive in language where truth is acknowledged to be a construction (an assertion that the speaker makes) rather than a reflection [or unmediated recording]. Thus we do not immediately assume that statements delivered in propria persona must be distorted or vague or unverifiable, whereas in film expressive and descriptive shots seem almost mutually exclusive. ${ }^{21}$

Alternatively, in Mekas's films there are endless possible choices of moments where the descriptive and the expressive fuse, as, for example: Pola's wedding scene, his Notes on the Circus (USA 1966), and his visit to Brakhage in Walden, also known as Diaries, Notes and Sketches (USA 1969), or the glimpses of Mekas's reunion with his mother in Reminiscences of a Journey to Lithuania (USA 1972). Mekas's gestural style and his cascades of evanescent images reflect his state of mind and emotions more than being a documentation of events. Following Merleau-Ponty and Sobchack's formulation, they offer an expression of his experience by experience. When Mekas is filming Pola's wedding, his way of shooting attests to his exalted feelings rather than to an aim to document the wedding (especially compared to traditional home movie recordings). The act of filming is the subject matter of this sequence as much as Pola's wedding is.

Mekas himself has explained the difference between a written and a filmed diary in his lecture on Reminiscences of a Journey to Lithuania:

21 Bruss, 'Eye for I', p. 306. Bruss bases her demonstration on autobiographically inspired feature films like Truffaut's The 400 Blows (F 1959) or Fellini's 81/2 (I/F 1963), in which the protagonist is not embodied by the filmmaker himself. Although she also mentions Kenneth Anger's Fireworks (USA 1947), Jean Cocteau's Testament of Orpheus (F 1960), and Joyce at 34 (USA 1972) by Joyce Chopra and Claudia Weill, these films lack, in her opinion, 'the value of identity'. The first two films are further deemed not to have provided 'a faithful reflection or representation of the person [of the filmmaker]' (p. 470). In the case of Joyce at 34, Bruss does not acknowledge that Joyce Chopra, the film's protagonist - admittedly filmed by the other co-filmmaker - also authored the film. For Bruss, films are a priori a collective work, the result of the work of a team in front of and behind the camera, which leads her to conclude 'that there is no real film equivalent to autobiography' (p. 461). 
When you write a diary, for example, you sit down, in the evening, by yourself, and you reflect upon your day, you look back. But in the filming, in keeping a notebook with the camera, the main challenge became how to react with the camera right now, as it's happening; how to react to it in such a way that the footage would reflect what I feel that very moment. If I choose to film a certain detail, as I go through my life, there must be good reasons why I single out this specific detail from thousands of other details. ${ }^{22}$

In the description of Walden in the Filmmaker's Cooperative Catalog, Mekas further specifies the particular stance he adopted when shooting his diary:

To keep a film (camera) diary, is to react (with your camera) immediately, now, this instant: either you get it now, or you don't get it at all. To go back and shoot it later, it would mean restaging, be it events or feelings. To get it now, as it happens, demands the total mastery of one's tools (in this case, Bolex): it has to register the reality to which I react and also it has to register my state of feeling (and all the memories) as I react. Which also means, that I had to do all the structuring (editing) right there, during the shooting, in the camera. All footage that you'll see in the Diaries is exactly as it came out from the camera: there was no way of achieving it in the editing room without destroying its form and content. ${ }^{23}$

A few years earlier, while shooting The Brig (USA 1964), Mekas had already experienced this creation with one's total body as tactile interaction in cinema, and considered this direct relationship between artist, tools, and materials as an essential difference between the New American Cinema and traditional cinema:

[T] he camera has become the extension of the artist's fingers, and the lens his third eye. [...] The camera movements are reflections of the body movements; the body movements are reflections of the emotional and thought movements - which, in their turn, are caused by what came in through the eye. A circle between the artist's eye and the camera eye is established. $^{24}$

22 Jonas Mekas, 'The Diary Film (A Lecture on Reminiscences of a Journey to Lithuania)', in Avant-Garde Film: A Reader Theory and Criticism, ed. by P. Adams Sitney (New York: New York University Press. 1978), 190-98 (p. 191).

23 Jonas Mekas, 'Walden', Film-Makers' Cooperative Catalogue, 5 (1971), pp. 234-35.

24 Jonas Mekas, 'On the tactile interactions in cinema, or creation with your total body', in Movie Journal. The Rise of a New American Cinéma (1959-1971). (New York: Macmillan, 1972), 
Before adopting these bodily expressions of perception as means of expression, Mekas had encountered them as a spectator, and had given a wonderful account of this viewing experience in his review of a retrospective of Marie Menken's films that took place in 1961 in New York.

The work of Marie Menken is the opposite of prose [...] film. [...] She transposes reality into poetry. [...] Menken sings. Her lens is focused on the physical world, but she sees it through a poetic temperament and with an intensified sensitivity. She catches the bits and fragments of the world around her and organizes them into aesthetic unities which communicate to us. [...]

Does Menken transpose reality? Or condense it? Or does she, simply, go direct to the essence of it? Isn't poetry more realistic than any realism? The realist sees only the front of a building, the outlines, a street, a tree. Menken sees in them the motion of time and eye. She sees the motions of heart in a tree. She sees through them and beyond them. She retains a visual memory of all that she sees. She re-creates moments of observation, of meditation, reflection, wonderment. A rain that she sees, a tender rain, becomes the memory of all rains she ever saw; a garden that she sees becomes a memory of all gardens, all color, all perfume, all midsummer and sun.

What is poetry? An exalted experience? An emotion that dances? A spearhead into the heart of man? We are invited to a communion, we break our wills, we dissolve ourselves into the flow of her images, we experience admittance into the sanctuary of Menken's soul. We sit in silence and we take part in her secret thoughts, admirations, ecstasies, and we become more beautiful ourselves. ${ }^{25}$

Doesn't Mekas's praise of Marie Menken's film poetry read like a description of his own work to come? And doesn't his vivid depiction of his viewing experience of Menken's film convert into words what we might like to say about our viewing experience of lyrical moments in Mekas's films, when we are invited to share his vision and feelings by dissolving ourselves into the flow of his images; in short, to experience his experience through the expression of his experience?

These instants of gestural subjectivity are traces of the act of production that settle, even more literally than Bruss imagined, her criterion of the

pp. 248-49.

25 Jonas Mekas, 'Praise to Marie Menken, the Film Poet', in Movie Journal. The Rise of a New Americian Cinéma (1959-1971) (New York: Macmillan, 1972), p. 47. 
'act-value'; in other words, autobiography has to be a personal performance. Mekas's way of filming exemplifies Bruss's assertion of the necessary inscription of 'the agent responsible for that action and how it is performed'. ${ }^{26}$ The 'last I' is irremediably absent, but the 'I shooting' is pervasively present. It is indeed a paradoxical figure of origin, but does it create a feeling of absence that is even more absent, as Metz argues, because the film is an unchangeable discourse that excludes a response? Metz, however, is writing about narrative cinema and does not expand his theory to non-fiction films. Metz makes only some marginal remarks about experimental or documentary films and is not concerned with autobiographical cinema or with films that have come to be known as 'lyrical'. ${ }^{27}$

In his concluding chapter, Metz discusses at length the possible distinction between narration and enunciation. From his point of view, narration is only a technical term referring to the enunciation in a narrative text and is a term that came into being because of the importance of narratives in our culture. Still, in a short paragraph, he concedes the existence of two cases where the enunciation can be distinguished from narration or narrative enunciation: the first is the large corpus of non-narrative texts, and the second is 'written or spoken narratives where one could distinguish, although uneasily, the narrative mechanisms which result from the idiom from those which would be independent from it'. ${ }^{28}$ Metz ends his discussion by acknowledging the importance of Käte Hamburger's phenomenological narrative theory. ${ }^{29}$ Contrary to Hamburger, however, Metz does not engage with the lyrical genre, to which Hamburger devotes a whole chapter, because it differs both from narrative fiction and from non-literary usage of language. In her phenomenological approach, the use of language in written narrative fiction is distinct from everyday language because for her, just as for Metz, one cannot attribute what is narrated 'to

26 Bruss, 'Eye for I', p. 300.

27 P. Adams Sitney coined the term 'lyrical film' by referring initially nearly exclusively to works by Stan Brakhage: 'The lyrical film postulates the film-maker behind the camera as the first person protagonist of the film. The images of the film are what he sees, filmed in such a way that we never forget his presence and we know how he is reacting to his vision. In the lyrical form there is no longer a hero, instead, the screen is filled with movement, and that movement, both of the camera and the editing, reverberates with the idea of a man looking.' P. Adams Sitney, Visionary Film. The American Avant-Garde, 1943-200o (Oxford/New York: Oxford University Press 2002), p. 160.

28 Metz, Lénonciation, pp. 187-89.

29 Metz strongly agrees with Hamburger's theory, although he underlines that she is concerned with de-anthropomorphising the subjects of fiction, and, unlike him, the subjects of enunciation; see L'énonciation, p. 196. 
a real I-Origo, but to fictive I-Origines'.$^{30}$ But lyrical poetry differs from narrative fiction because 'the lyrical I can be encountered only as a real and never as a fictive subject'. ${ }^{31}$ On the one side, the subject is real (as in non-literary usage of language); on the other, lyrical statements do not refer to reality, as does everyday usage of language. For Hamburger, the lyrical statement incorporates its object into the statement; it 'does not render the object of experience, but the experience of the object, as the content of its statement, ${ }^{22}$ regardless of whether or not it is a first-person poem or whether the experience is an actual or an imaginary one. The experience depicted in a poem cannot be subjected to verification, since it is not oriented to reality, nor does it function in a context of reality. We are dealing exclusively with the expression of the experience of the 'stating I'. As Hamburger emphasizes,

we no longer can, no longer may, ascertain whether the statement's content is true or false, objectively real or unreal - we are dealing only with subjective truth and reality, with the experience-field [Erlebnisfeld] of the stating I itself. [...] We are dealing only with that reality which the lyric I signifies as being its, that subjective, existential reality which cannot be compared with any objective reality which might form the semantic nucleus of its statement. ${ }^{33}$

It is important to note that Hamburger regards this identity only as a logical identity, and that she emphasizes the fact that the "poem presents the experience-field of the lyric I in the very variability and indeterminability of its significance', and that 'the respective difference or identity between the lyric I and the empirical I of the poet also belongs to this character of indeterminability' ${ }^{34}$ This indeterminability of the identity or non-identity of the 'lyrical I' with the 'empirical I' of the poet itself serves as evidence of the character of the lyric poem as reality statement. Hamburger also points out that lyrical inserts can be integrated into an epic fictional work (and vice versa).

The indexical nature of (analog) cinema complicates the status of filmic lyrical inserts. On the one hand, there is no doubt about the factual nature of the events that Mekas has captured with his Bolex camera. Pola's wedding or 
Mekas's reunion with his mother in Lithuania has taken place. The veracity of the facts related can be verified by comparison with other documents that describe the same events (thus fulfilling Bruss's 'truth-value' or Lejeune's 'referential pact'). On the other hand, the expression of his experience prevails over the documentation of the events.

The question of the logical identity and the points of convergence and divergence between the 'lyrical I' and the 'empirical I' is not only crucial with respect to the lyric but also to autobiography. Although Hamburger does deal with first-person narrative as a special or mixed form, the firstperson narratives she writes about are autobiographically inspired novels, and, even if she alludes several times to genuine autobiography, she never addresses it as such. ${ }^{35}$ Psychoanalysis and (post)structuralism should have dissuaded us from a reductionist conception of the human subject. Still, one cannot stress enough that the identity does not necessarily mean a centred, unified entity but rather a fragmentary, multiple, decentred self.

\section{Ross McElwee's Retrophrenic Voice}

The presence of the autobiographical I can be further refracted by the way the filmmaker composes and positions the voice-over. There are very few autobiographical films that do not include a voice-over commentary. Speech is necessary as it returns in fine with the commentary to flesh out context and to express feelings or reflections, or to digress on any subject present or absent in the image. In this respect, the autobiographical filmmaker resembles the autobiographical writer in terms that Dominique Noguez describes as 'egography, discourse about oneself rather than autobiography in the strict sense, because the latter are necessarily conveyed by an account' in the form of a voice-over commentary that adds 'thus a "rewriting" to the "writing" in images'. ${ }^{6}$

The voice-over narration presents strong affinities with the written autobiography. However, the autobiographical filmmaker also has to 'write' in images, as it were. Thus, he or she shapes the assemblage between the images and the words as well as between shots. One could even say that the art of filmic autobiographical filmmaking consists in conjugating images with speech, in finding a tone for this reflexive redundancy while fashioning 
the break between the visible and the spoken. The voice-over tethers the image - it can precede the image, it can follow it, or even refer to it laterally, as André Bazin wrote in his account of Chris Marker's Letter from Siberia (F 1958), where he salutes the birth of a new filmic genre, the film essay, and the creation of a new form of montage that Bazin proposes to name 'horizontal montage' or 'from ear to eye' ${ }^{37}$ This 'horizontal montage' reverses the relation between the visual and the auditory: speech does not dictate the image, nor does it subject itself to the image; rather, it forges a new form of audio-visual perception.

Ross McElwee is another partisan of the 'horizontal montage' 'from ear to eye', thus creating a subtle interlacing of speech and image. I would like to comment on two striking aspects of the composition of McElwee's voice-over commentaries, which he has used since Sherman's March: A Meditation on the Possibility of Romantic Love in the South During an Era of Nuclear Weapons Proliferation (USA 1985): his use of the present tense and his manner of dating or using temporal deixis. The editing of his films entails marathon undertakings comprising various creative decisions: identifying themes in his rushes, and lines of forces for a potential narration; unleashing structures from their diaristic backbone in order to relate them to the essay form; selecting material from older films and home movies; and composing and placing the commentary. ${ }^{38}$

Whereas McElwee writes and records the commentary during the editing, the voice-over does not comment on the images in the past tense but rather in the present tense. This present, moreover, is not that of the time of editing, when he rediscovers the images and seeks to capture his reaction to viewing the footage, but rather a 'past-present', as he gives the impression of commenting on the images at the very moment of shooting. More shrewdly, the manner of dating (or using temporal deixis) creates an effect of coexistence, as if he is commenting on the images for viewers during the projection of the film in a movie theatre. There are no dates

37 André Bazin, 'Lettre de Sibérie' [1958], translated into English as 'Bazin on Marker', trans. by Dave Kehr, Film Comment, 39/4 (2003), pp. 44-45.

38 This takes long periods of work: the montage of Sherman's March (USA 1985) began two years after the filming and took McElwee four years, and Bright Leaves (USA 2004) was shot over four years and the editing was in progress for five years, of which three paralleled the filming. My analysis of McElwee's voice-over commentary here draws on my essay 'Ross McElwee's Voice' where I also discuss McElwee's radical transformation of observational cinema through the introduction of his voice-over commentary in the first person. Dominique Bluher, 'Ross McElwee's Voice / La voz de Ross McElwee', in Landscape of the Self: The Cinema of Ross McElwee / Paisajes yo: El Cine de Ross McElwee, ed. by Efrén Cuevas and others (Madrid: Ediciones Internacionales Universitarias, 2007), pp. 135-49. 
given, no explicit indication of the year, month, or days, but there are deictic expressions such as 'two years ago', 'the next day', 'after a few months', or 'this morning', which relate the content not to a given chronological time but to a point relative to the time of the specific speech act.

McElwee's spoken text positions the situations in relation to the present of shooting, just as it merges them into the present of what is heard during the projection. In this manner, three presents superimpose themselves one on top of the other: the past-present (images), the present-present (speech utterance), and the future-present (projection); or, from another perspective, two pasts (the shooting and the recording of voice-over) actualize themselves in each new projection. This complex temporal expression evokes Saint Augustine's conception of time experienced as a simultaneous coexistence of three times - a present of the past, a present of the present, and a present of the future - rather than as a succession of past, present, and future (book XI of his Confessions ${ }^{39}$ ). McElwee himself has marvelously described this divide in a text for Trafic: 'A kind of schizophrenia sets in as you edit - or perhaps "retrophrenia" would be a better word - but at any rate, an odd sense of looking back from one present tense to what seems to be another very vivid present tense - the world as apprehended by the filmmaker a few years earlier. ${ }^{40}$ In Bright Leaves (USA 2004), he also acknowledges the presence of the future when he says, 'I can almost feel him [his son Adrian], looking back at me from some distant point in the future.' McElwee considers his son as future spectator who will see his films, but we can also consider this potential spectator as a stand-in for all future spectators.

What does this tell us about personal enunciation? Time is always a decisive issue in autobiography and diaries. One can even base the distinction between genres of personal discourses on the different temporal structures they adopt. Thus, the traditional autobiography, understood as retrospective narrative focusing on the story of the author's life, is characterized by a significant gap between the events recalled - let's say childhood - and the time, many years after, in which the author is writing his memoir. In contrast, the written diary, where the daily entries are usually put down on paper the same day, shortly after the events, creates a small but nevertheless significant interval between the act of writing and the events. Now consider

39 Saint Augustine, The Confessions of Saint Augustine, trans. by Edward Bouverie Pusey (London: Chatto \& Windus, 1909).

40 Ross McElwee, 'Trouver sa voix', trans. by Cécile Wajsbrot, Trafic, 15 (1995), 14-30 (pp. 28-9); accessible in English as 'Finding a Voice' on McElwee's website: http://rossmcelwee.com/articles. html, accessed 20 February 2014. 
cinema. In contrast with the written diary, there is no gap between events and the filming of the events; it is all about presentness - presentness of the event, presentness of the filmmaker while capturing it, and presentness of these former presents during the projection.

McElwee's 'retrophrenic present' is not only created by the present tense of the commentary but also by his artful composition of images and commentary. Of course, there are more conventional passages where the voice-over introduces the situation and the characters. At other moments, an ingenious alliance emerges between the images and the voice-over. One example is a hilarious scene toward the end of Bright Leaves. McElwee (as character) is chased by a yelping dog, who ruins a shot, while he (as narrator) says in the voice-over that he would have liked to have pensively traversed a garden strewn with pumpkins and plaster angels. This scene follows a visit to Marian Foster Fitz-Simons, the widow of Foster Fitz-Simons, the author of the novel Bright Leaf (1948), which Michael Curtiz brought to the screen in 1950, featuring Gary Cooper in the role of the rich owner of a tobacco plantation who is ruined by a rival. McElwee (as character) imagined this to be the tragic history of his own great-grandfather, who was once an important producer of cigarettes and who lost everything to the powerful Duke family. Marian Foster Fitz-Simons explains to him that the book is not based on his great-grandfather or on any other specific tobacco planter in the region. Curtiz's film, then, cannot be the 'Hollywood home movie' about his great-grandfather that the character McElwee had hoped for. The narrator McElwee follows this disappointing meeting with the sequence where he traverses the garden full of pumpkins and decorative plaster objects. To those images, which would be rather banal and trivial in themselves, he joins a deadpan commentary added during the final editing, after he knew the outcome of his inquiry, which supplies a comic and reflexive perspective on the situation; the images simply show McElwee being chased by a small dog trying to snatch his pant leg. Moreover, the dog 'obliges' him to interrupt his reflections and wait until the second take to continue the course of his thoughts:

How can this be? I suddenly find myself adrift, dogged by doubts as to my family's cinematic legacy, dogged, in fact, by a dog. This small hound, which came out of nowhere, has ruined the shot. Take two: As I was saying, I suddenly find myself adrift. Is it possible that my great grandfather's story didn't even stay alive down here for the thirty years until Bright Leaf was written? It's almost as if he's been 'disappeared' - exiled from local history. I think I need to do a little more research. 
The spectator, distracted, laughs more at the situation than from surprise at McElwee's persona's supposed naiveté. Thanks to the commentary, the dog literally becomes the visual expression of the doubts that assail him. It is not certain and not at all necessary that this scene took place just after the filmmaker's meeting with Marian Foster Fitz-Simons. Given that the film takes the form of an essay, the unfolding of events does not necessarily correspond to the temporality of the filmic organization. McElwee-as-narrator profits from our inclination, as Roland Barthes writes, to read the consecutive as the consequential. ${ }^{41}$ In my next example, the divide and liaison between pastness and presentness are played out not only verbally but through the mise-en-scène.

\section{Varda's Installations and (Re)enactments in Les plages d'Agnès}

In her last feature film, Les plages d'Agnès (F 2008), Varda recounts her amazing life story: her origins and childhood, her life as a woman, photographer, filmmaker, video artist, mother and grandmother, and as a joyous and grieving wife. Varda opens Les plages d'Agnès by taking up the part of an actor 'playing the role of a little old lady, pleasantly plump and talkative, telling her life story'. These are Varda's first words, heard while we see her walking backwards on the beach. Thus, Varda literally performs the retrospective stance characteristic of the autobiography: she is not only looking back, she is stepping backwards, and throughout the film Varda will reiterate this backward move on the different beaches that have marked her life and which will divide the film like chapters. By the same token, she establishes the autobiographical pact by identifying herself as the protagonist, narrator, and author of her film.

Les plages d'Agnès is constructed from her stories of the past, a recollection of memories, of reveries or something imaginary, as Varda says in Les plages d'Agnès. But beyond narrating episodes of her fascinating life, the way Varda stages and (re)enacts them is a means to represent the emotional significance of these happy or difficult periods as Varda remembers them for us 'today', or, more precisely, when she was making her film. These are simple but ingenious, reflected and reflexive cinematic representations of the past as well as of Varda's present, which, furthermore, render perceptible the discrepancies and the concurrences between the 'I' (the narrator Varda, creator of Les plages d'Agnès) and the 'me's' (the different and multifarious former 'Agnès' that Varda portrays). 
In his fine comment on Les plages d'Agnès, Raymond Bellour notes the importance of the installations in her film, such that one could even consider the film as a series of installations. He also discerns that the underlying principle of the film consists of 'the mise-en-scène as installation' and 'the installation as mise-en-scène', and reminds us that certain earlier films already contained 'virtual elements of pre-installation'. ${ }^{42}$ Each episode is interspersed with several of these installations / mises-en-scène. Some are simple and imaginative visualizations, as, for example, when Varda performs, through a cinematic transposition, Agnès' (second) 'birth' or 'conception'. While Varda's voice-over recounts how she, as a young adult, had her birthname 'Arlette' (given because she was conceived in city of Arles) officially changed to 'Agnès', we see her writing her given name, Arlette, with a stick in the sand and letting it be washed away by the waves. Some of these installations / mises-en-scène are hilariously funny, like the skits about the coal-fired stove, or about the difficulties encountered parking her first car in the courtyard of her house in the rue Daguerre. Even if these must have been difficult times, the way that Varda remembers them for us, their mise-en-scène, and their enactments underscore their present humorous anecdotal significance over the harshness of those days. There are also moments that she would prefer not to evoke, like her second sojourn in Los Angeles. When it is time to relate it, Varda walks backward on a pier in Santa Monica, surrounded by skateboarders, who are a kind of embodiment of the memories, which as she says, 'swarm around [her] like confused flies'. She admits that she hesitates to remember all of this past time. In the next shot, we see her in front of a giant mural of whales, and Varda seems to execute some Tai Chi-like movement backwards, her palms facing outward and pushing away an invisible wall. This wall becomes, through a split screen, a shot of a group practicing Tai Chi, which she had filmed in 1980 for her documentary Mur murs (about murals in the Los Angeles area). We see Varda on the left side in the present, on the right in the past.

René Magritte's painting Les amants (1928) serves as a starting point for a vivid image of her and Demy's sensual togetherness and carnal love. The shot starts with a close-up of a man and a woman pressed together

42 Raymond Bellour, 'Varda ou l'art contemporain. Notes sur Les plages d'Agnès', Trafic, 69 (2009), pp. 16-19. I have taken up and deepened Bellour's pertinent remarks on Les plages d'Agnès as an 'installed film' in my article 'Autobiography, (re-)enactment, and the performative selfportrait in Varda's Les plages d'Agnès/The Beaches of Agnès (2008)', Studies in European Cinema, 10/1 (2013), pp. 59-69. 
in a fond gesture, the two heads covered by some kind of cloth, just as in Magritte's painting. But when the camera tracks backward, it unveils two lovers who are not, as suggested in the painting, clothed but naked. Furthermore, the man has quite an impressive erection. 'We were flesh and blood beings. Lovers, like Magritte's', comments Varda, laconically. The installation sequence towards the end of the film, when Varda has to evoke Demy's death, ends with an enactment of George Segal's installation Alice Listening to Her Poetry and Music (1970). Linked together through superimpositions of breaking waves, the first two shots are close-ups of stumps and branches of dead trees; the other two show Varda, the first in a close-up facing the camera, against a darkish brick wall, wearing a white veil that reflects the waves. She turns away, and the next shot shows her sitting at a small metal table, covered from head to toe in a white outfit. The waves on her body fade slowly away, while Varda reaches out to turn on an old-fashioned radio on the table. Filled with strangeness and poetry, this sequence is shrouded in grief. No words - only silence - can evoke the unspeakable loss, this void of pain filled with silenced breaking waves and soothed by Bach's cantata Herz und Mund und Tat und Leben (Heart and Mouth and Deed and Life).

In Les plages d'Agnès, Varda plays out the inevitable copresence of Vardaas-protagonist and Varda-the-narrator. This occurs from the very first (re) enactment of the film in which Varda stages a childhood scene on the Belgian beach. It starts with Varda on the beach, displaying a couple of photographs in the sand, showing her and her siblings at the beach. The photographs show two little girls whom Varda would like to bring back to life. Thanks to the magic of an ellipsis, the next shot shows us two little girls, dressed just as in the photographs, playing 'market' with shells and artificial flowers. Cinema has this power to pass in a flash from the present to the past and to give a true-to-life representation of past events; countless flashbacks operate in this manner. The scene could have been just an illustration, a visualization of the past, if Varda hadn't entered the scenery she had created, interacting with the girls in front of the camera, musing about the significance of her recreation: 'I don't know what it means to recreate a scene like this. Do we relive the moment? For me, it's cinema, it's a game.'

This sequence, all at once, reminds me of, and stands in revealing contrast with, a sequence in Ingmar Bergman's Wild Strawberries (SWE 1957). Isak Borg (Victor Sjöström) slips into a dream-like state that transports him into the past, where he witnesses a painful moment in his young manhood when his brother is seducing his cousin Sara, to whom Isak is secretly engaged. Like Varda, the character Isak Borg 'creates' a true-to-life representation of 
the past, and, like Varda, Isak Borg is present in the scene from the past. But, in contrast to Varda, he is condemned to be a helpless observer. He can't be seen by the other characters, nor can he intervene. In contrast, Varda is anything but powerless; on the contrary, she affirms herself as simultaneously the producer and the protagonist of her autofictional account. In her film, the past does not come to her as an immutable appearance but rather has been created by Varda for the purpose of the film. This is all the more true since, according to Varda, her childhood has no particular importance to her. Thus, the laying bare of the mise-en-scène is not a simple demystification of the production process but a representation of the mediation of the past by the act of remembering.

But this is a representation of the way in which the act of remembering mediates the events that we usually consider as immutable. Just as Sigmund Freud pointed out at the end of his seminal text on 'Screen Memories' that memories are not stored at the time when the events are taking place; they are not retrieved but are formed when we recall them. ${ }^{43}$

There are some recollections of her adolescence in a similar vein to the aforementioned childhood scene on the Belgian beach. During the account of moments when her family lived on a stationary sailboat in the harbour of the Mediterranean port Sète, where they relocated during World War II, Varda appears and comments on the scene, while her legs dangle from the quay. Later in the film, when Agnès studies at the Ecole du Louvre in Paris, Varda crosses the back of the shot in the sailboat, while her younger incarnation (played by Anne-Laure Manceau, who, with bowl haircut and pointy nose, looks very much like the young Varda in the photographs from the period) reads on the bank of the Seine.

In these moments, the logically distinct roles of author, narrator, and protagonist are all at once conjoined to establish the autobiographical pact and sufficiently disjointed for one to perceive the discrepancies between the narrator Varda and the former and different 'Agnès' that the author Varda portrays in her film. The film is folding, as Metz describes enunciation,

43 'It may indeed be questioned whether we have any memories at all from our childhood: memories relating to our childhood may be all that we possess. Our childhood memories show us our earliest years not as they were but as they appeared at the later periods when the memories were aroused. In these periods of arousal, the childhood memories did not, as people are accustomed to say, emerge; they were formed at that time. And a number of motives, with no concern for historical accuracy, had a part in forming them, as well as in the selection of the memories themselves.' Sigmund Freud, 'Screen Memories', in The Standard Edition of the Complete Psychological Works of Sigmund Freud, trans. by James Strachey, 24 vols. (London: The Hogarth Press Ltd., 1962), III, 303-322 (p. 322). 
giving indications concerning the production process, or speaking 'to us of this text as an act'. ${ }^{44}$ As metadiscursive commentaries, these folds reveal the superposition of Varda-the-protagonist, Varda-the-narrator, and Varda-theproducer of the autobiographical account, as well as the fact that these 'I's' on and off screen do not match up. The author, 'the last I', is always outside of the text and can never be caught within it. Not only do these layerings create, as Metz says, a 'feeling of a site of absence, paradoxical figures of origin, even more "absent" in unchangeable discourses that exclude a response', 45 this site is also, if one may say, a rather crowded absence.

It took centuries and countless philosophical, theological, and juridical debates to form our Western notion of the human being as an autonomous, responsible, and conscious individual, before psychoanalysis and (post) structuralism, as well as modern philosophers and sociologists, dismantled this conception. Lejeune's semio-pragmatic conception of identity depends on the notion of the human being as a unity and of the proper name as the manifestation of this unity. His paratextual definition of autobiography does not take into account the fact, stressed by sociologists like Pierre Bourdieu, that in our societies, the proper name functions essentially as an authentication for legal purposes. And, in order for the name to serve as such, one has to disregard the biological and social changes that the individual undergoes through his life. ${ }^{46}$ One could imagine that if we had a different concept of the self, like those of certain tribes described by Marcel Mauss in 'A Category of the Human Mind: The Notion of Person; the Notion of Self', where 'every stage of life is named, personified by a fresh name, a fresh title, whether as a child, an adolescent or an adult', ${ }^{47}$ we might not have to resort to our sometimes convoluted and still ambiguous circumlocutions in order to refer to the different stages depicted and involved in creating an autobiographical account; for example, McElwee on screen (the protagonist) versus McElwee commenting on the images (the narrator) during the editing process, or Varda-child on the beach in Belgium (played by a young girl) compared with Varda-the-filmmaker who

\footnotetext{
44 Metz, L'énonciation, p. 20.

45 Ibid., pp. 189-9o.

46 Pierre Bourdieu, 'The Biographical Illusion' [1986], trans. by Yves Winkin and others, in Identity: A Reader, ed. by Paul du Gay and others (London: Sage Publications Thousand Oaks, in association with The Open University, 1987), 297-304 (p. 300).

47 Marcel Mauss, 'A Category of the Human Mind: The Notion of Person; the Notion of Self', trans. by W. D. Hall, in The Category of the Person: Anthropology, Philosophy, History, ed. by Michael Carrithers and others (Cambridge, UK: Cambridge University Press, 1985 [1938]), 1-25 (p. 9).
} 
is staging the scene in the film, and Varda, the extratextual or 'real' author of Les plages d'Agnès. They all bear the same name, but all the zest lies in the vertiginous layering of, and gaps between, the presented and presenting selves, the narrated and enunciative selves. Henri Michaux has given a superb résumé of these multiple and nevertheless omnipresent 'I's' in his afterword to Plume (1938): 'There is not one self. There are not ten selves. There is no self. ME is only a position in equilibrium. (One among a thousand others, continually possible and always at the ready.) An average of "me's," a movement in the crowd. In the name of many, I sign this book: ${ }^{48}$

Traditional autobiographies are usually subjected to a teleological conception of a life, leading to a conflation of the chronological and the logical, and these sorts of accounts become a way to distill an identity, a core if not a substance, with a certain consistency and permanency, despite the changes that this entity undergoes during her or his life. ${ }^{49}$ Paul Ricœur has summed up this paradoxical dilemma as 'the possibility of conceiving of change as happening to something which does not change. [...] The entire problematic of personal identity will revolve around this search for a relational invariant, giving it the strong signification of permanence in time. ${ }^{50} \mathrm{An}$ account or a narrative is a privileged means to discover such an identity, although Ricœur underlines an inherent double bind, since the narrative is also, in return, constructing the identity: 'The narrative constructs the identity of the character, what can be called his or her narrative identity, in constructing that of the story told. It is the identity of the story that makes the identity of the character. ${ }^{51}$ Les plages d'Agnès does not present Varda's life story as a narrative that overcomes the discontinuities between the portrayed

48 Henri Michaux, Plume [1938], in Darkness Moves. An Henri Michaux Anthology, 1927-1984, ed. and trans. by David Ball (Berkeley: University of California Press. 1994), p. 77 (emphasis in original).

49 As Lejeune notes laconically: 'Nine of ten autobiographies inevitably begin at the moment of birth and will then follow what is called "chronological 'order'"'; Lejeune, 'The Order of Narrative in Sartre's Les mots', in On Autobiography, trans. by Katherine Leary (Minneapolis: University of Minnesota Press, 1989), 70-107 (p. 70). Bourdieu makes a similar observation: 'As in Maupassant's title Une vie (A Life), a life is inseparably the sum of the events of an individual existence seen as a history and the narrative of that history. That is precisely what common sense, or everyday language, tells us: life is like a path, a road, a track [...] Life can also be seen as a progression, that is, a way that one is clearing and has yet to clear, a trip, a trajectory, a cursus, a passage, a voyage, a directed journey, a unidirectional and linear move ("mobility"), consisting of a beginning ("entering into life"), various stages, and an end, understood both as a termination and as a goal [...].' Bourdieu, 'The Biographical Illusion', p. 297.

50 Paul Ricœur, Oneselfas Another, trans. by Kathleen Blamey (Chicago: University of Chicago Press, 1992 [1990]), pp. 117-18.

$51 \quad$ Ibid., pp. 147-48. 
selves or closes the divides between narrated and the narrating selves; her mise-en-scène not only brings alive memorable moments of her life but discloses simultaneously the significance that these periods possessed at the point in time when she embarked on the making of Les plages d'Agnès.

One can content oneself with describing this co-presence of the different narrated and narrating selves by stressing the impersonal and non-anthropomorphic mechanism of these folds as metadiscursive commentaries and reflections on the act of production. One can also adopt a postmodern position that gives up an integrative perspective on the self in favour of a pluralistic self. In that case, the presence of multiple disjointed selves becomes an expression of the unattainable unity, of the ultimate absence of a 'last I'. By the same token, this viewpoint undermines the emphasis scholars have placed on the conception of the logical identity between author, narrator, and protagonist, which defines the autobiographical pact. This logical identity thus provides the backdrop for the perception and collation of the concordances and the discrepancies between the depicted and the depicting selves as they unfold horizontally (succession) and vertically (layering)..$^{2}$

The complexity of the cinematic production process, which involves several stages separated in time - shooting, editing, post-synchronization offers creative potential for extending the field of expression of the filmmaker's experience, which will be experienced simultaneously by the spectator during the projection. Mekas, McElwee, and Varda all embrace and shape this potential in different ways. In Reminiscences of a Journey to Lithuania, Mekas captures the feelings of exhilaration that take hold of him on his way back to Semeniskia to see his mother after twenty-five years of separation. Even if Mekas's glimpses express, first and foremost, his emotions at the very moment of shooting, they have been subtly heightened by the joyful and melancholic folk song and the crescendoing numbered intertitles, joined after the fact in postproduction. McElwee includes the various production steps in the creation of a 'retrophrenic present'. The composition and positioning of the commentary - as well as the editing are as much a part of this Augustinian presentness as the footage is. They are all enfolded into the expression of the expressive self and the shaping of our perception of this expressive self. But it must be noted that neither the naiveté of McElwee's screen persona nor the seemingly narrow lens of

$5^{2}$ Inherent to a postmodern approach is also a relativization of the truth-value, which accords to the expression of subjective truth and the author's self-perception and representation as much importance as to the actual factuality of the events. 
McElwee's family history prevent McElwee (the author) from addressing the medical, social, historical, political, economic, or cultural issues of the American South. In contrast to McElwee's 'retrophenic present', where the production steps converge towards an all-embracing experience of presentness, Varda's mise-en-scène plays out the interval between the narrating and the depicted selves. Where McElwee's treatment of the different instances to express 'the experience-field [Erlebnisfeld] of the stating I itself'53 leads to the impression of a superimposed presence, which is especially evident when his voice-over commentary adopts the form of an inner monologue, Varda's disunions extend the experience-field of the 'stating I' (and, in consequence, the spectator's field of experience), as, in particular, when Varda's distinct selves are literally co-present in the same image.

Not only is the last I always outside of the text, as Metz asserts, it is also the case that the textual representations of 'the I' do not lead to one ultimate self. However, I will never know to what extent Metz would agree that, in the case of autobiographical films, the traces left by the stating I are not metadiscursive indicators of an impersonal enunciation. Surely, they are 'speaking to us of this text as an act', ${ }^{54}$ commenting and reflecting upon the film, or rather upon the different stages of the production of the film. But they are not only speaking of the film as an act, they also give expression to various selves of the filmmaker, even though these selves come into existence only through the process of the filmmaking and are only experienced by the viewer during the projection. Metz's theory of enunciation deepens our understanding of complex textual figurations of the forever-absent and unattainable I, even or especially in autobiographical films, since the indexical inscriptions of the filmmaker bear the risk of being considered as representations of 'the I'. Still, in autobiographical films, these figurations are also instances of presentification (in the phenomenological sense of 'Vergegenwärtigung') of the experiencing I, that is to say, they are the mediated expressions of the experience of a real and singular subject at particular times.

\section{About the author}

Dominique Bluher is Lecturer and Director of M.A. Studies in the Department of Cinema and Media Studies at the University of Chicago. After 
studying in Berlin, she received her PhD in film studies from the University of Paris III (Sorbonne Nouvelle). She was co-editor of the journal Iris from 1992 to 2002. Subsequently, she was Lecturer in the Department of Visual and Environmental Studies at Harvard University; Maître de conférences at the Université Rennes 2; Visiting Professor at Brown University, Wellesley College, and Freie Universität Berlin; and Senior Fellow at the IKKM (Internationales Kolleg für Kulturtechnikforschung und Medienphilosophie) in Weimar. Her writings on French film theory, French cinema, and autobiographical films have appeared in many books and journals. She co-edited two anthologies on French non-fiction short films of the 1950s and 1960s and is currently working on two books related to autobiography and cinema. 


\title{
19. Metz with Deleuze
}

\author{
From Film-Philosophy to Film Theory and Back Again
}

Nico Baumbach

Tröhler, Margrit and Guido Kirsten (eds.), Christian Metz and the Codes of Cinema. Film Semiology and Beyond. Amsterdam University Press, 2018

DOI: $10.5117 / 9789089648921 / \mathrm{CH} 19$

\begin{abstract}
When Gilles Deleuze's Cinema 1 and Cinema 2 were published in the 1980 , they were frequently met with confusion within Anglo-American film theory because they explicitly rejected the methodological terrain that had come to dominate the field, a terrain that was derived from the path charted by Christian Metz. Since then, the tide has turned; increasingly, it appears that both psychoanalysis and structuralist approaches are out of favour, whereas Deleuze's influence is hard to escape. By examining Metz's conception of 'film theory' and Deleuze's philosophical project in relation to how film theory and film-philosophy have been understood within film studies, this essay suggests ways in which thinking about 'Metz with Deleuze' may be generative for the future of film studies.
\end{abstract}

Keywords: film semiotics/film semiology, film theory, film-philosophy, phenomenology, psychoanalytic theory of cinema, methodology

The title of this essay, 'Metz with Deleuze', may appear to promise something that I have no plans to deliver on. This is not a Lacanian 'avec', which reveals some silent affinity in which one speaks the truth of the other, nor do I plan, in the spirit of Deleuze, to produce a hybrid monster out of this encounter. Rather, the idea of bringing together Christian Metz and Gilles Deleuze comes from the desire to think about the current moment in film studies, especially in the Anglo-American context that I know best. My gesture is to posit a linkage where there appears to be a gap. What is the gap? It is, first of all, one between a certain conception of theory and a certain conception of philosophy, one with a history in film studies that extends beyond the two thinkers in question. It is also a question involving the goals 
and objects of writing, thinking about, and studying film. And finally, it is a question of politics: I want to use Metz and Deleuze to think about the relation between politics and film theory, or film-philosophy, in order to suggest that thinking about these authors together might be generative for thinking about the politics of cinema in film studies today.

I.

My story begins with the Spring/Summer 1973 issue of the influential British journal Screen: a special double issue devoted to 'Cinema Semiotics and the Work of Christian Metz'. The opening editorial, by Paul Willemen, announced the issue as a preemptive strike. A threat loomed, namely the imminent publication of the English translation of Jean Mitry's Esthétique et psychologie du cinéma [The Aesthetics and Psychology of the Cinema], and Willemen wished to thwart the 'dismal prospect' that Mitry's work would be mistaken for 'a massive breakthrough'. 'The present issue of Screen', he wrote, 'is [...] an attempt to help counter such a development'.

Willemen acknowledged that 'Mitry's mammoth work [...] represents a summing up, the concluding stage [...] of a particular history of thought about the cinema. Mitry's film-philosophy put a full stop after the prehistory of film theory.' However, it is Metz who 'establishes a break in the history of ideas relating to the object film'. Metz, he explained, did this by isolating the object of theory and asking 'the question of pertinence' with regard to cinematic discourse. ${ }^{2}$ Before him, theories of film were always an excuse to talk about something else. But with Metz and his idea of film as text or unit of discourse, the road toward a genuine film theory - a science in Louis Althusser's sense - could be laid out for the first time. Nonetheless, Willemen, echoing Metz, made it clear that the theory of film, or the science of cinesemiotics, did not yet exist. ${ }^{3}$ Metz had merely paved the way and set the groundwork for a film theory to come.

Reading this editorial forty years later, it is hard not to be struck by a certain irony. On the one hand, whether or not it was the intervention of this particular issue of Screen that made the difference, it seems almost absurd today to imagine that the discovery of Metz's work by the journal's readers

$1 \quad$ Paul Willemen, 'Editorial', Screen, 14/1-2 (1973), 2-7, (p. 2).

2 Ibid., p. 2. Metz's reviews of Mitry's two volumes were translated for this issue of Screen. To a large degree, Willemen was repeating Metz's own claims about Mitry.

3 Ibid., p. 3 . 
was under serious threat from a massive wave of devoted followers of Mitry. Mitry's work registered as barely a blip on the radar of English-language film studies - though, in fairness, the translation did not come out until much later - whereas Metz's major early essays became the central reference for film theory, which quickly established itself as the cutting edge of cinema studies.

Nonetheless, it is hard to escape the uneasy feeling that the goal of Metz's work - the establishment not only of a new, more systematic, more rigorous mode of film theory but also of a collective project worthy of being called a science and capable of progressing toward greater knowledge of its object has been largely abandoned. Indeed, since Metz and Willemen themselves admitted that such a science remained on the horizon, perhaps we need to acknowledge that this era of film theory never came into existence in the first place. In the debates over what happened to film theory, we might ask another question: was there ever such a thing?

This question becomes more provocative when we consider that the name that Willemen gives to the pre-history of film theory - 'film-philosophy' - is the very term that has been taken up in recent years in English-language film writing in opposition to the more piecemeal or middle-range theories of analytic philosophers and cognitivist theorists, as well as in opposition to 'Film Theory' à la Metz - or, rather, to the larger agenda or agendas of film theory in the 1970s, a period in film theory often reductively called Grand Theory. ${ }^{4}$ Film-philosophy is suddenly presented as an emergent field, albeit with a long history - a still uncharted heterogeneous realm of speculative thought about films and cinema. Indeed, today's discourse of film-philosophy - even as it encompasses a range of often divergent, if not mutually exclusive, philosophical perspectives - often explicitly makes the gesture of returning to questions that were central to pre-Metzian, or what is sometimes known as classical, film theory. This occurs through a renewed interest in the psychology of perception, in film as art, and in the phenomenological, ontological, metaphysical, or ethical questions found in a range of thinkers whose writings pre-date Metz's earliest essays. ${ }^{5}$

4 For 'piecemeal and middle range' theories influenced by cognitivism and/or analytic philosophy, see, for example, the contributors to Post-Theory: Reconstructing Film Studies, ed. by David Bordwell and Noël Carroll (Madison: University of Wisconsin Press, 1996) and Film Theory and Philosophy, ed. by Richard Allen and Murray Smith (Oxford: Oxford University Press, 1999). For a wider range of recent philosophies of film, including more ambitious work in the field, see the journal Film-Philosophy, which began in 2005. See also recent books by D.N. Rodowick, Robert Sinnerbrink, and John Mullarkey.

5 See October, 148 (2014); the issue titled 'A Return to Classical Film Theory?' features a roundtable discussion on, and numerous examples of, the return to classical film theory in 
Is this a regression? Or, rather, can the project of 'film theory' that Metz and Willemen advocated be considered a long detour, which can now be historicized and put behind us? The rise and fall of 'capital T' Theory (not only in film studies but also in the humanities more generally in the United States and elsewhere) has by now become a familiar narrative, and there is no need to rehash it in detail for the purposes of this essay. ${ }^{6}$ Rather, what I wish to do is to question whether there ever was such a Theory by looking more closely at Metz's idea of theory as well as at its relationship to, and placement within, broader conceptions of theory at the time.

The 1973 issue of Screen - predating by a year the publications of the English translations of both Film Language, which included Metz's major essays from the 196os, and Language and Cinema - introduced Metz's work to an English-speaking audience at the same time as it sought to inaugurate a new research trajectory toward the goal of an integrated theory of film. But Willemen's editorial and the choice of essays within the journal already make it clear that this goal, of a theory to come on the terms established by Metz, was challenged from within by one of the theoretical discourses associated with structural linguistics - namely Marxism. For example, the journal included a translation of an unsigned essay that had appeared in Cinéthique in 1972 concerning Metz's Language and Cinema (to which an exchange with Metz was appended) that concluded: 'In the final analysis, the revolutionary ideological results which we have been able to draw from Metz's researches are of no concern or interest to him.'7

The various currents of 1970 os film theory - and we might use Screen as the emblem for this moment, a role it often plays - all attempt in different ways to link three questions or problems: the relation of film to the social and historical world, the internal organization or structure of the film text or the filmic discourses, and the viewing experience of the spectator. The currents approach these questions using the following methodologies: historical materialism, semiotics, and psychoanalysis respectively. Of these methodologies, Metz was surely a - if not the - central figure of the latter two methodologies. He also made it clear that historical materialism was necessarily part of any larger theoretical project. But by preserving the semi-autonomy of the three perspectives, Metz's conception of theory could be separated from the discourses influenced by his work that sought to knot them together.

recent years.

6 See D.N. Rodowick, Elegy for Theory (Cambridge, MA: Harvard University Press, 2014) for the definitive history and analysis of the conceptualization of 'theory' within film studies.

7 'Cinéthique on Langage et Cinéma', Screen, 14, 1/2 (1973), 189 (p. 189). 
I'll briefly highlight several relevant aspects of film theory consistently emphasized by Metz from his early semiotic essays up through Language and Cinema and The Imaginary Signifier. Firstly, theory required the specification of its object. This meant a shift away from claims about cinema that were constructed at a broad level of generality: instead, he recognized that cinema is, as he put it, a 'multi-dimensional phenomenon' that does not 'lend itself to any rigorous and unified study'. ${ }^{8}$ For rigour, precision, and the possibility of theoretical progress, one needed a knowable object and a definite methodological perspective.

Secondly, Metz conceived of theory as strictly descriptive and made a firm distinction between a systematic and rigorous semiotics of cinema and any more prescriptive or normative theories that, however brilliant they may have been, lacked that very rigour that film theory now required. Indeed, it was more than just rigour but what Metz called a 'posture'. Discourses that used theory to rationalize taste or evaluative judgments, or moral or political positions of the writer, may, according to Metz, 'contain insights of considerable theoretical importance, but the writer's posture is not theoretical: the statement is sometimes scientific, the enunciation never'. ${ }^{9}$

Thirdly, for Metz, film theory was not to be conceived as the top-down application of terms from another discipline to that of film. Yet this is what he has been accused of, by Deleuze in particular: applying concepts from linguistics and psychoanalysis to cinema. While it is true that Metz was, in a sense, applying concepts from what he took to be the two major theories of signification - if not the only ones -what I wish to stress is that Metz never thought of theory as consisting of ready-made concepts for application, nor did he practice it along those lines. Rather, the borrowing of terms from other discourses such as linguistics, and later psychoanalysis, was treated as part of the preliminary process of an investigation, one that involved testing in order to measure the discourse's applicability and its limits, and then modifying the terms of the inquiry accordingly. In other words, semiotics must pass through the application of linguistic methods in order to get beyond those very methods. The mutual specification of approach and of object required by Metz led at each turn to a narrowing of short-term expectations, coupled with a plea for preserving the goal of larger expectations in the long term..$^{10}$

8 Christian Metz, Language and Cinema, trans. by Donna Jean Umiker-Sebeok (The Hague: Mouton, 1974), p. 9.

9 Christian Metz, The Imaginary Signifier: Psychoanalysis and the Cinema, trans. by Celia Britton and others (Bloomington: Indiana University Press, 1982), p. 10.

10 Metz, Language and Cinema, p. 73: 'It is because the analysis searches for a system that it must select from among the elements of the filmic text, retaining some as relevant and 
This last point is worth stressing. The excitement that Metz's work generated in Screen and elsewhere may have had as much to do with the shaping of a problematic that opened up the paths for future research as it did with the results that it obtained. However polemical Willemen may have been in his editorial preface, to reread the 1973 issue of Screen is to be confronted not with the dogmatism of Grand Theory but with the emergence of a problem field and terms for debate, as well as a sense of anticipation and of work to be done.

Nonetheless, the issue of Screen reflects the way in which much of the discourse of 1970s film theory differed from Metz's conception: at the time, theoretical inquiry was often avowedly prescriptive and emphatically political. How did Metz's conception of film theory relate to historical materialism or ideological criticism? For him, this was a complex problem that, at least for the time being, needed to be deferred. Semiotics, he argued, could not be absolutely isolated from the larger context, which included an investigation of the 'cinematic fact' (involving the technological, sociological, and economic context of cinema). At the same time, many of the elements that make up the cinematic fact must be bracketed in any serious examination of the 'filmic fact' as signifying event. ${ }^{11}$

When Metz, in his 1975 essay 'The Imaginary Signifier', asked 'What contribution can Freudian psychoanalysis make to the study of the cinematic signifier?', ${ }^{12}$ he did so with the suggestion that psychoanalysis was a necessary continuation of linguistics-inspired analysis within a broader semiotics. At the same time, he insisted that both must be 'set within the horizon of a third perspective, which is as it were their common and permanent background: the direct study of societies, historical criticism, the examination of infrastructures'. However, in his view, the 'junction is much less easy' here because it demanded a rigorous analysis of political economy, which has its own laws that would bring the semiologist far afield. ${ }^{13}$

Metz often suggested that the distinct, but nonetheless related, semiotic projects consisting on the one hand of the analysis of codes and textual systems, and on the other the metapsychology of the spectator, were both relevant to ideological criticism. As he put it 1978, 'From the beginning

temporarily [emphasis mine] ignoring others. For the text (the same text) also contains other traits, which will be pertinent to the study of diverse non-unique systems (i.e., codes) which are at work in the film.'

11 Ibid., p. 18.

12 Metz, Imaginary Signifier, p. 17.

13 Ibid., p. 18. 
on, semiotics was an endeavour to de-mystify dominant cinema. ${ }^{14}$ But his conception of theory continually thwarted the attempt to draw a straight line between this demystification and any larger political consequences.

In Language and Cinema, he summarized his project at that stage as the analysis of 'film texts in order to discover either textual systems, cinematic codes, or sub-codes'. Adding that while 'extra-cinematic codes' play an important role, their analysis must be excluded from this task because ' $[t]$ he extra-cinematic material found in films is as [...] varied as social life itself'. There is no science that will cover all aspects of films 'because films may be about anything'. And, ' $t$ the immoderation of the expectation only encourages cinematic journalism [emphasis in original]. ${ }^{15}$

'The Imaginary Signifier' notably revised the conditions of the inquiry in Lacanian terms. Psychoanalytic reflection on cinema was defined 'as an attempt to disengage the cinema-object from the imaginary and to win it for the symbolic'. ${ }^{16}$ Film texts, then, were associated with the imaginary and codes with the symbolic. Meanwhile, for a number of writers influenced by Metz, Althusser's use of Lacan's concept of the imaginary in his famous definition of ideology gave a more explicit political valence to the operation of disengaging the cinema-object from the imaginary and winning it for the symbolic. Before 'The Imaginary Signifier', Cinéthique had already noted the value of Metz's work for the political analysis of cinema while lamenting his failure to follow through on it, but now the link to an Althusserian Marxist film criticism seemed more direct. In addition, Althusser's conception of Marxist science as external to ideology seemed to authorize a continuation of Metz's ethos of theoretical rigour in the name of revolutionary criticism.

But in other, more explicitly Althusserian forms of ideological criticism, there was no attempt to hide a prescriptive dimension, coupling the criticism of dominant forms of cinema that effaced their marks of enunciation with a call for new forms of political cinema, forms that accomplished the very thing that Metz said theory was meant to do: wrest the symbolic from the imaginary. Peter Wollen, for example, brought together Metz's conception of theory with Bertolt Brecht's idea of political theatre to advocate a materialist cinema that countered ideology. According to Wollen, 'Brecht wanted to find a concept of "representation" which would account for a passage from perception/recognition to knowledge/understanding, from

14 Christian Metz, 'Discussion', The Cinematic Apparatus, ed. by Teresa de Lauretis and Stephen Heath (New York: St. Martin's Press, 1980), 166-71 (p. 168).

15 Metz, Language and Cinema, p. 150.

16 Metz, Imaginary Signifier, p. 3 . 
the imaginary to the symbolic'. ${ }^{17}$ Wollen took the terms of Metz's conception of theory and suggested that it could be realized within a film - a gesture never found explicitly in Metz's own work. Indeed, for Wollen and others, an aesthetic operation within a film could unite the three strands of theoretical inquiry - making the spectator aware of the structure of the film, his or her position watching it, and the larger historical and ideological conditions within which the film was produced.

This distinction between Metz's work and that of writers influenced by him (including the editors of Cinéthique, Peter Wollen, and others) should make it clear that there was no unified concept that we might call 'Theory' held by 1970 s film theory. We have rather a cluster or constellation of concerns that constitute a shared project that revolves around a will to theory but that never reaches anything like that third stage anticipated by Metz or Willemen where we pass from methodological pluralism into a true, not syncretic, synthesis in which diverse methods are profoundly reconciled.

The idea that Theory is some kind of unified discourse may be largely a construction of the enemies of the political and epistemological commitments of 1970 s film theory. With that in mind, it is worth investigating two dominant forms of the rejection of Althusserian-Lacanian and semiotic theory in American film studies. The first is the charge that 1970 s film theory was 'Grand Theory', a woolly term adopted by David Bordwell that has unfortunately been appropriated uncritically even by a number of film academics whose positions are at odds with Bordwell. He used the term in his contribution to a 1996 volume called Post-Theory: Reconstructing Film Studies, a volume that he co-edited with Noël Carroll. The editors proposed 'piecemeal theory' or 'middle-level research' in opposition to what they took as the outsized ambitions and outright mystification of the dominant currents of film theory. ${ }^{18}$

Bordwell's use of the term 'Grand Theory' is in opposition to its original meaning in a way that is instructive. C. Wright Mills coined the term in The Sociological Imagination to refer to the work of Talcott Parsons. Abstract, anti-empirical, and solely descriptive, the 'grand theory' (Mills, unlike Bordwell, did not capitalize the term) of Parsons's work was placed in opposition to any form of critical theory in the Marxian tradition that would seek to challenge the status quo and would in any way be normative or 
prescriptive. ${ }^{19}$ Since Bordwell objects in particular to the way in which theory was understood as hermeneutics, he has clearly departed from this conception. Instead, he uses the term 'Grand Theory' most prominently to refer to discourses, such as Marxism and psychoanalysis (Paul Ricœur's 'hermeneutics of suspicion'), ${ }^{20}$ that rooted all theory in terms of history and subjectivity and were therefore in strict opposition to what Mills called grand theory.

If there is any consistency to Bordwell's understanding of the 'Grand' part of 'Grand Theory', it is not in the idea of a specific kind of theory but in a specific use of it - theory taken as a totalizing, infallible doctrine that is then laid like a grid over its object of analysis. ${ }^{21}$ As we have seen, this was in every respect contrary to Metz's conception of theoretical investigation. If Metz, more than anyone else, was the central figure for an idea of theory that so-called post-theory was intended to topple, it is also ironic, as D.N. Rodowick points out, that he exemplified many of the very traits that Bordwell and his co-editor Noël Carroll demanded of good theorizing in opposition to Grand Theory. ${ }^{22}$ Metz proceeded by way of delimiting his object, and insisted on a descriptive - as opposed to prescriptive - theory, a theory that sought answers to clearly posed questions. He also defined a theoretical trajectory as a research programme open to objections, to refinement, with the goal of progress toward a unified theory still to come.

The objection that the post-theorists (whether those influenced by analytic philosophy or cognitivist psychology) have to Theory is articulated in the name of sober scholarship and research and is posed on epistemological grounds. Yet there is another recent tendency that objects to Theory as an injustice done to films and to the spectator. It uses against him Metz's admission that theory's relation to cinema is necessarily sadistic, ${ }^{23}$ and seeks restitution. The grounds are less epistemological than ethical and, in some cases, even metaphysical.

This second tendency might be seen as an inversion of Metz's definition of theory in 'The Imaginary Signifier'. In recent decades, it often seems as if the dominant assumption of writing on the moving image is that the goal is to disengage it from the symbolic and restore it to the imaginary.

19 C. Wright Mills, The Sociological Imagination (New York: Oxford University Press, 200o), p. 25 .

20 Paul Ricœur, Freud and Philosophy: An Essay on Interpretation, trans. by Denis Savage (New Haven: Yale University Press, 1970), p. 30.

21 Bordwell, 'Film Studies and Grand Theory', in Post-Theory, pp. 17-21.

22 Rodowick, Elegy for Theory, p. 200.

23 Metz, Imaginary Signifier, p. 15. 
The 'imaginary' as a concept is out of favour, in part through the influence of Deleuze and post-theory, so we might say instead that the goal is to restore cinema to its immanence as a heterogeneous bodily and/or cognitive experience. The keywords are affect, sensation, haptic, and tactile. We are increasingly told in insistent - if frequently vague - terms, that spectators are active; films, we are told, think and feel and are beings with bodies themselves. 'The body' has become something of a mantra. As Friedrich Kittler observed in 1999, "There seem to be entire branches of scholarship today that believe they have not said anything at all if they have not said the word "body" a hundred times. ${ }^{24}$ This second tendency - which often claims, in rather loose fashion, both phenomenology and Deleuze or Bergson as allies - takes two (frequently overlapping) forms: an emphasis on 1) a bodily active spectator, ${ }^{25}$ and 2 ) the film seen as having its own mode of thought, one that is not buried or hidden and in need of disengagement but singular and immanent to the film itself. ${ }^{26}$

It should be mentioned that this shift is further complicated by questions about the shift in the object itself and whether the narrative feature film Metz's king's highway of expression ${ }^{27}$ - can still be considered our dominant mode of film experience. Lev Manovich, for example, suggested over a decade ago that we needed to add 'live-action' to the list of implicit features characterizing the object that Metz had marked out for analysis - an object that, according to Manovich, we could safely confine to what cinema was in the 20 th century but would no longer be in the 21 st. $^{28}$

\section{II.}

The decline of Metz's influence in English-language film studies might be seen to correlate with a rise in Deleuze's influence. But Deleuze's relation to these newer tendencies in film studies and film-philosophy is more complicated than it may first appear. As I will argue, Deleuze stands in relation to the newer philosophical turn as Metz did to 1970s film theory:

24 Friedrich Kittler, Optical Media: Berlin Lectures 1999, trans. by Anthony Enns (Cambridge: Polity, 2010), p. 148.

25 Representatives of this current include Vivian Sobchack, Laura U. Marks, Steven Shaviro, and many others.

26 See, for example, Daniel Frampton's Filmosophy, analyzed below.

27 Christian Metz, Film Language: A Semiotics of the Cinema, trans. by Michael Taylor (New York: Oxford University Press, 1974), p. 94.

28 Lev Manovich, The Language of New Media (Cambridge, MA: MIT Press, 2001), p. 294. 
he is at once a central influence on this trend and at odds with its dominant tendencies.

If Deleuze has replaced Metz as perhaps the most common reference point in contemporary film studies, we must however note that there was a substantial lag. From the point of view of debates in academic film studies in the 1980s and 1990s, the arrival of Deleuze's two books on cinema seemed to be of no help to anyone. Offering a complex engagement with the history of Western film theory, the books also rejected the terminology that defined the central concerns of film theory at the time - dismissing all manner of Saussurian semiological approaches, psychoanalysis, and the language of ideology critique. At the same time, Deleuze's project was implicitly even more antagonistic to any form of cultural studies, on the one hand, or the kind of piecemeal descriptive theory of the sort promoted by the so-called post-theorists on the other.

As one example, Bordwell and Carroll's Post-Theory volume of 1996 could have treated Deleuze as either an ally of a sort for his opposition to linguistic and psychoanalytic approaches, or as a new antagonist - yet another French master thinker adopted uncritically as an absolute authority in opposition to careful scholarship. But there is not a single reference to Deleuze's books on cinema in the volume. A second example: a book entitled Reinventing Film Studies, edited by Linda Williams and Christine Gledhill and published in 2000, was presented as an attempt to assess the state of film studies at the time. Situating itself, unlike Post-Theory, as not strictly anti-theory, it nonetheless saw its mission tied to the fact that 'film theory [...] can no longer be the kind of overarching, "grand" theory that flourished in the 1970s. ${ }^{29}$ Once again, the book never mentions Deleuze.

But something has happened since then. As I'm writing this, two decades since Metz's passing, there have been twenty English-language books devoted exclusively to Deleuze and cinema, eighteen of which came out in the last decade and twelve in the last three years..$^{30}$

What is Deleuze's relation to the tradition of 1970 s film theory inaugurated by Metz? Deleuze proposes a reversal of the traditional relation between film and theory. His aim is not to work out a theory of film but instead to think of film as, in effect, theory, a mode of thought, a specific means for creating ideas that can give rise to the creation of new concepts within philosophy. Deleuze's cinema books, though they engage with film

29 Reinventing Film Studies, ed. by Christine Gledhill and Linda Williams (London/New York: Arnold Publishers and Oxford University Press, 200o), p. 5 .

30 These statistics are based on my own survey on Amazon.com. 
theory, are not within its lineage because they have no interest in film as cultural production or systematizable signifying practice, only as a way of thinking - as a specific aesthetic way of realizing ideas through percepts and affects or, more specifically in cinema's case, through movement and time. Beginning most explicitly in Difference and Repetition, Deleuze attempted to construct an 'image of thought' that inverts the basic methodology of Freudo-Marxism in French structuralist theories by suggesting that the limited 'critique of representation' practiced in these discourses already gives priority to representation over the singularities that representation appropriates. ${ }^{31}$ By affirming Bergson's equivalence between image and matter and by offering cinema, contra Bergson, as the realization of this equivalence, Deleuze treats the problematic of representation that much of 1970 s film theory revolved around as a false problem. ${ }^{32}$ Deleuze may also be seen to be inverting the Althusserian re-reading of Metz: rather than breaking us out of immediacy through distancing and shifting from understanding to knowledge, Deleuze wished to eliminate the distance between the viewer and the screen. Deleuze's model is the other pole of modernist theatre - Artaud rather than Brecht.

Beyond the many books devoted to explicating or applying Deleuze's cinema books, there has also been a veritable explosion of new film philosophies that take Deleuze as an inspiration. I'll briefly touch on one symptomatic example, a 2006 book by Daniel Frampton called Filmosophy. The title itself attempts to close the circle - not theories or philosophies of film but film as philosophy, philosophy as film: filmosophy. The concept of filmosophy is meant to be a way of writing about film as purely immanent thinking and feeling. Neither hermeneutics nor historicization nor ideology critique is relevant to filmosophy. There is no point in revealing codes or filmic systems because there is no source, no outside, no recourse to a 'language of representation' or to filmmaker or spectator that needs to be called upon to speak of the cinema effect. Cinema for Frampton cannot be thought of as reflexive or in terms of excess, supplement, void, or lack because all these concepts betray the film's own immanent expression. The language of production and technology adopted by film studies is therefore taking what a film does or is and recoding it in a language of representation that refers only to how it was made. "We should not be taught to see "zooms"

31 See Gilles Deleuze, Difference and Repetition, trans. by Paul Patton (New York: Columbia University Press, 1994), pp. 262-77.

32 Gilles Deleuze, Cinema 1: The Movement-Image, trans. by High Tomlinson and Barbara Habberjam (Minneapolis: University of Minnesota Press, 1991), p. 56. 
and "tracking shots", but led to understand intensities and movements of feeling and thinking. ${ }^{33}$ This may sound Deleuzian, but what does it mean to be 'led to understand' something that Frampton will have to claim that we already understand? In Frampton's words, 'We do not need instruction in how to "read" film, we only need a better language of those moving sound-images - we are already well suited to understanding film. ${ }^{34}$ That we are already suited to understanding film was, of course, one of the central objects of Metz's own inquiry. But for Frampton, this is not a fact we need to understand. Ultimately, Frampton's argument can only affirm a kind of transparency of images in the pure self-sufficiency of what he calls the 'filmind'. Because why do we need a language for these images at all if language applies a representational over-coding to images that are always already their own 'filmosophy'?

To get out of this tautology, which would seem to negate the need for his own project, Frampton affirms a poetics of interpretation. 'The film [...] might be said to be crying in empathy, sweating out loud, feeling pain for the character. The concept of the filmind should provoke these kinds of interpretations. ${ }^{35}$ What Deleuze attempts to create is a semiotics of moving images that presupposes an importance for philosophy as a creative practice separate from cinema; Frampton's Deleuzian reading is finally interested only in a descriptive language (generously termed poetic) that is still analogical and vague. Before we start 'sweating out loud', this 'better language' can be deferred in favour of a back and forth between speculative utopian claims that may sound vaguely Deleuzian, affirming film's equivalence to mind, and a repetitive insistence on the way academic 'film theory' re-territorializes the immanent singularities or intensities of film's own creative power. Pier Paolo Pasolini once claimed that theory was needed to avoid the 'obscure ontological background that involves explaining cinema with cinema' ${ }^{36}$ Frampton's manifesto is on behalf of that obscure ontological background - a vulgar romanticism in opposition to a vulgar formalism.

That certain claims by Deleuze might be used in an attempt to give authority to this project is not difficult to understand. According to Deleuze, 'no technical determination, whether applied (psychoanalysis, linguistics)

33 Daniel Frampton, Filmosophy: A Manifesto For a Radically New Way of Understanding Cinema (London: Wallflower Press, 2006), p. 169.

34 Frampton, Filmosophy, p. 169.

35 Ibid., p. 174 .

36 Pier Paolo Pasolini, Heretical Empiricism, trans. by Ben Lawton and Louise K. Barnett (Bloomington: Indiana University Press, 1988), p. 197. 
or reflexive, is sufficient to constitute the concepts of cinema itself'. ${ }^{37}$ He is not interested in causal arguments or the technical means to create specific effects. He is interested in the effects themselves as conditions for thought. Cinema, he writes, is 'neither a language system nor a language. It is a plastic mass, an a-signifying and a-syntaxic material, a material not formed linguistically [...]. It is not an enunciation, and these are not utterances. ${ }^{38}$ So what does philosophy have to say about cinema? Deleuze tells us that '[c]inema's concepts are not given in cinema'. Rather, '[c]inema itself is a new practice of images and signs, whose theory philosophy must produce as conceptual practice'. ${ }^{39}$ In other words, philosophy uses its own creative power to reflect upon the effects of cinema on thought.

Winning the cinematic object for the symbolic came to stand for the attempt to restore to cinema its absent causes and conditions of possibility. In this narrative, our experience of cinema as cinema was predicated on the effacement of what produced the image, which manifested itself in various forms: the properties of the apparatus itself and modes of perception embedded in it, the material substrate of the film, the photogram, ${ }^{40}$ the subject of enunciation, and finally History itself. The heterogeneity of this list made for numerous arguments and, in some cases, slippages about what constituted materialism in cinema. Even if there was no unanimity in the response to the goals of theory and political cinema, there was at least a framework for debate that presumed that there was nothing natural about cinema or narrative conventions. Film theory, on the one hand, and the New Waves and avant-gardes, on the other, were then needed to rescue cinema from the illusion of transparency.

Turning our attention to effaced mechanisms, showing up the film work, revealing the marks of enunciation - be it through breaking down the illusion of movement, the return of sprocket holes, or the return of the gaze - is of no interest to Deleuze, because for Deleuze nothing has been effaced. Deleuze announces in the introduction to Cinema 1: The Movement-Image that 'cinema is always as perfect as it can be'. ${ }^{41}$ Or in an interview: 'Every image is literal and must be taken literally. ${ }^{42}$ The equivalence of matter and

37 Gilles Deleuze, Cinema 2: The Time-Image, trans. by Hugh Tomlinson and Robert Galeta (Minneapolis: University of Minnesota Press, 1989), p. 280.

38 Deleuze, Cinema 2, p. 29.

39 Ibid.

40 I.e. the film frame considered as a still image.

41 Deleuze, Cinema 1, p. $\mathrm{x}$ (preface).

42 Gilles Deleuze, 'Portrait of the Philosopher as a Moviegoer', in Two Regimes of Madness: Texts and Interviews 1975-1995, ed. by David Lapoujade, trans. by Ames Hodges and Mike Taormina (New York: Semiotext(e), 2007), 213-21 (p. 215). 
image is also an identification of matter and its movement and temporality, being and becoming. The movement-image undoes the distinction between psychical and physical reality. There are no components of the movementimage that can be isolated to reveal how cinema works because "[c]inema begins with the movement-image - not with any "relation" between image and movement; cinema creates a self-moving image'. ${ }^{43}$ Deleuze takes the famous maxim of Husserl's phenomenology that 'consciousness is always consciousness of something' and argues that Bergson goes further by proposing that 'consciousness is something'. ${ }^{44}$ Hence an image, as a form of consciousness, has an autonomy and materiality that is only obscured by bringing in questions about a 'subject of enunciation'. To preserve the creative power of the new sign grasped as image, Deleuze rejects the Saussurian distinction between signifier and signified as well as the distinction made by Metz between imaginary and the symbolic.

Deleuze's objection to Metz, and to semiology more generally, is that it subordinates movement-images to narrative and structure. Deleuze argues that cinema always has narrative and structure but movement-images are primary and make up narrative, which is only a secondary effect. Meanwhile, according to Deleuze, to make cinema into images composed of utterances is to immobilize the image. ${ }^{45}$

Cinema, Deleuze tells us, automatically gives us the movement-image. And yet, he also tells us that the movement-image needs to be created. Cinema that gives us a movement-image or a time-image is cinema as artart understood as one of the three domains of creative practice in What is Philosophy?, along with science and philosophy itself. ${ }^{46} \mathrm{He}$ excuses what he takes to be Bergson's misreading of cinema in terms of 'natural perception' by acknowledging that the origins of cinema disguised its true novelty. ${ }^{47}$ It is only when cinema develops the resources of montage and can be attached to the name of an auteur that cinema can be cinema.

This is where philosophy comes in - providing concepts for the new kinds of images that the great works of cinema invent. Cinema, when it is art, creates percepts and affects through blocks of movement and time, but it doesn't create concepts. As he puts it,

43 Gilles Deleuze, Negotiations, trans. by Martin Joughin (New York: Columbia University Press, 1995), p. 65.

44 Deleuze, Cinema 1, p. 56.

45 Deleuze, Cinema 2, p. 27

46 Gilles Deleuze and Félix Guattari, What is Philosophy?, trans. by Hugh Tomlinson and Graham Burchell (New York: Columbia University Press, 1994), p. 12.

47 Deleuze, Cinema 1, p. 3. 
Film criticism faces twin dangers: it shouldn't just describe films but nor should it apply to them concepts taken from outside film. The job of criticism is to form concepts that aren't of course 'given' in films but nonetheless relate specifically to cinema, and to some specific genre of film [...]. Concepts specific to cinema, but which can only be formed philosophically. ${ }^{48}$

At some level, Deleuze faces the same problem as Metz. How can theory supplement cinema without betraying it? Both Metz and Deleuze sought a discourse on cinema that was not a mode of judgment nor a mode of interpretation nor explanatory generalizations about how film functions but rather constructions of the thinker that provide a supplement by way of classification. But ultimately they weren't writing about the same object the good object that the ordinary spectator seeks to preserve, which Metz wished to turn into an object for knowledge by treating it as a signifying practice, does not intersect with the art of movement and time that for Deleuze conditions a philosophy of images and signs. In Metz's terms, we might say that what had 'pertinence' for Metz's investigation did not have it for Deleuze, and vice versa.

III.

So where does this leave us? How do we turn this parallel montage into a last-minute rescue? To return to my title, this question of 'with', or of relation, is for both Metz and Deleuze a central one: namely, what is the relation between cinema and conceptual thought, or between the imaginary and the symbolic? The challenge is to understand the relation of what Lacan called a non-relation or what Deleuze called a 'disjunctive synthesis'. ${ }^{99}$ And I wonder if we might not do this for Metz and Deleuze themselves.

The motive force in Deleuze is ambiguously located between, on the one hand, an emphasis on the creative production of new images, and on the other, a restoration of perception and affection to a world from which it has been obscured. Deleuze makes this most explicit in speaking of digital and electronic images, when images become legible, not visible. 'Redemption, art beyond knowledge, is also creation beyond information.' What is needed according to Deleuze is a pedagogy that works against 'informatics' by

Deleuze, Negotiations, pp. 57-58.

49 Gilles Deleuze and Félix Guattari, Anti-Oedipus, trans. by Robert Hurley, Mark Seem, and Helen R. Lane (Minneapolis: University of Minnesota Press, 1983), p. 12. 
setting up 'the question which goes beyond it, that of its source and that of its addressee'..$^{50}$ It seems we have surreptitiously come back to the question of enunciation, to which Deleuze had objected in Metz's semiology. But we are not tied here to a simplified aesthetic of political modernism in which any gesture toward the apparatus can be read as necessarily politically radical. Rather, we may be in a place where we can think about an interrelation of Metz's project and Deleuze's project in a way that may challenge what I take to be the general lack of politics in many current modes of film theory and film-philosophy.

Today we find film theories that adhere to Metz's principles of posing answerable questions in respect to a circumscribed object. But this piecemeal theory has forsaken Metz's larger ambitions of an integrated theory that would ultimately be able to understand the relation between the dominant codes and conventions of mainstream cinema and the specific forms of desire inspired by cinema in terms of broader social, cultural, and historical forces. Meanwhile, new forms of film-philosophy inspired by Deleuze are too often tied to a bodily materialism, a romantic conception of art, or vague metaphysical speculations while forsaking the labour of conceptualization that for Deleuze needed to be a form of political resistance to the society of control and a world that we are losing the capacity to believe in.

Metz suspended the question of ideology critique because he saw the question of the relation to economy and the social and historical world as involving too many additional variables to be immediately linked to the goal of a rigorous theory of the film text and its relation to the spectator. But by providing the tools to begin thinking toward the progressive comprehension of signification in dominant cinema, he opened the door to theories of counter-cinema and ideological analysis. Deleuze, on the other hand, suspended the reading of dominant cinema, but he attempted to think the ways that cinema could challenge the reign of information and communication in the electronic age. Both Deleuze and Metz insisted on the political implications of the analysis of cinema while also avoiding the critique of cinema in favour of an attempt to conceptualize the signs that compose it. By thinking the disjunctive relation between what can be known about dominant modes of cinema at the level of signification and cinema's capacity to create new images and signs, we might return to the question of cinema's politics in a new way. 
About the author

Nico Baumbach is an Assistant Professor of Film Studies at Columbia University. His first book Cinema/Philosophy/Politics: Rancière, Badiou, Agamben and Film Theory Today is forthcoming from Columbia University Press. He is currently working on a book titled The Anonymous Image. 
Two Interviews with Christian Metz 



\title{
20. Thirty Years After
}

\author{
Elena Dagrada
}

Tröhler, Margrit and Guido Kirsten (eds.), Christian Metz and the Codes of Cinema. Film Semiology and Beyond. Amsterdam University Press, 2018

DOI: $10.5117 / 9789089648921 / \mathrm{CH} 20$

\begin{abstract}
Almost thirty years have passed since I had the privilege of interviewing Christian Metz in Bologna, where he was participating in a conference. The esteemed scholar had enthusiastically agreed to be interviewed for the first issue of a new cinema journal, Cinegrafie, produced exclusively by young people. My friend Guglielmo Pescatore and I had drafted an outline of ten questions, then I went to the appointment alone because I spoke French well. During our meeting, Metz talked with such ever-growing enthusiasm and generosity that the ten diligently formulated queries were swallowed up in a passionate conversation full of graciousness and the pleasure of communication. When I asked him a short time after the interview if he wanted to review the transcription I had prepared for publication, he confirmed his amiability by responding that he did not need to see it because he trusted that it was all right. When he received the journal, he was even more generous, promoting it among his students at his - for us young people in Italy legendary - seminar at the EHESS. He continued to promote all the issues we sent him by mail from Bologna to Paris.

Reading the interview again today, almost thirty years after, three points - among many - stand out.

The first is the humanity of Christian Metz, evident in every one of his answers, where the fragrance of life is never absent. He often evokes sentiments, especially of love: for the persons he had the chance to meet, for the beauty of those experiences he had the chance to have. But also love as a metaphor for the dynamics that distinguish the intellectual experience of the scholar and the theoretician, even if he finally comes to deny its significance. All that with the modesty and openness to self-criticism that characterize great figures.

The second is the longue durée of the Bazinian matrix of his thought, of which he was perhaps only partly aware. He was conscious of it in relation to the first phase of his semiologic reflection concerning analogy and language
\end{abstract}


without code. Perhaps he was not as aware of it in relation to another noted phase of his thought, the one concerning enunciation in classical cinema without marks of enunciation, which was ostensibly inspired by Emile Benveniste but was very similar to the considerations of André Bazin on invisible montage. It was no accident that Metz used the term 'transparency' (a term that is commonly attributed to Bazin, though Bazin never used it), even as he accused himself alone, with his constant intellectual honesty, for overusing the term.

The third is the equivalence of structuralism and theoretical approach, almost as if they were synonymous - as if structuralism was not a method or a model (something that Metz once again denies having ever proposed) but rather an approach, an intellectual attitude. For Christian Metz, semiology is an attitude, an attitude in opposition to approximation, to impressionism, to the slapdash mode dominating writing about cinema at that time. In his words, even the history of cinema, handled methodically with a theoretical attitude, becomes a structuralist history of cinema. And this is to be welcomed.

It is important to remember how much it was still necessary in those years to defend not only the legitimacy of cinema as an object of study but also the study of cinema itself, especially when conducted with a scientific approach analogous to that which the academic world recognized only for other forms of art. This was perhaps the most important battle Christian Metz fought, with farseeing clarity and inventiveness (even going to the point of soliciting the invention of new formulas of textual analysis that foreshadow hypertext and multi-media tools).

It was a battle that Christian Metz has certainly won.

\section{Translated from Italian by Barringer Fifield}

\section{About the author}

Elena Dagrada is Professor of Cinema Studies at the Università degli Studi di Milano. She was a member of the Executive Committee of DOMITOR (the international association for the study of early cinema) from 1993 to 1997, for which she wrote the second edition of the International Bibliography on Early Cinema (1995), and is currently President of the Italian Association for Research in Cinema History (AIRSC). Among her books are: Woody Allen. Manhattan (1996), where she also employs Christian Metz's Grand Syntagmatique; Levarianti trasparenti: I film con Ingrid Bergman di Roberto 
Rossellini (2005), winner of the Limina Prize for the Best Italian Film Studies Book and published in a second enlarged edition in 2008; and Between the Eye and the World: The Emergence of the Point-of-View Shot (2014). She also authored the lemma "Piano-sequenza" (Treccani Cinema Enyclopedia, Vol. IV, 2004) comparing André Bazin and Christian Metz's plan-séquence conception.

\section{About the translator}

Barringer Fifield is a graduate of Stanford University in California and La Sapienza University of Rome. In addition to translating, he has written historical 'interpretations' of cities like St. Louis, Pittsburgh, Naples, and Rome. 



\title{
21. The Semiology of Cinema? It Is Necessary to Continue!
}

\author{
A Conversation with Christian Metz \\ Elena Dagrada and Guglielmo Pescatore
}

Tröhler, Margrit and Guido Kirsten (eds.), Christian Metz and the Codes of Cinema. Film Semiology and Beyond. Amsterdam University Press, 2018

DOI: $10.5117 / 9789089648921 / \mathrm{CH} 21$

\begin{abstract}
This interview was conducted in Bologna in October 1988. The conversation unfolds along the three historical phases of Metz's work - the semio-linguistic, the semio-psychoanalytic, and the text-pragmatical phase on filmic enunciation. Metz self-critically returns to his proposition of a Grand Syntagmatique of film. In addition, he embeds his film-semiological approach in a meta-theoretical and meta-historical reflection, and talks about how much his thinking owes to André Bazin, Pier Paolo Pasolini, Jean Mitry, and many others.
\end{abstract}

Keywords: film semiotics/film semiology, Grand Syntagmatique, film phenomenology, psychoanalytic theory of cinema, enunciation theory, cinephilia

This interview was first published in Italian in the very first issue of Cinegrafie, 1/1 (February 1989), pp. 11-23. It was conducted by Elena Dagrada on 18 October 1988, in Bologna, starting from an outline of ten questions drawn up jointly with Guglielmo Pescatore. Christian Metz was in Bologna for a conference dedicated to the theme of La cultura italiana e le letterature straniere moderne. He was extremely cooperative and authorized publication of this transcript without having reviewed it.

In his last book, Jean Mitry talks about a young student who in 1964 came to him with a manuscript entitled 'The Cinema: Language or Language 
System?', ${ }^{1}$ which was destined to hold an important place in later studies of cinema. What doyou remember aboutJean Mitry and the situation of cinema theory in France at the beginning of the 196os?

I in fact spoke a lot with Jean Mitry because I greatly admired his work and still do. I don't remember the exact moment when I showed him that manuscript, because it happened a long time ago. But I do remember talking with him frequently. I thought - and I still think - that semiology should be based on all earlier theoretical production, and that it should not present itself as a moment of rupture, and even less as a so-called epistemological rupture. I also remember that Mitry's reaction at the time was extremely friendly - Jean Mitry was a truly kind person - even if he was a little frightened by this slightly crazed young man who often said the same things he was saying but in a different manner.

As for the theoretical situation at the beginning of the 1960s in France, well, there wasn't anything. Let's say that between Bazin, whose influence ended in 1958-59 or 1960, and the first book of Mitry in 1963, along with my article in 1964 and Mitry's second book in $1965,{ }^{2}$ there was a gap. Not a very big one, if you wish, four or five years, but noticeable. Those are not many years, yet still, they are many. It was a period when no-one spoke any longer of the theory of cinema; talk began again on my work and on Mitry's book. Certainly not in the same way because Mitry's book was a book looking at the past, a splendid summa of all that had been acquired in the past, while my work was looking at the future. In reality it was only a question of age - Mitry and I certainly did not have the same age. History is sometimes unjust, because Mitry's book is very important and it is for this reason that I absolutely wanted to review it at length in two articles, a hundred pages altogether, published then in Essais II. ${ }^{3}$

1 Metz's article, 'Le cinéma: langue ou langage', appeared first in Communications, 4 (1964) and was reprinted in Essais sur la signification au cinéma, 2 vols. (Paris: Klincksieck 1968), I, pp. 39-93. It was translated into English as 'The Cinema: Language or Language System?', in Film Language. A Semiotics of the Cinema, trans. by Michael Taylor (New York: Oxford University Press, 1974), pp. 31-91.

2 The books of Jean Mitry that Metz is referring to are the two volumes of Esthétique et psychologie du cinéma (Paris, Editions Universitaires, 1963 and 1965), later republished in English in one volume as The Aesthetics and Psychology of the Cinema, trans. by Christopher King (Bloomington: Indiana University Press, 2009).

3 Christian Metz, 'Une étape dans la réflexion sur le cinéma' [1964] and 'Problèmes actuels de théorie du cinéma' [1967], in: Essais sur la signification, 2 vols. (Paris: Klincksieck, 1972), II, pp. 13-34 and 35-86. 
What kind of education did you have?

I had a classical education, the most classical it is possible to have in France:I studied at the Ecole Normale Supérieure, I am an agrégé in Classical Letters, licencié in German, I have a diploma in ancient Greek history, in short, the education of a classical philologist. On the other hand, from a very early age, from the age of sixteen, I have been a militant cinephile. I was active in the Fédération Française des Ciné-clubs, a movement born in France after the Liberation, and during the last year of lycée I founded the cineclub of Béziers, the town where I lived at the time. As a militant, I was chairman of the cineclub for the preparatory classes for the Grandes Ecoles, at the Henri IV Lycée in Paris, and chairman of the cineclub of the Ecole Normale Supérieure. In short, I was a cinephile, I loved and I still love the cinema. My education was double: classical on one side - my parents, after all, were university professors - and cinephile on the other.

\section{How did you come to semiology?}

I got to semiology by myself because at that time there was no other way. There were no specific courses then. And come to think of it, there were not even courses in general linguistics; the first one was created by André Martinet at the end of the 1950s. Anyone who got into semiology got there through a friend or through his own reading.

Were you a friend of scholars like Roland Barthes and Algirdas J. Greimas who, like you, began to develop interest in semiology in those years?

I was a good friend of Barthes, and we remained good friends to the end. With Greimas it was different. In 1963, under the auspices and with the aid of Barthes, Greimas created a department of semio-linguistics in Lévi-Strauss's laboratory of social anthropology at the Collège de France. It was a great innovation at the time. Greimas needed a general secretary who dealt with organizational matters, and asked Barthes, who was his good friend, to suggest someone, and Barthes proposed me. I did not yet know him personally; it was Barthes who introduced me to him. That is how I got into the Ecoles des Hautes Etudes, where I still am. But I stayed with Greimas only four or five years, then I left him because I did not agree with the excessive rigidity of his theory. It is a theory I am not comfortable with because, how to say it, I think he adopted explanatory procedures that are more difficult to understand 
than the thing being explained. Therefore, even though we remained very friendly on a personal level, in 1968-69 I resigned and went back to Barthes. That is my story.

Let's go back to your article: after the publication of 'The Cinema: Language or Language System?', you had a chance to discuss the themes anew with Umberto Eco and Emilio Garroni during the Festival of Pesaro. Did that encounter in some way modify your views, especially your idea - which derived from Bazin - of language without code?

Yes, very much. It is true that my discussions with the 'Italian school' influenced me enormously because I belong to a generation which, in France, is fundamentally Bazinian. The influence of Bazin was huge and even now I am rather Bazinian. I mean my head isn't, but deeper down... It was precisely my Italian friends who focused my attention on the fact that a language can seem natural but that this impression of naturalness can be created by codes that are not natural - think of Eco's theory of iconism. It was under the influence of discussions with Eco and Garroni that I elaborated my theory of codes that 'construct' the analogy, in opposition to the codes that are added to the analogy.

Pier Paolo Pasolini also took part in the Pesaro meetings, and between the mid-196os and the beginning of the 197os he wrote some essays on the semiology of cinema that were received with some interest at that time. Later, though, Pasolini's contribution was ignored by the semiology of cinema. Still, don't you think that Pasolini had some interesting intuitions?

Yes, Pasolini was an extraordinary personality. When the Festival of Pesaro was in its first years - a great time - we were friends. I believe that in fact Pasolini had striking intuitions but that he expressed them 'badly', so to speak, on a scientific level, and this discredited him with scholars. For example, he said that cinema was a language [langue], and to support that he invented a definition of language [langue] that had value only for him ... He was a poet. This does not take away from the fact that Pasolini had extraordinary intuitions. I am thinking especially of the 'free indirect subjective' [caméra subjective indirecte libre] that I am using explicitly in the book I am working on now, but in a less poetical and more scientific sense. The idea is that of a free indirect discourse in cinema as one of the positions of enunciation frequent in films. 
The second Italian stage of your evolution as a researcher was Urbino. In 1972 you took part in the inauguration of the Centro internazionale di semiotica e linguistica; what can you tell us about this experience?

For me it was an important experience, especially from a didactic point of view. Initially the Urbino centre was conceived of as a permanent study centre; it was not organized for summer sessions as it is now. But it functioned for only one year. When we inaugurated it in January 1972, the idea was to gather a group of about twenty students chosen from all over the world who were to remain there an entire year with three different teachers each month. I took the first month, and therefore I can say that I 'created' the centre. I have a truly beautiful memory of it. Urbino in the middle of winter was like a ship in the middle of clouds, really, you never saw anything, it was always foggy. Students and teachers stayed at the same hotel, the Piero della Francesca. The college did not yet exist. With the students there was continuous contact, something I have never found again. We worked splendidly, all day, and everyone learned so many things. Students gave reports and professors altered their lessons on the basis of the students' questions. Then in the evening we all went dancing together. Marvelous! Later there were economic difficulties and Urbino became what it is today. In any case, for me it was an extraordinary human experience in teaching and in sociability.

Those were also the years of the widest spread of the Grand Syntagmatique, which has been one of your most cited but also most criticized elaborations. What do you think its importance then was, and what value might it have today?

I believe that if you consider the Grand Syntagmatique as it is, it in effect has no more value at all today because there are too many errors. On the other hand, I think that it was very useful at the time because it was the first systematic attempt to show that in film there are codes. I wanted to show that there is a code and I erred. It was too early, I was too ambitious, but I did demonstrate that there are codes and I believe that the liveliness of both praise and criticism was precisely due to the fact that someone, for the first time, said it. The fact then that there are not eight syntagmatic types has little importance. It was a question of affirming the code-like nature of a language that everyone considered natural, ineffable, artistic. 
Certainly the Grand Syntagmatique has been much criticized, it was applied around the world, and the most interesting thing is that in some cases it was applied and criticized contemporaneously, that is to say that it was applied with changes, and that is a good thing because these are cases of constructive criticism. Moreover it never stopped being spoken of, and the last person who did so in detail - I say this with sadness - was Michel Colin, who unfortunately died last Tuesday ${ }^{4}$ in a stupid accident on the road. Colin had written a long article entitled 'The Grand Syntagmatique Revisited' in which he demonstrated that I should have followed a different path. ${ }^{5}$ It is an article half in favour and half against the Grand Syntagmatique, which he elaborates anew in a form that is certainly not perfect but which nevertheless is a big step forward. Concerning this, a phrase of Raymond Bellour comes to mind that seems right to me. Bellour wrote, in an article on the film Gigi [Vincente Minelli, USA 1958], that the Grand Syntagmatique is operative ideally. ${ }^{6}$ I believe that that is a sufficiently exact expression: it means that ideally it permits the segmentation of a film, but in reality, no, it does not permit it. In other words, I think I had an idea, but I had it too early and I did not go into it deeply enough. Nonetheless if someone - not me, because I don't feel like it anymore - took up again everything that has been written for and against the Grand Syntagmatique, he could make a true syntagmatic, or at least truer. It is necessary to be modest in science.

The next stage in the evolution of your studies was the publication in 1971 of Language and Cinema. ${ }^{7}$ What do you think of the proliferation of textual analyses engendered by your suggestions in that volume?

I think that textual analysis has been an excellent thing. In the literary field, and in philology, there has always been the habit of speaking of a text only when one knew it well, when it was in front of one. While for cinema, one spoke of texts saying 'do you remember at the end of The Third Man... [Carol Reed, UK 1949]' and 'at the end' could mean at minute 120, 123, $126 \ldots$ Thus a habit of imprecision, of vagueness was created, as though not citing

$4 \quad 18$ October 1988.

5 Michel Colin, 'The Grand Syntagmatique Revisited' [1989], trans. by Claudine Tourniaire, in The Film Spectator: From Sign to Mind, ed. by Warren Buckland (Amsterdam: Amsterdam University Press, 1995), pp. 45-86.

6 Raymond Bellour, 'To Segment / To Analyse (on Gigi)' [1976], in The Analyses of Film, ed. by Constance Penley (Bloomington: Indiana University Press, 2000 [1979]), pp. 193-216.

7 Christian Metz, Language and Cinema, trans. by Donna Jean Umiker-Sebeok (The Hague/ Paris: Mouton, 1974 [1971]). 
a thing was normal. Textual analysis obliged researchers to see how a film is made, minute by minute. And it obliged them to go beyond the signified. Until then, one spoke of films in terms of the signified, one said 'it is the moment when Greta Garbo embraces Clark Gable' and this is the signified. No one ever said 'it is the moment when there is a shot/reverse shot'. Textual analysis makes it necessary to look also at the signifier, to observe for each frame the dimension of scale, the angle, the lighting - in short, to consider all the parameters of the signifier. The enormous development of textual analyses, however, I believe occurred under a double influence: Language and Cinema, of course, but also other works like those of Raymond Bellour and Marie-Claire Ropars, who in fact did the first textual analyses. I said that it was necessary to do these but I never did any, perhaps because I did not enjoy doing them. I pointed out a path, let's say, from a conceptual point of view, but it is necessary to pay homage to those who followed it. In chronological order, the first were Bellour and Ropars, then naturally the analyses came by the hundreds.

The second aspect of the problem is that this practice has its limits. It is evident that it is not possible to do an analysis of all existing films. Even if through textual analysis one understands the mechanism of the film, its functioning, a time arrives when it is necessary to stop. There are many problems: first of all it is a procedure requiring an enormous amount of time, and the results are illegible. A textual analysis is impossible to read.

I believe, therefore, that it is necessary to distinguish two things: in teaching cinema, above all for the youngest students, textual analysis is an irreplaceable pedagogical tool. As for written textual analysis, I believe that new formulas must be found; we are waiting for someone to invent new formulas, either with videocassettes or by writing in a different way. Because the books in which there is 'frame 347 , frame 348 ...' are really unreadable.

Doyou think the same thing about the descriptions of silent films made by the team coordinated by André Gaudreault? ${ }^{3}$

Silent films are perhaps the only field where this practice still finds justification, because there is a risk of losing them. Their descriptions are equally tiresome to read, but in the case of very old films they are justified by the fact that one day there will remain only the report of Gaudreault. But even here there are problems. Gaudreault would like to expand his reporting project to more countries. I saw the type of model 
report that he is proposing, and it is crazy, every thirty seconds of film becomes thirty pages and that is certainly not admissible. A solution must be found.

And concerning the chapter dedicated to tricks, which was published in 1972 in the second volume of the Essais sur la signification au cinéma, what do you think today?

That is something of mine that I would not change much, all the more so because I think it partly prefigured The Imaginary Signifier in its concept of the use of diegesis and in the recourse to the theory of denegation. ${ }^{9}$ Yes, I think I would still subscribe to it today.

What was the origin of your interest in psychoanalysis? When you published The Imaginary Signifier, didyou mean to move beyond your earlier semiotic interests, or did you intend this work as a continuation of them?

My interest in psychoanalysis was not born in a professional perspective, it was born in a personal perspective, because I had some existential problems and I chose to undergo psychoanalytic therapy, which lasted ten years. It was only after three or four years of therapy that psychoanalysis began to interest me as an intellectual field. At the beginning, no, it was as though I were going to the dentist, only it was a slightly special dentist... But I went to the sessions and that was that, I did not read anything on the subject. In a second phase, I began to glimpse a link with my work, and I began to read Freud, Melanie Klein, Lacan, etc. And it had nothing to do with a negation of my preceding work but was rather a deepening of it, since for me psychoanalysis does not replace semiology but is precisely a psychoanalysis of the code, of the institution of cinema, of the code of the spectator. I never did an anthropomorphic psychoanalysis of the cineaste or of the characters of a film, understood as individuals. There are already enough sentiments in life... From the moment psychoanalysis became linked to my work, it became semiotic psychoanalysis of the dispositive, of the code of cinema.

The Imaginary Signifier includes an essay, the one dedicated to Benveniste, which once again led the semiology of cinema in the following years, especially 
towards the problem of enunciation ${ }^{10}$. What are the differences between your approach to enunciation then and later studies on the subject?

I think that the main difference is that in that essay I was very affirmative, perhaps too much so, concerning the fact that in classical cinema there are no enunciation marks. I spoke of a story without discourse, or almost, and in that I went too far. At the same time, I think that that essay had the merit of proposing a theory, so to speak, that was extreme. But I do not think that it was exact, and today I think differently. Today I am struck by the fact that even in the most classical Hollywood films, there are continuously marks of enunciation, enunciative positions. Today my notion of transparency would be much subtler, and the researchers who have spoken of enunciation after me in effect do it much more subtly. I think no one can any longer believe in a transparency in the total way I meant. At the time, I had been struck by a trend toward transparency, and I went to the bottom of it. There is some excess in that article.

Recently, you returned to your semiological interests and published, in the new magazine Vertigo, a long article called 'The Impersonal Enunciation, or the Site of Film.'1" In this article, you express some reservations concerning the use of deictics in the theories of enunciation in film. Can you sum up the main points?

The main point is quite simple: the very notion of deixis in linguistics and also in logic or in pragmatics is linked to oral conversation. In oral conversation, the person is 'I' when he or she speaks and 'you' when another speaks, and it is the possibility of this exchange that defines deictics. An 'I' that cannot become 'you' is not an 'I' for a linguist, for Benveniste, for Jakobson, for a logician, for a psychoanalyst. An 'I' that cannot become 'you' is the definition of love. Deictics presuppose the possibility of exchange, and it is at the base of the theory of enunciation that was born precisely with that of deixis. This is very clear in Benveniste when, in the essay where he defines

10 Christian Metz, 'Story/Discourse (A Note on Two Kinds of Voyeurism)' [1975], in The Imaginary Signifier, pp. 89-98.

11 Christian Metz, published in English for the first time as 'The Impersonal Enunciation, or the Site of Film (In the margin of recent works on enunciation in cinema)' [1988], trans. by Béatrice Durand-Sendrail and others, New Literary History, 2/3 (1991), 747-72 (p. 749). This essay would appear, slightly modified, as the first chapter of Christian Metz's L'énonciation impersonnelle ou le site du film (Paris: Méridiens Klincksieck, 1991), pp. 9-36 (see the new translation by Cormac Deane of the whole book from Columbia University Press in 2016). 
story and discourse, he gives as examples conversation and written passages that reproduce conversations. ${ }^{12}$ Fundamentally I believe that, since this model of deixis is linked to the reversibility of' $\mathrm{I}$ ' and 'you'; it is not applicable to 'monodirectional' discourses, as Bettetini intends them, as in films or novels. ${ }^{13}$ What leads us to err is that there is an 'I' and a 'you' in the novel, but they are intradiegetic. What also leads to error is the fact that the film or the novel can say 'you' to the reader - 'Dear reader, you will be surprised ...' - but this is a case of a false 'you' because it cannot respond. My objection is basically very simple: deictics are linked to oral exchange, the ping-pong in which 'I' becomes 'you' and vice-versa, continually. Outside that, there can be no real deictics, they become anaphoras. In a monodirectional discourse, there is no author; there was a collective or individual one when the film was realized, but at the moment the film is shown the author is not there. In this case it is not possible to discover the enunciator, or rather the enunciator is the film, which is to say an object, a thing. I believe that deictics have the inconvenience of rendering anthropomorphic that which is not and to make bidirectional that which is monodirectional.

Do you think the same about the use of the concept of focalization, initially conceived of by Genette for literary analysis? ${ }^{\text {14 }}$

This question could be answered by François Jost better than by me. ${ }^{15}$ In any event, I am in substantial agreement with him. I, too, think that in a novel the problem of knowing in what way a character got information does not arise. If it is because he saw something, that is in any case a false vision, because it is a matter of words; if it is something he heard, it still is a matter of words; if he smelled something, it remains a matter of words. To say it differently - and in this Jost is wholly correct - in a novel the channel of information has no importance; the only thing that counts is if the character knows or does not know something. The character who knows is the focalizer and we do not ask if he knows because he heard, smelled, or saw.

12 Emile Benveniste, Problems in General Linguistics, trans. by Mary Elizabeth Meek (Coral Gables: University of Miami Press, 1971 [1966]).

13 Gianfranco Bettetini, La conversazione audiovisiva (Milan: Bompiani, 1984).

14 See, for instance, in Gérard Genette, Figures III (Paris: Seuil, 1972). A selection of the essays from this book has been translated as Narrative Discourse: An Essay in Method, trans. by Jane E. Lewin (Ithaca/New York: Cornell University Press, 1980).

15 Metz is referring to the book of François Jost, L'œil-caméra. Entre film et roman (Lyon: Presses Universitaires de Lyon, 1987). 
In cinema, everything is quite different because it is possible to see that a character has been informed of something because he has raised his head up very high, and in the film you see that through an unusual framing. So cinema makes pertinent not only the piece of information but also the channel through which this was obtained, all the more so because in films there are continually focalizations of pure knowledge, what the Anglo-Saxons call transvisualization. This is a very frequent phenomenon in American films. At the outset, the character speaks: 'I remember when I was young ...' and then the voice-over disappears and a flashback shows the content of the memory in images. From that moment on, it is a question of pure knowledge. The knowledge of the character who remembers is displayed, and you cannot say that the point of view is his nor that the point of hearing is his. It is only a focalization, as in a novel. In short, cinema presents much more complicated phenomena. It presents cases of focalization in Genette's sense, in which only the knowledge of a character is stated, as happens in a novel. But it also presents cases where we are informed that the character got information through sight, cases that Jost would call ocularization. Or, finally, cases in which the character got information by hearing: auricularization according to Jost's terminology.

There, even if I am in agreement with the theorization of Jost, I do not like his terminology. In fact, I think it can hinder the spread of his theory. Terminological questions are important because sometimes a badly chosen word wrongs an idea. It seems to me that the word 'focalization' is used so much by researchers that to try to change it would be counterproductive. For Jost, as I am writing in the book I am working on, it would have been better to say 'cognitive focalization', or visual, or auditory. In short, to say the same thing with simpler terms.

\section{What is the book that you are working on, the one you mentioned earlier?}

I am working on a book on enunciation, on the topographical forms of enunciation, those where the viewer, the film, the foyer can position themselves in their mutual relations. So, in the point-of-view shot, things stand a certain way, another way in the objective storytelling, still another in a mirror, etc. It is almost a topography of film textuality. My aim is to come up with a theory of enunciation free from anthropomorphism, free from the idea of 'I', 'you', 'he/she', etc. 
What do you think the prospects are for the theory of cinema?

What can I say? Currently, what characterizes the theory of cinema is a quite vigorous counterattack of American empiricism against structuralism, psychoanalysis, etc. - a counterattack that is not only scientific but also nationalistic, that is being developed by some researchers of the Anglo-Saxon area with sentiments that are decidedly xenophobic, anti-French. In part it is understandable because the United States has suffered France's intellectual colonialism for twenty years, and perhaps also Italy's. So now what is in fashion is the history of cinema, empirical studies, investigations... It is a very strong movement, probably because semiology and structuralism have been hegemonies for almost twenty years. But alongside this counterattack of empiricism and historicism, the theories inspired by structuralism, semiology, psychoanalysis remain nonetheless very strong even in the United States. It is simply that in the United States they are no longer the strongest. In France, yes, and I suppose the same is true of Italy even though I do not know the Italian situation well. Certainly there is a return to history, but in different forms. For example, in France there is a return to history which is another way of saying a return of imbeciles; but there is also another return to history, I am thinking for example of Jean-Louis Leutrat and his book on the Western, or of Jacques Aumont - they are doing structuralist history. And then there are cases apart, like that of David Bordwell, who along with all else is a formidable person: he works with a structuralist method, but he feels a visceral aversion to France, to Benveniste. He wrote a truly remarkable book and then he added considerations against people that were hardly polite... ${ }^{16}$

What will happen now? I believe that in some countries, as in France and Italy, theory will remain strong because in twenty years it has progressed greatly, even in institutions like universities. In the United States, the situation is more complex; one could suppose that theory will become progressively weaker, but I don't know. For countries like France and Italy however my diagnosis is not pessimistic.

Aside from this, I believe that the great period of structuralism has passed. There are historical periods that generally are not renewed, privileged moments caused by factors that are difficult to single out. It is evident, for example, that if a historian of ideas asked why in France - I use the example of France because it is the situation I know best - why in the 196os until 1975-76, there was Lévi-Strauss, Foucault, Barthes, Lacan, 
Derrida, etc., it would be difficult for him to find an explanation. If we take the fifty years preceding this period, it is not easy to find so many people. It is certain that something has ended, but it is not easy to see what. Perhaps the period has ended when general ideas were conceived - of structuralism, of theory - and now we continue only applying them. In other words, I have been struck by a contradiction between two things: on the one hand, when I look around me, and also inside me, I feel that something has ended, I myself no longer have the feeling of inventing. The book that I am writing now, for instance: I am working on it with pleasure but I do not have the feeling of inventing. How can I say it, they are things that are already familiar to me ahead of time... On the other hand, however, I see in me and around me that good work is continuing to get done. What remains incomprehensible is why there was that so very privileged period, and why it has ended. Perhaps it is because there is always a beginning of things, as in the youth of a person or when one is in love. It is something that is difficult to explain rationally, and I am struck by the sight of many researchers around me who continue to do work that is important and interesting.

\section{Like an amorous relation that moves forward well ...}

Yes, exactly, it moves forward well. There is no longer the same ardour of the beginning, but it has not yet run out. Once again, however, in the United States it is different. There, the battles are far harsher. While in France, I don't know in Italy, there are no longer battles between theory and other tendencies.

With regard to theory, unlike other researchers, you are a theoretician who has never personally applied his models to texts (apart from the syntagmatic analysis of Adieu Philippine [Jacques Rozier, F/I 1962]). Why?

I don't believe I have ever proposed models. The Grand Syntagmatique, yes, that was a model. But in the rest of my work, I never proposed real models, things that could be applied directly. In the case of textual analysis, for example, I said that it was necessary to do it but not how to do it. In Language and Cinema, I dedicated three chapters out of twelve to it, but their sole purpose was to show the difference between textual analysis and the analysis of codes. In any event, I am very sceptical about the notion of models. 
Let's say then that you have always given the go-ahead to various tendencies in theory but that you never stopped looking forward and your interests have changed from time to time.

Yes, this is very exact. How to say it - applying my ideas does not amuse me. When an idea is written down, it belongs to the community of researchers and it is up to them to say if it is good or bad, applicable or not applicable, semi-applicable, criticizable. I prefer to move on to something else. For this reason, I never applied the Grand Syntagmatique. I had my students apply it but personally I never applied it. I get bored ... Usually when I have finished a work, I feel a sort of void, and then I get another idea, and that is what then interests me. But there is something else: I am not the only one, there are many researchers who can verify to see if what I have done is good or bad. In short, that is not my job.

What then motivates you to do theory? Love for cinema? Do you think that love for cinema can stimulate the desire to theorize cinema?

No, I would say not. Unless in this love for cinema there is already a theoretical component, but that would be a tautology. I believe that a love for cinema in itself does not in the least impel theorizing about cinema. If anything, the opposite is true. I have been a Macmahonian cinephile, I participated in all the battles of film lovers in Paris, and all of my comrades-in-arms were stupid, even if they loved film and were fascinated by cinema. I believe that a love for cinema is indispensable for studying it, but that is certainly not sufficient. A shocking example is the level of movie magazines throughout the world: they are stupid magazines, even if those who read them love cinema and do so sincerely.

You don't even think that there is a link between the fecundity of cinema and the fecundity of theory?

No, I think it is rather the contrary. I mean that the theory of cinema was born in a moment when cinema already began to be in crisis, to produce an ever greater number of 'metacinematographic' works, like those of Godard - works that reflect on the death of cinema, works that already have something semiologic within themselves. In order for an art to become semiologic, self-reflective, it is necessary that it already be at its end, that it be an old art. I believe therefore that it is no accident that the theory of cinema was born in a moment when cinema already began to feel it was dead, to fold itself back into its past, to become commemorative ... 
Like theory on silent films today?

Exactly. I believe that the theory of cinema is more linked to the death of cinema than to its vitality.

Despite this, twenty years after your statement 'The time has come for a semiotics of the cinema', do you think it is necessary to continue to apply semiology to cinema?

Yes, absolutely. It is necessary to continue.

Translated from Italian by Barringer Fifield

\section{About the authors}

Elena Dagrada is Professor of Cinema Studies at the Università degli Studi di Milano. She was a member of the Executive Committee of DOMITOR (the international association for the study of early cinema) from 1993 to 1997, for which she wrote the second edition of the International Bibliography on Early Cinema (1995), and is currently President of the Italian Association for Research in Cinema History (AIRSC). Among her books are: Woody Allen. Manhattan (1996), where she also employs Christian Metz's Grand Syntagmatique; Levarianti trasparenti: I film con Ingrid Bergman di Roberto Rossellini (2005), winner of the Limina Prize for the Best Italian Film Studies Book and published in a second enlarged edition in 2008; and Between the Eye and the World: The Emergence of the Point-of-View Shot (2014). She also authored the lemma "Piano-sequenza" (Treccani Cinema Enyclopedia, Vol. IV, 2004) comparing André Bazin and Christian Metz's plan-séquence conception.

Guglielmo Pescatore is Professor of Cinema and Media Studies at the University of Bologna. His work is characterized by an attention to the phenomena of mutation, as concerns both textual forms and the social valences of audiovisual media. His research on TV series gave rise to a line of study dedicated to narrative ecosystems and 'vast' narratives (that is, narratives extended in time and space). His recent articles include 'Piracy

17 The reference is to the closing sentence of Metz's 'The Cinema: Language or Language System?', p. 91. 
and Consumption of Digital Goods' (2014), 'Selection and Evolution in Narrative Ecosystems: A Theoretical Framework for Narrative Prediction' (with V. Innocenti and P. Brembilla, 2014), 'Information Architecture in Contemporary Television Series' (with V. Innocenti, 2012), and 'Changing Series: Narrative Models and the Role of the Viewer in Contemporary Television Seriality' (with V. Innocenti, 2014). He is currently president of the Italian Academic Association of Film and Television Teachers (Consulta Universitaria del Cinema).

\section{About the translator}

Barringer Fifield is a graduate of Stanford University in California and La Sapienza University of Rome. In addition to translating, he has written historical 'interpretations' of cities like St. Louis, Pittsburgh, Naples, and Rome. 


\title{
22. Flashback to Winter 1990
}

\author{
Margrit Tröhler
}

Tröhler, Margrit and Guido Kirsten (eds.), Christian Metz and the Codes of Cinema. Film Semiology and Beyond. Amsterdam University Press, 2018

DOI: $10.5117 / 9789089648921 / \mathrm{CH} 22$

The following interview with Christian Metz was conducted in French by Dominique Bluher and myself in late January 1990. It was a semi-directive interview that every so often strayed into a wider discussion of a broader range of topics. For at least three hours, we talked not just about semiological film theory but also about films, especially Christian's love for classical cinema and for Ava Gardner (who had just died), and about the contemporary state of film theory, its development, and its place in academia. Both of us interviewers were young, both doctoral students under Metz's very careful and attentive (co-)supervision. We had attended his last seminar on filmic enunciation held at the University of Paris III (Sorbonne Nouvelle) since 1986 (though he was a professor at EHESS). At least for me, this seminar was not just an initiation into enunciation theory and the semiological perspective but into film-theoretical thought in general and into research as scholarly debate, for Christian's seminar truly was the place of open exchange that Roland Barthes talks about.

For Dominique and me, the interview was thus an opportunity to ask Christian everything we'd always wanted to know about film semiology, about his own career, and his relation to (film) scholarship. The interview proper was followed by a dinner during which these conversations continued. Such dinners in the $20^{\text {th }}$ arrondissement, where Dominique and I both lived at the time, would be repeated several times in small groups of three, four, or five during the years of his (premature) retirement, until his death in 1993. Christian was always interested in our positions and opinions - on the university, on questions of film theory, or on movies we had recently seen - as much as we were interested in his.

Dominique and I translated the interview (recorded on audiocassettes) into German, at the same time abridging and adapting it for publication in the Swiss periodical Filmbulletin, a magazine for a non-specialized readership little acquainted with film theory. (At the time, however, Filmbulletin 
did have a section - with greyed out pages - for more comprehensive discussions on film and cinema, including theoretical reflections.) Unfortunately, we did not transcribe the entire interview and the cassettes were lost over the years. But Christian did countercheck the German text at the time and suggested some clarifications and additions in his characteristically attentive way.

I still remember the cold February afternoon at the Gare de l'Est, when Dominique and I handed the text over - in a dot-matrix printed copy and on floppy disk - to Walter Ruggle, then co-editor-in-chief of Filmbulletin, who was returning to Switzerland after a short stay in Paris. The interview appeared in the magazine's second issue of 1990.

The goal of the interview was to give a non-academic audience an understanding of film semiology, its premises, and its stages of development as shaped by Christian - from linguistics through psychoanalysis to enunciation, with a focus on the latter, contemporary theoretical discussion (his book L'énonciation impersonelle ou le site du film was to be published shortly afterwards, in 1991). One of the magazine's requirements was to illustrate the theoretical concepts and lines of thought with examples. Unsurprisingly, Christian was an extremely cooperative conversational partner. Thus, the many concrete moments in the interview - addressing particular enunciative configurations rather than individual films - show his fundamental willingness and ability to communicate clearly, his commitment to intelligibility and transparency, and his methodically reflective approach: in short, his systematic and nuanced thinking 'at work', coupled with the total intellectual and physical presence that we all appreciated and that still resonates today, not just while I'm writing these lines.

\section{Translated from German by Susie Trenka}

\section{About the author}

Margrit Tröhler is Professor of Film Studies at the University of Zurich. She studied in Basel and Paris and was a doctoral student under the supervision of Christian Metz at EHESS. After his death, she completed her thesis under the direction of Francis Vanoye at the University of Paris X (Nanterre). She was co-editor of the journal Iris (Paris/Iowa) from 1992 to 2002 and President of the interdisciplinary Swiss Society for Cultural Theory and Semiotics (SSCS) from 2007 to 2014. Since 2009, she has also been the co-director of the National Centre of Competence in Research 'Mediality - Historical 
Perspectives', which focuses on the historicity of media. She has published widely on topics such as the intersection of fiction and nonfiction film, gender, aesthetics, and the history of film theory. She recently co-edited the historical anthology Die Zeit des Bildes ist angebrochen! Französische Intellektuelle, Theoretiker und Filmkritiker über das Kino. Eine historische Anthologie. 1906-1929 (with J. Schweinitz, 2016).

\section{About the translator}

Susie Trenka completed her PhD entitled Jumping the Color Line: Vernacular Jazz Dance in American Film, 1929-1945 at the University of Zurich, where she was also a research assistant, lecturer, and translator in the Department of Film Studies. She now lives in New Orleans, working as a freelance translator, film critic/writer, and swing dance teacher. 



\title{
23. 'I Never Expected Semiology to Thrill the Masses'
}

\author{
Interview with Christian Metz
}

Dominique Blüher and Margrit Tröhler

Tröhler, Margrit and Guido Kirsten (eds.), Christian Metz and the Codes of Cinema. Film Semiology and Beyond. Amsterdam University Press, 2018

DOI: $10.5117 / 9789089648921 / \mathrm{CH} 23$

\begin{abstract}
This interview, which the two young film scholars conducted with Metz in Paris in 1990, focuses on Metz's work on his last book, L'énonciation impersonnelle ou le site du film (1991), which he had brought up for discussion during his seminars beginning in 1986. At the same time, the conversation revolves around the historical evolution of the film-semiological approach and its limits as well as the relation between film theory and film analysis. Metz also talks about his relationship with theory, his scholarly attitude, and his love of film.
\end{abstract}

Keywords: film semiotics/film semiology, film phenomenology, psychoanalytic theory of cinema, enunciation theory, cinephilia

This interview with Christian Metz was conducted by Dominique Blüher and Margrit Tröhler in Paris in 1990. It was first published in German in the Swiss magazine Filmbulletin, 2 (1990), pp. 51-55, then reprinted in the Newsletter of the German Association of Film Scholars Film- und Fernsehwissenschaftliche Mitteilungen, 3/4 (1990), and translated into Dutch by Paul Verstraten for Versus, 3 (1991).

Christian, we've been wanting to askyou this for a long time: where does your interest in film theory come from?

One day, two things from my youth came together: for one thing, I've been a film buff since I was about fifteen, sixteen; by the time of the liberation of 
France, I already belonged to a film club in the small provincial town in Southern France where I grew up. The other thing was that I became interested in linguistics very early on, inspired by my father who was a professor of German philology. He was German by birth and I actually grew up bilingually, but I later forgot how to speak German - that has to do with oedipal issues... So my father gave me books on linguistics to read, especially Meillet and Vendryes, ${ }^{1}$ and I was totally fascinated. For an adolescent, these kinds of books are actually easier to understand than literature such as Marcel Proust, for instance.

So I had a strong interest in two things, but they stayed completely separate in my mind for a long time. And then, one day, I brought together my penchant for the theoretical with my passion for cinema. I was thirty years old at the time. And when I started work on my writings, the influence of Roland Barthes became very important to me, but especially the way he interacted with people.

\section{Semiology and Theory of Film}

In France, it is now common to speak of the 'theory of film' rather than the 'semiology of film' (as we can see with the title of the colloquium in Cerisy, 'Christian Metz et la théorie du cinema', for example). ${ }^{2}$ Are these terms synonyms for you?

Definitely not synonyms. Semiology is only one possible theoretical approach. But the two terms were considered nearly synonymous in France during the 196os and 1970s because semiology was so dominant within theory. That's no longer the case today: semiology triggered the development of theoretical works in various directions. So we now have many theoretical approaches that are not semiological, and that's a very good thing.

\section{What characterizes the semiological approach?}

Above all, the attention given to the signifier of the film. Before attending to the plot, the psychology of the characters, the representation of the social

1 See, for instance, their joint work, Antoine Meillet and Joseph Vendryes, Traité de grammaire comparée des langues classiques (Paris: Editions Champion, 1924), and Joseph Vendryes, 'Langage oral et langage par geste', in Journal de Psychologie normale et pathologique, XLIII (1950), pp. 7-33. [All notes were added for the present publication. They specify references made by Christian Metz during the interview in 1990.]

2 The conference proceedings were published in Iris, 10 (special issue Christian Metz et la théorie du cinéma / Christian Metz and Film Theory, ed. by Michel Marie and Marc Vernet, 199o). 
setting, semiology examines the way the images and sounds are deployed in a film: the editing, the sequencing (découpage), the movement of the camera, and so on - that's mainly what distinguishes semiology from other approaches. To me, semiology means above all the examination of the signifier in the sense of Barthes, probably the only person to whom I feel indebted intellectually. To this, I would add two more, secondary characteristics: the willingness to consider insights from linguistics as a discipline devoted to the signifier and an openness regarding psychoanalysis, because this includes a reflection on the signifier, as Lacan said in his brilliantly crazy manner, or, as he could have said, it is itself such a reflection.

\section{Would you agree in calling the semiological approach a scientific one?}

I don't like to use the word 'scientific'. First, because it would suggest that semiology is a fully developed science, which isn't the case (and this is true of all fields in the arts and humanities). And second, the argument of 'scientificity' can be abused to justify the dogmatic, normative pressure of a 'school' and of an intellectual dictatorship, which is another reason why I don't like the word 'scientific'. But of course, the semiological practice is characterized by a striving for 'scientificity'. Personally, I prefer to speak of a 'striving for accuracy'.

What does this 'striving for accuracy' mean for your work, specifically?

To be aware of every step you take. For example, you can propose a very adventurous hypothesis, provided that you're aware of it and you say so. I also mean a certain moral stance in scholarly interaction: to discuss differences in opinion as objectively as possible, without getting personal, and to cite the names and sources on which you base your arguments. Another aspect is to pursue an idea to the end, quite literally, with the greatest possible coherence. For my part, I've pursued every idea for years: I've been working on 'enunciation in film' for four years now, and I'm far from finished with it.

Does striving for accuracy in scholarly work also include developing a terminology?

In practice, I'm against a terminology that is harder to understand than the subject under discussion. But of course, you're forced to name the things you observe, since the phenomenon doesn't exist without the word; if the 
term 'voice-over' didn't exist, we couldn't discuss the various manifestations of this voice.

Going to the movies and approaching cinema theoretically - are you still able to link these two activities?

Yes, of course! Except in the first case you consume, enjoy, experience; and in the second, you analyze the film afterwards. It's basically like in real life: you go to bed with your lover, and afterwards you analyze their character - sort of an extension of the pleasure.

\section{History, Economy, and Film Analysis}

We would like to return to the differences between theoretical approaches: which aspects of film or cinema does semiology describe, and which aspects need to be accounted for with other methods? In other words: what are the limits of the semiological approach?

I think semiology can explain everything that Saussure calls 'internal analysis', that is, the construction of the film, the relationships between the motifs, the form of the signifier, the form of the signified, the content, and so on: everything that has to do with the internal structure of the film.

But semiology, the way I understand it, is a 'modest' discipline, which doesn't cover all areas: the history of film, for instance, should be approached with historical methods. History seems an essential discipline to me when it comes to examining the external aspects of film, such as the relationship between film and society during a specific period: what did it mean when the Communist Party financed a film by Jean Renoir in France in 1936? Also, there are the economic factors of cinema: the monetary flow is an extremely complicated issue, and cinema doesn't compare to other industries in this respect (René Bonnel works in this field in France, for instance, or Douglas Gomery in the US). ${ }^{3}$

Another approach I would like to mention is psychoanalysis. There are two distinct tendencies here: an approach that deals with the psychoanalysis of the characters, the plot, or the author and thus says something

3 See, for instance, René Bonnel, Le cinéma exploité (Paris: Ed. du Seuil, 1978) and La vingtcinquième image. Une économie de l'audiovisuel (Paris: Gallimard/FEMIS, 1989), and Douglas Gomery, The Hollywood Studio System (New York: St. Martin's Press, 1986). 
about the social significance of the film (as is done in literary criticism). Or the direction I have taken myself (and I am by no means the only one): the psychoanalysis of cinema as an institution, that is, of the camera, the projector, the seats in the theatre, the screen - of the entire 'cinema machine' or dispositif, the cinematic apparatus. This is related to semiology because it is the psychoanalysis of the 'code': in this sense, it belongs to the internal analysis. In the 1970s, I initiated this field of inquiry together with Jean-Louis Baudry. ${ }^{4}$ Today, it is less common in France, though Marc Vernet still works on it. ${ }^{5}$ But it is mostly the Anglo-American feminist theorists who do great work in this area, sometimes combining the two possibilities of discussing psychoanalysis in relation to cinema.

There is another, less theoretical semiological activity: film analysis. Canyou say a few words about that?

The 'textual analysis' of film, as it is also called, ideally examines every single shot of a film. In France, Marie-Claire Ropars and Raymond Bellour began analyzing film in this way around the same time. Marie-Claire Ropars was increasingly guided by Derrida's works, whereas Raymond Bellour was largely inspired by semiology. ${ }^{6}$ Since the 1970 s, the textual analysis of film has become widespread in France.

But in essence, it has dealt with the same issues as film theory. In Language and Cinema, I said that one can either examine a film in all its 'codes' (film analysis) or trace a 'code' across several films (film theory). ${ }^{7}$ By and large, I still believe that. For my current work, for instance, I discussed the various forms of the 'subjective shot' during several successive seminars. In this case, I start from theoretical possibilities in the sense of logical considerations, and then I analyze specific film sequences with respect to

4 See the two seminal articles by Jean-Louis Baudry: 'The Ideological Effects of the Basic Cinematographic Apparatus' [1970], trans. by Alan Williams, and 'The Apparatus: Metapsychological Approaches to the Impression of Reality in Cinema' [1975], trans. by Jean Andrews and others, both in Narrative, Apparatus, Ideology: A Film Theory Reader, ed. by. Philip Rosen (New York: Columbia University Press, 1986), pp. 286-98 and 299-318 respectively.

5 See, for instance, Marc Vernet, Figures de l'absence (Paris: Edition de l'Etoile/Cahiers du cinéma, 1988).

6 See, for instance, Marie-Claire Ropars-Wuilleumier, Le texte divisé. Essais sur l'écriture filmique (Paris: Presses Universitaires de France, 1981); Raymond Bellour, The Analysis of Film, ed. by Constance Penley; trans. by Ben Brewster and others (Bloomington/Indianapolis: Indiana University Press, 2000).

7 Christian Metz, Language and Cinema, trans. by Donna Jean Umiker-Sebeok (The Hague: Mouton, 1974 [1971]), pp. 70-78. 
their subjective shots. The films are a corpus for me (but also a body that I love), where I fish for examples. I'm an abstract person, I think in concepts. If I start with a specific film, I'm paralyzed. I cannot express my love for film that way.

But the theoretical and analytical activities are essentially the same. I think the differences are often overemphasized, even though the one cannot manage without the other. An example of the combination of the two activities is Pierre Sorlin's remarkable work in Sociologie du cinéma, which he sadly didn't pursue any further. ${ }^{8}$ His intention was to base the sociology of cinema on textual analysis.

\section{So would you say that semiology requires interdisciplinarity?}

Interdisciplinarity is surely talked about, but in practice, it is hard to realize. Even just raising the required money is difficult... I'm rather sceptical myself; I think interdisciplinarity is only possible if the scholars have excellent knowledge of at least two fields, otherwise the discussion will be at a very low level. But of course, semiology as such is interdisciplinary, as it consists of at least three heterogeneous fields: linguistics, film theory, and psychoanalysis.

It is exactly this combination of linguistics and psychoanalysis that characterizes your work. Why these approaches? Where do you see their commonalities and what is their connection with cinema?

I'm going to start with the last question: they have no special connection to cinema. They are two disciplines that are connected with everything, not just cinema but also literature, painting, or simply everyday life.

Well, what they have in common: they are the two disciplines interested in meaning as such. Of course, all scholarly disciplines deal with meaning, but these are the only ones dealing with the 'meaning of meaning' (though psychoanalysis is not a theoretical discipline as such). So they are very close to each other, contrary to all appearances.

However, linguistics, and its extension in rhetoric or narratology, deals with the 'secondary process' in the Freudian sense, and psychoanalysis with the 'primary process'. 
Shouldn't we today also consider broadening the semiology of cinema to a more general theory of audiovisual media?

Yes, I think that's absolutely necessary, considering how our society is developing. But I would like to add that a semiology of audiovisual media, or also of comics, could profit from the semiology of cinema. In order to figure out the differences, the studies in the field of cinema could be very helpful (since film theory has existed for longer and is therefore more advanced), and despite all the differences, there are a lot of commonalities.

\section{'Enunciation' in Film}

For four years now, you've been working on a new topic: enunciation in film (l'énonciation au cinema): what does 'enunciation' mean and what are the commonalities and differences between linguistic and cinematic enunciation?

I'll start with your second question: there is a fundamental difference. Linguistic enunciation is always concerned with the speech situation as examined by Benveniste and Jakobson. ${ }^{9}$ In a conversation, there are deictic words. There are many of them, but the most important ones are 'I' and 'you': they entail a real interchangeability between the conversational roles; a person is referred to as 'I' or 'you' depending on the context. And what is said influences the course of the conversation, which is redirected again and again. This contrasts with all completed works such as a novel, a film, a painting. Here, such redirecting is not possible: a spectator may find a film terrible, but it will proceed as intended. Nor is a reversal of the roles possible.

Enunciation refers to the activity, the abstract process, that creates the perceivable text: for every text, there is a production process generating the words or images and so forth. Thus, the enunciated (énoncé) presupposes the act of enunciation.

The enunciation can be opposed to the enunciated: if Jean says 'Pierre has come', then Jean is the subject of the enunciation and Pierre is the subject of the enunciated. Pragmatics, narratology, and linguistics all deal with this issue. If we read a novel by Jules Verne, for instance, then Jules Verne as a person is not present during the reading; yet there is a force advancing

9 Emile Benveniste, Problems in General Linguistics, trans. by Mary Elizabeth Meek (Coral Gables: University of Miami Press, 1971 [1966]); Roman Jakobson, Essais de linguistique générale, trans. by Nicolas Ruwet, 2 vols. (Paris: Minuit, 1963), I. 
the action, a production - yes, production, for I'm a materialist - talking to the reader, otherwise they wouldn't be reading the novel. But the reader has no counterpart they could talk to. Of course, Jules Verne did write this book in a physical sense, but at the symbolic level, he's not the producer, because the symbolic, the social, is happening now: the enunciation in the completed work happens at the moment of reading. That's the same with film: the enunciation manifests itself at the moment when someone views the film, without them having any influence on what is enunciated.

And while enunciation in a live conversation happens primarily through deixis, it is expressed through metadiscursive elements in completed works: we only have the discours revealing itself as such by referring to itself. This happens through an autoreferentiality (repli autoréférentiel) that can take many shapes.

\section{How does one recognize these metadiscursive elements in film?}

The enunciation leaves traces, but it is basically merged with the film and carries the text. We can only perceive a very small part of enunciation directly. In linguistics, these traces are called 'markers'. To avoid misunderstandings, I prefer to call them 'configurations'. In French, marque is too closely associated with a small, isolated detail in the corner of an image. 'Configuration' seems more appropriate to me, because enunciation is often apparent in the overall organization of a shot, in its force lines, so to speak. However, there are examples that justify the word marque, such as a fade-out or cross-fade, or any punctuation of the film that can be localized. But in a subjective shot, for instance, there are no features that can be localized - where does the subjectivity of the shot come from? It emerges through the force lines of the entire shot, the framing of the image, the point-of-view of a character.

\section{Can you give some other examples?}

I could list over a hundred configurations. But I can also group them a little, if only provisionally. One group would concern everything related to spectatorial address: the look into the camera; the voice of the person on screen addressing us (here, we can additionally distinguish between weak and strong address, that is, with or without the use of the second person); an off-screen voice or a written address (as in intertitles). Also everything that points to the image as such (as a rectangle) or to the screen (windows, paintings, mirrors, etc.), or the film-within-a-film in its numerous 
manifestations - that's the configuration of cinematic self-reflexivity par excellence. Another group consists of all the moments that stage elements of the cinematic apparatus: the showing of a camera or a spotlight, as in avant-garde cinema, to mark the film as a film. Further, everything that Michel Chion calls 'subjective sound', as well as the first-person voice, that is, the character narrating their experiences in a voice-over. ${ }^{10}$

But also what Francesco Casetti calls the 'objective, unreal image', which I would rather call 'objectively oriented': these are strongly marked configurations of the film that cannot be attributed to a person within the narrative (contrasting montage, high and low-angle shots, or the 'unleashed camera'). ${ }^{11}$ That's about it for now, though I've probably forgotten some.

\section{Forms of Enunciation or Narrative Forms?}

How does the perspective of enunciation theory differ from that of narratology? Or, to put it differently: how can you distinguish typical forms of enunciation from typical narrative forms?

The two terms are obviously not the same, because narratology only refers to narrative works. But in those works, the two forms coincide, because enunciation consists of narration. Essentially, narration and enunciation can be differentiated along two axes: when a work is non-narrative, like certain documentaries, or rather, experimental films (for example, Peter Gidal's 45 minutes of black screen), ${ }^{12}$ where we obviously still have enunciation. Second, in written text, there is the traditional distinction between linguistic phenomena (persons, tenses, verbs - which correspond to enunciation), and the art and technique of writing a novel (the choice of a narrative point of view; the presence or absence of an explicit narrator; the time in which the story is told). The latter are narrative forms in the strict sense. But if you look closely, it becomes more complicated, since the

10 Michel Chion, The Voice in Cinema, ed. and trans. by Claudia Gorbman (New York: Columbia University Press, 1999 [1982]).

11 Francesco Casetti, Inside the Gaze: the Fiction Film and its Spectator, trans. by Nell Andrew and others (Bloomington: Indiana University Press, 1998 [1986]).

12 Metz seems to be mistaken here: we have not been able to identify a film by Peter Gidal corresponding to this short description, nor has our research led to any results beyond Gidal's work. However, Martin Lefebvre has found some notes by Metz on Gidal's films Room Film (UK 1973) and Close up (UK 1983), where the filmmaker's experiments with the filmic image tend, at least momentarily, to a black screen. We thank Martin Lefebvre for this information. 
author uses language to write the novel. Thus, the narrative forms can only be realized through linguistic means (the verb tenses, the adverbs, the use of 'I' or 'he/she/it', and so on). But in principle, the two categories can be distinguished.

But to return to film: in the case of a narrative film, we have a work that is not linguistic, not based on a language system, because film is not a langue (aside from the dialogue spoken in the film). In the fiction film, narration creates the structure and thus also the enunciation. At the same time, the enunciation is solely dedicated to telling a story. In short, enunciation becomes narration and narration becomes enunciation. But only in this case. In non-linguistic narrative works, narration coincides with enunciation. But enunciation is the more comprehensive term, because it encompasses non-narrative works too.

\section{The Neutral Image and Transparency}

If every image presupposes an enunciation, as you put it, then there is no such thing as a neutral or 'objective' image. And yet, you and others talk about the configuration of the 'neutral image'.

The crucial point about the neutral image is that it doesn't really exist, since every shot in a film presupposes a choice of parameters. But if you want to define an image, you cannot help describing it with reference to the neutral image. However, the neutral image is a myth, comparable to the zero in mathematics. Each configuration must be understood as a deviation from an implicit, unmarked, mythical, and precise point. If you think of the off-screen voice as something special and remarkable, then that means that the on-screen voice is seen as the normal, the neutral. The same goes for the look into the camera, which is always a token of enunciation; this means that it appears unmarked, neutral, if a character looks somewhere else than into the camera. Nevertheless, a cinema lover recognizes very well what a neutral image is, which is defined historically, with reference to a period and genre. Take the ending of a classic Western as an example: our hero, in three-quarter shot, is riding toward a stony hill, a male voice is heard singing or humming off-screen - it cannot be any other way. That's a neutral image. A female voice in this case would completely change the shot, would mark it, and it wouldn't be a neutral image anymore. In this sense, the neutral image is a convention with respect to a country, a period, a genre - but empirically, it doesn't exist as such. 
So, if Hollywood cinema aims not to mark its images as such, then we could say that it claims the neutrality, or 'transparency' of its images?

Yes, but this 'transparency' is not an objective concept. It is the spectator's subjective impression, and as such, it is significant, even though it's basically a false impression. It is true that transparency has also been the goal of certain filmmakers, of a certain cinema. But, as David Bordwell has shown, this goal can never be reached. ${ }^{13} \mathrm{And}$, as he has also demonstrated, not all classical Hollywood films aspired to this transparency, either.

Doyou believe in the possibility of 'distancing' or 'estrangement', for instance by showing the elements of the cinematic apparatus?

Distancing effects are also features of enunciation. But I think that the spectator often assimilates them into the diegesis, that is, they give them a meaning at the level of the story, because the pleasure derived from the story is stronger. To really create an 'estrangement effect', the structure of the entire film needs to be devised towards estrangement. It's not enough to show a camera or a spotlight.

A very general question to conclude: when you beganyour work on the semiology offilm in the early 1960 , film studies in general was not a highly developed fieldyet. Since then, the movement has spread and developed in many different directions; but we wonder if the semiological approach doesn't remain very much limited to academia.

It's true that semiology has mostly developed in the academic context. But various aspects of semiology, such as the increased attention given to the signifier or the structure of works, are being carried out into the world by former students working in various fields.

The circulation of my books and their translations seem rather high to me for specialized literature (Language and Cinema and The Imaginary Signifier have reached 15,000 copies in France, and 100,000 copies including their translations). ${ }^{14}$ This shows that semiology is not limited to academia.

13 Metz is probably referring to David Bordwell's 'The Classical Hollywood Style, 1917-196o', in: David Bordwell, Janet Staiger, and Kristin Thompson, The Classical Hollywood Cinema. Film Style and Mode of Production to 1960. (New York: Columbia University Press, 1985), pp. 1-84.

14 Christian Metz, The Imaginary Signifier. Psychoanalysis and the Cinema, trans. by Celia Britton and others (Bloomington: Indiana University Press, 1982 [1977]). 
But you're right, the academic connection is strong and, I'd like to add, understandable and normal, as can be seen with all difficult and specialized subject areas - just think of crystallography...

On the other hand, I'm satisfied if just a few ideas from a book I write stick in the readers' heads. That's completely normal, all communication entails an enormous loss of information. I never expected semiology to be very widely disseminated; I wasn't keen on that, either. I never wanted to 'manufacture' semiologists. My aim was to raise awareness for the construction of films, for what I call the cinematic signifier. This also goes back to Barthes' influence.

Maybe another partial answer is that a discipline that questions the transparency of the cinematic signifier, that investigates and dissects the tools (language, images, and so on) we use on daily basis, will always be unpopular: who wants to destroy their beloved toys? Such a discipline is predestined to stir up resistance against itself. If you tell people, look how this cinema, claiming to be so transparent and leading you to believe its stories, is characterized by the act of enunciation (its production and ideology)', then people won't be pleased. This resistance has to do with the subject matter of cinema itself. And that's another reason why I never expected semiology to thrill the masses.

Translated from German by Susie Trenka

\section{About the authors}

Dominique Blüher is Lecturer and Director of M.A. Studies in the Department of Cinema and Media Studies at the University of Chicago. After studying in Berlin, she received her $\mathrm{PhD}$ in film studies from the University of Paris III (Sorbonne Nouvelle). She was co-editor of the journal Iris from 1992 to 2002. Subsequently, she was Lecturer in the Department of Visual and Environmental Studies at Harvard University; Maître de conférences at the Université Rennes 2; Visiting Professor at Brown University, Wellesley College, and Freie Universität Berlin; and Senior Fellow at the IKKM (Internationales Kolleg für Kulturtechnikforschung und Medienphilosophie) in Weimar. Her writings on French film theory, French cinema, and autobiographical films have appeared in many books and journals. She co-edited two anthologies on French non-fiction short films of the 1950s and 196os and is currently working on two books related to autobiography and cinema. 
Margrit Tröhler is Professor of Film Studies at the University of Zurich. She studied in Basel and Paris and was a doctoral student under the supervision of Christian Metz at EHESS. After his death, she completed her thesis under the direction of Francis Vanoye at the University of Paris X (Nanterre). She was co-editor of the journal Iris (Paris/Iowa) from 1992 to 2002 and President of the interdisciplinary Swiss Society for Cultural Theory and Semiotics (SSCS) from 2007 to 2014. Since 2009, she has also been the co-director of the National Centre of Competence in Research 'Mediality - Historical Perspectives', which focuses on the historicity of media. She has published widely on topics such as the intersection of fiction and nonfiction film, gender, aesthetics, and the history of film theory. She recently co-edited the historical anthology Die Zeit des Bildes ist angebrochen! Französische Intellektuelle, Theoretiker und Filmkritiker über das Kino. Eine historische Anthologie. 1906-1929 (with J. Schweinitz, 2016).

\section{About the translator}

Susie Trenka completed her PhD entitled Jumping the Color Line: Vernacular Jazz Dance in American Film, 1929-1945 at the University of Zurich, where she was also a research assistant, lecturer, and translator in the Department of Film Studies. She now lives in New Orleans, working as a freelance translator, film critic/writer, and swing dance teacher. 

Postscript 


\section{Cruclusiin.}

En mune, le langage in." ensiste

a prendre des frogumenk du redel, mais à les Griturer, les decoujer, les monter daus un chraim ordre, $\bar{a}$ les seuter siguifiauts, $\bar{a}$ en faice les etements diun dircerists, à leur faike dire qged. hais ce qqde, et st encore le unade lui-rueture quì le dit, aut in. (ot un pas un iplerue abshrait cenume la parble)

It $y$ a dine qqde d'unique dans le ciucuna, il combine \& duses qu'M u' avait pat crubiviler jeoqu'ici: la pebula brute all monde et lis subtilik's et raffinements de la parble humaine.

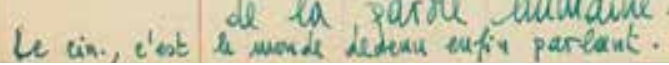

Fig. 24.1: Manuscript 'Conclusion'. Fonds Christian Metz, Bibliothèque du film, Paris: ms. CM1412 


\section{Conclusion}

In short, the 'cinematic language' consists of taking fragments of the real but breaking them up, editing them, assembling them in a certain order to make them meaningful, to transform them into elements of a discourse, to make them say something.

But in cinema, this something is still said by the world itself (and not by an abstract system such as verbal language).

Thus, there's something unique about cinema; it combines two things that hadn't been combined before: the raw presence of the world and the subtleties and refinements of human language. Cinema is the world finally speaking to us.

Translated from French by Susie Trenka

With our sincere gratitude to Michaël Metz who generously gave us permission to reproduce all the facsimiles in this volume - especially this one, which he loves very much, because he hears his father's voice and inflexion in it, speaking to him as a child about the world he was so passionate about. 



\section{Index - Names}

Aarseth, Espen 267-69

Agel, Geneviève 203 (fn)

Agel, Henri 203, 205-06

Albera, François 12, 38 (fn), 102 (fn), 385 (fn)

Allard, Laurence 107 (fn), 111, 113

Allen, Richard 414 (fn)

Althusser, Louis 22, 65, 247, 292, 416, 421-22, 426

Andrew, Dudley 22 (fn), 23, 37 (fn), 38, 40, 46 (fn), 99, 101, 103 (fn), 104, 230 (fn), 385

Andrews, Jean 463 (fn)

Anger, Kenneth 397 (fn)

Antonioni, Michelangelo 62, 151, 190

Appiah, Kwame Anthony 249

Aristotle 151, 194, 348

Arnheim, Rudolf 32 (fn), 53, 85, 115, 117-18,

$$
\text { 120-25, 148, 203, 229, 240, } 248
$$

Astruc, Alexandre 107

Augustine of Hippo (Saint Augustine) 404

Aumont, Jacques 28, 44, 86, 100-01, 104, 106, 183, $224,332,333$ (fn), 337, 374, $45^{\circ}$

Austin, J.L. (John Langshaw) 303, 371 (fn)

Baillou, François 138

Bakhtin, Michail M. 35, 36 (fn), 38o (fn)

Balázs, Béla, 53, 116, 118

Ball, David 411 (fn)

Balzac, Honoré de 329 (fn)

Baril, Jacques 70 (fn)

Barnard, Timothy 33 (fn), 179 (fn), 183, 202 (fn), 216 (fn), 223-24

Barnett, Louise K. 427 (fn)

Barthes, Roland 11, 16, 18, 20 (fn), 24, 27, 31, 37-39, 48, 56, 65-66, 74, 78, 80, 87, 91-92, 95, $113,116,120-21,127,129,134-44,147$ (fn), 167, 171-72, 237, 243, 256, 258, 275, 291 (fn), 298, 308,329 (fn), 334 (fn), 366, 374, 378, 406, 441, 442, 450, 455, 46o-61, 470

Baudoin, Patricia 39 (fn)

Baudry, Jean-Louis 11-12, 229, 463

Baumbach, Nico 22 (fn), 85, 415, 432

Bazin, André 52, 61, 86, 89, 116-21, 123, 129, 130, $144,148,150$ (fn), 155-56, 179, 183, 203, 205, $206(\mathrm{fn}), 224,236$ (fn)

Beineix, Jean-Jacques 180

Bellour, Raymond 19, 20 (fn), 23 (fn), 37, 38 (fn), 39,40 (fn), 47 (fn), 48, 53 (fn), 56 (fn), 63 (fn), 69, 70 (fn), 73 (fn), 75-80 (fn), 81, 83-86, 93 (fn), 99-100, 104, 170 (fn), 230 (fn)

Benjamin, Walter 118, 310

Bensmaïa, Réda 137 (fn)

Benveniste, Emile 16 (fn), 30 (fn), 32-33, 48, 116, $164,258,289,372,373$ (fn), 376-83, 385, 436, 446- 47,448 (fn), 450, 465

Bergala, Alain $385(\mathrm{fn})$

Bergman, Ingmar 408, 436, 453
Bergson, Henri 424, 426, 429

Bergstrom, Janet 22 (fn)

Bertin, Jacques 48

Besson, Luc 180

Bettetini, Gianfranco 33, 35, 48, 110, 232, 262 (fn), 448

Beylot, Pierre 332 (fn)

Bienjonetti, Anne 201 (fn)

Blackburn, Perry L. 254 (fn), 258-59

Blamey, Kathleen 411 (fn)

Blier, Bertrand 180

Blonsky, Marshall 248 (fn)

Blüher / Bluher, Dominique, 9, 17 (fn), 29 (fn), 34 (fn), 38 (fn), 44, 45 (fn), 47 (fn), 54-55 (fn), 65 (fn), 85, 87, 110 (fn), 391, 403 (fn), 413, 455, 459,471

Bogart, Humphrey (Bogey) 176

Boillat, Alain 28, 34 (fn), 44, 87, 110 (fn), 128, 131, 201 (fn), 209 (fn), 270, 369, 370-72 (fn), 379 (fn), 380 (fn), 387 (fn), 389

Boissier, Jean-Louis 111

Bolter, Jay David 389 (fn)

Bonitzer, Pascal 310 (fn)

Bonnel, René 462

Bordwell, David 369, 370 (fn)

Bourdieu, Pierre 39, 275, 410, 411 (fn)

Brakhage, Stan 397, 400 (fn)

Brando, Marlon 176

Branigan, Edward 33

Braque, Georges 112

Brecht, Bertolt 421, 426

Bremond, Claude 116

Bresson, Robert 151

Brewster, Ben 21 (fn), 73 (fn), 80 (fn), 88 (fn), 96 (fn), 202 (fn), 463 (fn)

Brialy, Jean-Claude 138

Britton, Celia 12, 21 (fn), 73 (fn), 85 (fn), 148 (fn), 236 (fn), 287 (fn), $363(\mathrm{fn}), 370$ (fn), 375 (fn), 419 (fn), 446 (fn), 469 (fn)

Brooks, Louise 176

Bruckman, Clyde 416

Bruneau, Jean 92

Brunet, Emilie 40

Bruni, Ciro 303 (fn)

Bruss, Elizabeth W. 393-94, 397, 399-400, 402

Buckland, Warren 13, 21 (fn), 36 (fn), 47 (fn), 87 (fn), 137 (fn), 214 (fn), 395, 444 (fn)

Buñuel, Luis 356-57, 359

Burch, Noël 202

Burchell, Graham 429 (fn)

Burgoyne, Robert 20 (fn), 26 (fn), 27 (fn)

Bussière, Raymond 176

Caillois, Roger 294-95

Cameron, James 180 
Carax, Leos 477

Carette, Julien 176

Carné, Marcel 89

Carrithers, Michael 410 (fn)

Carroll, Noël 417 (fn), 422-23, 425

Cartier-Bresson, Henri 273, 277-84

Casetti, Francesco 22 (fn), 26, 33, 34 (fn), 35, 42, 44 (fn), 48 (fn), 50, 52-53, 54 (fn), 84-86, 98, 101-02, 104, 107 (fn), 128, 137, 185, 199, 353, $385,388,467$ (fn)

Casey, Edward S. $5^{8}$ (fn), $15^{2}$ (fn)

Cavell, Stanley 301-07, 311-21, 323

Chabrol, Claude 138-39

Chaplin, Charles 174, 315-16, 362

Chateau, Dominique 23, 24, 34 (fn), 36 (fn), 43 (fn), 58 (fn), 96 (fn), 97-98, 147 (fn), 151, 152 (fn), 159-60 (fn), 201 (fn), $214(\mathrm{fn}), 230(\mathrm{fn})$, 248 (fn), 287 (fn)

Châteauvert, Jean 381

Chatman, Seymour 34 (fn)

Cherchi Usai, Paolo 203 (fn)

Chevassu, François 203

Chion, Michel 81, 467

Chiostri, Francesca 22 (fn)

Chomsky, Noam 47, 214 (fn), 232, 244, 259

Chopra, Joyce 397 (fn)

Clair, René 387 (fn)

Cocteau, Jean 397 (fn)

Cohen-Séat, Gilbert 37, 54, 59, 102-03, 116-18, $123,131,134-37,143,150,203$

Cohn, Dorrit 394

Colin, Michel 25, 123, 212 (fn), 214 (fn), 303 (fn), 444

Collins, Frank 193 (fn)

Comolli, Jean-Louis 382

Conley, Tom 39 (fn), 287

Cooper, Gary 176, 405

Copier, Marinka 267 (fn)

Coppola, Francis Ford 180

Coquet, Jean-Claude 94 (fn)

Cordingley, Anthony 143-44

Costa-Gavras 382

Courtés, Joseph 171

Coverdale, Linda 258 (fn)

Crist, Larry 171 (fn)

Cubitt, Sean 105

Cuevas, Efrén 403 (fn)

Curtiz, Michael 405

Dagrada, Elena 23, 25 (fn), 28 (fn), 34-35 (fn), 61 (fn), 435-36, 439, 453

Daly, Fergus $79(\mathrm{fn})$

Danesi, Marcel 254 (fn)

Darrieux, Danielle 176

de Certeau, Michel 39

de Lauretis, Teresa 421 (fn)

Dean, James 176

Deane, Cormac 12-13, 87 (fn), 113, 447 (fn)

Décarie, Kim 201 (fn)
Delahaye, Michel 258 (fn)

Deleuze, Gilles 337-38, 415-16, 419, 424, 425-31

Demy, Jacques 358, 362, 407-08

Derrida, Jacques 451, 463

Descartes, René 312

Diederichs, Helmut H. 123

Dietrich, Marlene 176

Doane, Mary Ann 22 (fn), 29, 31, 44 (fn), 285, 300

Doisneau, Robert 279

Doležel, Lubomír 132 (fn)

Dosse, François 18 (fn), 24 (fn)

Dreyer, Carl Theodor 354

du Gay, Paul 410 (fn)

Dubois, Philippe 101, 104, 310

Ducrot, Oswald 32, 381

Dufrenne, Mikel 58, 152, 154, 156, 159 (fn), 165, 286 (fn)

Dulac, Nicolas 202 (fn), 223 (fn), 387 (fn)

Dumas, Alexandre 81

Dupré-La-Tour, Claire 85

Durand-Sendrail, Béatrice 13, 447 (fn)

Duras, Marguerite 377

Eagle, Herbert 48 (fn)

Eco, Umberto 41 (fn), 48, 152, 232-33, 234 (fn), $245,261,262$ (fn), 275, 442

Edie, James M. 291 (fn)

Egoyan, Atom 327, 336, 339, 342 (fn), 343 (fig), 345-47 (fig), 348

Eisenstein / Ėjzenštejn, Sergei M. 53, 6o, 103, 116, 118-19, 123-24, 158-59, 174, 203, 247-48, 276, 363

Enns, Anthony $424(\mathrm{fn})$

Epstein, Jean 117

Eskelinen, Markku 267-68

Esposito-Torrigiani, Uccio 261 (fn)

Fahs, Charles 255

Fairfax, Daniel 47 (fn), 137 (fn)

Falconetti, Maria (also Renée) 182

Fargier, Jean-Paul 133 (fn)

Faucon, Térésa 331 (fn)

Feld, Steven 41 (fn)

Felix, Jürgen $25(\mathrm{fn})$

Fellini, Federico 33, 75, 185, 186 (fn), 193, 329, $35^{2}, 362,383,397$ (fn)

Feuillère, Edwidge 176

Fifield, Barringer 24, 436-37, 453-54

Fink, Bruce 64 (fn), 247 (fn), 299 (fn)

Flaubert, Gustave 92, 138 (fn)

Fleming, Victor 353

Flitterman-Lewis, Sandy 20 (fn), 34 (fn), 27 (fn)

Fontaine, Joan 75

Forrester, John 295 (fn)

Foster Fitz-Simons, Albert 405

Foster Fitz-Simons, Marian 405-06

Foucault, Michel 19, 28, 39, 64-65, 71-72, 74, $293,45^{\circ}$

Francis I 81

Frampton, Daniel 424 (fn), 426-27 
Francastel, Pierre 274-76

Franco, Francisco 282

Frangne, Pierre-Henry 387 (fn)

Frasca, Gonzalo 267, 478

Freeburg, Victor Oscar 148

Freud, Sigmund 29-30, 32 (fn), 48, 51 (fn), 71, 123, 148 (fn), 169-70, 173, 236, 287, 295, 298-99 (fn), 305, 310, 312, 354, 366, 374-75, 385-86, $409,420,423(\mathrm{fn}), 426,446,464$

Gabin, Jean 176

Gable, Clark 445

Galeta, Robert 338 (fn), 428 (fn)

Garbo, Greta 177, 445

Gardies, André 21 (fn), 33, 328 (fn)

Gardner, Ava 176, 455

Garroni, Emilio 25, 48, 232, 262 (fn), 442

Gaudreault, André 21 (fn), 33, 75, 84-86, 106, 178, 179 (fn), 183, 201, 202-03 (fn), 209 (fn), 216 (fn), 223-24, 329 (fn), 387, 445

Gauthier, Guy 24 (fn), 31 (fn), 40 (fn), 50 (fn), 84,90

Gauthier, Philipp 21 (fn), 201, 203 (fn), 223

Gehr, Ernie 361

Genette, Gérard 11, 32, 54, 62, 74, 175, 328, 329 (fn), 332, 371, 374, 381, 394 (fn), 448-49

Genvo, Sébastien 268

Geoghegan, Bernard Dionysius 243-44, 253 (fn), 254,255 (fn), 257

Gerstenkorn, Jacques 386

Ghatak, Ritwik 79

Gidal, Peter 467

Glassman, Deborah 24 (fn)

Gledhill, Christine 425

Godard, Jean-Luc 9o, 176, 183, 189, 190, 224, 349, $365,374,45^{2}$

Goffman, Erving 281

Goliot-Lété, Anne 33, 55, 85, 327, 334 (fn), 348

Gombrowicz, Witold 97

Gomery, Douglas 462

Gorbman, Claudia 467 (fn)

Grange, Marie-Françoise 85

Grant, Cary 75, 315

Gray, Hugh 121 (fn), 206 (fn)

Greimas, Algirdas J. 11, 16 (fn), 20 (fn), 92, 94, 148 (fn), 165, 167, 171, 193 (fn), 209 (fn), 256 (fn), $258,268,329$ (fn), 441

Griffith, D.W. 76, 203 (fn), 206-o8, 221 (fn), 223, $228(\mathrm{fn})$

Groupe $\mu$ [Belgian group of scholars] 172, 173 (fn)

Grusin, Richard 389 (fn)

Guattari, Félix 96, 429 (fn), 430 (fn)

Gunning, Tom 134 (fn), 178, 179 (fn)

Guzzetti, Alfred 73 (fn), 134 (fn)

Habberjam, Barbara 338 (fn), 426 (fn)

Halliday, Michael 259

Hamburger, Käte 32, 48, 391, 394, 400-02, 413 (fn)
Hardyck, Allyn 73 (fn), 81

Hartmann, Britta 34 (fn)

Harris, Roy 260 (fn)

Heath, Stephen 22 (fn), 78 (fn), 121 (fn21, 352, 421 (fn)

Hediger, Vinzenz 10, 127 (fn), 129 (fn), 144, 374 (fn)

Heidegger, Martin 315

Hitchcock, Alfred 75, 77, 284, 352

Hjelmselv, Louis 354 (fn)

Hockett, Charles 254, 259

Hodges, Ames 428 (fn)

Holenstein, Elmar 20 (fn), 39 (fn), 57-58, 59 (fn), $60,63-64$

Houillère, Jéremy 201 (fn)

Howard, Richard 16 (fn), 66 (fn), 74 (fn), 138 (fn)

Hubert, Sabino 380 (fn)

Hühn, Peter 395 (fn)

Huillet, Danièle 9o, 349, 365

Huisman, Denis 153 (fn)

Hurley, Robert 430 (fn)

Husserl, Edmund 58, 64, 429

Ince, Kate 127 (fn), 129 (fn), 137 (fn), 138 (fn), 140 (fn), 144

Ivanov, Vyacheslav V. 169 (fn)

Jacobs, Lewis 280 (fn)

Jacobson, Claire 255 (fn)

Jacquinot, Geneviève 21 (fn)

Jakobson, Roman 20 (fn), 30, 39, 47-48, 51

(fn), 57-6o, 63-64, 116, 170, 173, 196, 243-45, 251-26o, 265, 289 (fn), 374, 447, 465

Jenny, Laurent 112

Jerslev, Anne 229 (fn)

Joan of Arc 92

Joly, Martine 123 (fn)

Jones, Marc 127 (fn), 133 (fn)

Jory, Emmanuel 201 (fn)

Jost, François 33, 34 (fn), 54 (fn), 223, 329, 336, 387,388 (fn), 448, 449

Joughin, Martin 429 (fn)

Joyce, James 168 (fn)

Jullier, Laurent 96

Juul, Jesper 268

Kaczmarek, Ludger 17 (fn)

Kant, Immanuel 64, 245 (fn)

Kay, Lily E. 255 (fn)

Keaton, Buster 315-16

Kehr, Dave 403 (fn)

Kerbrat / Kerbrat-Orecchioni, Catherine 32, 110, 357

Kessler, Frank 12, 22 (fn), 25, 26 (fn), 30 (fn), 32 (fn), 36, 85, 115, 117 (fn), 125, 131 (fn), 132, 133 (fn), 137 (fn)

King, Christopher 207 (fn), 228 (fn), 440 (fn)

Kirsch, Florent (aka André Bazin) 129, 130 (fn), 150 (fn) 
Kirsten, Guido 17, 22 (fn), 26 (fn), 37, 42 (fn), $84-85,87,127,128$ (fn), 144, 331 (fn)

Kittler, Friedrich 424

Klein, Melanie 29, 48, 293, 297, 446

Koch, Gertrud 248 (fn)

Kracauer, Siegfried 118, 148

Krichane, Selim 27, 85, 251, 264 (fn), 267 (fn), 270

Kristeva, Julia 27, 174, 175, 236, 256 (fn), 378

Kuleshov, Lev V. 203

Kuntzel, Thierry 70, 170 (fn)

La Boétie, Etienne de 70

Lacan, Jacques 29, 30, 48, 51 (fn), 64, 170, 173, $236,255,285,287-88,290$ (fn), 292-99, 305, $415,421-22,430,446,45^{\circ}, 461$

Lacasse, Germain 380

Lacoste, Michèle 9, 26, 89 (fn), 212-13, 219 (fn)

Laffay, Albert 37, 52, 54, 109, 117-18, 122, 179 (fn)

Lafontaine, Céline 253 (fn), 255 (fn), 257 (fn)

Lagny, Michèle 31, 47

Lane, Helen R. 430 (fn)

Lang, Fritz 174, 347-48

Lanzmann, Claude 394 (fn)

Lapoujade, David 428 (fn)

Larkin, Erin 102 (fn)

Lavers, Annette 56 (fn), 138 (fn)

Lawton, Ben 259 (fn), 427 (fn)

Le Goff, Jacques 148 (fn)

Le Maître, Barbara 331 (fn)

Le Roux, Ronan 256 (fn)

Leary, Katherine $392(\mathrm{fn})$

Leblanc, Gérard 133 (fn)

Leconte, Bernard 21 (fn), 33 (fn)

Lefebvre, Martin 9, 13, 17 (fn), 23-24, 33, 34, 38 (fn), 42, 43-44 (fn), 54 (fn), 56 (fn), 58 (fn), 87-88, 99 (fn), 102 (fn), 130, 131 (fn), 133 (fn), $147,15^{2}$ (fn), 159 (fn), 160 (fn), 183, 201 (fn), 214 (fn), 221, 230 (fn), 248 (fn), 261 (fn), 287 (fn), 303 (fn), 386-87 (fn), 467 (fn)

Léger, Fernand 178 (fn)

Leirens, Jean 85,121

Lejeune, Philippe 392-394, 402, 410, 411 (fn)

Leone, Sergio 354

Leutrat, Jean-Louis $84,45^{\circ}$

Lévi-Strauss, Claude 11, 16 (fn), 39, 41 (fn), 48, 57

(fn), 65, 243-45, 253-256, 258, 378, 441

Lewin, Jane E. 32 (fn), 328 (fn), 448 (fn)

Lherminier, Pierre 107 (fn)

Lindekens, René 374 (fn)

Lotman, Yuri M. / Jurij 27 (fn), 169 (fn), 259, 260

Lowry, Edward 128, 129 (fn)

Lyant, Jean-Charles 394 (fn)

Lyotard, Jean-François 96, 161

Mahrer, Rudolf 381 (fn)

Malraux, André 118, 124

Manceau, Anne-Laure 409

Mannoni, Octave 303-04, 311-12, 379

Manovich, Lev 105, 107-109, 424
Mansfield, Jane 177

Marcheschi, Elena 107 (fn)

Marie, Michel 17 (fn), 18, 19 (fn), 22, 23 (fn), 28, 47 (fn), 69, 83, 89-91, 92 (fn), 94-95 (fn), 98 $(\mathrm{fn}), 109(\mathrm{fn}), 110,113(\mathrm{fn}), 137$ (fn), 201 (fn), 230 (fn), 331, 385-86, 460 (fn)

Marion, Philippe 86, 106, 223

Marker, Chris 403

Marks, Laura U. 424 (fn)

Martin, Jessie 341 (fn)

Martin, Marcel 37, 53, 118, 203, 205, 211-12

Martinet, André 41, 42 (fn), 47, $5^{2}$ (fn), 116, 229, 354 (fn), 441

Marx, Karl 71, 244, 247, 418, 421-23, 426

Matias, Diana 76 (fn)

Maupassant, Guy de 329, 411 (fn)

Mauss, Marcel 410

McElwee, Ross 402-06, 410, 412-13

McEwen, Alistair 245 (fn)

Meek, Mary Elizabeth 32 (fn), 289 (fn), 372 (fn), 448 (fn), 465 (fn)

Meillet, Antoine 46o

Mekas, Jonas 397-402, 412

Melehy, Hassan 18 (fn)

Méliès, Georges 30 (fn)

Meltzer, Françoise 17 (fn), 274 (fn)

Menken, Marie 399

Merleau-Ponty, Maurice 155, 236 (fn), 285, 290-91, 294, 395, 397

Metz, Michaël 9, 69, 495

Meyer, Rosemarie 9, 21 (fn)

Michaux, Henri 81, 411

Michelet, Jules 138 (fn)

Michotte van den Berck, Albert 37, 120, 133

Miller, Jacques-Alain 295 (fn)

Miller, Richard 65 (fn), 78 (fn), 172 (fn)

Mills, C. Wright 422-23

Minnelli, Vincente 76

Mitry, Jean 22, 37, 39 (fn), 52-53, 117-20, 123, 148, 155, 203, 205-09, 221 (fn), 228 (fn), 416-17, 439-40

Mitterrand, Frédéric 394 (fn)

Modot, Gaston 176

Molino, Jean 176 (fn)

Möller-Nass, Karl-Dietmar 25

Monroe, Marilyn 177

Montaigne, Michel de 257 (fn)

Montand, Yves $35^{8}$

Montani, Pietro 195

Morin, Edgar 37, 116, 118, 120, 176, 203

Morlay, Gaby 177

Morris, Charles W. 47

Mortimer, Lorraine 288 (fn)

Mullarkey, John 417 (fn)

Mulvey, Laura 29, 311 (fn)

Münsterberg, Hugo 85, 118, 148, 229, 240, 248, 274,288

Murnau, Friedrich Wilhelm 354

Murray, Janet 268 (fn) 
Nacache, Jacqueline $334(\mathrm{fn})$

Nagib, Lucia $229(\mathrm{fn})$

Nichols, Bill 34 (fn), 233 (fn), 245 (fn)

Nida, Eugene 259

Nieding, Gerhild 142 (fn)

Noguez, Dominique 402

Nowell-Smith, Geoffrey 33 (fn)

Odin, Roger 9, 17 (fn), 19 (fn), 21 (fn), 26 (fn), 28 (fn), 36, 40-41, 45-47, 48 (fn), $5^{2}$ (fn), 63 (fn), 83,329 (fn), 351-53, 355, 370 (fn), 388, 394-95

Ohler, Peter $142(\mathrm{fn})$

Olney, James 393 (fn)

Ophüls, Max 159, 160

Oudart, Jean-Pierre 29, 299

Oulipo [French group of writers and mathematicians] 168 (fn)

Ouspenski, P.D. $54(\mathrm{fn})$

Païni, Dominique 137 (fn)

Pajackowska, Claire 44 (fn)

Palmer, Elisabeth 41 (fn)

Panofsky, Erwin 275

Parsons, Talcott 422

Pascal, Blaise 310 (fn), 383

Pasolini, Pier Paolo 41 (fn), 48, 187, 232-33, 259, $427,439,442$

Patron, Sylvie $381(\mathrm{fn})$

Pavel, Thomas G. 265

Peirce, Charles S. 11, 20, 142 (fn), 234

Penley, Constance 75 (fn), 230 (fn)

Percheron, Daniel 19 (fn), 27 (fn), 40 (fn), 44-45 (fn), 50, 55 (fn), 63 (fn), 65 (fn), 75 (fn), 76, 92, 93 (fn), 94 (fn), 95-97 (fn), 99 (fn), 104 (fn), 112 (fn), $35^{2}, 383$

Perron, Paul 329 (fn)

Pescatore, Guglielmo 23, 25 (fn), 28 (fn), 34-35 (fn), 61 (fn), 435, 439, 453

Piaget, Jean 102

Picasso, Pablo 112

Plato 33 (fn), 177 (fn), 179 (fn), 216 (fn), 223, 387 (fn)

Polan, Dana 13, 34, 44, 55 (fn), 85, 87, 137 (fn), 164 (fn), 351, 367,372

Portmann, Sylvain 389

Powell, William 124 (fn)

Power, Tyrone 177

Preziosi, Donald 71 (fn)

Proust, Marcel 107, 155, 189, 329 (fn), 460

Pudovkin, Vsevolod 6o, 119, 123, 203, 206, 211 (fn)

Pusey, Edward Bouverie 404 (fn)

Quaintance, Mary 77 (fn)

Quéré, Louis 257

Rabouh, Sophie 201 (fn)

Rancière, Jacques 347, 348 (fn), 432

Renoir, Jean 99, 357, 462

Resnais, Alain 187, 354 (fn), 380 (fn), 387 (fn)

Rhodie, Sam $15^{\circ}$
Ricœur, Paul 394 (fn), 411, 423

Riesinger, Robert 9, 23, 25, 28 (fn), 30 (fn)

Riffaterre, Michael 394

Rivette, Jacques $25^{8}$ (fn)

Robbe-Grillet, Alain 337 (fn)

Robertson, Shari 41 (fn)

Rodowick, D.N. 9, 19 (fn), 22 (fn), 23-24, 39, 44 (fn), 48 (fn), 53 (fn), 85, 104, 198 (fn), 230 (fn), 301, 314 (fn), 321 (fn), 323, 372, 417 (fn), 418 (fn), 423

Ropars / Ropars-Wuilleumier, Marie-Claire 31, $47,84,89,363,379,380$ (fn), 388, 445, 463

Roques, Mario 135

Rose, Marilynn J. 32 (fn), 394 (fn)

Rosen, Philip 23, 27, 28 (fn), 41, 42 (fn), 43, 44 (fn), 48 (fn), 53, 85, 227, 229 (fn), 241 (fn), 247 (fn), 248 (fn), 249, 263 (fn), 463 (fn)

Rosenbaum, Jonathan 137

Rossellini, Roberto 103, 437, 453

Rothman, William 316 (fn)

Rousseau, Jean-Jacques 157, 159

Rozier, Jacques 26, 75, 89, 201, 210, 212 (fn), 213, $216,220,35^{2}, 362,45^{1}$

Rudy, Stephen 39 (fn)

Ruggle, Walter 456

Russell, Jane 177

Ruwet, Nicolas 465 (fn)

Ryan, Marie-Laure 267 (fn)

Sadoul, Georges 16 (fn), 150

Sahli, Jan 374 (fn)

Sahlins, Marshall 26 (fn), 59

Saint Augustine (Augustine of Hippo) 404

Santayana, George 313

Sartre, Jean-Paul 285, 290-91, 411 (fn)

Saussure, Ferdinand de 11, 20 (fn), 24, 35, 38, 41-42, 47, 57, 6o, 116, 147 (fn), 149 (fn), 154, $167,231-32,234,244,257-58,260,264,285$, $289,298,462$

Savage, Denis 423 (fn)

Sayles, John 334

Schaeffer, Jean-Marie 369-70, 395 (fn)

Schefer, Jean Louis 63,276

Schenk, Irmbert $36(\mathrm{fn})$

Scheppler, Gwenn 380 (fn)

Schneider, Alexandra 374 (fn)

Schüfftan, Eugen 274

Scott, Ridley 180

Searle, John R. 32, 371 (fn)

Sebeok, Thomas A. 196 (fn), 254, 256 (fn), 286 (fn)

Seem, Mark 430 (fn)

Segal, George 408

Segal, Jérôme 259 (fn), 254-55 (fn), 259 (fn)

Serceau, Daniel $133(\mathrm{fn})$

Shafto, Sally 89-9o, 348-49

Shakespeare, William 107

Shannon, Claude 254-58, 26o-61, 266

Shaviro, Steven 424 (fn)

Shaw, George Bernard 92

Sheridan Smith, A.M. 39 (fn) 
Shukman, Ann 27 (fn)

Sierek, Karl 36 (fn), 144

Simon, Jean-Paul 32, 34 (fn)

Sinnerbrink, Robert 417 (fn)

Sitney, P. Adams 398 (fn), 400 (fn)

Sjöström, Victor 408

Smith, George A. 222 (fn)

Smith, Murray 417 (fn)

Snow, Michael 361

Sobchack, Vivian 391, 395-397, 424 (fn)

Soderbergh, Steven 371

Solanas, Fernando E. 353

Solinski, Boris 268

Sorlin, Pierre 31, 47, 464

Souriau, Anne 38 (fn), 203, 205

Souriau, Etienne 37, 38 (fn), 79, 117, 123, 127, 128 (fni), 130-32, 203-05

Spielberg, Steven 151, 353

Stallone, Sylvester 159-60

Stam, Robert 20 (fn), 26 (fn), 27 (fn), 35, 36 (fn), 380 (fn)

Stendhal 107, 389

Stern, Daniel 73

Strachey, James 409 (fn)

Straub, Jean-Marie 382-83

Suino, Mark E. 27 (fn), 259 (fn)

Tanner, Alain 374

Taormina, Mike 428 (fn)

Taylor, Henry M. 9

Taylor, Michael 13, 17 (fn), 75 (fn), 86 (fn), 103 (fn), 116 (fn), 120 (fn), 130 (fn), 155 (fn), 186 (fn), 202 (fn), 231 (fn), 252 (fn), 290 (fn), 327 (fn), 379 (fn), 424 (fn), 440 (fn)

Taylor, Richard 124 (fn)

Ter Minassian, Hovig 268 (fn)

Tesson, Charles 98 (fn)

Thornton, Sara 273 (fn)

Tiliette, Xavier 130 (fn)

Timoshenko, Semjon A. 203

Tinguely, Jean $5^{0}$

Tisseron, Serge 111 (fn)

Todorov, Tzvetan 116, 256 (fn), 378

Tomlinson, Hugh 195 (fn), 338 (fn)

Tourniaire, Claudine 395 (fn), 444 (fn)

Travolta, John 159, 160, 182

Trenka, Susie 9, 66, 389-9o, 456-57, 470, 471, 475

Triclot, Mathieu 269, 270

Tröhler, Margrit 15, 29 (fn), 36 (fn), 38 (fn), 44-45

$(\mathrm{fn}), 47(\mathrm{fn}), 5^{1}(\mathrm{fn}), 54-55(\mathrm{fn}), 65(\mathrm{fn}), 66,69$,

$84-85,374$ (fn), 455, 456, 459, 470

Truffaut, François 183, 397 (fn)
Umiker-Sebeok, Donna Jean 12, 17 (fn), 73 (fn), 85 (fn), 96 (fn), 118 (fn), 134 (fn), 165 (fn), 197 (fn), 230 (fn), 252 (fn), 286 (fn), 355 (fn), 419 (fn), 444 (fn), 463 (fn)

Valéry, Paul 107, 284

Van de Walle, Jürgen 254

Van Dyke, W.S. 159

Vancheri, Luc 333 (fn)

Vanoye, Francis 21 (fn), 33, 66, 329 (fn), 348, 456,470

Varda, Agnès 354 (fn), 406-13

Vendryes, Joseph 460

Verne, Jules 159

Vernet, Marc 17 (fn), 19 (fn), 22, 23 (fn), 39 (fn), 31-32, 40 (fn), 40 (fn), 44 (fn), 45, 47 (fn), 50, $55(\mathrm{fn}), 63$ (fn), 65 (fn), 75 (fn), 76, 83-84, 90-92, 93-99 (fn), 104 (fn), 109 (fn), 110, 112-13 (fn), 137 (fn), 230 (fn), 273, 284, 239 (fn), 337, $35^{2}, 383,386,460$ (fn), 463

Verstraten, Paul 115, 459

Visconti, Luchino 155

Vollenweider, Lorenz 9, 66 (fn)

Von Neumann, John 256

Waldenstein, Maxim 259 (fn)

Wallon, Henri 121, 293-94

Wardrip-Fruin, Noah 268 (fn)

Weaver, Warren 254-55

Webber, Jonathan 290 (fn)

Weill, Claudia 397 (fn)

Welles, Orson 77, 174, $35^{2}$

Wenders, Wim 151

Whitfield, Francis J. 12, 47 (fn)

Wiener, Norbert 254-56, 26o

Willemen, Paul 416-18, 420, 422

Williams, Alan $463(\mathrm{fn})$

Williams, Annwyl 375 (fn)

Williams, Linda 425

Winkin, Yves 410 (fn)

Wittgenstein, Ludwig 301-03, 313 (fn), 321

Wollen, Peter 421-22

Wood, Robin 150

Worth, Sol 92

Wulff, Hans J. 17 (fn), 36 (fn)

Wuss, Peter 27 (fn), 252

Zemeckis, Robert 18o, 353

Zimmermann, Yvonne 36 (fn)

Zutavern, Julia 9, 17, 84-85, 144 


\section{Index - Film Titles}

¿Quéviva Mexico! (Grigoriy Aleksandrov \& Sergei M. Eisenstein, USA/MEX 1932) 158,160

81/2 (Federico Fellini, I/F 1963)

$33,75,185,186$ (fn), 193, 329, 352, 362, 383, $397(\mathrm{fn})$

A Day in the Country (Une partie de campagne, Jean Renoir, F 1936)

99

A Drama in the Air (Un drame dans les airs (Pathé [Gaston Velle], F 1904) $222(\mathrm{fn})$

A nous la liberté (René Clair, F 1931) 387 (fn)

Adieu Philippine (Jacques Rozier, F/I 1962) $26,75,89,201,210,212$ (fn), 213-15, 219 (fn), $35^{2}, 362,45^{1}$

Alice in the Cities (Alice in den Städten, Wim Wenders, FRG 1974)

151

As Seen through a Telescope (George A. Smith, UK 1900)

$222(\mathrm{fn})$

Attack on a China Mission (James Williamson, UK 1900) $202(\mathrm{fn}), 223$

Breathless (A bout de souffle, Jean-Luc Godard, F 1960) 176

Bright Leaf (Michael Curtiz, USA 1950) 405

Bright Leaves (Ross McElwee, USA/UK 2004) 403 (fn), 404-05

Citizen Kane (Orson Welles, USA 1941) 77,174

Close up (Peter Gidal, UK 1983) 467 (fn)

Contagion (Steven Soderbergh, USA/UAE 2011) 371

Destroy, She Said (Détruire, dit-elle, Marguerite Duras, F 1969) 377

Duel (Steven Spielberg, USA 1971) 151

Exotica (Atom Egoyan, CAN 1994) $327,339,340,343-47$ (fig)

Fireworks (Kenneth Anger, USA 1947) $397(\mathrm{fn})$
From Somalia with Love (Lettres d'amour en Somalie, Frédéric Mitterrand, F 1982) 394 (fn)

Gigi (Vincente Minelli, USA 1958) 444

Gone with the Wind (Victor Fleming, USA 1939) 353

Grand Illusion (La grande illusion, Jean Renoir, F 1937) 357

Grandma's Reading Glass (George A. Smith, UK 1900) $222(\mathrm{fn})$

Intolerance (D.W. Griffith, USA 1916) 76, 206, 208-09, 228 (fn), 354

Joyce at 34 (Joyce Chopra \& Claudia Weill, USA 1972) 397 (fn)

Last Year at Marienbad (L'année dernière à Marienbad, Alain Resnais, F/I 1961) 354 (fn)

L'avventura (Michelangelo Antonioni, I/F 1960) 62

La chinoise (Jean-Luc Godard, F 1967) 374

La Pointe Courte (Agnès Varda, F 1955) $374(\mathrm{fn})$

Le beau Serge (Claude Chabrol, F 1958) 138, 139 (fig)

Le jour se lève (Marcel Carné, F 1939) 89

Le retour d'Afrique (Alain Tanner, $\mathrm{CH} / \mathrm{F}$ 1973) $374(\mathrm{fn})$

Letter from an Unknown Woman (Max Ophüls, USA 1948)

159,182

Letter from Siberia (Lettre de Sibérie, Chris Marker, F 1958)

403

Limbo (John Sayles, USA 1999) 334,336

$M$ (Fritz Lang, GER 1931) $174,347-48$

Modern Times (Charles Chaplin, USA 1936) 174-75, 362-63

Moses and Aron (Mö̈se et Aaron, Jean-Marie Straub \& Danièle Huillet, FRG/AU/F/I 1975) 383

Mother (Mat, Vsevolod Pudovkin, SU 1926) $203(\mathrm{fn})$ 
Mural Murals (Mur murs, Agnès Varda, F/USA 1981)

407

Nazarin (Luis Buñuel, MEX 1959) 356-6o

Night and Fog (Nuit et brouillard, Alain Resnais, F 1955) $380(\mathrm{fn})$

North by Northwest (Alfred Hitchcock, USA 1959) $77,35^{2}$

Notes on the Circus (Jonas Mekas, USA 1966) 397

October, Ten Days That Shook the World (Oktyabr, Grigoriy Aleksandrov \& Sergei M. Eisenstein, SU 1928)

174-75, 363

Ordet (Carl Theodor Dreyer, DEN 1955) 354

Othon (Jean-Marie Straub \& Danièle Huillet, FRG 1969)

382

Pierrot le fou (Jean-Luc Godard, F/I 1965) 189

Reminiscences of a Journey to Lithuania (Jonas Mekas, USA 1972)

397-98 (fn), 412

Room Film (Peter Gidal, UK 1973) 467 (fn)

Scene on Every Floor (Un coup d'œil par étage, Pathé, F 1904)

$222(\mathrm{fn})$

Scenes from My Balcony (Ce que l'on voit de mon sixième, Pathé [Ferdinand Zecca], F 1901) $222(\mathrm{fn})$

Sherman's March (Ross McElwee, USA 1985) 403

Star Wars (George Lucas, USA 1977) 180,353

Staying Alive (Sylvester Stallone, USA 1983) 159-6o, 182

Strike (Stachka, Sergei M. Eisenstein, SU 1925) 203 (fn)

Sunrise: A Song of Two Humans (F.W. Murnau, USA 1928)

354

Suspicion (Alfred Hitchcock, USA 1941) 75

Tarzan the Ape Man (W.S. Van Dyke, USA 1932) 159

Testament of Orpheus (Le testament d'Orphée, Jean Cocteau, F 1960) 397 (fn)
The 400 Blows (Les quatre cents coups, François Truffaut, F 1959)

397 (fn)

The Battleship Potemkin (Bronenosets Potemkin, Sergei M. Eisenstein, SU1925)

173-74

The Beaches of Agnès (Les plages d'Agnès, Agnès Varda, F 2008) 406-08, 411-12

The Birth of a Nation (D.W. Griffith, USA 1915) 207

The Brig (Jonas Mekas, USA 1964) 398

The Cloud-Capped Star (Meghe Dhaka Tara, Ritwik Ghatak, IND 1960) 79

The Confession (L'aveu, Costa-Gavras, F/I 1970) 382

The Ex-Convict (Edwin S. Porter, USA 1904) 207-08 (fn), 209

The General (Clyde Bruckman \& Buster Keaton, USA 1926)

316

The Inquisitive Boots (Hepworth [Lewin Fitzhamon], UK 1905) 222 (fn)

The Ladies of the Bois de Boulogne (Les dames du Bois de Boulogne, Robert Bresson, F 1944) 151

The Middle of the World (Le milieu du monde, Alain Tanner, F/CH 1974) 374

The Third Man (Carol Reed, UK 1949) 444

Touch of Evil (Orson Welles, USA 1958) $35^{2}$

Three Seats for the 26th (Trois places pour le 26, Jacques Demy, F 1988) 358,362

Walden, also known as Diaries, Notes and Sketches (Jonas Mekas, USA 1969) 397-98

What Happened to the Inquisitive Janitor aka What Is Seen Through a Keyhole (Par le trou de la serrure, Pathé [Ferdinand Zecca], F 1901) 222 (fn)

Where No Vultures Fly (Harry Watt, UK 1951) 206 (fn)

Who Framed Roger Rabbit? (Robert Zemeckis, USA 1988) 353

Wild Strawberries (Smultronstället, Ingmar Bergman, SWE 1957) 408 